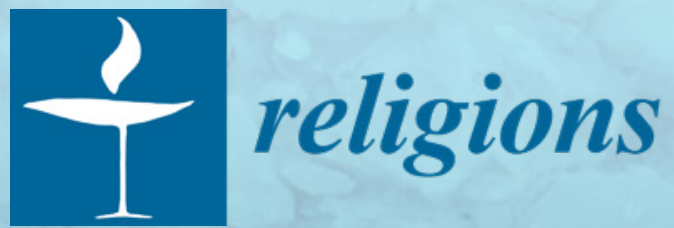

Archaeology and Ancient Israelite Religion

Edited by Avraham Faust Printed Edition of the Special Issue Published in Religions 


\section{Archaeology and Ancient Israelite Religion}





\section{Archaeology and Ancient Israelite Religion}

Editor

Avraham Faust

MDPI • Basel • Beijing • Wuhan $\bullet$ Barcelona $\bullet$ Belgrade $\bullet$ Manchester $\bullet$ Tokyo $\bullet$ Cluj $\bullet$ Tianjin 
Editor

Avraham Faust

Bar-Ilan University

Israel

Editorial Office

MDPI

St. Alban-Anlage 66

4052 Basel, Switzerland

This is a reprint of articles from the Special Issue published online in the open access journal Religions (ISSN 2077-1444) (available at: https://www.mdpi.com/journal/religions/special_issues/Israelite).

For citation purposes, cite each article independently as indicated on the article page online and as indicated below:

LastName, A.A.; LastName, B.B.; LastName, C.C. Article Title. Journal Name Year, Article Number, Page Range.

ISBN 978-3-03936-808-2 (Hbk)

ISBN 978-3-03936-809-9 (PDF)

Cover image courtesy of Avraham Faust.

(C) 2020 by the authors. Articles in this book are Open Access and distributed under the Creative Commons Attribution (CC BY) license, which allows users to download, copy and build upon published articles, as long as the author and publisher are properly credited, which ensures maximum dissemination and a wider impact of our publications.

The book as a whole is distributed by MDPI under the terms and conditions of the Creative Commons license CC BY-NC-ND. 


\section{Contents}

About the Editor $\ldots \ldots \ldots \ldots \ldots \ldots \ldots \ldots \ldots \ldots \ldots \ldots$

Avraham Faust

Archaeology of Ancient Israelite Religion(s): An Introduction

Reprinted from: Religions 2020, 11, 291, doi:10.3390/rel11060291 . . . . . . . . . . . . . . 1

Yosef Garfinkel and Madeleine Mumcuoglu

The Temple of Solomon in Iron Age Context

Reprinted from: Religions 2019, 10, 198, doi:10.3390/rel10030198 _ . . . . . . . . . . . 7

\section{Avraham Faust}

Israelite Temples: Where Was Israelite Cult Not Practiced, and Why

Reprinted from: Religions 2019, 10, 106, doi:10.3390/rel10020106 . . . . . . . . . . . . . 25

\section{William G. Dever}

Archaeology and Folk or Family Religion in Ancient Israel

Reprinted from: Religions 2019, 10, 667, doi:10.3390/rel10120667 . . . . . . . . . . . . . . 51

\section{Beth Alpert Nakhai}

Women in Israelite Religion: The State of Research Is All New Research

Reprinted from: Religions 2019, 10, 122, doi:10.3390/rel10020122 . . . . . . . . . . . . . 63

\section{Jonathan S. Greer}

The Zooarchaeology of Israelite Religion: Methods and Practice

Reprinted from: $2019,10,254$, doi:10.3390/rel10040254 . . . . . . . . . . . . . . 75

\section{Zev I. Farber}

Israelite Festivals: From Cyclical Time Celebrations to Linear Time Commemorations

Reprinted from: Religions 2019, 10, 323, doi:10.3390/rel10050323 . . . . . . . . . . . . . 95

\section{Jeremy Smoak and William Schniedewind}

Religion at Kuntillet Ajrud

Reprinted from: Religions 2019, 10, 211, doi:10.3390/rel10030211 . . . . . . . . . . . . . 115

\section{Irit Ziffer}

Moon, Rain, Womb, Mercy The Imagery of The Shrine Model from Tell el-Far'ah

North-Biblical Tirzah For Othmar Keel

Reprinted from: Religions 2019, 10, 136, doi:10.3390/rel10020136 . . . . . . . . . . . . . 133

\section{Aaron Greener}

Archaeology and Religion in Late Bronze Age Canaan

Reprinted from: Religions 2019, 10, 258, doi:10.3390/rel10040258 . . . . . . . . . . . . . 157

\section{David Ben-Shlomo}

Philistine Cult and Religion According to Archaeological Evidence

Reprinted from: Religions 2019, 10, 74, doi:10.3390/rel10020074

\section{Margreet L. Steiner}

Iron Age Cultic Sites in Transjordan

Reprinted from: Religions 2019, 10, 145, doi:10.3390/rel10030145 . . . . . . . . . . . . . 203 


\section{Craig W. Tyson}

The Religion of the Ammonites: A Specimen of Levantine Religion from the Iron Age II (ca. 1000-500 BCE)

Reprinted from: Religions 2019, 10, 153, doi:10.3390/rel10030153 . . . . . . . . . . . . . . . . . . 217 


\section{About the Editor}

Avraham Faust is Prof. of Archaeology at the Department of General History, Bar-Ilan University. He received his degree from Bar-Ilan University (Ph.D., 2000), and also studied at the University of Oxford (visiting graduate student, 1997-1998) and Harvard University (postdoc, 2002). He is currently directing the excavations at Tel 'Eton in the Judean Shephelah, and the survey in its vicinity, and he is also the director of The National Knowledge Center on the History and Heritage of Jerusalem and its Environs. His research interests include the archaeology of ancient Israel in the Bronze and Iron Ages (biblical archaeology), especially from social and anthropological perspectives, as well as aspects of settlement archaeology, ethnicity, processes of social complexity, and excavations and survey methods and methodology. Avi has more than 200 publications, covering various aspects of the region's archaeology from the Early Bronze Age to the Byzantine period, with a special focus on Iron Age society. Among the books he authored include Israel's Ethnogenesis: Settlement, Interaction, Expansion and Resistance (London: Equinox/Routledge, 2006), The Archaeology of the Israelite Society in the Iron Age II (Winona Lake: Eisenbrauns, 2012), Judah in the Neo-Babylonian Period: The Archaeology of Desolation (Atlanta: The Society of Biblical Literature; 2012), The Settlement History of Ancient Israel: A Quantitative Analysis (Ramat Gan: Rennert Center for Jerusalem Studies, 2015 (in Hebrew)) (with Zeev Safrai), and The Neo-Assyrian Empire in the Southwest: Imperial Domination and its Consequences (Oxford: Oxford University Press, in press). 



\title{
Editorial \\ Archaeology of Ancient Israelite Religion(s): An Introduction
}

\author{
Avraham Faust \\ Department of General History, Bar-Ilan University, Ramat-Gan 5290002, Israel; Avraham.Faust@biu.ac.il \\ Received: 28 May 2020; Accepted: 4 June 2020; Published: 15 June 2020
}

Keywords: archaeology; Israelite religion; Bible; biblical archaeology; Near Eastern archaeology; archaeology and religion; temples; cult

Israelite religion has always fascinated scholars. Hundreds of books and thousands of articles have attempted to shed light on its various aspects. Initial studies used the Bible as their main source of information and attempted to read it critically in order to learn about the religion of ancient Israel. With the advent of modern research in the Near East, mainly in Mesopotamia, more and more information on other Ancient Near Eastern religions was accumulated. The new data were initially used to illuminate Israelite religious practices as described in the Bible, but gradually led to the questioning of some of the accepted truisms that were based on the biblical narrative. Subsequently, new information was collected mainly through archaeological excavations, and archaeology, mainly in the land of Israel, had gradually become a major player in the study of ancient Israelite religion(s) and religious practices. ${ }^{1}$

The accumulating material evidence opened new research vistas and changed the scholarly discourse. The biblical framework for the study of ancient Israelite religion was gradually deserted by many, not only giving rise to much more critical approaches but also resulting in the abandonment of the view that one can speak of an Israelite religion in the singular, and many today prefer to speak about Israelite religions. ${ }^{2}$ Another important development was a broadening of the perspective, and the growing importance given to the local social context in which religious was practiced. Initially, studies focused on data that were (supposedly) directly related to religion and cult, like temples, figurines, etc. Many scholars, however, came to the understanding that Israelite society should be examined from broad, social perspectives. This view, initially strongly advocated by a number of biblical scholars (e.g., Gottwald 1979, 1985, 1986; Clements 1989) ${ }^{3}$ and later also advanced by archaeologists (e.g., Faust 2005, 2012; Dever 2012), resulted in embedding the study of Israelite religion within a broader social framework. Thus, the various evidence, combined with modern and post-modern trends and interests, led to a proliferation of new research questions and scholarly approaches to the data. Among the questions discussed today are the difference between the "official" and "popular" expression of religion; between the "biblical" religion and the "real" one, as practiced during the Iron Age; the role of the common people in various forms of religions; the place of women in Israelite cults; the loci of religious expression (in temples or in other spaces); what objects were used for religious purposes (e.g., figurines); how and when did monotheism evolve, and which other gods or goddesses

1 For the development of scholarship, and the growing role of archaeology, compare for example the following important contribution (none of which was written by an archaeologist) of (Kaufmann 1960; Ringgren 1966; Fohrer 1972; Albertz 1994; Niditch 1997; Zevit 2001; Hess 2007; Albertz and Schmitt 2012).

2 Cf., the terminology used in the titles of the following works, and its development: (Kaufmann 1960; Ringgren 1966; Fohrer 1972; Albertz 1994; Niditch 1997; Zevit 2001; Hess 2007). See also (Dever 1996; Mandell and Smoak 2019).

3 While its popularity declined later, these approaches did not disappear among biblical scholars, and see for example (Simkins and Cook 1999; Olyan 2012). 
were worshiped in ancient Israel; did Israel's God (YHWH) have a spouse; similarities and differences between the religious practices in Israel and Judah and those of other Iron Age religions; the religions of Israel's neighbors; the influence of the Assyrian empire on Israelite religion; aspects of continuity and change between the Iron Age religion and those that developed during the Second Temple period; and many others (it is impossible to mention here even a fraction of the relevant publications, though see for example Zwickel 1994; Niditch 1997; Zevit 2001; Dever 2008; Albertz and Schmitt 2012; Albertz et al. 2014; Hess 2007; Nakhai 2001; Meyers 2005; Faust 2010; Garfinkel and Mumcuoglu 2016; Olyan 2012).

As noted, the above concerns were to a large extent driven by the accumulating archaeological data. When considering the decrease in the historical value given to the biblical sources, it is no wonder that archaeologists and archaeological material came to dominate the discourse (see Bunimovitz and Faust (2010) for a summary of the development and a suggestion for future directions; see also Mandell and Smoak (2019)). Another result is the rise in the number of interdisciplinary studies and their significance (e.g., Albertz et al. 2014).

The massive amount of information on the various sub-themes related to Israelite religions, the shifting trends in scholarship, the multiplicity of approaches, and the interdisciplinary nature of the field means that no single scholar can master all the data. Indeed, there is currently (2020) no good and updated book that covers all or even most aspects pertaining to Israelite religion(s). ${ }^{4}$

This volume is a very partial attempt to fill some of this lacuna.

Most of the studies in this issue were archaeologically oriented, and almost all were designed to offer broad overviews of the topics or questions they address. The aim was that each article would cover a certain sub-theme in the study of ancient Israelite religion(s) and serve as a convenient starting point for this topic or question. The papers were expected, first and foremost, to serve as an updated introduction to specific topics and as a wide overview aimed at enabling the readers to enter the complex topics they discuss with a solid understanding of these issues. Given the significance of the various sub-themes, however, and the up-to-date nature of the discussion, most papers not only summarized the debates but also offered new insights into these topics and introduced new approaches or conclusions. These broad papers are accompanied by a few that are more limited in outlook but which present a significant, even if focused, scholarly contribution to certain questions.

While many sub-themes in the study of the ways the Israelites practiced religion are inevitably not covered in this issue, I feel that this collection of essays does present the readers with a very broad and updated study of many interrelated sub-themes, all related to the study of ancient Israelite religions. Thus, while the value of each the papers is clear, I also hope that such a collection as a whole will be a good starting point for the study of Israelite religion(s).

The first paper is Yosef Garfinkel's and Madeleine Mumcuoglu's article on The Temple of Solomon in Iron Age Context. The paper discusses what is probably the most celebrated religious building of ancient Israel-the Jerusalem temple. While no archaeological remains of this building were naturally uncovered, the authors' study of 10th century archaeological features suggests that the description of this building in 1 Kings is likely authentic and that it preserves a long and detailed description of the construction of a temple and palace in Jerusalem by King Solomon in the 10th century BCE. While previous generations of scholars accepted this description as an authentic account, skeptical approaches concerning the early stages of the Kingdom of Israel/Judah, the biblical text, and the archaeological record came to be dominant in the late 20th century, and quite a few scholars doubt whether any temple was constructed in Jerusalem in the 10th century BCE. The authors' detailed study of recent discoveries like a 10th century BCE building model from Khirbet Qeiyafa and an actual temple building of the 9th century BCE that was partially excavated in Moza shed light on the biblical description and support its early date.

4 Even broad studies, for example (Zevit 2001; Albertz and Schmitt 2012; Albertz et al. 2014), cannot cover everything. 
The Jerusalem temple is no doubt an extreme example of "state" religion. But does it exemplify how most of the people practiced their religion? This question is addressed by a number of studies.

My own contribution, Israelite Temples: Where was Israelite Cult not practiced, and why, critically reviews the loci of the Israelite cult, and claims that practicing the cult in temples-any temples-was an exception rather than a rule in ancient Israel. While most scholars in the late 20th and early 21st century believed that cultic activity in the kingdoms of Israel and Judah was practiced in various temples that were scattered throughout the kingdoms, a detailed study of the archaeological evidence reveals that Israelite cultic buildings were extremely rare, both in absolute terms and when compared to other ancient Near Eastern societies. Hence, the paper concludes that the evidence suggests that rather than viewing the few temples that were discovered by archaeologists, like these discovered at Arad, Dan, and recently apparently also in Moza, as exemplifying typical cultic activity, they should be viewed as exceptions that require a special explanation. After demonstrating this pattern, the article offers a possible explanation as to how such an outstanding practice was developed and adopted. One way or the other, this pattern suggests that cultic activity in temples was the exception rather than the norm and that the typical Israelite cult was practiced in the household and in other, non-temple settings, connecting us with the contributions of William Dever and Beth Alpert Nakhai.

William G. Dever's Archaeology and Folk or Family Religion in Ancient Israel draws attention to the way most of the people in Israel and Judah practiced their religion(s). The distinction between the official religion, whether as viewed by the king (or the "state") or as presented in the Bible, and the way most people practiced their cult, is an important one. While neglected until the late 20th century, the religious expressions of the common people are now at the center of lively discussion. Using a phenomenal approach, the paper summarizes and interprets archaeological data that may be used to illuminate religious practices in ancient Israel during the Iron Age. This picture, drawn on the archaeological evidence, is compared and contrasted with the one that is based on the biblical texts, leading to the identification of both convergences and significant differences between the two sets of data. Dever emphasizes the importance of archaeology in providing a real-life context for both artifact and texts, stressing also the limitations of the material evidence, which is mostly limited to religious practice, rather than belief. The stress on the local expression of religions fits nicely with my argument that actual temples were extremely rare in ancient Israel (above) as well as with Alpert Nakhai's study of the role of women in cults (below).

Beth Alpert Nakhai's paper, Women in Israelite Religion: The State of Research is All New Research, develops a theme that is fairly recent in scholarship, i.e., the place of women in Israelite cults. Historically, argues the paper, those studying Israelite religion have ignored the existence of women in Iron Age Israel, accounting neither for the religious beliefs of half of ancient Israel's population nor for the responsibilities that women assumed for maintaining religious rituals and traditions. Only in the last four decades have scholars begun to explore women's essential roles in Israel's religious culture. The article utilizes textual (biblical) evidence and archaeological information from sites throughout Israel, arguing that that some women had roles even within the Jerusalem Temple. Most women, however, residing in towns and villages throughout the land, undertook responsibility in clan-based and community-based religious rituals and rites, including pilgrimage, seasonal festivals, rites of military victory, and rites of mourning. These women fulfilled essential roles within the sphere of domestic or household religion. At home, they provided medico-magical healing for all family members, as well as care for women and babies throughout pregnancy, childbirth, and beyond.

Jonathan Greer's paper on The Zooarchaeology of Israelite Religion: Methods and Practice is somewhat different from most papers; beyond bringing fresh insights into some aspects of Israelite religion, its primary aim is to provide a methodological framework for the application of zooarchaeology to the study of Israelite religion for the purpose of providing an overview of this growing subfield for the non-specialist and for inviting further conversation among practitioners. Definitions of "zooarchaeology" and "Israelite religion" are explored, and the aim of reconstructing practices of Yahweh-centric religion is described. A methodology is suggested through a series of questions that may 
be applied to explorations of faunal remains, including those related to context, excavation technique, and analysis, and engagement with the Hebrew Bible. The essay concludes with an illustration from Tel Dan and affirmation of integrated methodologies that critically engage archaeological and textual data to form new syntheses.

Zev Farber's Israelite Festivals: From Cyclical Time Celebrations to Linear Time Commemorations is again different from most other papers in this volume, in this case by focusing on a biblical theme, i.e., the festivals. While the Pentateuch and later Jewish tradition associates the key pilgrimage festivals with stories about Israel's past; these festivals all began as agricultural or seasonal festivals. Using comparative evidence from the ancient Near East, and looking at the Covenant Collection through a redaction critical lens, the paper attempts to uncover the early history of these festivals and to reconstruct how they developed in stages. A similar process is evident with the Sabbath, which appears to have begun as a moon festival, as per certain biblical references and from comparative evidence, but which eventually developed into the seventh day of rest as part of the institution of the week and then came to be associated with the story of God resting after creation. These developments, from celebrating agricultural and lunar cycles to celebrating mnemohistorical events, can be seen as part of two parallel processes: the coalescing of Israelite cultural memory and the institution of the linear calendar as the dominant conception of time.

Jeremy Smoak's and William Schniedewind's paper, Religion at Kuntilal Ajrud, discusses one of the sites that is most closely associated with Israelite religion, Kuntilat Ajrud, with surprising conclusions. The discovery of early Hebrew inscriptions at this site has generated considerable discussion among scholars over the past few decades. While the fact that the inscriptions contain explicitly religious themes led many to conclude that the site had a cultic function, the authors challenge this assumption and argue that the inscriptions with religious themes are embedded in daily life as religion converges with scribal curriculum in ancient Israel. The inscriptions, however, provide insights into conceptions of the Israelite pantheon, divine theophany, and theomachy in early Israelian religious ideology, and are therefore important for the study of Israelite religion.

Irit Ziffer's paper on Moon, Rain, Womb, Mercy: The Imagery of The Shrine Model from Tell el-Far'ah North-Biblical Tirzah focuses on the imagery of the shrine model found at Tell el-Far'ah North, identified with biblical Tirzah which was the seat of the ruling dynasty of the northern kingdom in the early days of the northern kingdom. Using the find as a starting point, the paper examines the multiplicity of connotations, changeability, and ambiguity in the representation of the lunar crescent image in the figurative language of the ancient Near East. The article then offers a reconstruction of the model's place within the cult of the late 10th-early 9th century BCE.

The various expressions of Israelite religions, or of religious expressions in the kingdoms of Israel and Judah, cannot be divorced from their background, and a number of papers examine the religions of Israel's neighbors (in space and time), providing a context within which Israelite practices can be examined and with which they can be compared and contrasted.

Aaron Greener's paper on Archaeology and Religion in Late Bronze Age Canaan reviews some aspects of religion in the Late Bronze Age and the dozens of temples that were excavated in the Canaanite city-states of this era. These temples were the focal points for the Canaanites' cultic activities, mainly sacrifices and ceremonial feasting. Numerous poetic and ritual texts from the contemporary city of Ugarit reveal the rich pantheon of Canaanite gods and goddesses that were worshiped in the region. Archaeological remains of these rites include burnt animal bones and many other cultic items, such as figurines and votive vessels, which were discovered within the temples and sanctuaries. These demonstrate the diverse and receptive character of the Canaanite religion and ritual practices. The paper points to the increased Egyptian presence in Canaan towards the end of the period as influencing the local belief system and rituals in some areas, a fact that is demonstrated by the syncretic architectural plans of several of the temples, as well as by glyptic and votive items. Indeed, Late Bronze Age religious and cultic practices have attracted much attention from biblical scholars and researchers 
of the religion of Ancient Israel who are searching for the similarities and influences between the Late Bronze Age and the following Iron Age.

David Ben-Shlomo's paper, Philistine Cult and Religion according to the Archaeological Evidence, reviews and discusses the updated archaeological evidence for a Philistine cult and religion, and for a cult and religion in area of Philistia during the Iron Age. The evidence can be related to a public or official cult, represented in temple and shrine structures, and to that coming from households, representing possibly more popular religion. The evidence of a public cult, so far mostly from peripheral sites, includes largely cultural elements linked with the local Canaanite cult and religion, yet within households at the Philistine cities there is more evidence for cultic elements of Aegean affinity during Iron Age I.

Margreet L. Steiner's paper on Iron Age Cultic Sites in Transjordan reviews a number of Iron Age structures identified as cultic that have been excavated in Transjordan, from the territories of some of Israel's neighbors. This paper presents the evidence as published and discusses the relevance of the cultic identification of the structures, leading to a better understanding of the religious practices of Israel's neighbors to the east.

Craig W. Tyson's The Religion of the Ammonites: A Specimen of Levantine Religion from the Iron Age (ca. 1000-5000 BCE) zooms in on one of the least known of Israel's neighbors-the Ammonites, who lived in the region around Amman, Jordan. The paper investigates the religious traditions of the Ammonites through an analysis of the extant archaeological and textual sources. The analysis leads to the conclusion that the religious tradition of the Ammonites is an example of the broader religious tradition of the Iron Age II Levant. One distinguishing feature of Ammonite religion is the state god Milkom, whose name is probably an epithet for the god 'El, and who appears to be represented in a tradition of stone sculptures that have been found in the vicinity of Amman. The rest of the non-physical realm was understood to be inhabited by gods, goddesses, a variety of other non-human beings, and dead ancestors. Also visible in the extant evidence is a blending of local and foreign elements, especially those from Mesopotamia. Unique in this respect is the probable temple to the moon god at Rujm al-Kursi, which most likely reflects a local tradition of lunar worship influenced by the iconography of the Mesopotamian moon god Sîn.

While each article is important in its own right, and despite some obvious lacunae in the overall coverage of the volume, I hope that this book, on the whole, will serve as a good starting point for anyone who is interested in ancient Israelite religion(s), or the religions of Israel's neighbours, the context of the Bible, and the intersection between archaeology and religion at large.

Funding: This research received no external funding.

Conflicts of Interest: The author declares no conflict of interest.

\section{References}

Albertz, Rainer. 1994. A History of Israelite Religion in the Old Testament Period. Louisville: Westminster John Knox Press.

Albertz, Rainer, and Rüdiger Schmitt. 2012. Family and Household Religion in Ancient Israel and the Levant. Winona Lake: Eisenbrauns.

Albertz, Rainer, Beth Alpert Nakhai, Saul M. Olyan, and Rüdiger Schmitt, eds. 2014. Family and Household Religion: Toward a Synthesis of Old Testament Studies, Archaeology, Epigraphy, and Cultural Studies. Winona Lake: Eisenbrauns.

Bunimovitz, Shlomo, and Avraham Faust. 2010. Re-constructing Biblical Archaeology: Toward an Integration of Archaeology and the Bible. In Historical Biblical Archaeology and the Future: The New Pragmatism. Edited by Thomas Evan Levy. London: Equinox, pp. 43-54.

Clements, Ronald E., ed. 1989. The World of Ancient Israel: Sociological, Anthropological and Political Perspectives. Cambridge: Cambridge University Press. 
Dever, William. G. 1996. Archaeology and the Religions of Israel (Review of A History of Israelite Religion in the Old Testament Period. Volume I: From the Beginnings to the End of the Monarchy). Bulletin of the American Schools of Oriental Research 301: 83-90.

Dever, William G. 2008. Did God Have a Wife?: Archaeology and Folk Religion in Ancient Israel. Grand Rapids: Eerdmans.

Dever, William G. 2012. The Lives of Ordinary People in Ancient Israel: When Archaeology and the Bible Intersect. Grand Rapids: Eerdmans.

Faust, Avraham. 2005. Israelite Society in the Period of the Monarchy: An Archaeological Perspective. Jerusalem: Yad Ben-Zvi (Hebrew).

Faust, Avraham. 2010. The Archaeology of the Israelite Cult: Questioning the Consensus. Bulletin of the American Schools of Oriental Research 360: 23-35. [CrossRef]

Faust, Avraham. 2012. The Archaeology of Israelite Society in Iron Age II. Translated by Ruth Ludlum. Winona Lake: Eisenbrauns.

Fohrer, Georg. 1972. History of Israelite Religion. Nashville: Abingdon Press.

Garfinkel, Yosef, and Madleine Mumcuoglu. 2016. Solomon's Temple and Palace: New Archaeological Discoveries. Jerusalem: Bible Lands Museum.

Gottwald, Norman K. 1979. Tribes of Yahweh: A Sociology of the Religion of Liberated Israel, 1250-1050 B.C.E. Maryknoll: Orbis Books.

Gottwald, Norman K. 1985. The Hebrew Bible: A Socio-Literary Introduction. Philadelphia: Fortress Press.

Gottwald, Norman K., ed. 1986. Social Scientific Criticism of the Hebrew Bible and Its Social World: The Israelite Monarchy. Semeia. Decatur: Scholars Press.

Hess, Richard S. 2007. Israelite Religions: An Archaeological and Biblical Survey. Grand Rapids: Baker Academic.

Kaufmann, Yehezkel. 1960. The Religion of Israel: From its Beginnings to the Babylonian Exile. Translated by Moshe Greenberg. Chicago: University of Chicago Press.

Mandell, Alice, and Jeremy Smoak. 2019. The Material Turn in the Study of Israelite Religions: Spaces, Things, and the Body. The Journal of Hebrew Scriptures 19: 5.

Meyers, Carol L. 2005. Households and Holiness: The Religious Culture of Israelite Women. Minneapolis: Fortress Press.

Nakhai, Beth Alpert. 2001. Archaeology and the Religions of Canaan and Israel. ASOR Books. Boston: American Schools of Oriental Research.

Niditch, Susan. 1997. Ancient Israelite Religion. Oxford: Oxford University Press.

Olyan, Saul M., ed. 2012. Social Theory and the Study of Israelite Religion: Essays in Retrospect and Prospect. Resources for Biblical Studies. Atlanta: Society of Biblical Literature.

Ringgren, Helmut. 1966. Israelite Religion. Translated by David E. Green. Philadelphia: Fortress Press.

Simkins, Ronald A., and Stephen L. Cook, eds. 1999. The Social World of the Hebrew Bible: Twenty-Five Years of the Social Sciences in the Academy. Semeia. Atlanta: Society of Biblical Literature.

Zevit, Ziony. 2001. The Religions of Ancient Israel: A Synthesis of Parallactic Approaches. London: Continuum.

Zwickel, Wolfgang. 1994. Der Tempelkult in Kanaan und Israel: Studien zur Kultgeschichte Palästinas von der Mittelbronzezeit bis zum Untergang Judas. Forschungen zum Alten Testament. Tübingen: J.C.B. Mohr (Paul Siebeck).

(C) 2020 by the author. Licensee MDPI, Basel, Switzerland. This article is an open access article distributed under the terms and conditions of the Creative Commons Attribution (CC BY) license (http://creativecommons.org/licenses/by/4.0/). 
Article

\title{
The Temple of Solomon in Iron Age Context
}

\author{
Yosef Garfinkel * and Madeleine Mumcuoglu \\ Institute of Archaeology, The Hebrew University of Jerusalem, 9190501 Jerusalem, Israel; \\ madeleine.mumcuoglu@gmail.com \\ * Correspondence: garfinkel@mail.huji.ac.il
}

Received: 24 February 2019; Accepted: 13 March 2019; Published: 15 March 2019

\begin{abstract}
Kings preserves a long and detailed description of the construction of a temple and palace in Jerusalem by King Solomon in the 10th century BCE. Previous generations of scholars accepted this description as an authentic account. Accordingly, much literature on this text and the relevant archeological discoveries has accumulated. Since the 1980s, skeptical approaches to the early part of the Kingdom of Judah, the biblical text, and the archaeological record have been expressed. Some scholars doubt whether any temple at all was constructed in Jerusalem in the 10th century BCE. In the last few years, the picture has been changed by new discoveries from two Judean sites: a building model of the early 10th century BCE from Khirbet Qeiyafa and an actual temple building of the 9th century BCE from Motza. In this article, we present the history of research, some aspects of the biblical text and the contribution of the new discoveries. These enable us to place in context both the biblical text and the building it describes.
\end{abstract}

Keywords: Solomon's Temple; Khirbet Qeiyafa; Motza

\section{Introduction}

1 Kings preserves a long and detailed description of the construction of a temple and palace in Jerusalem by King Solomon in the 10th century BCE. The description of the palace is rather short, while the description of the temple is much longer. The palace, however, was much bigger and its construction required nearly twice the time needed to build the temple (13 years vs. 7 ). This indicates that, for the writer of the biblical text, the smaller temple was far more important than the bigger palace. In this way, three long chapters provide the reader with varied information about the form of the temple, the size of the different rooms, its construction materials, its decoration, its major cultic paraphernalia, and its dedication ceremony. As no archaeological excavations have been conducted on the site of the temple, there are no direct data relating to this building. All the research carried out on this topic is based on the analysis of the biblical text and on relevant archaeological discoveries.

Solomon's Temple attracts much attention and the relevant literature on the subject is vast. We will relate here only to the major contributions made by the modern research. Earlier attempts include mainly artistic representations, from the Dura Europos synagogue of the third century CE to later artists, such as Raphael Sanzio, Heinrich Bünting, Charles Chipiez, and Georges Perrot (Garfinkel and Mumcuoglu 2016, pp. 132-45). Biblical scholars have analyzed the text from the aspects of philology (see, for example, Stade 1887; Benzinger 1899; Möhlenbrink 1932; Busink 1970; Cogan 2001; Lemaire 2011; Galil 2012) and literary criticism (Hurowitz 1992, 2010). Archaeologists have contributed to the subject by adding data derived from various temples unearthed in the Levant (Watzinger 1933; Parrot 1954; Vincent 1956; Yadin 1956; Yeivin 1968; Aharoni 1973; Davey 1980; Margueron 1981; Fritz 1987; Meyers 1992; Zwickel 1999; Herzog 2000; Monson 2006; King and Stager 2001; Keel et al. 2004; Smith 2006; Ussishkin 2009).

What is the origin of the biblical text describing the construction of the temple? Opinions on the subject are varied. Until the rise of the "minimalist" theories, scholars accepted that the description 
dated from the period of the temple's construction, that is, from the time of Solomon, and that it had been kept in an archive in Jerusalem and at some point inserted into the biblical text (Montgomery 1934). Some scholars still hold this opinion today (Galil 2012). A literary analysis of the biblical description by Hurowitz $(1992,2010)$ led to a different dating of the text. He posited that this genre of writing, which describes in great detail and in a specific order the construction of a public building, originates in a literary style known from texts written in the Assyrian Empire in the 8th and 7th centuries BCE. Five main elements are found in both the Assyrian and the biblical descriptions:

1. The decision to build a temple (1 Kings 5:17-19).

2. The organization of the construction materials (1 Kings 5:20-26). Here we should include the rest of 1 Kings 5 (up to verse 32), which describes the levy of laborers who quarried the stones and prepared the timber used in the construction.

3. Description of the temple and the various cult objects it contained (1 Kings 6-7).

4. The dedication of the house to the god (1 Kings 8:1-11, 62-66).

5. The king's prayer (1 Kings 8:12-61).

Even if the literary design of these biblical passages was created under the influence of Assyrian literary traditions, however, this does not allow us to determine when the temple was constructed. It rather points to the possible period in which the current description was written or edited.

Liverani, who accepts the tradition that the temple in Jerusalem was built at the time of King Solomon, believes that no historical description of this building was preserved. Rather, the description that appears in the Bible is imaginary and was composed in the Persian period (Liverani 2003, p. 329). According to Edelman (2012), there was no temple in Jerusalem at the time of King Solomon, and the biblical description is in fact an account of the temple built by the returnees to Zion at the end of the 6th century BCE. An even more extreme approach claims that neither a palace nor a temple was built in Jerusalem during the Iron Age, and therefore that there was no real building at all and we have here merely a "verbal icon" (McCormick 2002).

It is interesting to follow the development of the research in the 20th century. On the one hand, modern scholarship has opened up a variety of new possibilities for understanding the descriptions of the temple. From the philological point of view, the text has been made clearer through the study of ancient Semitic languages such as Akkadian and Egyptian. Comparative research on manuscripts made it possible to identify scribal errors and distortions that have become embedded in the text. Archaeological excavations have uncovered similar temples that illuminate the cultural background shared with the temple in Jerusalem, such as the temples at Tell Tayinat in southern Turkey and at Ain Dara in northwestern Syria. Iconographic analysis of various artistic elements uncovered throughout the ancient Near East has clarified the form of various cult objects, such as mekhonot (stands) or cherubim (winged creatures). Scholars who believe that the tradition of the temple reflects historical reality have made great strides in understanding the biblical description.

But on the other hand, the development of minimalist approaches in biblical research has undermined the realist understanding. Scholars of the minimalist school have argued that no temple at all was built in Jerusalem at the time of Solomon. According to the most extreme of these scholars, the description of the temple is entirely imaginary. Thus, an attempt has been made to remove the basis for legitimate study of the temple from an architectural or historical perspective and move all the attention to the literary and ideological levels (see discussions: Van Seters 1997; Smith 2006).

Two recent discoveries in the Kingdom of Judah have changed the picture (Figure 1). First, a building model dated to the 10th century BCE unearthed at Khirbet Qeiyafa in 2011 sheds light on some technical terms mentioned in the biblical text and enables us to overcome some of the difficulties (Garfinkel and Mumcuoglu 2013, 2016, 2018). Second, a temple dated to the 9th century BCE was uncovered in 2012 at Motza, $5 \mathrm{~km}$ west of Jerusalem (Kisilevitz 2015). These new finds clearly show that the architecture described in the biblical text existed in the same era and region. The new data bear out the historicity of the biblical text, even if it was rewritten and edited centuries after the actual construction of the building. 


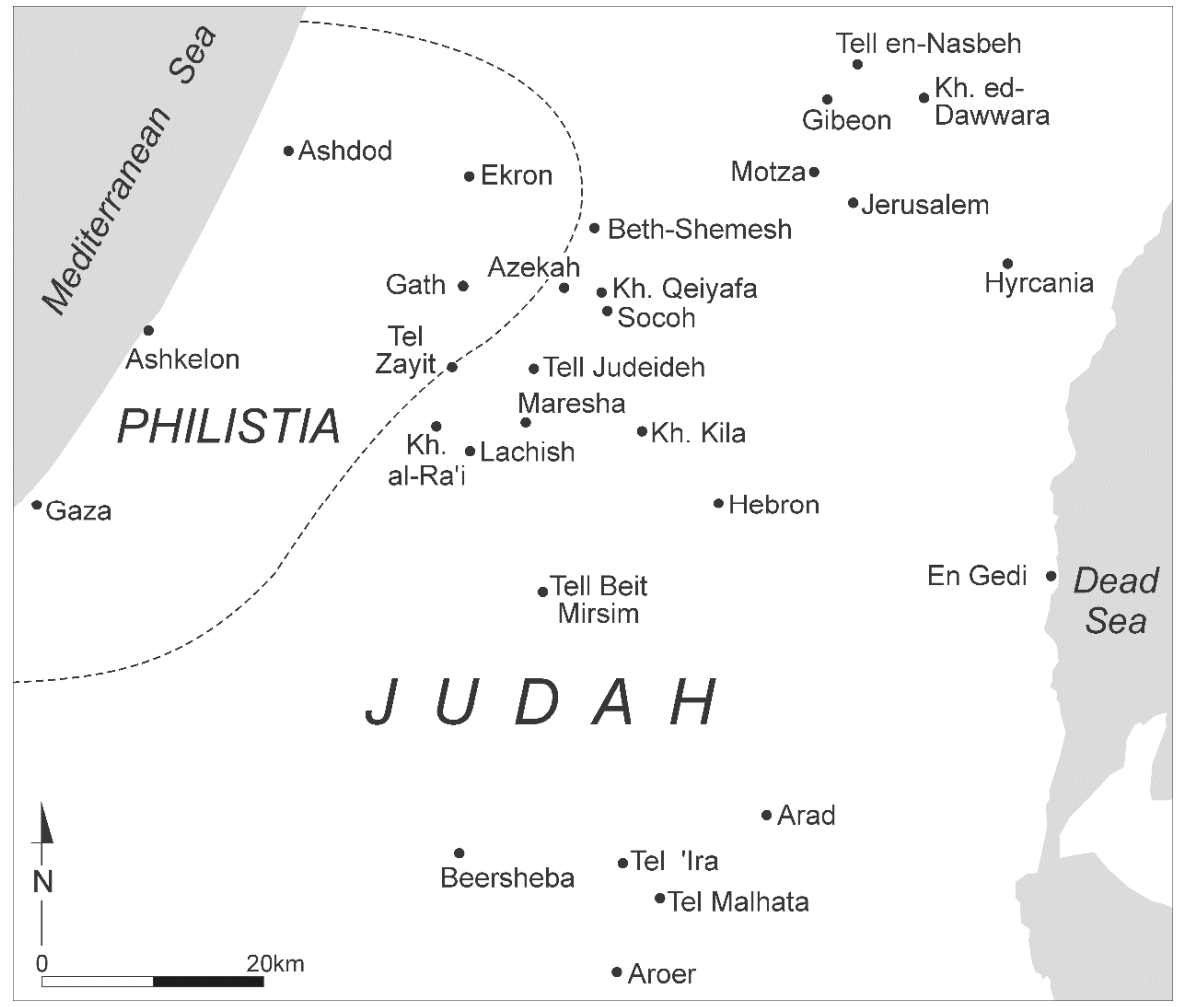

Figure 1. The Kingdom of Judah and the location of sites mentioned in the text.

\section{The Temple Structure}

The biblical text relates to three main aspects of the structure: its plan, its interior decoration and its courtyard. Here, we relate only to the first aspect: the plan. Architecturally speaking, the structure included five different components: the pair of columns at the entrance (Jachin and Boaz), the Forecourt (Ulam), the Outer Sanctum (Hechal), the Holy of Holies (Devir), and the side chamber (yatsia sover) (Figure 2). The first modern scholar to deal with Solomon's Temple was Bernhard Stade (1887). On the one hand, he delved deeply into the linguistics of the biblical text and the differences that appear in the Septuagint. On the other hand, he produced graphic reconstructions of the building, and his depiction of the façade is used to this day in various studies. It should be noted, however, that Stade's reconstructions added architectural elements that do not appear in the biblical text, such as steps in the front and triangular protrusions on the roof. 


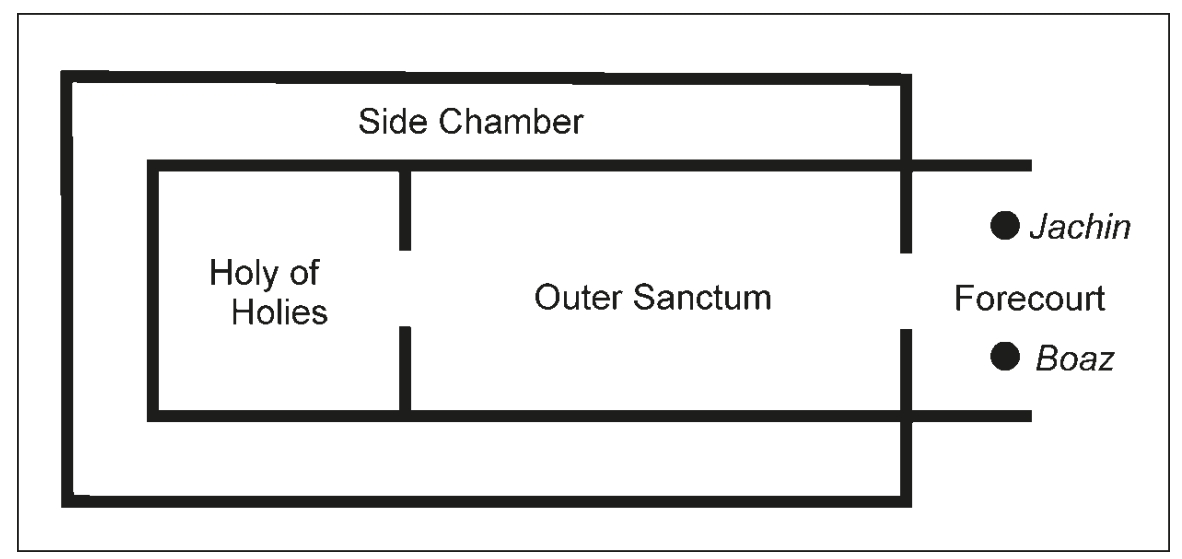

Figure 2. The different components of Solomon's Temple: the pair of columns at the entrance, the Forecourt, the Outer Sanctum, the Holy of Holies, and the side chamber.

Despite the detailed descriptions in the Bible, several aspects are unclear and various proposals have been put forward as to how the building's plan should be reconstructed. There are disagreements over various relatively minor details, such as:

1. The location of the columns in relation to the Forecourt: inside or just outside it?

2. The area of the side chamber: did it surround only the Outer Sanctum and the Holy of Holies or the Forecourt as well?

3. Different proposals for the superstructure of the building: for example, did it have windows?

Table 1 presents the main suggestions raised over the years regarding the various parts of the Solomon's Temple.

Table 1. Differences in opinion among scholars on architectural aspects of Solomon's Temple.

\begin{tabular}{|c|c|c|c|c|c|}
\hline Scholar & Jachin and Boaz & Forecourt & $\begin{array}{c}\text { Outer } \\
\text { Sanctum }\end{array}$ & Holy of Holies & Side Chamber \\
\hline Stade (1887) & $\begin{array}{l}\text { In front of the Forecourt, } \\
\text { supporting the roof }\end{array}$ & Roofed & Windows & $\begin{array}{l}\text { At the level of the } \\
\text { Outer Sanctum, with } \\
\text { attic }\end{array}$ & $\begin{array}{l}\text { Divided into chambers, } \\
\text { surrounding only the } \\
\text { Outer Sanctum and Holy } \\
\text { of Holies }\end{array}$ \\
\hline $\begin{array}{l}\text { Watzinger } \\
\text { (1933) }\end{array}$ & $\begin{array}{l}\text { Freestanding outside the } \\
\text { Forecourt }\end{array}$ & Roofed, two towers & Windows & Raised, staircase & $\begin{array}{l}\text { Divided into chambers, } \\
\text { surrounding the entire } \\
\text { building }\end{array}$ \\
\hline Vincent (1956) & $\begin{array}{c}\text { Freestanding outside the } \\
\text { Forecourt }\end{array}$ & Roofed, two towers & Windows & Low roof & $\begin{array}{l}\text { Divided into chambers, } \\
\text { surrounding the entire } \\
\text { building }\end{array}$ \\
\hline Yeivin (1968) & $\begin{array}{c}\text { Freestanding outside the } \\
\text { Forecourt }\end{array}$ & Roofed & Windows & Raised, no staircase & $\begin{array}{l}\text { Divided into chambers, } \\
\text { surrounding only the } \\
\text { Outer Sanctum and Holy } \\
\text { of Holies }\end{array}$ \\
\hline Busink (1970) & $\begin{array}{l}\text { Freestanding, outside the } \\
\text { Forecourt }\end{array}$ & $\begin{array}{c}\text { Roofed, two } \\
\text { additional columns }\end{array}$ & Windows & $\begin{array}{l}\text { Low chamber built } \\
\text { inside the Outer } \\
\text { Sanctum }\end{array}$ & $\begin{array}{l}\text { Divided into chambers, } \\
\text { surrounding only the } \\
\text { Outer Sanctum and Holy } \\
\text { of Holies }\end{array}$ \\
\hline $\begin{array}{l}\text { Hurowitz } \\
\text { (1992) }\end{array}$ & $\begin{array}{l}\text { Freestanding inside the } \\
\text { Forecourt }\end{array}$ & $\begin{array}{c}\text { Unroofed, bounded } \\
\text { by a wall in front }\end{array}$ & No windows & $\begin{array}{l}\text { Attic at the level of } \\
\text { the Outer Sanctum }\end{array}$ & $\begin{array}{l}\text { No chambers, surrounding } \\
\text { only the Outer Sanctum } \\
\text { and Holy of Holies }\end{array}$ \\
\hline $\begin{array}{c}\text { King and } \\
\text { Stager (2001) }\end{array}$ & $\begin{array}{l}\text { In front of the Forecourt, } \\
\text { supporting the roof }\end{array}$ & Roofed & No windows & Raised, staircase & $\begin{array}{l}\text { No chambers, surrounding } \\
\text { only the Outer Sanctum } \\
\text { and Holy of Holies }\end{array}$ \\
\hline $\begin{array}{c}\text { Garfinkel and } \\
\text { Mumcuoglu } \\
\text { (2016) }\end{array}$ & $\begin{array}{l}\text { In front of the Forecourt, } \\
\text { supporting the roof }\end{array}$ & Roofed & Windows & $\begin{array}{c}\text { Raised, staircase, } \\
\text { attic }\end{array}$ & $\begin{array}{l}\text { No chambers, surrounding } \\
\text { only the Outer Sanctum } \\
\text { and Holy of Holies }\end{array}$ \\
\hline
\end{tabular}




\section{Background: Temples in the Levant}

Temples, which are buildings used for venerating supernatural powers, were constructed in the southern Levant from late prehistory onward. Large temples of the second millennium BCE have been uncovered in various fortified cities, and smaller temples of the same period have been unearthed in rural settlements (Mazar 1992). A few years ago, a small temple of the Middle Bronze Age was uncovered near Jerusalem (Ein Mor 2011). The construction of a temple in Jerusalem was thus a commonplace initiative.

The location of the temple within the city of Jerusalem was commonplace as well. The biblical description places it and the palace close to one another, a well-known phenomenon in the ancient world. The renowned scholar Childe, one of the first to study urbanization in the ancient Near East, noted that the center of government in Mesopotamian cities included a palace, a temple, and silos (Childe 1950). Thus political, religious, and economic powers were all concentrated in one area. In the Classical world as well, it was customary to construct palaces and temples close to one another in the highest part of the city, called in Greek the "acropolis", that is, the upper city. In Jerusalem too, the temple and palace were built above the City of David at the highest topographical point of the city. Together they constituted the center of political and religious power in the Kingdom of Judah. In this respect, the biblical description fits well with the customary location of temples in ancient Near Eastern cities.

Archaeologists have also discovered Iron Age temples in the Levant, both outside and inside Judah, that are quite similar in their plan to the temple of Jerusalem. These are presented here in Figure 3, together with Solomon's Temple as described in the biblical text and the Judean temple of Motza.

Two temples dated to the Iron Age II were found at Tell Tayinat, located in the Amuq valley of southeastern Turkey. The site was first excavated by a team from the Oriental Institute of the University of Chicago (Haines 1971). A large palace and a temple were found one near the other. A second expedition excavated in the same area uncovered a second temple (Harrison 2012). Both temples are elongated, with one or two columns in the front, and are divided into three parts. The pillars and the tripartite plan closely resemble the plan of Solomon's Temple. These buildings, however, were not surrounded by a side chamber.

Another important close example is the temple of Ain Dara in northwestern Syria (Abu Assaf 1990). It is a monumental building, measuring $32 \times 38 \mathrm{~m}$, and includes many artistic items, such as statues and reliefs hewn in hard basalt. The entrance threshold is decorated by huge footprints, about $1 \mathrm{~m}$ long, which represent the feet of the deity stepping into his house. As pointed out by various scholars, the plan of the Ain Dara temple is particularly interesting in the context of discussion of Solomon's Temple. This is because the plan includes all five architectural components mentioned in the biblical text: two columns in front, Forecourt, Outer Sanctum, Holy of Holies, and side chamber. Moreover, the Holy of Holies is of equal length and width, creating a square room, as in the description of the Jerusalem temple. 


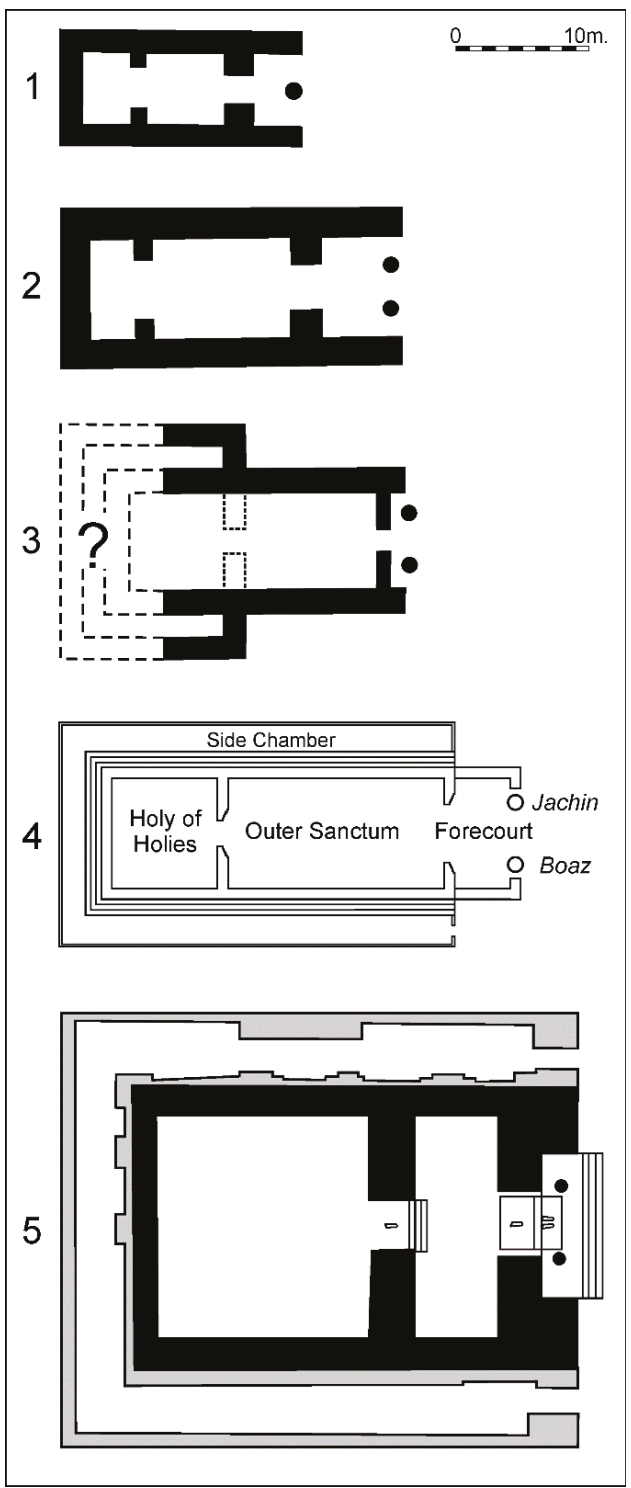

Figure 3. Various Iron Age temples in the Levant: 1. Tell Tayinat (Harrison 2012); 2. Tell Tayinat (Haines 1971); 3. Motza (Kisilevitz 2015); 4. Reconstructed plan of Solomon's Temple; 5. Ain Dara (Abu Assaf 1990).

\section{The Motza Temple}

The Motza temple is a momentous discovery that has brought about a complete transformation in the understanding of ancient cult in the Kingdom of Judah, and which has huge implications for understanding the biblical description of Solomon's Temple. Already in the 1990s, a large enclosure containing large silos for the storage of agricultural produce had been uncovered, dated from the 10th to 6th centuries BCE (Greenhut and De Groot 2009). In 2012, a temple of the 9th century BCE was discovered next to the silos (Kisilevitz 2015). The construction of the temple in this location was 
certainly not coincidental and attests to a close association between administration and cult in the Kingdom of Judah (Figures 4 and 5).

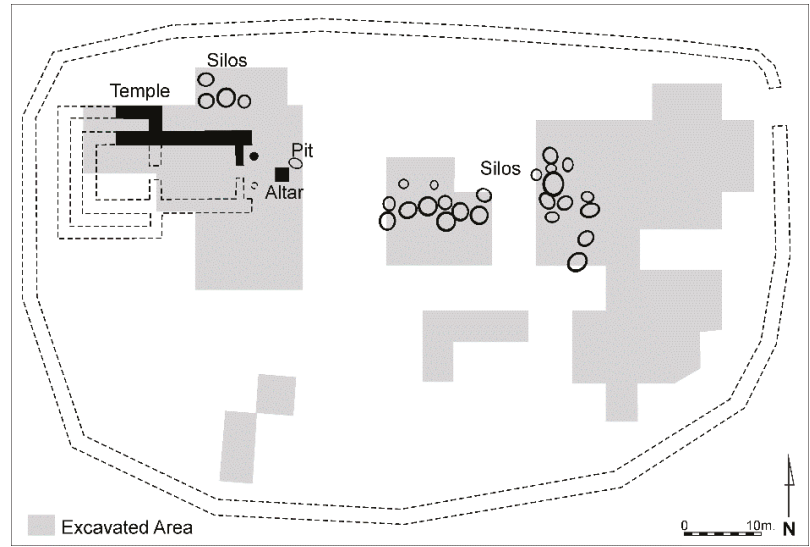

Figure 4. Schematic plan of the administrative compound at Motza. The excavated areas are shown in gray, and include the silos and the temple. It is likely that the entire complex was surrounded by a fence (based on Greenhut and De Groot 2009; Kisilevitz 2015).

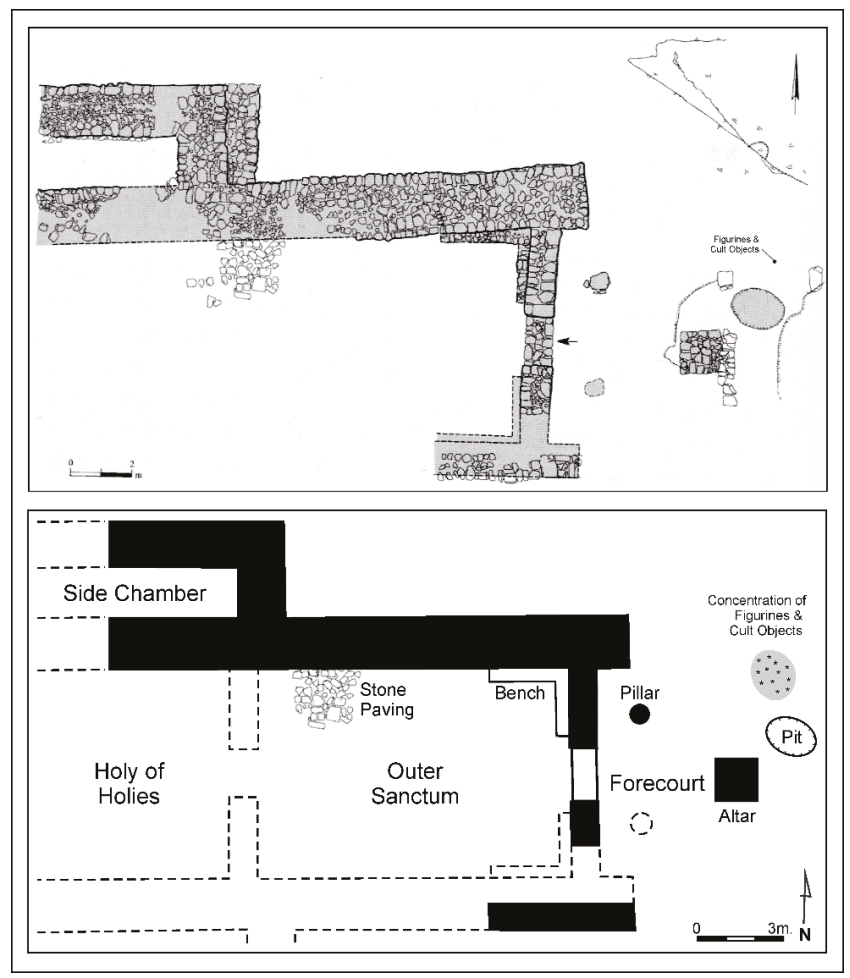

Figure 5. Plan of the remains of the temple (above, Kisilevitz 2015) and our interpretation (below).

The plan of the Motza temple is particularly relevant to our subject. Although only part of it is known to us, because the southern side had eroded away down the slope and part of the western 
side was not excavated, the parts that have been unearthed reveal the full plan. On the eastern side of the excavation area, an open courtyard with three important components was revealed. The first component is a square altar, $1.4 \mathrm{~m}$ wide on each side, built of medium-sized fieldstones and preserved to a height of three courses. The second component is the beaten-earth floor, on which were discovered a group of broken cult objects, including two figurines of horses, two heads of bearded males, and fragments of a stand decorated with lions. The third component is a pit in which large quantities of ash and the bones of young animals were buried. In the biblical tradition, young animals are suitable offerings for sacrifice. The discoveries in the courtyard of the temple show that cult activities were carried out there. When all the relevant data are published, a new chapter in the study of ancient religion in the Kingdom of Judah will begin.

The temple structure found west of the courtyard is a long, narrow building, whose dimensions in the area excavated are $10 \times 18 \mathrm{~m}$. The building is divided into five parts.

1. The Forecourt. The longitudinal walls protrude from the façade, an arrangement known in many temples that creates an entranceway in front of the closed rooms. This space and the open courtyard to its west are arranged along a straight axis.

2. Two columns. At the northern end of the Forecourt, a round stone base of a column was found. A second base had obviously been placed symmetrically at the southern end and, although it has not survived, it is reconstructed in the excavation plan. Was the front of the building roofed, or was it open-air and these columns were merely for decoration? Based on the various examples of pottery building models, it seems that the Forecourt was indeed roofed (Garfinkel and Mumcuoglu 2016, pp. 105, 123-25).

3. Central room. The structure was entered via an impressive, carefully built doorway, $1.7 \mathrm{~m}$ wide. Inside the structure, a bench was found abutting the northeastern corner.

4. Inner room. The western part of the building was probably partitioned off by an inner wall, creating the inner Holy of Holies. The inner room has not been fully excavated, and its western end is located outside the excavation area. In our understanding, this inner wall was probably located in line with the side chamber to its north, and immediately after the paved area of the central room.

5. Side chamber. A long, narrow chamber was built surrounding the outside of the western half of the building. The walls here were the same thickness as those of the rest of the building. In the small portion that is preserved, there is no entrance to this unit, either from the outside or from the inside of the temple.

The presence of a large, stone-built temple in the 9th century BCE at Motza, one hour's walk from Jerusalem, completely changes the picture of cult in the Kingdom of Judah. If there was a temple at a secondary administrative site, there would certainly have been a central temple in the kingdom's capital.

\section{The Khirbet Qeiyafa "Building Model"}

The site of Khirbet Qeiyafa is located in the Judean lowland, some $20 \mathrm{~km}$ southwest of Jerusalem. During seven seasons of excavations, a fortified city of the early 10th century BCE has been uncovered (Garfinkel and Ganor 2009; Garfinkel et al. 2014; Garfinkel et al. 2015; Garfinkel et al. 2016). In a building near the southern city gate, a cultic room was excavated. Here two building models were uncovered, one made from clay and the other carved in limestone.

The stone model is a carved box, $21 \mathrm{~cm}$ wide, $26 \mathrm{~cm}$ long, and $35 \mathrm{~cm}$ high. Figure 6 shows the object's façade after reconstruction (Garfinkel and Mumcuoglu 2013, 2016, pp. 37-46, 2018). The sides and back are simple flat walls, while the façade is elegantly profiled. In the center of the façade is a large rectangular doorway, $10 \mathrm{~cm}$ wide and $20 \mathrm{~cm}$ high. The entrance has three interlocking frames: the outer frame is the largest, the middle frame is smaller and recessed from the first toward the interior of the model, and the inner frame is the smallest, again recessed from the first two. This triple-recessed doorway forms three rows of lintels above the entrance and three rows of doorposts on either side. A 
fourth frame, which extends to the top of the structure, apparently represents the edge of the building but may indicate a fourth outer doorframe.

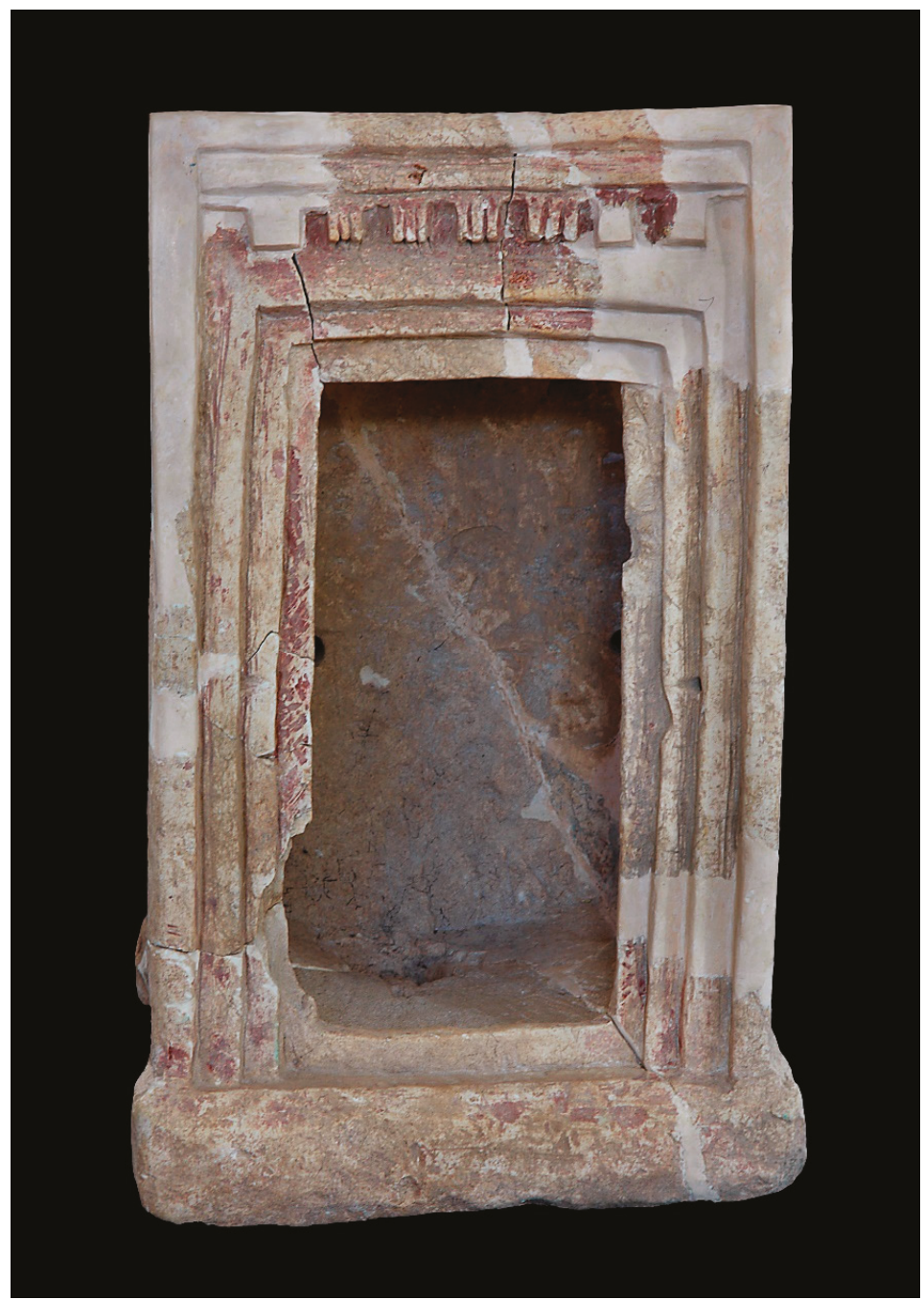

Figure 6. The façade of the stone building model from Khirbet Qeiyafa (Photograph by Gabi Laron).

Between the doorframe and the roof of the model is a row of protruding rectangular elements; each is divided by deep incisions into three smaller parallel rectangles. Four such protruding rectangles were fully preserved and remains of three others are visible, together creating seven such elements. This element, depiction in stone of wooden beams that support the roof, known as the triglyph, is a common feature of classical architecture.

The combination of iconographic and linguistic analysis indicates that the recessed opening depicted on the stone object are also described in the biblical text regarding the entrance to Solomon's palace and Solomon's Temple (Garfinkel and Mumcuoglu 2013, 2016). In the same way, the beams of the roof, organized three together like triglyph, are also described in the biblical text regarding the façade of Solomon's palace and temple (Garfinkel and Mumcuoglu 2013, 2016). 
The stone building model from Khirbet Qeiyafa indicates that the royal architecture described in the biblical text regarding Jerusalem in the 10th century BCE was indeed known in this region in the 10th century BCE.

\section{Solomon's Temple: Ground-Plan Architecture in Context}

In this section, we will discuss the five main parts of the temple and examine whether these architectural elements are known from temples in the Levant. If these elements are known from the archaeological record, then the biblical description is anchored in the context of its time. If, however, such architecture is not known in the period in question, it will be difficult to accept that the description reflects historical reality.

\section{Two Columns}

Two particularly magnificent bronze columns named Jachin and Boaz are described in the text. A pair of columns is present in various temples excavated in or around the Land of Israel. Two columns were found in front of the entrance to the Late Bronze Age temple at Hazor and in front of the Iron Age temples at Motza, Ain Dara in Syria, and Tell Tayinat in southern Turkey. Two columns can also be seen in several of the building models dated to the Iron Age (Garfinkel and Mumcuoglu 2016, pp. 112-13, 119, 123-25).

There are two opinions about the exact location of the columns and their function. Some see them as merely decorative and assume they were freestanding on either side of the doorway and did not support a roof. The other approach sees them as supporting the roof of the Forecourt, as shown on a clay building model from Idalion in Cyprus (Garfinkel and Mumcuoglu 2016, p. 105; Katz 2016, ).

\section{Forecourt (Ulam)}

The sacred structure included three rooms or spaces that were arranged on a straight axis, one after the other: their names, from the outside in, were Forecourt, Outer Sanctum, and Holy of Holies. The Forecourt was the first of these three elements. Other temples, such as the Late Bronze Age temple at Hazor and the Iron Age temples at Motza, Ain Dara, and Tell Tayinat, were built according to a principle of a central axis and a tripartite division.

It is unclear from the biblical description whether the Forecourt was a closed room, a roofed entranceway open at the sides, or an open courtyard surrounded by an enclosure wall. The appearance of the Forecourt would dictate the function of the columns of Jachin and Boaz. If the Forecourt was open-air, the columns would not have supported a roof and thus would have been purely decorative. However, if the Forecourt was roofed, the columns would have supported the roof. We do not know which of these situations prevailed, because the description of the Outer Sanctum contains the word "house" (beit), which includes the Outer Sanctum and the Holy of Holies, but not the Forecourt. Thus, various scholars have concluded that the Forecourt was enclosed by walls only at the sides and did not have a wall at the front. The building model from Idalion in Cyprus, however, does feature a roof in the front of the structure, resting on two columns with imposing capitals. Thus, it is likely that Jachin and Boaz supported a roof over the Forecourt.

\section{The Outer Sanctum (Hekhal)}

The Outer Sanctum was located after the Forecourt. It is described relatively clearly, and we are given the information that it was 40 cubits long, 20 cubits wide, and 30 cubits high. The entrance to the Outer Sanctum was built with four recessed doorposts (1 Kings 6:33). Inside the Outer Sanctum stood the gold-covered altar.

\section{The Holy of Holies (Devir)}

This is the innermost room in the building, 20 cubits long, 20 cubits wide, and 20 cubits high; that is, it was cube-shaped and each of its sides measured about $8 \mathrm{~m}$. The doorway of the Holy of Holies was built with five recessed doorposts (1 Kings 6:31). 
It should be noted that the Bible indicates that the Outer Sanctum was 30 cubits high, while the Holy of Holies was 20 cubits high, or $4 \mathrm{~m}$ lower. A number of suggestions have been made as to how this height difference was resolved architecturally. Vincent (1956) reconstructed the roof of the structure as stepped, with the back part, in the area of the Holy of Holies, being lower. Watzinger (1933) suggested that the floor of the Holy of Holies was higher and reconstructed a staircase, which is not mentioned in the biblical tradition. Another solution suggests a second story on top of the Holy of Holies and none atop the Outer Sanctum (Stade 1887; Hurowitz 1992). Busink (1970, p. 600) shows the Holy of Holies as a large wooden container inside the Outer Sanctum, rather than a separate architectural unit. This interpretation cannot be accepted, as excavated Iron Age temples are divided into three parts and the innermost room is separated by a true wall from the other parts of the building.

The height of the Holy of Holies in relation to the entire building can be established by archaeological data. In the Iron Age temples of Arad and Ain Dara and the Late Bronze Age temples at Tel Lachish and Tel Beth She'an, the floor of the Holy of Holies was higher than that of the Outer Sanctum (Aharoni 1973; Abu Assaf 1990; Ussishkin 2004, Figures 6.3, 6.30; Rowe 1940, Pls. VI, VII). In all of these temples there was a staircase from the Outer Sanctum to the Holy of Holies. Thus, in our proposal for the reconstruction of Solomon's Temple (as in Figures 7 and 8), we add a staircase in the Outer Sanctum and accept the reconstruction proposed by Watzinger (1933).
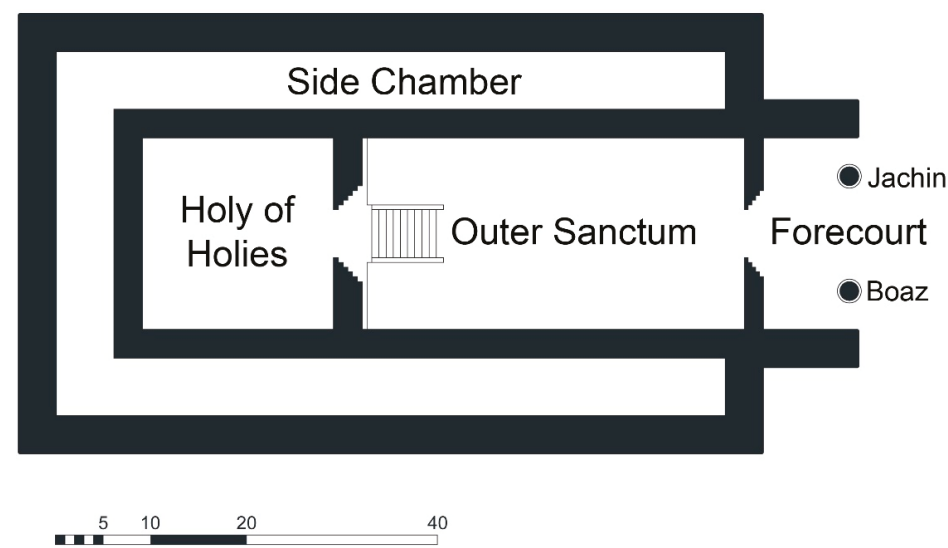

Figure 7. Ground plan of Solomon's Temple based on our analysis of the text and relevant archaeological data.
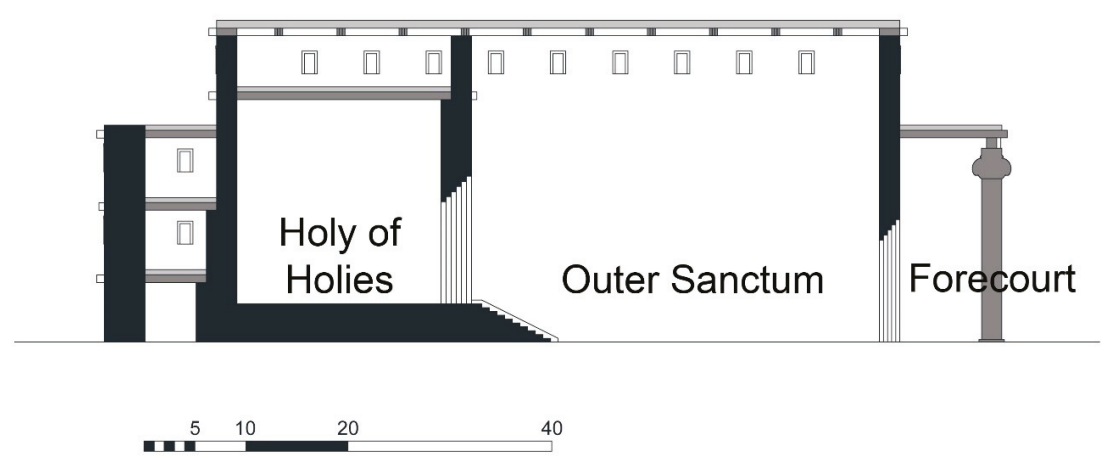

Figure 8. Longitudinal section through Solomon's Temple based on our analysis of the text and relevant archaeological data. 


\section{The Side Structure (Yatzia Sovev)}

The word yatzia appears to have two different meanings in the description of Solomon's Temple. The first meaning is a structure that surrounded the Temple, thus constituting a kind of exterior mantle for the building (1 Kings 6:5-6). The second meaning is an attic.

There are different opinions about the side chamber. Some scholars claim that it surrounded only the Outer Sanctum and the Holy of Holies, thus supporting the proposal that the Forecourt was an open courtyard rather than a roofed chamber. Other scholars reconstruct the side chamber as surrounding all three parts of the Temple- the Forecourt, the Outer Sanctum, and the Holy of Holies.

This type of temple architecture was known in the Levant only during the Iron Age (Davey 1980). Such temples were not constructed in later periods, making Edelman's (2012) suggestion to date the biblical description to the Persian period irrelevant.

\section{Solomon's Temple: Vertical Aspects of the Architecture in Context}

Thus far, we have presented the horizontal ground plan of the structure. We will now discuss three aspects relating to the superstructure: recessed doorframes, windows, and the beams of the roof.

\section{Four- and Five-Sided Doorposts}

The Bible relates that, in the entrance from the Forecourt to the Outer Sanctum, there were four mezuzot (doorposts) of olive wood (1 Kings 6:33). As for the entrance between the Outer Sanctum and the Holy of Holies, here there were five mezuzot (doorposts) of olive wood (1 Kings 6:31). The meaning of the terms "four mezuzot" and "five mezuzot" is not clear. The elaborate stone building model from Khirbet Qeiyafa, which includes a doorway ornamented with recessed frames, clearly shows that temple entrances could be decorated with four or five recessed frames (Garfinkel and Mumcuoglu 2013, 2016, pp. 46-58; Mumcuoglu and Garfinkel 2018).

\section{Windows}

The question of whether the Temple had windows is ostensibly a simple one, as the text mentions windows (1 Kings 6:4). However, the windows described by the Hebrew words sequfim ve'atumim mean "transparent and opaque." How can windows be both transparent and opaque? The King James Version translates it as "windows of narrow lights" and the Jewish Publication Society Tanakh translates these terms as "recessed and latticed." Rivers of ink have been spilt on this matter in the attempt to explain the biblical text (Zwickel 1999, p. 66; Monson 2006).

The idea that the temple had no real windows seems problematic for a number of reasons. First, windows let light into the building. In the ancient world, which lacked effective lighting devices, windows were the main source of light. Illumination was needed for the holding of various ceremonies in the building, as well as for cleaning and maintenance work. Second, windows ventilated the structure, preventing the development of mold, damp and bad odors. The Temple certainly contained costly items made of organic materials, such as the walls paneled with cedar, wooden furnishings, clothing and woven textiles. These would have deteriorated if the interior was dark and damp. Third, clay building models that depict temples usually feature windows (Muller 2002; Katz 2016; Garfinkel and Mumcuoglu 2016, pp. 102-5).

Additional artistic evidence of the presence of windows in temples comes from ivories that show a female figure at a window, interpreted as a statue of a goddess in a temple. As pointed out by various scholars, this is the type of window described in the biblical text (Yadin 1956, p. 181; Cogan 2001, p. 238; Garfinkel and Mumcuoglu 2016, pp. 56-8; but see Millard 1989).

\section{Roof Beams Organized in Groups of Three (Slaot)}

The expression slaot appears in various contexts in the description of the Temple. In principle, the term refers to wooden planks, for example in "planks of cedar" and "planks of cypress" (1 Kings 6:15). Such planks were used to panel the interior walls of the Outer Sanctum and the Holy of Holies. We do 
not accept the traditional interpretation of the term slaot as side chambers. The Khirbet Qeiyafa stone building model clearly indicates that these are wooden planks organized in groups of three, like the triglyphs of Classical architecture (Garfinkel and Mumcuoglu 2013).

There are also planks surrounding the Outer Sanctum and the Holy of Holies in the description of the Temple (1 Kings 6:5). Here, we should note the words of the prophet Ezekiel, who describes the Temple with slaot, in groups of three, 30 times, surrounding the Outer Sanctum and the Holy of Holies (Ezekiel 41:6). In this way's Ezekiel presents the slaot as wooden planks organized in groups of three, like the triglyphs in the Khirbet Qeiyafa building model.

From Ezekiel's description of the Temple and the building model from Khirbet Qeiyafa, we conclude that the slaot that surrounded the Outer Sanctum and the Holy of Holies were roof beams organized in groups of three.

\section{Height of the Building}

Each part of the Temple had a different height. The Outer Sanctum was 30 cubits high, the columns were 23 cubits high (18 cubits plus 5 cubits of the capitals), the Holy of Holies was 20 cubits high, and the attic 5 cubits high. There is no information at all about the height of the three-story side chamber. It is unlikely that a temple that was meant to be such an impressive structure would consist of a patchwork of wings. Thus, we chose only two heights: 30 cubits for the Outer Sanctum and the Holy of Holies in the center of the building, and 20 cubits for the surrounding parts. Thus, the height of each of the three stories of the side chamber wing was 6.6 cubits. We slightly shortened the cumulative height of the columns (including the capitals) to 20 cubits instead of 23 cubits.

\section{Reconstructing the First Temple Using Architectural Computer Software: Problems and Solutions}

Together with the architect Roy Albag, we prepared a three-dimensional reconstruction of Solomon's Temple, using computerized architectural software. The basic data were of course taken from the biblical text. As work proceeded, various architectural problems emerged, to which the biblical text does not provide clear answers. Detailed discussion of the main problems and the solution chosen to overcome them is presented elsewhere (Garfinkel and Mumcuoglu 2016, pp. 181-88). The final graphic results are presented here in four figures. Figure 7 presents the ground plan of the building, Figure 8 presents a longitudinal section through the building, Figure 9 presents the building in an isometric view, and Figure 10 presents the façade.

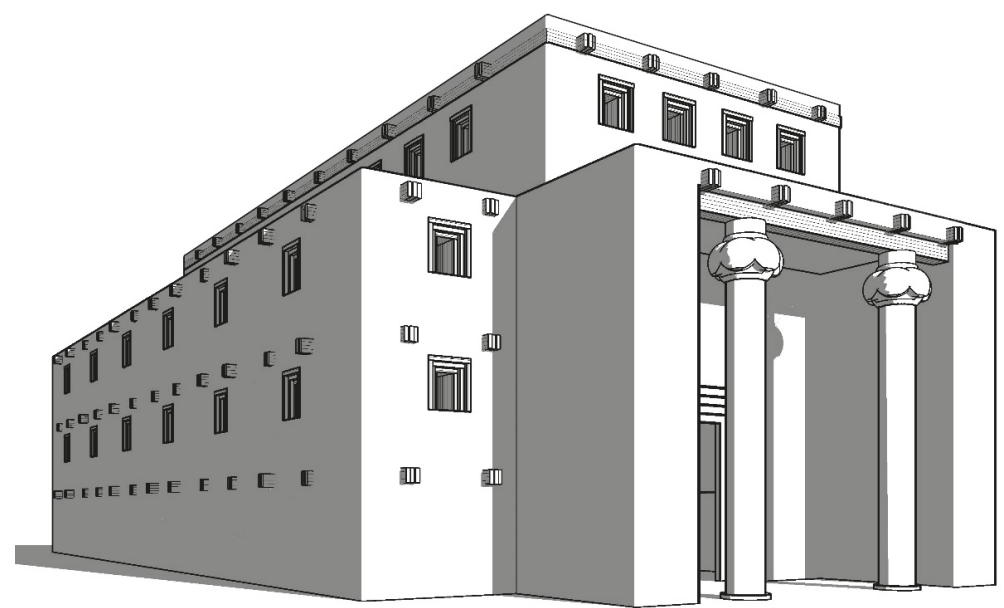

Figure 9. Isometric reconstruction of Solomon's Temple based on our analysis of the text and relevant archaeological data. 


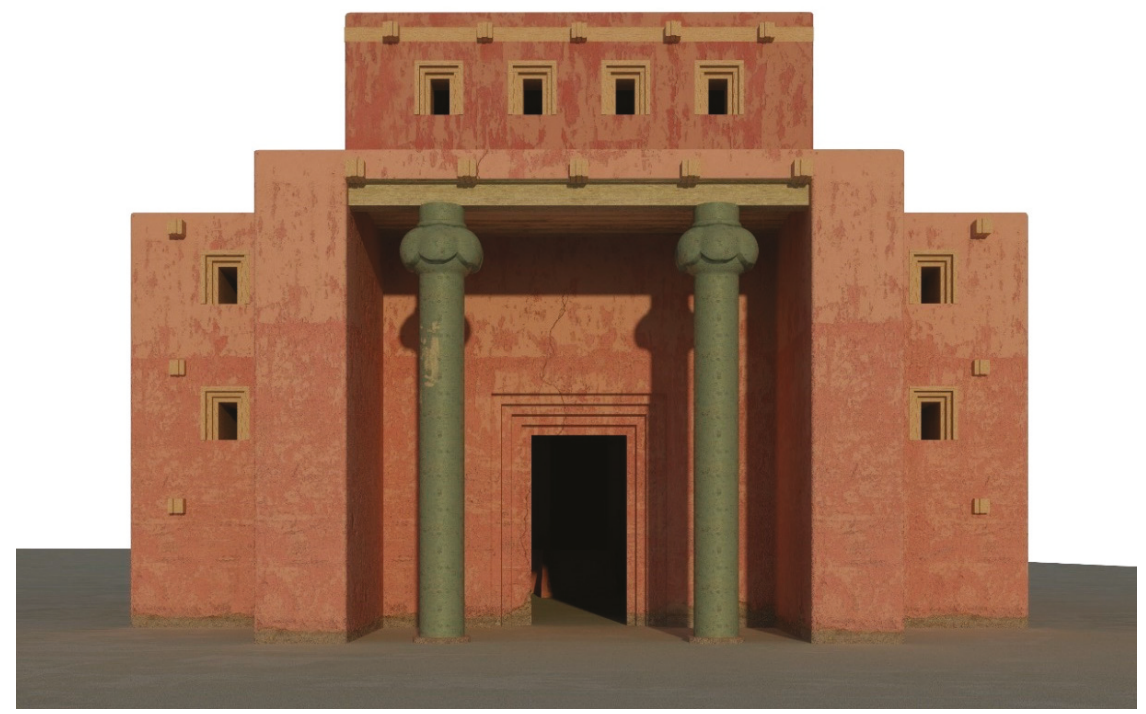

Figure 10. Reconstruction of the façade of Solomon's Temple based on our analysis of the text and relevant archaeological data.

\section{Summary}

As noted in the introduction, modern scholarship debates the question of whether it is possible that a temple was built in Jerusalem as early as the 10th century BCE. The new finds uncovered at Khirbet Qeiyafa and Motza give a clear positive answer to the question, for a number of reasons.

1. Culturally speaking, the building model from Khirbet Qeiyafa attests that the architectural concept of state-sponsored construction already existed in the 10th century BCE in Judah, and that it included recessed frames around doorways and the arrangement of roof beams in groups of three (triglyphs).

2. Practically speaking, the temple at Motza shows that temples were built in Judah and that they included five architectural components: two columns in the front, Forecourt, Outer Sanctum, Holy of Holies, and side chamber. These components are known from the temple at Ain Dara in Syria, as well as from the biblical description of Solomon's Temple. It seems that the building at Motza was a modest, rural imitation of the style of the large, grand temples built in ruling centers in the Iron Age Levant.

3. From a literary point of view, the biblical description of the plan of Solomon's Temple, which describes two columns in the front (Jachin and Boaz), Forecourt, Outer Sanctum, Holy of Holies, and side chamber, conforms in all of its components to the temples at Motza and Ain Dara. The biblical description of the superstructure, doorposts with "four mezuzot" and "five mezuzot" and slaot all around, conforms to the façade of the stone building model from Khirbet Qeiyafa, which includes doorways decorated with recessed frames and roof beams organized in groups of three (triglyphs). The stone model helps us to understand the biblical text much better, and we can see that the description of Solomon's Temple includes typical architectural components of public and royal construction during the Iron Age. The very presence of the stone building model and the Motza temple creates a major problem for the minimalists, who argue that the entire description of the construction of the Temple is a literary creation of a time centuries after the age of Solomon. The stone model and the Motza temple show, independently of the biblical tradition, that this construction style was indeed known in Judah in the 10th and 9th centuries BCE.

4. Another aspect that should be emphasized in the context of Solomon's construction projects is the number of recessed frames around each opening. In Solomon's palace, there were three recessed 
frames. At the entrance to the Outer Sanctum of the Temple, there were four recessed frames. At the entrance to the Holy of Holies, there were five recessed frames. The more important the house or the room, the greater the number of frames around the door. As it is said with regard to Hanukkah candles, "One ascends in holiness and does not descend." In fact, we can see that the biblical tradition actually uses an architectural language that is able to rank and emphasize the important doorways by means of construction style.

5. The type of temple architecture described in the biblical text was known in the Levant only during the Iron Age and was discontinued in later periods. Thus, we can infer that the text relates to an Iron Age context rather than to a later one.

One of the main tasks of the historian is to compare and cross-reference sources. If different sources attest independently to the same phenomenon, the historical reliability of that phenomenon is greatly enhanced. Thus, the biblical description of Solomon's Temple, the stone building model from Khirbet Qeiyafa, and the temple from Motza correspond to one another, hence confirming the historicity of the biblical tradition.

Author Contributions: Y.G. and M.M. were equally involved in the research and writing of this article. Architect Roy Albag organized the 3D reconstruction of Solomon's Temple.

Funding: This research received no external funding.

Conflicts of Interest: The authors declare no conflict of interest.

\section{References}

Abu Assaf, Ali. 1990. Der Tempel von Ain Dara. Mainz am Rhein: Philipp von Zabern.

Aharoni, Yohanan. 1973. The Solomonic Temple, the Tabernacle and the Arad Sanctuary. In Orient and Occident: Essays Presented to Cyrus H. Gordon on the Occasion of his Sixty-fifth Birthday. Edited by Harry A. Hoffner. Berlin: Neukirchen-Vluyn, pp. 1-8.

Benzinger, Immanuel. 1899. Die Bücher der Könige. Freiburg: J.C.B. Mohr.

Busink, Theodor A. 1970. Der Tempel von Jerusalem, von Salomo bis Herodes: eine archaeologisch-historische Studie unter Beruecksichtigung des westsemitischen Tempelbaus. Leiden: Brill.

Childe, Gordon V. 1950. The Urban Revolution. The Town Planning Review 21: 3-17. [CrossRef]

Cogan, Morton. 2001. I Kings (Anchor Bible). New York: Doubleday.

Davey, Christopher J. 1980. Temples of the Levant and the Buildings of Solomon. Tyndale Bulletin 31: 107-46.

Edelman, Diana V. 2012. What Can We Know about the Persian-Era Temple in Jerusalem? In Temple Building and Temple Cult. Edited by Jens Kamlah. Wiesbaden: Harrassovitz Verlag, pp. 343-68.

Ein Mor, Daniel. 2011. A Cultic Structure of the Middle Bronze IIB-C Period in Nahal Refa'im (Walajah). New Studies in the Archaeology of Jerusalem and its Region 5: 67-77. (In Hebrew)

Fritz, Volkmar. 1987. Temple Architecture: What Can Archaeology Tell Us about Solomon's Temple? Biblical Archaeology Review 13: 38-49.

Galil, Gershon. 2012. Solomon's Temple: Fiction or Reality? In The Ancient Near East in the 12th-10th Centuries BC: Culture and History. (Alter Orient und Altes Testament 392). Edited by Gershon Galil, Ayelet Gilboa, Aren M. Maeir and Dan'el Kahn. Munster: Ugarit-Verlag, pp. 137-48.

Garfinkel, Yosef, and Saar Ganor. 2009. Khirbet Qeiyafa Vol. 1. The 2007-2008 Excavation Seasons. Jerusalem: Israel Exploration Society.

Garfinkel, Yosef, and Madeleine Mumcuoglu. 2013. Triglyphs and Recessed Doorposts on a Building Model from Khirbet Qeiyafa: New Light on Two Technical Terms in the Biblical Descriptions of Solomon's Palace and Temple. Israel Exploration Journal 63: 135-63.

Garfinkel, Yosef, and Madeleine Mumcuoglu. 2016. Solomon's Temple and Palace: New Archaeological Discoveries. Jerusalem: Bible Lands Museum Jerusalem \& Biblical Archaeology Society.

Garfinkel, Yosef, and Madeleine Mumcuoglu. 2018. A Limestone Portable Shrine. In Khirbet Qeiyafa Vol. 4, Excavation Report 2009-2013: Art, Cult and Epigraphy. Edited by Yosef Garfinkel, Saar Ganor and Michael G. Hasel. Jerusalem: Israel Exploration Society, pp. 101-26. 
Garfinkel, Yosef, Saar Ganor, and Michael G. Hasel. 2014. Khirbet Qeiyafa Vol. 2. The 2009-2013 Excavation Seasons. Stratigraphy and Architecture (Areas B, C, D, E). Jerusalem: Israel Exploration Society.

Garfinkel, Yosef, Katarina Streit, Saar Ganor, and Paula J. Reimer. 2015. King David's City at Khirbet Qeiyafa: Results of the Second Radiocarbon Dating Project. Radiocarbon 57: 881-90. [CrossRef]

Garfinkel, Yosef, Igor Kreimerman, and Peter Zilberg. 2016. Debating Khirbet Qeiyafa: A Fortified City in Judah from the Time of King David. Jerusalem: Israel Exploration Society.

Greenhut, Zvi, and Alon De Groot. 2009. Salvage Excavations at Tel Motza-The Bronze and Iron Age Settlements and Later Occupations; Jerusalem: Israel Antiquities Authority.

Haines, Richard C. 1971. Excavations in the Plain of Antioch II. The Structural Remains of the Later Phases. Chicago: Oriental Institute publications.

Harrison, Timothy P. 2012. West Syrian megaron or Neo-Assyrian Langraum? The Shifting Form and Function of the Tell Tayinat (Kunulua) Temples. In Temple Building and Temple Cult. Edited by Jens Kamlah. Wiesbaden: Harrassovitz Verlag, pp. 3-21.

Herzog, Zeev. 2000. The Temple of Solomon: Its Plan and Archaeological Background. In The History of Jerusalem, The Biblical Period. Edited by Shmuel Ahituv and Amihai Mazar. Jerusalem: Yad Izhak Ben-Zvi, pp. 155-74. (In Hebrew)

Hurowitz, Victor. 1992. I Have Built You an Exalted House: Temple Building in the Bible in Light of Mesopotamian and Northwest Semitic Writings. Sheffield: JSOT Press.

Hurowitz, Victor A. 2010. "Solomon Built the Temple and Completed It." Building the First Temple According to the Book of Kings. In From the Foundations to the Crenellations. Essays on Temple Building in the Ancient Near East and Hebrew Bible. Edited by Mark J. Boda and Jamie Novotny. Münster: Ugarit-Verlag, pp. 281-302.

Katz, Hava. 2016. Portable Shrine Models. Ancient Architectural Clay Models from the Levant. BAR International Series 2791; Oxford: British Archaeological Reports.

Keel, Othmar, Ernst A. Knauf, and Thomas Staubli. 2004. Salomons Tempel. Fribourg: Fribourg Academic Press.

King, Philip J., and Lawrence E. Stager. 2001. Life in Biblical Israel. Louisville: Westminster/John Knox Press.

Kisilevitz, Shua. 2015. The Iron IIA Judahite Temple at Tel Moza. Tel Aviv 42: 147-64. [CrossRef]

Lemaire, André. 2011. The Evolution of the 8th-Century B.C.E. Jerusalem Temple. In The Fire Signals of Lachish: Studies in the Archaeology and History of Israel in the Late Bronze Age, Iron Age, and Persian Period in Honor of David Ussishkin. Edited by Israel Finkelstein and Nadav Na'aman. Winona Lake: Eisenbrauns, pp. 195-202.

Liverani, Mario. 2003. Israel's History and the History of Israel. London: Equinox.

Margueron, Jean. 1981. Les origines syriennes du temple de Jérusalem. Le monde de la Bible 20: 31-33.

Mazar, Amichai. 1992. Temples of the Middle and Late Bronze Ages and the Iron Age. In The Architecture of Ancient Israel_From the Prehistoric to the Persian Period. Edited by Aharon Kempinski and Ronny Reich. Jerusalem: Israel Exploration Society, pp. 161-89.

McCormick, Clifford M. 2002. Palace and Temple: A Study of Architectural and Verbal Icons (Beihefte zur Zeitschrift für die alttestamentliche Wissenschaft 313). Berlin: De Gruyter.

Meyers, Carol. 1992. Temple, Jerusalem. In Anchor Bible Dictionary. Edited by David N. Freedman. New York: Doubleday, vol. 6, pp. 350-69.

Millard, Alan R. 1989. The Doorways of Solomon's Temple. Eretz-Israel 20: 135-39.

Möhlenbrink, Kurt. 1932. Der Tempel Salomos: Eine Untersuchung seiner Stellung in der sakral Architektur des alten Orients. Stuttgart: Kohlhammer.

Monson, John. 2006. The Ain Dara Temple and the Jerusalem Temple. In Text, Artifact, and Image-Revealing Ancient Israelite Religion. Edited by Gary M. Beckham and Theodore J. Lewis. Providence: Brown Judaic Studies, pp. 273-99.

Montgomery, James A. 1934. Archival Data in the Book of Kings. Journal of Biblical Literature 53: 46-52. [CrossRef]

Muller, Béatrice. 2002. Les "maquettes architecturales" du Proche-Orient ancien. Beyrouth: Institut Français d'archéologie du Proche-Orient.

Mumcuoglu, Madeleine, and Yosef Garfinkel. 2018. Crossing the Threshold: Architecture, Iconography and the Sacred Entrance. Oxford: Oxbow.

Parrot, André. 1954. Le temple de Jérusalem. Neuchâtel: Delachaux \& Niestle.

Rowe, Alan. 1940. The Four Canaanite Temples of Beth-Shan. Philadelphia: University of Pennsylvania Press. 
Smith, Mark S. 2006. In Solomon's Temple (1 Kings 6-7): Between Text and Archaeology. In Confronting the Past. Archaeological and Historical Essays on Ancient Israel in Honor of William G. Dever. Edited by Seymour Gitin, Edward J. Wright and J. P. Dessel. Winona Lake: Eisenbrauns, pp. 275-82.

Stade, Bernhard. 1887. Geschichte des Volkes Israel, Vol. 1. Berlin: G. Grote'sche, pp. 292-343.

Ussishkin, David. 2004. The Renewed Archaeological Excavations at Lachish (1973-1994). Tel Aviv: Institute of Archaeology, Tel Aviv University.

Ussishkin, David. 2009. The Temple Mount in Jerusalem during the First Temple Period: An Archaeological View. In Exploring the Longue Durée: Essays in Honor of Lawrence E. Stager. Edited by David Schloen. Winona Lake: Eisenbrauns, pp. 473-83.

Van Seters, John. 1997. Solomon's Temple: Fact and Ideology in Biblical and Near Eastern Historiography. Catholic Biblical Quarterly 59: 45-57.

Vincent, Louis-Hugues. 1956. Jérusalem de l'Ancien Testament. Paris: J. Gabalda.

Watzinger, Karl. 1933. Denkmäler Palästinas: eine Einführung in die Archäeologie des Heiligen Landes. Leipzig: Hinrichs. Yadin, Yigal. 1956. The First Temple. In Sepher Yerushalayim. Jerusalem, its Natural Conditions, History and Development from the Origins to the Present Day. Edited by Michael Avi-Yonah. Jerusalem: Bialik Institute, pp. 176-90. (In Hebrew)

Yeivin, Shmuel. 1968. Solomon's Temple. In Encyclopaedia Miqra'it. Jerusalem: Bialik Institute, vol. 5, pp. 328-46. (In Hebrew)

Zwickel, Wolfgang. 1999. Der salomonische Tempel. Mainz am Rhein: Philipp von Zabern.

(C) 2019 by the authors. Licensee MDPI, Basel, Switzerland. This article is an open access article distributed under the terms and conditions of the Creative Commons Attribution (CC BY) license (http:/ / creativecommons.org/licenses/by/4.0/). 

Article

\title{
Israelite Temples: Where Was Israelite Cult Not Practiced, and Why
}

\author{
Avraham Faust \\ The Department of General History, Bar-Ilan University, Ramat Gan 5290002, Israel; avraham.faust@biu.ac.il \\ Received: 7 January 2019; Accepted: 7 February 2019; Published: 12 February 2019
}

\begin{abstract}
Most scholars in the late 20th and early 21st century believed that cultic activity in the kingdoms of Israel and Judah was practiced in various temples that were scattered throughout the kingdoms. Still, a detailed study of the archaeological evidence on Israelite cult reveals that Israelite cultic buildings were extremely rare, both in absolute terms and when compared to other ancient Near Eastern societies, suggesting that cultic activity in temples was the exception rather than the norm and that typical Israelite cult was practiced in the household and in other, non-temple settings. Hence, the evidence suggests that rather than viewing temples, like the one in Arad, as exemplifying typical cultic activity, they should be viewed as exceptions that require a special explanation. The first part of the article develops and updates the suggestion, first raised about ten years ago, that Israelite temples were indeed extremely rare. Given the ancient Near Eastern context, however, such practices seems to be exceptional, and the second part of the article will therefore explain why was such a unique pattern not identified in the past, and will suggest a possible explanation as to how was such an outstanding practice developed and adopted.
\end{abstract}

Keywords: Israelite religion; temples; ancient Israel; cultic buildings; shrines; sanctuaries; biblical archaeology; egalitarian ethos

\section{Introduction}

Modern scholarship seems to have been fascinated by Israelite religion(s), and numerous attempts were made to reconstruct ancient Israelite cult. Initially, research focused on the interpretation supplied by the various texts, but as the archaeological evidence gradually accumulated, the material record came to play a major role in these reconstructions (e.g., Alpert Nakhai 2001, pp. 8-16; Zevit 2001, pp. 1-80; see also Hess 2007, pp. 43-80). While various questions surrounding Israelite religion(s) were left undecided, a consensus had been gradually established regarding the nature of Israelite cult practices, and especially on their spatial dimension. According to this consensus, Israelite cult was practiced in temples or shrines, i.e., houses built for cultic purposes in general and to house a deity in particular, and until Josiah's reforms of the late seventh century BCE such structures existed in every Israelite city, town, and village (e.g., Holladay 1987; Zevit 2001; Schmitt 2014, and many more references below). While this consensus was based on a possible reading of the biblical data, it contradicted the archaeological information available, and a few years ago I challenged this consensus (Faust 2010), and demonstrated that Iron Age Israelite temples were a rare phenomenon, and that cult was usually practiced in more simple settings, and not in buildings erected especially for this purpose.

While this view was adopted by some (below), other scholars still repeat the older maxim (e.g., Schmitt 2014; Geller 2016, p. 312, and more below), and in this article, which is part of a general issue on Archaeology and Israelite Religion, I would like to update the main arguments raised in my original paper, and then to advance one step further and to offer a possible explanation for the Israelite practice 
of preferring simpler cultic settings, in contrast to most other ancient Near Eastern societies in which temples were common. ${ }^{1}$

\section{Preliminary Notes on the Definition and Identification of Cultic Buildings}

Before beginning the archaeological survey, I would like to briefly comment on the terminology used in reference to cultic buildings and on the mere identification of buildings as cultic in the first place.

\subsection{Cultic Buildings, Temples, Shrines, and Sanctuaries}

In the following I use the term "cultic building" in a comprehensive manner, and take it to refer to any structure that was built specifically for religious purposes.

Notably, scholars used various terminologies to describe cultic buildings and activities. Examples include Zevit (2001, pp. 123-24), which referred (among other terms) to "cult complex," "cult center," "temple," "temple complex," and "shrine", Dever's (e.g., Dever 2005, pp. 111, 135, 167) discussion of "local shrines," "public open-air sanctuaries," and "monumental temples", and Schmitt's (2014, partial list) "neighborhood shrine", "village shrine", "city temple", "regional sanctuary", and "supra-regional sanctuary" (see also Holladay 1987, and see especially 282, n. 1; Zwickel 1994, p. 9; Hess 2007, pp. 39, 312-314). While a sort of hierarchy seems to be inherent in all of these studies (and will be discussed below), and although most do have an internal consistency in their use of the various terms, there is clearly no systematic terminology across studies.

For our purposes, therefore, any building that was used specifically for cultic activities (see below, Section 2.2) will be included within the broad definition of a cultic building adopted here. Although the distinction between the various possible sub-types of cultic structures is not important for our purposes_-and is not used in any consistent way throughout scholarship in any case ${ }^{2}$ _for clarity I will use either the term "cultic structures" (or "buildings") or "temples" (unless when quoting others).

It should also be noted that this paper will not systematically discuss expressions of religion within the household or finds that are interpreted as small cultic corners within buildings (see for example (Albertz and Schmitt 2012); and various papers in (Albertz et al. 2014), and references, and a few examples at the beginning of Section 5). Nor will I try to identify the biblical terms of those buildings (e.g., Smith 2002; Alpert Nakhai 2001; Zevit 2001; Haran 1981).

\subsection{Identifying Cultic Buildings}

Identifying cult in archaeology is notoriously difficult (cf., Flannery 1976, pp. 329-33). Various scholars, however, have offered explicit methods to overcome the difficulties of interpreting archaeological finds as indicating cult. The most famous and influential study on the identification of cultic sites is Renfrew's (1985) study of the sanctuary at Phylakopi (see also Renfrew 1994; Renfrew and Bahn 2012, pp. 403-8; Levy 2006). Renfrew examined a number of traits which he viewed as indicative of cult, relating to settings, architecture and finds, for example, a setting or architecture that focuses attention or creates a boundary between this world and another one, or that exhibits evidence of participation and offerings to a deity.

Since in this article I do not intend to review and examine each and every cultic building identified in the past, it is important to note that some previous scholarship has explicitly attempted to follow

1 Identifying sites as Israelites is not always straightforward, and various criteria were offered over the years (e.g., Dever 2003; Bloch-Smith 2003; Faust 2006a, and references). While no consensus had been reached, during the Iron II, which is the focus of this paper, the questionable sites are fewer and, moreover, there is usually an agreement whether a certain temple was Israelite or not. Moreover, at this time there seems to have been an intended policy in Israel and Judah, expressed for example in the fate of the temples in sites like Megiddo, Tel Qasile, and others (discussed in Section 5.3), allowing us to examine the situation in these kingdoms at large.

2 This can be exemplified by the treatment of Arad. As we will see below (Section 3.2 for example) not only do different scholars use different terms to describe this structure, but sometimes the same scholar used different terms interchangeably. 
Renfrew's criteria, and this is especially true for some of the studies which were used to compile the "lists" of cultic buildings referred to below (e.g., Zevit 2001, pp. 82-83; Alpert Nakhai 2001, pp. 35-36; Hess 2007, pp. 37-39; Schmitt 2014, and others). Moreover, since the phenomenon addressed in this paper is very striking, little subtleties are not important, and unless the entire scholarly literature is completely useless, the pattern identified is extreme and requires an explanation. Thus, as problematic as some past studies are, it is clear that many of the buildings, at least, have enough traits to qualify them as "cultic." Finally, the same (whether good, or loosely defined) criteria were applied to all structures discussed in this article, including those of the Bronze Age and the Iron Age, and any obvious differences in their distribution would therefore require an explanation.

In light of the above, I would like to suggest that the patterns that will be discussed below regarding the distribution and frequency of cultic buildings are valid, and are not a result of the application of different criteria to different societies or eras, or of inappropriate methods of identifying cultic buildings. Hence, despite the difficulties inherent in past scholarship, the existing "database" of cultic structures is valid for comparative purposes and for identifying patterns in the distribution, usage, and even existence of such structures. Thus, different patterns are significant and meaningful, and are clearly a result of past behavior and not of biased data collection or from differences in interpretation.

\section{Israelite Places of Worship: The Consensus}

The earliest attempts to study Israelite religion and to identify cultic buildings or temples on the basis of the archaeological finds were eclectic and derived from incidental finds (see, e.g., the assessment of Wright 1978, p. 149). Following the accumulation of archaeological discoveries of cultic buildings and mainly religious items, however, and in light of critical analysis of the biblical information on Israelite religion(s), many scholars have attempted to systematically reconstruct the location and manner in which Israelite religion(s) was practiced. As far as cultic buildings were concerned, there was a growing consensus regarding their place in the social landscape of Israelite Iron Age society, and in the late 20th and early 21st century it was agreed that there were various loci of cult, from the individual household, through villages, urban and regional temples, to even more central temples in the national capitals.

\subsection{Typology of Israelite Cultic Buildings: The Emerging Consensus}

We shall begin our survey with Holladay's (1987) highly influential article, "Religion in Israel and Judah under the Monarchy: An Explicitly Archaeological Approach." Holladay identified various loci of cult, and created a typology of those buildings and spaces. He concluded which type of cult was typical of what setting (urban, regional, etc.) based on the characteristics of the structures he identified, and then extrapolated from these finds to the reality in Israel and Judah at large. He distinguished between "established" regional shrines and "state" temples on the one hand, and "non-conformist" shrines on the other. The term "non-conformist" shrine refers to buildings in which the cult practiced deviated from the state-sponsored religion. Holladay's "typology" of cultic buildings suggests that the "established worship" was practiced at the town and the national level, as well as at the neighborhood level (Holladay 1987, pp. 267-68).

Other scholars followed, and although the typologies are not identical, the concept of central, regional, and local cultic centers at several levels is widely accepted. Thus, Richard Hess (2007, pp. 297-314) followed Holladay's classification, at least in its general outlines, he refers to the existence of "local shrines" (p. 312), concluding that "[D]uring the later divided monarchy [eighth to sixth centuries $\mathrm{BC}$ ] the high places continued as state-sponsored religious centers, while cult centers appeared at village sites, along trade routes, and in alternative nonconformist contexts" (p. 314). William Dever also viewed the evidence as indicative of a similar reality, and concluded that different temples were built in many locales (e.g., Dever 2005, p. 174, but see Dever 2017, and more below). Ziony Zevit (2001), in what is perhaps one of the most detailed attempt to reconstruct Israelite religions, 
scrutinized the archaeological (and non-archaeological) evidence, referring to various temples and cultic buildings, and also concluded that "the religion was practiced differently at home, village, sanctuary, urban temple, and extra-urban sanctuary" (2001, p. 265). Rudiger Schmitt's (2014) recent typology is among the most detailed, and included, among other types or locales, also "neighborhood shrine", "village shrine", "city temple", "regional sanctuary", and "supra-regional sanctuary." And Oded Borowski (2003, p. 54), in describing the daily life in biblical Israel, also wrote, "[ ... ] it is safe to assume that every city and town had a cult center or a shrine" (see also p. 24). A reality in which cultic buildings are found throughout the landscape is also depicted by Beth Alpert Nakhai (2001, but see below) and S.A. Geller (2016, p. 312).

Many biblical scholars who discussed the cultic changes following the religious reforms of the late Iron Age also noted that local temples were prevalent before those reforms. Hence Hagedorn (2005, p. 204) refers to "(A)ll the local shrines which have previously been centers [ . . ]" Vogt (2006, pp. 44, 46) also speaks about the "local sanctuaries" that existed until the time of Josiah (see also (Albertz 1994, pp. 128, 206); for the multiplicity of such buildings, (see also Smith 2002, p. 161; McNutt 1999, pp. 176-78)).

Common to these studies and typologies is the conclusion that the Israelites built temples or cultic buildings in almost every locale, and that beyond the household cult, there were cultic structures in neighborhoods, villages, towns, and there were even regional cultic centers, and central temples in the national capitals. The following quote, regarding "the relationship between local and central sanctuaries," reflects the consensus that "[ . . ] during the whole monarchical period [until the time of Josiah. A.F.] both existed side by side" (Kessler 2008, p. 89). ${ }^{3}$

\subsection{The Logic Behind the Typology}

The above-mentioned studies meticulously studied the available archaeological evidence that could be, directly and indirectly, related to Israelite religion and cult. These scholars looked at every possible clue, in order to reconstruct every possible form of religious practice, and then extrapolated from the available information in order to understand Israelite religion(s) at large. All studies explicitly or implicitly agree that the fragmentary data uncovered is representative of a larger whole. William Dever (2005, pp. 170-75), for example, after discussing the temple at Arad, wrote, "(A)ll things considered, there is no reason to suppose that the Arad temple is unique or even exceptional. Rather it appears to be an example of what was probably a widespread phenomenon-local temples" (p. 175). Hess (2007, p. 303), in a similar vein, suggested that "[T]he sanctuary at Arad probably represents a regional center" (see also Hess 2007, p. 312), and Albertz (1994, p. 128) viewed it as a "regular temple complex," and an example of "provincial sanctuaries" (see also Geller 2016, p. 332).

While these studies are exemplary in their detailed analysis of the archaeological evidence and in their interdisciplinary approach, in which the archaeological information is interpreted in light of the data available from a critical analysis of the textual sources, my 2010 article aimed to show that they are wrong, and what they viewed as "examples" are in reality exceptions.

The next sections, therefore, aim to show that a more archaeologically contextual approach to the available data indicates that the evidence used for extrapolation and which served as the basis for reconstructing Israelite cult places is the exception, rather than the rule. The emerging picture, therefore, is not representative; by multiplying the exceptions, we do not get a picture of the whole, but rather a distorted image, requiring a new approach to Israelite religion.

3 Many scholars were of course aware of the fact that not all the structures were temples or buildings erected solely for cultic purpose (see below). Still they discussed the finds as part of a spectrum, assuming the existence of many such structures, and subsequently did not identify their rarity (and see more below). 


\section{The Context: Non-Israelite Temples in the Bronze and Iron Ages}

Below we will review the scarce evidence for cultic buildings in Iron II Israel and Judah, but in order to assess this data, I would first like to put it in perspective, and will therefore briefly examine the evidence from non-Israelite cult places. Reviewing the reality in other cultures of the Bronze and Iron Age Levant (cf., Greener, Steiner, Ben-Shlomo, and Tyson, all in this issue) will give us a background against which to examine and compare the situation in Israel and Judah.

Temples are ubiquitous in Bronze Age sites (e.g., Greener, this issue; see also Bunimovitz 2019). While a comprehensive discussion is beyond the scope of this article, the next section will briefly discuss a few periodical or topical case studies.

\subsection{Late Bronze Age Temples}

Although Late Bronze Age strata were unearthed at quite a few sites, the exposure of those levels is usually limited. This limited exposure is a result of a combination of factors, including the demographic decline which characterized the period and the fact that many sites either did not have Late Bronze Age occupation whatsoever, or that occupation from this period was relatively limited in scope (Gonen 1992b, pp. 216-17; Bunimovitz 1995, pp. 321-24; 2019; see also Greener, in this issue, and more below), as well as the fact that in most instances the Late Bronze layers were deep below the mound's surface, and hence only limited exposure is possible. The number of Late Bronze Age dwellings that were excavated, for example, is limited (e.g., Gonen 1992b, p. 221), and this is of course a result of this limited exposure (more below). Still, despite the limited archaeological exposure, more than 20 Late Bronze Age temples were unearthed over the years throughout the country (for a general treatment, see Alpert Nakhai 2001, pp. 119-60; Hess 2007, pp. 125-40; Gonen 1992b, pp. 222-32; Mazar 1992a, pp. 169-83; Ottosson 1980; Wright 1985, pp. 218-23; Bunimovitz 2019; see also Greener, this issue). A selective list of temples includes Shechem, Hazor (apparently five temples), Megiddo, Lachish (at least two temples), Tel Mevorakh, Beth Shean, Timnah, Amman airport, Tel Kitan, Pella, Tel Nami, and probably also Tell Abu Hawam, Tell Abu Al-Kharaz, Tell Deir 'Alla, Tell Safut, Kh. Umm ad-Dananir, and Shiloh. In addition, Nahariya, Tel Mor, Gezer, and perhaps even Mt. Gerizim (if they are dated to the early phase of the Late Bronze Age) might also be included in the list. ${ }^{4}$ A recent find from Tall el-'Umayri (Herr and Clark 2009, pp. 76-81) might supplement the list of Late Bronze Age temples.

The evidence, therefore, clearly shows that during the Late Bronze Age temples were common. There was apparently at least one temple in each settlement, including relatively small settlements, and in many cases there was even more than one such building at a settlement. Furthermore, quite a few temples were unearthed outside settlements (e.g., the Fosse Temple at Lachish and the Amman airport temple), providing additional evidence of the wide distribution of temples in this era.

\subsection{Bronze Age Rural Temples}

Due to the demographic decline of the Late Bronze Age, no examples of Late Bronze Age villages have been excavated to an extent that allows for any social analysis. However, the data from Middle Bronze Age villages are quite illustrative.

Six Middle Bronze Age villages were excavated or surveyed to an extent that allows some reconstruction of settlement planning and community organization, and they were discussed in detail

4 This is a partial list composed mainly of sites mentioned by Gonen (1992b, pp. 222-32), and Alpert Nakhai (2001, pp. 119-60), and excludes some sites in which no architectural remains (or other sufficient evidence) were unearthed, e.g., Aphek, Ashkelon, Ashdod, and even Jaffa, as well as the structure north of Jerusalem. I would like to note that Mazar (1992a, pp. 169-83) was more critical, rejecting the identification of the some of the above-mentioned sites as temples, but even he (in an article originally published in Hebrew in 1987) identified more than 10 such buildings. Furthermore, since Mazar did not discuss all the relevant sites (e.g., Pella), and as a few sites were discovered only after he published his paper, it is clear that even the most critical "counting" will end up with at least 15 Late Bronze Age temples. 
in an attempt to reconstruct the communities that inhabited them (Faust 2005). The sites are Tell el-Hayyat (Falconer 1994, 1995), Tel Kitan (Eisenberg 1976, 1993b), Givat Sharet (near Beth-Shemesh) (Bahat 1975, 1993), Nahal Rephaim (Eisenberg 1993a), Manahat (Edelstein 1993), and probably Kfar Rupin (Gophna 1979). Interestingly, in all six sites, temples were unearthed. Sometimes the temples were large and dominated the settlement (Tell el-Hayyat and Tel Kitan), while in others the temples were relatively small (Nahal Rephaim, Manahat, and Givat Sharet). Still, despite differences between the sites, the existence of temples is characteristic, and in most cases the identification of the structures as temples seems well established. Clearly, temples are a typical feature of Middle Bronze Age villages.

This indicates that in the Bronze Age, temples were prevalent also in rural settings, and that there was probably a temple or cultic building in every Canaanite village (Faust 2005).

\subsection{Iron Age Temples outside the Kingdoms of Israel and Judah}

As part of the context in which we will evaluate the evidence from Israel and Judah, it is also worthwhile to examine the situation in other Iron Age polities and regions, outside the kingdoms of Israel and Judah.

Although the polities surrounding Israel and Judah were excavated to a much more limited extent than the latter, temples are a relatively frequent find in those regions. In Philistia (i.e., the Philistines cities and their periphery, including, probably, Canaanite settlements; see also Ben Shlomo in this issue), for example, series of Iron Age temples were found at Tel Qasile (Mazar 1980), Ekron/Miqne (Dothan 2003; Gitin 2003), and another one was unearthed at Nahal Patish (Nahshoni 2009a; 2009b). Recently, a temple was also reported at Tell es-Safi/Gath (see, e.g., Dagan et al. 2018). It is likely that a temple existed also in Yavneh, but since only the favissa was excavated, and not the actual structure, we cannot discuss it here (Kletter et al. 2010, 2013, regardless of the ethnicity of the inhabitants). ${ }^{5}$ Temples therefore seem to be a typical feature in sites in Philistia and its surroundings. Notably, Ekron, and Gath are the only sites of the above-mentioned four sites that existed in the Iron II, and are therefore the only ones which yielded also Iron II temples (Iron I temples were unearthed in three of the sites).

Although excavations in Moab are extremely limited, a cultic building was recently found at Khirbat al-Mudayna (Daviau and Steiner 2000), and another at Ataruz (Ji 2012). Another late Iron Age temple was discovered in Tell Damiya (Petit and Kafafi 2016), whose population was most likely Canaanite, and another in Rujm al Kursi in Ammon (for a recent overview, see Steiner, Tyson, in this issue).

Cultic structures were also found outside settlements, such as at Wadi Thamad site 13 in Moab (Daviau 2006), at Kh. Qitmit in the Negev (Beit Arieh 1991, 1995) and also just outside the fort of 'En Hazeva in the Aravah (Cohen and Yisrael 1995, pp. 224-28). Whether those structures should be associated with the Edomites (e.g., Beit Arieh 1991, 1995; for Qitmit) or any other group is of less importance (we tend to associate the phenomenon with the Arabian trade), and it is clear that the relevant group(s) in the southern parts of Israel and Jordan built special structures for cultic purposes.

Temples are also known in the Iron Age polities to the north of Israel and Judah. Despite the limited exposure, Iron II temples were unearthed in various sites in the Aramean states to the north, e.g., at Tell Tayinat, 'Ain Dara, Aleppo, and Hama (Akkermans and Schwartz 2003, pp. 370-75, and references). The same is true for the Phoenician cities-while excavations are extremely limited in number and scope, Iron Age Phoenician cultic buildings were exposed at Sarepta, Tell Sukas, Tell Arqa, and probably at Kition (e.g., Markoe 2000, pp. 125-29). ${ }^{6}$

5 Some scholars identified a temple also at Ashdod (e.g., Wright 1985, p. 224; Dothan 1993, p. 100; Alpert Nakhai 2001, p. 197). Still, it is likely this was only a cult room, part of a larger building (Mazar 1992a, p. 186), and in order to err at the side of caution, it will not be discussed here.

6 For a longer list of suggested non-Israelite temples, see (Alpert Nakhai 2001, p. 197, note 26), but the cultic nature of some is not certain. 
Although most of these regions were only sparsely excavated when compared to the situation in the kingdoms of Israel and Judah, the finds there include many temples, which seem to be a common feature there.

\section{Temples in Iron II Israel and Judah}

Despite the large number of excavations of Iron Age II levels in Israel and Judah, and the large overall exposure of many sites, and notwithstanding the great academic interest in Israelite religion, hardly any temples or buildings devoted to cultic purposes were unearthed in the kingdoms of Israel and Judah. One can scrutinize the list of cultic structures supplied by various scholars, but to no avail. Most of the Iron II cult places are caves or cultic corners or rooms within structures (and the mere cultic nature of many is doubted). Thus, the finds in Lachish (Aharoni 1975), Megiddo (Zevit 2001, pp. 219-31 and references), Tell el-Farah (N) (Zevit 2001, pp. 238-41 and references), and more, are just cultic rooms or corners, i.e., rooms (or even parts thereof) that were used for cultic purposes, each located within a larger, non-religion complex. These are clearly not temples, and while they were used in the past to show that cult was widespread (by scholars who accepted the "consensus", see above), there was never real justification to call them temples or cultic buildings.

The only "real", secure temple excavated in the two polities is the one at Arad (Aharoni 1993; Herzog 1997, and references; Figure 1), and it appears that another one was discovered recently in Moza (e.g., Kisilevitz 2015). The complex at Dan might also be included (Biran 1994, pp. 159-233; Figure 2), although the identification of the latter is probably dependent on the biblical text.

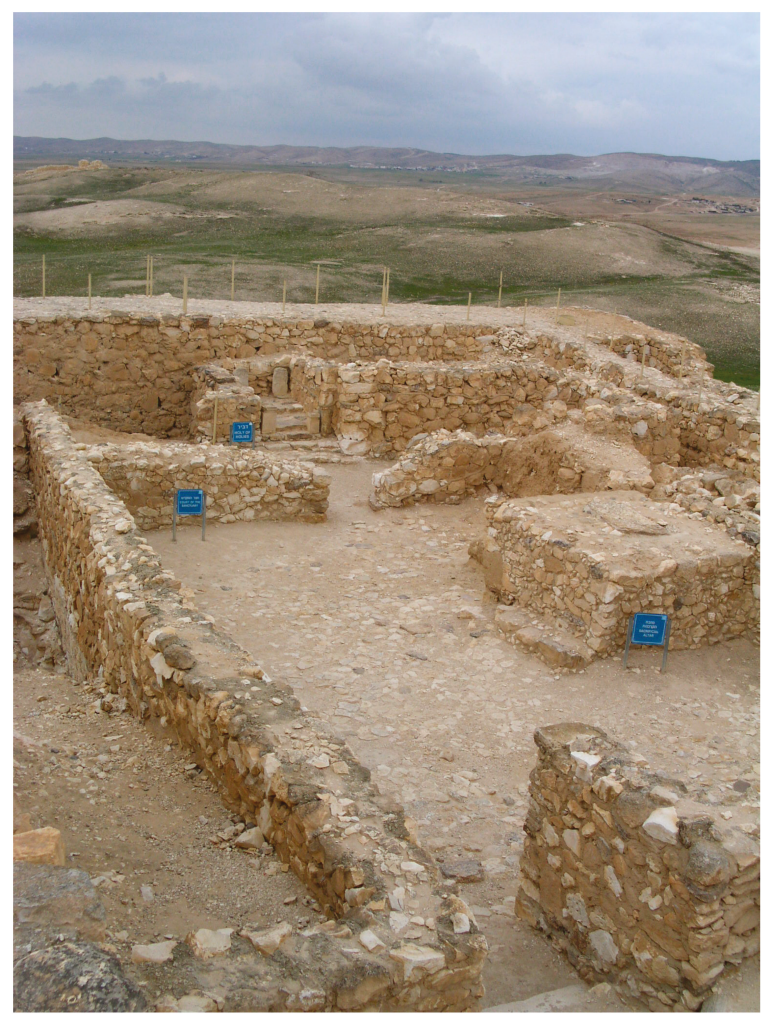

Figure 1. A photograph of the temple at Arad, after its reconstruction (photographed by the author). 


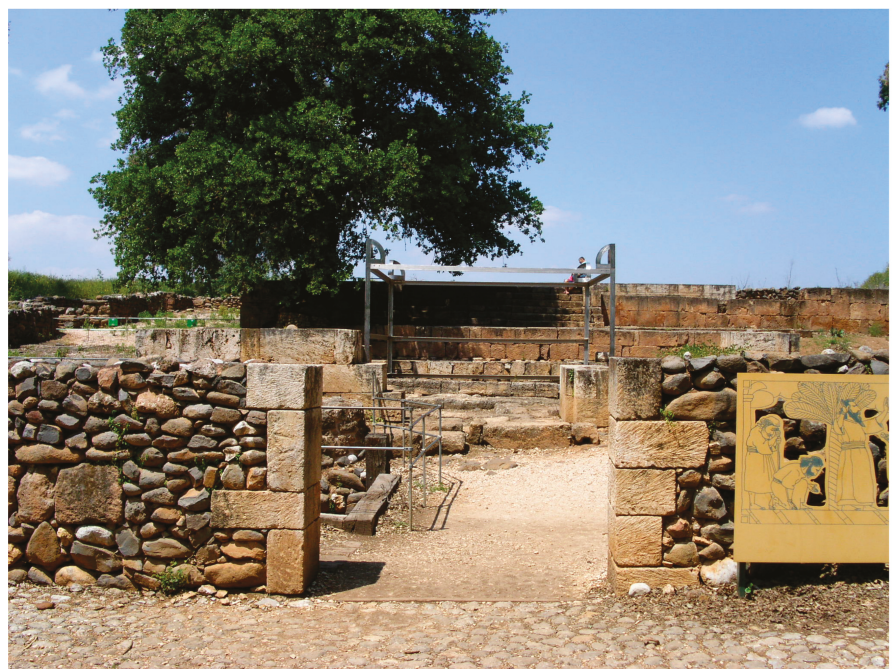

Figure 2. A photograph of the Tel Dan (reconstructed) cultic complex, with the platform at the background (photographed by the author).

The scarcity of finds is well known. Amihai Mazar (1992a), in an article on the temples of the Bronze and Iron Ages, devotes a lengthy discussion to the many temples of the second millennium BCE (pp. 161-83), and then notes the paucity of evidence for temples in the Iron II (p. 183): "(W)hereas finds from the Late Bronze Age are abundant, only a small number of sacred structures from the Iron Age II (tenth-sixth centuries B.C.) have been uncovered in Israel. These buildings are diversified in form and each of them is problematic" (p. 183; emphasis added). The only two examples of excavated Iron Age II temples cited by Mazar (published before the recent excavations in Moza) are indeed the temple at Arad and the complex at Dan (Mazar 1992a, pp. 184-86; see also Niditch 1997, p. 19).

Other scholars, moreover, include only the temple at Arad in the list of excavated Israelite temples (e.g., Ottosson 1980, p. 108; see also Fritz 1995, p. 147; Wright 1985, pp. 214, 252; Dever 2005, p. 170). The scarcity of temples is also expressed, indirectly, by Gabriel Barkay (1992) in his chapter on the Iron Age II in The Archaeology of Ancient Israel (Ben-Tor 1992); although this is the largest chapter in the book (and rightly so, given the large exposure of levels from this period), it does not even include a section or heading on temples and cultic structures, in stark contrast to chapters on earlier epochs (for example, Gonen 1992b, pp. 222-32; Kempinski 1992, pp. 174-75, 196-97).

Many of the above-quoted scholars who discussed Israelite religion(s) were of course aware of the paucity of the evidence, and Dever $(2005$, p. 170) explicitly wrote that "(T)he only known full-fledged Israelite temple of the monarchic period is the one excavated at Arad [ ... ]" (see also Dever 1983, p. 573). And Zevit admitted (Zevit 2001, p. 124) "(B)y quirk of fate, the clearest incontrovertible examples of cult sites relative to the religion of Israelites come from excavations at sites belonging to Israel's Iron Age neighbors [ . . . ]“ (see also Wright 1985, pp. 248-249; Fritz 1995, p. 145).

It is important to note we are not suggesting that the temples at Arad and perhaps Moza (along with the probable one at Dan) were the only cultic building(s) that existed in Iron Age II Israel and Judah-it is quite clear that there was one in Jerusalem, for example, and one can assume that there were a few more (either of the few mentioned by name in the Bible, like Bethel, or some that were not mentioned) which were not yet discovered — but the evidence suggests that such buildings were a rare phenomenon, much rarer than in the Bronze Age or in the surrounding Iron Age polities. While a more quantitative assessment will be presented below, I would first like to review the detailed information 
available from a series of urban and rural settings in the kingdoms of Israel and Judah, in order to demonstrate that should temples be prevalent, they were indeed expected to be found.

\subsection{Urban Iron Age II Israelite Settlement}

Iron II levels were exposed in dozens of sites in the Kingdoms of Israel and Judah, sometimes extensively so. Still, as noted above, practically no temples were found in archaeological excavations in these settings. For example, the site at Beth-Shemesh was excavated almost entirely by three expeditions (Bunimovitz and Lederman 2009; and additional references), but no temple was found. At Tell en-Nasbeh (biblical Mizpah), too, almost the entire Iron Age II city was exposed (Zorn 1993a, 1993b; and references; Figure 3), but no temples were found. The situation in Tell Beit-Mirsim is similar (Albright 1943, 1993; although its exposure was less massive). Large areas were excavated also in Beersheba (e.g., Herzog and Singer-Avitz 2016), but despite the search, no such temple was found (a dismantled horned altar was discovered, but no cultic building, and contrary to some assumptions, an altar did not have to belong to a temple). It should be noted that the excavation of Iron II levels at other sites—e.g., Megiddo, Hazor, and Tell el-Fara'h (N)—also greatly exceed most of the Late Bronze Age settlements, but no Iron II cultic buildings were unearthed there too. The contrast with the scarcely excavated Late Bronze Age towns is clear.

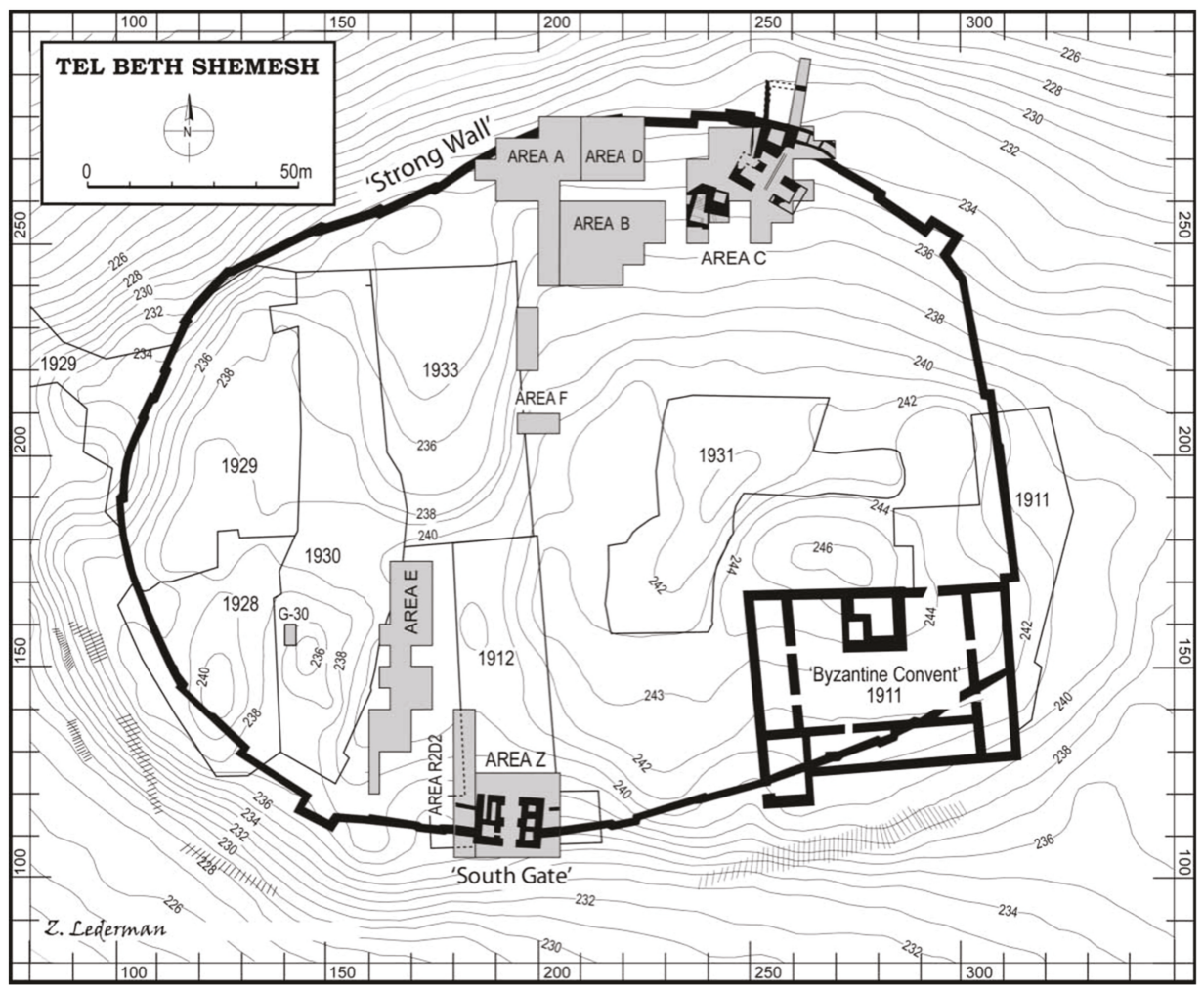

Figure 3. A plan of the mound of Tel Beth-Shemesh, with excavation areas marked. Despite the wide exposure of Iron II levels (in practice, all excavation areas, noted on the plan), no temples were uncovered (Bunimovitz and Lederman 2013, p. 7; courtesy of the Tel Beth-Shemesh excavations expedition). 


\subsection{Rural Temples and Israelite Settlements}

A number of Israelite Iron II villages were also widely exposed (e.g., Faust 2000), especially at Kh. Jemein (Dar 1986; Figure 4) and Beit Arye (Riklin 1997) that were excavated in their entirety, as well as Kh. Jarish (Amit 1989-1990), and others. Still, despite the fact that this exposure was larger than that of the Bronze Age villages described above, and notwithstanding the eagerness of archaeologists to find evidence for Israelite cult, no temples were found. The contrast with the Middle Bronze Age villages described above is striking.

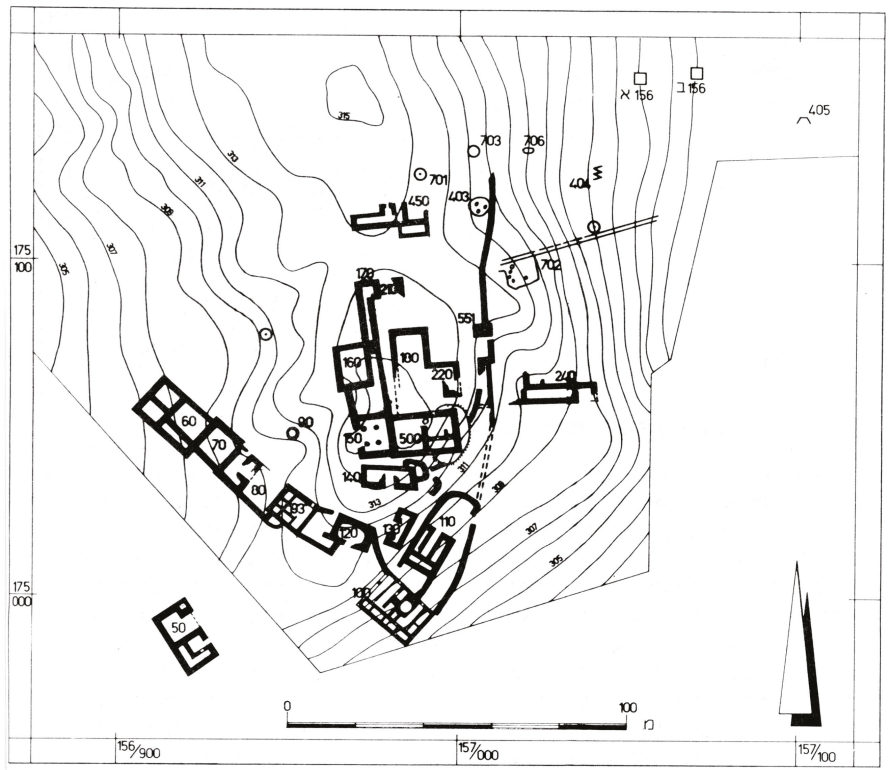

Figure 4. A plan of Kh. Jemein. Most of this Iron Age village was excavated, but no temple was unearthed (courtesy of Shimon Dar).

\subsection{The Fate of Older Canaanite Temples in Israelite Controlled Areas}

An additional evidence for the scarcity of temples in the kingdoms of Israel and Judah comes from the fate of existing Iron I Canaanite temples once they were incorporated within Israelite territories. Indeed, the transformation in the function of locales which for centuries served for sacred purposes is most revealing. Ottosson (1980, p. 106), for example, writes, "(A)t sites such as Megiddo, Hazor, and Shechem, where clearly delimited temple areas could be excavated, however, the cultic tradition vanishes completely during the Iron Age" (see also Halpern 2000, p. 559). At Megiddo the change is most noticeable, and with the destruction of Megiddo VI in the early 10th century, the millennia long cultic tradition came to an end, and no temple stood any more in what used to be Megiddo's sacred precinct. At Shechem, the Canaanite Fortress Temple (strata XVI-XV), was destroyed already at some point during the Iron Age I and never rebuilt in the later, probably Israelite phases (Stager 1999, and references). At Hazor, too, although the Late Bronze Age city boasted a number of temples (above), no temples were unearthed in the small Iron II city that was built in the 10th century BCE. Even more striking is the fact that the area of one the Canaanite cultic complex, located within the smaller Iron Age city, was left as an unbuilt, empty area-as Sandhaus (2013, p. 111) wrote: “The Israelite city developed around these ruins and always avoided building on top of them, possibly as a result of some sort of building ban on this location." Cessation in cultic activity in the Iron II can also be seen in Tel Qasile and Beth-Shean. In the former, the temple area grew and developed in the course of strata 
XII-X, but only scant remains were found after the stratum X temple was devastated, indicating at most some ephemeral use in the area after it was most likely incorporated with the Israelite polity (for the scanty remains, see Mazar 1980, pp. 50-53; 2009b, p. 327). And at Beth-Shean (according to Mazar's interpretation, e.g., Mazar 2006, pp. 34-35; 2009a, pp. 27-28), too, the earlier temples ceased to exist in the Iron Age IIA, apparently when the site was incorporated within the Israelite state.

Clearly, other than at Arad, probably Moza, and perhaps also Dan (along with Jerusalem, which is known from literary sources ${ }^{7}$ ), no temples are known from Iron Age II Israel and Judah. Given the contextual data from other epochs or polities this is striking, and in the following section we will attempt to show how extreme the rarity of temples in Israel and Judah is.

\section{Israelite Temples in Context: A Quantified Analysis}

Since, as we have seen above, Iron Age II levels were exposed to a much greater extent than those of the Late Bronze Age, if Iron II temples were as prevalent as those of the Late Bronze Age, then many dozens of Iron II temples should have been found.

This is a result of a number of factors (presented at length in Faust 2010; see also Faust and Safrai 2015, and therefore only presented briefly here).

First, the Iron II was a much more densely populated period, with a much higher population than the Late Bronze Age; common estimates are in the scale of 8:1. ${ }^{8}$ Although the numbers can be contested, the general trends are safe (as the various studies used the same methods and coefficients). ${ }^{9}$

The difference can be seen not only in the estimated population, but also in the number of excavated sites. The New Encyclopedia of Archaeological Excavations in the Holy Land (NEAEHL; Stern 1993) and the salvage excavations databases (e.g., Faust and Safrai 2005, 2015) serve as a general guide (the latter covers only Cisjordan, and while the former includes also a few sites in Transjordan, those were not counted). ${ }^{10}$ The number of sites in the NEAEHL (which is biased toward large sites and mounds) in which settlement remains from the Late Bronze Age were found is only 87, while the number of the Iron II settlements is 158 . When the salvage excavations database (biased toward small, rural sites) is examined, the difference is even larger. While only 45 Late Bronze Age settlement sites might be inferred, the number of the Iron II sites is $136 .{ }^{11}$ The above shows that the Iron II was far more populated than the Late Bronze Age, and that sites from the Iron Age II were excavated to a much larger extent than those of the Late Bronze Age. Hence, more remains of all types (including cultic buildings) are expected to have been found in those Iron II levels, should they have been present there in the same frequency.

Furthermore, the above reveals only part of the gap between the two periods, since it takes into account only the number of sites and not the extent of exposure of the different strata. Many Iron II levels, which are typically the upper levels in most ancient mounds, were exposed to a large extent (as noted above), while no Late Bronze Age sites were excavated to such a degree. And since the former were usually also larger, this means that the actual difference in exposure is much larger than that revealed by looking only at the number of sites.

7 And apparently a few other temples that are attested in the Bible.

8 Cf., Broshi and Finkelstein (1992) estimate of some 400,000 peoples for the Iron II, with Dever's (2003, p. 98) and Stager's (1998) estimate of some 50,000 for the Late Bronze Age. Other scholars suggested slightly lower (46,000 people according to Herzog 1999, p. 48) or higher (60,000 people according to (Broshi 1993a, p. 423); 60,000-70,000 people according to (Broshi 1993b, p. 14)) figures for the Late Bronze Age, but these differences are marginal compared with the gap with the Iron Age figures.

9 Notably, these figures compare the Late Bronze Age population with the entire population of the Iron II, and not only to the kingdoms of Israel and Judah. According to Broshi and Finkelstein (1992, p. 54), the latter's population was 332,500 (west of the Jordan River only), i.e., six to seven times larger than the estimated population of the entire country in the Late Bronze Age.

10 For extensive discussion of these sources of information, see Faust and Safrai 2015.

11 The vast majority of the excavations were carried out within the boundaries of the Iron Age II kingdoms of Israel and Judah. 
The number of Late Bronze Age versus Iron Age dwellings unearthed can serve as a good example of this gap. Gonen (1992b, p. 221), for example, had already noted the scarcity of excavated dwellings from the Late Bronze Age. Daviau scrutinized the evidence for excavated structures from the Late Bronze Age (Daviau 1993, pp. 219-436), and while she concluded that the data on many of the structures was insufficient for her purposes, her study gives an idea as to the number of complete structures that were exposed. A generous counting of complete houses will arrive at no more than 45 Late Bronze Age buildings throughout the country (including structures which Daviau did not study in detail due to the lack of data on the finds unearthed). Since the above was a generous estimate, it is safe to assume that enlarging the number to 50 Late Bronze Age dwellings will be the maximal figure possible. ${ }^{12}$

As far as the Iron Age II is concerned, however, well over $200^{13}$ Iron II dwellings were exposed in Israel and Judah. We believe that if the evidence will be thoroughly examined then the number will be larger, especially if the non-Israelites regions (e.g., the coast and the northern valleys) will also be taken into account. To err on the side of caution, let us compare the high figure of 50 Late Bronze Age dwellings, and the low estimate of 200 Iron II dwellings. If these figures are taken as a rough guide to the areas that were exposed in both periods, we should expect to find four times more Iron II finds than similar finds from the Late Bronze Age, should their relative frequency be similar. Therefore, if finds were random, we should expect Iron II temples to be more numerous at least by a factor of four than those of the Late Bronze Age. Since at least 20 Late Bronze Age temples were unearthed, then no less than some 80 Iron Age temples would have been found, if they were as frequent in this period as in the Late Bronze Age. Since this is not the case, and unequivocal Iron Age temples were found only at Arad, probably Moza, and perhaps also at Dan, it is clear that the finds are not random, and the difference is remarkable and requires an explanation.

The same is true when comparing the Iron Age II finds in Israel and Judah with their neighbors. Given the extensive exposure of so many sites in Judah and Israel, the absence of temples is striking, especially when compared to Philistia, Phoenicia, Moab, and other nearby regions (above). While the dearth of information from most regions makes a comparison very tricky, the situation in Philistia, where the number of excavations is known, enables it. Iron II temples were uncovered at Ekron and Gath (above). ${ }^{14}$ Two temples might seems a small figure, but when taking into account that only four Iron II sites which are clearly Philistine were excavated to any extent (in addition to Ekron and Gath, also Ashdod and Ashkelon), and that in all four only a small fraction of their area was exposed, then one must conclude that temples were common in Iron II Philistine sites. Given the above, it is likely that a few temples existed in every Philistine city. Hence, the contrast between the situation in non-Israelite sites (Philistine and others alike) and in the Israelite ones is striking.

\section{The Rarity of Israelite Temples: A Summary and an Update}

The survey of non-Israelite cultic structures in the Bronze and Iron Age puts the archeological finds in the Kingdoms of Israel and Judah in their proper context. The archaeological evidence discussed by previous studies on Israelite religion(s) might indeed relate to cult, but as far as cultic structures

12 The aim in "counting" the structures is not to arrive at an estimate of the number of Late Bronze Age buildings, nor at the total and exact number of the excavated dwellings. Rather, it is aimed to establish a basis of comparison between periods (below). If a few more houses were excavated after Daviau's book was published (or even if some structures were not discussed by her) is immaterial for our purposes, as this would not change the overall picture, especially as we exaggerate the number of Late Bronze Age structures in order to err on the side of caution.

13 Faust (2012, pp. 207-12), for example, mentioned some 120 complete houses, but this is only a partial list (originally compiled in 1997, for other purposes) of complete houses, and one could have added, even at the time the list was compiled, many dozens of additional structures at various sites. Thus, for example, Faust discussed only 26 structures at Tell en-Nasbeh (Faust 2012, pp. 72-77) whereas Zorn (1993b, pp. 116-20) analyzed more some 70 structures at this level most of which can be regarded as "complete." At Beth-Shemesh Faust discussed only three (3) structures, while dozens were exposed. A similar situation exists in additional sites, e.g., at Beersheba, Tell Beit Mirsim, and more, and hence 200 is a very conservative figure. Note that some scholars suggested that a temple was found also at Ashdod and perhaps Yavneh (see above). 
(like Arad) are concerned, those are rare exceptions rather than the rule. As a whole, and despite the wide exposure, "real" temples are practically missing in the archaeological record of Iron Age II Israel and Judah. There was no "city temple," "village temple," or "neighborhood temple" in those polities, and there were no regional cultic centers spread across the landscape-at least not identifiable special buildings that were built for this purpose!

Clearly, the lack of cultic buildings is an important feature of Israelite religion. This stands in stark contrast to the way the Canaanite religions were practiced in the Bronze Age, and also to the religious practices in other Iron Age polities (and to some extent even by non-Israelites in the kingdoms of Israel and Judah; cf., Faust 2012, pp. 242-43), but appears to be a key to understanding Israelite religious practices.

I first published this conclusion in 2010, and while the initial publication did not draw much explicit discussion, it appears that the observation that Israelite temples were a rare phenomenon and that Israelite cult was mostly practiced in simpler settings is gradually getting wider attention, and is now accepted by various authorities who study Israelite religion. ${ }^{15}$ William Dever (2017, p. 503), for example noted recently that "For the majority of people, even in urban centers, religious beliefs and practices were focused on family rituals" (see also p. 497), and Carol Meyers (2017, p. 11), stated that "[ ... ] it should be emphasized that household rituals were the major and often only kind of ritual activity experienced by most Israelites. Large temple complexes were rare in ancient Israel, in contrast to surrounding areas." Zev Farber (2018, p. 441), in his recent overview of the religion of Judah in the 8 th century BCE summarized that "In short, for the most part, Israelites and Judahites did not built temples." And Alpert Nakhai (2015, p. 93) noted that worship "was decentralised and locally-based, in contrast to the better-known components of worship, the formal temples that served the monarchy and other elites" (see also Houston 2013, p. 152; Ortiz 2018, p. 24). Clearly, the lack of built temples is a unique characteristic of Israelite religion, and this must be addressed and analyzed.

\section{Why Was the Pattern Not Identified}

If temples are indeed so rare, why was this pattern not identified a long time ago? While this question is only of secondary importance of course, it is still intriguing-how could such a clear pattern be missed?

It seems that a combination of factors led to the fact that the obvious pattern was not identified, at least not explicitly.

First of all, it appears as if biblical data and interpretations were influencing previous scholarship, and many scholars attempted to reconstruct a religion which was to a large extent expected on the basis of the interpretation of the texts. As noted, Israelite religion was a focus of intensive research, and hence prior knowledge influenced research questions and agendas; if to be more specific, scholars "knew" that the Israelite religion was practiced all over the country until Josiah's reforms, and therefore reconstructed such a religion (or religions). ${ }^{16}$ The following quote illustrates how biblical-driven conceptions shaped historical reconstructions, "(A)t the end of the monarchy in Judah the relationship between local and central sanctuaries was reversed. While in the pre-state period there were only local sanctuaries, and during the whole monarchical period both existed side by side, under Josiah at the end of the seventh century the local sanctuaries were closed and the cult was centralized in Jerusalem" (Kessler 2008, p. 89; see also Hagedorn 2005, p. 204; Vogt 2006, pp. 44, 46).

Since the existence of such "local" temples was simply assumed, and with the absence of sufficient "examples" from the Iron Age, scholarship drifted to two solutions to illustrate the cultic landscape of Israel and Judah until the time of Josiah:

15 I am not aware of any explicit attempt to challenge my argument, but many still follow the old consensus, for example (Schmitt 2014; Geller 2016, p. 312).

16 For the significance of Josiah's (and Hezekiah's) reforms in this context, see, e.g., (Albertz 1994; Vogt 2006); see also (Fritz 1995, p. 145; Borowski 2003, p. 24). 
(1) Scholars used the data about the distribution of Bronze Age Canaanite temples, assuming (usually implicitly) that it was similar, to reconstruct an Iron Age cultic landscape that is full with cultic buildings. ${ }^{17}$

(2) The few exceptional Iron Age cultic buildings in Israel and Judah were explicitly regarded as representative, and were used to complement the picture that was drawn on the basis of hypothesis derived from the Bible and, as noted above (\#1), on the cultic landscape of the Bronze Age (and that of other Iron Age polities) (e.g., Zevit 2001, p. 124; Dever 2005, p. 170; Geller 2016, p. 312; see also Wright 1985, pp. 248-49; Fritz 1995, p. 145, and see above).

While such an integrative methodology, which incorporates updated archaeological data with critical textual analysis, is usually the right approach, it has its risks. It appears that in this case, the biblical-driven expectations led (1) to a strong will to look for evidence for cult in general and cultic structures in particular (and it also encouraged the interpretation of finds as cultic, even when the evidence was dubious), and (2) to extrapolate from the finds, i.e., to use the data that was unearthed as an example of what must have been the reality elsewhere. This is of course the right procedure when the finds are representative, but this does not seem to be the case here, and the unique exceptions which required explanations were treated as representative examples of Israelite cult-places.

To this we can add another factor that contributed to the fact that this pattern was not addressed, and the influence of biblical scholarship and the situation in other Near Eastern societies of the Bronze and Iron Ages is exacerbated by the tendency of archaeologists to explain the evidence unearthed and, with a large degree of justification, to ignore "things" that were not found. As noted by Lamberg-Karlovsky (1985, p. 23), archaeologists are "burdened by their occupational hazard with a materialist bias." This is the reason why we (as archaeologists) usually tend to explain what there is, and ignore what there isn't. The study of Iron Age burials (to be discussed at some length below) can serve as another example. Hardly any Iron Age I (and early Iron Age II) burials were unearthed in Israel and Judah, but although this was "known" (e.g., Tappy 1995, pp. 65-66; Ilan 1997a, p. 385; 1997b, p. 220), the pattern was not systematically addressed until recently (Kletter 2002; Faust 2004). Studies of Iron Age burial practices concentrated (quite naturally) on the famous Judahite tombs of the late Iron Age and on the few tombs from the earlier phases of the period, and the "absence" of the finds during most of the period was not systematically dealt with. In this case, the few early tombs that were unearthed were discussed, and the degree of continuity between them and those of the preceding and succeeding periods was analyzed, but the most important element- that most of the population was not buried in such tombs-was usually not even mentioned until recently, let alone explained. It seems that after well over 100 years of extensive archaeological research in ancient Israel, we cannot ignore elements that were supposed to be found, but were not, and the absence or rarity of finds—-temples in this case-must be acknowledged. ${ }^{18}$

\section{Why Were Temples Not an Integral Part of Israelite Cult?}

Identifying the pattern, and noting that Israelites cult was not commonly practiced in temples, is the most important observation, and it has significant implications for the study of ancient Israelite religious practices.

This observations, however, naturally leads to two new questions: (1) why were temples not an integral part of Israelite cultic practices? and (2) how was Israelite cult practiced?

The second question will be dealt with in a separate article, and in the remainder of this paper I would like to offer an initial, even if probably only partial, answer to the first question: Why was Israelite cult practiced differently than other ancient Near Eastern religions?

17 In some cases, previous studies of Israelite religion(s) treated also Iron Age non-Israelite sites, and this added to the confusion.

18 For countering a possible claim that one cannot learn from the absence or rarity of such finds, see (Faust 2010, p. 30); see also (Stephens 2011). 
It appears that one possible answer is that this was probably a result of Israelite ethos and worldviews. For reasons to be recapitulated below, it was suggested by many that Israelite society had an ethos of "simplicity" and "egalitarianism", and that many overt signs of hierarchy and power were not viewed favorably. The existence of temples, and of temple personnel (i.e., official priests), transmit a clear message of hierarchy and social differentiation, and their lack (or rarity) is therefore suitable for a society that does not view signs of hierarchy positively. While it is possible that this ethos, evidence for whose existence will be presently discussed, is one of the causes for the scarcity of temples, it is important to emphasize that it is possible that other causes were perhaps directly related to Israelite religion religious practices. While a detailed discussion of Israelite religion is beyond the scope of this paper, it must be stressed that even if the rarity of temples had deeper, religious, causes, than the discussed ethos made this phenomenon socially acceptable, despite its being unique in the socio-cultural landscape of the ancient Near East.

\subsection{Israelite Ethos of Simplicity and Egalitarianism}

Many studies, on the basis of various considerations, textual and material alike, concluded that an ethos of egalitarianism and simplicity existed in Israelite society. Before focusing on the material evidence for this ethos, which is our main concern here, I should note that that many biblical scholars and historians, on the basis of various texts, claimed that Israelite society had such an ideology (e.g., Lods 1932; Wolf 1947; Albright 1961, p. 119; Mendenhall 1962; Kelso 1968, p. 48; Speiser 1971; Gordis 1971, pp. 45-60; Humphrey 1978; Gottwald 1979; Lenski 1980; Cross 1988; Berman 2008; Shapira 2009). ${ }^{19}$ While the texts are problematic sources, and each interpretation is met with counter-interpretations, the plethora of evidence for this ethos in so many biblical genres cannot be easily dismissed. Moreover, the ancient Israelites' material culture, which seems more straightforward, clearly support the existence of such an ethos. In the section below I would therefore like to present some of the material patterns that expose this ethos (for a more extensive discussion, see Faust forthcoming).

Before outlining the evidence, however, it must be stressed that we are not discussing an egalitarian society—such societies do not exist—but a society that has an ethos of egalitarianism. In such a society, many overt signs of hierarchy are not accepted, but others might be found, along with evidence for real stratification (see (Faust 2004, 2011, 2013), and many references; cf., (Parker Pearson 1982). Even pre-monarchic Israel had various form of leadership (like the elders), and this is clearly true for the stratified Iron II society, which had a full spectrum of hierarchy, from kings, though administrators, to the local elders (e.g., Reviv 1989; Faust 2012, and references). As we will see, the discussed ethos coexisted with actual stratification, and while not negating it, it did limited some expressions of hierarchy (while allowing others, cf., Stein 1994; Blanton 1998; Faust forthcoming).

\subsubsection{Lack of Royal Inscriptions}

A phenomenon that was acknowledged but only little discussed in the past is the lack of royal inscriptions in the kingdoms of Israel and Judah. We have noted that the territories of the kingdoms of Israel and Judah were excavated to a much larger extent than any other polity in the region, and have indeed yielded much larger quantities of finds of various sorts. Thus, Israel and Judah produced more ostraca than any other state in the region (e.g., Ahituv 1992). When one examines the quantity of royal inscriptions, however, the situation changes dramatically. Although not abundant in any polity, all polities in the region yielded such inscriptions (e.g., Gitin et al. 1997; Biran and Naveh 1993, 1995; McCarter 1996, pp. 84-96, and many others), with the exception of Israel and Judah (e.g., Na'aman 2002,

19 This ethos was seen as expressed in various biblical laws (like the law of the king, I Samuel 8: 7-18), passages and stories (like the story of Abimelech, Judges 9), and institutions (like the Edah; see Wolf 1947 for references). 
p. 94; Hallo 2003, pp. xxiii-xxvi; Rendsburg 2007). ${ }^{20}$ We are witnessing a strange pattern, in which the polities that were excavated much more intensively than all the others, and whose finds are much more numerous, are lacking royal inscriptions. ${ }^{21}$

This pattern cannot be an accident, as the large number of excavations indicates. I believe that in accordance with the other traits discussed in this section, the Israelite society did not generally approve of this genre (see also Stein 1994; Blanton 1998, p. 162 for a similar interpretation in a different context). ${ }^{22}$

\subsubsection{Tradition of Not Decorating Pottery}

It is well known that the Iron Age (both Iron I and II) highland pottery in particular, and the pottery in the kingdoms of Israel and Judah in general, was non-decorated (e.g., Dever 1995, p. 205; Mazar 1992b, p. 290; Bloch-Smith and Nakhai 1999, p. 76). ${ }^{23}$ While practiced already in the Iron Age I, this is much more noticeable in the Iron Age II, when many of the nearby polities/cultures did use decorated pottery, sometimes extensively (Faust 2006a, pp. 41-48; 2013). Decoration on pottery is used to convey messages of various sorts (David et al. 1988; Faust 2006a, with additional references), and the lack of any decoration is a very suitable channel not only of a message of difference from other societies, but also of egalitarianism and simplicity. Many scholars referenced the lack of decoration as a characteristic of Israelite pottery (e.g., Dever 1995, p. 205; Mazar 1992b, p. 290; Bloch-Smith and Nakhai 1999, p. 76), so the mere phenomenon does not need a detailed discussion, and I will exemplify it with Building 101 at Tel 'Eton. This residency, destroyed by the Assyrian army in the late 8th century BCE, was some $225 \mathrm{~m}^{2}$ large (on the ground floor), and ashlar stones were embedded in the structure's corners and doorways (e.g., Faust et al. 2017). The wealth of the inhabitants was expressed also in the finds within the structure, which included some 200 complete pottery vessels, including dozens of storage jars, many of which were discovered with their content, clearly indicating that large quantities of surpluses were stored in this large dwelling. Remains of cedar, imported from Lebanon, and the composition of the faunal assemblage, are also indicative of the inhabitant's wealth. Still, not a single vessel, out of some 200 pottery vessels uncovered in it, was decorated! This clearly exemplifies the phenomenon discussed here (and we will return to this example below).

What could be the explanation for the phenomenon? While a full discussion of style is beyond the scope of the present paper (e.g., Wiessner 1990; David et al. 1988; Faust 2002), suffice it here to refer, as an illuminative example, to an interesting parallel. A similar phenomenon of lack of decoration, though in a completely different time and place, was observed by Ivor Noel-Hume (1974, p. 108). He noticed that the earliest English delftware (in London) was usually elaborately decorated, but after the civil war potters began to produce undecorated plain vessels. Only after the restoration in 1660 did decorated pottery become popular again. Deetz $(1996$, p. 81) summarized this trend: "Puritan attitudes toward decoration of everyday objects might have had an effect on the delftware industry in the London area in the form of a reduction of the amount of decorated pottery before the Restoration." Deetz (1996, pp. 81-82), furthermore, attributes the lack of decoration on various artifacts in Anglo-America to Puritan attitudes. It seems to me that the situation in Iron Age Israel was

20 The Siloam Inscription does not mention the king, and cannot be regarded as royal in this sense.

21 Notably, other evidence for writing is found (like the above mentioned ostraca), so it cannot be claimed that illiteracy is the cause for the pattern.

22 Such inscriptions would probably be found in the future in some special circumstances, e.g., in non-Israelite regions of the kingdom of Israel or in palatial contexts (and rarely, perhaps even in Israelite cities or villages). The general pattern, however, seems substantial, and it is not likely to be affected by such (expected) future discoveries (cf., also Na'aman 2002, p. 94).

23 Slip and burnish are not regarded here as decoration. 
somewhat similar, and that we are witnessing a process in which an ethos, even if of a different type, is responsible for the 'simple' pottery and for the lack of decoration. ${ }^{24}$

\subsubsection{Avoidance of Imported Pottery}

Another well-known Israelite trait is the rarity of imported pottery (e.g., Dever 1995, p. 204; Bloch-Smith and Nakhai 1999, p. 76; Faust 2006a, 2006b, 2013). Obviously, this trait is much more significant in the Iron II, following the resumption of trade in the eastern Mediterranean, but is manifested in the Iron Age I by the almost total absence of Philistine pottery in the highlands. Indeed, imported pottery is extremely rare, and is often missing altogether, in Israelite sites, despite extensive evidence for trade in the very same sites (as was suggested in the past for various sites and regions, for example the Beersheba-Arad valleys in the seventh century BCE; Faust 2006a, pp. 49-64; 2006b; see also Lipschitz and Biger 1991). I will exemplify this phenomenon, again, with Building 101 at Tel 'Eton. Although cedars were discovered in the building, indicating wealth and participation in international trade, and despite additional evidence for wealth (above; see also Faust et al. 2017), not even one out of the nearly 200 complete pottery vessels unearthed in the building was imported. The rarity of imported pottery seems to reflect the same ethos of simplicity.

\subsubsection{The Lack (or Extreme Rarity) of Burials}

As already noted, hardly any Iron Age burials are known in the highlands prior to the 8th century BCE, an issue discussed at length by Kletter (2002) and myself (Faust 2004; see also Tappy 1995, pp. 65-66; Ilan 1997a, p. 385; 1997b, p. 220; Barkay 1994, p. 160, note 211; Dever 2003; Suriano 2018, pp. 59-60). This stands in sharp contrast to the Late Bronze Age in all parts of the country (highlands and lowlands; e.g., Gonen 1992a; Gonen 1992b, pp. 240-45), and to the Iron Age I in the lowlands (Bloch-Smith 1992; Kletter 2002; see also Lehmann and Varoner 2018). Tombs and burials could form an important channel for the transmission of messages of social difference and status, and they clearly served this purpose in the Late Bronze Age (e.g., Bunimovitz 1995, p. 326). While there was a variety of burials in Late Bronze Age Canaan, which could result from several reasons of which social hierarchy is but one, the Iron I lacks even the "multiple cave burials" that characterized the highland throughout most of the second millennium BCE (Gonen 1992b, p. 245), therefore breaking a continuity that prevailed through wide segments of Canaanite society for almost 800 years (Bunimovitz 1995, p. 331). Even if a few Iron I burials are identified in the highlands (Bloch-Smith 2004; see also Livingstone 2002), the general pattern is striking: during the Late Bronze Age the highlands were only sparsely settled but many tombs are known (Gonen 1992a; 1992b, p. 240-45; Eisenstadt et al. 2004; Peleg and Eisenstadt 2004; Peleg 2004), while during most of the Iron Age the area was filled with settlements, but such burials are practically absent (until the appearance of the Judahite tomb in the late 8th century BCE; Faust and Bunimovitz 2008, and many references). This means that in the kingdoms of Israel the tradition of burying only in simple inhumations prevailed until the destruction of the kingdom in the 8th century BCE. Notably, the egalitarian ethos was maintained even in the Judahite tomb, by the equal treatment accorded to all the dead (e.g., Barkay 1999, p. 97). ${ }^{25}$

Clearly, most individuals during this period were buried in simple inhumations (Faust 2004), but the lack of any observable burials is a clear reflection of an egalitarian ideology (not reality!), and exhibits a

24 Notably, this trait is very noticeable already in the Iron Age I, when it stands in contrast to the reality in the lowlands regions at the time (Faust 2006a), as well as to the situation during the closing phase of the Late Bronze Age (e.g., Franken and London 1995).

25 It is possible that the few similar tombs that were unearthed in the territories of the kingdom of Israel suggest that the tombs began to appear in the kingdom's last days, in tandem with the development of the Judahite tomb, only that the Assyrian conquests prevented its development and wider acceptance in this polity. It is more likely, however, that most such tombs in the territories of the kingdom of Israel are related to activities of Judahites in these territories during the period of Assyrian rule or even after its collapse. One way or the other, no such burials were apparently used in the kingdom of Israel during most of its existence. 
sharp contrast to Late Bronze Age Canaanite traditions. As burials have an important social role, they are a chief vehicle through which such an ideology can be expressed and channeled. ${ }^{26}$

\subsubsection{The Four-Room House}

As claimed elsewhere (Bunimovitz and Faust 2002, 2003; Faust and Bunimovitz 2003, 2014), an egalitarian ideology is reflected in the plan of the four-room house. This can be seen most clearly in an analysis of movement within this house. The four-room plan enables easy access to every room, and is lacking any hierarchy in the structuring of the rooms; unlike other dwellings (cf., Gilboa et al. 2014), there are hardly any movement restrictions, and once in the central room, one can go directly to the desired space. Again, this seems to reflect an ideology of egalitarianism.

\subsection{Israel's Ethos and Israelite Temples}

This is not the place to discuss any of these traits in details, as each of them deserves an article of its own (see also Faust 2004, 2006a, 2011; Faust and Bunimovitz 2014), but the important thing is that they all attest to the same phenomenon-that the Israelite population had an ideology of simplicity and egalitarianism (such accordance between various facets of culture is expected; see Deetz 1996; David et al. 1988, p. 378; Hodder and Hutson 2003). Thus, while society was stratified, the ideology influenced behavior in many ways that are reflected in the finds. No society is truly egalitarian, and the Israelite society was clearly not, especially during the Iron Age II (the period of the Monarchy). The ideology, however, influenced many traits, as we have seen here, and although reality was different and stratification can clearly be seen in many settlements (even if not in all, and see detailed discussion in Faust 2012), the ethos had a major influence on Israel's material culture and the extreme rarity of temples was possibly one of them. As noted above, it is possible that rarity of temples should also be examined within a more religious context, and while this question is beyond the scope of the present paper it is clear that the discussed ethos at least enabled the Israelite society accept the scarcity of temples, although it run counter to the practice in most other ancient Near Eastern societies.

While the ethos had earlier "origins" (Faust 2015), it was adopted as a major factor in Israel's self-identification in the Iron I, when society was fairly simple and the ethos was more in line with reality (although society was not egalitarian even at this time). Still, the ethos continued to be a dominant feature in Israel's self-perception also in the Iron II, and although society became more and more stratified, various material traits betray the existence of this ethos. The rarity of temples was just another reflection of this ideology, and we should attempt to understand the "local" reasons for the existence of each of the few temples that did exist, rather than assume that they are representatives. It is likely that the mere existence of this ethos made it easier, at a later stage, for society to accept the idea of a centralized cult. For our purpose, sufficient it is to note that it is likely that the ideology of egalitarianism and simplicity was one of the reasons for the scarcity of temples in Iron II Israel and Judah or, in the least, it allowed its wide-scale acceptance.

\section{Summary and Conclusions}

Temples have an important role in many periods and societies, and are therefore abundant in many cultures, dominating the cultural and even the built landscape of many regions. Still, despite the exposure of large areas_-sometimes almost complete settlements—hardly any Iron II Israelite buildings devoted to cultic activity were unearthed by archaeologists.

Given the many excavations and the large exposure of Iron II settlements in Israel and Judah-exposure that greatly exceeds that of other periods and regions-this rarity seems to be

26 For examples where burials reflect an egalitarian ethos, although the society is highly stratified, see Metcalf and Huntington (1991, p. 134) regarding Saudi Arabia, and Parker Pearson (1982) regarding England. For a detailed discussion, see (Faust 2004); forthcoming, and references. 
a significant aspect of Israelite religion. No matter how the Israelites practiced their religion, the archaeological evidence suggests that it was not usually performed in temples or buildings erected for cultic purposes. The observation that in the kingdoms of Israel and Judah built temples were rare is an important step in understanding the religious practices within those polities.

It is possible that the causes for the rarity of temples are connected to the Israelite ethos of simplicity and egalitarianism and the associated worldviews. But even if other reasons are responsible for the phenomenon, the discussed ethos is at least responsible for the acceptance of this unique type of religious expression among the Israelites. This ideology is expressed in a variety of texts, as well as in the lack (or, in the likely event that such will be discovered, in the extreme rarity) of royal inscriptions, in the extreme rarity of decoration on pottery vessels, in the extreme rarity of imported pottery, in the spatial configuration of the four-room house, and more. It is not surprising that temples, whose mere existence contradict this ideology, are also extremely rare, in accordance with this ethos. One way or the other, we must acknowledge that unlike its neighbors, Israelite cult was only rarely practiced in temples. The next step should be to study the settings in which the cult was actually practiced, both within the household (a topic that does receive some scholarly attention) and outside of it.

Acknowledgments: I would like to thank the anonymous reviewers for their comments.

Conflicts of Interest: The author declares no conflict of interest.

\section{References}

Aharoni, Yohanan. 1975. Investigations at Lachish: The Sanctuary and the Residency (Lachish V). The Emery and Claire Yass Publications in Archaeology 4. Tel Aviv: Tel Aviv University.

Aharoni, Miriam. 1993. Arad, the Israelite Citadels. In The New Encyclopedia of Archaeological Excavations in the Holy Land. Edited by Ephraim Stern. New York: Simon and Schuster, vol. 1, pp. 82-87.

Ahituv, Shmuel. 1992. Handbook of Ancient Hebrew Inscriptions from the Period of the First Commonwealth and the Beginning of the Second Commonwealth. Jerusalem: Bialik Institute. (In Hebrew)

Akkermans, Peter M.M.G., and Glenn M. Schwartz. 2003. The Archaeology of Syria: From Complex Hunter-Gatherers to Early Urban Societies (ca. 16,000-300 BC). Cambridge: Cambridge University.

Albertz, Rainer. 1994. A History of Israelite Religion in the Old Testament Period: From the Beginnings to the End of the Monarchy. Louisville: Westminster John Knox Press, vol. 1.

Albertz, Rainer, and Rudiger Schmitt. 2012. Family and Household Religion in Ancient Israel and the Levant. Winona Lake: Eisenbrauns.

Albertz, Rainer, Beth Alpert Nakhai, Saul M. Olyan, and Rüdiger Schmitt, eds. 2014. Family and Household Religion: Toward a Synthesis of Old Testament Studies, Archaeology, Epigraphy, and Cultural Studies. Winona Lake: Eisenbrauns.

Albright, William F. 1943. The Excavation of Tell Beit Mirsim, III: The Iron Age. Annual of the American Schools of Oriental Research. New Haven: ASOR, pp. 21-22.

Albright, William F. 1961. The Archaeology of Palestine. Harmondsworth: Penguin.

Albright, William F. 1993. Beit Mirsim, Tell. In The New Encyclopedia of Archaeological Excavations in the Holy Land. Edited by Ephraim Stern. New York: Simon and Schuster, vol. 1, pp. 177-80.

Alpert Nakhai, Beth. 2001. Archaeology and the Religions of Canaan and Israel. ASOR Books 7. Boston: American Schools of Oriental Research.

Alpert Nakhai, Beth. 2015. Where to Worship? Religion in Iron II Israel and Judah, 90-101. In Defining the Sacred: Approaches to the Archaeology of Religion in the Near East. Edited by Nicola Lanery. Oxford: Oxbow.

Amit, David. 1989-1990. Khirbet Jarish. Excavations and Surveys in Israel 9: 157-58. (In Hebrew)

Bahat, Dan. 1975. Excavations at Giv'at Sharett Near Beth-Shemesh. Qadmoniot 30-31: 64-67. (In Hebrew)

Bahat, Dan. 1993. Beth-Shemesh, Givat Sharet. In The New Encyclopedia of Archaeological Excavations in the Holy Land. Edited by Ephraim Stern. New York: Simon and Schuster, vol. 1, pp. 54-253.

Barkay, Gabriel. 1992. The Iron Age II-III. In The Archaeology of Ancient Israel. Edited by Amnon Ben-Tor. New Haven: Yale University Press, pp. 302-73.

Barkay, Gabriel. 1994. Burial Caves and Burial Practices in Judah in the Iron Age. In Graves and Burial Practices in Israel in the Ancient Periods. Edited by Itamar Singer. Jerusalem: Yad Ben-Zvi, pp. 96-164. (In Hebrew) 
Barkay, Gabriel. 1999. Burial Caves and Dwellings in Judah during the Iron Age II: Sociological Aspects. In Material Culture, Society and Ideology: New Directions in the Archaeology of the Land of Israel. Edited by Avraham Faust, Aren. M. Maeir and Ramat Gan. Jerusalem: Yad Ben-Zvi, pp. 96-102. (In Hebrew)

Beit Arieh, Itzhaq. 1991. The Edomite Shrine at Horvat Qitmit in the Judean Negev: Preliminary Excavation Report. Tel Aviv 18: 93-116. [CrossRef]

Beit Arieh, Itzhaq. 1995. Horvat Qitmit: An Edomite Shrine in the Biblical Negev. The Emery and Claire Yass Publications in Archaeology 11. Tel Aviv: Tel Aviv University.

Ben-Tor, Amnon. 1992. The Archaeology of Ancient Israel. New Haven: Yale University Press.

Berman, Joshua A. 2008. Created Equals: How the Bible Broke with Ancient Political Thought. Oxford: Oxford University. Biran, Avraham. 1994. Biblical Dan. Jerusalem: Israel Exploration Society.

Biran, Avraham, and Joseph Naveh. 1993. An Aramaic Stele Fragment from Tel Dan. Israel Exploration Journal 43: 81-98.

Biran, Avraham, and Joseph Naveh. 1995. The Tel Dan Inscription: A New Fragment. Israel Exploration Journal 45: $1-18$.

Blanton, Richard E. 1998. Beyond Centralization: Steps toward a Theory of Egalitarian Behavior. In Archaic Statesin Archaic States. Edited by Gary M. Feinman and Joyce Marcus. Santa Fe: Institute of Advanced Studies, pp. 135-72.

Bloch-Smith, Elizabeth. 1992. Judahite Burial Practices and Beliefs about the Dead. Sheffield: Sheffield Academic Press.

Bloch-Smith, Elizabeth. 2003. Israelite ethnicity in Iron I archaeology preserves what is remembered and what is forgotten in Israel's history. Journal of Biblical Literature 122: 401-25. [CrossRef]

Bloch-Smith, Elizabeth. 2004. Resurrecting the Iron I Dead. Israel Exploration Journal 54: 77-91.

Bloch-Smith, Elizabeth, and Beth Alpert Nakhai. 1999. A Landscape Comes to Life: The Iron I Period. Near Eastern Archaeology 62: 62-127. [CrossRef]

Borowski, Oded. 2003. Daily Life in Biblical Times. Atlanta: Society of Biblical Literature.

Broshi, Magen. 1993a. Methodology of Population Estimates: The Roman-Byzantine Period as Case Study. In Biblical Archaeology Today, 1990: Proceedings of the Second International Congress on Biblical Archaeology. Edited by Avraham Biran. Jerusalem: Israel Exploration Society, pp. 420-25.

Broshi, Magen. 1993b. The Population of Iron Age Palestine. In Biblical Archaeology Today, 1990: Pre-Congress Symposium: Population, Production and Power. Edited by Avraham Biran and Joseph Aviram. Jerusalem: Israel Exploration Society, pp. 1-14.

Broshi, Magen, and Israel Finkelstein. 1992. The Population of Palestine in Iron Age II. Bulletin of the American Schools of Oriental Research 287: 47-60. [CrossRef]

Bunimovitz, Shlomo. 1995. On the Edge of Empires-The Late Bronze Age (1500-1200 BCE). In The Archaeology of Society in the Holy Land. Edited by Thomas E. Levy. London: Leicester University Press, pp. 320-31.

Bunimovitz, Shlomo. 2019. The Late Bronze Age. In Introduction to the Archaeology of the Land of Israel from the Neolithic to Alexander's Conquests. Edited by Avraham Faust and Hayah Katz. Ra'anana: The Open University of Israel. (In Hebrew)

Bunimovitz, Shlomo, and Avraham Faust. 2002. Ideology in Stone: Understanding the Four Room House. Biblical Archaeology Review 28: 32-41, 59-60.

Bunimovitz, Shlomo, and Avraham Faust. 2003. Building Identity: The Four Room House and the Israelite Mind. In Symbiosis, Symbolism and the Power of the Past: Canaan, Ancient Israel and Their Neighbors from the Late Bronze Age through Roman Palestine. Edited by William G. Dever and Seymour Gitin. Winona Lake: Eisenbrauns, pp. 411-23.

Bunimovitz, Shlomo, and Zvi Lederman. 2009. The Archaeology of border communities: Renewed excavations at Tel Beth-Shemesh part I, the Iron Age. Near Eastern Archaeology 72: 114-42. [CrossRef]

Bunimovitz, Shlomo, and Zvi Lederman. 2013. Solving a Century-Old Puzzle: New Discoveries at the Middle Bronze Gate of Tel Beth-Shemesh. Palestine Exploration Quarterly 145: 6-24. [CrossRef]

Cohen, Rudolf, and Yigal Yisrael. 1995. The Iron Age Fortresses at En Haseva. Biblical Archaeologist 54: 223-35. [CrossRef]

Cross, Frank M. 1988. Reuben, First-Born of Jacob. Zeitschrift für die alttestamentliche Wissenschaft 100: 46-65. [CrossRef]

Dagan, Amit, Maria Eniukhina, and Aren M. Maeir. 2018. Excavations in Area D of the Lower City: Philistine Cultic Remains and Other Finds. Near Eastern Archaeology 81: 28-33. [CrossRef] 
Dar, Shimon. 1986. Hirbet Jemein-A First Temple Village. In Western Samaria in Shomron Studies. Edited by Shimon Dar and Ze'ev Safrai. Tel Aviv: Hakibutz Hameuchad, pp. 13-73. (In Hebrew)

Daviau, P.M. Michèle. 1993. Houses and their Furnishings in Bronze Age Palestine: Domestic Activity Areas and Artefacts Distribution in the Middle and Late Bronze Age. JSOT/ASOR Monographs Series 8; Sheffield: Sheffield Academic.

Daviau, P.M. Michèle. 2006. Hirbet el-Mudēyine in its Landscape, Iron Age Towns, Forts, and Shrines. Zeitschrift des Deutschen Palästina-Vereins 122: 14-30.

Daviau, P.M. Michèle, and Margreet Steiner. 2000. A Moabite Sanctuary at Khirbat al-Mudayna. Bulletin of the American Schools of Oriental Research 320: 1-21. [CrossRef]

David, Nicholas, Judy Sterner, and Kodzo Gavua. 1988. Why Pots are Decorated. Current Anthropology 29: 365-89. [CrossRef]

Deetz, James. 1996. In Small Things Forgotten, An Archaeology of Early American Life. New York: Anchor.

Dever, William. G. 1983. Material Remains and the Cult in Ancient Israel: An Essay in Archaeological Systematics. In The Word of the Lord Shall Go Forth. Edited by Carol L. Meyers and Michael O'Connor. Winona Lake: Eisenbrauns, pp. 571-87.

Dever, William. G. 1995. Ceramics, Ethnicity, and the Questions of Israel's Origins. Biblical Archaeologists 58: 200-13. [CrossRef]

Dever, William. G. 2003. Who Were the Israelites and Where Did They Come From? Grand Rapids: Eerdmans.

Dever, William. G. 2005. Did God have a Wife? Archaeology and Folk Religion in Ancient Israel. Grand Rapids: Eerdmans.

Dever, William. G. 2017. Beyond the Texts: An Archaeological Portrait of Ancient Israel and Judah. Atlanta: SBL Press.

Dothan, Moshe. 1993. Ashdod. In The New Encyclopedia of Archaeological Excavations in the Holy Land. Edited by Ephraim Stern. New York: Simon and Schuster, vol. 1, pp. 93-102.

Dothan, Trude. 2003. The Aegean and the Orient: Cultic Interactions. In Symbiosis, Symbolism and the Power of the Past: Canaan, Ancient Israel and Their Neighbors from the Late Bronze Age through Roman Palestine. Edited by William. G. Dever and Seymour Gitin. Winona Lake: Eisenbrauns, pp. 189-213.

Edelstein, Gershon. 1993. Manahat-A Bronze Age Village in Southwestern Jerusalem. Qadmoniot 103-104: 92-102. (In Hebrew)

Eisenberg, Emanuel. 1976. The Temples at Tel Kittan. Qadmoniot 36: 105-9. (In Hebrew)

Eisenberg, Emanuel. 1993a. Nahal Rephaim-A Bronze Age Village in Southwestern Jerusalem. Qadmoniot 103-104: 82-91. (In Hebrew)

Eisenberg, Emanuel. 1993b. Kitan, Tel. In The New Encyclopedia of Archaeological Excavations in the Holy Land. Edited by Ephraim Stern. New York: Simon and Schuster, vol. 3, pp. 878-91.

Eisenstadt, Irina, Khaled Arabas, and Zur Ablas. 2004. A Late Bronze Age Burial Cave at Zawata. In Burial Caves and Sites in Judea and Samaria From the Bronze and Iron Ages (Judea and Samaria Publications 4). Staff Officer of Archaeology - Civil Administration of Judea and Samaria and Israel. Edited by Hananya Hizmi and Alon De-Groot. Jerusalem: Antiquities Authority, pp. 77-106.

Falconer, Steven. 1994. Early Village Life in the Jordan Valley: A Study of Rural, Social and Economic Complexity. In Archaeological Views from the Countryside, Village Communities in Early Complex Societies. Edited by Glenn M. Schwartz and Steven E. Falconer. Washington: Smithsonian Institution, pp. 121-42.

Falconer, Steven. 1995. Rural Responses to Early Urbanism: Bronze Age Household and Village Economy at Tell el-Hayyat, Jordan. Journal of Field Archaeology 22: 399-419.

Farber, Zev. 2018. Religion in Eighth-Century Judah: An Overview. In Archaeology and History of Eighth-Century Judah. Edited by Zev I. Farber and Jacob L. Wright. Atlanta: Society of Biblical Literature, pp. 431-53.

Faust, Avraham. 2000. The Rural Community in Ancient Israel during the Iron Age II. Bulleting of the American Schools of Oriental Research 317: 17-39. [CrossRef]

Faust, Avraham. 2002. Burnished Pottery and Gender Hierarchy in Iron Age Israelite Society. Journal of Mediterranean Archaeology 15: 53-73. [CrossRef]

Faust, Avraham. 2004. Mortuary Practices, Society and Ideology: The Lack of Iron Age I Burials in Highlands in Context. Israel Exploration Journal 54: 174-90.

Faust, Avraham. 2005. The Canaanite Village: Social Structure of Middle Bronze Age Rural Communities. Levant 37: 105-25. [CrossRef]

Faust, Avraham. 2006a. Israel's Ethnogenesis: Settlement, Interaction, Expansion and Resistance. London: Equinox.

Faust, Avraham. 2006b. Trade, Ideology and Boundary Maintenance in Iron Age Israelite Society. In A Holy Community. Edited by Marcel Purthuis and Joshua Schwartz. Leiden: Brill, pp. 17-35. 
Faust, Avraham. 2010. The Archaeology of the Israelite Cult: Questioning the Consensus. Bulletin of the American Schools of Oriental Research 360: 23-35. [CrossRef]

Faust, Avraham. 2011. How Were the Israelites Buried: The Lack of Iron Age I Burial Sites in the Highlands in Context. In The Highlands Depth: Ephraim Range and Binyamin. Edited by Aharon Tavger, Zohar Amar and Miriam Billig. Research Studies. pp. 12-32.

Faust, A. 2012. The Archaeology of Israelite Society in Iron Age II. Winona Lake: Eisenbrauns.

Faust, Avraham. 2013. Decoration versus Simplicity: Pottery and Ethnic Negotiations in Early Israel. Ars Judaica 9: 7-18.

Faust, Avraham. 2015. The Emergence of Iron Age Israel: On Origins and Habitus. In Israel's Exodus in Transdisciplinary Perspective: Text, Archeology, Culture and Geoscience. Edited by Thomas E. Levy, Thomas Schneider and William H. C. Propp. Cham: Springer, pp. 467-82.

Faust, Avraham, and Shlomo Bunimovitz. 2003. The Four Room House: Embodying Iron Age Israelite Society. Near Easter Archaeology 66: 22-33. [CrossRef]

Faust, Avraham, and Shlomo Bunimovitz. 2008. The Judahite Rock-Cut Tomb: Family Response at a Time of Change. Israel Exploration Journal 58: 150-70.

Faust, Avraham, and Shlomo Bunimovitz. 2014. The House and the World: The Israelite House as a Microcosm. In Family and Household Religion: Toward a Synthesis of Old Testament Studies, Archaeology, Epigraphy, and Cultural Studies. Edited by Rainer Albertz, Beth Alpert Nakhai, Saul M. Olyan and Ruediger Schmitt. Winona Lake: Eisenbrauns, pp. 143-64.

Faust, Avraham, and Ze'ev Safrai. 2005. Salvage excavations as a source for reconstructing settlement history in Ancient Israel. Palestine Exploration Quarterly 137: 139-58. [CrossRef]

Faust, Avraham, and Ze'ev Safrai. 2015. The Settlement History of Ancient Israel: A Quantitative Analysis. Ramat Gan: Rennert Center for Jerusalem Studies, Bar-Ilan University. (In Hebrew)

Faust, Avraham, Hayah Katz, Yair Sapir, Assaf Avraham, Ofer Marder, Guy Bar-Oz, Ehud Weiss, Chen Auman-Chazan, Anat Hartmann-Shenkman, Tehilah Sadiel, Oren Vilnay, Michael Tsesarsky, Pariente Sarah, Oren Ackermann, Natasha Timmer, Ofir Katz, Dafna Langgut, and Mordechay Benzaquen. 2017. The Birth, Life and Death of an Iron Age House at Tel 'Eton, Israel. Levant 49: 136-73. [CrossRef]

Faust, Avraham. Forthcoming. Between Reality and Ideology: Revisiting Israelite Ethos of Egalitarianism and Simplicity.

Flannery, Kent V. 1976. The Early Mesoamerican Village. New York: Academic Press.

Franken, Hank M., and Gloria London. 1995. Why Painted Pottery Disappeared at the End of the Second Millennium BCE. Biblical Archaeologist 58: 214-22. [CrossRef]

Fritz, Volkmar. 1995. The City in Ancient Israel. Biblical Seminar 29. Sheffield: Sheffield Academic.

Geller, Stephen A. 2016. Priests and Ritual. In The Wiley Blackwell Companion to Ancient Israel. Edited by Susan Niditch. Chichester: John Wiley, pp. 297-316.

Gilboa, Ayelet, Ilan Sharon, and Jeffrey R. Zorn. 2014. An Iron Age Canaanite/Phoenician courtyard house at Tel Dor: A comparative architectural and functional analysis. Bulletin of the American Schools of Oriental Research 372: 39-80. [CrossRef]

Gitin, Seymour. 2003. Israelite and Philistine Cult and the Archaeological Record in Iron Age II: The "Smoking" Gun Phenomenon. In Symbiosis, Symbolism and the Power of the Past: Canaan, Ancient Israel and Their Neighbors from the Late Bronze Age through Roman Palestine. Edited by William G. Dever and Seymour Gitin. Winona Lake: Eisenbrauns, pp. 279-95.

Gitin, Seymour, Trude Dothan, and Joseph Naveh. 1997. A Royal Dedicatory Inscription from Ekron. Israel Exploration Journal 47: 1-16.

Gonen, Rivka. 1992a. Burial Patterns and Cultural Diversity in Late Bronze Age Canaan. Winona Lake: Eisenbrauns. Gonen, Rivka. 1992b. The Late Bronze Age. In The Archaeology of Israel. Edited by Amnon Ben-Tor. New Haven: Yale University Press, pp. 211-57.

Gophna, Rivka. 1979. A Middle Bronze Age II Village in the Jordan Valley. Tel Aviv 6: 28-33. [CrossRef]

Gordis, Rivka. 1971. Primitive Democracy in Ancient Israel. In Poets, Prophets and Sages, Essays in Biblical Interpretation. Edited by Robert Gordis. Bloomington-London: Indiana University Press, pp. 45-60.

Gottwald, Norman K. 1979. The Tribes of Yahweh. New York: Orbis Books.

Hagedorn, Anselm C. 2005. Placing (a) God: Central Place Theory in Deuteronomy 12 and at Delphi. In Temple and Temple Worship in Biblical Israel. Edited by John Day. London and New York: T\&T Clark, pp. 188-211. 
Hallo, William W. 2003. Introduction: The Bible and the Monuments. In The Context of the Scripture. Edited by William W. Hallo and K. Lawson Younger. Volume Two: Monumental Inscriptions from the Biblical World. Leiden: Brill, pp. xxi-xxvi.

Halpern, Baruch. 2000. Centre and Sentry: Megiddo's Role in Transit, Administration and Trade. In Megiddo III, The Emery and Claire Yass Publications in Archaeology 11. Edited by Israel Finkelstein, David Ussishkin and Baruch Halpern. Tel Aviv: Tel Aviv University, pp. 535-77.

Haran, Menahem. 1981. Temples and Cultic Open Areas as Reflected in the Bible. In Temples and High Places in Biblical Times. Edited by Avraham Biran. Jerusalem: The Hebrew Union College, pp. 31-37.

Herr, Larry G., and Douglas R. Clark. 2009. From the Stone Age to the Middle Ages in Jordan: Digging Up Tall al-'Umayri. Near Eastern Archaeology 72: 68-97. [CrossRef]

Herzog, Ze'ev. 1997. The Arad Fortresses. In Arad. Edited by Ruth Amiran, Ornit Ilan, Michael Sebanne and Zeev Herzog. Tel-Aviv: Hakibbutz Hameuchad and the Israel Exploration Society, pp. 113-292. (In Hebrew)

Herzog, Ze'ev. 1999. The Canaanite City between Ideology and Archaeological Reality. In Material Culture, Society and Ideology: New Directions in the Archaeology of the Land of Israel. Edited by Avraham Faust and Avraham Maeir. Ramat Gan: Bar-Ilan University, pp. 42-50. (In Hebrew)

Herzog, Ze'ev, and Lily Singer-Avitz. 2016. Beer-Sheba III: The Early Iron IIA Enclosed Settlement and the Late Iron IIA-Iron IIB Cities. Tel Aviv: The Institute of Archaeology, Tel Aviv University.

Hess, Richard S. 2007. Israelite Religions: An Archaeological and Biblical Survey. Grand Rapids: Baker Academic.

Hodder, Ian, and Scott Hutson. 2003. Reading the Past, 3rd ed. Cambridge: Cambridge University.

Holladay, John S. 1987. Religion in Israel and Judah under the Monarchy: An Explicitly Archaeological Approach. In Ancient Israelite Religion: Essays in Honor of Frank Moore Cross. Edited by Patrick D. Miller, Paul D. Hanson and Samuel Dean McBride. Philadelphia: Fortress, pp. 249-99.

Houston, Walter J. 2013. Pentateuch (SCM Core Text). London: SCM.

Humphrey, Sarah C. 1978. Anthropology and the Greeks. London: Routledge and Kegan Paul.

Ilan, David. 1997a. Burial Sites. In Oxford Encyclopedia of Archaeology in the Near East 1. Edited by Eric Meyers. New York: Oxford University Press, pp. 384-86.

Ilan, David. 1997b. Tombs. In Oxford Encyclopedia of Archaeology in the Near East, 5th ed. Eric Meyers. New York: Oxford University Press, pp. 218-21.

Ji, Chang-Ho. 2012. The Early Iron Age II Temple at Hirbet Atarus and Its Architecture and Selected Cultic Objects. In Temple Building and Temple Cult Architecture and Cultic Paraphernalia of Temples in the Levant (2.- 1. Mill. B.C.E.), Proceedings of a Conference on the Occasion of the 50th Anniversary of the Institute of Biblical Archaeology at the University of Tübingen, Tübingen, Germany, 28-30 May 2010. Edited by Jens Kamlah. Wiesbaden: Harrassowitz, pp. 203-21.

Kelso, James L. 1968. The Excavations of Bethel (1934-1960). AASOR 39. Cambridge: ASOR.

Kempinski, Aharon. 1992. The Middle Bronze Age. In The Archaeology of Ancient Israel. Edited by Amnon Ben-Tor. New Haven: Yale University Press, pp. 159-210.

Kessler, Rainer. 2008. The Social History of Ancient Israel: An Introduction. Minneapolis: Fortress.

Kisilevitz, Shua. 2015. The Iron IIA Judahite Temple at Tel Moza. Tel Aviv 42: 147-64. [CrossRef]

Kletter, Raz. 2002. People without Burials? The Lack of Iron I Burials in the Central Highlands of Palestine. Israel Exploration Journal 52: 28-48.

Kletter, Raz, Irit Ziffer, and Wolfang Zwickel. 2010. Yavneh I: The Excavations of the 'Temple Hill' Repository Pit and the Cult Stands (OBO 30). Fribourg and Gottingen: Academic Press and Vandenhoeck and Ruprecht.

Kletter, Raz, Irit Ziffer, and Wolfang Zwickel. 2013. Yavenh II: The 'Temple Hill' Repository Pit (OBO 30). Fribourg and Gottingen: Academic Press and Vandenhoeck and Ruprecht.

Lamberg-Karlovsky, Clifford Charles. 1985. The Near Eastern 'Breakout' and the Mesopotamian Social Contract. Symbols 8: 8-11, 23-24.

Lehmann, Gunnar, and Oz Varoner. 2018. Early Iron Age Tombs in Northern Israel Revisited. Tel Aviv 45: 235-72. [CrossRef]

Lenski, Gerhard. 1980. Review of N.K. Gottwald, The Tribes of Yahweh. Religious Studies Review 6: 275-78.

Levy, Thomas E. 2006. Archaeology, Anthropology and Cult: The Sanctuary at Gilat, Israel. London: Equinox.

Lipschitz, Nili, and Gideon Biger. 1991. Cedar of Lebanon (Cedrus Libani) in Israel during Antiquity. Israel Exploration Journal 41: 167-75. 
Livingstone, David. 2002. A Middle Bronze Age II and Iron Age I Tomb (No. 65) at Khirbet Nisya. Atiqot 43: 17-35.

Lods, Adolphe. 1932. Israel, from Its Beginning to the Middle of the Eighth Century. New York: A.A. Knauf.

Markoe, Glenn E. 2000. Phoenicians. Berkeley and Los Angeles: University of California.

Mazar, Amihai. 1980. Excavations at Tel Qasile, part one: The Philistine Sanctuary: Architecture and Cult Objects. Qedem 12. Jerusalem: The Institute of Archaeology, The Hebrew University of Jerusalem.

Mazar, Amihai. 1992a. Temples of the Middle and Late Bronze Age and the Iron Age. In The Architecture of Ancient Israel from the Prehistoric to the Persian Period. Edited by Aharon Kempinski and Hannah Katzenstein. Jerusalem: Israel Exploration Society, pp. 161-87.

Mazar, Amihai. 1992b. The Iron Age I. In The Archaeology of Israel. Edited by Amnon Ben-Tor. New Haven: Yale University Press, pp. 258-301.

Mazar, Amihai. 2006. Beth-Shean from the Late Bronze Age IIB to the Medieval Period. In Excavations at Beth-Shean 1989-96, Volume I: From the Late Bronze Age to the Medieval Period. Edited by Amihay Mazar. Jerusalem: IES and the Hebrew University of Jerusalem, pp. 26-47.

Mazar, Amihai. 2009a. Introduction and Overview. In Excavations at Beth-Shean 1989-96, Volume III: The 13th-11th Century BCE Strata in Areas N and S. Edited by Nava Panitz-Cohen and Amihay Mazar. Jerusalem: IES and the Hebrew University of Jerusalem, pp. 1-32.

Mazar, Amihai. 2009b. The Iron Age Dwellings at Tell Qasile. In Exploring the Longue Duree: Essays in Honor of Prof. Lawrence E. Stager. Edited by David Schloen. Winona Lake, Indiana: Eisenbrauns, pp. 319-36.

McCarter, P. Kyle. 1996. Ancient Inscriptions. Washington: Biblical Archaeology Society.

McNutt, Paula. 1999. Reconstructing the Society of Ancient Israel. Louisville: Westminster John Knox.

Mendenhall, George. 1962. The Hebrew Conquest of Palestine. The Biblical Archaeologist 25: 66-87. [CrossRef]

Metcalf, Peter, and Richard Huntington. 1991. Celebrations of Death, the Anthropology of Mortuary Ritual. Cambridge: Cambridge University Press.

Meyers, Carol. 2017. Contributing to Continuity: Women and Sacrifice in Ancient Israel. In Women, Religion, and the Gift: An Abundance of Riches (Sophia Studies in Cross-cultural Philosophy of Traditions and Cultures). Edited by Morny Joy. Cham: Springer, vol. 17, pp. 1-19.

Na'aman, Nadav. 2002. The Past that Shapes the Present: The Creation of Biblical Historiography in the Late First Temple Period and After the Downfall. Jerusalem: Yeriot.

Nahshoni, P. 2009a. A Philistine Temple in the Northwestern Negev. Qadmoniot 138: 88-92. (In Hebrew)

Nahshoni, Pirhiya. 2009b. Evidence for Cult in a Rural Shrine in the Northwestern Negev. Paper presented at a conference on Philistines in Southern Israel: New Studies, Ben-Gurion University, Beer-Sheva, January 14.

Niditch, Susan. 1997. Ancient Israelite Religion. New York and Oxford: Oxford University Press.

Noel-Hume, Ivor. 1974. A Guide to Artifacts of Colonial America. New York: Knopf.

Ortiz, Steven M. 2018. The United Monarchy. In Behind the Scenes of the Old Testament: Cultural, Social, and Historical Contexts. Edited by Jonathan S. Greer, John W. Hilber and John H. Walton. Grand Rapids: Baker Academic, pp. 208-15.

Ottosson, Magnus. 1980. Temples and Cult Places in Palestine. BOREAS: Uppsala Studies in Ancient Mediterranean and Near Eastern Civilizations, 12. Uppsala: Acta Universtatis Upsaliensis.

Parker Pearson, Michael. 1982. Mortuary Practices, Society and Ideology: An Ethnoarchaeological Case Study. In Symbolic and Structural Archaeology. Edited by Ian Hodder. Cambridge: Cambridge University Press, pp. 99-113.

Peleg, Yuval. 2004. Early Roman Farmhouse and Late Bronze Age Burial Cave East of Otniel. In Burial Caves and Sites in Judea and Samaria from the Bronze and Iron Ages (Judea and Samaria Publications 4). Edited by Hananya Hizmi and Alon De Groot. Jerusalem: Staff Officer of Archaeology—Civil Administration of Judea and Samaria and Israel Antiquities Authority, pp. 260-84.

Peleg, Yuval, and Irina Eisenstadt. 2004. A Late Bronze Age Tomb at Hebron (Tell Rumeideh). In Burial Caves and Sites in Judea and Samaria from the Bronze and Iron Ages (Judea and Samaria Publications 4). Edited by Hananya Hizmi and Alon De Groot. Jerusalem: Staff Officer of Archaeology—Civil Administration of Judea and Samaria and Israel Antiquities Authority, pp. 231-59.

Petit, Lucas, and Zeidan Kafafi. 2016. Beyond the River Jordan: A Late Iron Age Sanctuary at Tell Damiyah. Near Eastern Archaeology 79: 18-26. [CrossRef] 
Rendsburg, Gary. 2007. No Stelae, No Queens: Two Issues Concerning the Kings of Israel and Judah. In The Archaeology of Difference: Gender, Ethnicity, Class and the 'Other' in Antiquity. Edited by Douglas R. Edwards and C. Thomas McCollough. Boston: American Schools of Oriental Research, pp. 95-107.

Renfrew, Colin. 1985. The Archaeology of Cult: The Sanctuary at Phylakopi. London: British School at Athenes and Thames and Hudson.

Renfrew, Colin. 1994. The Archaeology of Religion. In The Ancient Mind: Elements of Cognitive Archaeology. Edited by Colin Renfrew and Ezra B.W. Zubrow. Cambridge: Cambridge University, pp. 47-54.

Renfrew, Colin, and Paul Bahn. 2012. Archaeology: Theories, Methods and Practice, 6th ed. London: Thames and Hudson.

Reviv, Hanoch. 1989. The Elders in Ancient Israel: A Study of a Biblical Institution. Jerusalem: Magnes.

Riklin, Shim'on. 1997. Bet Arye. Atiqot 32: 7-20. (In Hebrew)

Sandhaus, Débora. 2013. Hazor in the Ninth and Eighth Centuries B.C.E. Near Eastern Archaeology 76: 110-17. [CrossRef]

Schmitt, Rüdiger. 2014. A Typology of Iron Age Cult Places. In Family and Household Religion: Toward a Synthesis of Old Testament Studies, Archaeology, Epigraphy, and Cultural Studies. Edited by Rainer Albertz, Beth Alpert Nakhai, Saul M. Olyan and Rüdiger Schmitt. Winona Lake: Eisenbrauns, pp. 265-86.

Shapira, Amnon. 2009. Democratic Values in the Hebrew Bible. Tel-Aviv: Hakibbutz Hameuchad. (In Hebrew)

Smith, Mark S. 2002. The Early History of God: Yahweh and Other Deities in Ancient Israel. Grand Rapids and Cambridge: Eerdmans.

Speiser, Ephraim A. 1971. The Manner of the Kings. In The World History of the Jewish People. Edited by Benjamin Mazar. Jerusalem: Masada, vol. 3, pp. 280-287.

Stager, Lawrence E. 1998. Forging an Identity: the Emergence of Ancient Israel. In The Oxford History of the Biblical World. Edited by Michael David Coogan. New York: Oxford University, pp. 123-75.

Stager, Lawrence E. 1999. The Fortress-Temple at Shechem and the 'House of El, Lord of the Covenant. In Realia Dei: Essays in Archaeology and Biblical Interpretation in Honor of Edward F. Campbell, Jr., at His Retirement. Edited by Prescott H. Williams and Theodore Hiebert. Atlanta: Scholars Press, pp. 228-49.

Stein, Gil. 1994. Economy, Ritual and Power in 'Ubaid Mesopotamia. In Chiefdoms and Early States in the Near East: The Organizational Dynamics of Complexity. Edited by Gil Stein and Mitchell S. Rothman. Madison: Prehistory Press, pp. 35-46.

Stephens, Christopher. 2011. A Bayesian approach to absent evidence reasoning. Informal Logic 31: 46-65. [CrossRef] Stern, Ephraim, ed. 1993. The New Encyclopedia of Archaeological Excavations in the Holy Land. Jerusalem: The Israel Exploration Society and Carta.

Suriano, Matthew. 2018. A History of Death in the Hebrew Bible. New York: Oxford University Press.

Tappy, Ron. 1995. Did the Dead Ever Die in Biblical Judah. Bulletin of the American Schools of Oriental Research 298: 59-68. [CrossRef]

Vogt, Peter T. 2006. Deutronomic Theology and the Significance of Torah: A Reappraisal. Winona Lake: Eisenbrauns.

Wiessner, Polly. 1990. Is there a Unity to Style? In The Uses of Style in Archaeology. Edited by Margaret Wright Conkey and Christine Ann Hastorf. Cambridge: Cambridge University Press, pp. 105-12.

Wolf, C. Umhau. 1947. Traces of Primitive Democracy in Ancient Israel. Journal of Near Eastern Studies 6: 98-108. [CrossRef]

Wright, George Ernest. 1978. A Characteristic North Israelite House in Archaeology. In the Levant: Essays for Kathleen Kenyon. Edited by Roger Moorey and Peter Parr. Warminster: Aris \& Phllips, pp. 54-149.

Wright, George R.H. 1985. Ancient building in South Syria and Palestine. Leiden: Brill.

Zevit, Ziony. 2001. The Religions of Ancient Israel: A Synthesis of Parallactic Approaches. London and New York: Continuum. Zorn, Jeffrey. 1993a. Tell en- Nasbeh. In The New Encyclopedia of Archaeological Excavations in the Holy Land. Edited by Ephraim Stern. New York: Simon and Schuster, vol. 3, pp. 1098-102. 
Zorn, Jeffrey. 1993b. Tell en-Nasbeh: A Re-Evaluation of the Architecture and Stratigraphy of the Early Bronze Age, Iron Age and Later Periods. Unpublished Ph.D. dissertation. Berekely, CA, USA.

Zwickel, Wolfgang. 1994. Der Templkult in Kanaan und Israel (FAT 10). Tubingen: J.C.B Mohr (Paul Siebeck).

(C) 2019 by the author. Licensee MDPI, Basel, Switzerland. This article is an open access article distributed under the terms and conditions of the Creative Commons Attribution (CC BY) license (http://creativecommons.org/licenses/by/4.0/). 
Article

\title{
Archaeology and Folk or Family Religion in Ancient Israel
}

\author{
William G. Dever \\ Lycoming College, Williamsport, PA 17701, USA; gaber@lycoming.edu \\ Received: 14 November 2019; Accepted: 26 November 2019; Published: 12 December 2019
}

\begin{abstract}
This article will summarize and interpret archaeological data that may be used to illuminate the religion of ancient Israel, ca. 1200-600 BCE, while using a phenomenal approach. The resultant portrait will be compared with one drawn from the texts of the Hebrew Bible, which suggests both convergences and significant differences. The conclusion will emphasize that archaeology does best in providing a real-life context for both artifact and texts. However, it is mostly limited to religious practice, rather than belief.
\end{abstract}

Keywords: ancient Israel; Israelite religion; folk religion; family religion

\section{Introduction}

This discussion will focus on how recent archaeological excavation and research may affect our understanding or religious beliefs and practices in ancient Israel during the settlement era and the monarchy, ca. 1200-600 BCE. In particular, we shall contrast a portrait that is based on material culture remains with that derived from texts, i.e., primarily those of the Hebrew Bible.

\section{Defining Terms, and Some Caveats}

"Religion" is notoriously difficult to define; but, for the purposes of discussion, we shall regard religion here as:

A structured set of beliefs, values, symbols, and ritual practices that strives to relate the individual and society to the numinous, or the realm of the gods, perceived as the ultimate reality and authority.

A further distinction can be made, if only for heuristic reasons. The phenomenon of religion, whatever the individual peculiarities, can be analyzed by separating (1) belief and (2) practice. Such a separation has been criticized in principle, but its usefulness cannot be denied.

The former, or belief, is often systematized as theology, being usually enshrined in sacred texts, or Scripture, and overseen by clerics. This more abstract but institutionalized aspect of religion is sometimes described as "orthodoxy", presumably in contrast to more popular "folk" religion, as practiced by the majority (Ackerman 1992, pp. 1-2). The formal and institutionalized expression of religion has also been aptly characterized as "book religion" (Van der Toorn 1996, passim).

This is the "religion" of the Hebrew Bible-the ideal, never the reality throughout the Iron Age. It is the vision that is exalted of the handful of elites who wrote the Hebrew Bible. They sought to shape not only theology, but also the cult. Yet, "cult" is practice, what the majority of the population was actually doing. The real religion(s) of ancient Israel largely consisted of everything that the biblical writers condemned.

In recent discussions of the topic here, the latter, or "folk religion", is usually termed "family" or "household" religion, the focus being on what archaeology is best equipped to observe: the actual, widespread practice of religion at the household level.

Van der Toorn seems to be the first to have advanced the term "family religion" (Van der Toorn 1996). However, Berlinerblau, along with others, had already questioned such dichotomies as 
"popular" vs. "official" (Berlinerblau 1996). Earlier Holladay had coined the term "non-conformist" (Holladay 1987), but it did not find any support.

Not all the widespread practices of religion can be subsumed under the rubric of "family/household religion". What these practices have in common is that they are "non-orthodox", that is, not in conformity with what we shall call here "book religion" (following van der Toorn). Thus, Holladay's suggestion has some merit.

Now, there are a number of synthetic works employing the rubric of "family religion", (see Bodel and Olyan 2008; Albertz and Schmitt 2012; Dever 2017; and, especially many of the essays in Albertz 2014).

As we shall see, the archaeological evidence at our disposal rarely adds anything relevant to orthodox theology, except to describe in passing the historical and socio-cultural context in which the canonical texts may have first taken shape. None of that contextual information, however comprehensive, can explain or legitimize what becomes the official religion. Even that minimal contribution is only possible if the religion in question is (or claims to be) "historical". Archaeology can deal quite well with material culture remains—the physical—but by definition it cannot deal with metaphysical phenomena. Therefore, archaeology cannot comment on early Islam, because, despite the claims of traditional, non-critical Muslim historiographers, there is no known historical context of Muhammed's early life, or the composition of the Koran, or the initial spread of Islam. In contrast, since the mid-19 cent., Judaism and Christianity—both claiming to be "historical religions" — have been subjected to rigorous critical scrutiny with regard to their Scriptures. However, Islam has escaped any such scrutiny, so hoping to excavate the Qibla in Mecca, or "Muhammed's birthplace", would be irrelevant. There are some archaeological commentaries on early Judaism and Christianity, but they are beyond our purview here.

Religion, in whatever form it takes, largely deals with the metaphysical, while archaeology deals specifically with the physical world. To be sure, we assume that the things humans make and use faithfully embody their behavior, and therefore reflect their thoughts. Nevertheless, such data can only be inferred, and in any case remain speculative. As Binford reminded us, archaeologists are poorly equipped to be paleo-psychologists (Binford 1982, pp. 162-63).

Here, we shall employ a phenomenological approach that is sometimes called "functionalism", because it focuses more on what societies actually do than upon larger social theories.

Let us specify further what we mean by a "phenomenological" or "functionalist" approach. Such an approach operates, as follows:

1. It relies upon observing society directly, in action rather than in theory.

2. It does not necessarily "reconstruct", but uses typical case studies.

3. It seeks to understand society "from within" - what folks say about themselves—whether through words or symbolic actions.

4. It emphasizes individual creativity, rather than trying to develop large-scale "typologies".

5. Its objective is Geertz (1973) "thick description", not necessarily explanation.

6. It makes use of "organic models", assuming that social systems operate in some ways like biological systems (notions of interacting "subsystems", seeking and maintaining equilibrium).

7. Its methods are basically inductive, that is, working from the particular to the general, rather than deductive, or seeking "law-like generalizations".

8. It does not eschew ideology, but it assumes that the exact content of belief systems is irretrievable, although their observation is possible through inference.

\section{Previous Scholarship}

Israelite religion, like Christianity, is usually considered to be "historical", that is, rooted not in moral philosophy, or merely a sociological construct, but is instead derived from an empirically documented historical context. In our case, that would be the Iron Age in the southern Levant 
ca. $1200-600 \mathrm{BCE}$, specifically the area that is now occupied by the modern state of Israel plus the West Bank.

Despite some skeptical voices, the political, socio-economic, and cultural history of a real-life "ancient Israel" in the Iron Age in this region can now be written with some confidence-especially when the archaeological data, not the biblical texts, are taken as the primary evidence. The texts then become secondary, of limited value.

Yet, history-writing in biblical studies has not flourished in many years. That is due to the "literary turn" in biblical studies—-that is, a turn away from history-writing—which has been heavily influenced by postmodernism (Dever 2001a, pp. 1-52; see also state-of-the art treatments in Barr 2000; Collins 2005). However, we now have the first archaeologically-based history of ancient Israel, with full references to earlier literature (Dever 2017).

Ever since the beginning of modern biblical scholarship in the mid-19th century, scholars of the Hebrew Bible have assumed that the goal was first a comparative critical understanding of the text; then, based on that achievement, a more accurate history of ancient Israel; and, finally, an authoritative portrait of what was considered to be the final, enduring contribution of the Hebrew Bible: its religion. This was clearly a project of the Enlightenment, which was an essential part of the foundations of the "Western cultural tradition" (now much maligned; cf. Tarnas 1991; Gress 1998).

Not surprisingly, from the mid-19th cent. onward, numerous ambitious "histories of ancient Israelite religion" appeared. However, until the early 20th cent., none had the advantage of possessing the only possible external evidence, which was increasingly supplied by archaeology as it came of age. Most of these works were little better than paraphrases of the Hebrew Bible and thus largely useless. More lamentable still, many were Christian "Old Testament theologies"—-modern dogmatic constructs read back into the Hebrew Bible.

With no new data, works of the Religions geschicte school and of various theological and sociological approaches eventually ran out of steam. Not until recently has archaeology inspired a revival of interest in ancient Israelite religion. Even so, up to now, only a few works on Israelite religion have attempted to synthesize the burgeoning archaeological data. Among the first was Zevit's The Religions of Ancient Israel: A Parallactic Approach (Zevit 2001); and, Dever, Did God Have a Wife? Archaeology and Folk Religion in Ancient Israel (Dever 2005). These were followed in 2012 by the collaboration of two German biblicists, Albertz and Schmitt, Family and Household Religion in Ancient Israel and the Levant, a remarkably thorough work by non-specialists in archaeology.

There are also now a few other works on specific topics, as well as some brief surveys here and there. Curiously, there are no significant publications by Israeli archaeologists, although they are the closest to the data, but the reasons are beyond our purview here. Israeli archaeologists, almost all secularists, are no doubt negatively influenced by the hostility of the Orthodox toward them and their work. Thus, they tend to avoid the subject of religion altogether.

\section{An Archaeological and Phenomenological Portrait}

Turning now to recent specific archaeological data that may best illuminate the religions (sic) of ancient Israel, we shall take what we have called above a "phenomenological" approach. We must recognize that writing the history of such a religion (or any other) is beyond the limits of our evidence, even though the archaeological data are more dynamic than the biblical text,, being frozen as it is in one point in time.

This survey of the realia must be cursory and the bibliographic references kept to a minimum. We shall organize the discussion in terms of the specific categories of material culture remains.

\subsection{Temples}

We have no direct archaeological evidence of the only temple that the Hebrew Bible recognizes, which was supposedly constructed in Jerusalem by Solomon in the 10th cent. BCE. The Temple Mount has never been excavated for obvious reasons. The elaborate description in II Kings contains many 
obscure Hebrew terms. Thus, such a temple long seemed fanciful. Yet, today we have more than two dozen Bronze and Iron Age monumental Canaanite, Phoenician, Aramean, and other temples in the Levant. They provide close parallels for the plan and nearly all the decorations and furnishings of the fabled Solomonic temple (see Meyers 1992; Dever 2001a, pp. 144-47; Dever 2005, pp. 96-98; Bloch-Smith 2002; Monson 2000; Monson 2005).

The only excavated ancient Israelite temple was found in the 1960s at Arad, east of Beersheba' dating to the 8 th cent. BCE. Like the Jerusalem temple, it has a tripartite plan. In the outer, open courtyard, there is a large altar made of unhewn stones (fitting the biblical requirement). A small bronze lion was found on a low stone bench at the foot of the altar, a token animal that is associated with the old Canaanite Mother Goddess "Asherah" (below).

Flanking the entrance to the small inner sanctum (Heb. děvir) were two stylized four-horned incense altars. On the back wall stood two (originally three) large standing stones, with the biblical māșșēbôth, usually commemorating the appearance or presence of a deity-in this case, notably a pair of deities (below).

Among the other finds at Arad was a Hebrew ostracon (inscribed potsherd) that referred to "the temple of Yahweh", with Yahweh being the name of Israel's national deity here, presumably the temple at Arad. Other Arad ostraca contain the personal names of priestly families that are known from the Bible.

The standing stones were found not in situ, but carefully laid down under a secondary floor and plastered over, perhaps in the 7th cent. BCE. Some have taken this as evidence of the cult reforms attributed to King Josiah, described in detail in II Kings 23. Among his efforts was the removal from cult places the "asherahs", tree-like symbols of the goddess Asherah. If so, the Arad standing stones likely represent Yahweh and his consort Asherah (or perhaps three deities; below, see provisionally Herzog 2001; Herzog 2002; Na'aman 2002; Dever 2017, p. 497; cf. generally Zevit 2001, pp. 169-71; Dever 2005, pp. 170-75; Albertz and Schmitt 2012, pp. 123-25).

\subsection{Regional Sanctuaries}

According to the orthodox program of the biblical writers, there is only one official sanctuary, the temple in Jerusalem-although the vociferous condemnation of other sanctuaries is the best proof of their existence.

At Dan, on the extreme northern border with Israel (still today), an entire cultic complex was found, one that probably served as a regional sanctuary in the 10th-8th cent. BCE, when Dan was, in effect, the cultural capital of the northern kingdom of Israel.

The principal installations at Dan were an altar in the gate plaza with five small standing stones (Heb. māsșēbôth) and several offering bowls; a large elevated dressed stone platform, approached by a flight of steps, evidently the biblical "high place" (Heb. bāmāh), which is usually condemned as "Canaanite"; fragments of a monumental stone four-horned altar, as well as a smaller broken altar; an olive-pressing installation, for producing the appropriate oils for liturgical uses; a bronze workshop that produced, among other things, a fine offering bowl and a priestly scepter head; ceramic offering stands and bowls; and, both male and female figurines.

The Dan cult complex is a parade example of the regional sanctuaries that the Hebrew Bible expressly forbids, the ideal being, a single, central royal sanctuary in Jerusalem. In the hill country of Ephraim and Manasseh to the south, the "Bull Site" is an isolated hilltop sanctuary of the 10th century BCE. At Dan, there was even a functioning priesthood, as opposed to the official Jerusalem Levitical priests. (The material is only partially published; but see Biran 1994; Arie 2008; Zevit 2001, pp. 180-96; Dever 2005, pp. 139-51; Albertz and Schmitt 2012, pp. 221-38).

At Tell el-Farah in the Samaria hillcountry, northern Israel's first capital Tirzeh, another regional cult center was found. It featured a city gate shrine with a large standing stone and an olive press or basin; and, small finds, such as female figurines and a naos or terra cotta model temple of the sort that is usually associated with the goddess Asherah. The prominence of the gate installation, where 
many people customarily came and went, shows that this, like the Dan shrine, served a larger region. Its features included a temenos or stone enclosure wall; a paved platform; a standing stone; an altar (?); bronze, silver, and ceramic fragments; animal bones; and, a perfectly preserved bronze Zebu bull of Anatolian type, like an earlier Canaanite one found at Hazor. In the Canaanite pantheon the epithet of the principal male deity El was "Bull", the bull being an old symbol of both fertility and ferocity (Zevit 2001, pp. 176-80; Dever 2005, pp. 135-36; Albertz and Schmitt 2012, p. 234).

In Judah to the south, Cult Room 49 at Lachish, belonging to the 9th cent. BCE (the early monarchy) features a rectangular building with low benches around the walls. It was found to be filled with terra cotta offering stands; various kinds of cultic vessels; and, small stylized four-horned incense altars. Its public location suggests that it may have served a relatively large clientele (Zevit 2001, pp. 213-18; Dever 2005, pp. 116-17; Albertz and Schmitt 2012, pp. 123-25).

\subsection{Neighborhood Shrines}

These are smaller shrines, usually in small town and villages. One such installation is at Ta'anach, near Megiddo in the Jezreel Valley region, which dates to the 10th cent. BCE and contemporary with the founding of the Jerusalem temple. The "Cultic Structure" consists of a room some 25 feet square in a residential area, containing an olive press; a cistern; a bin, a basin, and trough; a hearth and an oven; ceramic vessels; iron knives; a bowl full of astragali (sheep/goat knuckle bones) for casting lots; a mold for making female figurines; and, two remarkable terra cotta offering stands with elaborate iconography, some motifs clearly connected with Asherah the "Lion Lady". In particular, the mold for mass-producing figurines suggests that this shrine may have served the whole village (Zevit 2001, pp. 235-37, 318-25; Dever 2005, pp. 151-55, 209-352; Albertz and Schmitt 2012, pp. 169-72).

"Cult Room 65" at 'Ai, north of Jerusalem, belongs to the 12th cent. BCE early Israelite settlement. It was a small mudbrick structure with low benches around the walls. Specialized cult vessels were in front of a low altar, and on the altar was a large circular fenestrated terra cotta offering stand, the windows for wafting incense, and the top with provision for a removable offering bowl. The stand is unique; around the bottom, below the fenestrations, are several clear, protruding human feet. While orthodox religion according to the Second Commandment forbids any representation of an "invisible Yahweh"; in less sophisticated circles one might at least depict his foot-a visible symbol of his cultic presence (Zevit 2001, pp. 153-156; Dever 2005, pp. 112-13; Albertz and Schmitt 2012, pp. 74-76).

\subsection{Household Shrines}

Thanks to the growing attention that is paid to the archaeological investigation of domestic areas, and especially women's roles in religious practices as in effect the de facto priests, we now have a number of Israelite household shrines.

At Megiddo, "Cult Corner 2081" of the 10th cent. Str. VA/IVB was located in the entrance hall of a large, well-constructed building. The area contained small four-horned incense altars; terra cotta offering stands; numerous ceramic vessels, some "exotic" in nature; a stone offering table; stone mortars and pestles; a bowl containing sheep/goat astragali; and, quantities of burned grain. These implements clearly reflect the use of animal and food offerings, and possibly communal feasting.

In Jerusalem, literally under the shadow of the Temple, a 7th cent. BCE domestic house on the Ophel Hill revealed a domestic shrine in Area G (L. 976) that contained miniature stone altars; grinding stones; chalices, cooking pots, and other vessels; horse-and-rider figurines; arrowheads; a ring; and, a stone weight. Additionally, from this house was a collection of bullae, or clay signet-ring impressions from the seals of papyrus scrolls (Shiloh 1986).

At Lahav (Tel Halif) in the southern Judean hillcountry, a house that ended in the 701 BCE Assyrian destruction yielded an almost intact domestic inventory. In one corner of the typical pillar-courtyard ("four-room") house (Room G 8005) were stone altars; a fenestrated offering stand; a fragmentary female figurine; and, numerous storage and cooking vessels. Elsewhere, similar items suggest that many houses possessed such cult corners (Hardin 2010, pp. 124-60; Albertz and Schmitt 2012, pp. 134-36). 
Many of the 9th-8th cent. BCE Beersheba houses produced evidence of domestic shrines, as witnessed by cultic vessels; small stone altars; animal and human female figurines; amulets and beads; cylinder seals; and, ostrich eggs (Aharoni 1973, passim).

\subsection{Shrines at Forts}

We have already discussed the temple at Arad, which is best considered, not as a "household shrine", but as a place of worship incorporated into a small hilltop fort, where probably only a few conscripted soldiers were in residence. Nevertheless, the rites of worship were probably the same as those of the families from which they came-perhaps given a special concern for personal survival, when considering the implicit dangers of being posted at this isolated border fort.

A unique sanctuary and shrine as an integral part of a fortress-cum-caravansevai (way-station) and pilgrim site is Kuntillet 'Ajrûd (Horvat Teman), in the remote southwestern Sinai desert. This remarkable 8th cent. BCE site was discovered in the late 19th cent., but it was not excavated until the 1970s, and it was only fully published in 2012.

The shrine comprises two long narrow rooms flanking the double-entryway gate, entered only via the gate threshold. These chambers feature low mudbrick benches; plastered walls; and, a favissa partitioned off beyond the back wall. There were few objects found in these two rooms, but on the plastered walls here and in the adjoining courtyard there were numerous painted Hebrew inscriptions, many of them with accompanying pictorial representations on two large storejars.

These inscriptions, although best perhaps considered as graffiti, constitute our largest corpus of non-biblical liturgical Hebrew texts. Many are blessing formulae, but they invoke, not only the name of Yahweh, but also of El, Ba'al, and Asherah.

The pictorial scenes include a lion and an iconic tree-with both symbols directly connected with the goddess Asherah. Another scene depicts a half-nude female, sitting on the sort of lion throne that elsewhere is principally associated with deities. The accompanying Hebrew inscription is a blessing formula for someone deceased that ends with the phrase "May X be blessed by Yahweh of Samaria and his Asherah".

Some scholars have taken the Hebrew term 'ašerah to simply refer to a tree-like symbol that is often associated with Asherah, not the goddess herself. However, here reading is forced, especially if the seated female depicted next to the inscription represents Asherah. To be sure, of the 40 or so times the word 'ašerah occurs in the Hebrew Bible, most do refer to a symbol of Asherah, a tree, or a wooden pole that should be chopped to pieces and burned. However, in at least five or six passages, the term 'ašerah is associated with the well known male deity Ba'al. Thus, we have "Ba'al and Asherah;" and if Ba'al is a deity here, so is Asherah (Meshel 2012; cf. Dever 1984; Olyan 1998; Hadley 2000; Becking 2001; Dever 2005, pp. 160-67; Zevit 2001, pp. 374-79).

\subsection{Cult Paraphernalia}

There are various combinations of cult paraphernalia at all the foregoing sacred places. Many of these objects functioned in ways whose meanings we can infer. The small stone altars, for instance, would have been used for food and drink offerings of the sort that are well attested in both the Hebrew Bible and Canaanite lore. Additionally, the belief or rationale behind such actions is clear: the gods have given us bountiful crops and increasing flocks, so we are obligated to return a symbolic portion. We have a few large stone altars, for animal sacrifice, such as those at Dan, where in the small shrine there are iron shovels for clearing away the ashes on the altar. However, animal sacrifice would have been costly and thus relatively rare in most rural homes.

Among the many objects that were found in the smaller shrines and domestic cultic places are quantities of storejars, chalices, and cooking pots, along with burned bones. This leads us to suppose that, in feeding the gods, one could enjoy the feast themselves, not just priests (as in the Hebrew Bible). This could then be a form of sympathic magic: insuring continued prosperity, in the company of its givers (London 2011). 
Other kinds of offerings and rites can be reconstructed from the artifacts that we have. The small four-horned altars have been shown to have been used principally for burning incense, another act that was thought to please the gods.

The large circular terra cult stands, often fenestrated and with a receptacle at the top for placing a small removable bowl, are clearly for incense and food-drink offerings.

Another kind of offering is a libation in which liquids, like water or wine (and perhaps milk), were ceremoniously poured out in the presence of the gods. This practice is illustrated by several kernoi, or "trick-vessels". A bowl has a hollow ring for a rim, to which are attached several animal heads and other symbolic objects (pomegranates). When the bowl is filled then tilted back and forth, one head can drink up the liquid while the other acts as a spout to pour it out. These kernoi derive from Philistia and are also known in Cyprus; but later, they were freely adopted in the Israelite cult (Dever 2001b).

The female terra cotta figurines are probably the most significant artifacts, but also the most enigmatic. We have more than 2000 of them, from all sorts of contexts: shrines, tombs, and especially in household assemblages. There are three principle types: (1) a nude figure holding a circular object at the breast; (2) a nude figure with a mold-made head, cupping prominent breasts; and, (3) a similar but cruder figure with the head made simply by pinching the clay.

The first type appears as early as the 10th cent. BCE; and, the circular object could be interpreted either as a sun disc, a mold-made cake, or a frame drum. The second and third types typically only appear in Judah in the late 8th-early 6th cent. BCE, during the Assyrian campaigns. These are female figurines often called "fertility figures". Albright dubbed them dea nutrix figurines. Nowadays, political correctness prefers simply to invoke notions of "plenty".

The fundamental question is identity and function: do these female figurines represent the familiar goddess Asherah; or, are they simply votives, human figures in effect symbolic "stand-ins" of the goddess? Scholarly opinion is divided, but the figurines are increasingly directly identified with the goddess herself. In this case, it would clearly be the old Canaanite mother goddess Asherah, the only female goddess that is recognized in the Hebrew Bible, whose cult we now know was widespread. The fierce denunciation of her by the biblical writers is ample evidence of the reality.

In any case, these female figurines have something to do with women soliciting the help of the goddess in conceiving bearing and nurturing babies-the ultimate and difficult task of surviving. This is what religion in the ancient world was all about for most folk: not orthodox theology, but myth and magic. As one observer has said: these are "prayers in clay" (Zevit 2001; c.f. further Kletter 1996; Hadley 2000; Meyers 2007; Darby 2014).

A final class of cultic objects commonly occur principally with burials. In tombs that are typically in the south in the 8th-7th cent. BCE, which are house-like rock-cut chambers, we have such items as valuables from every day life, such as stone and bronze tools; pottery vessels of all kinds, including lamps; various kinds of amulets; and, sometimes miniature furniture like tables and chairs. These artifacts underline the fact that these are family tombs, which have been repeatedly used for generations. In the Hebrew Bible the dead are said to have been "gathered to the fathers". It has been suggested that families may have periodically visited the tombs to feast and "feed the dead", but there is little evidence for such practices. In any case, there is some sense that the dead linger on, at least in living memory (Lewis 1989; Bloch-Smith 1992; Schmidt 1994; Osborne 2011).

\subsection{Pictorial Representations}

One aspect of phenomena that are associated with cult places and practices has often been overlooked, that is, iconography, or symbols that convey meaning through pictorial representations. The neglect may have stemmed from taking the Hebrew Bible's Second Commandment at face value: there was no art in ancient Israel, because any pictorial representation was expressly forbidden.

However, we now know that, while ancient Israelite culture was relatively aniconic when compared with that of her neighbors, there were occasional uses of visual symbols that would constitute art, and art often has connotations for religion. We have already discussed the female figurines as icons 
of some sort; and, the few naoi we have are also relevant. The "proto-Ionic" capitals at several sites employ vegetal motifs. Engraved ivory inlays from several sites borrow motifs from Phoenician art, often retaining older Canaanite concepts. The cult stand at Taanach certainly constitutes art of some sophistication. Finally, we have elaborate pictorial scenes at Kuntillet 'Ajrûd and, even though they are unique thus far, it is reasonable to expect other such discoveries. However, ancient Israelite iconography is best reflected in the numerous seals and seal impressions that we have.

There is now a considerable literature on glyptic art, with much of it stemming from the influence of the "Freibourg school", biblicists, who are also art historians. Thus, one of the most recent syntheses of the archaeological data on Israelite religion devotes a great deal of space to seals and seal impressions, not only for the personal names and offices that they contain, but also for symbols that have religious connotations (Albertz and Schmitt 2012).

Most of the symbols are borrowed of course, principally Egyptian and Mesopotamia. They reveal, in particular, how easily such "pagan" symbols—often associated with foreign deities—were introduced into the Israelite cult. Moreover, it has been shown that both the epigraphic data and the iconography of these seals are conspicuously lacking in any of the central theological themes of the Hebrew Bible (Schroer 1987; Keel 1997; Keel and Uehlinger 1998; and especially Albertz and Schmitt 2012, influenced by the "Freibourg school").

\section{Comparing the Biblical Ideal with the Archaeological Reality}

From the foregoing summary of Iron Age material culture remains, we have drawn a portrait, if not of ancient Israel religious beliefs, then of actual practices throughout Israel's 600-year history. The question is how does that portrait compare with the biblical portrait-that is, what if anything does the archaeological evidence add to our understanding?

The answer may lie in certain disconnects, places where the archaeological evidence, taken as primary here, is at variance with the biblical portrait, or it even flatly contradicts it. One instance is obvious. In the Hebrew Bible, monotheism is the norm, the only approved practice of worship, and said to have been already ordained with the Mosaic covenant with Yahweh at Sinai. However, the archaeological data now accepted by most scholars makes it clear that, in practice, most of the Israelite population practiced polytheism (or monolatry) from the settlement horizon to the exile. Only during the return of the survivors to Judah in the late 6th cent. BCE, the Persian era, did monotheism finally triumph - and that to be a disaster for the lesson to be learned. The old gods had finally failed; but, for centuries they had been adequate.

When the prophet Jeremiah rebuked the exiles in Egypt for "baking cakes for the Queen of Heaven", they replied that it was working just fine for them (Jer. 44:15-23). Additionally, most scholars now identify the Queen of Heaven as Asherah (not "Astarte", as previously).

Another tacit recognition of non-Yahwistic practices is seen in a protest of the prophet Ezekiel, who declares: "Your origin and your birth are of the land of the Canaanites; your father was an Amorite, and your mother a Hittite" (Ezek. 16).

There are other biblical passages that acknowledge the plurality of deities. In Genesis chapter 1, it said that the gods (plural in the Hebrew) declare: "Let us make mankind in our image, male and female". In the Ten Commandments, Yahweh says: "Do not have any other gods before me"; but the Hebrew text reads 'al pĕnāy, literally "in my face". There are other gods; but, you should not insult Yahweh by throwing them up in his face. In these and other biblical passages where we see "feminine" aspects of Yahweh, there may be a way of reconciling the apparent contradictions of text and artifact, that is, a way of deconstructing the biblical narrative.

In several cases, our archaeological data compliment rather than contradict the biblical portrait. The various animal, food, drink, and incense offerings that we see all comport well with biblical injunctions; but, they should only be practiced in Jerusalem under priestly supervision.

Does the more fully fleshed out portrait here, based on archaeological data, mean that we no longer need the biblical text? That is not the case. For one thing, while archaeology enables us to perform 
some forms of history-writing, such as socio-economic, cultural, and technological history, it is poorly equipped to undertake most intellectual history, since we typically lack texts. (That does not mean, as some sceptics maintain, that archaeology is "mute"). For a history of many of the main ideas about religion, we will always need the biblical texts, however limited. Fortunately, we are now discovering more and more non-biblical texts (for the non-biblical texts, see Ahituv 2008; Rollston 2010).

It must also be acknowledged that, while archaeology illuminates many religious practices more effectively than the Bible, there are often commonplace practices that we may assume, but that are not reflected in the archaeological record and not likely to be. These would include: circumcision; other rites of passage; prayers, songs, incantations, and other sayings; and, perhaps many rituals that we may imagine, whether attested in the Hebrew Bible or not.

These caveats lead us to the conclusion that, while the newer and more accurate information provided by archaeology could be helpful, it may not be essential, at least for many believers. They may sometimes seek "proofs", as were expected in the early days of the "Biblical archaeology" movement. However, in the end, literalists will manage without hard evidence by viewing the Bible through the eyes of faith. After all, many religions, for which we have no archaeological (that is, truly historical) data, do survive, and flourish. However, despite its limitations, archaeology is of some value, for many archaeologists do not hesitate to reconstruct prehistoric religion, even though we have no textual evidence.

\section{Conclusions}

Here, we have asked with reference to religion: What can archaeology do; and, what can it not do? We have stressed that archaeology's main contribution to the study of ancient Israelite religion is to provide a "real-life" context, for both the biblical text and its ideals, as well as for widespread religious practices that may not always be in accordance. However, even the most comprehensive archaeological data cannot explain, much less legitimize, Scripture and the religion it enshrines. Archaeology is descriptive, not prescriptive.

\section{Notes}

The general literature on archaeology and cult is beyond our purview here. Many of the recent discussion are part of the "archaeology of mind", "cognitive", or "cognitive-processsual" movements in the post-processual era (that is, since the 1990s). See (Hodder 1988; especially Renfrew 1982; Renfrew 1985; Renfrew 1994; Renfrew 2007; Renfrew et al. 1994; Bell 1997; Kyriakidis 2007. See also literature on "history from things", as Kingery 1996). Nevertheless, specific case-studies where there newer models have proven to be superior in "reading the past" are relatively rare.

Funding: This research received no external funding.

Conflicts of Interest: The author declares no conflict of interest.

\section{References}

Ackerman, Susan. 1992. Under Every Green Tree: Popular Religion in Sixth-Century Judah. HSM 46. Atlanta: Scholars Press.

Aharoni, Y. 1973. Beer-Sheba I. Tel Aviv: Tel Aviv University.

Ahituv, Shmuel. 2008. Echoes from the Past: Hebrew and Cognate Inscriptions from the Biblical Period. Jerusalem: Carta.

Albertz, Rainer, ed. 2014. Family and Household Religion: Toward a Synthesis of Old Testament Studies, Archaeology, Epigraphy, and Cultural Studies. Winona Lake: Eisenbrauns.

Albertz, Rainer, and Rüdiger Schmitt. 2012. Family and Household Religion in Ancient Israel and the Levant. Winona Lake: Eisenbrauns.

Arie, Eran. 2008. Reconsidering the Iran Age II Strata at Tel Dan: Archaeological and Historical Considerations. Tel Aviv 35: 6-64. [CrossRef] 
Barr, James. 2000. History and Ideology in the Old Testament: Biblical Studies at the End of a Millennium. Oxford: Oxford University.

Becking, Bob, ed. 2001. Only One God? Monotheism in Ancient Israel and the Veneration of the Goddess Asherah. New York: Sheffield Academia.

Bell, Catherine M. 1997. Ritual: Perspectives and Dimensions. Oxford: Oxford University.

Berlinerblau, Jacques. 1996. The Vow and Popular Religious Groups of Ancient Israel: A Philological and Sociological Inquiry. JSOT Supp 210. Sheffield: Sheffield University.

Binford, Lewis R. 1982. Meaning, Inference and the Material Record. In Ranking, Resource and Exchange: Aspects of Early European Society. Edited by Collin Renfrew and Stephen J. Shennan. Cambridge: Cambridge University, pp. 160-63.

Biran, Avraham. 1994. Biblical Dan. Jerusalem: Israel Exploration Society.

Bloch-Smith, Elizabeth. 1992. Judahite Burial Practices and Beliefs About the Dead. JSOT/ASOR Monograph Series 7; Sheffield: JSOT.

Bloch-Smith, Elizabeth. 2002. Solomon's Temple: The Politics of Ritual Space. In Sacred Time, Sacred Space: Archaeology and the Religion of Israel. Edited by Barry M. Gitlen. Winona Lake: Eisenbrauns, pp. 83-94.

Bodel, John, and Saul M. Olyan, eds. 2008. Household and Family Religion in Antiquity. Malden: Blackwell.

Collins, John J. 2005. The Bible After Babel: Historical Criticism in a Postmodern Age. Grand Rapids: Eerdmans.

Darby, Erin D. 2014. Interpreting Judean Pillar Figurines: Gender and Empire in Judean Apotropaic Ritual. FAT 2:69. Tübingen: Mohr Siebeck.

Dever, William G. 1984. Asherah, Consort of Yahweh? New Evidence from Kuntillet Ajrud. Bulletin of the American Schools of Oriental Research 255: 27-37. [CrossRef]

Dever, William G. 2001a. What Did the Biblical Writers Know and When Did They Know It? What Archaeology Can Tell Us about the Reality of Ancient Israel. Grand Rapids: Eerdmans.

Dever, William G. 2001b. Iron Age Kernoi and the Israelite Cult. In Studies in the Archaeology of Israel and Neighboring Lands. Edited by Samuel R. Wolf. Chicago: Oriental Institute, University of Chicago, pp. 119-31.

Dever, William G. 2005. Did God Have a Wife? Archaeology and Folk Religion in Ancient Israel. Grand Rapids: Eerdmans.

Dever, William G. 2017. Beyond the Texts: An Archaeological Portrait of Ancient Israel and Judah. Atlanta: SBL Press.

Geertz, C. 1973. The Interpretation of Cultures. New York: Basic Books.

Gress, David. 1998. From Plato to NATO. The Idea of the West and Its Opponents. New York: Free Press.

Hadley, Judith M. 2000. The Cult of Asherah in Ancient Israel and Judah: Evidence for a Hebrew Goddess. University of Cambridge Oriental Publications 57. Cambridge: Cambridge University Press.

Hardin, James Walker. 2010. Households and the Use of Domestic Space at Iron II Tell Halif: An Archaeology of Destruction (Lahav II). Winona Lake: Eisenbrauns.

Herzog, Zeev. 2001. The Date of the Temple at Arad: Reassessment of the Stratigraphy and the Implications for the History of Religion in Judah. In Studies in the Archaeology of the Iron Age in Israel and Jordan. JSOTS up 331. Edited by Amihai Mazar. Sheffield: Sheffield Academic Press, pp. 156-78.

Herzog, Zeev. 2002. The Fortress Mound at Tel Arad: An Interim Report. Tel Aviv 29: 3-109. [CrossRef]

Hodder, Ian. 1988. Reading the Past: Current Approaches to Interpretation in Archaeology. Cambridge: Cambridge University.

Holladay, John S. 1987. Religion in Israel and Judah under the Monarchy: An Explicitly Archaeological Approach. In Ancient Israelite: Essays in Honor of Frank Moore Cross. Edited by Patrick P. Miller, Paul D. Hanson and S. Dean Macbride. Philadelphia: Westminster John Knox, pp. 249-99.

Keel, Othmar. 1997. The Symbolism of the Biblical World: Ancient Near Eastern Iconography and the Book of Psalms. Winona Lake: Eisenbrauns.

Keel, Othmar, and Christoph Uehlinger, eds. 1998. God, Goddesses, and Images of God in Ancient Israel. Minneapolis: Fortress Press.

Kingery, W. David, ed. 1996. Learning from Things: Method and Theory of Material Culture Studies. Washington: Smithsonian Institution.

Kletter, R. 1996. The Judean Pillar Figurines and the Archaeology of Asherah. Oxford: BAR International Series.

Kyriakidis, Evangelos, ed. 2007. The Archaeology of Ritual. Cotsen Advanced Seminar 3. Los Angeles: Cotsen Institute of Archaeology, University of California, Los Angeles.

Lewis, Theodore J. 1989. Cults of the Dead in Ancient Israel and Ugarit. HSM 30. Atlanta: Scholars Press. 
London, Gloria. 2011. A Ceremonial Center for the Living and the Dead. Near Eastern Archaeology 74: 216-25. [CrossRef]

Meshel, Zeev. 2012. Kuntillet 'Ajrud (Horuat Teman): An Iron Age II Religious Site on the Judah-Sinai Border. Jerusalem: Israel Exploration Society.

Meyers, Carole L. 1992. Temple, Jerusalem. In Anchor Bible Dictionary. Edited by David Noel Freedman. New York: Doubleday, vol. 6, pp. 350-69.

Meyers, Carole L. 2007. Terra Cottas without Texts: Judean Pillar Figurines in Anthropological Perspective. In To Break Every Yoke: Essays in Honor of Marvin Chaney. Edited by Robert B. Coote and Norman K. Gottwald. Sheffield: Sheffield Phoenix, pp. 115-30.

Monson, John. 2000. The New 'Ain Dara Temple: Closest Solomonic Parallel. Biblical Archaeology Review 26/3: 20-35.

Monson, John. 2005. Solomon's Temple. In Dictionary of the Old Testament Historical Books: A Compendium of Contemporary Scholarship. Edited by Bill T. Arnold and Hugh G. M. Williamson. Downers Grove: Intervarsity Press, pp. 929-35.

Na'aman, Nadar. 2002. The Abandonment of Cult Places from the First Temple Period. Ugarit-forschungen 34: 585-602.

Olyan, Saul M. 1998. Asherah and the Cult of Yahweh in Israel. SBLMS 34. Atlanta: Scholars Press.

Osborne, James F. 2011. Secondary Mortuary Practice and the Bench Tomb: Structure and Practice in Iron Age Judah. Journal of Near Eastern Studies 70: 35-53. [CrossRef]

Renfrew, Colin. 1982. Towards an Archaeology of Mind: An Inaugural Lecture Before the University of Cambridge on 30 November 1982. Cambridge: Cambridge University.

Renfrew, Colin. 1985. The Archaeology of Cult: The Sanctuary at Phylakapi. British School of Archaeology at Athens Supplementary Volume 18. London: British School of Archaeology at Athens.

Renfrew, Colin. 1994. Towards a Cognitive Archaeology. In The Ancient Mind: Elements of Cognitive Archaeology. Edited by Colin Renfrew and Ezra B. W. Zubrow. Cambridge: University of Cambridge.

Renfrew, Colin. 2007. The Archaeology of Ritual, of Cult, and of Religion. In The Archaeology of Ritual. Bristol: ISD LLC, pp. 109-22.

Renfrew, Colin, Ezra B. W. Zubrow, and Francoise Audouze, eds. 1994. The Ancient Mind: Elements of Cognitive Archaeology. Cambridge: Cambridge University.

Rollston, Christopher A. 2010. Writing and Literacy in the World of Ancient Israel: Epigraphic Evidence from the Iron Age. ABS 11. Atlanta: Society of Biblical Literature.

Schmidt, Brian B. 1994. Israel's Beneficent Dead: Ancestor Cult and Necromancy in Ancient Israelite Religion and Tradition. FAT 11. Tubinger: Mohr Siebeck.

Schroer, Sylvia. 1987. Israel Gab es Bilder: Nachrichten von darstellender Kunst in Alten Testament. OBO 74. Göttingen: Vandenhoeck \& Ruprecht.

Shiloh, Y. 1986. A group of Hebrew bullae from the City of David. Israel Exploration Journal 36: 16-38.

Tarnas, Richard. 1991. The Passion of the Western Mind: Understanding the Ideas That Have Shaped Our World View. New York: Ballantine.

Van der Toorn, Karel. 1996. Family Religion in Babylonia, Syria, and Israel: Continuity and Change in the Forms of Religious Life. SHANE 7. Leiden: Brill.

Zevit, Ziony. 2001. The Religions of Ancient Israel: A Synthesis of Parallactic Approaches. London: Continuum.

(C) 2019 by the author. Licensee MDPI, Basel, Switzerland. This article is an open access article distributed under the terms and conditions of the Creative Commons Attribution (CC BY) license (http://creativecommons.org/licenses/by/4.0/). 

Article

\title{
Women in Israelite Religion: The State of Research Is All New Research
}

\author{
Beth Alpert Nakhai \\ Arizona Center for Judaic Studies, The University of Arizona, Tucson, AZ 85721, USA; \\ bnakhai@email.arizona.edu
}

Received: 5 January 2019; Accepted: 21 January 2019; Published: 19 February 2019

\begin{abstract}
Historically, those studying Israelite religion have ignored the existence of women in Iron Age Israel (1200-587 BCE). They have, therefore, accounted neither for the religious beliefs of half of ancient Israel's population nor for the responsibilities that women assumed for maintaining religious rituals and traditions. Such reconstructions of Israelite religion are seriously flawed. Only in the last four decades have scholars, primarily women, begun to explore women's essential roles in Israel's religious culture. This article utilizes evidence from the Hebrew Bible and from archaeological sites throughout Israel. It demonstrates that some women had roles within the Jerusalem Temple. Most women, however, resided in towns and villages throughout the Land. There, they undertook responsibility for clan-based and community-based religious rituals and rites, including pilgrimage, seasonal festivals, rites of military victory, and rites of mourning. They fulfilled, as well, essential roles within the sphere of domestic or household religion. At home, they provided medico-magical healing for all family members, as well as care for women and babies throughout pregnancy, childbirth, and beyond. They, and the men in their communities, worshipped Yahweh, Israel's primary deity, and the goddess Asherah, as well; for most people, these two divinities were inextricably linked.
\end{abstract}

Keywords: religion; women; Israel; Judah; Iron Age; domestic religion; family religion; rituals; worship; Jerusalem Temple; feminist studies; archaeology; Hebrew Bible; Old Testament; Yahweh; Asherah

European and American exploration of Ottoman Palestine in the nineteenth and early-twentieth century was fueled, to a great extent, by an interest in Israelite religion, since the Lands of the Bible were understood to hold foundational truths about what was commonly understood as the inevitable supremacy of Christianity. The whole region, from the Levantine coast to ancient Ur, was seen as the geographic and spiritual backdrop to the story of Jesus, a story that highlights exemplary acts by a number of women. How ironic it is, then, that the scholars who engaged in the study of ancient Israel felt no compunction about disregarding the existence of women within Israel's population, thereby eliminating (inter alia) women's engagement with religion as a topic of discussion. What this means is that most of what scholars have assumed they knew about Israelite religion is wrong, because it has excluded consideration of women (and children), that is, consideration of more than half the population of ancient Israel. It also means that almost everything known today about women's participation in Israelite religion is newly acquired knowledge. This paper considers the problems created by the exclusion of women from reconstructions of ancient Israel. It then presents a more complete reconstruction, one that incorporates both archaeological and biblical evidence to highlight the spiritual and ritual worlds of women in Iron Age Israel (1200-587 BCE).

\section{What Does Traditional Scholarship Look Like?}

Only in the past four decades have women populated scholarly reconstructions of ancient Israel life, whether religious, or historical, or anything else. And this is not to say that in the past forty years, women have been included in all reconstructions of Israel's past. It has been surprisingly 
easy, for example, for (male) biblical scholars and archaeologists to write about "daily life" - the quotidian responsibilities upon which all of life's grand activities are predicated-and to exclude women (Nakhai 2005). One has to wonder who they thought was doing all that work. As easy as it has been to exclude Israelite women when discussing the responsibilities and chores of daily life, easier still has it been to exclude their active role in Israelite religion (Nakhai 2007). This point is particularly critical because there is, in many people's eyes, a direct link between the religion of ancient Israel and modern-day Judaism and Christianity; therefore, reconstructions of women's roles in biblical antiquity have influenced expectations for women's roles in contemporary society. ${ }^{1}$

What accounts for the unduly limited attention that traditional scholarship has paid to religious ritual and belief as experienced by Israelite women? This question must be answered in the first place by stressing that it is not correct to assume-as scholars have traditionally done- that women did not matter in ancient religion. As it turns out, the near-absence of women in the Bible is not because women had no religious lives, but rather because women were not players within the monarchical, prophetic, priestly, scribal, and other dominant communities that crafted the demonstrably androcentric Bible. ${ }^{2}$ However, the narrow lens of the Hebrew Bible has been, until recent decades, the primary lens through which scholars have engaged with Israelite religion.

Who, we next ask, are the scholars who so misrepresented the roles of women in Israelite religion? Whether priests, ministers, rabbis, or professors, whether seminary-educated or university-trained, they have generally been men who owed their intellectual heritage to that long line of male scholars who began writing sacred text in Israel's Iron Age and who have been interpreting it ever since. Just as men monopolized religious leadership from ancient times to modernity, so too have men dominated the study of ancient Israel and its religion. Like biblical scholars, archaeologists (who have often held theological degree), have typically focused on bastions of male authority and elite governance, choosing to excavate palaces and temples, city walls and gates. In short, the exclusion of Israelite women as a topic of scholarly study has been, albeit unwittingly, predicated upon a belief system that has supported male privilege and suppressed women's agency, meaning that the biases of the past have been perpetuated in the present.

What, then, have such reconstructions of Israelite religion looked like? They have been, in short, androcentric, favoring men, the Temple and its priests, the Jerusalem royalty, and other elites. ${ }^{3}$ They have accepted the biblical trope that vilifies the practice of community and private religion and as they do so, they have perpetuated the erasure of women from the story of Israel. ${ }^{4}$ The cumulative impact of these factors upon the reconstruction of women's roles in ancient Israelite religion is clear. The marginalization of women's roles in ancient religion has served to validate the marginalization of women throughout the millennia.

\section{Now: What Does Contemporary Scholarship Look Like?}

As is well documented, it is women who most often engage in gender-related discussions, whether they are advocating for gender equity in the workplace and at home, or reconstructing the lives of

1 For a discussion of the negative consequences of this approach, as found in European (primarily German) biblical scholarship, see Albertz (1994, pp. 1-17).

2 For the challenges faced when utilizing the Hebrew Bible to reconstruct the lives of Iron Age women, see Nakhai (2007, 2018a, pp. 195-99).

3 Ismar J. Peritz's 1898 article, "Women in the Ancient Hebrew Cult," is a rare exception. Peritz (1898) endeavored to identify every biblical reference to women's religious activities. He considered women's participation in religion to have been legitimate, and he criticized those scholars who dismissed women's agency in cultic and ritual matters.

4 Two examples make the point. William F. Albright, the "father of biblical archaeology," included nothing whatsoever about women's religious practices or beliefs in his highly influential Archaeology and the Religion of Israel (Albright 1942). In his classic study, Ancient Israel: Its Life and Institutions, Roland de Vaux restricted his consideration of women to only a few biblically determined social categories: wife, divorcée, widow, and slave (de Vaux 1961). 
women in antiquity. ${ }^{5}$ Change is afoot, though, since in the twenty-first century, men have begun to join women in the study of ancient women. Our brief overview of scholarship on women in Israelite religion looks at the 1970s and beyond, the decades in which women began their assault on what had been male hegemony over the study of the Hebrew Bible and the New Testament. ${ }^{6}$ Feminist biblical scholars have engaged in a two-pronged approach: identifying women in scripture and amplifying their voices, and challenging the notion of male dominance and patriarchy to the exclusion of women's authority and agency. Among the first were Trible $(1973,1979,1984)$ and Bird $(1974,1987)$; other important contributions soon followed (see, inter alia, Bal 1989; articles in Day 1989b; Exum 1993; Newsom and Ringe 1992; Brenner 1993 and subsequent volumes; Meyers 2000). ${ }^{7}$

What about the archaeological contribution? Already in 1984, Conkey and Spector (1984) had published "Archaeology and the Study of Gender," which systematically addressed the subject of gender within the field of archaeology. Several years later, Carol Meyers published Discovering Eve: Ancient Israelite Women in Context, integrating archaeology with biblical studies in its reconstruction of women's lives; spiritual and ritual dimensions were among the topics explored (Meyers 1988, 2005, 2012). In 1997, Conkey and Gero (1997) emphasized the "the centrality of feminist thought" to all aspects of archaeological method and theory, and discussed an "explosion of literature on archaeological gender" (p. 413). In the study of ancient Israel, and especially of Israelite religion, there is now some sense of this "centrality" - but even now, one would be hard-pressed to experience the "explosion."

Archaeological data is not curated. Material culture, the remnants of myriad lives lived, has an unpredictable quality. It does not "speak" to reality; rather, it reflects realities that otherwise remain unseen. Inanimate objects require archaeologists to give them voice and this means that, just as occurs with ancient texts, the physical past can be misunderstood. That said, archaeologists have begun to alter our understanding of women's religious beliefs and ritual practices. Their "discovery" of Israelite women has gone hand-in-hand with their "discovery" of non-elite men and rural communities; recently, attention is being paid to children, as well (Garroway 2014, 2018). Evidence for these groups is best revealed through household, family, or domestic archaeology (see, inter alia, Daviau 1993; Albertz 1994; Hardin 2010; articles in Yasur-Landau et al. 2011; Dever 2012; see also Perdue et al. 1997). ${ }^{8}$ As it turns out, women's household tasks and responsibilities are made evident, and so, too, are their acts of domestic piety. It is in the domestic sphere that women's agency, whether practical or spiritual, was most clearly articulated—and is now being illuminated through recourse to artifactual and architectural remains (see, inter alia, van der Toorn 1994, 1996; Daviau 2001; articles in Bodel and Olyan 2008; Meyers 2010; Albertz and Schmitt 2012; articles in Albertz et al. 2014).

\section{Women in Ancient Israelite Religion}

What does a reconstruction of Israelite religion that includes women look like? Two points are, perhaps, the most fundamental. The first is that, under the broad umbrella of religion, women and men did not have the same roles, but together they shared responsibility within the spheres of ritual and belief as they endeavored to ensure the well-being of their families, their kin groups, and their nation. The second is that, notwithstanding biblical attestations to the contrary, Israelite religion was not devoted exclusively to Israel's male deity, Yahweh (the LORD). Rather, the goddess Asherah was worshiped alongside Yahweh; the worship of both deities was essential to some-although not to

5 At the same time, not all women study ancient women, nor should they be expected to. For the challenges faced by women working in Near Eastern archaeology, see Nakhai (2018a, pp. 291-95).

6 For a history of women engaged in biblical interpretation, see (Newsom 1992; Bellis 2000).

7 See Bellis (2007), which contains an overview of women in the Bible. Essential to this overview is Bellis's presentation of-and engagement with-the ideas of a wide range of female scholars who have published books and articles on biblical women.

8 Albertz notes that "... the personal piety of family members constituted a specific stratum of beliefs and ritual practices within the religion of ancient Israel and Judah," prior to and during the Monarchy (Albertz 2010, p. 135; see also Albertz 1994). 
all-members of the community of Israel (Freedman 1987; Olyan 1988; Hadley 2000; Ackerman 2003a; Meyers 2005; Dever 2005). Biblical passages and archaeological evidence suggest that Asherah was worshipped not only in Jerusalem and Judah, in the south, but also at the Israelite cult centers of Samaria, Bethel, and Dan, in the north (1 Kgs 16:33; 2 Kgs 13:6, 17:16, 23:15; Amos 8:13-14; for the inscription from Kuntillet 'Ajrud in the Sinai Desert, which mentions "Yahweh of Samaria and his Asherah, see (Dever 1984; Freedman 1987). ${ }^{9}$ Other deities, including Baal (inter alia, 1 Kgs 16:31-32, 18:19; 2 Kgs 21:3), the Queen of Heaven (Jer 7:17-18, 44:17-19), and Tammuz (Ezek 8:14), were worshipped by some, as well. ${ }^{10}$

At the pilgrimage site of Shiloh in the Central Highlands, Israel's heartland in its formative period (Iron Age I; 1200-1000 BCE), excavators uncovered ritual objects, although the sanctuary itself no longer exists (Nakhai 2001, p. 171). Biblical stories testify to women worshipping there.

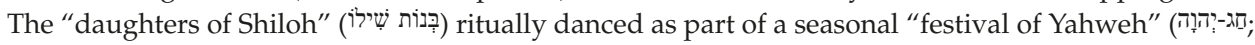
Judg 21:19-21), while Penninah and Hannah, together with their husband Elkanah, went to Shiloh on annual pilgrimages to "bow down and sacrifice to Yahweh of Hosts" (1 Sam 1:1-28). A contemporary open-air sanctuary, now called the Bull Site, was excavated in the hills of Manasseh, farther to the north (Nakhai 2001, pp. 170-71). These and other pilgrimage sanctuaries, some of which are known from the Bible (for Bethel, see, inter alia, 1 Sam 10:3-5; for Gilgal, see, inter alia, 1 Sam 10:8, 11:14-16), were maintained by priests; however, as the narratives about the Shiloh sanctuary make clear, women were not excluded from worshipping at them. Indeed, it was Micah's unnamed mother who underwrote

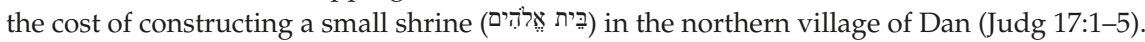

From early in the Monarchy (Iron Age II; 1000-587 BCE), worship in Israel and Judah took place in multiple venues, including the Temple in Jerusalem, officially sanctioned places of worship throughout the land, pilgrimage sanctuaries, village shrines, housing compounds, and individual homes (Nakhai 2001, pp. 176-93; Nakhai 2015; Schmitt 2014). ${ }^{11}$ The Bible describes religious rituals that were carried out both at mandated times, especially within the Temple, and in response to specific needs such as funerals or celebrations of military victories (see, inter alia, Nakhai 2001, pp. 44-73; Meyers 2005; Ackerman 2016). Some religious figures, including prophets and seers, necromancers and diviners, did not operate from officially sanctioned sites. A brief overview illuminates the roles women fulfilled within the broad spectrum of Israelite religion.

The dominant biblical voice, articulated by Temple priests, Deuteronomists, Ezra and Nehemiah, and many others, demanded the worship of Yahweh alone and advocated for the exclusivity of Temple worship. While men and women alike were commanded to worship Yahweh (Ex 20:1-2; Deut 5:6), only men from the lineage of Zadok, the first of the Temple priests (1 Kgs 2:35, 4:1-4), could officiate at the Temple. However, several passages indicate that some women fulfilled circumscribed roles within

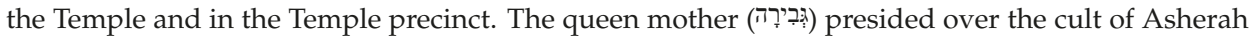
(1 Kgs 15:13), which was celebrated within the Temple (2 Kgs 18:4; 2 Kgs 21:7, 23:6), while women, working within the Temple precinct, wove garments for the cult statue (2 Kgs 23:7; Ackerman 2003b). ${ }^{12}$ They may, as well, have played drums in musical processions within the Temple (Ps. 68:26; Ackerman 2003b). A poorly understood form of Temple engagement (קָּזָּ); commonly [mis]translated as Temple

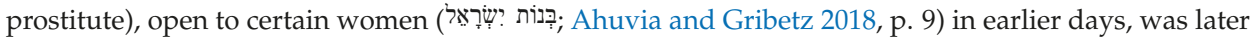
forbidden to them (Deut. 23:18). By the time of the Temple's destruction by the Babylonians, some women within the Temple precinct lamented the god Tammuz (Ezek 8:14).

9 For further discussion of Asherah in Jerusalem and, additionally, Anat at Bethel and Astarte at Dan, all three of them linked to Yahweh, see Freedman (1987).

10 See Ackerman (1992, pp. 37-99) for a discussion of this passage, which concludes that some women worshipped the god Tammuz. Zevit, on the other hand, suggests that the reference is to a certain kind of ritual wailing rather than to the worship of a specific deity (2001, pp. 555-61).

11 The Jerusalem Temple was constructed by Solomon (mid-10th c. BCE; 1 Kgs 6:1-8:65) and destroyed by the Babylonians (587 BCE; 2 Kgs 25:8-9). For a recent discussion of "popular" and "official" religion, see Stavrakopoulou (2010).

12 This statue was sometimes described as a sacred pole, symbolic of the Tree of Life (Deut 16:21). 
Women participated in public ceremonies in Jerusalem. These include the sacred celebrations when David brought the Ark to Jerusalem (2 Sam 6:1-17), and when Solomon placed the Ark in his newly constructed Temple (1 Kgs 8:1-14, 65-66). In the late-eighth century, the era of King Hezekiah and the prophet Isaiah, a new code of law (now, Deut 12-26) was adopted in Jerusalem (2 Kgs 18:1-6). From here on, women were included in the injunction to celebrate pilgrimage festivals and share in sacral meals, not only within their communities but also in the Temple precinct (Deut 12:12, 18; 14:22-26; 15:19-23; 16:9-15). While the Bible provides no description of the public ceremony in which Hezekiah's covenant was adopted, it does describe women participating in a comparable covenant ceremony a century later, when King Josiah reestablished Hezekiah's code of law (2 Kgs 23:1-3).

A number of biblical passages make it clear that the Monarchy facilitated worship at a limited number of sanctuaries throughout the Land (1 Kgs 12:31; $2 \mathrm{Kgs}$ 23:5). One such sanctuary has been discovered at the military fortress at Arad; at Beersheba, some $40 \mathrm{~km}$ due west, the remains of a massive stone four-horned altar were found. Lachish, Judah's second largest city, contained a small, bench-lined sanctuary filled with ritual objects. In the north, assemblages of ritual objects were found at Megiddo, an Israelite administrative center. Royal sanctuaries at Dan and Bethel are described in the Bible (inter alia, $1 \mathrm{Kgs} \mathrm{12:28-30);} \mathrm{finds} \mathrm{from} \mathrm{Dan} \mathrm{support} \mathrm{that} \mathrm{narrative.} \mathrm{While} \mathrm{ritual} \mathrm{objects} \mathrm{vary} \mathrm{from}$ site to site, overall, they included something from the following: massive stone four-horned altars;

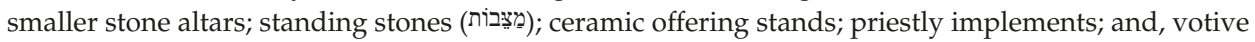
vessels. As at the Temple, worship at these sites was likely restricted to men; at Arad and Beersheba, inscriptions on ostraca link their priests to those at the Jerusalem Temple. At the same time, the paired altars and standing stones in the Holy of Holies of the Arad sanctuary intimate the worship of Asherah alongside Yahweh (Holladay 1987; Nakhai 2001, pp. 177-87; Nakhai 2011, 2015, pp. 91-92; Zevit 2001, pp. 122-349; Schmitt 2014).

The Bible also gives witness to a multiplicity of smaller shrines on hilltops and within villages throughout the Land (see, inter alia, 2 Kgs 17:9-11). Before the Temple was constructed, these shrines-like the pilgrimage sanctuaries at Shiloh, Bethel, Gilgal, and elsewhere-had raised no concerns. ${ }^{13}$ David, for example, went to Bethlehem, his family's village, to participate in a familial festival of sacrifice (1 Sam 20:5-7, 28-29). Given what is known about women worshipping at Shiloh, it is likely that in Bethlehem too, the women in the family participated alongside the men. In the days of the kings, as Israel's population grew, the number of small, local places of worship would have increased accordingly. Israel's long-established social structure, which emphasized the tribe (שָׁ) ), clan

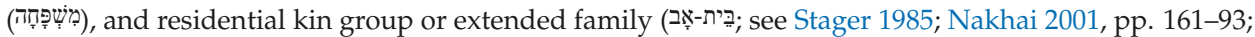
Dever 2012, pp. 156-58; Faust 2012, pp. 172-74), meant that the traditional, pre-monarchical, modes of worship flourished during the Monarchy. The oft-repeated Deuteronomistic condemnation of local places of worship, over which the Jerusalem priesthood had no control-and perhaps, in reality, made no effort to control until the Deuteronomistic reforms of the era of Isaiah and Hezekiah (Deut 12-26; 2 Kgs 18:22) and, a century later, of Josiah (2 Kgs 22:8-23:25) — attests to their widespread popularity.

It is in these village settings that women's participation in religious rituals is most evident. Several points are particularly relevant. The first is that community and family worship was the exclusive province neither of men nor of women. Their essential concerns, concerns about which one would entreat the Divine, were for health, sustenance, and progeny, and these were concerns shared by everyone. Elders in towns and villages, heads of households, and individuals as well, all shared responsibility for the physical—and hence spiritual—maintenance of the community (Nakhai 2011). This means that no one was exempt from religious responsibilities, although those responsibilities would have varied according to social status and gender. A passage in Jeremiah, in which (so the story goes) the people of Judah, in exile in Egypt after the Babylonian destruction of their Temple and their homeland, turn against the prophet, highlights the shared responsibilities of the entire

13 For the agricultural roots of Israel's pilgrimage festivals, see Albertz (1994, pp. 82-91). 
community-women and men, royalty, elite and commoners, in Jerusalem and throughout the Land-in worship rituals (Jer 44:15-19).

Extensive archaeological evidence has clarified what the Bible only hints at, by means of condemnation (e.g., 2 Kgs 17:9-11), that religion was practiced not only in state-sponsored sanctuaries, but also in community and domestic settings, and at burial sites. In towns such as Mizpah (Tell en-Nasbeh), Tirzah (Tell el-Far'ah [N]), and Rehov (Tel Rehov), simple "shrines of the elders" were fashioned within housing complexes for use by extended families (Nakhai 2011). The common assumption that "elders" (זٓקנים) were men fails to consider the fact that the Hebrew "masculine" plural can include women. It also ignores those biblical passages that highlight the responsibility that all

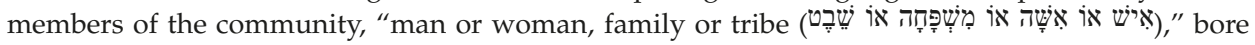
toward Israel's public and private religious obligations (Deut 29:17; Nakhai 2014a, p. 63). Women, as well as men, would have been counted among Israel's elders, adjudicating conflicts, dispensing justice, and-most significant for this discussion-participating in ritual ceremonies (Nakhai 2011). Even more specifically, the Bible delineates positions of authority that women held within their communities (for

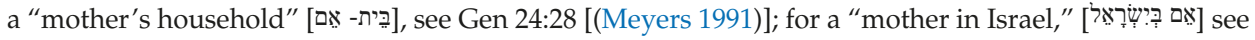
Judg 5:7; for a female elder at the gates of the town, see Prov 31:31). Women, like men, could take the vows of the Nazirite and thereby enter a community of people consecrated to Yahweh (Num 6:1-21; Judg 13:6-14).

Worship took place not only at community and family shrines but also within the home. In Iron Age Israel, women participated fully in the domestic economy, not only as household workers but as partners in a heterarchical society in which responsibilities for food production and household maintenance were shared by women and men alike (Prov 14:1, 31:10-31; Meyers 1988, 2006, 2013; Ebeling 2010; Nakhai 2014a). This means that women had access to the material goods (grains, livestock, oils, wine) that were used in Israel's most common religious rituals, the rituals of sacrifice and offering (Jer 44:15-19; Prov 7:14). Domestic religion was, in particular, the responsibility of women, who more fully occupied the four-room house, as the typical Israelite house is known. It was both their place of residence and their primary workplace, where they managed the storage of food products, fuels, and other necessities, the production of textiles and clothing, and the preparation of meals for daily consumption and for festivals and ritual celebrations (Dever 2012, pp. 142-205; Faust 2012, pp. 213-29; Faust and Bunimovitz 2014; Meyers 2014). What this means is that each ritual act that took place within the home transformed that home, or at least some part of it, into sacred space. At the same time, given the many domestic tasks taking place in and around the house and housing compound, this sacralization was impermanent, meaning that space, like people, "multi-tasked" (Nakhai 2014a, p. 56).

For their domestic rituals, women used clothing and textiles made of fabrics dyed in specially chosen colors, or woven, knotted or twisted in special ways, to perform acts of apotropaia and healing (Gen 38:27-30). A panoply of small, easy-to-move cultic objects that might include figurines, votive vessels, lamps, little stone altars, ceramic offering stands, amulets, specially colored beads, and more, some configuration of which is found in most four-room houses, highlights women's agency in domestic religion (Meyers 2005; Willett 2008; Nakhai 2011, pp. 355-59; 2014a, p. 56). Of particular concern to women were the risks of childbirth-related morbidity and mortality, and the dangers posed by infant and childhood illness and death. Demographic studies show that the average lifespan for women was thirty, as compared to forty for men; a third of children died by age five, and half by age eighteen (Willett 2008, pp. 79-81; Nakhai 2018b, p. 109). Along with midwifery, many other healthcare responsibilities fell under the purview of women. They assumed responsibility for medico-magical tasks, blending remedies both spiritual and practical (Gerstenberger 2014). The healer's arsenal included apotropaia, incantations, spells, prayers, blessings, and vows, echoes of which are found in the Bible (Gen 30:14-17; 1 Sam 1:10-13, 26-27; Judg 17:2; Jer 44:15-19; Prov 7:14, 31:2). Even the naming of babies reflected women's personal piety; the names women chose often mirrored the concerns and beliefs they shared with their families and communities (Albertz 2012, pp. 245-367). 
Within villages and homes, as well as in tombs and a cave in Jerusalem, Judaean pillar-based figurines were common. More than a thousand of these small, simple ceramic pieces depicting a female figure whose arms support her breasts, come from eighth-seventh century Judah (see, inter alia, Kletter 1996; Darby 2014). Presumably, they were used to invoke the protection of the Goddess, who would provide succor and sustenance for those who beseeched her (see, inter alia, Dever 2005, 2014; Willett 2008, pp. 93-97; Nakhai 2014b, pp. 183-85). Rachel (Gen 31:19-35) and Michal (1 Sam 19:11-17) both used figurines (teraphim; household shrine at Dan commissioned by Micah's mother (Judg 17:5, 18:14-20). Such images, used by women in domestic contexts and eventually forbidden to them in the reforms of Hezekiah and Josiah (2 Kgs 23:24), may have been used for the purpose of divination (1 Sam 15:23).

The four-room house may also have been the setting in which laws of ritual purity were fulfilled. It is not possible to conclusively situate the prescriptive and proscriptive Priestly laws delineated in the book of Leviticus beyond the confines of the Temple. At the same time, it is not impossible that laws of ritual purity, those dealing with menstruation, sexual intercourse, and childbirth (Lev 12:1-8, 15:18-33, $18: 19,20: 18)$, and those dealing with the preparation and serving of food for everyday consumption and for familial and community celebrations (Lev 11:1-46), had traction within at least some households beyond the Temple community (e.g., Gen 31:35; 2 Sam 11:2-5). The layout of the four-room house may have allowed for privacy and seclusion while facilitating access to women's work areas (see Faust and Bunimovitz 2003, p. 29; Faust 2012, pp. 223-24; Faust and Katz 2017, pp. 13-16). If laws of ritual purity were observed at home, their implementation would have been, primarily, the responsibility of women, providing yet another way in which they engaged with the Divine.

Women shared in the tasks and ritual acts required to properly care for the dead, whether preparing corpses for burial, determining burial locations, or participating in burial rites and the subsequent annual commemorations (Ebeling 2010, pp. 129-46; Schmitt 2012, pp. 429-73; Nakhai 2018b, pp. 113-15). Wise women, skilled in singing dirges, led laments of mourning (2 Sam 1:24

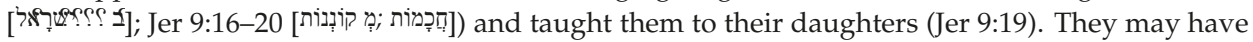
been the same women who engaged with the realm of war; several biblical passages attest to women leading victory celebrations with song, dance, and the playing of drums (Exod 15:20-21; Judg 5:1-31,

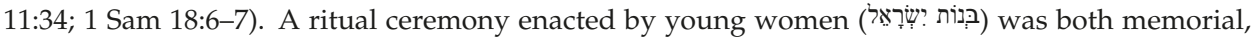
mourning the death of Jephthah's daughter, and celebratory, marking the transition from girlhood to womanhood; it took place in the wilds of nature (Judg 11:36-40; Trible 1984, pp. 100-101; Day 1989a; Ahuvia and Gribetz 2018, p. 7).

The Bible makes it clear that men held no monopoly over knowing the will of God. Yahweh or his divine messengers appeared to some women (Eve in Gen 3:13; Hagar in Gen 16:7-14, 21:17-21; Sarah in Gen 18:9-15; Samson's unnamed mother in Judg 13:2-21). Some women were prophets (Miriam [Ex 15:20-21; Num 12:1-2], Deborah [Judg 4:4], Huldah [2 Kgs 22:11-20], Isaiah's unnamed wife [Isa 8:3-4],

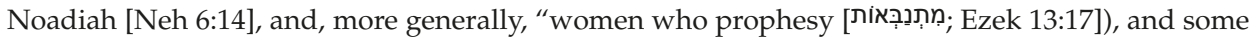

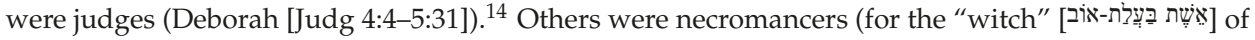
Endor, who not only conjured the ghost of Samuel but also slaughtered a calf and prepared and baked unleavened bread to serve King Saul, see 1 Sam 28:7-25; see also Lev 20:27) and wise women (for

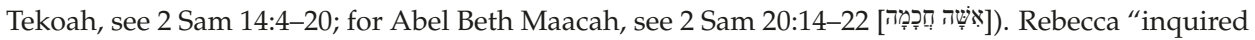

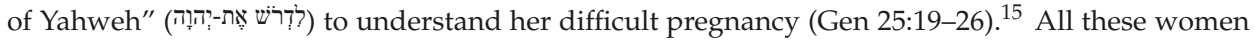
accessed the Divine through their own actions. ${ }^{16}$

14 For women as prophets and as priests, see Ackerman (2002). For female prophets, whether named and unnamed, operating on their own or in guilds, see Gafney (2008).

15 The Hebrew root $d r \check{s}$ is typically used for prophetic inquiries.

16 For the work of diviners, soothsayers, magicians, and witches, who might heal by appealing to divinities other than Yahweh, see Gerstenberger (2014). 


\section{Final Thoughts}

The fact that the stories of these women, and others as well, appear in the Bible demonstrates that women in at least some Israelite communities fulfilled meaningful religious functions. That there are so few of these stories speaks to the androcentric biases of the biblical authors, editors, and redactors. That so little has been known about women, including information about their religious beliefs and behaviors, can be attributed both to the androcentric nature of the Hebrew Bible and to the enthusiasm with which this androcentrism has been embraced by male scholarship over the millennia. Archaeology has become an invaluable resource for reconstructing the lives of women and examining their religious behaviors. The relationship between the Bible and archaeology is two-way. That is, evidence from each explicates otherwise obscure passages or realia in the other; taken together, they expand our ideas about what was possible, and about what was. The scholarly biases of the past are now being contested by female scholars—and by their likeminded male colleagues—who together strive to develop reconstructions of ancient Israelite religion that highlight both its inclusivity and its diversity.

Acknowledgments: My thanks to Avi Faust for inviting me to contribute to this special issue. Thanks, too, to the two anonymous reviewers whose thoughtful comments helped to improve the paper. A version of this paper was presented at the 2018 annual meeting of the Association for Jewish Studies.

Conflicts of Interest: The author declares no conflict of interest.

\section{References}

Ackerman, Susan. 1992. Under Every Green Tree: Popular Religion in Sixth-Century Judah. Harvard Semitic Monographs 46. Atlanta: Scholars Press.

Ackerman, Susan. 2002. Why Is Miriam Also among the Prophets? (And Is Zipporah among the Priests?). Journal of Biblical Literature 121: 47-80. [CrossRef]

Ackerman, Susan. 2003a. At Home with the Goddess. In Symbiosis, Symbolism, and the Power of the Past: Canaan, Ancient Israel, and Their Neighbors from the Late Bronze Age through Roman Palaestina. Edited by William G. Dever and Seymour Gitin. Winona Lake: Eisenbrauns, pp. 455-68.

Ackerman, Susan. 2003b. Women and the Worship of Yahweh in Ancient Israel. In Confronting the Past: Archaeological and Historical Essays on Ancient Israel in Honor of William G. Dever. Edited by Seymour Gitin, J. Edward Wright and J. P. Dessel. Winona Lake: Eisenbrauns, pp. 189-97.

Ackerman, Susan. 2016. Women in Ancient Israel and the Hebrew Bible. Oxford Research Encyclopedia of Religion. [CrossRef]

Ahuvia, Mika, and Sarit Kattan Gribetz. 2018. "The Daughters of Israel”: An Analysis of the Term in Late Ancient Jewish Sources. The Jewish Quarterly Review 108: 1-27. [CrossRef]

Albertz, Rainer. 1994. A History of Israelite Religion in the Old Testament Period. Volume I: From the Beginnings to the End of the Monarchy. Translated by John Bowden. Louisville: Westminster John Knox.

Albertz, Rainer. 2010. Personal Piety. In Religious Diversity in Ancient Israel and Judah. Edited by Francesca Stavrakopoulou and John Barton. London: T\&T Clark, pp. 135-46.

Albertz, Rainer. 2012. Personal Names and Family Religion. In Family and Household Religion in Ancient Israel and the Levant. Edited by Rainer Albertz and Rüdiger Schmitt. Winona Lake: Eisenbrauns, pp. 245-367.

Albertz, Rainer, and Rüdiger Schmitt. 2012. Family and Household Religion in Ancient Israel and the Levant. Winona Lake: Eisenbrauns.

Albertz, Rainer, Beth Alpert Nakhai, Saul Olyan, and Rüdiger Schmitt, eds. 2014. Household Religion: Toward a Synthesis of Old Testament Studies, Archaeology, Epigraphy, and Cultural Studies; Proceedings of the International Conference at Westfälisches Wilhelms-Universität Münster, April 1st-3rd, 2009. Winona Lake: Eisenbrauns.

Albright, William Foxwell. 1942. Archaeology and the Religion of Israel: The Ayer Lectures of the Colgate-Rochester Divinity School, 1941. Baltimore: Johns Hopkins.

Bal, Mieke. 1989. Anti-Covenant: Counter-Reading Women's Lives in the Hebrew Bible. Bible and Literature Series 22. Sheffield: Almond. 
Bellis, Alice Ogden. 2000. Feminist Biblical Scholarship. In Women in Scripture: A Dictionary of Named and Unnamed Women in the Hebrew Bible, the Apocryphal/Deuterocanonical Books, and the New Testament. Edited by Carol Meyers. Boston and New York: Houghton Mifflin, pp. 24-32.

Bellis, Alice Ogden. 2007. Helpmates, Harlots, and Heroes: Women's Stories in the Hebrew Bible, 2nd ed. Louisville: Westminster John Knox.

Bird, Phyllis. 1974. Images of Women in the Old Testament. In Religion and Sexism: Images of Women in Jewish and Christian Traditions. Edited by Rosemary Radford Ruether. New York: Simon \& Schuster, pp. 41-88.

Bird, Phyllis. 1987. The Place of Women in the Israelite Cultus. In Ancient Israelite Religion: Essays in Honor of Frank Moore Cross. Edited by Patrick D. Miller Jr., Paul D. Hanson and S. Dean McBride. Philadelphia: Fortress, pp. 397-419.

Bodel, John, and Saul M. Olyan, eds. 2008. Household and Family Religion in Antiquity. Malden: Blackwell.

Brenner, Athalya. 1993. A Feminist Companion to the Song of Songs. Feminist Companion to the Bible 1. Sheffield: Sheffield Academic Press.

Conkey, Margaret W., and Joan M. Gero. 1997. Programme to Practice: Gender and Feminism in Archaeology. Annual Review of Anthropology 26: 411-37. [CrossRef]

Conkey, Margaret W., and Janet D. Spector. 1984. Archaeology and the Study of Gender. In Advances in Archaeological Method and Theory 7. Edited by Michael Schiffer. New York: Academic Press, pp. 1-38.

Darby, Erin. 2014. Interpreting Judean Pillar Figurines: Gender and Empire in Judean Apotropaic Ritual. Forschungen zum Alten Testament 2. Tübingnen: Mohr Siebeck.

Daviau, P. M. Michèle. 1993. Houses and Their Furnishings in Bronze Age Palestine: Domestic Activity Areas and Artefact Distribution in the Middle and Late Bronze Ages. JSOT/ASOR Monograph Series 8. Sheffield: JSOT.

Daviau, P. M. Michèle. 2001. Family Religion: Evidence for the Paraphernalia of the Domestic Cult. In The World of the Aramaeans II: Studies in History and Archaeology. Edited by P. M. Michèle Daviau, John W. Wevers and Michael Weigl. JSOT Supplement Series 325. Sheffield: Sheffield Academic, pp. 199-229.

Day, Peggy L. 1989a. From the Child Is Born the Woman: The Story of Jephthah's Daughter. In Gender and Difference in Ancient Israel. Edited by Peggy L. Day. Minneapolis: Fortress Press, pp. 58-74.

Day, Peggy L., ed. 1989b. Gender and Difference in Ancient Israel. Minneapolis: Fortress Press.

de Vaux, Roland. 1961. Ancient Israel: Its Life and Institutions. New York: McGraw Hill.

Dever, William G. 1984. Asherah, Consort of Yahweh? New Evidence from Kuntillet 'Ajrûd. Bulletin of the American Schools of Oriental Research 255: 12-37. [CrossRef]

Dever, William G. 2005. Did God Have a Wife?: Archaeology and Folk Religion in Ancient Israel. Grand Rapids: Eerdmans.

Dever, William G. 2012. The Lives of Ordinary People in Ancient Israel: Where Archaeology and the Bible Intersect. Grand Rapids: Eerdmans.

Dever, William G. 2014. The Judean "Pillar-Base Figurines.". In Household Religion: Toward a Synthesis of Old Testament Studies, Archaeology, Epigraphy, and Cultural Studies, Proceedings of the International Conference at Westfälisches Wilhelms-Universität Münster, April 1-3, 2009. Edited by Rainer Albertz, Beth Alpert Nakhai, Saul M. Olyan and Rüdiger Schmitt. Winona Lake: Eisenbrauns, pp. 129-41.

Ebeling, Jennie R. 2010. Women's Lives in Biblical Times. London and New York: T\&T Clark.

Exum, Cheryl J. 1993. Fragmented Women: Feminist (Sub)versions of Biblical Narratives. JSOT Supplement Series 163. Valley Forge: Trinity International.

Faust, Avraham. 2012. The Archaeology of Israelite Society in Iron Age II. Winona Lake: Eisenbrauns.

Faust, Avraham, and Shlomo Bunimovitz. 2003. The Four Room House: Embodying Iron Age Israelite Society. Near Eastern Archaeology 66: 22-31. [CrossRef]

Faust, Avraham, and Shlomo Bunimovitz. 2014. The House and the World: The Israelite House as a Microcosm. In Household Religion: Toward a Synthesis of Old Testament Studies, Archaeology, Epigraphy, and Cultural Studies; Proceedings of the International Conference at Westfälisches Wilhelms-Universität Münster, April 1-3, 2009. Edited by Rainer Albertz, Beth Alpert Nakhai, Saul M. Olyan and Rüdiger Schmitt. Winona Lake: Eisenbrauns, pp. 143-64.

Faust, Avraham, and Hayah Katz. 2017. The Archaeology of Purity and Impurity: A Case-Study from Tel 'Eton, Israel. Cambridge Archaeological Journal 27: 1-27. [CrossRef]

Freedman, David Noel. 1987. Yahweh of Samaria and His Asherah. Biblical Archaeologist 50: 241-49. [CrossRef] Gafney, Wilda C. 2008. Daughters of Miriam: Women Prophets in Ancient Israel. Minneapolis: Fortress Press. 
Garroway, Kristine Henriksen. 2014. Children in the Ancient Near Eastern Houseshold. Explorations in Ancient Near Eastern Civilizations 3. Winona Lake: Eisenbrauns.

Garroway, Kristine Henriksen. 2018. Growing Up in Ancient Israel: Children in Material Culture and Biblical Texts. Archaeology and Biblical Studies 23. Atlanta: SBL Press.

Gerstenberger, Erhard S. 2014. Healing Rituals at the Intersection of Family and Society. In Household Religion: Toward a Synthesis of Old Testament Studies, Archaeology, Epigraphy, and Cultural Studies; Proceedings of the International Conference at Westfälisches Wilhelms-Universität Münster, April 1st-3rd, 2009. Edited by Rainer Albertz, Beth Alpert Nakhai, Saul M. Olyan and Rüdiger Schmitt. Winona Lake: Eisenbrauns, pp. 165-81.

Hadley, Judith M. 2000. The Cult of Asherah in Ancient Israel and Judah: Evidence for a Hebrew Goddess. Cambridge: Cambridge University Press.

Hardin, James W. 2010. Lahav II: Households and the Use of Domestic Space at Iron II Tell Halif: An Archaeology of Destruction. Reports of the Lahav Research Project Excavations at Tell Halif, Israel vol. 2. Winona Lake: Eisenbrauns.

Holladay, John S., Jr. 1987. Religion in Israel and Judah under the Monarchy: An Explicitly Archaeological Approach. In Ancient Israelite Religion: Essays in Honor of Frank Moore Cross. Edited by Patrick D. Miller Jr., Paul D. Hanson and S. Dean McBride. Philadelphia: Fortress, pp. 249-99.

Kletter, Raz. 1996. The Judean Pillar-Figurines and the Archaeology of Asherah. BAR International Series 636. Oxford: British Archaeological Reports.

Meyers, Carol. 1988. Discovering Eve: Ancient Israelite Women in Context. New York and Oxford: Oxford University. Meyers, Carol. 1991. "To Her Mother's House": Considering a Counterpart to the Israelite Bêt 'áb. In The Bible and the Politics of Exegesis: Essays in Honor of Norman K. Gottwald on His Sixty-Fifth Birthday. Edited by David Joblin, Peggy L. Day and Gerald T. Sheppard. Cleveland: Pilgrim Press, pp. 39-51.

Meyers, Carol, ed. 2000. Women in Scripture: A Dictionary of Named and Unnamed Women in the Hebrew Bible, the Apocryphal/Deuterocanonical Books, and the New Testament. Boston and New York: Houghton Mifflin.

Meyers, Carol. 2005. Households and Holiness: The Religious Culture of Israelite Women. Minneapolis: Fortress Press.

Meyers, Carol. 2006. Hierarchy or Heterarchy? Archaeology and the Theorizing of Israelite Society. In Confronting the Past: Archaeological and Historical Essays on Ancient Israel in Honor of William G. Dever. Edited by Seymour Gitin, J. Edward Wright and J. P. Dessel. Winona Lake: Eisenbrauns, pp. 245-54.

Meyers, Carol. 2010. Household Religion. In Religious Diversity in Ancient Israel and Judah. Edited by Francesca Stavrakopoulou and John Barton. London: T\&T Clark, pp. 118-34.

Meyers, Carol. 2012. Women's Religious Life in Ancient Israel. In Women's Bible Commentary. Edited by Jacqueline E. Lapsley, Sharon H. Ringe and Carol A. Newsom. Louisville: Westminster John Knox, pp. 354-61.

Meyers, Carol. 2013. Rediscovering Eve: Ancient Israelite Women in Context. New York and Oxford: Oxford University Press.

Meyers, Carol. 2014. Feast Days and Food Ways: Religious Dimensions of Household Life. In Household Religion: Toward a Synthesis of Old Testament Studies, Archaeology, Epigraphy, and Cultural Studies; Proceedings of the International Conference at Westfälisches Wilhelms-Universität Münster, April 1st-3rd, 2009. Edited by Rainer Albertz, Beth Alpert Nakhai, Saul M. Olyan and Rüdiger Schmitt. Winona Lake: Eisenbrauns, pp. 225-50.

Nakhai, Beth Alpert. 2001. Archaeology and the Religions of Canaan and Israel. Atlanta: ASOR.

Nakhai, Beth Alpert. 2005. Daily Life in the Ancient Near East: New Thoughts on an Old Topic. Religious Studies Review: A Quarterly Review of Publications in the Field of Religion and Related Disciplines 31: 147-53. [CrossRef]

Nakhai, Beth Alpert. 2007. Gender and Archaeology in Israelite Religion. Compass Religion 1: 512-28. [CrossRef]

Nakhai, Beth Alpert. 2011. Varieties of Religious Expression in the Domestic Setting. In Household Archaeology in Ancient Israel and Beyond. Edited by Asaf Yasur-Landau, Jennie R. Ebeling and Laura B. Mazow. Culture and History of the Ancient Near East 50. Leiden: Brill, pp. 347-60.

Nakhai, Beth Alpert. 2014a. The Household as Sacred Space. In Household Religion: Toward a Synthesis of Old Testament Studies, Archaeology, Epigraphy, and Cultural Studies; Proceedings of the International Conference at Westfälisches Wilhelms-Universität Münster, April 1-3, 2009. Edited by Rainer Albertz, Beth Alpert Nakhai, Saul M. Olyan and Rüdiger Schmitt. Winona Lake: Eisenbrauns, pp. 53-71. 
Nakhai, Beth Alpert. 2014b. Mother-and-Child Figurines in the Late Bronze-Persian Period Levant. In Material Culture Matters: Essays on the Archaeology of the Southern Levant in Honor of Seymour Gitin. Edited by John R. Spencer, Robert A. Mullins and Aaron J. Brody. Winona Lake: Eisenbrauns, pp. 165-98.

Nakhai, Beth Alpert. 2015. Ways of Believing: Religious Practice in Iron Age Israel. In Defining the Sacred: Approaches to the Archaeology of Religion in the Near East. Edited by Nicola Laneri. Oxford: Oxbow Books, pp. 90-101.

Nakhai, Beth Alpert. 2018a. Factors Complicating the Reconstruction of Women's Lives in Iron Age Israel (1200-587 B.C.E.). In Studying Gender in the Ancient Near East. Edited by Saana Svärd and Agnès Garcia-Ventura. State College: Eisenbrauns, pp. 289-313.

Nakhai, Beth Alpert. 2018b. When Considering Infants and Jar Burials in the Middle Bronze Age Southern Levant. In Tell It in Gath: Studies in the History and Archaeology of Israel. Essays in Honor of A. M. Maier on the Occasion of His Sixtieth Birthday. Edited by Itzhaq Shai, Jeffrey R. Chadwick, Louise Hitchcock, Amit Dagan, Chris McKinney and Joe Uziel. Ägypten und Altes Testament 90. Münster: Zaphon, pp. 100-28.

Newsom, Carol A. 1992. Women as Biblical Interpreters before the Twentieth Century. In Women's Bible Commentary. Edited by Sharon H. Ringe and Carol A. Newsom. London: SPCK; Louisville: Westminster John Knox, pp. 11-24.

Newsom, Carol A., and Sharon H. Ringe, eds. 1992. The Women's Bible Commentary. London: SPCK; Louisville: Westminster John Knox.

Olyan, Saul M. 1988. Asherah and the Cult of Yahweh in Israel. SBL Monograph Series 34. Atlanta: Scholars Press.

Perdue, Leo G., Joseph Blenkinsopp, John J. Collins, and Carol Meyers, eds. 1997. Families in Ancient Israel. Louisville: Westminster John Knox.

Peritz, Ismar J. 1898. Women in the Ancient Hebrew Cult. Journal of Biblical Literature 17: 111-48. [CrossRef]

Schmitt, Rüdiger. 2012. Care for the Dead in the Context of the Household and Family. In Family and Household Religion in Ancient Israel and the Levant. Edited by Rainer Albertz and Rüdiger Schmitt. Winona Lake: Eisenbrauns, pp. 429-73.

Schmitt, Rüdiger. 2014. A Typology of Iron Age Cult Places. In Household Religion: Toward a Synthesis of Old Testament Studies, Archaeology, Epigraphy, and Cultural Studies; Proceedings of the International Conference at Westfälisches Wilhelms-Universität Münster, April 1-3, 2009. Edited by Rainer Albertz, Beth Alpert Nakhai, Saul M. Olyan and Rüdiger Schmitt. Winona Lake: Eisenbrauns, pp. 265-86.

Stager, Lawrence E. 1985. The Archaeology of the Family in Ancient Israel. Bulletin of the American Schools of Oriental Research 260: 1-35. [CrossRef]

Stavrakopoulou, Francesca. 2010. "Popular" Religion and "Official" Religion: Practice, Perception, Portrayal. In Religious Diversity in Ancient Israel and Judah. Edited by Francesca Stavrakopoulou and John Barton. London: T\&T Clark, pp. 37-58.

Trible, Phyllis. 1973. Depatriarchalizing in Biblical Interpretation. Journal of the American Academy of Religion 41: 30-48. [CrossRef]

Trible, Phyllis. 1979. Eve and Adam: Genesis 2-3 Reread. In Womenspirit Rising: A Feminist Reader in Religion. Edited by Carol P. Christ and Judith Plaskow. New York: Harper \& Row, pp. 74-83.

Trible, Phyllis. 1984. Texts of Terror: Literary-Feminist Readings of Biblical Narratives. Philadelphia: Fortress Press. van der Toorn, Karel. 1994. From Her Cradle to Her Grave: The Role of Religion in the Life of the Israelite and the Babylonian Woman. Sheffield: JSOT Press.

van der Toorn, Karel. 1996. Family Religion in Babylonia, Syria, and Israel: Continuity and Change in the Forms of Religious Life. Studies in the History and Culture of the Ancient Near East 7. Leiden: Brill.

Willett, Elizabeth A. R. 2008. Infant Mortality and Women's Religion in the Biblical Periods. In The World of Women in the Ancient and Classical Near East. Edited by Beth Alpert Nakhai. Newcastle upon Tyne: Cambridge Scholars Publishing, pp. 77-96.

Yasur-Landau, Asaf, Jennie R. Ebeling, and Laura B. Mazow, eds. 2011. Household Archaeology in Ancient Israel and Beyond. Culture and History of the Ancient Near East 50. Leiden: Brill.

Zevit, Ziony. 2001. The Religions of Ancient Israel: A Synthesis of Parallactic Approaches. London and New York: Continuum.

(C) 2019 by the author. Licensee MDPI, Basel, Switzerland. This article is an open access article distributed under the terms and conditions of the Creative Commons Attribution (CC BY) license (http:/ / creativecommons.org/licenses/by/4.0/). 

Article

\title{
The Zooarchaeology of Israelite Religion: Methods and Practice
}

\author{
Jonathan S. Greer \\ Grand Rapids Theological Seminary, Cornerstone University, Grand Rapids, MI 49525, USA; \\ jonathan.greer@cornerstone.edu
}

Received: 5 January 2019; Accepted: 3 April 2019; Published: 7 April 2019

\begin{abstract}
This essay aims to provide a methodological framework for the application of zooarchaeology to the study of Israelite religion for the purpose of providing an overview of this growing subfield for the non-specialist and for inviting further conversation among practitioners. Definitions of "zooarchaeology" and "Israelite religion" are explored and the aim of reconstructing practices of Yahweh-centric religion is described. A methodology is suggested through a series of questions that may be applied to explorations of faunal remains, including those related to context, excavation technique and analysis, and engagement with the Hebrew Bible. The essay concludes with an illustration from Tel Dan and affirmation of integrated methodologies that critically engage archaeological and textual data to form new syntheses.
\end{abstract}

Keywords: zooarchaeology; Israelite religion; sacrifice; offering; Yahwistic worship; sacred feasting; faunal remains; animal bones; cult; ritual; Tel Dan; Hebrew Bible

\section{Introduction}

There has been increasing interest in the field of zooarchaeology and its application to the study of the religious practices associated with ancient Mediterranean peoples in recent years. This interest is due to the recognition of the value of the analysis of faunal remains for approaching questions of religion and has resulted in animal bone studies moving out of the appendices of archaeological reports to become integral components of more robust understandings of ancient peoples. This is especially the case in ancient Greek and Roman contexts (Ekroth and Wallensten 2013; Ekroth 2013), and this same trend may be observed in various societies from the southern Levant, in general, and ancient Israel, in particular (Lev-Tov and Kansa 2017).

This essay aims to provide a methodological framework for the application of zooarchaeology to the study of Israelite religion. Definitions and aims are provided before guidelines for a suggested methodology are set forth and problems are considered. Questions of context, excavation techniques and analysis, and the applicability of texts from the Hebrew Bible are explored for the purpose of providing an overview of this growing subfield for the non-specialist and encouraging further conversation among practitioners.

\section{Definitions and Aims}

At the outset, it is important to define the terms employed when we speak of the "zooarchaeology of Israelite religion," as well as the aims of this subfield. This is especially so in regard to current debates surrounding ancient Israel and its relationship to the texts of the Hebrew Bible portraying its history. 


\subsection{Defining Terms}

By "zooarchaeology," sometimes known as "archaeozoology" or simply "animal bone archaeology" (see Hesse and Wapnish 1985 and Gifford-Gonzalez 2018 for discussions of the terms), we mean the analysis of animal bones undertaken to explore archaeological questions about the relationships between animals and peoples in the past (cf. Hesse and Wapnish 1985; Davis 1987a; O'Connor 2008; Reitz and Wing 2008; Sykes 2014; Gifford-Gonzalez 2018). In this application, we are particularly interested in the human side of the relationship. As such, zooarchaeology involves the excavation and identification of teeth and animal bone fragments from common domesticates, wild game, and fish and birds, ${ }^{1}$ that are analyzed to address questions related to issues such as herd management and animal consumption, with an eye toward opening windows of insight to the economic, social, and cultic aspects of a given society.

Defining our use of "Israelite religion" is more complex due to the variety of applications, and/or misapplications, of the very term "Israelite" and what such a designation may or may not imply regarding religion. The source of the complexity is disagreement about the degree of the difference between the "Israel" described in the Hebrew Bible (sometimes called "Biblical Israel"; cf. Davies 2007), on the one hand, and a certain people group named "Israel" that is identified in inscriptions, on the other. ${ }^{2}$

The discussion is further complicated by new understandings of how people groups form and identify and the growing recognition that the way many think of ethnic descriptors today, especially in light of recent advances in genetics, is very different from the way ancient peoples conceptualized identity (cf. Barth 1969; Emberling 1997; Finkelstein 1997; Jones 1997; Sparks 1998; Brett 2002; Insoll 2004; Miller 2008; Faust 2006, 2017). As has long been noted, even among contemporary societies, ethnic differences do not necessarily correspond to cultural differences (see, especially Barth 1969; cf. Eriksen 2015, pp. 97-108). Indeed, various ethnicities may share a common cultural identity, and that identity may be more flexible and varied than is often assumed, thus complicating correlations between material culture and ancient peoples. Such groups are defined both internally and externally by comparison with "the other," and the establishment and negotiation of certain boundaries-or, better, frontiers (cf. Eriksen 2015, p. 105, following Cohen 1994, pp. 121-22)—that are established (or emerge) to define "in" and "out." These frontiers, further, expand and contract over time depending on the interaction with, or isolation from, other groups.

For many ancient societies, "religion" served as a fundamental frontier-defining system, and it retains this power in many societies to this day. Religion-here restricted to certain beliefs, symbols, and practices centered on the worship of a certain deity, or a larger pantheon of deities-often differentiated one group from another, or a conglomeration of groups from others. In the case of ancient Israel, according to biblical texts and epigraphic remains from the Iron Age II (10/9th c.-6th c. BCE), the cult was centered on the deity know as Yahweh, but there is also evidence in both corpora that Israelites worshiped a number of different deities (or venerated their symbols), as well (cf. Smith 2002; Dever 2005). Due to such diversity, instead of using the term "religion," some justifiably prefer to speak of "religions" in the plural to represent this reality (e.g., Zevit 2001; Hess 2007; Stavrakopoulou and Barton 2010). The way in which Yahweh was viewed in relationship to these other deities is

1 Other microfauna, such as rodents and reptiles, are beyond the scope of this inquiry in that there is not conclusive evidence that such species were consumed by peoples associated with ancient Israel in the southern Levant during the Iron Ages.

2 The name is first attested in the Merenptah stela at the end of the 13th c. BCE and while some question the reading of ysri3r as "Israel," the r/l interchange between Egyptian and Semitic languages is expected (cf. Hoch 1994, p. 430) and the use of the hieroglyphic determinatives following the appellation makes it quite clear that the reading identifies a foreign, unsettled people group, as opposed to those centered in city-states, such as Ashkelon and Gezer also mentioned in the inscription (cf. Kitchen 1994, p. 76; Stager 1985, pp. 60*-61*). The name is again mentioned in inscriptions from the 9th c. BCE, namely in the Mesha Stela and the Tel Dan inscription discussed below, and, though some question the equation of these terms, that they are related to each other is likely. For a full discussion of the various views associated with these debates, see (Moore and Kelle 2011). 
complicated by a range of opinions regarding the incorporation of the Hebrew Bible and the dating of certain religious traditions, as well as by how one understands the epigraphic remains. That said, our earliest inscribed monuments from the period of the Hebrew kingdoms (9th c. BCE), i.e., the Mesha Inscription (Tebes 2018) and the Tel Dan stela (Younger 2018), both associate these kingdoms, northern Israel and southern Judah (or, more specifically, "the House of David"), with the worship of Yahweh and no other deity, explicitly in the case of the former and by association in the theophoric names of the kings mentioned (though in broken contexts) in the latter. In that both monuments were commissioned by adversaries, in them we have an etic association with Yahweh that is in concert with the emic association of Yahweh portrayed in the biblical texts, whatever their dates of composition. Thus, regardless of any diversity among the religious expressions within ancient Israel in regard to the worship of other deities or their representative icons, the association of Yahweh with the Israelite kingdoms (Israel and Judah) was understood and officially projected in such a way that, at least by the 9th c., it served as a frontier to differentiate Israel from Moab and Aram-Damascus, in these instances, as well as in others elsewhere (cf. Faust 2017).

In this paper, then, we take "Israelite religion" to be those beliefs, symbols, and practices centered on the worship of Yahweh during the Iron Age and Persian periods in the southern Levant, while the diversity of religious expression that would have included other deities alongside of Yahweh is fully recognized (cf. Albertz 1994; Miller 2000; Zevit 2001; Smith 2002; Hess 2007; Stavrakopoulou and Barton 2010, among others). In this regard, and in light of the above discussion of ethnicity, while the designation of "Israelite religion" is retained, rightly understood, our endeavor may be more accurately defined as the zooarchaeology of Yahweh-centric religion.

\subsection{Defining Our Aim}

Even with such definitions established, our aim must be somewhat restricted in that "beliefs" of ancient peoples are particularly difficult to ascertain and are often confined to the realm of speculation, especially in the absence of epigraphic remains. Further, our modern conceptions of "what religion is" differ from culture to culture today, let alone from culture to culture in the past, and individual perceptions are biased towards one's own religious frameworks (Renfrew 1994; Zevit 2001). That said, behavioral characteristics and sequences of ritual practices associated with worship may contribute to understanding beliefs and this practice of a particular religion, i.e., the "cult," is accessible through archaeological methods in a way that belief is not. Indeed, various paradigms have been established through which excavated materials may be explored in order to identify cultic activity. For example, following Renfrew's well-know "indicators of ritual" (Renfrew 1985; 1994; Renfrew and Bahn 2016, pp. 413-21) that have been adapted for the context of ancient Israel in a number of studies (e.g., Gilmour 2000; Zevit 2001; Davis 2013), ritual practices may be reconstructed where we identify architecture or material culture that: 1 . may be associated with particular deities or deities' dwellings; 2 . focuses attention; 3. establishes boundaries between levels of holiness; and/or 4. suggests offerings, either votive or sacrificial.

Here zooarchaeology can play a special role, especially with regard to this last identifier of remains that suggest offering in that many offerings consist of meat, whether symbolically destroyed, buried, or consumed by officiates or other participants. Indeed, food is central in the practice of religion, and meat, in that its procurement requires animal death, is often elevated in its importance. Regardless of the way such meat is handled, bones are often all that remains and the analysis of these remains can shed light on the full spectrum of religiously-charged eating events, which arguably includes all consumption, from the most seemingly mundane everyday meal to the highest holy feast.

Indeed, zooarchaeology has been applied intensively to particular dietary habits associated with religious prescriptions regarding meat for everyday consumption in ancient Israel, especially regarding the question of pork prohibition (e.g., Harris 1985; Hesse 1990; Faust and Lev-Tov 2011; Sapir-Hen et al. 2013; Sapir-Hen et al. 2015; Sapir-Hen 2016; Faust 2018)—notably, far more complex of an issue than is often assumed (Hesse and Wapnish 1997; 1998)-and also those dietary laws 
concerning birds and fish (Altmann forthcoming; Altmann and Angelini forthcoming; Altmann and Spiciarich forthcoming). Explorations of tomb offerings have also been enriched by faunal analysis (Horwitz 2001; Lev-Tov and Maher 2001), and such results, though underutilized, may play a key role in ongoing discussions about the existence, nature, and extent of a cult of the dead in ancient Israel (cf. Bloch-Smith 1992; Schmidt 1996; Hays 2015). Faunal analyses have been particularly central to studies of sacrifice and have provided keys to unraveling ritual sequences (Hesse et al. 2012), and also for evaluating potential congruences between faunal data and sacrificial practices described in the Hebrew Bible (Wapnish and Hesse 1991; Greer 2013).

Thus, our aim for a zooarchaeology of Israelite religion, as described above, is to reconstruct practices-more specifically, those practices related to eating, offerings, and sacrifice- that may be associated with Yahweh-centric worship, and then to integrate these findings with other data sets, such as those from analyses of architecture, artifacts, and, if possible, textual witnesses, to form syntheses that engage the phenomenological, social, economic, and/or historical import of such practices.

\section{Toward a Methodology}

While there are many manuals describing the methods of zooarchaeology (e.g., Hesse and Wapnish 1985; Davis 1987a; O'Connor 2008; Reitz and Wing 2008; Sykes 2014; Gifford-Gonzalez 2018), as well as many studies that apply archaeology to the study of Israelite religion (e.g., Nakhai 2001; Albertz and Schmitt 2012; Zevit 2001; Dever 2005; Hess 2007; Stavrakopoulou and Barton 2010), there has been less attention on methodologies specifically focused on a zooarchaeology of Israelite religion that integrate these studies and also engage recent developments in faunal analysis and biblical studies. That said, there are some notable exceptions (Horwitz 1999; Wapnish and Hesse 1991) and many zooarchaeologists working in the southern Levant operate along similar lines and incorporate these various subfields in a number of works (Greer 2013; Lev-Tov and Kansa 2017). Here, we aim to provide a methodological framework represented in such works that also incorporates recent developments, while further addressing some of the recurrent problems regarding the use of biblical texts. This framework is presented by a series of questions that may be posed by investigators approaching animal bone remains in order to understand ancient Israelite religion.

\subsection{What Is the Context?}

Central to any archaeological inquiry is the question of context. In the case of explorations of the practice of Israelite religion, an immediate problem is that there was not any clear division between "secular" and "sacred" in the way that may exist in many post-Enlightenment modern societies today. Indeed, all practices were religious in one way or another and are represented in the household, public spaces, and tombs, as well as in shrines and temples. That said, such practices were sacred in different ways and seem to have existed on a continuum of "embeddedness" (Renfrew 1994), that is, a spectrum of variation in the degree to which such practices were embedded in the everyday activities of this world (such as eating a daily meal) or focused in a special way on experiencing the world of the supernatural (such as participating in a temple feast). Traditionally, architecture and artifacts have been the primary identifiers employed within such paradigms, but in recent decades, animal bones have been recognized as equally important (Horwitz 1999). Indeed, the most plausible identifications of cultic contexts engage a variety of data sets.

\subsubsection{What Type of Space Is It?}

For households or other communal domestic spaces, evidence of religious practice is prevalent especially in so-called "cult corners" (cf. examples in Zevit 2001). Such spaces are usually identified by the high concentration of vessels that are generally associated with cultic practices, such as chalices, censers, and zoomorphic vessels, as well as architectural features such as low benches, which served as resting places for many of the vessels. Animal bone finds in these contexts also show variance with 
nearby deposits, though, as will be discussed below, we suggest that greater care should be exercised in determining the nature of the deposit.

Tombs are also inherently ritual spaces, often with sequences conveyed in their layouts and associated epigraphic remains (Mandell and Smoak 2017). Animal bone finds are especially important in such contexts for distinguishing between tomb deposits that may be connected to these rituals and random deposits of non-primary accretions, as tombs were often secondarily used as dumping spots. Here, Horwitz (1987) distinguishes chance animal bone finds from intentional food offerings or sacrifices by evaluating a number of factors including: (1) the degree of association of the bones with a tomb or human remains; (2) a restricted range of species present (e.g., only sheep and goats); (3) evidence of intentional carcass element distribution (e.g., a lack of butchering refuse, such as phalanges, and the presence of heads typical of certain offerings [Horwitz 2001; Lev-Tov and Maher 2001]), that may include (4) articulated units (especially limb portions), and may exhibit (5) side preference; as well as (6) age-based, and (7) sex-based selection. Identification of primary concentrations is essential for determining the nature of the deposit and whether such remains represent a cultic meal with dead or a votive offering for the dead.

Temples and shrines are set apart by their dominant purpose of the veneration of the deity (or deities) and all of the associated activities, communal and restricted, that comprise worship. Here architectural features that follow particular patterns are often initial indicators (Holladay 1987; Zevit 2001; Mierse 2012), as well as the presence of an altar or a variety of altars. In rare cases, actual images or representative symbols of deities may be uncovered as well. Animal bones from temple contexts are often found in intentionally buried deposits resulting from votive deposits, favissa burials, and pits associated with sacrificial refuse or with the remains of sacred meals (e.g., Greer 2013). Major temples are comparatively rare in the southern Levant during the Iron Age (cf. Faust 2010, 2019), with the notable exceptions of Arad (Aharoni 1968; Aharoni 1993; Herzog et al. 1984; Herzog 1997), Moza (Kisilevitz 2015) and Dan (Biran 1994; Davis 2013; Greer 2013, 2017).

\subsubsection{Is It a Deposit?}

A problem in a number of publications is the failure to determine the specific nature of the context from which the animal bone sample was recovered. Complications can arise even when the locus may be "secure," as defined by chronologically homogenous ceramic assemblages, clear site matrix relationships, and/or sharply defined architectural or stratigraphic features. Unlike ceramic remains, faunal remains recovered from "floors," for example, tell us less than most assume about any associated practices and may represent the activities of subsequent inhabitants when that floor was no longer used as a living space. This is due to the simple fact that animal bones are "trash," and people generally do not live in their trash. That is, it is unlikely that people, ancient or modern, would consume a portion of an animal, then dump its remains on the floor and leave them there while they rot and fill the space with their stench. Likewise, the discovery of an articulated animal carcass near an altar is neither evidence of a sacrifice left in situ, nor of a sacred meal during which the worshipers carefully picked the meat off each bone without disturbing the articulation. No, animal bones, whether resulting from a highly charged meal in a domestic space or a festival in a temple, were collected and discarded in communal middens, or saved and buried in intentional deposits. It is important to remember, too, that the find spots of these deposits should not necessarily be associated with the spaces of the eating events. Animal bones discovered outside of such concentrations are more likely surface scatter from disturbed deposits, perhaps used as fill and sometimes even as fuel, and are less helpful for approaching questions other than presence and absence of certain species across the stratum. Still, questions of presence and absence can play important roles in dietary differences based on religious prohibitions, rightly understood, as may be in the case of the pig mentioned above.

Bones discarded in communal middens result in high concretions of faunal material in spaces defined by architectural features, from simple pits to slots in between walls from previous strata, as well as in silos and tombs and other abandoned features that are used secondarily as dumping spots. 
In that these bones, once religiously charged by their association in cultic activities, are now mixed with the bones discarded from everyday meals (or less religiously charged meals), their usefulness for reconstructing details of those cultic activities is minimal. Bones from concentrated deposits, however, are rich with potential for recovering details about ritual practices and should be the focus of inquiry.

\subsubsection{What Type of Deposit Is It?}

Even when deposits are identified, far too often such are simply identified as "sacrificial remains" when, in fact, they may represent various types of religiously charged deposits with very different characteristics. Identifying these differences is especially important if one seeks to speculate regarding the cognitive dimensions of the significance of these deposits for ancient peoples.

Deposits resulting from burnt offerings, for example, will consist of fine ash and, if any elements can even be identified, they will be intensely charred and denatured often obscuring their analysis. Such finds are only rarely reported in archaeological reports of the southern Levant, though they have been identified in Aegean archaeology (Forstenpointner 2003). In all likelihood, such deposits are often missed or misidentified in excavation.

Votive deposits, as symbolic offerings that were not consumed, are most readily identified by their articulation with other bone elements. That is, the discovery of a fully articulated limb of a particular animal would render it highly unlikely that it had been consumed in that most elements become disarticulated in the butchering process. Further, even those units that retain their articulation in the butchering process become separated in the final stages of preparation prior to cooking, such as in the disjointing and chopping undertaken to fit portions into a cooking pot, and even more so in the cooking process itself, typically an extended stewing. Such votive portions are most typical in tombs and may be viewed as symbolic portions for feeding the dead, but have also been discovered buried in jars or in pits in the floors of sanctuaries often exhibiting a side preference (Davis 2008; Greer forthcoming).

Most animal bone finds, as mentioned above, are the remains of eating events and when discovered in religiously charged contexts they may be confidently associated with sacred feasting. In contexts where there is an altar structure or other paraphernalia associated with the slaughter of animals, such as in a temple, one may further suggest that such are the remains of sacrificial meals. In contrast to the remains of burnt offering and votive deposits, these bones are often from the meaty portions of the animal, though not exclusively, and exhibit postmortem modifications such as cut marks and breakage patterns associated with the disarticulation and chopping of the portions into smaller units for cooking.

Considering the difference in the type of religiously charged deposits here discussed, we suggest that greater precision should be applied to potential designations of excavated remains as each exhibits different characteristics. Here, too, we suggest greater clarity in speaking about "sacrifice," in that most sacrifices are evidenced in the form of sacred feasts.

\subsubsection{Is the Context Yahwistic?}

Associating deposits, whether from burnt offerings, votive offerings, or the remains of sacred meals, with Yahweh-centric worship is a complicated endeavor due to many of the factors discussed in Section 2.1. Our strongest evidence comes from specific mention of Yahweh in any associated epigraphic remains, such as one finds at the gate shrine of the desert caravansary site of Kuntillet 'Ajrud or in certain tomb inscriptions such as Khirbet el-Qom (Dever 2005). Such may also be suggested by names with Yahwistic theophoric elements that are discovered in close association with other finds that suggest a temple context, such as at Arad (Aharoni 1968; Herzog et al. 1984) or at Tel Dan (Biran 1994), yet this is not as straight forward. Iconography represented in certain artifacts found at an installation, too, may be associated with Yahwistic imagery, most notably, the images of the Taanach cult stands that are often connected to Yahweh and (the) Asherah (Taylor 1993; Zevit 2001; Dever 2005).

The style of particular structures or artifacts and their measurements, such as the field stone altar at Arad (Herzog et al. 1984, p. 11; Zevit 2001, pp. 169-70), have also been associated with Yahwistic worship in the context of other finds. So, too, the presence of an altar kit, including what may be a bowl 
for catching sacrificial blood (Greer 2010), as well as the proportions of architectural features (Davis 2013; Greer 2013), and iconographic features (Ackerman 2013) at Tel Dan have been associated with Yahwistic worship. Similar associations have been suggested in the discovery of horned altars, such as at Beersheva (Zevit 2001, pp. 171-74). There are, however, two potential problems with this second category of identification: (1) they are often based on associations with biblical texts (an issue that will be discussed below), and (2) without further epigraphic association with Yahweh, such features may be shared by other non-Yahwistic sanctuaries as well, as exemplified in the architecture of Ain Dara (Monson 2000) or variations of horned altars associated with Philistine and Aegean contexts (Gitin 2002; Sala 2018).

Less helpful are determinations of Yahweh-centric worship made purely on mention of a location that is associated with Yahweh in the Bible in that sites were often the home of various peoples with differing religious allegiances, as the texts themselves describe, and this varied over time. Another problem is that the dating and composition of biblical texts is not straightforward and this can complicate the association of certain sites with Yahweh. Such may be the case with the Mount Ebal site that clearly exhibits evidence of cultic activity (Hawkins 2012), along with evidence of feasting (Horwitz 1986), but seems unlikely to be associated with the altar of Joshua even if historicity is granted in that our earliest textual traditions, evidenced later in the Samaritan Pentateuch and confirmed against the Masoretic text by evidence from readings from the Old Greek traditions and a Qumran fragment, place this altar on Gerizim (cf. Knoppers 2013, pp. 202-3, with references). Determining the religious affiliation of a site based on the presence or absence of certain animal bone remains, such as the lack of pig bones in cult areas at Qeiyafa (Garfinkel 2017, though listing other factors as well), is also insufficient in that worship sites associated with other deities, such as the gate shrine at Geshur, also exhibited these same sacrificial avoidances (Fisher 2005; Greer 2013, p. 100 n. 10), not to mention the complexities associated with the absence of pig remains (Hesse and Wapnish 1997; 1998). While such sites may well have been Yahweh-centric, there is not enough evidence from animal bones alone to determine their affiliation and our strongest cases can be made when evidence from multiple sources - epigraphic, artifactual, architectural, and biblical—is compounded in addition to the zooarchaeological evidence under consideration.

\subsection{How are Bones Excavated?}

Once a context is established, standard methods of excavation, as they pertain to animal bones, usually entail hand collecting any visible remains of bones and placing them in paper bags marked by area, locus, square, and collection date to be analyzed later by a zooarchaeologist. Many digs now also mandate sieving, either wet or dry, and/or flotation protocols, but usually only as a random sampling technique (one out or every five buckets, for example) or in areas that have been identified as particularly important for one reason or another (a midden, for example). This lack of comprehensive sieving, of course, biases the collection toward larger species-e.g., sheep, goats, cattle, deer, pig, etc.-and significantly underrepresents smaller species that may be present in a particular sample. Such random sampling can, however, indicate presence and absence of fish and birds and certain microfauna (i.e., rodents and reptiles) and even with comprehensive sieving, element counts should not be used to calculate percentages of species due to the inevitable loss via natural taphonomic processes, discussed below, that disproportionately underrepresent smaller species.

Other problems at the collection stage pertain to the selection bias of the excavators, often volunteers with little experience, who may single out certain bones that are larger, such as a whole metapodial, or more interesting to the untrained eye, such as an astragalus. They may further miss the relationship of articulated bones and the importance of associating them together even if in different baskets or even loci. Another problem is that bone elements may be destroyed by a pick or trowel in excavation resulting in the collection of only pieces of shattered bone, sometimes even spread between buckets, or the complete obliteration of diagnostic features of a particular element, thus significantly skewing element counts. With large digs that have been in the field for years, an added dimension 
is potential staff turnover in which case one cannot be confident that the same protocol in collection technique was applied equally across the sample.

While these are all very real problems in recovering a sample, a simple counter measure is to maintain the presence of a trained zooarchaeologist on site who can equip volunteers and provide oversight to collection methods. A further advantage to such presence is interaction among the staff onsite regarding particular questions of context that may be examined through faunal analysis; such cannot occur when zooarchaologists analyze remains without an understanding of the context and, conversely, excavators may make different decisions in the field with a more complete understanding of the animal bone remains.

\subsection{How Are Bones Analyzed?}

As in all archaeological research, samples are analyzed with particular questions in mind. That said, regardless of questions posed, certain features of faunal specimens are typically assessed due to their applicability to a wide range of questions. Such include the anatomical identification, orientation, and size of individual elements, the various taxa from which the specimens likely derive, the age and sex if it can be determined, and the nature, location, and frequency of postmortem modifications to the bone (Hesse and Wapnish 1985; Davis 1987a; O'Connor 2008; Reitz and Wing 2008; Gifford-Gonzalez 2018).

\subsubsection{What Is Recorded and How Is It Determined?}

The initial identification takes place on the elemental level, in that related taxa and to a large extent all vertebrate mammals, share anatomical similarities (Davis 1987a). The closer the relationship, the more similar the anatomy. Once the element is identified and sided, either left, right, or indeterminate, identification is made regarding the taxa.

Identification of element and taxon is made by a visual comparison of the morphological features of a specimen, often supplemented by metrical data (von den Driesch 1976), with elements in comparative collections derived from excavated and/or modern remains, as well as with elements depicted in various standard manuals (Sisson et al. 1975; Schmid 1972; cf., Niven et al. 2009). While the anatomy of certain domestic species has changed some over the millennia in terms of size due to commercial animal farming, it is not so much as to obscure identification.

Typically, common domesticates, especially sheep, goat, and cattle, dominate the assemblages of the southern Levant, though deer and pig occur in significant numbers in certain regions during certain periods. Of these, sheep and goats are notoriously difficult to differentiate though this can be done with some degree of confidence for certain elements depending on the experience of the zooarchaeologist (Boessneck 1969; Zeder and Lapham 2010). Various bird and fish species are also quite frequent, as are remains from other animals that were not typically consumed, such as donkey and dog. Elements that cannot usually be identified at the species level (e.g., vertebrae, long bone shaft fragments, and rib fragments) are grouped in larger categories based on size and are not typically used for calculating species percentages.

Age at death is estimated by osteological and dental maturity based on the state of fusion in the former (Silver 1969; Zeder 2006) and on the eruption and attrition of teeth in the latter (Payne 1973; Grant 1982; Greenfield and Arnold 2008). The sex of the animal can be determined by certain elements such as the pelvis (Greenfield 2006a), though due to the fragmentary and limited nature of such indicative elements sex-based comparisons are only common for large samples.

Postmortem modifications to the bone, such as cut and chop marks, are also recorded and may be associated with the activities of slaughtering, processing, preparation, and consumption, often based on ethnographic parallels (cf. Binford 1978, 1981; Klenck 1995; Grantham 1995, 2000). Associated practices are also reconstructed through experimental archaeology that seeks to replicate ancient practices in ways that produce similar remains to what was excavated, as has been applied especially for Greek sacrifice (Forstenpointner et al. 2013). Modifications due to gnawing from dogs or rodents (Marean and Spencer 1991), weathering (Behrensmeyer 1978), or burning (Shipman et al. 1984) are 
also recorded, as well as any deformations of the bone due to sickness and/or injury (Siegel 1976; Baker and Brothwell 1980).

Recent scientific advances have transformed the field in terms of providing new data sets for exploration (Gifford-Gonzalez 2018). The most common of these applications include advances in microscopy applied to differentiate between different cut marks and the technologies that produced them (cf. Shipman 1981a; Greenfield 1999, 2006b), isotopic analysis applied to determine grazing contexts and migration patterns (Gifford-Gonzalez 2018, pp. 503-10; Arnold 2018), and studies of ancient DNA applied to bring greater precision to species identification (Gifford-Gonzalez 2018, pp. 511-30), among others.

\subsubsection{How Are Bones Counted and Compared?}

Before bones can be counted and compared, one must first determine how well the excavated sample represents what was deposited in the past, i.e., understanding and accounting for the taphonomic processes that contribute to the creation of certain deposits and the modification and eventual destruction of their contents over time (Shipman 1981b; Hesse and Wapnish 1985; Lyman 1994). Such differences must then be evaluated as to the statistical probability that the observed difference was created by intentional processes and may not be explained by random selection (Lyman 2008).

Once taphonomic realities have been considered, bones are then quantified, and discussion continues about the best way to count bones that is both reliable, i.e., replicable, and valid, i.e., that it measures what it aims to measure ( $\mathrm{O}^{\prime} \mathrm{Connor} 2008$, pp. 54-67). The two most frequently employed procedures are those that base their analysis on raw counts of identified specimens, recorded as NISP (number of identified specimens), and those that seek to estimate the minimum number of individual animals present in a sample, recorded as MNI (minimum number of individuals). There are strengths and weaknesses to both in that each assumes a different context (Hesse and Wapnish 1985, pp. 112-16; Gifford-Gonzalez 2018, pp. 385-412): NISP assumes that the specimens derive from a large number of animals that have all been processed at different times and places, and deposited in mixed contexts (such as in a midden), thus rendering it unlikely that two or more bones derive from the same animal; MNI assumes the opposite scenario, i.e., that the bones are likely to have come from a small number of animals killed and deposited at the same time (such as a tomb). The once-common practice of weighing bone material is no longer employed in most workflows for faunal specialists due to inherent problems with its validity (Chaplin 1971; Casteel 1978).

Assessing the frequency of bone element representation in certain analytic categories has also been important in the application of zooarchaeology to the study of Israelite religion. Such analyses of carcass part distribution - that is, distributions based on differences between the representation of bones associated with certain groups of elements, such as the "head" (crania and teeth), "trunk" (vertabrae and ribs), "limbs" (scapulae, humerii, radii, ulnae, femorae, tibae, and long bone shafts), and "feet" (phalanges)—can indicate the syntax of butchering procedures, and has been applied to cultic settings (Hesse et al. 2012). Of special importance has been the difference between deposits that indicate a dominance of right or left sided portions in cultic contexts across the ancient Mediterranean (e.g., Davis 1987b, 2008; Marom and Zuckerman 2012; Greer forthcoming).

\subsection{What Are the Results?}

Most questions that relate to a zooarchaeology of Israelite religion are informed by assessing differences between certain assemblages, once they have been excavated and analyzed. Differences are often observed in terms of species representation, age at death groupings, carcass part distributions, and other factors of comparison, and are then evaluated statistically. Such assessments of difference take place at the regional level, for example in the presence or absence of pig remains at certain sites (but see above), or at the local level concerning very specific contexts, for example the contents of one pit compared to another in the courtyard of a temple (see below). Trends over time are also assessed, such as in a comparison of the percentage of sheep and goats to cattle during different phases of settlement history at a particular site or in comparison to other sites. 


\subsection{How, If at All, Do the Results-Understood in Context-Relate to the Bible?}

For better or worse, archaeologists working with remains from the Iron Age and Persian periods in the southern Levant are forced to, at least in one way or another, engage the Bible. For some this engagement is dismissive and for others it is intensive, but to ignore it completely would be irresponsible and, indeed, even though certain recent works may claim distance from it, it is impossible to ignore (cf. Miller 1991). This is not a negative reality, however, for any archaeology in this region that would jettison the Bible in such endeavors would be out of step with other archaeologies that take place in regions where written sources exist, e.g., ancient Greece or Mesoamerica. For, whatever the date and ideology of a certain textual tradition, such works provide rich resources of comparative material for an archaeologist. Indeed, a major difference with the Bible is that it still serves as an important religious text for a wide array of contemporary Jewish and Christian faith communities and, thus, the results of research often have bearing on the way such communities understand these texts to function as Scripture.

Even if it may be agreed that the Bible should be engaged (or is engaged, regardless of claims to the contrary), the question is how it should (or is) engaged, and much ink has been spilled over this question (e.g., Mazar 1992; Dever 2001, 2017; Silberman and Finkelstein 2002; Grabbe 2008; Levy 2010; Ebeling et al. 2017, to name a few). By and large, the discussion takes place in terms of certain historical claims that the Bible is understood to make, ushering in the "did it happen or not" sorts of debates, whether about the exodus, "conquest," or the extent (or existence) of a Davidic or Solomonic kingdom (cf. Moore and Kelle 2011). In many ways this rationalistic — even positivistic-approach has been encouraged by the incorporation of the hard sciences and an over confidence in the assured results such techniques can provide. Often missing from the discussions is an examination of the ancient genres employed in the biblical works and how they functioned, accompanied by a nuanced understanding of the claims that are being made and the purpose for which such events are recounted (Halpern 1996).

While evaluation of such historical claims, rightly understood, is important and indeed an essential backdrop for our discussion as it pertains to the existence of an Israelite presence in the southern Levant, it is not our focus here and, beyond establishing presence, such has less relevance for a discussion of religion and, thus, for assessing how the results of zooarchaeological studies relate to the Bible. This is due to the fact that the relevance of biblical texts for the study of Yahwistic religion is less bound by discussions of dates and events in that many elements of the practice of religion, in general, are remarkably stable across cultures. Such stability is likely to have been the case for ancient Israel, as may be paralleled in Mesopotamia (cf. Linssen 2004), even if meaning of particular rituals changed (Altmann forthcoming). That is, whether aiming to reconstruct Yahwistic practices from the Late Bronze/Iron I, Iron II, or Persian/Hellenistic periods that may be related to zooarchaeology, many of the general elements may have looked the same regardless of time period, whether sacrifice, rituals, or sacred meals that would have generated faunal remains, and these would have paralleled practices in the cultures around them.

\subsubsection{How Do Ancient Near Eastern Practices Relate to Practices Described in the Bible?}

Parallels to biblical cultic practices have been observed in Egyptian, Hittite, Mesopotamian, Ugaritic, and other contexts, demonstrating numerous points of contact while undoubtedly also illustrating differences on both the intercultural and intracultural levels (e.g., Weinfeld 1983; Milgrom 1991; Hess 2007; Knohl 2015).

In terms of methodology, then, any zooarchaeological inquiry into the practice of Yahwistic religion should be informed by a comparative exploration of these ancient Near Eastern texts and images, as well as the Bible, in ways comparable to other studies that integrate written and visual materials alongside of zooarchaeological and other excavated data, so that such similarities and differences may be assessed (cf. Wapnish and Hesse 1991; Wapnish 1993; Lev-Tov and McGeough 2007; Popkin 2013; Ekroth and Wallensten 2013; Greer 2013). 


\subsubsection{How Do Critical Methodologies Applied in Biblical Studies Affect the Understanding of Texts?}

When seeking to understand how zooarchaeological finds relate to the Bible, the same rigor that is applied to archaeological methods should be applied to textual studies. Just as it would be inappropriate for a text-centric inquiry to tack on a general reference to archaeology that ignores all of the complexity of stratigraphy, taphonomy, and radiocarbon dating, for instance, so too it is less than responsible to make general assertions about "what the Bible says" or the dating of certain traditions without carefully engaging source and redaction critical issues, textual criticism (especially in light of recent developments in Qumran and Septuagint studies), and literary studies, particularly in terms of genre. The Bible is a complex, multilayered ancient collection of textualized traditions from the Late Bronze/Iron Ages through the Persian/Hellenistic periods that needs to be engaged critically and carefully by researchers with broad training and in consultation and collaboration with specialists outside one's area of expertise before one should attempt essential syntheses.

\section{An Illustration: Faunal Remains from Area T, Tel Dan, Israel}

An application of this methodology may be briefly illustrated in recent work on faunal material from Tel Dan by applying the series of questions outlined above (see Greer 2013 for the full discussion, elements of which are summarized here).

\subsection{Determining Context}

Tel Dan (Tell el-Qadi) is one of the northernmost sites within modern Israel, close to the Lebanese and Syrian borders, with remains from the Neolithic through early modern periods (Biran 1994). It is situated on the largest spring in the region, fed by snow melt from nearby Mt. Hermon, that forms one of the headwaters of the Jordan River. Due the abundant source of water and the site's location in the upper Hula Valley, a series of local and international ancient routes passed through Dan over the millennia resulting in periods of dense occupation by various peoples (Ilan $2019 \mathrm{fc}$; Thareani 2016). Evidence of religious veneration at the site, especially in the vicinity of the spring, is attested in archaeological material as early as the Late Bronze Age and well into the Hellenistic Period. The architectural remains from the Iron Age IIA-B (10th/9th-8th centuries BCE) in Area T above the spring are especially prominent and are associated with high concentrations of animal bone remains.

\subsubsection{What Type of Space Serves as the Context for the Faunal Remains?}

The architectural remains from Area T have many features that line up with Renfrew's "indicators of ritual" (Renfrew 1985, 1994; Renfrew and Bahn 2016, pp. 413-21; cf. Gilmour 2000; Zevit 2001), and such have been applied specifically in this case (Davis 2013). Indeed, the area has all of the hallmarks of a major, regional temple complex. Construction features associated with the 9th-8th c. BCE, Strata III and II in Biran's (1994) assessment, include fine ashlar masonry with slots for cedar beams typical of palaces and temples, a massive substructure for a large, elevated building, and parallel casemate side-chambers on the western and eastern boundaries of the precinct. The decorative techniques and other features, too, emphasize monumental display resonating with garden motifs typical of temples (Ackerman 2013). In the center of the complex, the base of a large altar was discovered as well as a single horn that, when compared to proportions from other altars, allows for a reconstructed altar of $4.75 \times 4.75 \mathrm{~m}$ and, thus, apparently the largest altar ever discovered in the region.

The artifact remains, too, support the identification of the space as a temple as evidenced in the discovery of several smaller altars, seven-spouted oil lamps, perforated "incense" cups, cultic stands, metal implements associated with animal slaughter and processing, and even what has been identified as an altar kit found in situ consisting of a bowl, pair of shovels, incense pan, possibly a meat fork, and a sunken pot with charred animal remains (Greer 2010).

Evidence from the architecture and available artifacts, especially when combined with the discovery of massive concentrations of animal bone remains both in charred deposits and in deposits 
from the remains of meals, leaves little doubt that the space functioned as a major temple during the Iron Age IIA-B especially during the 9th-8th c. BCE (cf. Greer 2013, 2017; Davis 2013).

\subsubsection{Were the Animal Bones Found in Intentional Deposits?}

While thousands upon thousands of animal bones were discovered as scatter throughout the complex, the analysis (Greer 2013) focused on seven deposits: two from the western chamber complex and five from the central courtyard around the altar. Each was identified by the excavators as an intentional deposit based on architectural features, such as a slot created by two walls in one case or as clearly defined pits in other cases (one even ringed with small stones), or architectural features that were used secondarily as a deposit location, such as an olive press basin from an earlier stratum reused as a bone repository in the subsequent stratum.

\subsubsection{What Type of Deposits Are Represented?}

Though deposits of charred material were discovered elsewhere in the precinct, these seven deposits were interpreted as the remains of eating events based on the lack of extensive burning and patterns of cut marks and chop marks associated with the preparation and consumption of meals (cf. Binford 1978, 1981; Grantham 1995, 2000; Klenck 1995). Associated artifacts, such as metal and flint blades as well as cooking pots and eating vessels, also suggested that these pits contained the remnants of meals.

\subsubsection{Can the Context Be Associated with Yahwistic Worship?}

Primary evidence that the sanctuary may be associated with Yahwistic worship comes in the form of an 8th c. seal impression with the name 'Immadiyaw, a theophoric name meaning "Yahweh is with me," found on a vessel fragment in a chamber attached to the precinct (Biran 1994, pp. 199-201), complemented by other Yahwistic names discovered elsewhere on the site associated within this time period, though names in and of themselves are not definitive. Secondary evidence includes the association of certain artifacts with those employed in Yahwistic worship as described in the Hebrew Bible as well as distribution patterns of animal bone remains that correspond with biblical prescriptions described below, though evidence in this category parallels practices in other cultures. Also at the secondary level are several traditions in the Hebrew Bible that identify the site as a Yahwistic worship center, albeit heterodox if not idolatrous in the eyes of the biblical writers: Judges 17-18; 1 Kgs 12:28-33; Amos 8:14. The convergence of these pieces of evidence-epigraphic, artifactual, faunal, and biblical-have been argued to suggest that the temple was Yahwistic in nature (Greer 2017).

\subsection{How Were the Bones Excavated?}

The faunal remains from these deposits were collected according to standard procedures of the Biran period of excavation (cf. Wapnish and Hesse 1991). Such included hand collecting bones and storing them in paper bags and boxes marked by area, locus, square, and collection date that were later analyzed by zooarchaeologists (Wapnish and Hesse 1991; Greer 2013). No sieving was carried out, thus biasing the collection toward larger species.

\subsection{How Were the Bones Analyzed?}

After the anatomical identification, orientation, and size of individual elements was recorded, the taxa from which the specimens likely derived, as well as the age and sex (if possible) and any postmortem modifications to the bone were determined.

\subsection{What Were the Results?}

Our research questions, tempered by the collection bias toward large animals, then led us to focus our study on sheep and goat remains from these intentional deposits. When these remains 
were compared among the various deposits, several statistically significant, non-random patterns of distribution were identified. Highlighting one for illustrative purposes here, it was noted that the percentage of bone elements from right-sided meaty longbone portions was about double the percentage from left-sided portions in the western chambers, but that this pattern was reversed among the courtyard deposits where the percentage of bone elements from left-sided meaty longbone portions was about double the percentage from right-sided portions.

\subsection{How, If At All, Do the Results-Understood in Context-Relate to the Bible?}

Biblical scholars will be quick to notice the correspondence of a different treatment for right-sided and left-sided portions and the prescriptions in biblical Priestly texts that allot right-sided portions of the "fellowship offerings" to ancient Israelite priests (cf. Exod 29:27-28; Lev 7:32-33). The correspondence is obscured somewhat, however, by evidence of side-preference across the ancient Near East and complicated further by text-critical issues among the extant versions, namely the Masoretic Text, the Qumran texts, and the Greek/Septuagint manuscripts, and even more so by internal differences within each textual tradition concerning which portion is allotted to the priests (cf. Greer forthcoming). That said, when complications are engaged and differences are distilled, what remains is archaeological evidence for a preference for right-sided limb portions discovered in the context of a Yahwistic temple of the 9th-8th c. BCE and a congruence of this discovery with one of the dominant traditions represented in the biblical texts among various versions. This, then, may have significance for the composition, date, and regional orientation of traditions now contained in the Priestly source of the Pentateuch (see, further, Greer forthcoming).

\section{Conclusions}

The future for a zooarchaeology of Israelite religion is bright indeed thanks to pioneering archaeological methodologies developed by a previous generation that are maintained and built upon with new developments in scientific techniques, as well as more and more data from textual sources that may be compared and contrasted with biblical texts coming to light and an increasing nuance to the critical engagement of these texts that has been developing in biblical studies. This essay has sought to outline these trends and to encourage the integration of archeological and textual studies centered on the topic of Israelite religion. It has suggested a methodology that may be outlined by a series of questions:

- What Is the Context?

$$
\begin{array}{ll}
\text { What Type of Space Is It? } \\
\text { Is It a Deposit? } \\
\text { What Type of Deposit Is It? } \\
\text { Is the Context Yahwistic? }
\end{array}
$$

- How are Bones Excavated?

- How are Bones Analyzed?

What Is Recorded and How Is It Determined?

How Are Bones Counted and Compared?

- What Are the Results?

- How, If at All, Do the Results-Understood in Context-Relate to the Bible?

How Do Ancient Near Eastern Practices Relate to Practices Described in the Bible?

How Do Critical Methodologies Applied in Biblical Studies Affect the Understanding of Texts? 
With new samples of faunal remains coming from previously unknown and recently excavated sites of Israelite cultic practice, such as Tel Moza, as well as from numerous examples of household cults, and from new analyses of materials from sites excavated by a previous generation, we anticipate a sustained and enduring impact of integrated methodologies and look forward to new syntheses.

Funding: This research received no external funding.

Acknowledgments: I wish to thank Avi Faust for his invitation to contribute to this special issue, and for his comments on the paper, and I am also grateful for the comments of my anonymous reviewer and for those given by Nimrod Marom. Any shortcomings and mistakes are my own.

Conflicts of Interest: The author declares no conflict of interest.

\section{References}

Aharoni, Yohanan. 1968. Arad: Its Inscriptions and Temple. The Biblical Archaeologist 31: 1-32. [CrossRef]

Davis, Andrew R. 2013. Tel Dan in Its Northern Cultic Context. Archaeology and Biblical Studies. Atlanta: Society of Biblical Literature.

Ackerman, Susan. 2013. E-Dan. Journal of Ancient Near Eastern Religions 13: 153-87. [CrossRef]

Albertz, Rainer. 1994. A History of Israelite Religion in the Old Testament Period. Volume 1: From the Beginnings to the End of the Monarchy. Translated by J. Bowden. Louisville: Westminster/John Knox Press.

Albertz, Rainer, and Rudiger Schmitt. 2012. Family and Household Religion in Ancient Israel and the Levant. Winona Lake: Eisenbrauns.

Altmann, Peter, and Anna Angelini. Forthcoming. To Eat or Not to Eat? Collected Essays on the Biblical Dietary Law. Archaeology and the Bible. Tübingen: Mohr Siebeck.

Altmann, Peter, and Abra Spiciarich. Forthcoming. Chickens, Partridges, and the /tor/ of Ancient Israel and the Hebrew Bible. Israel Exploration Journal.

Altmann, Peter. Forthcoming. Banned Birds: The Birds of the Dietary Laws. Archaeology and the Bible. Tübingen: Mohr Siebeck.

Arnold, Elizabeth R. 2018. Climate and Environment of the Levant. In Behind the Scenes of the Old Testament: Cultural, Social, and Historical Contexts. Edited by Jonathan S. Greer, John W. Hilber and John H. Walton. Grand Rapids: Baker Academic, pp. 21-27.

Baker, John R., and Don R. Brothwell. 1980. Animal Diseases in Archaeology. London: Academic Press.

Barth, Fredrik. 1969. Introduction. In Ethnic Groups and Boundaries: The Social Organization of Culture Difference. Edited by Fredrik Barth. Boston: Little, Brown and Co., pp. 9-38.

Behrensmeyer, Anna K. 1978. Taphonomic and Ecologic Information from Bone Weathering. Paleobiology 4: 150-62. [CrossRef]

Binford, Lewis Roberts. 1978. Nunamiut Ethnoarchaeology. Studies in Archeology. New York: Academic Press.

Binford, Lewis Roberts. 1981. Bones: Ancient Men and Modern Myths. New York: Academic Press.

Biran, Avraham. 1994. Biblical Dan. Jerusalem: Hebrew Union College.

Bloch-Smith, Elizabeth. 1992. Judahite Burial Practices and Beliefs About the Dead. Sheffield: JSOT Press.

Boessneck, Joachim. 1969. Osteological Differences between Sheep (Ovis aries Linné) and Goat (Capra hircus Linné). In Science in Archaeology. Edited by Don R. Brothwell and Eric S. Higgs. New York: Praeger, pp. 331-58.

Brett, Mark G., ed. 2002. Ethnicity and the Bible. Boston: Brill.

Casteel, Richard W. 1978. Faunal Assemblages and the "Wiegemethode" or Weight Method. Journal of Field Archaeology 5: 71-77.

Chaplin, Raymond E. 1971. The Study of Animal Bones from Archaeological Sites. London: Seminar Press.

Cohen, Anthony P. 1994. Self Consciousness. London: Routledge.

Davies, Philip R. 2007. The Origins of Biblical Israel. London: T \& T Clark.

Dever, William G. 2001. What Did the Biblical Writers Know and When Did They Know It? What Archaeology Can Tell Us About the Reality of Ancient Israel. Grand Rapids: Eerdmans.

Dever, William G. 2005. Did God Have a Wife? Archaeology and Folk Religion in Ancient Israel. Grand Rapids: Eerdmans.

Dever, William G. 2017. Beyond the Texts: An Archaeological Portrait of Ancient Israel and Judah. Atlanta: SBL Press. 
Ebeling, Jennie, J. Edward Wright, Mark Elliot, and Paul V. M. Flesher, eds. 2017. The Old Testament in Archaeology and History. Waco: Baylor.

Ekroth, Gunnel. 2013. What We Would Like the Bones to Tell Us: A Sacrificial Wish List. In Bones, Behaviour, Belief: The Zooarchaeological Evidence as a Source for Ritual Practice in Ancient Greece and Beyond. Edited by Gunnel Ekroth and Jenny Wallensten. Stockholm: Svenska Institutet i Athen, pp. 15-30.

Ekroth, Gunnel, and Jenny Wallensten, eds. 2013. Bones, Behaviour, Belief: The Zooarchaeological Evidence as a Source for Ritual Practice in Ancient Greece and Beyond. Stockholm: Svenska Institutet i Athen.

Emberling, Geoff. 1997. Ethnicity in Complex Societies: Archaeological Perspectives. Journal of Archaeological Research 5: 295-344. [CrossRef]

Eriksen, Thomas Hylland. 2015. Fredrik Barth: An Intellectual Biography. London: Pluto Press.

Faust, Avraham. 2006. Israel's Ethnogenesis: Settlement, Interaction, Expansion and Resistance. London: Equinox/Routledge.

Faust, Avraham. 2010. The Archaeology of the Israelite Cult: Questioning the Consensus. Bulletin of the American Schools of Oriental Research 360: 23-35. [CrossRef]

Faust, Avraham. 2017. An All-Israelite Identity: Historical Reality or Biblical Myth? In The Wide Lens in Archaeology: Honoring Brian Hesse's Contributions to Anthropological Archaeology. Edited by Justin Lev-Tov, Paula Hesse and Allan Gilbert. Atlanta: Lockwood, pp. 169-92.

Faust, Avraham. 2018. Pigs in Space (and Time): Pork Consumption and Identity Negotiations in the Late Bronze and Iron Ages of Ancient Israel. Near Eastern Archaeology 81: 276-99. [CrossRef]

Faust, Avraham. 2019. Israelite Temples: Where Was Israelite Cult Not Practiced, and Why. Religions 10: 106. [CrossRef]

Faust, Avraham, and Justin Lev-Tov. 2011. The Construction of Philistine Identity: Ethnic Dynamics in 12th-10th Centuries Philistia. Oxford Journal of Archaeology 30: 13-31. [CrossRef]

Finkelstein, Israel. 1997. Pots and People Revisited: Ethnic Boundaries in the Iron Age I. In The Archaeology of Israel: Constructing the Past, Interpreting the Present. Edited by Neil A. Silberman and David B. Small. London: A\&C Black.

Fisher, Toni. 2005. A Zooarchaeological Analysis of Change in Animal Utilization at Bethsaida from Iron Age II through the Early Roman Period. Ph.D. dissertation, University of Tennessee, Knoxville, TN, USA.

Forstenpointner, Gerhard. 2003. Promethean Legacy: Investigations into the Ritual Procedure of 'Olympian' Sacrifice. In Zooarchaeology in Greece: Recent Advances. Edited by Eleni Kotjabopoulou, Yannis Hamilakis, Paul Halstead, Clive Gamble and Paraskevi Elefanti. London: British School at Athens, pp. 203-13.

Forstenpointner, Gerhard, Alfred Galik, and Gerald E. Weissengruber. 2013. The Zooarchaeology of Cult: Perspectives and Pitfalls of an Experimental Approach. In Bones, Behaviour, Belief: The Zooarchaeological Evidence as a Source for Ritual Practice in Ancient Greece and Beyond. Edited by Gunnel Ekroth and Jenny Wallensten. Stockholm: Svenska Institutet i Athen, pp. 233-42.

Garfinkel, Yosef. 2017. Khirbet Qeiyafa in the Shephelah: Data and Interpretations. In Khirbet Qeiyafa in the Shephelah. Edited by Silvia Schroer and Stefan Münger. Orbis Biblicus et Orientalis 282. Fribourg: Academic Press, pp. 5-59.

Gifford-Gonzalez, Diane. 2018. An Introduction to Zooarchaeology. Cham: Springer.

Gilmour, Garth. 2000. The Archaeology of Cult in the Ancient Near East: Methodology and Practice. Old Testament Essays 13: 283-92.

Gitin, Seymour. 2002. The Four-Horned Altar and Sacred Space: An Archaeological Perspective. In Sacred Time, Sacred Place: Archaeology and the Religion of Israel. Edited by Barry M. Gittlen. Winona Lake: Eisenbrauns, pp. 95-123.

Grabbe, Lester L. 2008. Ancient Israel: What Do We Know and How Do We Know It? New York: T \& T Clark.

Grant, Annie. 1982. The Use of Tooth Wear as a Guide to the Age of Domestic Ungulates. In Ageing and Sexing Animal Bones from Archaeological Sites. Edited by Bob Wilson, Caroline Grigson and Sebastian Payne. Oxford: B.A.R., pp. 91-108.

Grantham, Billy J. 1995. Dinner in Buqata: The Symbolic Nature of Food Animals and Meal Sharing in a Druze Village. In The Symbolic Role of Animals in Archaeology. Edited by Kathleen Ryan and Pam J. Crabtree. Philadelphia: University of Pennsylvania Museum of Archaeology and Anthropology, pp. 73-78.

Grantham, Billy J. 2000. Qasrin and the Druze: A Cuisine-Based Model of Bone Distributions on Archaeological Sites. Near Eastern Archaeology 63: 9-19. [CrossRef] 
Greenfield, Haskel J. 1999. The Origins of Metallurgy: Distinguishing Stone from Metal Cut-marks on Bones from Archaeological Sites. Journal of Archaeological Science 26: 797-808. [CrossRef]

Greenfield, Haskel J. 2006a. Sexing Fragmentary Ungulate Acetabulae. In Recent Advances in Ageing and Sexing Animal Bones, Proceedings of the 9th Conference of the International Council of Archaeology, Durham, August 2002. Edited by Deborah Ruscillo. Oxford: Oxbow, pp. 68-86.

Greenfield, Haskel J. 2006b. Slicing Cut Marks on Animal Bones: Diagnostics for Identifying Stone Tool Type and Raw Material. Journal of Field Archaeology 31: 147-63. [CrossRef]

Greenfield, Haskel J., and Elizabeth R. Arnold. 2008. Absolute Age and Tooth Eruption and Wear Sequences in Sheep and Goat: Determining Age-at-Death in Zooarchaeology Using a Modern Control Sample. Journal of Archaeological Science 35: 836-49. [CrossRef]

Greer, Jonathan S. 2010. An Israelite Mizrāq at Tel Dan? Bulletin for the American Schools of Oriental Research 358: 27-45. [CrossRef]

Greer, Jonathan S. 2013. Dinner at Dan: Biblical and Archaeological Evidence for Sacred Feasts at Iron Age II Tel Dan and Their Significance. Boston/Leiden: Brill.

Greer, Jonathan S. 2017. The Cult at Dan: Aramean or Israelite? In Wandering Arameans: Arameans outside Syria-Textual and Archaeological Perspectives. Edited by Angelika Berlejung, Aren M. Maeir and Andreas Schüle. LAS 5. Wiesbaden: Harrasowitz, pp. 3-18.

Greer, Jonathan S. Forthcoming. The "Priestly Portion" in the Hebrew Bible Considered in Its Ancient Near Eastern Context and Implications for the Composition of P. Journal of Biblical Literature.

Halpern, Baruch. 1996. The First Historians: The Hebrew Bible and History. University Park: Pennsylvania State University Press.

Harris, Marvin. 1985. Good to Eat: Riddles of Food and Culture. New York: Simon and Schuster.

Hawkins, Ralph K. 2012. The Iron Age I Structure on Mt. Ebal: Excavation and Interpretation. Winona Lake: Eisenbrauns.

Hays, Christopher B. 2015. A Covenant with Death: Death in the Iron Age II and Its Rhetorical Uses in Proto-Isaiah. Grand Rapids: Eerdmans.

Herzog, Ze'ev. 1997. The Arad Fortresses. In Arad. Edited by Ruth Amiran, Ornit Ilan, Michael Sebanne and Ze'ev Herzog. Tel-Aviv: Israel Exploration Society, pp. 113-292. (In Hebrew)

Herzog, Ze'ev, Miriam Aharoni, Anson F. Rainey, and Shmuel Moshkovitz. 1984. The Israelite Fortress at Arad. Bulletin of the American Schools of Oriental Research 254: 1-34. [CrossRef]

Hess, Richard S. 2007. Israelite Religions: An Archaeological and Biblical Survey. Grand Rapids/Nottingham: Baker Academic/Apollos.

Hesse, Brian. 1990. Pig Lovers and Pig Haters: Patterns of Palestinian Pork Production. Journal of Ethnobiology 10: 195-225.

Hesse, Brian, and Paula Wapnish. 1985. Animal Bone Archaeology: From Objectives to Analysis. Manuals on Archaeology. Washington: Taraxacum.

Hesse, Brian, and Paula Wapnish. 1997. Can Pig Remains Be Used for Ethnic Diagnosis in the Ancient Near East? In The Archaeology of Israel: Constructing the Past, Interpreting the Present. Edited by Neil Asher Silberman and David B. Small. JSOTSup 237. Sheffield: Sheffield Academic, pp. 238-70.

Hesse, Brian, and Paula Wapnish. 1998. Pig Use and Abuse in the Ancient Levant: Ethnoreligious BoundaryBuilding with Swine. In Ancestors for the Pigs: Pigs in Prehistory. Edited by S. Nelson. Philadelphia: University of Pennsylvania Museum Press, pp. 123-35.

Hesse, Brian, Paula Wapnish, and Jonathan S. Greer. 2012. Scripts of Animal Sacrifice in Levantine Culture-History. In Sacred Killing: The Archaeology of Sacrifice in the Ancient Near East. Edited by A. Porter and G. Schwartz. Winona Lake: Eisenbrauns, pp. 217-35.

Hoch, James E. 1994. Semitic Words in Egyptian Texts of the New Kingdom and Third Intermediate Period. Princeton: Princeton University Press.

Holladay, John S. 1987. Religion in Israel and Judah Under the Monarchy: An Explicitly Archaeological Approach. In Ancient Israelite Religion: Essays in Honor of Frank Moore Cross. Edited by Patrick D. Miller, Paul D. Hanson and S. Dean McBride. Philadelphia: Fortress Press, pp. 249-99.

Horwitz, Liora Kolska. 1986. Faunal Remains from the Early Iron Age Site on Mount Ebal. Tel Aviv 13: 173-89. [CrossRef] 
Horwitz, Liora Kolska. 1987. Animal Offerings from Two Middle Bronze Age Tombs. Israel Exploration Journal 37: 251-55.

Horwitz, Liora Kolska. 1999. The Contribution of Archaeozoology to the Identification of Ritual Sites. In The Practical Impact of Science on Near Eastern and Aegean Archaeology. Edited by Scott Pike and Seymour Gitin. London: Archetype, pp. 63-69.

Horwitz, Liora Kolska. 2001. Animal Offerings in the Middle Bronze Age: Food for the Gods, Food for Thought. Palestine Exploration Quarterly 133: 78-90. [CrossRef]

Ilan, D. 2019 fc. Dan IV: The Early Iron Age Levels. Annual of the Nelson Glueck School of Biblical Archaeology. Jerusalem: Hebrew Union College.

Insoll, Timothy. 2004. Archaeology, Ritual, Religion. New York: Routledge.

Miller, James C. 2008. Ethnicity and the Hebrew Bible. Currents in Biblical Research 6: 170-213. [CrossRef]

Miller, J. Maxwell. 1991. Is It Possible to Write a History of Israel without Relying on the Hebrew Bible? In The Fabric of History: Text, Artifact and Israel's Past. Edited by Diana V. Edelman. JSOTSup 127. Sheffield: Sheffield Academic Press, pp. 93-102.

Jones, Siân. 1997. The Archaeology of Identity: Constructing Identities in the Past and Present. London: Routledge.

Kisilevitz, Shua. 2015. The Iron IIA Judahite Temple at Tel Moẓa. Tel Aviv 42: 147-64. [CrossRef]

Kitchen, Kenneth A. 1994. The Physical Text of Merenptah's Victory Hymn (The 'Israel Stela'). The Journal for the Society for the Study of Egyptian Antiquities 24: 71-76.

Klenck, Joel D. 1995. Bedouin Animal Sacrifice Practices: Case Study in Israel. In The Symbolic Role of Animals in Archaeology. Edited by P. J. Crabtree and K. Ryan. Philadelphia: University of Pennsylvania Museum of Archaeology and Anthropology, pp. 57-72.

Knohl, Israel. 2015. P and the Traditions of Northern Syria and Southern Anatolia. In Text, Time, and Temple: Literary, Historical and Ritual Studies in Leviticus. Edited by Francis Landy, Leigh M. Trevaskis and Bryan Bibb. Sheffield: Sheffield Phoenix Press, pp. 63-69.

Knoppers, Gary N. 2013. Jews and Samaritans: The Origins and History of their Early Relations. Oxford: Oxford University Press.

Lev-Tov, Justin E., and Sarah Whitcher Kansa. 2017. The Zooarchaeology of Early Historic Periods in the Southern Levant. In The Oxford Handbook of Zooarchaeology. Edited by Umberto Albarella, Mauro Rizzetto, Hannah Russ, Kim Vickers and Sarah Viner-Daniels. Oxford: Oxford University Press, pp. 367-82.

Lev-Tov, Justin, and Edward F. Maher. 2001. Food in Late Bronze Age Funerary Offerings: Faunal Evidence from Tomb 1 at Tell Dothan. Palestine Exploration Quarterly 133: 91-110. [CrossRef]

Lev-Tov, Justin, and Kevin McGeough. 2007. Examining Feasting in Late Bronze Age Syro-Palestine Through Ancient Texts and Bones. In The Archaeology of Food and Identity. Edited by Katheryn C. Twiss. Carbondale: Southern Illinois University, pp. 85-111.

Levy, Thomas E., ed. 2010. Historical Biblical Archaeology and the Future: The New Pragmatism. London: Equinox.

Linssen, Marc J. H. 2004. The Cults of Uruk and Babylon: The Temple Ritual Texts as Evidence for Hellenistic Cult Practises. Cuneiform Monographs 25. Leiden/Boston: Brill.

Lyman, R. Lee. 1994. Vertebrate Taphonomy. Cambridge: Cambridge University Press.

Lyman, R. Lee. 2008. Quantitative Paleozoology. Cambridge Manuals in Archaeology. Cambridge: Cambridge University Press.

Aharoni, Miriam. 1993. Arad, the Israelite Citadels. In The New Encyclopedia of Archaeological Excavations in the Holy Land. Edited by Ephraim Stern. New York: Simon and Schuster, vol. 1, pp. 82-87.

Mandell, Alice, and Jeremy Smoak. 2017. Reading and Writing in the Dark at Khirbet el-Qom: The Literacies of Ancient Subterranean Judah. Near Eastern Archaeology 80: 188-95. [CrossRef]

Marean, Curtis W., and Lillian M. Spencer. 1991. Impact of Carnivore Ravaging on Zooarchaeological Measures of Element Abundance. American Antiquity 56: 645-58. [CrossRef]

Marom, Nimrod, and Sharon Zuckerman. 2012. The Zooarchaeology of Exclusion and Expropriation: Looking Up from the Lower City in Late Bronze Age Hazor. Journal of Anthropological Archaeology 31: 573-85. [CrossRef]

Mazar, Amihai. 1992. Archaeology of the Land of the Bible, 10,000-586 B.C.E. Anchor Bible Reference Library. New York: Doubleday.

Mierse, William E. 2012. Temples and Sanctuaries from the Early Iron Age Levant: Recovery after Collapse. Winona Lake: Eisenbrauns. 
Milgrom, Jacob. 1991. Leviticus 1-16: A New Translation with Introduction and Commentary. Anchor Bible. New York: Doubleday.

Monson, John. 2000. The New 'Ain Dara Temple: Closest Solomonic Parallel. Biblical Archaeology Review 26: 20-35.

Moore, Megan Bishop, and Brad E. Kelle. 2011. Biblical History and Israel's Past: The Changing Study of the Bible and History. Grand Rapids: Eerdmans.

Nakhai, Beth Alpert. 2001. Archaeology and the Religions of Canaan and Israel. ASOR Books. Boston: American Schools of Oriental Research.

Niven, Laura, Teresa E. Steele, Hannes Finke, Tim Gernat, and Jean-Jacques Hublin. 2009. Virtual Skeletons: Using a Structured Light Scanner to Create a 3D Faunal Comparative Collection. Journal of Archaeological Science 36: 2018-23. [CrossRef]

O'Connor, Terry. 2008. The Archaeology of Animal Bones. Texas A\&M University Series; College Station: Texas A\&M University Press.

Miller, Patrick D. 2000. The Religion of Ancient Israel. London/Louisville: SPCK/Westminster-John Knox.

Payne, Sabastian. 1973. Kill-off Patterns in Sheep and Goats: The Mandibles from Aşvan Kale. Anatolian Studies 23: 281-303. [CrossRef]

Popkin, Peter R. W. 2013. Hittite Animal Sacrifice: Integrating Zooarchaeology and Textual Analysis. In Bones, Behaviour, Belief: The Zooarchaeological Evidence as a Source for Ritual Practice in Ancient Greece and Beyond. Edited by Gunnel Ekroth and Jenny Wallensten. Stockholm: Svenska Institutet i Athen, pp. 101-14.

Reitz, Elizabeth Jean, and Elizabeth S. Wing. 2008. Zooarchaeology. Cambridge Manuals in Archaeology. Cambridge/New York: Cambridge University Press.

Renfrew, Colin. 1985. The Archaeology of Cult: The Sanctuary at Phylakopi. London: British School of Archaeology at Athens.

Renfrew, Colin. 1994. The Archaeology of Religion. In The Ancient Mind: Elements of Cognitive Archaeology. Edited by Colin Renfrew and Ezra B. W. Zubrow. Cambridge/New York: Cambridge University Press, pp. 47-54.

Renfrew, Colin, and Paul Bahn. 2016. Archaeology: Theories, Methods and Practice. New York: Thames \& Hudson.

Davis, Simon J. M. 1987a. The Archaeology of Animals. New Haven: Yale University Press.

Davis, Simon J. M. 1987b. The Faunal Remains from Tell Qiri. In Tell Qiri, a Village in the Jezreel Valley: Report of the Archaeological Excavations 1975-1977. Edited by Amnon Ben-Tor, Yuval Portugali, Miriam Avissar, Uri Baruch and Melvin Hunt. Jerusalem: The Hebrew University, pp. 249-50.

Davis, Simon J. M. 2008. 'Thou Shalt Take of the Ram...the Right Thigh; for It Is a Ram of Consecration...' Some Zoo-archaeological Examples of Body-part Preferences. In Uomini, Piante e Animali nella Dimensione del Sacro. Edited by Francesco D'Andria, Jacopo De Grossi Mazzorin and Girolamo Fiorentino. Lecce: Universita delgi studi de Lecce, pp. 63-70.

Sala, Maura. 2018. Beyond Dagon: Resilience and Entanglement of Canaanite Backgrounds in Sacred Buildings and Cult Practices of Early Iron Age Philistia. In Tell it in Gath: Studies in the History and Archaeology of Israel. Essays in Honor of Aren M. Maeir on the Occasion of his Sixtieth Birthday. Edited by Itzhaq Shai, Jeffrey R. Chadwick, Louise Hitchcock, Amit Dagan, Chris McKinny and Joe Uziel. Münster: Zaphon, pp. 352-74. Sapir-Hen, L. 2016. Pigs as an Ethnic Marker? You Are What You Eat. Biblical Archaeology Review 42: 41-43, 70.

Sapir-Hen, Lidar, Guy Bar-Oz, Yuval Gadot, and Israel Finkelstein. 2013. Pig Husbandry in Iron Age Israel and Judah: New Insights Regarding the Origin of the 'Taboo'. Zeitschrift des Deutschen Palastina-Vereins 129: 1-20.

Sapir-Hen, Lidar, Meirav Meiri, and Israel Finkelstein. 2015. Iron Age Pigs: New Evidence on their Origin and Role in Forming Identity Boundaries. Radiocarbon 57: 307-15. [CrossRef]

Schmid, Elisabeth. 1972. Atlas of Animal Bones: For Prehistorians, Archaeologists and Quaternary Geologists/Knochenatlas: Für Prähistoriker, Archäologen und Quartärgeologen. New York/Amsterdam: Elsevier.

Schmidt, Brian B. 1996. Israel's Beneficent Dead: Ancestor Cult and Necromancy in Ancient Israelite Religion and Tradition. Winona Lake: Eisenbrauns.

Shipman, Pat. 1981a. Applications of Scanning Electron Microscopy to Taphonomic Problems. Annals of the New York Academy of Sciences 376: 357-85. [CrossRef] [PubMed]

Shipman, Pat. 1981b. Life History of a Fossil: An Introduction to Taphonomy and Paleoecology. Cambridge: Harvard University Press.

Shipman, Pat, Giraud Foster, and Margaret Schoeninger. 1984. Burnt Bones and Teeth: An Experimental Study of Colour, Morphology, Crystal Structure and Shrinkage. Journal of Archaeological Science 11: 307-25. [CrossRef] 
Siegel, Jane. 1976. Animal Paleopathology: Possibilities and Problems. Journal of Archaeological Science 3: 349-84. [CrossRef]

Silberman, Neil Asher, and Israel Finkelstein. 2002. The Bible Unearthed: Archaeology's New Vision of Ancient Israel and the Origin of Its Sacred Texts. New York: Free Press.

Silver, Ian A. 1969. The Ageing of Domestic Animals. In Science in Archaeology: A Survey of Progress and Research. Edited by Don R. Brothwell and Eric S. Higgs. London: Thames \& Hudson, pp. 283-302.

Sisson, Septimus, James Daniels Grossman, and Robert Getty. 1975. Sisson and Grossman's The Anatomy of the Domestic Animals, Fifth ed. Philadelphia: Saunders.

Smith, Mark S. 2002. The Early History of God: Yahweh and the Other Deities in Ancient Israel. Grand Rapids: Eerdmans.

Sparks, Kenton. L. 1998. Ethnicity and Identity in Ancient Israel: Prolegomena to the Study of Ethnic Sentiments and Their Expression in the Hebrew Bible. Winona Lake: Eisenbrauns.

Stager, Lawrence E. 1985. Merenptah, Israel and the Sea Peoples: New Light on an Old Relief. Eretz Israel 18: $56^{*}-64^{*}$.

Stavrakopoulou, Francesca, and John Barton, eds. 2010. Religious Diversity in Ancient Israel and Judah. London: T \& T Clark.

Sykes, Naomi Jane. 2014. Beastly Questions: Animal Answers to Archaeological Issues. London: Bloomsbury.

Taylor, John G. 1993. Yahweh and the Sun: The Biblical and Archaeological Evidence for Sun Worship in Ancient Israel. JSOTSup 111. Sheffield: JSOT Press.

Tebes, Juan Manuel. 2018. The Mesha Inscription and Relations with Moab and Edom. In Behind the Scenes of the Old Testament: Cultural, Social, and Historical Contexts. Edited by Jonathan S. Greer, John W. Hilber and John H. Walton. Grand Rapids: Baker Academic, pp. 286-92.

Thareani, Yifat. 2016. Enemy at the Gates? The Archaeological Visibility of the Aramaeansat Dan. In In Search of Aram of Aram and Israel: Politics, Culture and Identity. Edited by I. de Hulster, M. Oeming and O. Sergi. Tübingen: Mohr Siebeck, pp. 169-97.

von den Driesch, Angela. 1976. A Guide to the Measurement of Animal Bones from Archaeological Sites: As Developed by the Institut für Palaeoanatomie, Domestikationsforschung und Geschichte der Tiermedizin of the University of Munich. Peabody Museum Bulletin. Cambridge: Peabody Museum of Archaeology and Ethnology, Harvard University.

Wapnish, Paula. 1993. Archaeozoology: The Integration of Faunal Data with Biblical Archaeology. In Biblical Archaeology Today, 1990: Proceedings of the Second International Congress on Biblical Archaeology. Edited by Avraham Biran and Joseph Aviram. Jerusalem: Israel Exploration Society, pp. 426-42.

Wapnish, Paula, and Brian Hesse. 1991. Faunal Remains from Tel Dan: Perspectives on Animal Production at a Village, Urban, and Ritual Center. Archaeozoologia 4: 9-86.

Weinfeld, Moshe. 1983. Social and Cultic Institutions in the Priestly Source against Their Ancient Near Eastern Background. In Proceedings of the Eighth World Congress of Jewish Studies. Jerusalem: Humanities Press, pp. 95-129.

Younger, K. Lawson. 2018. The Tel Dan Inscription and the Deaths of Joram of Israel and Ahaziah of Judah. In Behind the Scenes of the Old Testament: Cultural, Social, and Historical Contexts. Edited by Jonathan S. Greer, John W. Hilber and John H. Walton. Grand Rapids: Baker Academic, pp. 293-98.

Zeder, Melinda A. 2006. Reconciling Rates of Long Bone Fusion and Tooth Eruption and Wear in Sheep (Ovis) and Goat (Capra). In Recent Advances in Ageing and Sexing Animal Bones, Proceedings of the 9th Conference of the International Council of Archaeology, Durham, UK, 23-28 August 2002. Edited by Deborah Ruscillo. Oxford: Oxbow, pp. 87-118.

Zeder, Melinda A., and Heather A. Lapham. 2010. Assessing the Reliability of Criteria Used to Identify Postcranial Bones in Sheep, Ovis, and Goats, Capra. Journal of Archaeological Science 37: 2887-905. [CrossRef]

Zevit, Ziony. 2001. The Religions of Ancient Israel: A Synthesis of Parallactic Approaches. London: Continuum.

(C) 2019 by the author. Licensee MDPI, Basel, Switzerland. This article is an open access article distributed under the terms and conditions of the Creative Commons Attribution (CC BY) license (http://creativecommons.org/licenses/by/4.0/). 

Article

\title{
Israelite Festivals: From Cyclical Time Celebrations to Linear Time Commemorations
}

\author{
Zev I. Farber ${ }^{1,2}$ \\ 1 TheTorah.com, Project TABS (Torah and Biblical Scholarship), Passaic, NJ 07055, USA; \\ zev.farber@thetorah.com \\ 2 Kogod Research Center, Shalom Hartman Institute, Jerusalem 9108001, Israel; zev.farber@shi.org.il
}

Received: 18 January 2019; Accepted: 9 May 2019; Published: 14 May 2019

\begin{abstract}
The Pentateuch and later Jewish tradition associates the key pilgrimage festivals with stories about Israel's past. Nevertheless, these festivals all began as agricultural or seasonal festivals. Using comparative evidence from the ancient Near East, and looking at the Covenant Collection, the earliest biblical law collection, through a redaction critical lens, we can uncover the early history of these festivals and even how they developed in stages. A similar process is evident with the Sabbath, which appears to have begun as a moon festival, as per certain biblical references and from comparative evidence, but which eventually developed into the seventh day of rest as part of the institution of the week, and then comes to be associated with the story of God resting after creation. These developments, from celebrating agricultural and lunar cycles to celebrating mnemohistorical events, can be seen as part of two parallel processes: the coalescing of Israelite cultural memory and the institution of the linear calendar as the dominant conception of time.
\end{abstract}

Keywords: Israelite festivals; Sabbath; calendars; pilgrimage festivals; full-moon celebrations; harvest celebrations; firstborn rituals; first produce rituals

\section{Introduction: Experiencing Time}

After smelling the burnt offerings offered him by Noah after the flood, ${ }^{1}$ YHWH decides that he will no longer curse the earth on account of humanity (Gen 8:22): "So long as the earth endures, seedtime and harvest, cold and heat, summer and winter, day and night shall not cease." 2 The verse in Genesis paints a picture of a cyclical world, where one time or season follows another without end. The final item, day and night, is different from the other three in that it is about the daily cycle, while the others are about the yearly cycle.

The first pair, seed time and harvest time, happen in the autumn and spring respectively, and, they are the inverse of each other, since one harvests that which the other plants. The next two, cold and heat/summer and winter are ostensibly synonymous with each other, with the pairs being written one after the other in a boustrophedonic or chiastic pattern (ABBA). Thus, the verse presents the reader with three cycles that $\mathrm{YHWH}$ is promising not to interrupt: agricultural, seasonal, and astronomical.

As observed by Mercea Eliade, time can be experienced as linear or cyclical (Eliade 1959). ${ }^{3}$ Modern calendars emphasize linear time. They begin from a fixed point (creation of the world, Mohamed's hijra

1 It has been argued that the original context of this verse in the J story was not after a flood, but after a drought (Dershowitz 2016).

2 All quotes from the Hebrew Bible follow the NJPS (New Jewish Publication Society) translation with some adjustments by the author.

3 This dichotomy is somewhat artificial as humans likely always experience aspects of both, but it is a useful heuristic to paint human experience of time in broad strokes. 
to Mecca, etc. $)^{4}$ and continue from there. For instance, in the Gregorian calendar, the year 2018 is two thousand and eighteen years since the officially recognized birth of Jesus. But this linear conception of forward movement from a fixed point in the past is not the only way in which we experience time. In addition to imagining time as a line, humans also imagine it as an endless circling. This is what is being pictured by the verse about days and seasons.

\section{Festivals at Set Times}

An important part of calendars in all cultures is the marking of festivals celebrating something of importance at a given time of year. Festivals can celebrate both kinds of time. For example, the Pennsylvania Dutch celebration of Groundhog Day, is tied to the belief that a groundhog knows whether the winter cold will be long or short in a given year, based on whether it sees its shadow or not when it emerges on February 2. This yearly ritual of watching the groundhog is not tied to some event in the past or a commemoration of previous Groundhog Days; rather, it is simply part of the cycle of winters. The Jewish festival of Tû bə-Šabāt, the New Year for Trees, is essentially the same, as it simply marks the point of midwinter. At the opposite end of the spectrum would be July 4th, which celebrates American independence from England, or the practice of celebrating one's anniversary or birthday.

Sometimes a festival, on its face, may appear to be celebrating something in linear time, while at the same time, be masking a more basic or primal celebration of something in cyclical time (Z. I. Farber 2018, pp. 443-44,449-50). This masking of a cyclical time festival with a linear time conception (commemorating an important event) seems to underlie what happened with the Israelite festivals found in the Hebrew Bible.

The aim of this paper (in accordance with the aim of the entire issue) is to present an overview of the topic, rather than a detailed and comprehensive argument for a new thesis. Even so, the way the material will be presented should present the reader with a new, overall picture of the development of the Israelite festival calendar. To do this, we will look at the development of the texts, in the light of source and redaction criticism, as well as with comparative models in the ancient Near East. Nevertheless, as the paper is necessarily broad in scope, in order to cover this large topic, many of the specific defenses of given claims and readings will have to rely on works cited in the bibliography where the original research is presented in detail. ${ }^{5}$

\section{Moon Festivals (Hōdeš and Šabbāt/Kēse')}

The ancient Israelites/Judahites celebrated two moon holidays monthly. The New Moon festival was called Hōdeš, which comes from the Hebrew root ש.T.r meaning "new." The full moon festival was called either $\breve{S} a b b \bar{a} t$, a loanword from the Akkadian name for this day $(\breve{S} a b a t t u / \breve{S} a p a t t u)^{6}$ or, less commonly, Kēse', another word for full moon that also appears in Aramaic and Syriac. ${ }^{7}$

In early biblical texts, these holidays are often paired together. Thus, in 2 Kings 4 (8th cent.), ${ }^{8}$ when the woman whose son has died wishes to see the prophet Elisha at once, her husband (who does

4 It does not matter whether these are actual historical events, or mnemohistorical fictions. In either case, this is the internal or constructed logic of the calendar.

5 For an overview of the biblical material, see (Soulnier 2012, pp. 71-82).

6 The idea of Shabbat as Vollmondfest goes back to the work of Johannes Meinhold $(1905,1909)$. Recent arguments in favor of this theory can be found in J. L. Wright (2015), Grund (2011), and Robinson (1988). A succinct summary of the argument can be found in (Albertz [1992] 1994, pp. 408-9). The connection is rejected by a number of scholars, who see the sound similarity as coincidental and the differences between the two as extreme. See (Levine 2008, p. 77; Tigay 1998a, pp. 22-25).

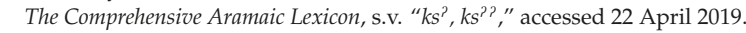

8 There is never a consensus on the dating of biblical texts, and a full attempt to argue the dating of each would treble the size of this essay, so I will briefly note in discussions as to when I date a text and why. In this case, though the Deuteronomistic History is certainly no earlier than the late 7th century, and much is even post-exilic, the work was based on earlier sources, which it incorporated. In this case, the stories of the northern prophets, Elijah and Elisha, are most likely northern traditions. Following (Rofé [1982] 1988, p. 73), I see Elisha's vita set in the late 9th century and penned before the destruction of the north in the late 8 th century. 
not know their son has died) asks her (v. 23): "Why are you going to him today? It is neither Hōdeš nor Šabbāt." This implies that seeking an audience with a prophet or religious figure was something people would do on these festivals.

These were days when people would assemble, and offerings be brought to God, as implied by Isaiah's criticism (Isa 1:13): "Bringing oblations is futile, incense is offensive to Me. Hōodeš and Šabbāt, proclaiming of solemnities, assemblies with iniquity, I cannot abide" (early 7th cent.). In connection with Isaiah's description of days of "proclaiming," Psalm 81:3[4] (8th cent.) describes how the horn would be blown on these holidays: "Blow the horn on Hōdeš, on Kēse' for our festival day." 9

From Amos' rebuke of the northern Israelites' business practices (8th cent.), we can deduce that business was not conducted on these days (8:4-6):

${ }^{4}$ Listen to this, you who devour the needy, annihilating the poor of the land, ${ }^{5}$ saying, "If only Hōdeš were over, so that we could sell grain; Šabbāt, so that we could offer wheat for sale, using an ephah that is too small, and a shekel that is too big, tilting a dishonest scale, ${ }^{6}$ and selling grain refuse as grain!..."

Other passages show that these festivals were often celebrated as family meals. For instance, when the seductress in Proverbs is convincing the young man that her husband is going to be gone for a long time, she says (Prov 7:20): "He took his bag of silver with him and will return only on the day of Kése'" (8th cent. or earlier). ${ }^{10}$ The family feast day concept is also the premise of the story about David's retreat from Saul in 1 Samuel 20:

24 ... Hōdeš came, and the king sat down to partake of the meal. ${ }^{25}$... but David's place remained vacant. ... ${ }^{27}$ On the day after Hōdeš, the second day, ${ }^{11}$ David's place was vacant again. So Saul said to his son Jonathan, "Why didn't the son of Jesse come to the meal yesterday or today?" 28 Jonathan answered Saul, "David begged leave of me to go to Bethlehem. ${ }^{29}$ He said, 'Please let me go, for we are going to have a family feast in our town and my brother has summoned me to it. ..." 34 Jonathan rose from the table in a rage. He ate no food on the second day of Hōdeš ... (9th cent. $)^{12}$

The above sketch likely reflects the practice of the pre-exilic period in Israel and Judah. Each one of these festivals changes in later texts, starting in late pre-exilic Judah (7th century) and continuing into the exilic and post-exilic periods. Hōdeš mostly disappears from popular practice, though it remains "on the books" for priests, as it involves a special set of sacrifices in the Temple (Num 28:11-15) accompanied by ritual trumpet blasts as a reminder (zîkārôn) before YHWH (Num 10:10).

The transformation of Šabbāt was much more radical. First, the original Šabbāt or Kēse' disappears entirely, even from the Priestly sacrificial lists. This may have happened for the same reason that Hōdeš vanishes as a festival. At one point, these two festivals celebrated the cyclical moon cycle, which goes from full-to-new-to-full. At some point, the relationship to the moon cycle changed, and the main conceptualization of this cycle became a way to mark time. (We will return to this point in a later section.) As such, Hōdeš became important, not as a moon celebration, but as the beginning of a month.

9 This is a northern psalm, so it should be dated to before the destruction of the north.

10 This observation fits with the view of Carr (2011), who dates much of Proverbs, including chp. 1-9 to the early monarchic period (pp. 403-31). Other scholars date Proverbs, especially chp. 1-9 much later. See, e.g., (Schmid [2008] 2012, pp. 186-89), who dates it as late as the Ptolemaic period.

11 According to this source, Hōdeš may have been celebrated for two days. Perhaps this is connected to the ancient Near Eastern practice of also marking the day of the moon's disappearance ( $\bar{u} m$ bubbulim) which would come right before the new moon (Horowitz 1998, pp. 162-63).

12 Samuel is one of the oldest, if not the oldest, narrative books in the Bible. Though it shows editorial layers, as with most biblical books, the stories connecting Saul and David are early enough that they still reflect 10 th century realities (Fleming 2012, p. 105). 
Consequently, the full moon Šabbāt lost its meaning, since there is little reason to mark the middle of a month. ${ }^{13}$

Nevertheless, the name Šabbāt does not disappear. Rather, it is reinterpreted. In later texts, $\breve{S} a b b \bar{a} t$ is no longer the name of the full-moon day but is understood as deriving from the Hebrew root meaning "rest." It thus gets connected to an entirely different ancient rule, found in the 8th century Covenant Collection, requiring Israelites to rest every seven days (Exod 23:12):

Six days you shall labor, but on the seventh day you shall cease (תשְּ ), so that your ox and your donkey may have relief, and the son of your maidservant and the resident alien may be refreshed. ${ }^{14}$

This rule originally expressed the need to give rest or vacation to one's servants and animals, and may very well have been observed by different Israelites on different days, since there was, as yet, no concept of days of the week. The number seven was likely chosen for its symbolic importance.

The creation of a seventh-day Šabbāt came together with a fixing of the weekly calendar, a practice that begins with the Assyrian $\bar{u} m \bar{u}$-lemnut $\bar{u}$, (always written in Sumerian logograms, UD.HUL.GAL ${ }_{2}$ ), meaning, "evil days." 15 The inclusion of such days in Mesopotamian menologies (ritual calendars) goes back at least to the 10th century B.C.E., but in its earlier phases, the exact days varied according to month (Landsberger 1915, pp. 119-26; Langdon 1935, pp. 73-90). By the time of the late Neo-Assyrian Empire, however, the $\bar{u} m \bar{u}$-lemnut $\bar{u}$ occur on days 7, 14, 19, 21, and 28. With the exception of the 19th, the rest of the days are clearly based on lunar quarters, with the last day or two of the month $(\bar{u} m$ bubbulim) likely not counted as part of the division but instead as a festival (Langdon 1935, p. 89).

On these days, the king was warned against certain practices, such as conducting business, eating cooked food, changing clothes, riding on his chariot, etc. For example, we are told regarding day 7 of the month in the Neo-Assyrian calendar:

[Lucky] and sinister. King as shepherd of the peoples may eat no cooked flesh and baked bread. He may not change his garments, may not make sacrifices, ride in a chariot, nor speak as a lord. Seer shall not prophesy and physicians not practice. Unsuited for doing anything desirable. (Langdon 1935, p. 75)

Similarly, a letter written to a Neo-Assyrian king states:

The 19th day (is the day) of wrath ... an auspicious day, an evil day. The shepherd of the great people does not eat anything cooked on fire; he does not change the garment of his body, put on clean ones, nor does he perform a sacrifice. The king does not ride a chariot, nor speak in an authoritative tone. (Parpola [1983] 2007, p. 206)

Parpola notes that these days have a somewhat contradictory character, both positive ("lucky or auspicious") and negative ("bad or evil"):

These days were not simply "inauspicious": every "evil day" is characterized in the series Inbu Bēl Arhi as "auspicious" (UD ŠE). The attribute "evil" probably derives from a learned association of every seventh day of the month (the principal lunar phases) and their multiple $(7 \times 7=49=30=19$ : the 19th day $)$ with the seven evil demons, through number symbolism. (Parpola [1983] 2007, p. 178)

It is easy to see the connection between a system of every seven days being declared special and off-limits to certain types of activities and what becomes the Judean Sabbath day by the late first

13 Grund (2011, pp. 136-42) discusses the moon festivals from this perspective in the section aptly titled "Linear and cyclical views of time in Israel and its environment" (Lineare und zyklische Zeitauffassung in Israel und seiner Umwelt).

14 See also, Exod 34:21, which seems to be working with the same model.

15 See CAD (Chicago Assyrian Dictionary), Volume 9 (L), s.v. "Lemnu," C3, p. 122. (Gelb 1956-2010). 
Temple or exilic period, and many scholars have made this connection. Certainly, as Jeffrey Tigay cautiously notes, one cannot argue for a simple adoption of the $\bar{u} m \bar{u}$-lemnut $\bar{u}$ by the Judeans, due to a number of important differences:

- The Mesopotamian practice was to divide the month by quarters, not to have a seven-day week;

- The Mesopotamian days included day 19 either with or in place of 21, and sometimes neither of these;

- The days were generally seen as negative (though not exclusively so).

Despite these differences, even Tigay admits that the connection is attractive and that the $\bar{u} m \bar{u}$-lemnutū were likely at least a factor in the reimagining of Šabbāt (Tigay 1998b, pp. 93-96). Therefore, rather than dismissing this connection, we might suggest that the Judean practice, inspired by the connection with the seventh-day vacation rule, disentangled the Šabbāt from the lunar month entirely, and connected their rest day for workers with the Neo-Assyrian rest days for the king (and other officials), emphasizing the solemn importance of these days, and the importance of not profaning them with work. This process would have begun in the 7th century, when Judah was a vassal state to Assyria.

Significantly, Šabbāt's reinvention as a weekly rather than monthly holiday, not only made it much more frequent, but changed the nature of the more ancient day of rest by turning "every seventh day" (a subjective counting) into "every Day Seven" (a communal, fixed counting), thereby incorporating weeks into the communal calendrical conscience. This is a significant development, since weeks, unlike lunar months or solar years, do not reflect natural phenomena, but rather, are based on human conceptual schemes, which may explain why Šabbāt continued to undergo two further, contradictory conceptual changes, both of which attempt to make sense of the law.

First, in the Deuteronomic school, the day-of-rest law was explained as existing because God took Israel out of Egypt (Deut 5:15). In other words, it is loosely connected to linear time. This is not really a radical change, since the conceptual link is clear: Israel should treat their slaves and workers well, remembering how unfairly they were treated in Egypt. Second, the Priestly revision-probably from post-exilic scribes of the Holiness school ${ }^{16}$ — connects the seventh-day Šabbät to the creation of the world and claims that the reason Šabbāt must be observed is because it commemorates God's resting on the seventh day (Gen 2:1-3; Exod 20:10, 31:17).

In sum, looking at the moon festivals, we can see the virtual disappearance of two festivals that originally celebrated natural, cyclical phenomenon. Hōdeš, which celebrated the new moon is discontinued in everything but name, remaining only as a Temple-based sacrificial law, while Šabbāt as a celebration of the full moon disappears entirely, reemerging as the name of a seventh-day holiday, inspired by the exodus from Egypt and commemorating God's creation of the world. We will see that similar developments took place with other festivals as well.

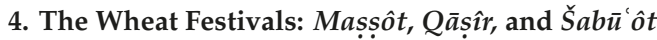

The Covenant Collection in Exodus (21:1-23:19) is believed by many scholars to be the oldest of the Pentateuchal legal collections (Levinson 1997; D. Wright 2009). It includes a description of three festivals (Exod 23:14-17):

${ }^{14}$ Three times a year you shall hold a festival for Me: ${ }^{15}$ The Feast of Mașsôt (Unleavened Bread) you shall observe- eating unleavened bread for seven days as I have commanded you-at the set time in the Hōdeš (New Moon) of 'Ābîb (Green Ears), for in it you went forth

16 Although for a long time, $\mathrm{H}$ was considered to be earlier than $\mathrm{P}$ and pre-Exilic, for the past two decades, the majority of scholars have embraced the idea that $\mathrm{H}$ is a revision of $\mathrm{P}$ or even the editor of the Pentateuch itself. As such, without taking a position on whether $\mathrm{P}$ is pre- or post-exilic, it seems quite likely that $\mathrm{H}$ is, though some scholars disagree. (See Knohl [1995] 2007; Schectman and Baden 2009). 
from Egypt; and none shall appear before Me empty-handed; ${ }^{16}$ and the Feast of the Qāsîr (Harvest), of the first produce of your work, of what you sow in the field; and the Feast of 'Asitp (Ingathering) at the end of the year, when you gather in the results of your work from the field. ${ }^{17}$ Three times a year all your males shall appear before the Sovereign, YHWH.

The three holidays here are not of a piece. The first is described as a commemoration of the exodus from Egypt, the latter two as agricultural holidays, celebrating the successful growth season of certain products. And yet, part of the difference derives from redactional supplements (supplements are indented):

\section{The Feast of Mașsôt-}

you shall observe, eating unleavened bread for seven days as I have commanded you-

at the set time in the Hōodeš of 'Ābîb,

for in it you went forth from Egypt;

The first supplement is easy to recognize, since this phrase was added into a number of biblical passages, interrupting the flow of the text (e.g., Exod 12:15-16, 13:6; Deut 16:3). ${ }^{17}$ The second was part of the attempt to redefine many different observances as being commemorations of the exodus (more on this later). Thus, the oldest layer of the Mașôt passage follows the same structure as the other two: name of festival plus season of observance.

And yet, the festivals are still not of a piece. The time for celebrating Mașôt is marked by a date, while the time for celebrating Q Q⿳亠şir and 'Assîp is marked by an agricultural stage, when you harvest or gather the given product. Moreover, the meaning of the latter festivals is clear-thanksgiving for a good harvest-whereas the meaning of the Mașôt festival is opaque. What are the unleavened flatbreads for?

The first clue comes from the date- the first of the month of "Green Ears" ('Ābîb). ${ }^{18}$ To what grain does this refer? An important find that sheds light on the agricultural calendar for ancient Canaan/Israel is what scholars call "the Gezer Calendar," discovered in 1908 at Tel Gezer by R.A.S. Macalister, and dated to the 10th century (roughly the time of David according to biblical chronology). I will quote the calendar in full, as we will make reference to other parts of it later in the piece.

His double-month is ingathering. His double-month is sowing. His double-month is late-planting. His month is chopping flax. His month is barley harvest. His month is harvest and measuring. ${ }^{19}$ His double-month is pruning. His month is summerfruit. Abiya (trans., P. Kyle McCarter, COS 2, 2003, p. 222 [\#2.85]). (Hallo and Younger 2003) ${ }^{20}$

For our purposes, it should be noted that immediately preceding the wheat harvest is the barley harvest. Wheat was a much more significant product to the farmers than barley, and as we already see in the Gezer Calendar, where the word "harvest" without a modifier refers to wheat harvest. Similarly, the Bible also specifies "barley harvest" when it has this in mind (2 Sam 21:9, Ruth 1:22), whereas the word "harvest time" on its own, likely refers to the wheat harvest. In any event, Exodus 34, which is a later revision of parts of Exodus 23 (Gesundheit 2002), specifically states that the holiday of Qāsîr celebrates the wheat harvest. But what about the festival of Mașôot?

17 Although many scholars still read this text as coming from one author, a number of scholars have suggested redaction along the lines discussed above. The specific, critical redaction suggestion here is based on Gesundheit (2002). Reinhard Kratz refers to the addition in v. 15 as "syntactically clumsy" (Kratz [2000] 2005, pp. 142, 152 n49). A middle position, in which the author of the whole passage is the author of the Covenant Collection, but that this author was reworking older material, is found in Wright (2009, pp. 310-11).

18 As Hödeš can mean month, the phrase could be translated as "at the set time in the month of green ears." This would then assume that the reader knows the set time for this festival.

19 The translation of this word is disputed. Others, such as King and Stager (2001, pp. 88-89) suggest "feasting."

20 The language of this document, specific translations of given words, and even the nature of the document, are all matters of dispute. See discussion in (Talmon 1963; Lemaire 1976; Young 1992; Sivan 1998). 
The Hebrew word Mașsôt, in the biblical text, refers to flatbreads, likely made from barely (Avrahami 2018). As the stores of wheat would have been depleted if not entirely used up by this point in the year, flatbreads would have been the only bread available in this season; green ears of wheat can be eaten parched (qālûy in biblical terms, known today by the Arabic term, freekeh), but cannot be made into flour for baking. What is the festival's meaning?

On one level, it seems possible that the festival celebrates the barley harvest (Schmidt [1968] 1983, p. 120). If so, it would work well with the other two festivals, as each celebrates a different harvest. And yet, this only partially explains the festival for two reasons. First, if it were to be exactly like the other two festivals, then one would imagine the first barley being offered not eaten. Second, the verse never mentions this being the time of gathering barley. Instead, the only marker is a date, and this is a reference to the green ears of unripe wheat, not the ripe barley.

Thus, the eating of (barley) flatbreads may have been an apotropaic ritual to ensure the success of the wheat harvest (Propp [1999] 2010, pp. 429-34). Specifically, it appears to be a privation ritual, the logic of which comes from the idea that showing wealth can bring about the opposite. We know from other biblical passages that in years of plenty, the stores of wheat grain could last into and even past the next year's wheat season (Lev 26:10). And yet, as fates and gods are capricious in many cultures' conceptions, eating baked wheat bread at the beginning of the wheat harvest season could be understood as implying that the farmers have "no need" of this new crop or any divine help. Such an implication could anger the relevant deities, causing them to demonstrate how much they are needed by destroying the crops with blight or bad weather.

An argument for the likelihood of this interpretation comes from the concomitant ritual act that, although not mentioned in the Covenant Collection or the Ritual Decalogue (and thus perhaps a later development), appears in all other references to this festival: the prohibition to eat leaven (Exod 12:15, 13:3, Deut 16:3) and the requirement to remove all leaven from one's midst (Exod 12:19-20, 13:7, Deut 16:4). Noting this, Yael Avrahami (2018) has argued that the ritual of the Mașôt festival mimics the practice of a bad year by having the Israelites live as if they had no wheat in stock. Such an act of self-privation was meant to ensure the opposite; as the deity would not want his people to go hungry, he would watch over the growing wheat and ensure the harvest went well.

According to this, the wheat harvest had two festivals attached to it. Mașsôt before the harvest as an apotropaic ritual, and Qāșîr when the wheat was harvested, as a ritual of thanksgiving. And yet, this brings up a new problem: the first cut of wheat-the referent of "the first produce (bîkkûr-) of one's work"- would be very soon after the festival of Mașôt, since the first cut would take place later that same month. This hardly seems as it if were two different times or seasons.

The description of the bîkkûrim grain offering in Leviticus implies that the first cut was not of ripe grain but of green ears (Lev 2:14):

If you bring a grain offering of first produce to $\mathrm{YHWH}$, you shall bring green ears (' $\bar{a} b \hat{b} b$ )

parched with fire, grits of the fresh grain, as your grain offering of first produce.

If son, Mașsôt and Qāșîr would have been contiguous festivals, one after the other. Good evidence of such a practice can be found in an alternative ritual that appears in the Holiness legislation. Leviticus 23-24 is a festival calendar, which begins in the spring. According to this calendar, Mașsôt is a seven-day festival that begins on the 15th of the month, i.e., the full moon (vv. 6-8), as opposed to the new moon of Exodus 23. Immediately after this holiday, the text lays out another ritual:

10 ... When you enter the land that I am giving to you and you reap its harvest, you shall bring a sheaf ('omer), the first of your harvest to the priest. ${ }^{11}$ He shall elevate the sheaf before YHWH for acceptance in your behalf; the priest shall elevate it on the day after Šabbāt ... ${ }^{14}$ Until that very day, until you have brought the offering of your God, you shall eat no bread or parched grain or fresh ears; it is a law for all time throughout the ages in all your settlements.

The ritual here does not describe itself as a festival (hag) and yet it uses the key words that describe the Qāșîr festival in Exodus 23, i.e., it describes what is to be done with the first cut. As the final verse 
forbids the consumption of any wheat products, including parched or raw wheat, it would seem that the law envisions such a cut to be taken from the very first green ears, and that the ritual of bringing the sheaf ('omer) is what permits consumption of wheat. ${ }^{21}$

The ritual logic of this offering goes hand in hand with that of the Mașsôt festival, which is its mirror image. Both likely originated as independent rituals to ensure a good harvest. The ' $\bar{m} m e r$ is a classic offering to God of the first produce and is a variation on what the Priestly text in Leviticus 2 calls the grain offering of the first produce. The Mașôt ritual is before the first cut and is an apotropaic ritual also aimed at ensuring the successful harvest. Unlike the Mașsôt festival here, the 'ōmer offering is not given an exact date, except for "after the Šabbät," a vaguery that has caused no end of religious polemic for millennia.

And yet, as the Holiness Text here is making use of an older law, it seems possible that Šabbāt refers not to the Priestly seventh day (as referenced at the beginning of the chapter) but to the 15th of the month. If so, then the verse does include an exact date, the 16th, and it would be the second day of the seven-day Mașsôt Festival, which is, in fact, the day many Jewish sects (including contemporary rabbinic Jews) mark the day of the 'omer.

A further piece of evidence that this may have been the intention comes from a passage in the book of Joshua, which describes what happens after the Israelites enter the land and offer the paschal offering for the first time (Josh 5):

5:10 ... the Israelites offered the paschal sacrifice on the fourteenth day of the month, toward evening. 5:11 On the day after the paschal offering, on that very day, they ate of the produce of the country, mașsôt and parched grain. 5:12 On that same day, when they ate of the produce of the land, the manna ceased. The Israelites got no more manna; that year they ate of the yield of the land of Canaan.

According to this text, the Israelites ate flatbreads and parched grain on the same day, the 15th of the month, and this was their first consumption of the local grain. This appears to be a mythical origin story for the ritual of waiting until midmonth to eat from the local produce. The 'omer text differs only by having one follow the other; first the day in which barley flatbread is consumed (15th), then the offering of the new green ears of wheat, which permits the consumption of the new wheat of that season (16th).

Returning to the Covenant Collection legislation, if its Mașsôt festival was originally just one day, and celebrated on the first of the month, when was its Qāsî̀ festival? The text never says, but, since agricultural patterns remained relatively constant, one would imagine that it came within days or at most, two weeks or so later. Such a proximity of dates would only have been possible in a society in which local altars abounded. It is hardly surprising that as time went on, and the centralization of worship in the Temple in Judah became the official standard, the 'omer ritual merged with Mașsôt. As a consequence, the celebration of the first-produce festival was pushed off until the end of the harvest season instead of its beginning.

We can see this in the dating of the festival in Deuteronomy (7th cent.) as well as that of the Holiness school (exilic/post-exilic):

Deut 16:9 You shall count off seven weeks; start to count the seven weeks when the sickle is first put to the standing grain. ${ }^{10}$ Then you shall observe the Festival of Šabu' $\hat{o} t$ (Weeks) for YHWH your God, offering your freewill contribution according as YHWH your God has blessed you.

Lev 23:15 And from the day on which you bring the sheaf of elevation offering-the day after the Šabbāt-you shall count off seven weeks. They must be complete: ${ }^{16}$ you must count until

21 For a discussion of the relationship between the 'omer offering and the first cut in Exodus, see (Weyde 2004, pp. 74-79). 
the day after the seventh week-fifty days; then you shall bring an offering of new grain to YHWH. ${ }^{17}$ You shall bring from your settlements two loaves of bread as an elevation offering; each shall be made of two-tenths of a measure of choice flour, baked after leavening, as first produce (bîkkûrîm) to YHWH ... ${ }^{21}$ On that same day you shall hold a celebration; it shall be a sacred occasion for you; you shall not work at your occupations ...

These two texts assume that the dating of this festival should be seven weeks after the first cut. Leviticus never names this festival, but the offering is still described as bîkkûrîm, first produce, as it was in Exodus. However, instead of offering the first cuts of new grain, bread is offered. In other words, the festival celebrates the final product of the wheat harvest. Deuteronomy does not say anything about new produce, and simply names the festival after the counting process. Notably, Deuteronomy does have a bîkkûrîm-like ritual in chapter 26, though again it does not use that term:

${ }^{1}$ When you enter the land that $\mathrm{YHWH}$ your God is giving you as a heritage, and you possess it and settle in it, ${ }^{2}$ you shall take some of every first produce of the soil, which you harvest from the land that $\mathrm{YHWH}$ your God is giving you, put it in a basket and go to the place where YHWH your God will choose to establish His name. ${ }^{3}$ You shall go to the priest in charge at that time and say to him, "I acknowledge this day before YHWH your God that I have entered the land that YHWH swore to our fathers to assign us." 4 The priest shall take the basket from your hand and set it down in front of the altar of YHWH your God. ${ }^{5}$ You shall then recite as follows before YHWH your God ... . ${ }^{10}$.. You shall leave it before YHWH your God and bow low before $\mathrm{YHWH}$ your God. ${ }^{11}$ And you shall enjoy, together with the Levite and the stranger in your midst, all the bounty that YHWH your God has bestowed upon you and your household.

The text never clarifies when this is to occur, and even to what products it refers when describing "every first produce," though it is hard to imagine it refers only to wheat. ${ }^{22}$ Thus, in Deuteronomy, we seem to have a total separation between the festival of $\breve{S}_{a} b \bar{u}^{\prime} \hat{o} t$, as an outgrowth of the older Qāșir festival, and the practice of bringing first produce as an offering at the Temple. The text in Exodus 34:22 would seem to be a hybrid in this regard, since the name of the festival was changed to Šabu' $\hat{o} t$ and yet, according to the simple meaning of the verse at least, the festival is still based on the bringing of the first cuts.

In Leviticus 23, the connection between first cuts and the festival remains implied, since on this festival, bîkkûrîm are brought, and it is connected by this counting ritual to the earlier day, when the first cut is brought. In both cases, however, the first cut ritual and celebration are separated, with the latter being moved to the end of the season. The tension between a first-produce festival and an end-of-season festival is never really solved in this text, and it can be seen clearly in how the 3rd century BCE book of Jubilees attempts to deal with it (Jub 6:20-21):

Now you command the Israelites to keep this festival during all their generations as a commandment for them: one day in the year during this month, they are to celebrate the festival because it is the festival of weeks and it is the festival of firstfruits. This festival is twofold and of two kinds. (Vanderkam 1989, p. 40)

As stated above, having an artificial first-produce holiday at the end of the season, fifty days after the first cut ritual, is likely a result of the centralization of the cult which would have made separating a Mașột festival from a first cut festival, virtually impossible for people living outside Jerusalem.

Despite the permutations Q Qussîr undergoes in its transformation into Šabu' $\hat{o} t$, no biblical text connects it to a mnemohistorical event-i.e., a ritual that commemorates an event from Israelite cultural

22 This problem is what lead the Qumran sect to have three separate bîkkûrîm festivals, each fifty days after the other (Sweeney 1983). 
memory-the way Mașșôt is connected to the story of the exodus. ${ }^{23}$ Thus, Qāṣ̂rr/Šabū ôt/Bîkkûrîm remains a purely agricultural festival in the Bible. Nevertheless, its transformation into a commemoration is only postponed; in the Second Temple Period, the festival becomes associated with God's revelation at Sinai. ${ }^{24}$

\section{5. 'Āsîp, Sukkôt, and the Autumn New Year}

The third festival in the Covenant Collection list is 'A $\bar{s} \hat{\imath} p$, the Festival of Ingathering. But to what form of produce does this refer? The Gezer calendar quoted above opens with "his double-month is ingathering" which must occur in the autumn, considering its placement. The product being ingathered is most likely olives, which are gathered after the summer fruit has been picked (Borowski 2003, p. 28; King and Stager 2001, pp. 88-89), perhaps also grapes. The festival calendar in Exodus 23 refers to 'Asîp being "at the șe $\bar{e}^{\prime} t$ of the year," which could mean the "end of the year" or alternatively, "the emergence of the year" (HALOT 3886) (Köhler and Baumgartner [1967-1995] 1994-2000).

Beginning the year with the ingathering fits with the Gezer calendar, which opens with the ingathering. It also works with what we know from many extra-biblical sources, uncovered over the past two centuries of archaeological excavation, namely, that the ancient Near East had two different periods in which the new year could be marked: Autumn and Spring, which is reflected in the Akkadian names for these months.

Autumn opens with the month of Tašrìtu—from the Akkadian šurrû, meaning "beginning," likely a reference to the time of planting. ${ }^{25}$ This also marks the beginning of the rainy season in the Levant, which lasts until spring. Spring begins with the month of Nissanu-from the Akkadian word for "first-produce," 26 since, as discussed above, this was the time when wheat began to ripen. It seems hardly coincidental that the two core harvest festivals, Qāṣ̂r and 'Asîp are celebrated in the autumn and spring. Instead, it would seem that these two festivals marked the two new years for the ancient Israelites.

It may seem strange to imagine two new-years, since, from the perspective of linear, calendrical time, it is necessary to mark one, and begin the year at a clear point. Nevertheless, as noted at the beginning, from the perspective of cyclical time, each of these marks a beginning and is a kind of new year. In fact, we know that in Mesopotamia, each of these new year seasons was marked by a festival called the Akītu (Bidmeade 2002, pp. 1, 44; Cohen 1993, pp. 306, 327).

We know of an overlapping autumn calendar, from Ugarit, the celebration of which began in the previous month, which was when they gathered grapes from the vine:

On the month of Rashu-Yeni ("Beginning of Wine"), on the day of the New Moon (ym.hdt;), cut a bunch of grapes for Ilu $(=\mathrm{El})$ as a piece offering (shelamim) ...

The text continues by describing how the king makes preparations starting on the 14th, and then, on the 15 th begins a seven-day celebration. Finally,

On the day of the new moon of \{the following month, equivalent to Tašrìtu\} ... the king will offer a sacrifice ... on the roof where there will be dwellings of branches, four on one side four on the other, a ram as burnt offering, a bull and a ram as peace offering, to be repeated seven times. According to what is in his heart, the king will speak. (Pardee 2002, pp. 63-65)

23 Mnemohistory differs from history in that it is not an attempt to retrieve the past, but rather, to construct it. For a general introduction to this field, see (Halbwachs [1941] 1992; Assmann 2006). For the application to biblical literature, see (Davies 2008; Edelman and Ben-Zvi 2013).

24 The Book of Jubilees connects it with other covenants as well, such as God's covenant with Noah (Jub 6:21) and the birth of Isaac (Jub 16:13).

$25 C A D$ vol. 18 (Tav), pp. 297-98, s.v. tašrītu. (Gelb 1956-2010).

26 CAD vol. 11a (N-2), pp. 265-66, s.v. nisannu. (Gelb 1956-2010). 
This month-long ritual ends with the New Moon celebration on Tašritu. In the middle of the month comes a seven-day festival. This is highly reminiscent of what we know about the equivalent holiday 'Āsîp in other biblical texts, namely Sukkôt (Del Olme Lette 2004).

Deut 16:15 You shall hold a festival for YHWH your God seven days, in the place that YHWH will choose; for YHWH your God will bless all your crops and all your undertakings, and you shall have nothing but joy. ${ }^{27}$

Of particular interest is the reference to dwellings of branches, which is reminiscent of the supplementary biblical commands about this festival at the end of Leviticus 23:

${ }^{39}$ Mark, on the fifteenth day of the seventh month, when you have gathered in (פ.0.א) the yield of your land, you shall observe the festival of YHWH to last seven days ... ${ }^{40}$ On the first day you shall take the product of hadar trees, branches of palm trees, boughs of leafy trees, and willows of the brook, and you shall rejoice before YHWH your God seven days ... . 42 You shall live in booths seven days; all citizens in Israel shall live in booths, ${ }^{43}$ in order that future generations may know that I made the Israelite people live in booths when I brought them out of the land of Egypt, I YHWH your God.

As it is difficult to imagine the direct borrowing of Israel or Judah from Ugarit, it is more likely that the text from both cultures reflect versions of the same practices that have ancient roots in the region. The purpose of these branches and booths differ in the Ugaritic and biblical conception. In Ugarit, these dwellings were for the gods, and the king would then be able to go up on the roof and speak with them, making his requests. In Leviticus, there are two different conceptions-the first is so that the people can rejoice with lovely branches, and the second so they themselves can dwell in the booths. In the Persian Period, these two conceptions were merged, with the booths being made of lovely branches (Neh 8:15). Nevertheless, the ancient origins of the Israelite/Judahite ritual may be seen in the Ugaritic practice (De Moor 1972, p. 22; Waganaar 2005, p. 23).

Another notable element in the festival at Ugarit is that the celebration was multipodal. Significantly, it featured a seven-day festival starting on the 15th (full moon) of the sixth month, and concluded on the first of the seventh month (new moon). In the Priestly and Holiness calendars, we see something similar. The first of the seventh month is a festival of horn blasts, the tenth of the month is a time for atonement and cleansing (Yôm Hakipppürîm), both of the people and of the sanctuary, and the 15th marks the seven (or eight) day festival of Sukkôt.

It would seem that, in this tradition, we have a month-long celebration, as described in Nehemiah 8, with the New Year element coming at the beginning instead of the end. Dividing the new year proper from the agricultural festival allowed Sukkot to concentrate on celebrating the ingathering season, as well as to look forward to the upcoming rainy season. Although the biblical text does not discuss Sukkôt as a rain festival, this is certainly what the festival marks in the Second Temple period, and it seems reasonable to assume that this goes back to earlier times, since Iron Age Israel and Judah were also agricultural societies depending on rainfall.

Comparative evidence, as well as later tradition, point to the virtual certainty that the autumn festivals marked the new year, and that this was the meaning of the festival of horn blasts in the Priestly literature. In fact, the connection between horn blasts, enthronement ceremonies, and ancient Near Eastern new year festivals suggest the likelihood that $\mathrm{YHWH}$ was ceremonially enthroned on this new year celebration in the First Temple period (Mowinckel 1962, vol. 1, pp. 107-92). Nevertheless, the biblical texts only state that it is the first of the seventh month. Why is the new year's element being

27 The two festivals were a month apart, but they are still versions of the same basic autumn new year celebration. Note that according to 1 Kings 12:32-33, the northern kingdom of Israel celebrated its autumn festival the month after Judah's (i.e., month 8 and not month 7), perhaps because produce ripens later in the north (Talmon 2005). 
suppressed here? The answer may come from the realities of the exilic period and the influence of Babylonian culture. To quote Julye Bidmeade (2002, p. 44):

Initially, the Mesopotamian calendar was based on a lunar cycle-the occurrence of the rising new moon after sunset indicated the beginning of the new month. The full moon marked the middle of the month, and the $\bar{u} m$ bubbulim (the day of disappearance) indicated the end of the month .... Eventually the calendar was adjusted to correspond to the solar year. The year was divided into two six-month periods determined by the equinoxes. Because of this division, the celebration of a New Year could occur both at Nisannu and at Tašritu. However, in lexical lists, economic documents, and other official inscriptions, Nisannu is always the first month of the Standard Mesopotamian calendar.

I would argue that the Israelite calendrical conception goes through a similar shift. Beginning with a celebration of cycles, the moon cycle and the seasonal/agricultural cycle, the moon and year become ways of marking linear time. As such, it became important to fix the beginning of the month and the beginning of the year. ${ }^{28}$ For this reason, the Priestly or Holiness text makes it clear the spring month is the first month of the year (Exod 12:2). This is also why the Ritual Decalogue, which revises parts of the Covenant Collection," ${ }^{29}$ describes 'A sîp occurring not at the "end (or emergence) of the

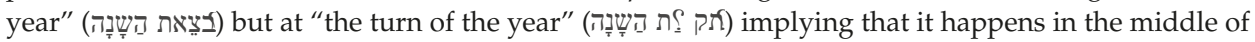
the year, as would be the case in a spring calendar.

It may even be that this is what brought about the use of numbered month-names as opposed to what we find in some ancient passages in the book of Kings, in which at least certain months have other names:

In the four hundred and eightieth year after the Israelites left the land of Egypt, in the month of $Z \bar{i} w$ - that is, the second month-in the fourth year of his reign over Israel, Solomon began to build the House of YHWH. (1 Kgs 6:1)

And in the eleventh year, in the month of Bûl—that is, the eighth month-the House was completed according to all its details and all its specifications. (1 Kgs 6:38)

All the men of Israel gathered before King Solomon at the Feast, in the month of 'Ētanntm-that is, the seventh month. (1 Kgs 8:2)

We can add to this list the name 'Âb̂tb, encountered above, which was the older name for what becomes the first month. These month names probably reflect what the local Canaanite population used as well (Vanderkam 1998, p. 6), but the priestly scribes, who accepted the Babylonian imperial calendar, and wished to emphasize that the year began in the spring, adopted numbers as names. That this did not necessarily filter down into popular practice is implied from the fact that, at least in the exilic period, the Jews adopted the Babylonian names of the months and did not use numbers.

The official adoption of the spring new year goes together with the cancellation of the full moon Šabbāt and the reconceptualization of Hōdeš not as a moon celebration but as the beginning of a month. In short, the originally cyclical month-time that went from full-to-new-to-full, etc., became a way of marking the beginning of the month, which was determined to be at Hōdeš. Full moon Šabbāt was no longer marked, though in Tishrei and Nissan, it remained as the date of the great agricultural festivals Sukkôt and Mașșôt. In addition, it is hardly coincidental that three other "festivals" in the later

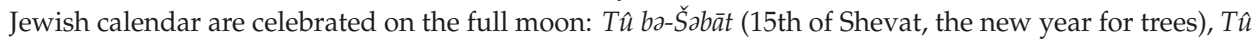
$b{ }^{\prime}{ }^{\prime} A b$ (15th of Av, the festival of love), and $\breve{S} a b \bar{u}^{\prime} \hat{o} t$, celebrated on the 15th of Sivan according to the sectarian calendar.

28 This was a standard trajectory of calendars in the ancient period, including the Egyptian and Greek calendars (Stern 2012).

29 The claim here that the Ritual Decalogue revises the Covenant Collection follows (Gesundheit 2002, pp. 12-43). This is contra the view that this text was older and perhaps even the source for the passage in the Covenant Collection. 


\section{Animal Husbandry Rituals (Firstborns and Pesah)}

In the biblical account of history, the conflict between farmers and shepherds goes back to the first brothers in human history, with Abel as the shepherd and Cain as the farmer. The conflict story is connected to the very different lifestyle that farmers and shepherds lived. Farmers were entirely sedentary, tilling the same plots of ground year after year. Although some shepherds were sedentary, others would travel with their flocks, taking them to different pastures depending on the season (Borowski 1998, pp. 40-45). Even so, the two cultures did not live entirely independently of each other, as semi-nomads relied on grains grown by farmers while the farmers were in need of meat, skins, milk, and wool from the shepherds.

The book of Genesis depicts Israel's ancestors consistently as shepherds, and Exodus depicts Moses as a shepherd, thus showing that the biblical authors were conscious of animal husbandry as being an important and even respected part of their culture. It would be surprising, therefore, if among the festivals and rituals of ancient Israel, we did not find some that were specifically the province of shepherds. Moreover, whereas large flocks of sheep and goats would generally be kept by wandering shepherds, cows and bulls were kept by farmers, and they would have had rituals of their own relevant to these animals (Knauf and Guillaume 2016, pp. 57-59).

The Covenant Collection has a doublet of laws having to do with offering first produce and firstborns to $\mathrm{YHWH}$, in chps. 22 and 23 respectively:

Exod 22:28 You shall not put off the skimming of the first yield of your vats. ${ }^{30}$ You shall give

Me the first-born among your sons. ${ }^{29}$ You shall do the same with your cattle and your flocks:

seven days it shall remain with its mother; on the eighth day you shall give it to Me.

Exod 23:19 The choice first produce of your soil you shall bring to the house of YHWH your

God. Do not allow the kid to grow fat on its mother's milk. ${ }^{31}$

The laws here emphasize that the first of many products go to $\mathrm{YHWH}$, ostensibly as sacrifices: wine, sons, cattle and flocks, produce (wheat?), and flocks again. These verses may derive from a unit separated by the splicing in of other laws. The main idea of these laws was to bring the "firsts" to YHWH immediately, and this is emphasized in both iterations of the animal law. In most cases, the animals would have been born in the winter and weaned in the spring, but the verse insists that the firstborn should be offered almost immediately, without waiting for weaning.

That the first of these laws is about wine production fits with what we saw about the Ugaritic calendar, which began preparation for the autumn new year celebration in the month of new wine, though from the Gezer calendar, we might infer that the grape gathering season was in early summer. Perhaps the first wine is a little later than first "grape juice," or perhaps the wine offering was supposed to come in the summer and not the autumn.

We will skip for a moment the offering of firstborn sons, which would not be a yearly ritual, of course, as it would only occur once per mother. Nor would it be limited to a given season, since human births happen any time of the year.

As for bringing the first born of animals, sheep and goats give birth between December and February (Borowski 1998, pp. 52, 82 n17; Hirsch 1933, p. 59). If the firstborn animals are to be brought before they are weaned, this means midwinter. Cows go into heat periodically, and their sexual cycle is not seasonal, so a firstborn calf can be born at any time of the year.

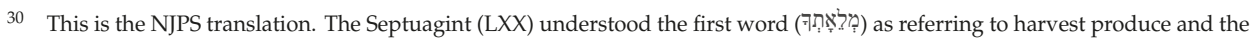

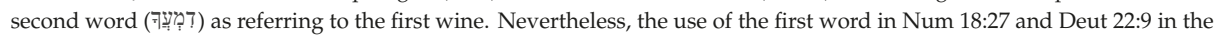
context of vineyards and wine production implies that this term is also connected to wine. The phrase may simply be a hendiadys here (HALOT 2121). (Köhler and Baumgartner [1967-1995] 1994-2000).

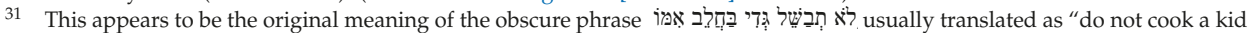
in its mother's milk." For an alternative translation, see (Schorch 2010). 
First produce, assuming this is a reference to wheat, would be cut in the spring as discussed above. In fact, this rule overlaps with the festival of $Q \bar{a} s \underline{\hat{r}} r$ which celebrates the bringing of the first cut of wheat. This overlap suggests a radical possibility hinted at above:

The three festivals, Mașsôt, Qāșîr, and 'Āsîp are not original to this text, but were added. Originally, the rule was not about festivals but simply that each Israelite male must appear at his local altar three times a year with the appropriate offerings. This is implied not only by the overlap but also by the fact that Mașṣot and Qāsîr themselves overlap, i.e., they come about in the same season.

This suggestion solves a number of textual problems. For instance, 23:15 and 23:17 say the same thing in different words. This is best explained as a Wiederaufnahme (resumptive repetition), often a sign that a supplement was added into the text. ${ }^{32}$ Second, the festivals of Mașṣôt and Qāṣ̂̀r are separated by a phrase that seems unrelated to the Mașsôt festival but closely related to the general statement in the previous verse. Here is how I would reconstruct what happened with this text-I use two indentations to show two levels of editing and underlining to show the Wiederaufname (Exod 23:14-17):

Three times a year you shall hold a festival for Me:

The Feast of Mașsôt (Unleavened Bread) you shall observe, eating unleavened bread for seven days as I have commanded you-

at the set time in the Hōdeš (New Moon) of 'Ābîb (Green Ears), for in it you went forth from Egypt;

and none shall appear before Me empty-handed; ${ }^{33}$

and the Feast of the $Q \bar{a} s \hat{\imath}^{\prime} r$ (Harvest), of the first produce of your work, of what you sow in the field; and the Feast of 'Asîp (Ingathering) at the end of the year, when you gather in the results of your work from the field.

Three times a year all your males shall appear before the Sovereign, YHWH.

The original did not specify a time or a name, since it was understood that the person should come to his local altar when his produce or animal was ready for sacrifice. I suggest that in this pre-redacted version of the "three festival" law, we have a competing set of rituals, which a later scribe reinterpreted to be a reference to "famous" communal festivals, and chose three agricultural ones, even though two (Mașșot and $Q \bar{a} s \underline{\hat{\imath}} r$ ) were related to the same event (first cut of wheat) and would be celebrated at the same time.

Part of the ritual for each of these appearances at the altar seems to have been an animal sacrifice, which may have been the original meaning of the phrase "none shall appear before me empty-handed." 34 The same "rush" we see in the laws of the first produce or firstborn can be seen with the sacrifice, which is the import of v. 18:

Exod 23:18 You shall not offer the blood of My sacrifice with anything leavened; and the fat of My festal offering shall not be left lying until morning.

The existence of altar rituals unconnected to the pilgrimage festivals fits with what we know from other biblical texts that there were festivals that existed that are not mentioned in the Pentateuchal law codes. Shilo, for instance, had its own festival (Judg 21:19, 1 Sam 1:3, 2:19) and the account of how maidens weep yearly over Jephthah's daughter (Judg 11:40) explains an existing festival. And these

32 Exodus 34 lacks the opening of this pericope, possibly because the author of the Ritual Decalogue saw the redundancy and removed it. He also has the phrase "don't see my face empty-handed" after the description of the firstborn offering which he adds here.

33 Perhaps the scribe put the Massôt text before this phrase since it is the one festival that comes with no produce, since it is an apotropaic ritual and not an offering ritual. Alternatively, it could just have been an error.

34 This may also be the import of the Cain and Abel story-YHWH does not accept sacrifices of vegetation only. 
are just examples that happened to be noted in biblical verses. Moreover, individual families may have had their own family festivals.

\section{Pesah: An Apotropaic Ritual}

The most famous of all festival offerings is the pesah, which has an elaborate ritual with clear apotropaic connotations. A number of scholars have suggested that this began as a way of protecting the flock, before the shepherd moves them to spring pastures. Yet, the ritual is very much focused on the house. For this reason, other scholars have suggested it originates as an offering not to YHWH but to the family, ancestor deity (Zevit, pp. 280-81).

A third group of scholars have suggested that it has its origins in an apotropaic ritual to protect babies, similar to the Akkadian lullabies to protect newborns from being snatched by Lamashtu (Propp [1999] 2010, pp. 434-39; W. Farber 1989, pp. 34-39; 1990). This would connect the ritual with the story behind the ritual, which becomes so central to it, that it saved the Israelite firstborns.

I suggest a related possibility, that this was a family ritual to protect the house in lieu of the sacrifice of the firstborn. To clarify, let us return to the law in Exodus 22:28, which commands the offering of the firstborn son to $\mathrm{YHWH}$. Although some interpret this to mean dedicating the son to serve at an altar, others understand this to be a requirement for child sacrifice. This is the only biblical law collection that requires child sacrifice (Levenson 1993, pp. 3-17). The binding of Isaac story (Gen 22), which originally ended with the son being sacrificed (Yoreh 2010, pp. 65-78), may be the only other biblical text that looks on this favorably. Although Leviticus 27:28-29 does allow for human sacrifice, this is not a requirement, and probably refers to a slave. ${ }^{35}$

Other texts are quite negative about it, such as Psalm 106:37-38, which speaks of this as worship of demons, or the passages in Kings (2 Kgs 23:10) and Jeremiah (7:31-32, 19:11-14) that describe the Tophet, where children were sacrificed (Stavrakopoulou 2012-2013). Nevertheless, all of these texts take it for granted that Israelites sacrifice their children, and the reference to a Tophet points to a ritual shared with the Phoenicians and Carthaginians, for which we have archaeological evidence (Vainstub 2010). Whereas Jeremiah claims that this practice has not been sanctioned by YHWH at all, Ezekiel claims that child sacrifice was indeed commanded by God, but only as an expression of his anger towards his people:

Jer 32:35 and they built the shrines of Baal which are in the Valley of Ben-hinnom, where they offered up their sons and daughters to Molech-when I had never commanded, or even thought of commanding, that they should do such an abominable thing, and so bring guilt on Judah.

Ezek 20:25 Moreover, I gave them laws that were not good and rules by which they could not live: ${ }^{20: 26}$ When they set aside every first issue of the womb, I defiled them by their very gifts—-that I might render them desolate, that they might know that I am YHWH.

In keeping with the negative attitude of the prophets, the later law collections adjust the requirement for child sacrifice, taking one of two approaches. One interpretation is that the child is to be donated to serve at the local altar. The story of Samuel's youth is an example of this. It is also the assumption of the Priestly author in the book of Numbers, who argues that the law became defunct when YHWH commanded the Levites be exchanged for the firstborn in a giant redemption ritual:

Num 3:40 YHWH said to Moses: Record every first-born male of the Israelite people from the age of one month up, and make a list of their names; ${ }^{3: 41}$ and take the Levites for Me, $\mathrm{YHWH}$, in place of every first-born among the Israelite people ...

35 The story of Jephthah's daughter (Judg 11:39) is about child sacrifice as well, but the narrator does not appear to look upon this with favor. 
The other approach was to require that the firstborn son be redeemed. This is then integrated into the general laws of firstborn offerings:

Exod 13:12 you shall set apart for YHWH every first issue of the womb: every male firstling that your cattle drop shall be YHWH's. 13:13 But every firstling ass you shall redeem with a sheep; if you do not redeem it, you must break its neck. And you must redeem every first-born male among your children.

This alternative conception of firstborn offerings is then incorporated into the Ritual Decalogue, in the section dealing with festivals, as is the Pesah offering. I suggest that both the redemption ritual and the Pesah offering are ways of dealing with the cancellation of child sacrifice. The redemption ritual has an obvious connection, since the money is in place of the offering, but the Pesah, which may have its origin in one of the other reasons surveyed above, has a subtler connection as an apotropaic ritual protecting the house. The blood of the animal victim "fools" the destroyer, coming to kill the son, and the consumption of the animal victim by the entire household bonds them together in safety. Certainly, the staying power of the pesah seder ritual as the ultimate expression of Jewish family solidarity has stood the ritual-anthropological test of time.

\section{Festivals as Commemorations}

Multiple parallel processes seem to have been at work in the reinterpretation of the festivals from what was surveyed above, to what the Bible and later Jewish tradition present as their main themes.

Calendar-We noted already that as the calendar moves from cyclical time to linear time, bipodal festival pairs such as Hōdeš and Šabbāt/Kēse', or Qūṣ̂tr and 'Āsîp, lose their meaning or even become problematic. As they could no longer express the yin-yang of moon and season, they needed to be reinterpreted or cancelled. Thus, Hödeš became nothing more than a priestly sacrificial rite, in honor of the new month, and Šabbāt/Kēse' as such disappeared entirely. Qāṣ̂̀r was split into a simple sheave offering ('omer) and a festival celebrated at the end of the wheat harvest season, Šabu' ${ }^{\prime} t$, even though it still ostensibly brought the first produce (bîkkûrîm). 'Ásîp keeps its place, though it becomes known for the branches and booths as opposed to the ingathering. Moreover, it stops being the marker of the new year, at least officially. Even the spin off festival of the horn blasts, which was almost certainly meant to mark the new year on Hōdeš instead of Šabbāt/Kèse' is reinterpreted as simply the festival of the seventh month. In this case, though, the subterfuge ultimately fails, since rabbinic Judaism reintroduces this festival as the new year celebration, despite the fact that this contradicts the Pentateuch directly and explicitly.

Communal-It may be that the agricultural achievements celebrated in the Qāṣ̂r and 'A sîp festivals were once not festivals at all, but rather, offerings required from each individual family. This would make the produce offerings parallel to the system we find for firstborn animals, which are not tied to a festival, but are required to be brought forth immediately. Perhaps this has to do with the coalescing of Israelite and Judahite worship places over time, or perhaps these two approaches existed simultaneously in competing groups. Whatever the case, eventually the produce requirements became part of the festivals and tied to specific dates, whereas the firstborn offerings remain unbound to a specific date, at least officially.

Mnemohistorical-Finally, the greatest conceptual change that the festivals undergo is their integration into Israel's emerging narrative about itself, specifically, the connection to the exodus story (Schmidt [1968] 1983, pp. 117-26). Pesah stops being about protecting Israel's babies or firstborn sons, but about how YHWH protected Israel's firstborn sons in Egypt. The same is true about the redemption of the firstborn; YHWH owns all firstborn Israelite males because he saved Israel's firstborn males in Egypt. Even firstborn animals are explained this way, and the exodus story is redacted to include the death of firstborn Egyptian animals. Mașsôt stops being about protecting the wheat harvest with an apotropaic deprivation ritual and becomes about commemorating Israel's rushed escape from Egypt without bread. Even Sukkôt, in the very latest stage of textual revision, is described as commemorating 
the booths that the Israelites lived in when dwelling in the wilderness (Lev 23:43), something which does not even appear in any biblical narratives, and may have its origins in the post-exilic period (Weyde 2004, p. 128). The one harvest festival that is not reinterpreted in the Bible, that of Šabu' $\hat{o} t$, is interpreted in Second Temple and Rabbinic literature as commemorating the revelation of the Decalogue at Mount Sinai.

Perhaps the most interesting example of historical reinterpretation is that which began not as a festival at all: the ancient law requiring Israelites to rest, and let their workers and slaves rest, every seven days. We noted above how this was first regularized to be every day seven, as part of the new division of time into weeks, and how it took over the term $\breve{a} a b b \bar{a} t$ from the defunct full-moon festival.

The next step was to interpret this law in light of the exodus, and say that Israel must allow its slaves to rest since they were not given this privilege when they were slaves in Egypt. Eventually, in the Priestly or Holiness version of the Decalogue, and other Priestly or Holiness passages, this was reinterpreted again to commemorate, not the exodus, but the creation of the world. God rests on the seventh day, and thus Israel should imitate God and do the same.

This is the only festival in the Pentateuch that is reinterpreted in light of a Genesis story and not an Exodus story. In fact, the Genesis story was written, or at least heavily revised, to explain the practice, just as many of the exodus details were written to explain the Pesah, Maṣsôt, and the firstborn laws.

\section{Conclusions}

As the Pentateuch's editors were conservative, we can still see the outlines of the original festivals and their meanings. Moreover, the Pentateuch never completely reworked the festival system into the new historical conception, nor did the editors of the other biblical books try to make all of the references cohere with the later Priestly/Holiness system. The next step in this development was taken in the 3rd century BCE by the author of Jubilees, who not only grounds Šabu' $\hat{o} t$ in the Sinai story, but regrounds all the festivals in Genesis stories as well, giving each both a patriarchal and exodus heritage. ${ }^{36}$

Funding: This research received no external funding.

Conflicts of Interest: The author declares no conflict of interest.

\section{References}

Albertz, Rainer. 1994. A History of Israelite Religion in the Old Testament Period. 2 vols. Translated by John Bowden. The Old Testament Library. Louisville: Westminster John Knox Press. First published 1992 in German.

Assmann, Jan. 2006. Religion and Cultural Memory: Ten Studies. Stanford: Stanford University Press.

Avrahami, Yael. 2018. Why Do We Eat Matzah in the Spring. Available online: https://thetorah.com/why-do-weeat-matzah-in-the-spring/ (accessed on 18 January 2019).

Bidmeade, Julye. 2002. The Akitu Festival: Religious Continuity and Royal Legitimation in Mesopotamia. Gorgias Dissertations. Near Eastern Studies 2. Piscataway: Gorgias Press.

Borowski, Oded. 1998. Every Living Thing: Daily Use of Animals in Ancient Israel. Walnut Creek: AltaMira Press. Borowski, Oded. 2003. Daily Life in Biblical Times. Atlanta: SBL.

Carr, David. 2011. The Formation of the Hebrew Bible: A New Reconstruction. Oxford: Oxford University Press.

Cohen, Mark E. 1993. The Cultic Calendars of the Ancient Near East. Bethesda: CDL Press.

Davies, Philip R. 2008. Memories of Ancient Israel: An Introduction to Biblical History Ancient and Modern. Louisville: Westminster John Knox Press.

De Moor, Johannes C. 1972. New Year with Canaanites and Israelites. Kampen: J.H. Kok.

Del Olme Lette, Gregorio. 2004. Sûkkot: From Ugarit to the Talmud-The Survival of a Ritual "in the Terrace" [in Spanish]. Miscelánea de Estudios Árabes y Hebraicos: Sección Hebreo 53: 249-69.

Dershowitz, Idan. 2016. Man of the Land: Unearthing the Original Noah. ZAW 128: 357-73. [CrossRef]

36 This, however, was not adopted by Rabbinic Judaism, and thus died out for the most part after the Judean rebellion(s) against Rome, though the tradition continued in the Ethiopian Jewish community, which held on to Jubilees. 
Edelman, Diana V., and Ehud Ben-Zvi, eds. 2013. Remembering Biblical Figures in the Late Persian and Early Hellenistic Periods: Social Memory and Imagination. Oxford: Oxford University Press.

Eliade, Mircea. 1959. The Sacred and the Profane: The Nature of Religion. New York: Harcourt, Brace and Company. Farber, Walter. 1989. Schlaf, Kindchen, Schlaf! Winona Lake: Eisenbrauns.

Farber, Walter. 1990. Magic at the Cradle: Babylonian and Assyrian Lullabies. Anthropos 85: 139-48.

Farber, Zev I. 2018. Religion in Eighth-Century Judah: An Overview. In Archaeology and History of Eighth-Century Judah. Edited by Zev I. Farber and Jacob L. Wright. Ancient Near East Monographs 23. Atlanta: SBL, pp. 431-53.

Fleming, Daniel. 2012. The Legacy of Israel in Judah's Bible. Cambridge: Cambridge University Press.

Gelb, Ignace J., and et al. 1956-2010. The Assyrian Dictionary of the Oriental Institute of the University of Chicago. 21 vols. Chicago: The Oriental Institute of the University of Chicago.

Gesundheit, Shimon. 2002. Three Times a Year: Studies on Festival Legislation in the Pentateuch. FAT 82. Tübingen: Mohr Siebeck.

Grund, Alexandra. 2011. Die Entstehung des Sabbats: Seine Bedeutung für Israels Zeitkonzept und Erinnerungskultur. FAT 75. Tübingen: Mohr Siebeck.

Halbwachs, Maurice. 1992. On Collective Memory. Translated and Edited by Lewis A. Coser. Chicago: University of Chicago Press. First published 1941 in French.

Hallo, William W., and K. Lawson Younger Jr. 2003. The Context of Scripture. Leiden: Brill, vol. 2.

Hirsch, Siegfried. 1933. Sheep and Goats in Palestine. Tel Aviv: Palestine Economic Society.

Horowitz, Wayne. 1998. Mesopotamian Cosmic Geography. Winona Lake: Eisenbrauns.

King, Philip J., and Lawrence E. Stager. 2001. Life in Biblical Israel. Library of Ancient Israel. Louisville: Westminster John Knox Press.

Knauf, Ernst Axel, and Philippe Guillaume. 2016. A History of Biblical Israel: The Fate of the Tribes and Kingdoms from Merenptah to Bar Kochba. Worlds of the Ancient Near East and Mediterranean. Sheffield: Equinox.

Knohl, Israel. 2007. The Sanctuary of Silence: The Priestly Torah and the Holiness School. Winona Lake: Eisenbrauns. First published 1995.

Köhler, Ludwig, and Walter Baumgartner. 1994-2000. The Hebrew and Aramaic Lexicon of the Old Testament (HALOT), 3rd ed. 5 vols. Revised by Johann J. Stamm. Translated by M. E. J. Richardson. Leiden: Brill. First published 1967-1995 in German.

Kratz, Reinhard. 2005. The Composition of the Narrative Books of the Old Testament. Translated by John Bowden. New York: T\&T Clark. First published 2000 in German.

Landsberger, Benno. 1915. Der Kultische Kalender der Babylonier und Assyrer. Leipzig: J.C. Hinrichs.

Langdon, Steven. 1935. Babylonian Menologies and the Semitic Calendars. London: British Academy.

Lemaire, Andre. 1976. A Schoolboys' Exercise on an Ostracon at Lachish. Tel Aviv 3: 109-10. [CrossRef]

Levenson, Jon D. 1993. The Death and Resurrection of the Beloved Son: The Transformation of Child Sacrifice in Judaism and Christianity. New Haven: Yale University Press.

Levine, Baruch A. 2008. Scripture's Account: The Sabbath. In Torah Revealed, Torah Fulfilled: Scriptural Laws in Formative Judaism and Earliest Christianity. Edited by Jacob Neusner, Bruce D. Chilton and Baruch A. Levine. New York: T\&T Clark, pp. 77-88.

Levinson, Bernard. 1997. Deuteronomy and the Hermeneutics of Legal Innovation. New York: Oxford University Press.

Meinhold, Johannes. 1905. Sabbat und Woche im Alten Testament: Eine Untersuchung. Göttingen: Vandenhoeck und Ruprecht.

Meinhold, Johannes. 1909. Die Entstehung des Sabbats. ZAW 29: 81-112. [CrossRef]

Mowinckel, Sigmund. 1962. The Psalms in Israel's Worship. 2 vols. Translated by D. R. Ap-Thomas. New York: Abingdon, Translated from 1951. Offersang og sangoffer: salmediktningen i Bibelen. Oslo: H. Aschehoug \& Co.

Pardee, Dennis. 2002. Ritual and Cult at Ugarit. Writings from the Ancient World 10. Atlanta: SBL.

Parpola, Simo. 2007. Letters from Assyrian Scholars to the Kings Esarhaddon and Assurbanipal. Part II: Commentary and Appendices. Winona Lake: Eisenbrauns. First published 1983.

Propp, William H. C. 2010. Exodus 1-18. Anchor Yale Bible II. New Haven: Yale University Press. First published 1999.

Robinson, Gnana. 1988. The Origin and Development of the Old Testament Sabbath: A Comprehensive Exegetical Approach. Beiträge zur biblischen Exegese und Theologie. Frankfurt am Main: Peter Lang.

Rofé, Alexander. 1988. The Prophetical Stories. Jerusalem: Magnes. First published 1982 in Hebrew. 
Schmid, Konrad. 2012. The Old Testament: A Literary History. Translated by Linda M. Maloney. Minneapolis: Fortress Press. First published 2008 in German.

Schmidt, Werner. 1983. The Faith of the Old Testament: A History. Translated by John Sturdy. Philadelphia: Westminster Press. First published 1968 in German.

Schorch, Stefan. 2010. "A Young Goat in Its Mother's Milk"? Understanding an Ancient Prohibition. VT 60: 116-30. [CrossRef]

Schectman, Sarah, and Joel S. Baden. 2009. The Strata of the Priestly Writings. Abhandlung zur Theologie des Alten and Neuen Testaments 95. Zurich: TVZ.

Sivan, Daniel. 1998. The Gezer Calendar and Northwest Semitic linguistics. Israel Exploration Journal 48: 101-5.

Soulnier, Stéphane. 2012. Calendrical Variations in Second Temple Judaism New Perspectives on the 'Date of the Last Supper' Debate. Leiden: Brill.

Stavrakopoulou, Francesca. 2012-2013. The Jerusalem Tophet: Ideological Dispute and Religious Transformation. SEL 29-30: 137-58.

Stern, Sacha. 2012. Calendars in Antiquity: Empires, States, and Societies. Oxford: Oxford University Press.

Sweeney, Marvin A. 1983. Sefirah at Qumran: Aspects of the Counting Formulas for the First-Fruits Festivals in the Temple Scroll. BASOR 251: 61-66. [CrossRef]

Talmon, Shemaryahu. 1963. The Gezer Calendar and the Seasonal Cycle of Ancient Canaan. Journal of the American Oriental Society 83: 177-87. [CrossRef]

Talmon, Shemaryahu. 2005. What's in a Calendar? Calendar Conformity, Calendar Controversy and Calendar Reform in Ancient and Medieval Judaism. In Seeking Out the Wisdom of the Ancients: Essays Offered to Honor Michael V. Fox on the Occasion of His Sixty-Fifth Birthday. Edited by Ronald L. Troxel, Kelvin G. Friedel and Dennis R. Magary. Winona Lake: Eisenbrauns, pp. 451-60.

Tigay, Jeffrey. 1998a. Week. In Time and Holy Days. Edited by Jacob Licht. The Biblical Encylopaedia Library 3. Jerusalem: Bialik, pp. 15-26. (In Hebrew)

Tigay, Jeffrey. 1998b. Shabbat. In Time and Holy Days. Edited by Jacob Licht. The Biblical Encylopaedia Library 3. Jerusalem: Bialik, pp. 83-100. (In Hebrew)

Vainstub, Daniel. 2010. Human Sacrifices in Canaan and Israel. Beer-Sheva 19: 117-204. (In Hebrew).

Vanderkam, James C. 1989. The Book of Jubilees. Corpus Scriptorum Christianorum Orientalium 511. Scriptores Aethiopici 88. Lovanii: Peeters.

Vanderkam, James C. 1998. Calendars in the Dead Sea Scrolls: Measuring Time. New York: Routledge.

Waganaar, Jan A. 2005. Origin and Transformation of the Ancient Israelite Festival Calendar. Wiesbaden: Otto Harrassowitz Verlag.

Weyde, Karl William. 2004. The Appointed Festivals of YHWH. FAT 2. Tübingen: Mohr Siebeck.

Wright, David P. 2009. Inventing God's Law: How the Covenant Code of the Bible Used and Revised the Laws of Hammurabi. Oxford: Oxford University Press.

Wright, Jacob L. 2015. Shabbat of the Full Moon (part 1), How and When the Seventh Day Became Shabbat (Part 2). Available online: http://thetorah.com/shabbat-of-the-full-moon/,https://thetorah.com/how-and-when-theseventh-day-became-shabbat/ (accessed on 18 January 2019).

Yoreh, Tzemah. 2010. The First Book of God. BZAW 402. Berlin: De Gruyter.

Young, Ian. 1992. The Style of the Gezer Calendar and Some "Archaic Biblical Hebrew" Passages. Vetus Testamentum 42: 362-75. [CrossRef]

Zevit, Ziony. The Religions of Ancient Israel: A Synthesis of Parallactic Approaches. New York: Continuum.

(C) 2019 by the author. Licensee MDPI, Basel, Switzerland. This article is an open access article distributed under the terms and conditions of the Creative Commons Attribution (CC BY) license (http://creativecommons.org/licenses/by/4.0/). 

Article

\title{
Religion at Kuntillet 'Ajrud
}

\author{
Jeremy Smoak * and William Schniedewind * \\ Near Eastern Languages and Cultures, UCLA, Los Angeles, CA 90095, USA \\ * Correspondence: smoak@humnet.ucla.edu (J.S.); williams@humnet.ucla.edu (W.S.)
}

Received: 31 January 2019; Accepted: 13 March 2019; Published: 19 March 2019

\begin{abstract}
The discovery of early Hebrew inscriptions at the site of Kuntillet 'Ajrud has generated considerable discussion among scholars over the past few decades. The fact that the inscriptions contain explicitly religious themes led some to conclude that the site had a cultic function. In the present article, we challenge this assumption and argue that the inscriptions with religious themes are embedded in daily life as religion converges with scribal curriculum in ancient Israel. The inscriptions provide insights into conceptions of the Israelite pantheon, divine theophany, and theomachy in early Israelian religious ideology.
\end{abstract}

Keywords: Kuntillet 'Ajrud; theomachy; theophany; blessings; religion; Hebrew inscriptions; scribal curriculum

The inscriptions from Kuntillet 'Ajrud form what are perhaps the most significant textual data outside of the biblical literature for the religion of the northern kingdom of Israel during the early Iron Age. While the inscriptions are most often studied for what they reveal about the history of the goddess Asherah, they also provide glimpses into the pantheon of the northern kingdom. Since the inscriptions date to the late ninth and early eighth centuries, they provide a unique window into the pre-Deuteronomic religious landscape of Israel and Judah. Several of the inscriptions feature poetic descriptions of theophanies and theomachies involving El, Baal, and Yahweh. These poetic texts represent some of our earliest examples of Hebrew poetry from the early Iron Age and offer a unique window into the background of early biblical poetic compositions (i.e., Ex 15; Judg 5; Deut 33, etc.). And, the complete corpus of inscriptions attest to the breadth of literary genres that Israelian scribes learned as part of the scribal curriculum in the early Iron Age.

Significant discussion of the site has focused on its function. Following the initial publications, most studies (with some exceptions) interpreted the site as a religious site. These interpretations were particularly influenced by some of the artistic representations as well as the references to blessings in the name of "Yahweh and his 'asherah". The complete publication of the site (Ahituv and Eshel 2015; Meshel 2012); however, now calls for the different approach to the site, its inscriptions, and its religion (e.g., Schniedewind 2014; Blum 2013). The approach that we take here differs from previous studies by arguing that the inscriptions attest to the role that religion played within the scribal curriculum of early Iron Age Israel and Judah. More than graffiti, the inscriptions were executed elegantly and reflect the religious landscape of scribes learning their trade. We contend that Kuntillet 'Ajrud was not a religious site. Instead, the inscriptions represent the embeddedness of religious ideas and practices within the Israelian scribal education. At this site we have a window into the way that religious discourse permeated multiple streams of Israelian administration from epistolary conventions and personal names to the composition of poetic texts. The knowledge of divine names, religious blessings, and poetic hymns about the gods not only had some role in daily life in ancient Israel, it also formed a crucial part of scribal curriculum and practice. 


\section{The Interpretation of the Site}

Kuntillet 'Ajrud sits in the barren wilderness of the central Sinai. The site itself was first discovered in 1869 by Palmer (1871), who believed that he had found Gypsaria, an old Roman trading fort on the road between Eilat and Gaza. However, later archaeological investigations refuted his dating and identification. Still, Palmer correctly intuited that the site must have been a strategic location along the ancient trade route. This route from the Red Sea to the Mediterranean is known today as the Darb el-Ghazza in Arabic, that is, "the Gaza Road". This route would have begun at the Red Sea near the site of ancient Eilat and/or Ezion-geber (Tell el-Kheleifeh), gone past Kuntillet 'Ajrud, then towards Kadesh Barnea (Tel-Qudeirat), and up to Gaza, where it reached the Mediterranean Sea. Thus, with respect to its location, it would have served as a caravanserai. The site of Kuntillet 'Ajrud itself lies just off the direct path of this route via the Wadi Quraiya, about $10 \mathrm{~km}$ to the west. The other major caravanserai along this route, Kadesh Barnea, also lies just off the direct route from Eilat to Gaza. In this respect, neither Kuntillet 'Ajrud nor Kadesh-Barnea lie on the most direct Darb el-Ghazza route, but they both provided convenient water sources along this trade route.

The site of Kuntillet 'Ajrud itself is situated on a solitary hill overlooking Wadi Quraiya (M.R. 094954) approximately $50 \mathrm{~km}$ south of Kadesh-barnea. The excavators of Kuntillet 'Ajrud found several shallow wells nearby that would have provided a perennial water source suitable for a small fortress, and the Arabic name actually means "hill of the water-well" (Meshel 2012, p. 3). Since the central Sinai receives less than three inches of rain per year, Kuntillet 'Ajrud provided one of the few water sources along the Darb el-Ghazza.

The function of the site has been hotly debated subject in the scholarly literature (see Hadley 1993, 2000, pp. 106-20; Dijkstra 2001, pp.17-21; Mastin 2005, 2009; Singer-Avitz 2009, pp. 115-17; Hutton 2010, pp. 187-89; Na'aman 2011, pp. 314-19, 2013, pp. 40-45, 50-51; Schmidt 2013). Ze'ev Meshel's official publication of the site is subtitled, “An Iron Age II Religious Site” (Meshel 2012). However, the revised Hebrew edition of the site eliminates this reference to a religious site, and it also replaces the original chapter by Pirhiya Beck on the art that argued for a religious interpretation with a chapter by Tallay Ornan that interpreted the art within the context of the palace and state (see Ahituv and Eshel 2015). Indeed, the evidence for a specifically religious function in Meshel's original site report as well as in the secondary literature is unconvincing. While the site has inscriptions and drawings with religious themes, this does not necessitate a religious interpretation for the site as a whole. Rather, religion was part of the daily life of soldiers, scribes, and merchants that used the site.

To begin with, the religious interpretation of the site stems from the two well-known inscriptions that seem to mention "Yahweh and his 'asherah". In addition, many of the drawings seem to have religious themes. Thus, the site is often deemed a religious site populated by priests (according to Meshel) despite the fact that, as pointed out by Judith Hadley, the site has no temple, shrine, or cultic objects (see Hadley 1993). Hadley's objections are cogent, and her view has been followed by some scholars (e.g., Schniedewind 2014, pp. 272-75). Nevertheless, many scholars have offered explanations for the lack of a shrine or cultic objects at a religious site. For example, Brian Schmidt focuses on the drawings and inscriptions in the bench room while admitting that the site has "None of the standard diagnostics-altars, conventional figurines, or zoomorphic, anthropomorphic, and composite vessels - indicative of cult were found in the bench room or in locus 13" (Schmidt 2016a, p. 21). Schmidt shares the view of Etan Ayalon and Zeev Meshel that non-ritual objects, such as a chalice, could have been used for ritual purposes (see Ayalon 2012, p. 271n8). Another approach is offered by Nadav Na'aman and Nurit Lissovsky, who invent a new cultic focus for the site without a shrine or cultic objects: "The point of departure for the discussion is the conjecture that a prominent sacred tree (or a sacred grove) grew in the vicinity of the site" (Na'aman and Lissovsky 2008, p. 198). The appeal to a sacred tree, of course, links with both the mention of the goddess Asherah in the inscriptions as well as Asherah imagery in the drawings on the site. There was water, so it does stand to reason that there were trees in the vicinity, but this is hardly a sound basis for a religious interpretation of the site. 
The evidence for a religious function offered by Meshel's site report is also fragile. One argument is that an unusual amount of linen was found at the site, and this is supposedly related to the wardrobe of priests. In the chapter on textiles, Avigail Sheffer and Amalia Tidhar point out that according to Ezek 44:17-18, priests were required to wear linen in the temple as opposed to wool (Sheffer and Tidhar 2012, p. 307). However, this is a rather thin thread to bear the weight of a religious interpretation of the site. The authors seem to feel that finding linen garments would be surprising in the desert. Yet, as Susan Ackerman intuits, it is likely the arid climate for this trading post rather than the religious function that explains the preservation of linen (Ackerman 2008, p. 28). Moreover, it is not even clear whether the linen was worn, traded, or both. The problematic nature of this argument is confirmed by the acknowledgement that Meshel tucks away in an Appendix, namely that the presence of linen "has ceased to be unique since the discovery of similar textiles at Kadesh Barnea" (Sheffer and Tidhar 2012, p. 308). Meshel is thus forced to posit that there were also priests at Kadesh Barnea, citing 1 Chr 26:30-32. Of course, it is possible that priests or Levites traveled this trade route, but it is unlikely that they choose these sites specifically to establish as cultic sites. In addition, the presence of linen in the archaeological record or the possibility that there were trees near the site hardly makes a good case for interpreting the overall site as having a religious function.

The narrow religious interpretation of the site is centered in the interpretation of the inscriptions and drawings. Here, a religious interpretation seems to be required only when we do not sufficiently acknowledge that religion is part of daily life-not just something done at cultic shrines. With regard to the drawings, for example, Tallay Ornan has shown that all the Kuntillet 'Ajrud drawings have direct parallels in neo-Assyrian palace reliefs, not cultic shrines (Ornan 2015, 2016). As Ornan also points out, "The image of the king on the entrance pilaster of Building A define it as a royal edifice ... ", and Ornan concludes, "Like other state-supervised centres in the Negev [e.g., Arad], the outpost of Kuntillet 'Ajrud included a cultic architectural unit" (Ornan 2016, p. 22). In other words, there is no reason to associate them narrowly with a religious site. It is also worth pointing out that there are four inscriptions with the military title "Commander of the Fortress" (śr ' $r$ ) at the site. Three of these inscriptions on located on storage jars and one on the plastered walls of the fortress (Ahituv et al. 2015, pp. 80-81, 113; Schniedewind 2019). Now that the entire corpus of inscriptions has been published, a contextual examination suggests that the pottery inscriptions are mostly ephemeral texts related to a trading post or elementary scribal exercises likely composed by military scribes (Schniedewind 2014). In sum, the inscriptions and art nicely complement the architecture of the site, which looks like a typical desert fortress that built for the use of the Israelian state. The supposed unique character of the site likely more reflects its builders—namely, the Israelian state—rather than any unique religious character.

Finally, the identity of the occupants of the fortress is itself a matter of some discussion and begs the question as to whose religion the site should be related. The fortress is usually assumed to be Israelian based on the personal names that use the distinctively Israelian -yaw theophoric as well as the references to "Yahweh of Samaria" (Ahituv 2014, p. 31). Although the location of the site within the central Sinai would normally point to a Judean hegemony, the pottery excavated at the site also points strongly to the Israelian heritage of its occupants (see Ayalon 2012). In this respect, the Israelian personal names and the references to "Yahweh of Samaria" dovetails nicely with the material culture. With regard to the script, Ziony Zevit correctly points out that the "Phoenician" script likely reflects an early stage in the development of a Hebrew national script (Zevit 2001, p. 377-78). Thus, the label "Phoenician" is anachronistic, because distinctively Hebrew script was only beginning to emerge during the occupation of the site in the late ninth and early eight century BCE. In the final report, Meshel follows the scholarly consensus that the script may be Phoenician, but linguistic features like spelling and morphology are Hebrew (Ahituv et al. 2012, p. 122). Zevit's hypothesis also highlights the problem with describing the "Hebrew" national script as a unified script. We must allow that the Israelian and Judean scripts may have had their own separate histories, with the Israelian script retaining its connection with the Phoenician coast longer than the Judean script. At this point, the 
evidence is insufficient, but Kuntillet 'Ajrud suggests some independence in the development of the Israelian script. This observation also underscores the importance of not conflating Israelian and Judean religion. Kuntillet 'Ajrud is a site that gives evidence of Israelian religion during the Iron IIB period (ca. 840-721 BCE).

\section{Israelian Religion in Daily Life}

One key to a religious interpretation of the site has been the drawings, but in our view, these serve more to highlight aspects of religion in daily life. The early studies of the drawings were done by Beck $(1982,2012)$. Unfortunately, much of the discussion of the drawings has focused on the identity of the two apparent deities—possibly Bes and Asherah—on Pithos A (see Schmidt 2016b). The image of the lion pictured under the "tree of life" with gazelles certainly suggests the goddess Asherah. Indeed, the tree imagery might have been particularly significant here at a desert oasis. It is certainly possible that we have a crude drawing the Egyptian deity Bes, but it must be emphasized that this is not elegant artwork, but rather doodlings. Moreover, the Egyptian god Bes is also associated with animals, many of whom are illustrated on the pithoi (lions, bulls, gazelle, boar). While these animals can be associated with deities, they also seem to be the types of animals one might encounter in the region. In this respect, the animals as well as the deities are reflections of daily life. A possible Egyptian deity depicted on a pithos aligns nicely with the writing mșry "Egyptian" in a list of names on Pithos B (KA 3.10:6). Given its location, it is certainly plausible that Egyptians frequented the site as traders and merchants, perhaps some even worked at the site. Tallay Ornan's recent study highlights that the Kuntillet 'Ajrud drawings all find nice parallels in neo-Assyrian palace reliefs (Ornan 2015). While her analysis undermines the interpretation of the site as a specifically religious site, it does not make the site a palace either. She suggests a state-sponsored military fortress, which makes sense. While the plaster wall drawings could have a state sponsored purpose, the drawings on the pithoi certainly do not. In addition, even the plaster wall drawings should be seen as expressions of religious art applied to various contexts of daily life. For this reason, we contend that both the drawings and the inscriptions reflect the ways that religion and religious themes were embedded within a variety of streams of Israelite culture.

The inscriptions have been a particular focus for the religious interpretation of the site. While Kuntillet 'Ajrud is the most extensive extra-biblical textual evidence we have for early Israelian religion, it is easy to overstate or misrepresent the significance of various inscriptions. One example illustrates this point. The final report on Kuntillet 'Ajrud suggests, "The authors of the inscriptions believed in the power of prayer to influence God" (Ahituv et al. 2012, p. 133). This is undoubtedly true, but the authors base this statement on lines 2-3 of inscription 3.9, which they translate, "If he would urge, YHW will give him according to his wishes". It is important to read the whole inscription to contextualize the significance of its use at the fortress of Kuntillet 'Ajrud.

We would reconstruct and translate KA 3.9 as follows: (1) [ $m r \mathrm{PN}^{1}{ }^{\prime} m r l \mathrm{PN}^{2}$ brktk ]lyhwh.ht $m t^{\urcorner} n$

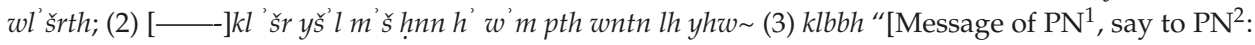
I bless you ]by Yahweh of the Teman and by his 'asherah. [--]whatever he asks from a man, he will give generously. In addition, if he petitions, then Yahwe(h) will give to him according to his desire". Now here it becomes clear that we have a practice letter and after the formal opening, the second part (lines 2-3) forms the body of the scribal exercise. This type of exercise is not unusual in the near east. We have a remarkably similar student exercise at Ugarit (KTU 5.9), which is a letter that begins with a formal introduction then proceeds in the body to include a "reciprocal formula" and then gives a humorous grammatical exercise of the verb ytn "to give" (Schniedewind forthcoming, chp. 5). Parallels to this reciprocal formula can be found in a variety of places. For example, in a Sam alian Inscription, we find, wmz 's'l mn 'lhy ytn ly "And whatever I shall ask from my god, may he give to me" (KAI 214:4), and later in the same inscription, wmh 's'l mn 'lhy mt ytnw ly "and whatever I shall ask from my god, surely he shall give me" (11. 12-13). Scholars have also suggested several biblical correlates for Kuntillet 'Ajrud inscription, including: Ps 20:5 ytn lk klbbk "He shall give to 
you according to your desire" (also see Ps 37:21, 26; 112:5). In sum, reciprocal-type formulas can be adduced in a variety of texts from a variety of places.

We may imagine that reciprocal language would have been learned and memorized from school exercises, then applied in a variety of daily contexts-some specifically religious and others rather mundane. As Avi Shveka points out, the reciprocal formula uses stock scribal terminology typical of requests known from Ebla, Amarna, and elsewhere in the near east (Shveka 2005, pp. 298-99). A nice illustration in biblical literature is Hiram's letter to Solomon, which encodes this general paradigm (1Kgs 5:22): “Hiram sent word to Solomon: 'I have heard that you have sent to me, and I will do

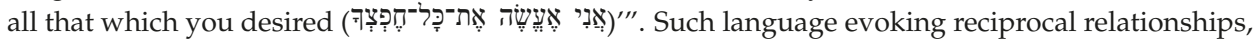
requests, and gifts could be adapted to a variety of contexts, including prayers. In sum, we should understand the reciprocal formula in KA 3.9 as a stock expression-but also as something that reflects deeply embedded social and religious values.

\section{The Use of Blessing Formulas}

A large number of the inscriptions from the site are blessing formulas. Nine blessings in total were discovered at the site (Ahituv et al. 2012, pp. 127-28). While there are a variety of forms of blessings attested most studies have focused upon the blessings that reference the two gods Yahweh and Asherah (Mandell 2012; Dijkstra 2001; Dietrich and Loretz 1992; Hadley 2000). However, it should be emphasized at the outset that the blessings are different in function from the inscribed blessings discovered at the sites of Khirbet el-Qom and Ketef Hinnom (Smoak 2016, pp. 12-60). The blessings at Kuntillet 'Ajrud are exercises written by scribes who were learning to write epistolary correspondence. That is, most of the blessings were not related to religious practice at the site. Rather, they reflect the long tradition of use of blessings in letter writing in West Semitic administrative correspondence (see already Lemaire 1981, pp. 26-28; Chase 1982, pp. 65-66; Catastini 1982, pp. 127-34).

Most of these blessing formulas appear on two pithoi discovered in the main building of the site. The single exception to this is a blessing that was inscribed upon the rim of a stone basin discovered near the eastern entrance to the site. This blessing reads, "to/of 'Obadyaw son of 'Adna, blessed be he to YHW" (Ahituv et al. 2012, p. 76). Studies have pointed to the large size of the basin on which the inscription appears and the form of the inscription as evidence for the religious nature of the site (Tigay 2007, p. 345*). There may be good reason for interpreting this particular blessing as a request for the person who donated the object to the site to be blessed by the deity. However, the presence of the blessing on the object does not necessarily point to the religious function of the site (Dijkstra 2001, p. 23). Inscriptions containing petitions for divine blessings are found on a variety of objects and in a variety of contexts in the Iron Age Levant. The appearance of such blessings in a variety of contexts points to their use in daily life rather than an exclusive setting in temples or cultic areas.

All of the other blessing formulas were written in ink on two pithoi discovered in a bench room in the main building. For example, the following inscription was written in red ink on Pithos A (3.1) (Ahituv et al. 2012, p. 87):

[Message of ... ] [-]M[-]K: "Speak to Yaheli, and to Yo'asa, and to [ ... ] I have [b]lessed you to YHWH of Shomron (Samaria) and to his 'asherah" (3.1).

This particular blessing formula, with the Piel verb in the suffix conjugation form followed by a genitival lamed prefixed to a personal name, appears in several other Iron Age inscriptions (Ahituv et al. 2012, p. 127). The formula functions as a petition to the deity to bless the individual identified in the inscription. A longer blessing formula appears on Pithos B (KA 3.6). The blessing reads (Ahituv et al. 2012, p. 95),

Message of Amaryaw:

"Say to my lord, are you well? I have blessed you to YHWH of Teman and his 'asherah. May he bless you and may he guard you, and may he be with my lord [forever(?)]". 
In this inscription, we have several features that mark it as a letter exercise. First, the introductory phrase ' $m r+$ PN ("Message of 'Amaryaw") is the standard opening in Ugaritic, Akkadian, and Iron Age Hebrew letters (Pardee and Sperling 1982, p. 145; Cunchillos 1999, pp. 359-74; Huehnergard 1999, pp. 375-89). Such letters open with the phrase "Says PN" followed by a question about the well-being of the recipient. This question is reflected in line 4 of this inscription where we have the phrase "Are you well?" This is followed by two blessing formulas (Thomas 2009, pp. 21-22). The first one, "I have blessed you by ... " is similar to the formula on the stone basin described above. The second one, located in lines 7-9, exhibits prefix verbal forms (yrbk, yšmrk, and $y h y$ ) instead of the suffix forms verbal forms attested in the blessing in line 4 . The blessing in lines 7-9, with it pairing of the verbs "bless" and "guard/keep," closely resembles the lexical and syntactic formulation of the biblical priestly blessing of Numbers 6:24-26:

ybrkk yhwh wyšmrk

y'r yhwh pnyw 'lyk wyhnk

yś' yhwh pnyw 'lyk wyśm lk šlwm

May Yahweh bless you and guard you;

May Yahweh make his face to shine upon you, and be gracious to you;

May Yahweh lift up his face upon you, and give you peace.

As studies have noted, the blessing from Kuntillet 'Ajrud contains a close parallel to the first line of the biblical blessing (v. 24) (Zevit 2001, p. 396). The blessing from Kuntillet 'Ajrud indicates that the biblical blessing is a development of stock blessing language known from epistolary exercises and correspondence. The biblical blessing has adopted the lexical and syntactic formula of this shorter blessing and developed it to include additional blessings invoking the divine face of Yahweh (Smoak 2016, pp. 116-18).

The parallels between the blessings at Kuntillet 'Ajrud and the biblical priestly blessing are also instructive for what they reveal about Israelian and Judahite religions. Whereas Kuntillet 'Ajrud's blessings include references to Yahweh's 'asherah, the priestly Judahite formulation in the book of Numbers only refers to Yahweh. While this is not necessarily surprising, the contrast sheds light on some of the chronological and regional differences in the religions of Israel and Judah during the Iron Age. In terms of the variations of this blessing formula in the Iron Age the fact that we now have a formulation with striking similarities to the biblical version at Ketef Hinnom in Jerusalem becomes especially relevant. Ketef Hinnom's blessings also lack inclusion of any references to Yahweh's 'asherah. Additionally, whereas the Kuntillet 'Ajrud inscriptions connect Yahweh's blessings to his cultic locales at Samaria and Teman, the formulation in Numbers reflects an attempt to connect the blessing with Yahweh's temple in Jerusalem.

\section{The Israelite Pantheon at Kuntillet 'Ajrud}

As noted at the beginning of the study, it is hard to overstate the importance of the inscriptions for understanding early Israelite religion. Taken together, the inscriptions contain references to the names of several gods, including El, Yahweh, Baal, and Asherah. The reflection of the Israelian pantheon evidenced by the inscriptions is consistent in certain ways with the biblical texts, as we will explain below. The difficulties involved in dating the biblical texts, however, highlights the significance of the inscriptions. The picture of the Israelian pantheon provided by the inscriptions can be dated securely to the late ninth and early eighth centuries. It may be assumed, however, that this picture was not invented at Kuntillet 'Ajrud. It was well-known poetry or liturgy that was merely used there. In this way, the inscriptions offer a chronological anchor of sorts for the development of the pantheon. As we will stress below, the secure date of the inscriptions confirms certain arguments that scholars have made about characteristics of the Israelian pantheon during the early Iron Age.

The plaster texts at Kuntillet 'Ajrud are the most significant for reconstructing the history of the pantheon at the site. The most substantive of the reconstructed plaster texts is KA 4.2 (4.1 in the 
Hebrew edition) (Ahituv et al. 2012, pp. 110-14; Ahituv et al. 2015, pp. 109-11). ${ }^{1}$ This inscription was discovered on one of the plaster walls near the western entrance to the bench room of the main building. The text poses certain difficulties owning to its fragmentary state. However, it seems clear that it refers to the names of three deities and contains allusions to both a theophany and a theomachy. The English publication transcribes and translates the inscription as follows (Ahituv et al. 2012, p. 110):

1. ] $\check{n} n t[$

2. ]br'š.wbzrh.'l.br[m.y]hw[h

3. ]r.wymsn.hrm.wydkn. $[g] b n m[$

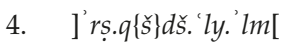

5. ] ${ }^{\circ} h k n[l] b r k . b ' l . b y m . m l h m h$

6. ]lšm 'l bym mlh[mh

1. ... ] second time /years [ ...

2. ]in earthquake. In addition, when El shines forth in the [heights. Y]HW[H ...

3. $] R$ The mountains will melt, the hills will crush $[\ldots$

4. ] earth. The Holy One over the gods [ . .

5. ] prepare (yourself) [to] bless Ba'al on a day of battle [ . .

6. ] to the name of $\mathrm{El}$ on the day of bat[tle ...

Although many of these readings are tentative (see especially Blum 2013), several observations about the Israelian pantheon still arrive out of the inscription with some certainty. First, lines two and six refer to the divine name El. That the god El was worshipped in Israel and Judah in the early Iron Age is confirmed by both biblical and extrabiblical evidence (Smith 2002, pp. 32-43, 2001, p. 141; Cross 1973, pp. 44-75; Hermann 1999, pp. 278-79). Several biblical texts indicate that early in Israel's history, El stood in a hierarchical relationship to the god Yahweh. Most notably, 4QDeut and the Septuagint describe Yahweh as one of the sons of El (see discussion in Smith 2004, pp. 108-9; Himbaza 2002):

When the Elyon gave to the nations their inheritance,

When he separated humanity,

He fixed the boundaries of the peoples

According to the number of divine beings ('lhym).

Indeed Yahweh's portion is his people,

Jacob his allotted heritage.

As many studies have noted, the MT version of the end of v. 8b-which has "according to the number of the sons of Israel" - is difficult to understand (Joosten 2007, p. 549). The Qumran and Septuagint variants; however, provide a more convincing reading of the verse as "according to the number of divine beings ('lhym). This reading results in a description of Elyon allotting each people a territory and a deity.

Recently, Jan Joosten has made the compelling argument that the MT reading "sons of Israel" in v. $8 \mathrm{~b}$ reflects a theological emendation to an original text that read bny śr ' $l$ "the sons of Bull El". (Joosten 2007, p. 551). Assuming that the noun śr "Bull" appeared in the proto-Masoretic text explains how the MT ended up with "sons of Israel". The MT emended the phrase śr ' $l$ "Bull of El" by adding one more yod taken from the end of the noun bny "sons of" and attaching it to the beginning of the

1 Also note earlier translations of the text in Dobbs-Allsopp et al. (2004, pp. 234-36) and McCarter (2000, p. 173). The official publication now revised in a Hebrew edition (Ahituv et al. 2015, pp. 71-121). The revised Hebrew edition relies on alterative readings (some otherwise unpublished) by Erhard Blum (see Blum 2013, pp. 21-54). 
noun śr "Bull". This resulted in the sequence of words that would have looked very similar to the expression bny yśr 'l "sons of Israel". It would have also resulted in a reworking of the text that fit the larger theological understandings of the MT.

Joosten's argument reinforces the view of some scholars that Deuteronomy 32 reflects a view of the Israelite pantheon that reckons El and Yahweh as separate deities (Smith 2002, pp. 48-49; Eissfeldt 1956, p. 29). According to this view, vv. 8-9 describe Elyon as the deity at the top of the pantheon who apportioned the nations their inheritance. In verse 8 , El assigns the nations different gods "according to the number of divine beings". The use of the particle $k \hat{\imath}$ at the beginning of v. 9 is best understood as emphatic, conveying the sense of "indeed" or "and lo" (Tigay 1996, p. 303). The particle serves to introduce and reinforce the statement in v. 9 that Yahweh was one of the sons of Elyon who came from a region outside of the land of Canaan (i.e., Edom/Teman).

Genesis 49 reflects a similar view of the Israelite pantheon in the early Iron Age. The poem describes the last words of Israel's ancestor Jacob to his sons. Given the difficulties involved in its interpretation, we quote an extended part of it here,

18 I wait for your salvation, O Yahweh.

...

${ }^{24}$ Yet his bow remained taut,

and his arms were made agile

by the hands of the Bull of Jacob,

by the name of the Shepherd, the Rock of Israel,

25 by El, your father, who will help you,

by the Shadday who will bless you

with blessings of heaven above,

blessings of the deep that lies beneath,

blessings of the breasts and of the womb.

26 The blessings of Father, Hero, Almighty,

the blessings of the eternal mountains,

the bounties of the everlasting hills;

may they be on the head of Joseph,

on the crown of him of the chosen of his brothers.

Following several studies on this text, we understand these verses to describe the god El as a deity distinct from Yahweh (Freedman 1987, pp. 324-25; Cross 1973, pp. 54-56; Smith 2002, pp. 32, 48-49). Verse 18 alludes to a petition for help from the god Yahweh as part of the description of the tribe of Dan (see vv. 16-18). Several verses later, the description of the tribe of Joseph repeats several epithets for the god El (vv. 22-26): "Mighty One" ('byr) (v. 24), El ('l) (v. 25), Shadday (šdy) (v. 25) (Cross and Freedman 1975, pp. 95-96; Smith 2002, p. 49). For reasons that we describe in more detail below, it is noteworthy that the description of $\mathrm{El}$ in these verses connect the god to "eternal mountains" and "the everlasting hills".

The descriptions of the pantheon in these poetic biblical texts frame an understanding of the descriptions of El and Yahweh in the plaster inscription. Whereas Deuteronomy 32 and Genesis 49 reckon $\mathrm{El}$ and Yahweh as distinct gods, the plaster text may be interpreted as converging them by placing their names in parallel lines (see Ahituv et al. 2012, p. 133; 2014, p. 36). To be sure, there are difficulties involved in reconstructing the verb preceding the name $\mathrm{El}$ in line two and this argument must remain very tentative. It would appear, however, that the end of the line contains a reference to Yahweh (Ahituv et al. 2012, pp. 110-11). This would mean that the two lines attest to the process whereby El's name was identified with the god Yahweh (Ahituv et al. 2012, p. 130). This is not surprising, given that several biblical texts dating later than the poems described above converge El's name and characteristics with the god Yahweh. The identification of the name El and El epithets with 
Yahweh is particularly noticeable in the first two verses of Psalm 91: "You who live in the shelter of Elyon, who abide in the shadow of Shadday, will say to Yahweh, "My refuge and my fortress; my God ('lhy)". The identification of El with Yahweh also occurs in a variety of biblical texts that render the name El into a noun in construct with elohim in the expression "God of gods is Yahweh" (cf. Ex. 6:2-3; Josh 22:22; Smith 2002, pp. 33-35).

The plaster inscription is unique; however, in the way that it parallels El and Yahweh in what appears to be a description of divine theophany or divine-warrior march. While it is difficult to reconstruct the language of line two, line three refers to the "mountains melting" and the "hills crushing". The beginning of line four may continue this imagery if the reconstruction of the word "land" or "earth" is correct. The expression "the mountains melt" recalls similar imagery in several biblical texts where the context is also a divine-warrior theophany (cf. Micah 1:4; Ps. 97:5; see Ahituv et al. 2012, p. 111).

The appearance of the expression "the Holy One" in line four also provides an important window into the Israelian pantheon in the ninth-eighth centuries. While it seems reasonably clear that the line reads "the Holy One" it is less certain that the clause that follows this divine epithet is to be reconstructed as "over the gods". If we are correct that the phrase should be reconstructed as "the Holy One over the gods," then we may have a text that reflects the emergence of Yahweh to the top of the Israelian pantheon. Ahituv, Eshel, and Meshel suggest that the expression may "refer to the defeat of the gods by YHWH (Ahituv et al. 2012, p. 133). Alternative readings, however, are possible (Blum 2013, pp. 26-27; Ahituv et al. 2015, p. 109). The expression is reminiscent of those biblical texts that focus upon the incomparability of the gods to Yahweh (e.g., Ps. 29:1; 89:7). Read as part of the following two lines, the expression may describe Yahweh's dominion over Baal and the name of El.

Alternatively, $b^{\prime} l$ here may be taken as the noun "lord" rather than a proper noun. Admittedly, it is difficult to decide between these options. The fact that the noun stands in parallel to the phrase "the name of El" would seem to support the view that the text understands the names as hypostases of Yahweh, or at least that the text is identifying the gods with Yahweh (Ahituv et al. 2012, p. 133; see also Dobbs-Allsopp et al. 2004, p. 236). According to this view, the inscription might be interpreted to reflect the convergence of not only El and Yahweh but also Baal and Yahweh.

The identification of Baal with Yahweh in this plaster text is consistent with the picture of the pantheon preserved in several biblical texts. Again, it is the collection of poetic texts in the biblical literature that provide us the best glimpses of the process by which Baal imagery was applied to Yahweh. Psalm 18 is particularly relevant because it conflates imagery of El, Baal, and Yahweh (Smith 2002, pp. 55-56):

Yahweh also thundered in the heavens,

and Elyon uttered his voice,

hailstones and coals of fire.

And he sent out his arrows,

and scattered them;

he flashed forth lightnings.

and routed them

Then the channels of the sea were seen ...

In this text, Yahweh is the subject of the thundering in the heavens and the deity is paired with the epithet Elyon, one of the names associated with the god El (Smith 2002, p. 56). The verbs thundering, uttering, and flashing in the verses recall storm imagery associated with Baal. If we are correct that this plaster inscription conflates Yahweh with Baal and El, then we have an inscription that stands close to what scholars have suggested happened in the period of the early Israelite monarchy, namely, that much of Baal's imagery was applied to the god Yahweh. This is particularly the case with the so-called divine march poems in the biblical literature. The imagery of the divine march and theophany would have held an especially significant import for the monarchies of Israel and Judah. The application of 
Baal imagery, especially warrior and divine march imagery, to Yahweh would have been important for the emergence of the image of Yahweh as the divine patron of Israelite and Judahite kings. Our plaster text takes on added meaning against the background of this development. The inscription appears to reflect the practice of conflating Yahweh and Baal in the composition of a hymn that would have had wide resonance within Israelian royal ideology and practice. Describing Yahweh as the Holy One over Baal and the name of El reflected the emergence of the Israelian polity within the southern Levant during the ninth-eighth centuries.

A reference to Baal also appears in a fragment of a plaster text discovered near the entrance to the Western Storeroom (4.4.1). The location of the discovery of this fragment led the excavators to suggest that it may formed part of a larger text written on the doorposts of the entrance (Ahituv et al. 2012, p. 117). Only two words of the fragment can be read with any certainty:

] b'l.bql[

] Baal in voice [

In the Hebrew edition, Ahituv, Eshel, and Meshel offer a different reading of the fragment (Ahituv et al. 2015, p. 117):

]$p^{\prime} l b q^{\circ}[$

We maintain that the reconstruction $b^{\prime} l b q l$ is the better one, and that the phrase should be translated "Baal with (his) voice". The letter peh in the reconstruction $p$ ' $l$ is poorly preserved. However, peh as a Hebrew letter is rather infrequent in contrast with bet, and in this respect its reconstruction here is less probable. The traces certainly could fit the bet, as the editors originally read the text. Likewise, the lamed in bql is tentative, but certainly a possible reading. To be sure, it is a tentative reconstruction, but, in our estimation, a plausible reconstruction that has much more contextual merit. Indeed, a reference to Baal's voice here would recall imagery in the Ugaritic Baal myth. Perhaps most relevant here is the description of Baal's voice thundering as part of the theophany associated with his taking up residence in his palace (KTU 1.4 VII 25-31; Smith 1994, p. 110)

He opens a window in this house, window in the midst of the pala[ce].

Baal open[s] a break in the [clou]ds,

Ba[al g]ives his holy voice $(q h l q d \check{s})$

Baal repeats the is[sue of?] his [li?]ps,

His ho[ly?] voice, the earth [sha?]kes.

Similar imagery appears with Yahweh in a variety of biblical texts. Most notably, Psalm 29 repeats the expression "the voice of Yahweh" as part of a description of divine theophany (see Schniedewind 2017). As studies have noted, the description of Yahweh's voice in this text is highly reminiscent of Baal's thundering in his temple in the Ugaritic Baal myth (Smith 2001, p. 75; Cross 1950, pp. 19-21; Pardee and Pardee 2000, pp. 115-28). The qol is also a metaphor for the sound of earthquakes, as we see in biblical texts such as Exodus 19 and Psalm 18. In this respect, the metaphor works especially nicely in the context of Kuntillet 'Ajrud's proximity to the earthquake faults along the Rift Valley. Since we understand Baal as originally a storm god, then the use of qol "voice" to refer to earthquakes illustrates another way that Israelian scribes re-appropriated language and imagery.

Another important aspect of the inscriptions is the way that they reflect an understanding of the local manifestations of Yahweh (Smith 2016, pp. 91-92; Sommer 2009, p. 39; Hutton 2010, p. 177-210). As noted above, several of the blessings refer to "Yahweh of Shomron (Samaria)" and "Yahweh of Teman" (Ahituv et al. 2012, p. 130). These expressions draw attention to the various local manifestations of different gods in the early Israelite pantheon. The pairing of certain gods with toponyms is a common feature of West Semitic literature, indicating that the deity was regarded as the lord over or owner 
of the city or region (McCarter 1987, p. 140-41). Indeed, as Jeremy Hutton argues, the fact that the inscriptions connect Yahweh with two different locales-Samaria and Teiman-may reflect competition between different sites associated with the deity (Hutton 2010, p. 178). In this way, the inscriptions provide an important window into the different places to which Yahweh's presence was connected before the rise of the Deuteronomic movement in the late Judean monarchy (Ahituv et al. 2012, p. 130; cp. Deut. 12).

The expression "Yahweh and his "asherah" appears in two of the inscriptions at the site, as described above. The difficulties involved in understanding the expression—particularly the word "his "asherah" - deserve some further discussion here. The expression stands close to another epigraphic find from Khirbet el-Qom, which also contains a blessing that refers to Yahweh and his 'asherah (Zevit 1984, pp. 39-47, 2001, p. 361). The main problem involved in interpreting the expression at Kuntillet 'Ajrud has to do with the presence of the possessive suffix "his" on the noun 'šrth (Dever 1984, pp. 21-37, 1999, pp. 9*-15*; Hadley 1987, pp. 50-62; Tropper 2001, pp. 81-106). This grammatical form has resulted in two lines of interpretation. First, several studies argue that the presence of the suffix on the deity's name means that the expression refers not to the goddess but to a cultic object (Olyan 1988, pp. 33-35; Miller 1986, p. 247; McCarter 1987, p. 143). Support for this line of argumentation also comes from the fact that we do not have any evidence for the goddess on Phoenician, Israelian, or Judean inscriptions in the first millennium (Keel and Uehlinger 1998, p. 229). The biblical texts also may be interpreted to support the conclusion that by the eighth century the term 'asherah did not refer to a goddess, but instead to a cultic object. For example, several biblical texts place a definite article on 'asherah, indicating that some type of religious object and not a proper name is meant (1 Kgs 15:13; 18:19; $2 \mathrm{Kgs}$ 21:7; 23:4,7; see Keel and Uehlinger 1998, p. 231).

The other option is that Asherah here refers to the name of an independent goddess and the consort of Yahweh. Studies have also argued that the problem of the suffix on the noun may be explained by the fact that the term 'asherah in the inscriptions stands for the idea of consort more than the personal name Asherah (Margalit 1990; Meshel 1979; Dever 2005, pp. 165-66). Given the fact that the inscriptions at Kuntillet 'Ajrud do not contain any actual description of A/asherah, it is difficult to choose between the options presented here. We might note in conclusion, however, that the verb brk in both inscriptions is formulated in the singular. This indicates that, regardless of how we understand 'srth here, the blessing conveys that it is the god Yahweh who gives the blessing (Sommer 2009, pp. 47-48).

More recently, it has been proposed that 'šrth at Kuntillet 'Ajrud (as well as Kh. el-Qom) may not refer to the deity or a cult object, but rather to a "temple". Sass (2014), for example, argues that a goddess Asherah in the West Semitic pantheon is largely based on reconstructions. Moreover, he points out that many of the supposed biblical references to Asherah never use this name. Thus, we find "the Queen of Heaven" and not Asherah (e.g., Jer 44:15-19). Sass does not, however, discuss the important

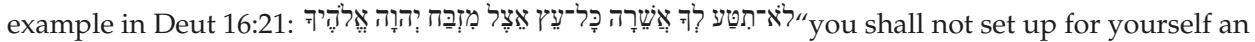
A/asherah - any sacred pole- beside the altar of the LORD your God". The reference to "Yahweh and 'šrth" at Kuntillet "Ajrud (as well as Kh. el-Qom) seems to echo an element of this prohibition. Here, an interpretation of "temple" or "shrine" cannot be made to fit. The indiscernibility of a goddess Asherah in the biblical text is much more likely the work of biblical editors (see Olyan 1988, pp. 1-22). In addition, texts like Deut 16:21 seem intent on demoting the goddess into a mere cultic object. Could this already be going on at Kuntillet 'Ajrud? In this case, we might be able to explain the unusual form of 'šrh with a suffix.

The comparisons between these biblical texts and the plaster text at Kuntillet 'Ajrud described here raise an intriguing question. Where do these texts come from? It is unlikely that these texts were composed by the scribes at Kuntillet 'Ajrud. More likely, they were known compositions that were copied. If we take advanced cuneiform literature as a model, students copied well-known texts as a means of learning (see Robson 2001). Thus, the edubba borrowed literary and liturgical texts for use with students. At Kuntillet 'Ajrud we can assume something similar was happening. These were literary 
and liturgical texts used in daily life that were borrowed as school exercises. The parallels in religious and literary themes and language that we can identify with texts like Psalm 18, Genesis 49, Habakkuk 3 , or Deuteronomy 32 suggest that the ideas were not unique to the plaster wall texts. Indeed, the texts were chosen because they reflected well-known religious ideas as well as often-used literary techniques. The close parallels that this plaster text shares with the biblical poetic texts about divine theophany and the pantheon suggest that we have here exercises taken from known Israelian liturgical texts. It seems likely that these texts were both memorized and copied (see Carr 2005, pp. 27-28, 71-74). This literature is largely lost since the biblical canon was collected and edited in Jerusalem by Judean scribes. Nevertheless, hints remain of some of the common religious themes and literary tropes. If we are correct that the plaster texts reflect the training of scribes in memorizing and perhaps copying literary texts, then the site also provides a unique glimpse into the function that such poetic texts held in scribalism. Practicing the composition of texts about divine theophany and theomachy would have been relevant to the situation of a soldier scribe at a fortress like Kuntillet 'Ajrud.

\section{Theophany}

In inscription 4.2, lines two and three appear to describe a theophany involving El and Yahweh, or El identified as Yahweh. The official publication suggested the verb $z r h$ "to shine forth", probably because this best fits the general context (see Ahituv et al. 2012, p. 110). However, the zayin is partially effaced, and it has been alternatively reconstructed as a yod-that is, yrh "month" (Blum 2013, p. 31; Ahituv et al. 2015, p. 109). The problem with this alternative is that it does not make as much sense of the context. Moreover, the letter zayin could fit the traces even if yod seems more likely. In any case, even if line two is not reconstructed to include the verb, zrh, the imagery in line three still closely resembles theophany scenes in the biblical texts (Deut 33:2; Isa 60:2; Hab 3:3; Ahituv 2014, p. 32). In these biblical texts, the shining forth of Yahweh connotes the luminosity that occurs in the divine march and the cultic presence and holiness of the god. Deuteronomy 33:1-2 illustrate this function of the verb in the context of a divine march scene:

Yahweh came from Sinai,

and dawned from Seir upon us;

he shone forth from Mount Paran,

With him were myriads of holy ones;

At his right a, a host of his own.

As these verses show, zrh often conveys the divine appearance of Yahweh from the southeast. It alludes to the imagery of the sunrise and formed part of the constellation of terms used to associate deities with solar symbolism in the Iron Age (Smith 2002, p. 149; Weinfeld 1984, p. 126). Especially noteworthy here are the references to Sinai, Seir, and Mount Paran, which lie to the south and southeast of Kuntillet 'Ajrud.

The expression "the mountains melt" recalls the imagery of several biblical poems and carry forward theophany language. The imagery stands particularly close to the description of mountains shattering in Hab 3:6:

He stopped and shook the earth;

He looked and made the nations tremble.

The eternals mountains were shattered,

Along his ancient pathways

the everlasting hills sink low.

This passage from Habakkuk shares the imagery of mountains and hills quaking and shattering with line two of the plaster inscription. This imagery is undoubtedly drawn from the experience of frequent earthquakes in this region of the world (which is close the Great Rift Valley that divides the African and Arabian tectonic plates). This comparison is especially relevant here because the poem in Habakkuk 
3 locates the theophany of Yahweh in the region of Teman and Paran (v. 3) (Smith 2012, pp. 1-27). Similar to the plaster inscriptions, Habakkuk 3 remembers Yahweh's origins in the region of Teman, mountainous landscape of the southeast (see Emerton 1982, pp. 2-20; Ahituv 2014, p. 32).

The use of the verb mss "melt" here in the theophany scene parallels the occurrence of the verb in Micah 1 and Psalm 97 (Ahituv et al. 2012, p. 111; Dobbs-Allsopp et al. 2004, p. 235; Keel and Uehlinger 1998, p. 244). Both passages employ the verb as part of descriptions of theophanies where the march of the deity causes the land to convulse and melt. The use of the verb in these two biblical texts parallels the plaster text here further with the use of the plural noun "mountains" (hrym) alongside the verb "melt" (mss). Micah 1:4 reads, "The mountains shall melt under him and the valleys burst open", whereas Psalm 97:5 reads, "Mountains melt like wax at Yahweh's presence".

It is not surprising that the plaster texts from Kuntillet 'Ajrud would include references to divine theophany language. The ability of a scribe to compose poetry that described the cultic presence of a deity would have stood at the very center of advanced scribal curriculum. While many studies focus upon the way that such imagery might be interpreted to reflect religious ideas, our texts from Kuntillet 'Ajrud offer a window into the types of religious motifs that scribes worked with as part of the practice of copying and memorizing poetic texts. Indeed, it is for this reason that it is not surprising that the small excerpts of poetry evident at this site bear close parallels to those biblical texts that describe divine theophanies and attendant imagery. The copying of texts that describe the gods in solar imagery would have had an especially important place in the training of scribes in the Iron IIB period. During this period, solar imagery was employed to describe both the king and the god, as both the textual and iconographic sources indicate (Smith 2002, pp. 154-55; Keel and Uehlinger 1998, pp. 248-81).

\section{Theomachy}

The last two lines of plaster inscription 4.2 describe a battle involving Baal and the name of El. If we are correct that line four alludes to Yahweh as the Holy One over the gods, then we may have in lines four through six a description of a divine battle between Yahweh and lesser deities. Although this must remain tentative, if this reading is accepted, it locates this text within the tradition of theomachies in West Semitic literature. Line 5 contains a call for Baal to be blessed on the day of war. The divine warfare imagery is reminiscent of several biblical texts that invoke blessings in connection with battles. Particularly noteworthy here are the calls for the tribes to bless Yahweh in the context of his divine march from Edom and Seir in Judges 5 (Ahituv et al. 2012, p. 114; also Wearne 2015, pp. 99-119). The relevant sections of the poem read: "when people volunteered-bless Yahweh!" (v. 2) and "the volunteers among the people-bless Yahweh!" (v. 9). The use of these phrases in Judges 5 is relevant here, because the context is a theophany of Yahweh and the description of Yahweh as a divine warrior. In the song, the call for the tribes to bless Yahweh appears alongside descriptions of Yahweh's march from Edom and Seir (v. 4), the quaking of mountains (v. 5), and reference to war in the gates.

Line 6 parallels line 5 with the phrase "to the name of El on the day of war". It is worth noting that this phrase, yôm milhāmāh, appears in a variety of biblical texts (see Hos 10:14; Amos 1:14; Prov 21:31; cp. Deut 20:3; 1 Sam 13:22). Here we presumably have another call for a blessing on the day of war, but in this case the blessing is directed toward the name of El. The call for a blessing for the name of a deity is well known in the biblical texts. Invocations for Israel to bless Yahweh appear frequently in contexts marked by theophany imagery and divine warrior language. Blessing or giving thanks to the name of Yahweh is a characteristic feature of the language of the enthronement psalms (Ps 96:2; 97:12). Psalm 96 describes Yahweh as the God "above all the gods" who takes up residence in his sanctuary as the king who created the world. The psalm begins by calling for his subjects to "sing to Yahweh, and bless his name" (v. 2).

Similarly, Psalm 113 focuses upon the incomparability of Yahweh among the gods. He sits high above the gods and rules over the nations. Significantly, the first two verses of the psalm invoke blessings for his name before the descriptions of his royal residence above the earth. Taken together, these psalms locate the invocations for blessing the name of Yahweh directly before descriptions of 
his incomparability and residence above the nations. While there are no clear references to divine battle in these psalms, the imagery is not far from it. The focus upon the incomparability of Yahweh, references to Yahweh's kingship, and the imagery of divine judgment and creation locate them within the traditional language of theomachy in West Semitic literature. Hence, these biblical texts provide the larger context for the meaning of the reference to blessing the name of El alongside theophany imagery in our plaster text. It is not surprising that the plaster text with its references to divine theophany the "Holy One" would also invoke blessings for the name of a deity on the day of battle. This is characteristic language of theophany and theomachy texts in the biblical literature.

A reference to the noun šm "name" in the context of theomachy and theophany is also not surprising. Studies have long argued that the noun in both Ugaritic and Hebrew texts signifies the cultic presence of a deity (Smith 2001, p. 74; McCarter 1987, p. 147; McBride 1969, p. 135-37; Sommer 2009, pp. 26-27). Particularly relevant here are those texts that employ the imagery of the divine name in contexts marked by divine war. Again, the theophany imagery of Psalm 29 is especially instructive. As Mark Smith observes, the expression "glory of his name" (kbd šmw) in this psalm conveys a sense of "the name as a divine quality with martial qualities" (Smith 2001, p. 74). In several other biblical texts, the imagery of the divine name appears in contexts where the concern is a theophany of Yahweh for protection against enemies (Isa 63:9; Ps 29:2). These texts make it clear that the construct of the noun $\check{s} m$ + divine name reflects the wider significance that the name of a deity played in descriptions of theomachies in Near Eastern literature (Lewis 2011).

Recently, Ted Lewis has invoked a substantial body of texts to argue that the name of a deity had a specific application in human and divine warfare (Lewis 2011, pp. 219-21). His description of the use of the expression "name of YHWH" in Isa 30:27-33 is especially instructive here:

The name of Yahweh (šm-yhwh) comes from afar,

In blazing wrath ...

His tongue like a devouring fire,

His breadth like a raging torrent...

In raging wrath,

In a devouring blaze of fire,

In tempest, and rainstorm, and hailstones.

Truly, Assyria, who beats with the rod,

Shall be cowed by the voice of Yahweh.

Lewis notes that the expression "name of deity" in certain contexts stands in parallel for physical weapons (Lewis 2011, p. 222). Based upon this evidence, he argues that the name of a god was used as an incantation in military contexts as an effective weapon of war. Summarizing the import of this observation for thinking about West Semitic poetry about divine war, he concludes, "As the name of the deity was invoked by humans in their battles, so too the names of warrior deities were used on a cosmic scale" (Lewis 2011, p. 222). Such arguments fit the context of the reference to the "name of El" in the plaster text. The text invokes the name of El on the day of battle. Although it is unclear how the name of $\mathrm{El}$ is being marshalled in this text or against whom it is going to battle, its function is clear. Our plaster text invokes the name of $\mathrm{El}$ as part of the preparations for divine battle. Invoking a blessing for the deity and summoning the name of the deity were part of verbal performances associated with war preparations.

One of the most well-known biblical accounts of divine warfare is the "Song of the Sea" (Exod 15). The song also highlights the importance of the divine name, šm, alongside the divine warrior. The song begins as an account of YHWH's glorious triumph. Enemies are subdued and cast into the Sea (v. 1b). The victor is proclaimed: "YHWH is a man of war ('yš mlhmh), YHWH is his name" (v. 3). Based on its conclusion (v. 17), we may presume that the text was used as a temple liturgy. In its narrative context, it is merely a victory hymn. This reminds us of the imagery of the theomachy alluded to in the plaster text at Kuntillet 'Ajrud, but the parallel is primarily thematic. If the reconstruction of line 3 as a 
reference to Yahweh as the Holy One is accepted, then we might have in these lines a description of Yahweh battling against Baal and the name of El. While it is possible that these divine names refer to hypostases of Yahweh, this must remain only a tentative hypothesis. It might be that we have a text that describes Yahweh over the gods Baal and the name of El. Taken together, then, lines 3-5 may refer to a battle between Yahweh and the lesser gods that resulted in Yahweh emerging victorious as the Holy One over the gods. In this case, we would have an Israelian text that offers a window into the emergence of the "divine warrior" Yahweh as a national god of the northern kingdom over Baal.

\section{Conclusions}

We return to the original point that we raised at the beginning of the study. Was Kuntillet 'Ajrud a religious site? Our contention here is that strictly speaking it was not. However, we also note that the interpretation of the site over the past few decades reflects the ways in which religion is often defined and studied in our field. Some of the first studies asked whether or not the site was a religious site. The debates over this question that followed tended to discuss this question from a top-down approach. Discussion of the religion of the site was framed within the question of whether or not there was evidence for the site to be identified as a cultic or religious site. The search for the religious nature of Kuntillet 'Ajrud was closely tied to the interpretation of the architecture, furniture, and location of the site. That is, did it have an altar or a shrine? We argue here that the study of Kuntillet 'Ajrud provides a heuristic model for thinking about the definition of religion in ancient Israel. It is common to define religion within the parameters of architecture with the goal of locating the places of religion. Temples, shrines, altars, and other cultic locals are deemed the places of religion. As a result, there is a tendency to study Israelite and Judean religion through the search for the locations of religious practice. The problem with this, of course, is that religion formed in many ways the very fabric of daily life in ancient Israel and Judah, as more recent studies have emphasized (Stavrakopoulou and Barton 2010; Albertz and Schmitt 2012). While many of our texts that offer a window into the religious life of ancient Israel and Judah reflect the ideology of the elite, we must remember that the archaeological remains of these regions reflect a picture of religion embedded within all streams of Israelite and Judean life and within all of the spaces in which such streams were located (i.e., houses, gateways, seals, amulets, bodies, etc.) (see Dijkstra 2001, p. 22).

When we think about the way that religion permeated the scribal exercises and other materials at Kuntillet 'Ajrud we may approach the question from a different angle. Kuntillet 'Ajrud may not have been a religious site, but it attests to the great import that religion held in the education and practice of Israelian scribes in the early Iron Age. Indeed, religious themes so permeated the texts left by the scribes at the site that it became difficult not to interpret it as a religious site. However, was Kuntillet 'Ajrud constructed to function as a cultic site? No. The site's religious character only arrived when scribes used its walls and other materials to practice educational curriculum. Here we have a picture of religion embedded within the scribal curriculum of the northern kingdom of Israel. This picture of religion reminds us of the extent to which the biblical texts also offer a window into the melding of religion and scribalism.

Author Contributions: The authors contributed equally to all parts of the article.

Funding: This research received no external funding.

Conflicts of Interest: The authors have no conflicts of interest.

\section{References}

Ackerman, Susan. 2008. Asherah, the West Semitic Goddess of Spinning and Weaving? Journal of Near Eastern Studies 67: 1-30. [CrossRef]

Ahituv, Shmuel. 2014. Notes on the Kuntillet 'Ajrud Inscriptions. In "See, I Will Bring a Scroll Recounting What Befell Me" (Ps 40:8): Epigraphy and Daily Life-From the Bible to the Talmud. Edited by Esther Eshel and Yigal Levin. Göttingen: Vandenhoeck \& Ruprecht. 
Ahituv, Shmuel, and Esther Eshel, eds. 2015. To Yahweh Teiman and His Ashera, the Inscriptions and Drawings from Kuntillet 'Ajrud. Jerusalem: Israel Exploration Society/Yad Ben Zvi.

Ahituv, Shmuel, Esther Eshel, and Zeev Meshel. 2012. The Inscriptions. In Kuntillet 'Ajrud: An Iron Age II Religious Site on the Judah-Sinai Border. Edited by Zeev Meshel. Jerusalem: Israel Exploration Society, pp. 73-142.

Ahituv, Shmuel, Esther Eshel, and Zeev Meshel. 2015. Inscriptions and Their Interpretation. In To Yahweh Teiman and His Ashera, the Inscriptions and Drawings from Kuntillet 'Ajrud. Edited by Shmuel Ahituv and Esther Eshel. Jerusalem: Israel Exploration Society/Yad Ben Zvi, pp. 71-121.

Albertz, Rainer, and Rüdiger Schmitt. 2012. Family and Household Religion in Ancient Israel and the Levant. Winona Lake: Eisenbrauns.

Ayalon, Etan. 2012. The Pottery Assemblage. In Kuntillet 'Ajrud: An Iron Age II Religious Site on the Judah-Sinai Border. Edited by Zeev Meshel. Jerusalem: Israel Exploration Society, pp. 205-78.

Beck, Pirhiya. 1982. The Drawings from Horvat Teiman (Kuntillet 'Ajrud). TA 9: 3-68.

Beck, Pirhiya. 2012. The Drawings. In Kuntillet 'Ajrud: An Iron Age II Religious Site on the Judah-Sinai Border. Edited by Zeev Meshel. Jerusalem: Israel Exploration Society, pp. 143-204.

Blum, Erhard. 2013. Die Wandinschriften 4.2 und 4.6 sowie die Pithos-Inscrift 3.9 aus Kuntillet 'Ağrūd. ZDPV 129: 21-54.

Carr, David. 2005. Writing on the Tablet of the Heart: Origins of Scripture and Literature. New York: Oxford University Press.

Catastini, Alessandro. 1982. Le iscrizioni di Kuntillet 'Ajrud e il profetismo. Annali 42: 127-134.

Chase, Debra A. 1982. A Note on an Inscription from Kuntillet 'Ajrud. BASOR 246: 63-67. [CrossRef]

Cross, Frank M. 1950. Notes on a Canaanite Psalm in the Old Testament. BASOR 117: 19-21. [CrossRef]

Cross, Frank M. 1973. Canaanite Myth and Hebrew Epic: Essays in the History of the Religion of Israel. Cambridge: Harvard University Press.

Cross, Frank M., and David Noel Freedman. 1975. Studies in Ancient Yahwistic Poetry. Grand Rapids: Eerdmans.

Cunchillos, Jesús-Luis. 1999. The Ugaritic Letters. In Handbook of Ugaritic Studies. Edited by Wilfred G. E. Watson and Nicolas Wyatt. Leiden: Brill, pp. 359-74.

Dever, William G. 1984. Asherah, Consort of Yahweh? BASOR 255: 21-37.

Dever, William G. 1999. Archaeology and the Ancient Israelite Cult: How the Khirbet el-Qom and Kuntillet 'Ajrud 'Asherah Texts Have Changed the Picture. In Frank Moore Cross Volume in Eretz-Israel 26. Edited by Baruch A. Levine, Philip J. King, Joseph Naveh and Ephraim Stern. Jerusalem: Israel Exploration Society, pp. 9*-15*.

Dever, William G. 2005. Did God Have a Wife? Archaeology and Folk Religion in Ancient Israel. Grand Rapids: Eerdmans.

Dietrich, Manfred, and Oswald Loretz. 1992. "Jahe und sine Aschera": Anthropomorphes Kultbild in Mesopotamien. Ugarit und Israel: Das biblische Bilderverbot. Münster: Ugarit-Verlag.

Dijkstra, Meindert. 2001. "I Have Bless you by YHWH of Samara and His Asherah": Text with Religious Elements from the Soil Archive of Ancient Israel. In Only One God? Monotheism in Ancient Israel and the Veneration of the Goddess Asherah. Edited by Bob Becking. London: Sheffield Academic, pp. 26-31.

Dobbs-Allsopp, Frederick, Jimmy Jack Roberts, Choon Leong Seow, and Richard Whitaker. 2004. Hebrew Inscriptions: Texts from the Biblical Period of the Monarchy. New Haven: Yale.

Eissfeldt, Otto. 1956. El and Yahweh. JSS 1/1: 25-37. [CrossRef]

Emerton, John A. 1982. New Light on Israelite Religion: The Implications of the Evidence of the Inscriptions from Kuntillet 'Ajrud. ZAW 94: 2-20. [CrossRef]

Freedman, David N. 1987. Who Is Like Thee Among the Gods? The Religion of Early Israel. In Ancient Israelite Religion: Essays in Honor of Frank Moore Cross. Edited by Patrick D. Miller Jr., Paul D. Hanson and S. Dean McBride. Philadelphia: Fortress, pp. 315-35.

Hadley, Judith. 1987. Some Drawings and Inscriptions on Two Pithoi from Kuntillet 'Ajrud. VT 37: 180-213.

Hadley, Judith. 1993. Kuntillet 'Ajrud: Religious Centre or Desert Way Station? PEQ 125: 115-24. [CrossRef]

Hadley, Judith. 2000. The Cult of Asherah in Ancient Israel and Judah: Evidence for a Hebrew Goddess. Cambridge: Cambridge University Press.

Hermann, Wolfgang. 1999. El. In Dictionary of Deities and Demons in the Bible. Edited by Karel van der Toorn, Bob Becking and Pietr W. van der Horst. Leiden: Brill, pp. 278-79.

Himbaza, Innocent. 2002. Dt 32, 8, une correction tardive des scribes: Essai d'interprétation et de datation. Biblica 83: $527-48$ 
Huehnergard, John. 1999. The Akkadian Letters. In Handbook of Ugaritic Studies. Edited by Wilfred G. E. Watson and Nicolas Wyatt. Leiden: Brill, pp. 375-89.

Hutton, Jeremy M. 2010. Local Manifestations of Yahweh and Worship in the Interstices: A Note on Kuntillet 'Ajrud. JANER 10: 177-210. [CrossRef]

Joosten, Jan. 2007. A Note on the Text of Deuteronomy xxxii 8. VT 57/4: 548-55. [CrossRef]

Keel, Othmar, and Christoph Uehlinger. 1998. Gods, Goddess, and Images of God in Ancient Israel. Minneapolis: Fortress.

Lemaire, André. 1981. Les écoles et la formation de la Bible dans l'ancien Israel. Friebourg and Göttingen: Editions Universitaires/Vandenhoeck Ruprecht.

Lewis, Theodore. 2011. 'Athtartu's Incantations and the Use of Divine Names as Weapons. JNES 70/2: 207-27.

Mandell, Alice. 2012. 'I Bless You to YHWH and His Asherah'-Writing and Performativity at Kuntillet 'Ajrud. MAARAV 19: 131-62.

Margalit, Baruch. 1990. The Meaning and Significance of Asherah. VT 40: 264-97. [CrossRef]

Mastin, Brian A. 2005. A Note on Some Inscriptions and Drawings from Kuntillet 'Ajrud. PEQ 137: 31-32. [CrossRef]

Mastin, Brian A. 2009. The Inscriptions Written on Plaster at Kuntillet 'Ajrud. VT 59: 99-115.

McBride, Samuel Dean. 1969. The Deuteronomic Name Theology. Ph.D. dissertation, Harvard University, Cambridge, MA, USA.

McCarter, P. Kyle. 1987. Aspects of the Religion of the Israelite Monarchy: Biblical and Epigraphic Data. In Ancient Israelite Religion: Essays in Honor of F. M. Cross. Edited by Patrick D. Miller, Paul D. Hanson and S. Dean McBride. Philadelphia: Fortress.

McCarter, P. Kyle, Jr. 2000. Kuntillet 'Ajrud Plaster Wall Inscription (2.47D). In The Context of Scripture: Monumental Inscriptions. Edited by William W. Hallo. Leiden: Brill, pp. 171-72.

Meshel, Zeev. 1979. Did Yahweh Have a Consort? The New Religious Inscriptions from the Sinai. BAR 5/2: 24-35.

Meshel, Zeev. 2012. Kuntillet 'Ajrud (Horvat Teman): An Iron Age II Religious Site on the Judah-Sinai Border. Jerusalem: IES.

Miller, Patrick. 1986. The Absence of the Goddess in Israelite Religion. HAR 10: 239-48.

Na'aman, Nadav. 2011. The Inscriptions of Kuntillet 'Ajrud Through the Lens of Historical Research. UF 43: 299-324.

Na'aman, Nadav. 2013. A New Outlook at Kuntillet 'Ajrud and Its Inscriptions. MAARAV 20/1: 39-51.

Na'aman, Nadav, and Nurit Lissovsky. 2008. Kuntillet 'Ajrud, Sacred Trees and the Asherah. TA 35: 186-208.

Olyan, Saul. 1988. Asherah and the Cult of Yahweh in Israel. Atlanta: Society of Biblical Literature.

Ornan, Talley. 2015. The Drawings from Kuntillet 'Ajrud. In To Yahweh Teiman and His Ashera, the Inscriptions and Drawings from Kuntillet 'Ajrud. Edited by Shmuel Ahituv and Ester Eshel. Jerusalem: Israel Exploration Society/Yad Ben Zvi, pp. 44-68. (In Hebrew)

Ornan, Talley. 2016. Sketches and Final Works of Art: The Drawings and Wall Paintings of Kuntillet 'Ajrud Revisited. TA 43: 3-26. [CrossRef]

Palmer, Edward. 1871. The Desert of the Exodus: Journeys on Foot in the Wilderness of the Forty Years' Wanderings. London: Bell and Daldy.

Pardee, Nancy, and Dennis Pardee. 2000. Gods of Glory Ought to Thunder: The Canaanite Matrix of Psalm 29. Edited by Lowell Handy. Psalm 29 through Time and Tradition. Eugene: Pickwick.

Pardee, Dennis, and S. David Sperling. 1982. Handbook of Ancient Hebrew Letters: A Study Edition. Chico: Scholars Press. Robson, Eleanor. 2001. The Tablet House: A Scribal School in Old Babylonian Nippur. RA 95: 39-66. [CrossRef]

Sass, Benjamin. 2014. On epigraphic Hebrew 'ŠR and 'ŠRH, and on Biblical Asherah*. Transeuphratène 46: 47-66.

Schmidt, Brian. 2013. Kuntillet 'Ajrud Pithoi Inscriptions and Drawings: Graffiti or Scribal-Artisan Drafts? MAARAV 20: 52-82.

Schmidt, Brian. 2016a. Materiality of Power: Explorations in the Social History of Ancient Israelite Magic. Tübingen: Mohr Siebeck.

Schmidt, Brian. 2016b. Gender marking, overlapping and the identity of the Bes-like figures at Kuntillet Ajrud. In History, Archaeology and The Bible Forty Years After "Historicity". London: Routledge, pp. 101-27.

Schniedewind, William. 2014. Understanding Scribal Education in Ancient Israel: A View from Kuntillet 'Ajrud. MAARAV 21: 271-93. 
Schniedewind, William. 2017. The Voice of God, and Thunderstorms in the Eastern Mediterranean. In Rethinking Israel: Studies in the History and Archaeology of Ancient Israel in Honor of Israel Finkelstein. Winona Lake: Eisenbrauns, pp. 365-69.

Schniedewind, William. 2019. Commander of the Fortress? Understanding an Ancient Israelite Military Title. BAR 45: 39-44, 70 .

Schniedewind, William. forthcoming. The Finger of the Scribe. New York: Oxford University Press.

Sheffer, Avigail, and Amalia Tidhar. 2012. Textiles and Basketry. In Kuntillet 'Ajrud: An Iron Age II Religious Site on the Judah-Sinai Border. Edited by Zeev Meshel. Jerusalem: Israel Exploration Society, pp. 289-312.

Shveka, Avi. 2005. A Trace of the Tradition of Diplomatic Correspondence. JSS 50: 298-320.

Singer-Avitz, Lily. 2009. The Date of Kuntillet 'Ajrud: A Rejoinder. TA 36: 110-119.

Smith, Mark S. 1994. The Ugaritic Baal Cycle: Volume 1: Introduction with Text, Translation \& Commentary of KTU 1.1-1.2. Leiden: Brill.

Smith, Mark S. 2001. The Origins of Biblical Monotheism: Israel's Polytheistic Background and the Ugaritic Texts. Oxford: Oxford University Press.

Smith, Mark S. 2002. The Early History of God: Yahweh and the Other Deities in Ancient Israel. Grand Rapids: Eerdmans.

Smith, Mark S. 2004. The Memoirs of God: History, Memory, and the Experience of the Divine in Ancient Israel. Minneapolis: Fortress.

Smith, Mark S. 2012. God in Israel's Bible: Divinity Between the World and Israel, Between the Old and the New. CBQ 74: 1-27.

Smith, Mark S. 2016. Where the Gods Are: Spatial Dimensions of Anthropomorphism in the Biblical World. The Anchor Yale Bible Reference Library. New Haven: Yale University Press.

Smoak, Jeremy D. 2016. The Priestly Blessing in Inscription and Scripture: The Early History of Numbers. Oxford: Oxford University Press.

Sommer, Benjamin. 2009. The Bodies of God and the World of Ancient Israel. Cambridge: Cambridge University Press. Stavrakopoulou, Francesca, and John Barton. 2010. Religious Diversity in Ancient Israel and Judah. London: T. \& T. Clark. Thomas, Benjamin. 2009. The Language of Politeness in Ancient Hebrew Letters. Hebrew Studies 50: 17-39. [CrossRef]

Tigay, Jeffrey. 1996. Deuteronomy: The JPS Torah Commentary. Philadelphia: Jewish Publication Society.

Tigay, Jeffrey. 2007. The Priestly Reminder Stones and Ancient Near Eastern Votive Practices. In Shai le Sara Japhet. Studies in the Bible, its Exegesis and its Language. Edited by Moshe Bar-Asher. Jerusalem: Bialik Institute, pp. 339-55.

Tropper, Josef. 2001. Der Gottesname Yahwa. Vetus Testamentum 51/1: 81-106. [CrossRef]

Wearne, Gareth. 2015. The Plaster Texts from Kuntillet 'Ajrud and Deir 'Alla: An Inductive Approach to the Emergence of Northwest Semitic Literary Texts in the First Millennium B.C.E. Ph.D. dissertation, Macquarie University, Sydney, Australia.

Weinfeld, Moshe. 1984. The Kuntillet 'Ajrud Inscriptions and Their Significance. SEL 1: 121-30.

Zevit, Ziony. 1984. The Khirbet el-Qôm Inscription Mentioning a Goddess. BASOR 255: 39-47. [CrossRef]

Zevit, Ziony. 2001. The Religions of Ancient Israel: A Synthesis of Parallactic Approaches. London and New York: Continuum.

(C) 2019 by the authors. Licensee MDPI, Basel, Switzerland. This article is an open access article distributed under the terms and conditions of the Creative Commons Attribution (CC BY) license (http:/ / creativecommons.org/licenses/by/4.0/). 


\title{
Moon, Rain, Womb, Mercy The Imagery of The Shrine Model from Tell el-Far'ah North-Biblical Tirzah For Othmar Keel
}

\section{Irit Ziffer}

MUSA, Eretz Israel Museum Tel Aviv, 2 Haim Levanon St., Tel Aviv 6997501, Israel; irit.ziffer@gmail.com

Received: 6 January 2019; Accepted: 12 February 2019; Published: 25 February 2019

\begin{abstract}
The present article focuses on the imagery of the shrine model found at Tell el-Far'ah North, Biblical Tirzah, seat of the ruling dynasty of the Northern Kingdom in the early days of the Israelite monarchy. It examines the multiplicity of connotations, changeability and ambiguity in the representation of the lunar crescent image in the figurative language of the ancient Near East. Finally, the article offers a reconstruction of the model's place within the cult of the late 10th-early 9th century BCE.
\end{abstract}

Keywords: Tell el-Far'ah North; shrine model; moon; rain; womb; mercy; household religion

The present article seeks to examine the multiplicity of connotations, changeability and ambiguity in the representation of the crescent moon image in the ancient Near East in visuals and texts. My point of departure is the shrine model found at Tell el-Far'ah North, Biblical Tirzah, seat of the ruling dynasty of the Northern Kingdom in the early days of the Israelite monarchy. I shall look into the various qualities of the moon crescent and the multi-level figurative language it carried, and attempt a possible reconstruction of how the imagery was understood in its time.

The model under discussion (Figure 1) is a hand-built cubical house-shaped structure with a large front opening and a single niche, representing a shrine. The rectangular opening with a grooved threshold is flanked by two fluted pillars with applied capitals of inward curling volutes topped by buds. The fronton bears an applied crescent shape whose horns terminate in punctured pellets. The crescent form is filled with four columns delineated by incised lines, holding four (two outer columns), five and six punctures. Three dots punctured vertically flank the crescent shape. Incised zigzags lines appear above the capital volutes, the junctures of their lines emphasized by punctures. 


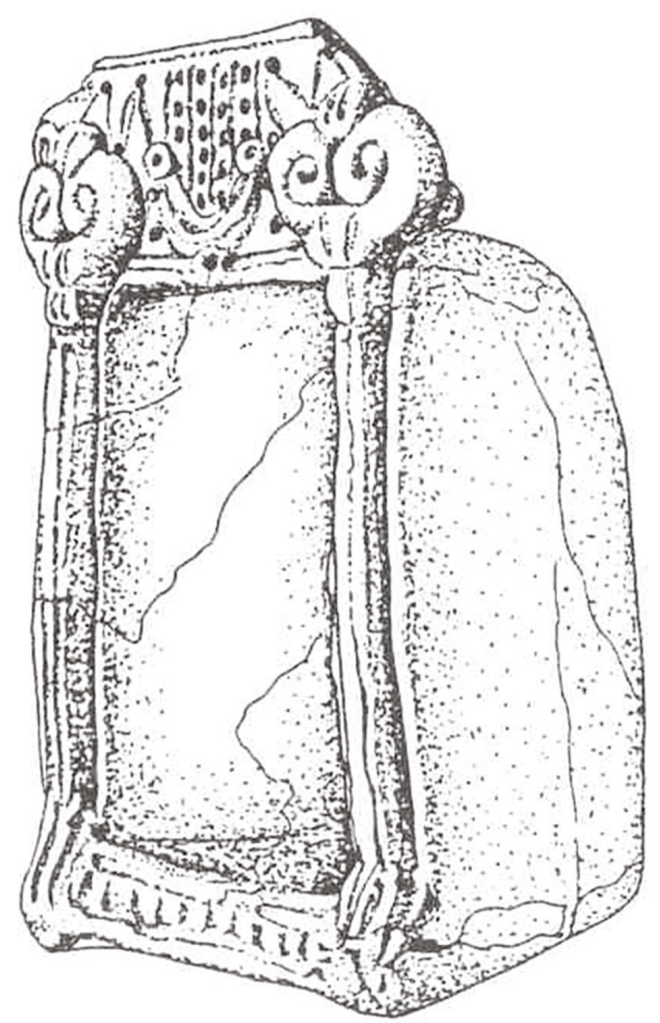

Figure 1. Tell el-Far'ah shrine model (Keel and Uehlinger 1992: Figure 188a).

The shrine model, kept in the Louvre, Paris (AO 2689), was retrieved from pit 241 (therefore stratigraphic context not secure) dug in relation to house 149B near the city gate in stratum VIIb. Stratum VIIb is dated to the Late Iron IIA, late 10th-early 9th century BCE, after Omri had already moved the capital to Samaria (Kleiman 2018 and previous literature therein). A standing stone and a basin found near the city gate of testify to cultic activities that took place there (Chambon 1984, pp. 38, 77-78, Plan B; Bernett and Keel 1998, pp. 53-59). Fragments of two additional shrine models were unearthed at the site. One is a painted round column with drooping petals. The other, found on the floor of house 440, stratum VIIb, comprising the lower left corner of an architectural model similar to the complete shrine, seems to have been imported to Tell el-Far'ah from a distant workshop located in Phoenicia, according to petrographic analysis, or in Northern Israel, perhaps the vicinity of Tel Dan, according to Neutron Activation Analysis results (Muller 2002, pp. 53-54; Katz 2016, pp. 43-44, 60). Such shrine models were uncovered in tombs, private houses, temples and shrines as well as in temple-related context (Daviau 2008; Berkheij-Dol 2012: Appendix B; Kletter 2015). In the domestic context, they served as prophylactic amulets protecting the family and promoting procreation and the abundance of the home and were used in household ritual activity (Mazar 2016, pp. 32e-35e, 5254). They kept the real shrines and real images alive and kindled the devotion of those who possessed or dedicated them (van der Toorn 1999, p. 94; van der Toorn 2002, pp. 58-59).

Presumably, the niche, referring to the inner room in the real temple, the Holy of Holies, housed a figurine of a deity, its attribute animal or a scared emblem. Perhaps the niche was left empty, evoking rather than displaying the divine figure (Kletter 2015, p. 75). 


\section{Previous Interpretations}

Previous interpretations have taken the fronton motifs and palmette pillars as symbols of a goddess. Michaël Jasmin related the crescent and columns to a fertility goddess of the Astarte or Asherah type, who is usually represented by the crescent, dove, lion and date palm (Jasmin 2013, p. 397). Silvia Schroer has pointed out that the female aspect of the moon is enhanced by the palmette volutes, an abbreviated form of the date palm, the tree or palmette pillars substituting for the figure of the (naked) goddess (Schroer 2018, pp. 68, 270-71, 284). Ziony Zevit noted the uniqueness of the punctures pattern within the crescent, where a disc is usually found (Zevit 2001, p. 337). Zevit's observation is important, since it supports the idea, that the dots in the crescent shape held special significance within the imagery, not just a mere decorative device or the outcome of fear of empty space. William Dever postulated that the dots represent the stars of the Pleiades, astronomical symbols closely associated with "Asherah/Astarte" and later with Tanit (Dever 2016, p. 195). However, the dots count numbers more than the 7 stars of the Pleiades. Othmar Keel and Christoph Uehlinger suggested that the dots may represent rain drops, in accordance with the Northern Syrian tradition of depicting rain (Keel and Uehlinger 1992, p. 184).

\section{Suggested Reading of Motifs}

I embrace Keel and Uehlinger's reading of the motifs and wish to add on the multivalence of the image of raindrops falling into the lunar crescent. Interestingly, the crescent appears on a seal impressed handle found in stratum VIIb at Tell el-Far'ah, showing two figures next to a crescent on a moon (Keel 2010, pp. 6-7, no. 9) (Figure 2). Unlike other depictions of the crescent moon flanked by human figures who raise their hands towards the crescent, on a pole or hovering between them (Ornan et al. 2017), the arms of the figures on the seal impressed handle stretch down along the sides of their bodies.

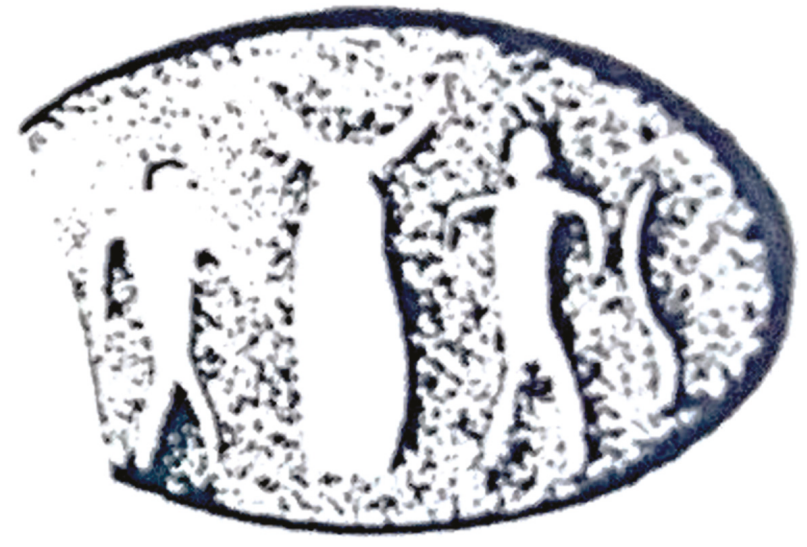

Figure 2. Tell el-Far'ah seal impressed handle, depicting figures flanking a lunar crescent on a pole (Keel 2010, pp. 6-7, no. 9).

\subsection{Rain Imagery in the Ancient Near East}

Jacques Cauvin demonstrated that two dominant ideological symbols, the woman and the bull, appear in art on both sides of the Taurus Mountains as early as the eighth millennium BCE, representing the advent of the woman and bull religion. Woman and bull, emblematic of the female fertility goddess responsible for both rain and birth, and the virile male god, appear at the very same time as the earliest evidence of rain-fed agriculture and animal husbandry. To this day in Northern Syria and Northern Mesopotamia, agriculture is based almost entirely on rainfall with its concomitant thunderstorms and rainbows. The rolling thunder recalls the lowing of a bull or the sound it makes 
when it paws the ground. Bull heads, even bull figures, surrounded by dots, appear on the Halaf painted pottery of Northern Mesopotamia, dating 6600/6500-6000 BCE. It seems reasonable to interpret these dots as raindrops. Most revealing is the scene on a Halaf bowl from Arpachiya (Figure 3). Here, the outer face of the bowl shows bull heads surrounded by dots, while the inner face of the bowl's wall features next to a bull hunt scene two naked women flanking and holding a square form fringed on three sides, which may be interpreted as a sheet of rain (Ziffer and Shalem 2015, pp. 46263). ${ }^{1}$

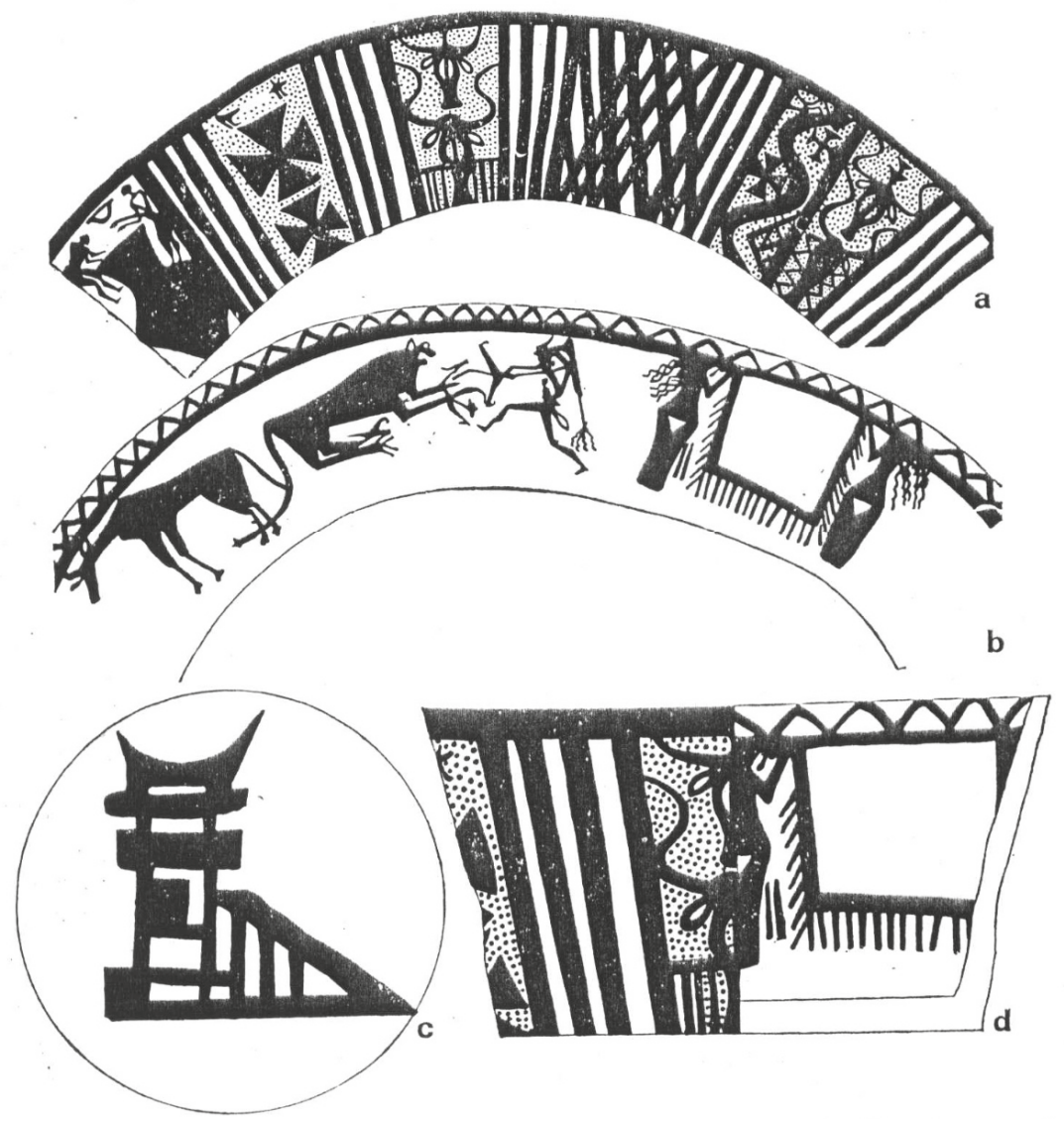

Figure 3. Bowl from Arpachiya, depicting bulls, naked women and rain (Hijara et al. 1980: Figure 10).

In the Akkadian glyptic period, the storm god, holding flail and forked lightning on a winged lion spewing water streams (Boehmer 1965, pls. XXX: 363, 366, XXXI: 367, 369, 371), stands or drives a chariot drawn by a lion dragon spewing jets of water (Boehmer 1965, pl. XXXI: 372-374). The storm god cracks a whip or carries a mace. ${ }^{2}$ He is depicted with his consort, the naked goddess, holding with both hands a lightning rod or bundles of lightning rods (Figure 4) or a watery strap, standing on her own lion dragon spewing water (Boehmer 1965, pl. XXXI: 368) or on the lion dragon harnessed to the god's chariot (Boehmer 1965, pp. 372-73). Mounted on a bull with outstretched arms, she stands

(Garfinkel 2018), who regards the scene as the earliest representation of weaving with a loom.

2 (Black and Green 1992, pp. 110-11), Figure 89. Boehmer tends to interpret the whip as thunder, to van Loon the cracking of the whip signifies lightning, (van Loon 1990, p. 365). 
in a rain shower depicted as a sheet of wavy lines (Boehmer 1965, pp. 63-64, pl. XXXI: 369; MayerOpificius 1984, p. 202). In the background, moon crescent and sun may be depicted, or the moon may be represented alone. One seal shows winged lion dragons diving from heaven along with the storm god and the naked goddess on their lion dragon mounts. The lion dragons represent the roaring dark thunderclouds (Jacobsen 1976, p. 7). Likewise, the lowing of the goddess' bull was the thunder that brought rain. The bull would become the storm god's symbol in the west, and the storm clouds were called "Adad's bull-calves" (Lambert 1985, p. 436; Black and Green 1992, pp. 110-11).

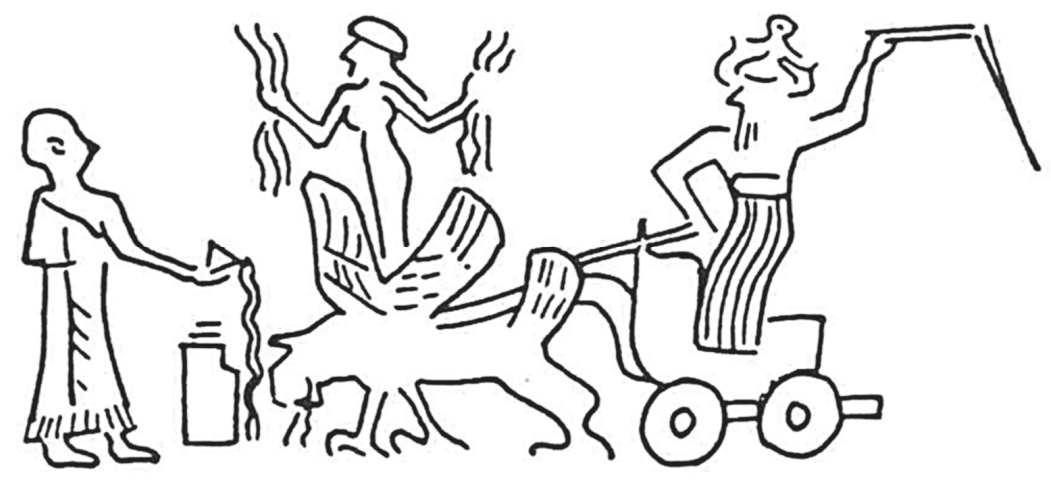

Figure 4. Naked goddess with lightning bundles on a lion dragon harnessed to the storm god's chariot (Leinwand 1992: Figure 13).

In the Anatolian glyptic of the Assyrian trade colonies period, the storm god stands on a lion holding a forked lightning symbol and a spear (Özgüç 1965, nos. 8, 11a-b, 13), or on a bull grasping a limp snake by the head (a defeated enemy). A god wearing a moon crescent mounted on a bull may appear with the storm god, possibly signaling him as a local lunar storm god (Özgüç 1965, no. 71; Leinwand 1992: Figure 16; Ornan 2001, p. 16) (Figure 5). He appears with his consort, the naked goddess, who grasps a circle of strokes indicating rain. Between the goddess and the god on the bull grasping a snake are diagonal strokes, possibly rain.

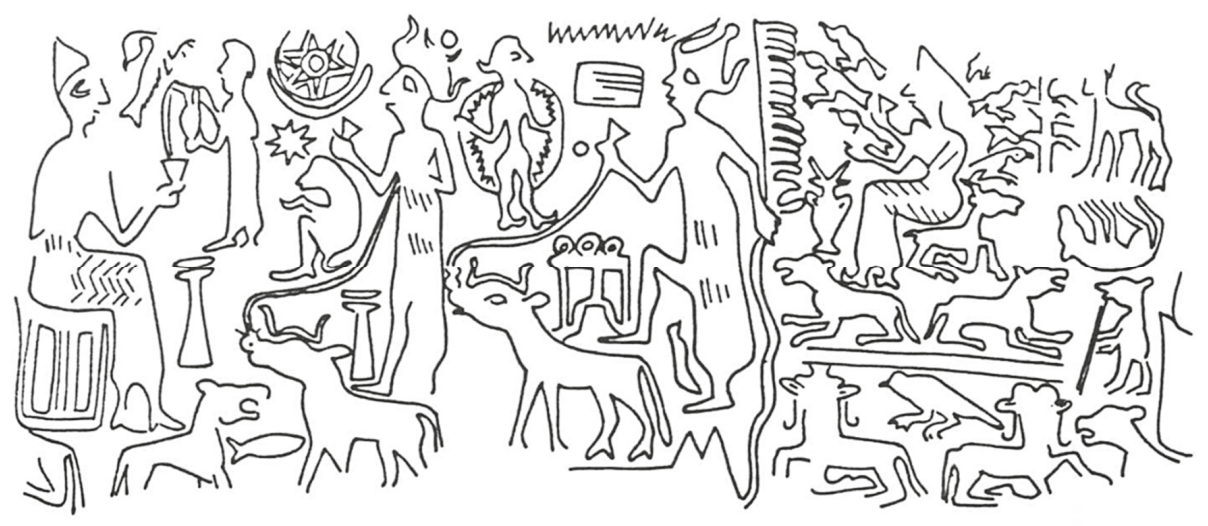

Figure 5. Anatolian seal impression showing the storm god on a bull, a naked goddess lifting her skirt and rain (Leinwand 1992: Figure 16). 
In the Old Babylonian glyptic, the storm god is identified by his name in the seal inscription. Grasping the lightning fork, he rests his foot on a recumbent bull, his attribute animal, below a crescent. The inscription reads "Adad (dIshkur), son of An-na" (Fales and Del Fabbro 2017, pp. 16465 , cat. no. 110). The lightning fork, the storm god's symbol, appears on a bull without the anthropomorphic manifestation of the god, together with the naked goddess, moon and sun above her (Figure 6). The seal inscription reads: Adad (dIškur) Shala (dša-la), providing the naked goddess' name. ${ }^{3}$ Shala was the consort of the god Ishkur/Adad. Adad was the storm god of the north and the west, whose name was derived from the Western Semitic root * $h-d-d$, meaning "thunder", as in the name of the Syrian storm god, Baal/Hadad (Schwemer 2008, pp. 125, 135-37). Shala was a goddess of Hurrian extraction, her name meaning "daughter". Her epithets indicate that she was the goddess of rainfall and therefore she was invested with power over harvests. Her light features allude to lightening (Schwemer 2006, 2008, pp. 147-49). In the god lists, Shala is the consort of the storm god Ishkur. She was venerated with Adad in the Mesopotamian cult centers from the second millennium BCE on. A hymn to the temple of the storm god Ishkur at Karkara, é-u4-gal-gal(-la), "House of Great Storms", where he was head of the pantheon, reads "House of Ishkur, your front (is) abundance, your 'back' (is) luxury/ Your foundation (is) a steer, ...". The text is broken and then reads: "the sacred furrow, Holy furrow, teat of heaven (sending) rain for the late barley" (Sjöberg and Bergamann 1969, p. 36, Temple Hymn 27: lines 328-32; 116-17). Here, Shala is described specifically as a rain-giving breast.

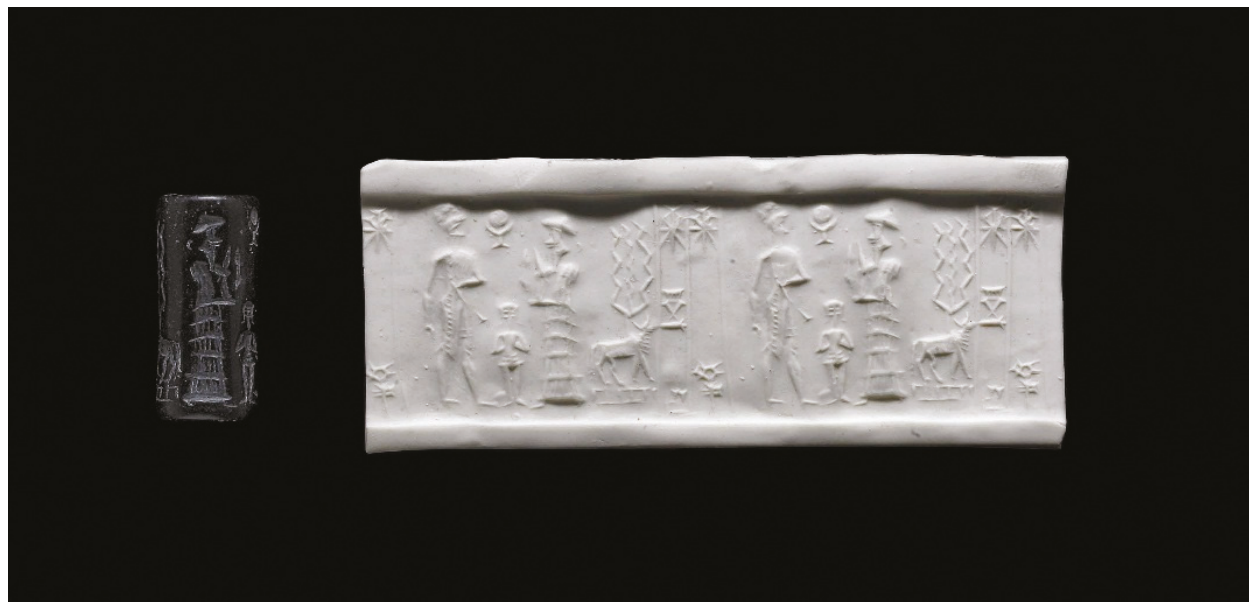

Figure 6. Cylinder seal inscribed Adad, Shala. () The Trustees of the British Museum.

In Syrian glyptic of the second quarter of the second millennium BCE, the goddess frequently appears lifting her skirt with diagonal protrusions (Figures 7-9), reminiscent of her Anatolian counterpart (Figure 5). ${ }^{4}$ She is depicted with the storm god in a smiting stance, holding a spear, or a snake or plant symbolizing his power to generate vegetation. He stands on mountains tethering a kneeling bull, with the animal acting as her pedestal (Figure 9). The bull-mounted structure housing the stripping goddess may take the form of a guilloche (Figure 7) or of striations, resembling those on the goddess' skirt (Figure 8). In ancient Near Eastern art, wings signified the celestial sphere, while the guilloche signified flowing water (Collon 1975, p. 194) and represented fertility in general (Otto

3 https://www.britishmuseum.org/research/collection_online/collection_object_details/collection_image _gallery.aspx?ass.

4 According to van Loon (1992) the goddess with up-lifted skirt represented the rainbow. 
2016). The configurations of guilloche and wings are therefore pictorial expressions of rain from heaven. ${ }^{5}$

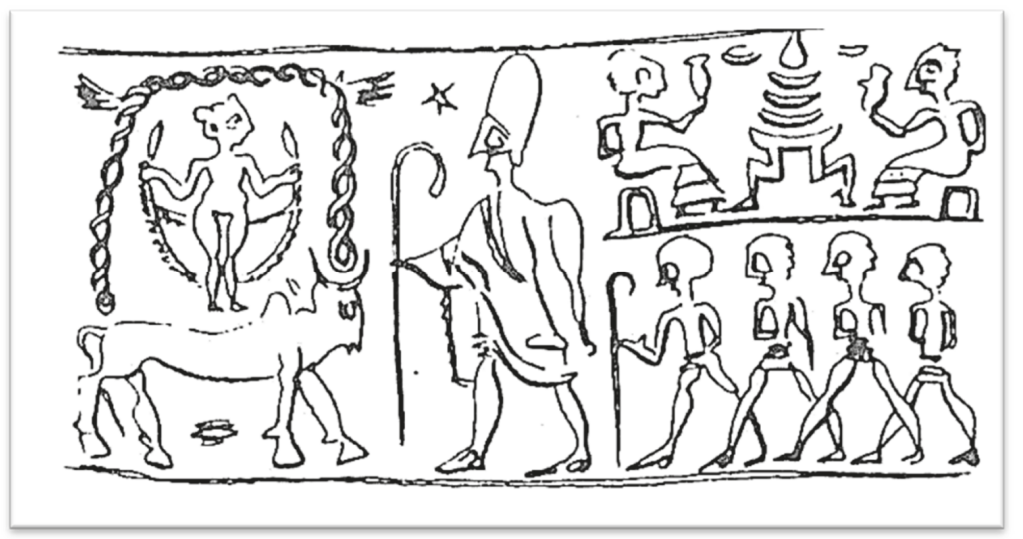

Figure 7. Syrian seal: Naked goddess on the back of a bull, lifting her skirt, under a winged guilloche (Amiet 1960: Figure 11).

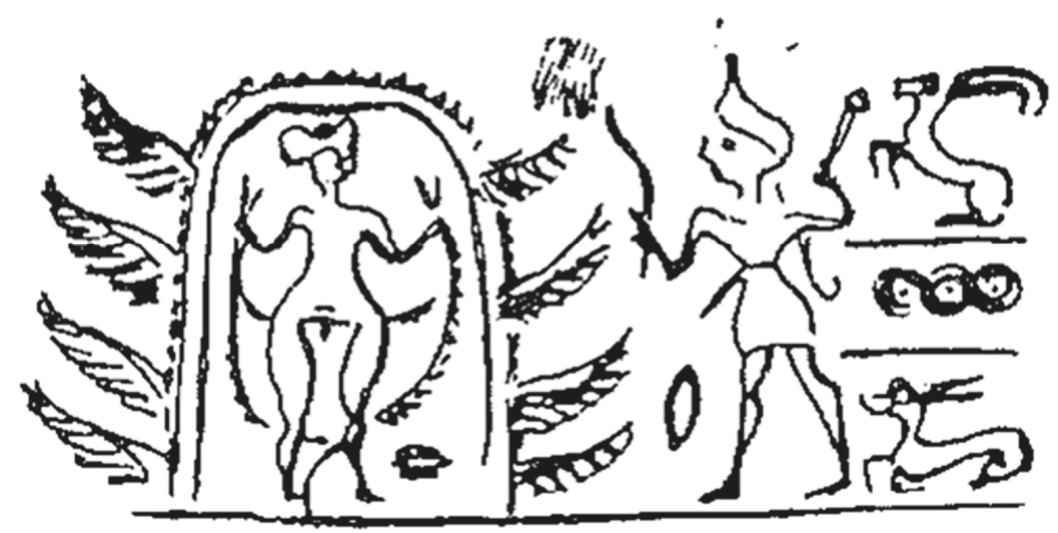

Figure 8. Syrian seal: Naked goddess in a winged structure and storm god (Amiet 1960: Figure 10).

Compare the Urnamma stele upper register of both faces, showing flying goddesses pouring undulating streams of water from vases above the seated king, which Jacobsen construed as mythopoetic representations of the rain clouds ((Jacobsen 1987), p. 393 note 24; (Suter 2000): Figure 33a-f for the various reconstructions of the stele). The same goddess dives down on Gudea's stele top in Berlin ST. 1-2 (Suter 2000): Figures 17, 19d, pl. B. 


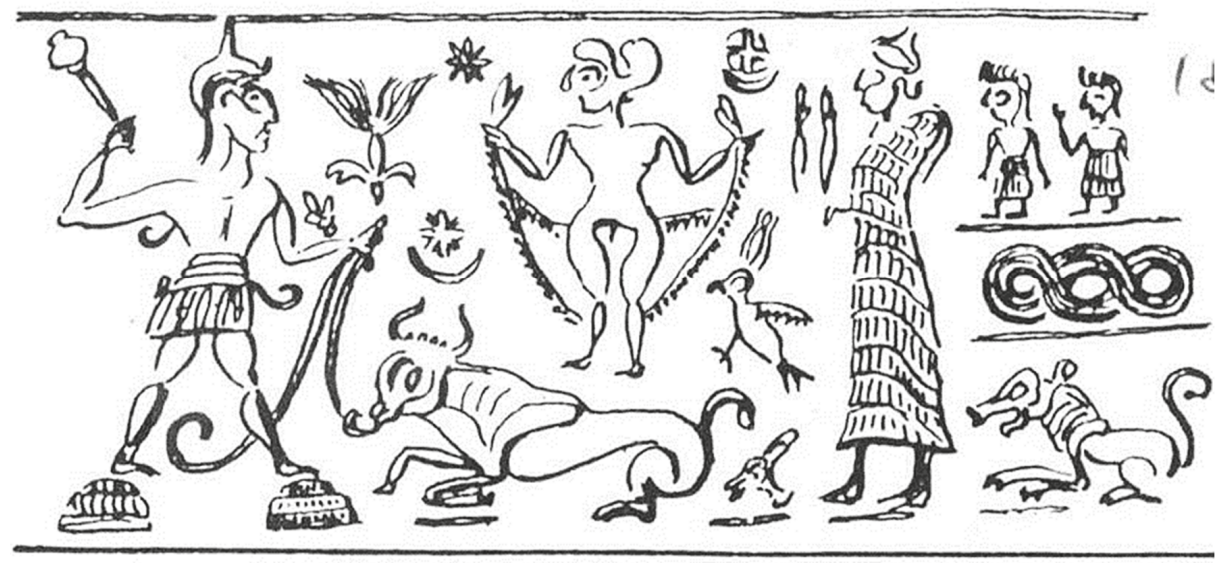

Figure 9. Syrian seal showing goddess lifting her skirt on a bull tethered by the storm god (Amiet 1960: Figure 14).

In the Hittite-Hurrian sphere, the naked goddess maintained her association with the storm god. Surrounded by a guilloche band, the two deities standing on the back of bulls face each other, with the goddess spreading her sheet garment (Otto 2016: Figure 10d). Disrobing, she stands facing the storm god in his chariot, pulled by a pair of bulls that he controls by reins. Streams flow from her shoulders, which connect to the guilloche (water) that stretches above the storm god's chariot (Figure 10). At Emar, the goddess' skirt is made of globules representing raindrops (Beyer 2001, p. 213, nos. E9, E10).

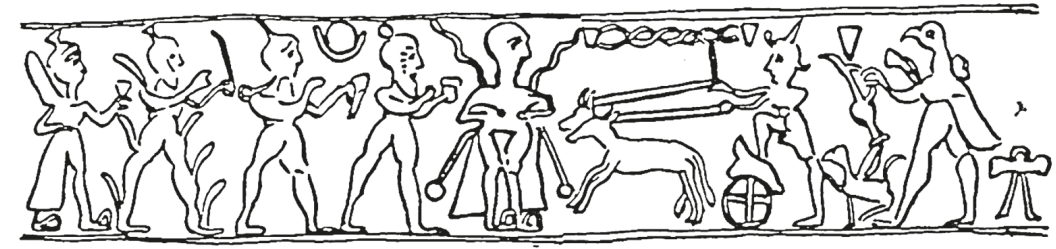

Figure 10. Hittite seal: Disrobing goddess facing the god riding his chariot, guilloche between (Leinwand 1992: Figure 23).

On a seal impression from Nuzi of the 14th century BCE, rain is pictured as a splash of globules accompanying the storm god on his lion dragon, grasping lightning forks with both hands (Figure 11). Instead of the naked goddess, two goats standing back to back stand on (her) lion (Stein 1988, pp. 176-78, Figure 1). ${ }^{6}$

6 Undulated lines, possibly rain, appear behind a god on a bull on a Mitannian seal impression from (Beyer 2001, p. 227, no. E41). 


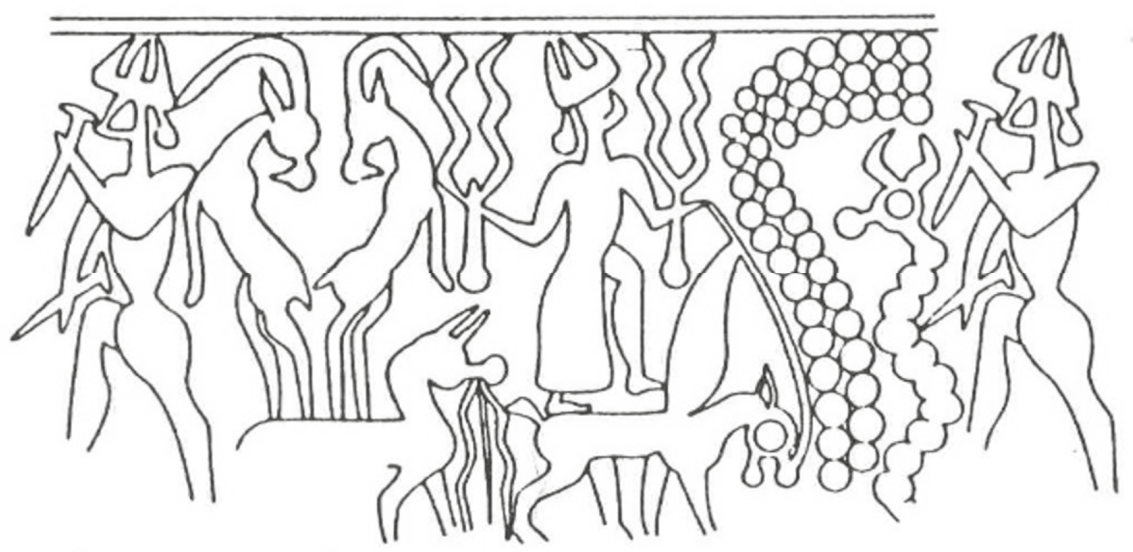

Figure 11. Splash of dots before the weather god holding lightning forks who stands on a lion dragon (Stein 1988: Figure 1).

The last appearance of the goddess holding open her rain-sheet garment behind her back is on the Hasanlu gold bowl, found in a 9th century BCE context (Figure 12) (Winter 1989). Here, she stands on two rams, alongside Teshshup the storm god, who subdues the stone monster, son of the god Kumarbi, as he fights for preeminence among the Hurrian storm gods. Globules (raindrops or hail) connect the storm god in his chariot, harnessed to a bull spweing jets of water, with the same god as he fights the monster, and with the naked goddess who unfolds her robe, made of a square sheet with delineated columns filled with dots, symbolizing rain. The goddess wears a crescent-shaped pendant on her neck (Figure 12a). Behind the storm god are the sun god and the moon god in their chariots pulled by equids. ${ }^{7}$

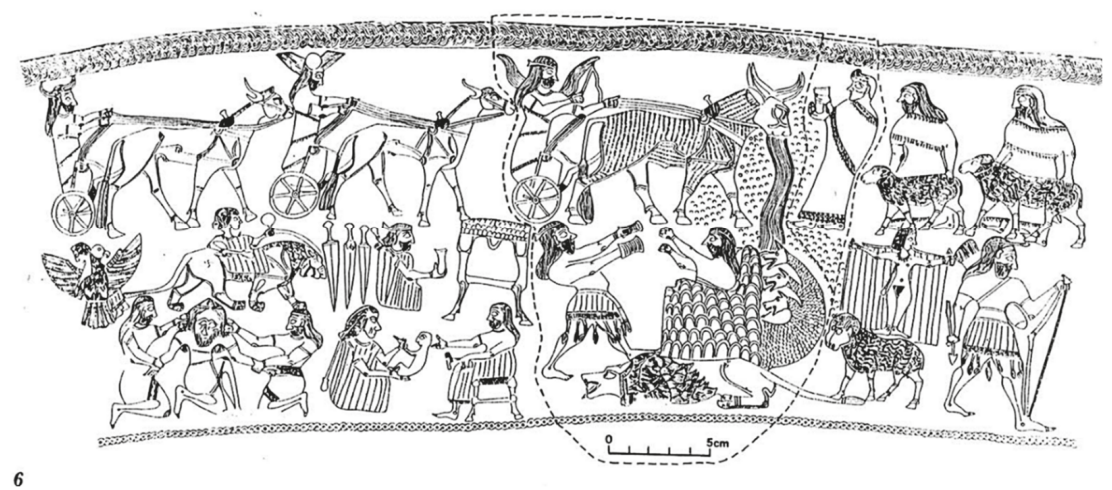

(a)

7 For the moon god's chariot functioning as a celestial visible effect, the halo, see (Rochberg 1996, pp. 479-82). 


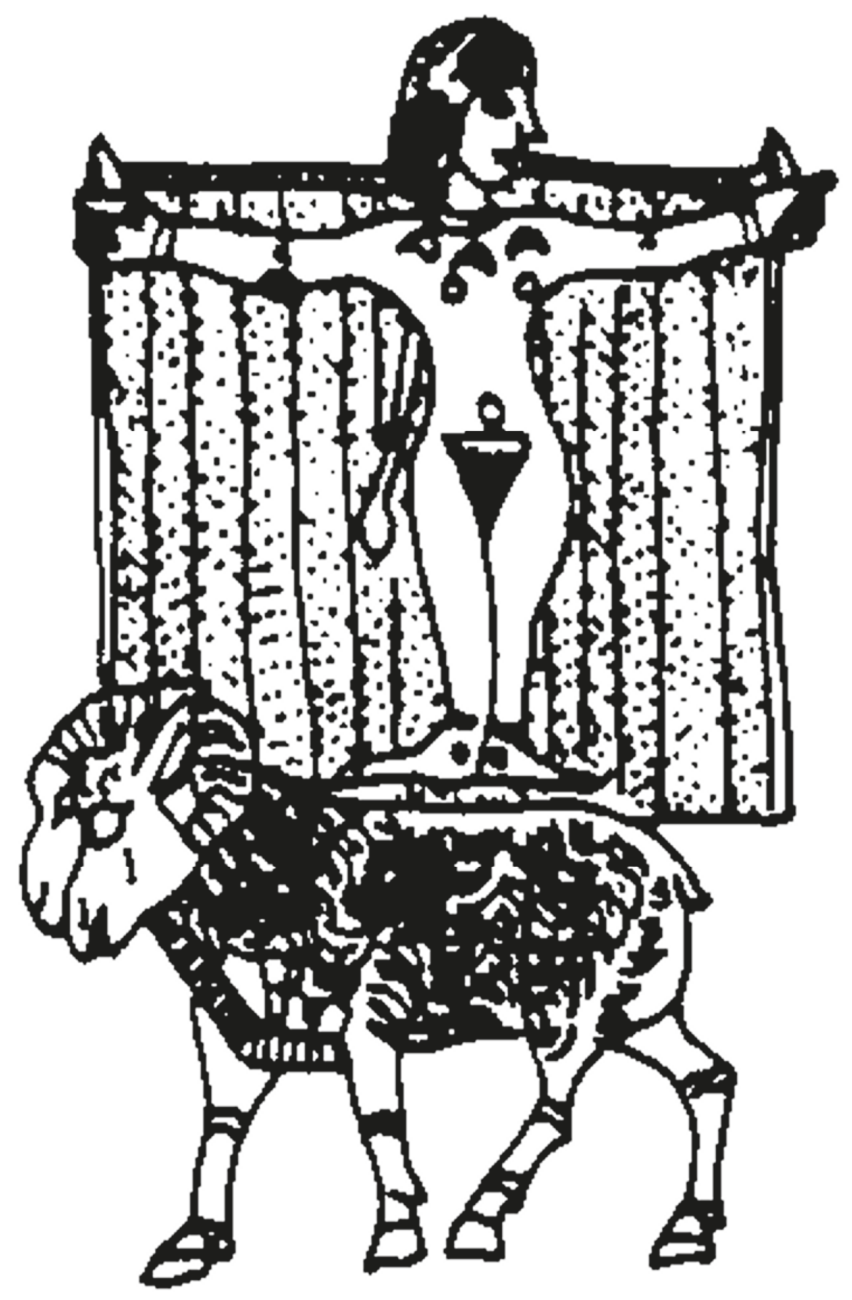

(b)

Figure 12. (a) Hasanlu gold bowl: rain drops connecting storm god and disrobing goddess (Winter 1989: Figure 6); (b) Hasanlu gold bowl, detail: rain goddess wearing three crescent pendants.

The moon and sun that appear along with the storm god and the rain goddess are celestial bodies, and hence they may be understood as a metaphor for the firmament that separates the waters above from the waters below, where the celestial bodies are visible (Mayer-Opificius 1984, p. 201; Rochberg 2010a, pp. 341, 344). ${ }^{8}$ Additionally, belonging to the celestial sphere are meteorological phenomena - dew, rain, snow, hail, lightning and storm winds - that issue from openings in the sky to release them (Bartelmus 2001, pp. 93-95, 98, 106). ${ }^{9}$ An Akkadian cylinder seal from Nippur shows the stars as the source for rain above the enthroned sun god (Collon 1987, no. 765). In the Middle Assyrian period, a winged disk supported by a kneeling Atlantid figure separates the upper waters from the lower ones. Undulating lines, indicating water, may issue from the winged disk, embodying the firmament (Matthews 1990, p. 110, note 236, nos. 499, 501) (Figure 13). In Mesopotamian literature, the divine sky had generative powers often described metaphorically in terms of the sky's rains as

Compare Genesis 1: 15-17.

Compare Deuteronomy 28: 12; Jeremiah 10: 12-13, 51: 15-16; Psalms 135: 6-7. 
the semen engendering the vegetation on earth (Rochberg 2010a, p. 341). ${ }^{10}$ In Akkadian, the sky is explained as ša mê "of water" (Hebrew: šămayim) and the rain is the "water of heaven", ŠÈG (written A.AN) (Rochberg 2010a, pp. 344, 354). The iconography of the "water of heaven" always shows the rain coming down from the upper field of the artwork, whether by means of undulated lines, globules or as a sheet of columns filled with dots. The Tell el-Far'ah model conforms with the latter convention.

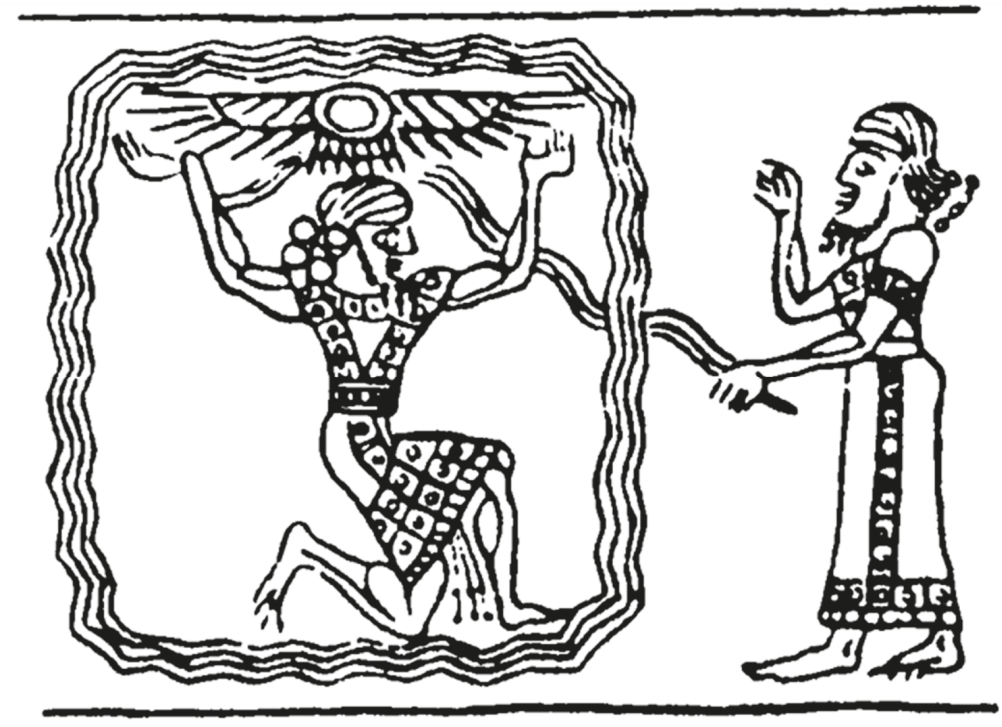

Figure 13. Middle Assyrian seal depicting a kneeling figure supporting a winged sun that separates the waters above from the waters below (Matthews 1990, no. 501).

\subsection{Moon Imagery, Womb and Compassion}

In the ancient Near East time was defined according to the lunar calendar, marking the beginning of the month by the first sighting of the thin moon crescent. Therefore, the moon god was the most important deity of the three luminary siblings. The moon god Nanna/Suen/Sin was the big brother of the sun god Utu/Shamash and Venus (Inanna/Ishtar), his little brother and little sister (Horowitz 2012, p. 9). ${ }^{11}$ In art, the moon was depicted as the thin recumbent new moon crescent as observed in the Middle Eastern sky, like a bowl or a boat. The lunar crescent, Akkadian: uskaru, from Sumerian U4.SAKAR = Nanna (CAD U/W 278-79; Krebernik 1995, p. 360), was the moon god's most common attribute and his epithet (Collon 1992, pp. 20-21).

At the beginning of the month, Sin rises with horns (cusps), associating the moon waxing with cattle and with the herdsmen and referring to the astral and pastoral aspects of the god (Jacobsen 1976, p. 124; Veldhuis 1991, p. 1). In Mesopotamian literature, the moon god Nanna/Suen/Sin, was referred to as the "astral holy bull calf" who shines in the heavens and spreads bright light in the night. The horns of the moon god (crescent) carry the bovine metaphor (Rochberg 2010b, p. 352), with the white brightness recalling milk (Verderame 2014, p. 93). Because of his horns, the moon god is be qarni "Lord of the Horns", (CAD Q: 137, qarnu 3a). A sealing from Choga Mish dating from the late fourth millennium BCE depicts a large figure seated on a bull (-throne), while a squatting small figure behind him touches a crescent moon standard (Kantor and Delougaz 1996: pl. 151:B).

10 Halos surrounding the sun and the moon can be an indication of rainstorms (Rochberg 2016, pp. 142, 187).

11 In the Sumerian tradition Nanna was the father of Inanna and Utu (Black and Green 1992, p. 182). 
The month (Akkadian: (w)arhu) lasted from the evening of the first visibility of the new moon ((Akkadian: $(w) \operatorname{arhu})$ CAD A/2: 259-263, arhu A) ${ }^{12}$ after a night or two when the moon is invisible until the next new moon crescent was seen, and lasted 29 or 30 days. Calculating an average month close to $291 / 2$ days, and the twelve new moons calendar equal to about 354 days, the lunar calendar is $11^{1 / 4}$ days short of the solar year. To achieve synchronization between the solar year and the lunar month and keep pace with the major festivals that are connected to the agricultural seasons, an extra intercalary lunar month is necessary, slightly more often than once every three years (Hunger 2009; Steele 2011; Horowitz 2012).

The unevenness of a $291 / 2$ day-lunar cycle was corrected in the early third millennium BCE, when archaic administrative accounts were based on a 30-day month and a 360-day year (Bauer et al. 1998, pp. 121, 126). Thirty, the number of days in the ideal month was used to write the name of the Mesopotamian moon god, d30 (Black and Green 1992, p. 135). The writing d30 for labeling the moon god spreads westward and is attested in the second millennium at Emar for Šaggar (also written dHAR, Fleming 2000, p. 32), god of the moon (Dalley and Teissier 1992, p. 90). The god Šaggar also occurs at Ugarit, in god lists (Pardee 2002, pp. 17, 19 line 14 dHAR=Šaggar, 46 line 31) and in the Baal Cycle (Smith 1997, p. 145). ${ }^{13}$

The moon god's name 30, referring to the lunar cycle, brings to mind the moon god's title inbu bèl arhi "fruit, lord of the new month", referring to the cyclical self-begettal of the child-moon from the old moon of the last month (Lambert 1987, pp. 2, 29). ${ }^{14}$ The lunar cycle of 29-30 days was therefore associated with the menstrual cycle (Verderame 2014, p. 93) as well as with the fruit of the womb. Small wonder, therefore, that new-moon crescent shaped ornaments, Akkadian: uskaru (CAD U/W: 278, c) Hebrew: śahărōn שִ שִ (Isaiah 3:18), were a popular piece of female adornment (Golani 2013, pp. 157-59), and were connected with birth giving and nursing (Figures 12a and 14) (Beck 2002, pp. 385-91; Ornan 2007). ${ }^{15}$

2 Compare the West Semitic root ירח used to designate "month" and "moon" (Rendsburg 2009, p. 170).

13 At Emar, the god Šaggar had a significant role in promoting the welfare of the herds (Fleming 2000, pp. 15657). It has been connected with Hebrew šeger (שֶֶֶׁ) in the Aramean Ballam text from Deir 'Alla (שגר ועשרת). In the Bible, שגר refers to the firstling of cattle drop and sheep flocks (שגר אלפיך ועשתרות צאנך), and parallels the issue of the human womb (רחם) (Exodus 13: 12) and (פרי בטן) (Deuteronomy 7:13, 28:4, 8,51). There may be a connection between the name Šaggar and the Sumerian logogram $\mathrm{U}_{4}$. SAKAR, Akkadian uskaru "lunar crescent" or Sin. Thus, it may refer to the moon metaphorically as a young bull. The same moon god appears at Ebla in the third millennium in a literary text as ${ }^{\mathrm{S} S a-n u-g a-r u ~ c o r r e s p o n d i n g ~ t o ~ I ~ I T I ~}$ "one month"/new moon" in a parallel text and is preceded by 2 SI, perhaps "two horns", which reinforces the metaphor of the new moon as a young bull (Dalley and Teissier 1992, pp. 90-91).

14 In Mesopotamian love lyrics, inbu had sexual overtones "fruit, flower, sexual appeal" (Krebernik 1995, pp. 361, 366).

15 For New Kingdom feeding bottles in the shape of a woman wearing a crescent pendant, nursing a baby, or pressing her breast to collect the milk in a vessel, see (Brunner-Traut 1970: Figures 5 and 10). For crescent pendants worn by male figures in the Bronze and Iron Ages Near East, see (Ilan 2016). Iconography as well as archaeological finds confirm the use of crescent pendants by women, children and animals (as charms to promote harmonious growth) since ancient Egypt. In Greece, they go back to the Mycenaean period (Dasen 2003, p. 280); when buried with the dead, crescent pendants carried the hope of re-birth (Ziffer 1990, pp. 82*, 116). 


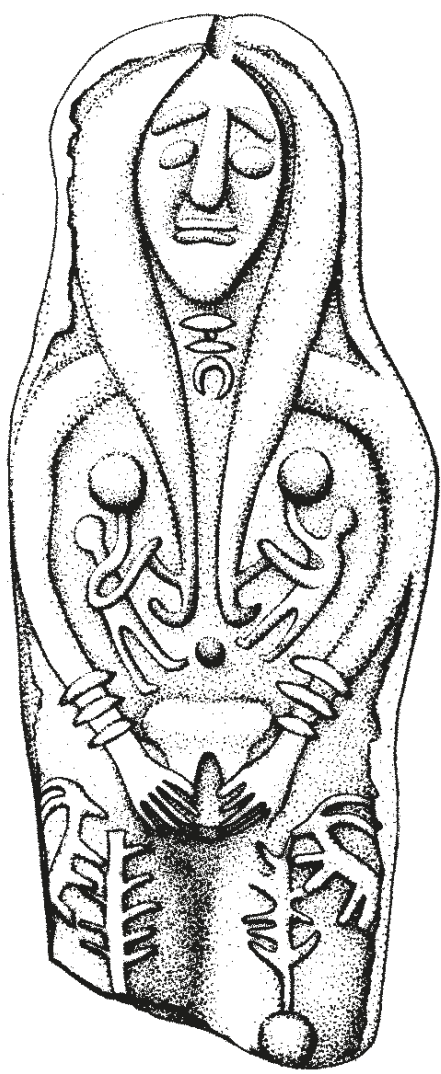

Figure 14. Revadim plaque figurine of a naked woman with babies wearing a crescent pendant (Ornan 2007: Figure 3).

Another name of the Nanna/Suen, dGIŠ.NU11.GAL "alabaster", suggests the lustrous white appearance of the moon crescent (Rochberg 2010a, p. 326). Yet another name of the moon god was DILIM2.BABBAR "shining bowl", a loanword from Akkadian tilimtu, which was considered to be an attribute of the moon god. Moreover, the tilimtu bowl was shaped as a boat, another metaphor for the moon god (Steinkeller 2016). Among the surviving finds which may be connected with tilimtu "shining bowl", are the gold and silver bowls that were found in the tomb of Puabi, moonlike and boat-like (Woolley 1934, pls. 164, 171b with bull's head engraved on side). ${ }^{16}$ Picturing the moon god

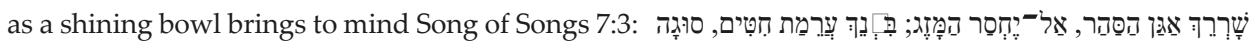
"Your navel is a rounded bowl-may it not lack mixed wine! Your belly, a heap of wheat encircled with lilies". Literally, the navel (LXX: omphalos) is like a half-moon bowl 'ăgan hassahar (Jastrow 1903, p. 960 סה).

In the Bible, the belly, (here swollen like a heap of wheat) is synonymous with the womb,

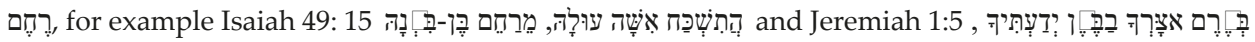

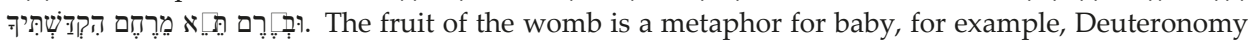
7:13 (Erbele 1999, p. 138). The Aramaic root $b-t-n$ appears as a noun "womb" and as a verb "to be

16 Stol (1992, p. 249) concludes that the moon as bowl, boat and fruit represent the moon in all stages of growth, particularly the last one, which is the brightest. 
pregnant", "pregnant woman", "pregnancy" and "conception" (ירחי ב $\square$ "the nine months of pregnancy") (Jastrow 1903, p. 158; Sokoloff 1990, p. 91; Sokoloff 2009, p. 137; Tal 2000, p. 94). ${ }^{17}$

The womb is a metaphor for a virgin. At Ugarit, the noun $r h m$ signifies the "womb" and by metonymy also "nubile girl, damsel", said of the goddess Anat (Del Olmo Lete and Sanmartín 2003, p. 737; Smith 1997, p. 121), rḥm ' $n t$ and rhmy, Rahmay is a goddess' name (Smith 2006, p. 20, lines 13, $16 ; 89-90) . r h m t$, a nubile woman, appears in the Mesha inscription, describing the king's massacre at Nebo of "seven thousand men and boys, women and girls and maidens" (Na'aman 2007, p.

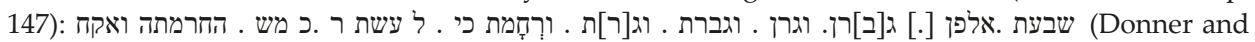
Röllig 2002, pp. 41-42, no. 181:16-17) and in Judges 5:30 "Are they not finding, are they not dividing

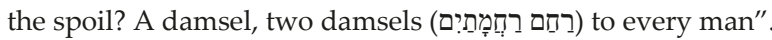

In Semitic languages, the root $r-h-m$ is multivalent. Derived from the root are the noun "womb", the verb "to pity" and the noun "pity, mercy". Thus, Akkadian rēmu, rīmu, rêmu (CAD R: 262-265) denotes "womb" "uterus", written syllabically or with the Sumerian logogram ARHUŠ, which by extension means "pity, compassion" (Attinger 1993, p. 441 §275); Ugaritic rḥm "womb" and "to have

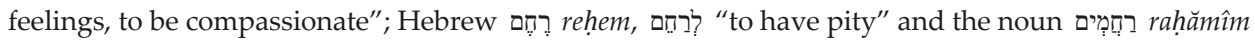
(Jenni and Westermann 1976, pp. 762-68; Maier 2014, pp. 182-89). In Qumran Aramaic and Samaritan Aramaic רחם denotes "womb", "to love", "love", and רחמין denotes "mercy" (Cook 2015, pp. 221-22; Tal 2000, p. 828). In Arabic رحُم رَجْ rahim, rihm denote "womb", and by metonymy "relationship, kinship". From the same root are the verb زَحمَة رَحَّ "to have mercy, to have compassion", and rahmah "pity, compassion, sympathy" (Wehr 1980, pp. 331-32). The Semitic roots indicate that birthing/motherhood and mercy are connected. Dorothea Erbele argued that רחם "womb" is a gendered term, the singular form reserved for the womb of women, and רחמים, the abstract plural, refers to the inner site of compassionate emotions (Erbele 1999, p. 136; Levine 2002, pp. 338-39).

Moreover, Gary Rendsburg has demonstrated that the Semitic root $r-h$ - $m$ occasionally bore the meaning "rain" in the Bible (Isaiah 49:10; Hosea 2:23-25; Psalms 110:3) as well as South Arabian (Rendsburg 1983, p. 361; Johnstone 1977, p. 103) and Ethiopian (Rendsburg 1983, p. 357; Leslau 1991, p. 336).

The multiple meanings associated with the root $r-h-m$ may be traced in the visual evidence. As mentioned above, Akkadian rēmu, rīmu may be written with the logogram ÁRHUŠ. The archaic sign is composed of the signs TÙR "cow pen" with inscribed MUNUS "woman". TÙRxMUNUS also means littu "cow". The sign TÙR = Akkadian tarbașu "cow pen" closely resembles the reed hut from which calves and newborn sheep emerge in Uruk art (Figure 15a,b). In ancient Mesopotamia, TÙR = tarbașu "cow pen", also denoted "halo" (Figure 16). The lunar halo, TÙR ša Sin, alluded not only to the closed circle of the cattle pen, but was also related the moon god's association with animal husbandry and the pastoral and bovine world (Verderame 2014, pp. 92-93). ${ }^{18}$ Notably, in the midthird millennium BCE, a crescent moon appears on the pen lintel above the open door (Figure 17a,b). The image renders the concept of the inner, protected place, the womb, enclosing the embryo, the open door expressing the child's release at birth. The crescent may represent the image the fetus moving like a boat along the birth canal (Couto-Ferreira 2014, pp. 294-95).

17 (Sharvit 1972) on the oriental version (Genizah, Cochin and Singili, India) of "Ehad mi yodea" song in the Passover Haggadah, employing the Aramaic term for the nine months of pregnancy.

18 Compare o "an enclosed place, especially the enclosure for cattle near a dwelling" (Jastrow 1903, p. 960). 


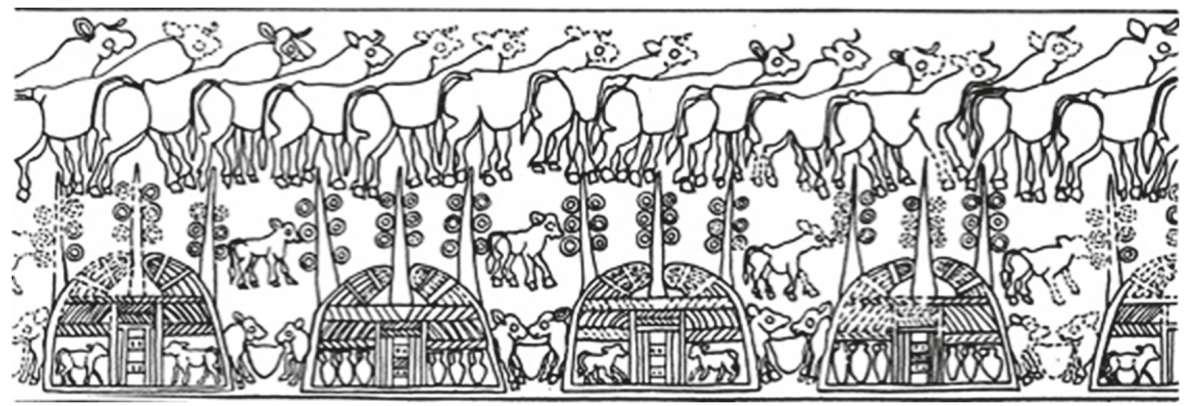

(a)

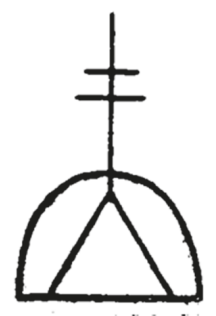

(b)

Figure 15. (a) Cylinder seal depicting cows emerging from the cow pen (Delougaz 1968: Figure 11). (b) Archaic sign TÙR, cow pen. 


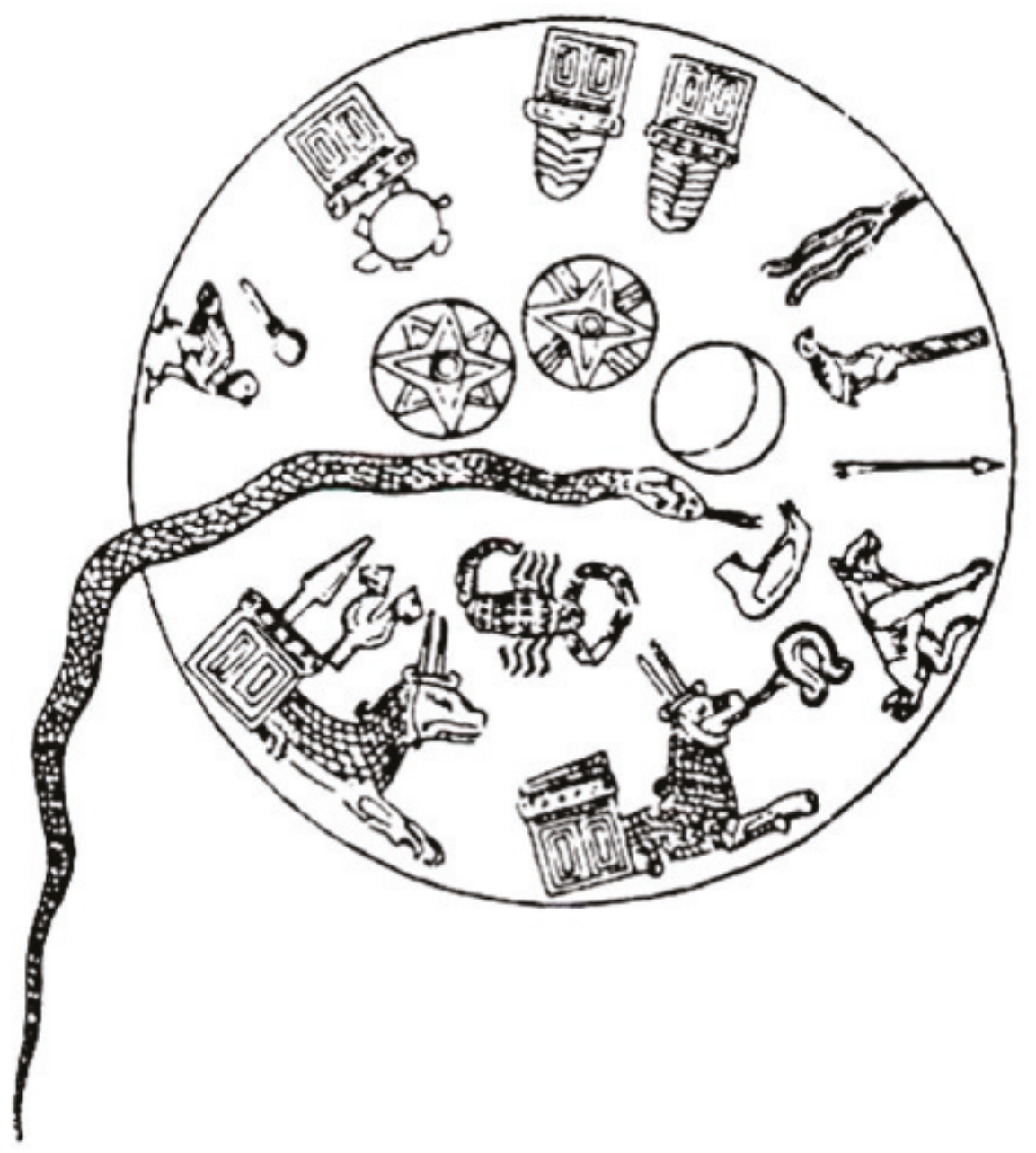

Figure 16. Babylonian kudurru-relief (11th century BCE), depicting the lunar halo: crescent enclosed within a sphere (Seidl 1989: Figure 13).

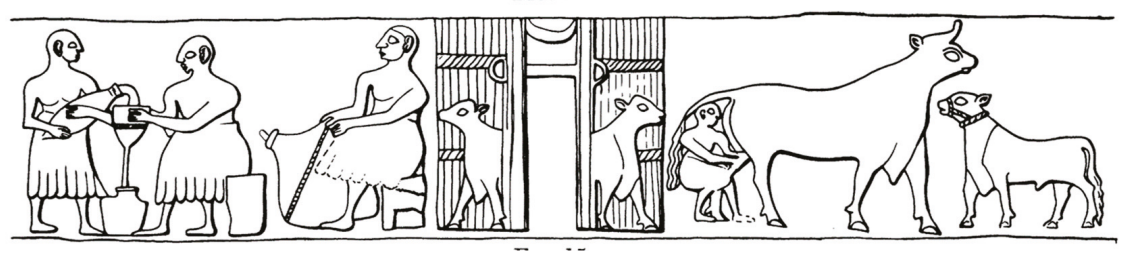

(a) 


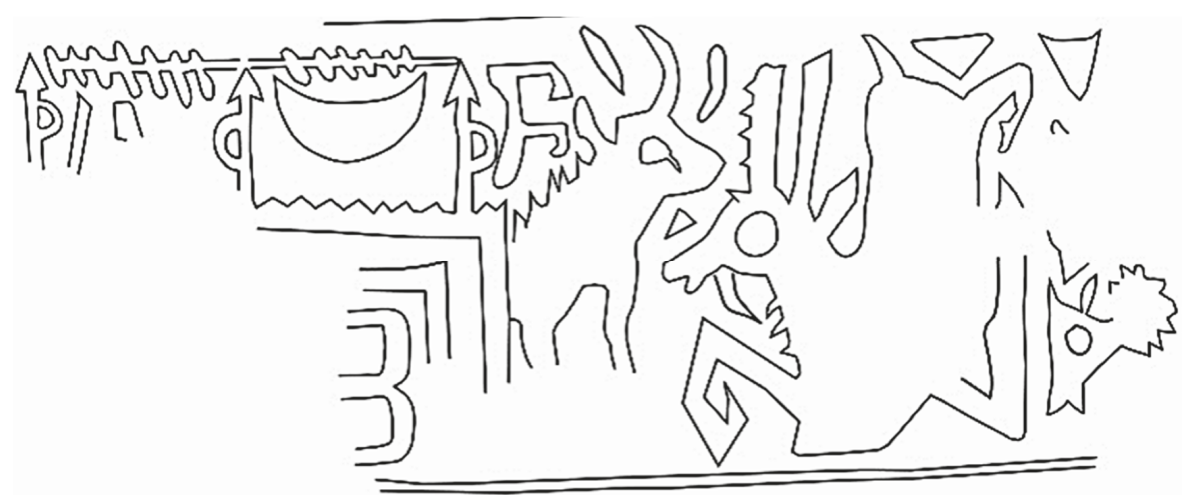

(b)

Figure 17. (a) Ubaid temple inlaid frieze: cow pen with lunar crescent (Delougaz 1968: Figure 15). (b) Seal impression showing cow pen with lunar crescent from Konar Sandal (Pittman 2012: Figure 5b).

The Sumerian goddess responsible for both human and animal fertility was Nintur, literally "mistress birth hut". The element TUR in her name was written with the sign TUR5, TU(D), which seems to have been originally the "birth hut" of the cow pens and sheepfolds, picturing a hut with a reed bundle on top (Figure 18), where cows were taken when they were ready to calve. Metaphorically, it designated the human womb, Sumerian ŠÀ.TÙR, "inside the cow-pen", Akkadian šassuru, signifying the inner, sheltered place in the woman's body, from which the baby emerges (Jacobsen 1976, pp. 107, 250 n. 130; Stol 2000, p. 75; Steinert 2017, pp. 205-6), as well as the birth goddesses' name, the personified womb (CAD Š: 146, šassuru Ac). This explains the meaning of the sign TUR5, TU(D) "to give birth", Akkadian (w)alädu. The birth goddess was also named bèlet rême "lady of the womb" and her attribute was the omega-shaped sign, interpreted after Egyptian parallels as a representation of a cow's uterus (Frankfort 1944). The omega sign was also associated with the moon as evidenced by a Middle Assyrian seal found at Samsat, depicting the moon god in a boat, holding a crescent standard and an omega symbol, connecting him with conception and childbirth (Collon 1992, p. 25) (Figure 19). ${ }^{19}$

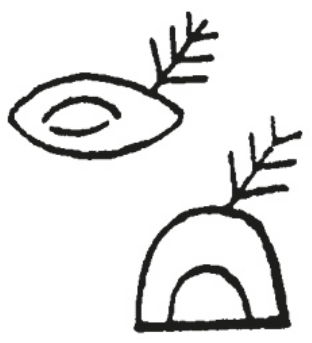

Figure 18. Archaic sign TUR5.

19 The configuration of the crescent with the omega symbol has its antecedents in the art of the Middle Bronze Age in Babylonia and Syria (Keel 1989): Figures 34-36. Ulrike Steinert concludes that the omega symbol could stand for the womb and birth, a sign for divine mercy and good fortune, as well as an apotropaic sign (Steinert 2017, pp. 206-23). 


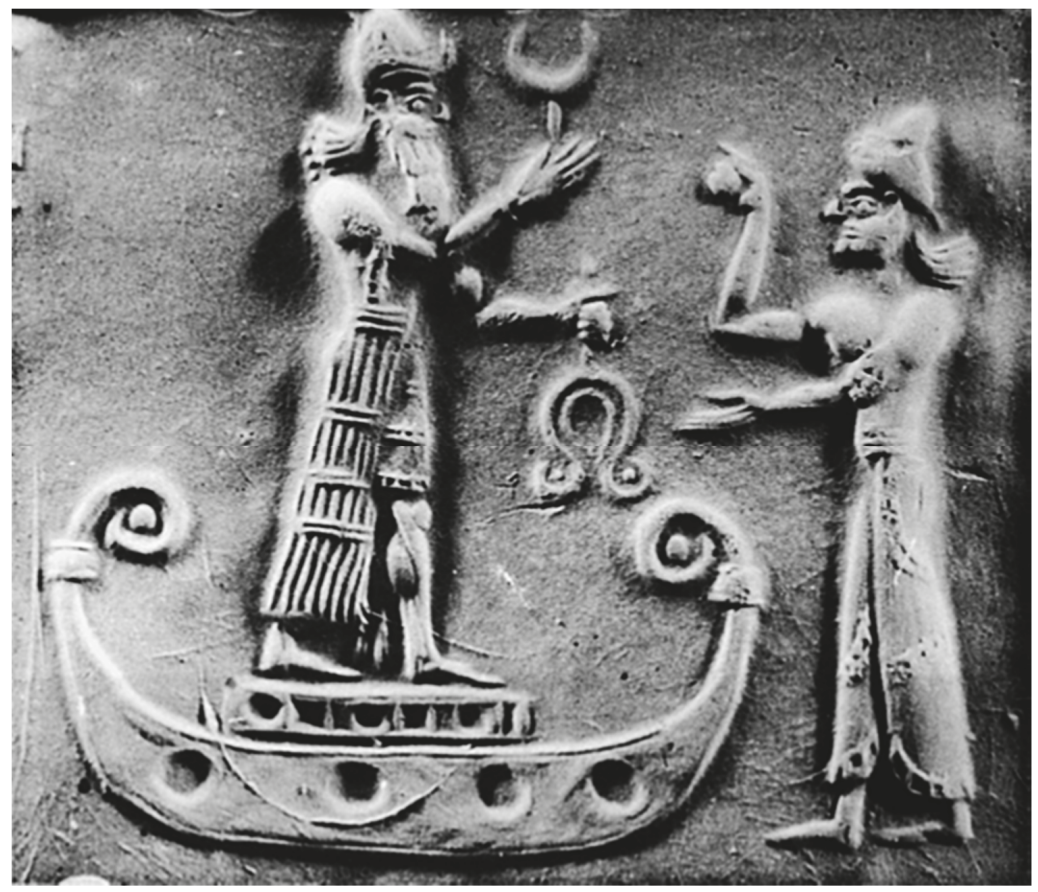

Figure 19. Seal from Samsat: Moon god in a boat, holding crescent and omega signs (Özgüç 1987, p. 436, no. 13).

Calving became a metaphor for human delivery. The incantation "A Cow of Sin", which goes back to the Ur III period, was recited for the woman in travail. It relates that moon god Sin lusted for a cow, mounted her and impregnated her. When the cow was due to give birth, labor pangs gripped her and became too exhausted and unable to deliver the calf until the moon god sent two spirits to assist her and she finally gave birth. The supplication is that like the cow, the woman in labor should give birth easily. Niek Veldhuis drew attention to the word-play in the incantation, littu "cow" a pun for ālittu "childbearing woman", and arhu "cow" placed in chiastic position to the homonym arhu "month" (Veldhuis 1991, pp. 22, 37, 49). Birth incantations of the Cow of Sin, or incantations containing references to cows and cattle pens used during childbirth to accelerate the delivery and protect the newborn child, are attested in the second millennium BCE, not only in Mesopotamia but also in Ugarit and Anatolia (Couto-Ferreira 2014, p. 296). The reference to the cow must reflect observations of calving, which has the potential of being very exhausting and strenuous for the cow, and it is possible that the cow gives up on the delivery. Soon after the calf is born, it is up and nurses. An Akkadian seal found, at Tell Brak, graphically picturing the stages of calving and nursing could easily have served as a prophylactic amulet for childbirth (Figure 20). The image of the cow-sucklingcalf became a metaphor for motherly love and care of which an Egyptian tableau on the sarcophagus of queen Kawit (c. 2051-2030) from Deir el-Bahri is a visual manifestation. In this milking scene, the cow sheds a tear in distress, because she cannot suckle the newborn calf, tied to her left front leg, while a herdsman milks her for his own purposes (Keel 1980, pp. 48-49, Figure 6). From the New Kingdom on, the Egyptian expression "to feel compassion, to love" 3mś was written with the cowsuckling-calf signifier (Keel 1980, pp. 82, 84, Figure 46), a "mute" hieroglyph that provided additional information about the word (Goldwasser and Grinevald 2012, p. 17), namely the phenomenon of the cow's feelings for her calf as a graphic icon for love. Telling is the passage in the Baal myth, where the loving virgin Anat ( $r h m$ ' $n t$ ) longing for Baal is described in terms of a cow's love for calf or a ewe's love for her lamb (Smith 1997, p. 155). The design of an Old Babylonian seal picturing the storm god on his lion dragon, brandishing the lightning fork, together with the cow-suckling-calf alludes 
to the god's dispensing rains, thus assuring the fertility of the land, as well as the procreation of animals and humans alike (Figure 21).

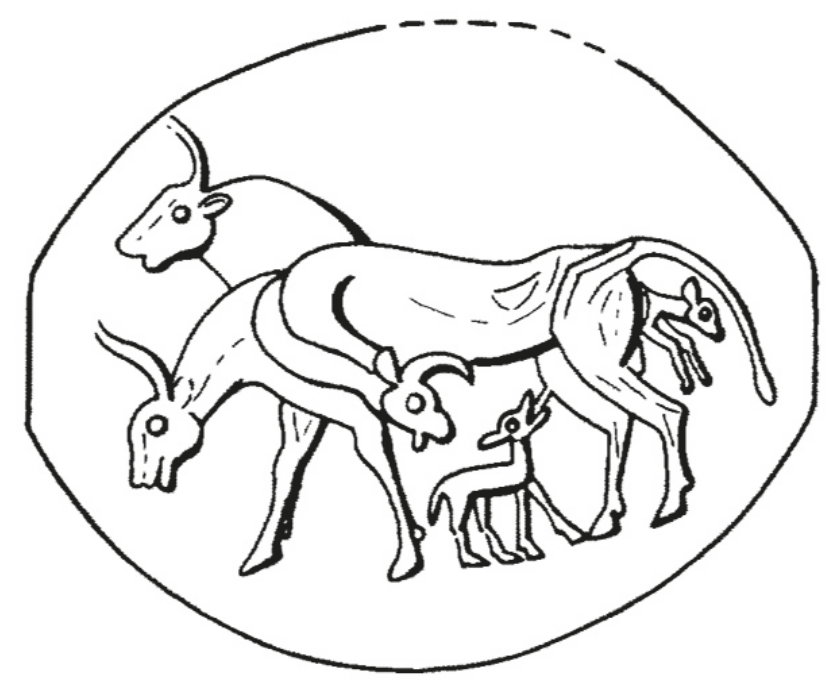

Figure 20. Akkadian stamp seal from Tell Brak, depicting the calving process (Delougaz 1968: Figure 18).

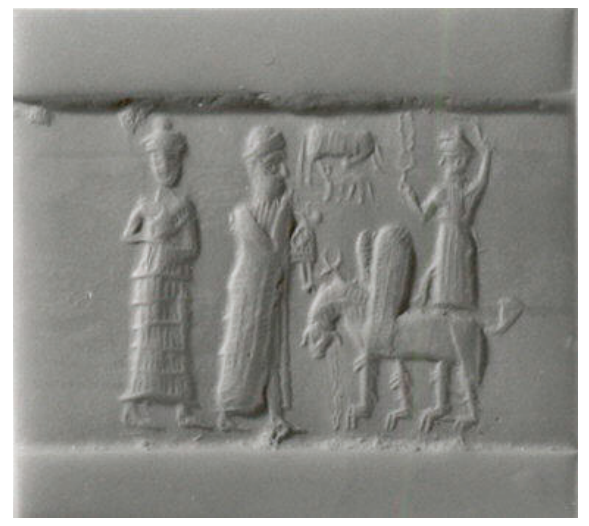

Figure 21. Old Babylonian cylinder seal with storm god on a lion dragon holding a forked lightning and a cow-suckling-calf. CC Metropolitan Museum of Art CS1987.96.6.

\section{The Tell el-Far'ah Shrine Model: Meaning and Conclusions}

What insights may be gained from the above discussion on the composite imagery and related concepts integrated in the shrine model from Tell el-Far'ah, biblical Tirzah? How was this visual makeup possibly perceived in its time and how may the life of this artefact be evaluated?

The owner of the model may have ordered for himself/herself a model with crescent, rain drops and trees, or perhaps he or she acquired a ready-made artefact with for its imagery at the potter's workshop. It is doubtful that the owner was aware of the laden multivalence of the images. However, he or she was aware of the numinous strength of these emblems. The owner perceived the images as ambiguous. By ambiguity, I follow Robert Koehl's definition, namely that ambiguity is something that is "capable of being understood in more than one way, something that covers a wider range of 
human experience, expression and behavior" (Koehl 2016, p. 469). Thus, the believer may have associated the horned moon not only with the moon god but also with the storm god, generator of rain clouds. The visual amalgamation of moon and storm is known from the first millennium imagery, perhaps a lunar storm god, as represented by reliefs from Malatya, Carchemish and the 9th8th century BCE Aramean stele from Bethsaida (Bernett and Keel 1998, pp. 87-92; Ornan 2001). The clay model of sacred architecture, a cheap object for humble piety, kindled the devotion of the person who possessed it, who attributed divine power and efficacy derived from the deity to the replica. For the believer, the model functioned as a means to call upon the deity in supplication. The emblems were a visual manifestation of the natural cycles and seasons (moon), and carried the promise of blessing, correlating the various cycles of agriculture (rain, and tree) and animal husbandry, as well as the fruit of the womb and a wish for a speedy parturition.

Shrine models were part of the domestic cult in Israel. Domestic cult was practiced in the individual's home, and in larger households, where communal feasting took place. Building CP at Tel Rehov (stratum IV, 9th century BCE) with its halls of benches and cult objects, cooking facilities and serving vessels, dubbed "Elisha's House" after the name Elisha inscribed on a sherd (partly reconstructed) found in one of its chambers, may have hosted such cultic activities (Mazar 2016, p. 35e). Amihai Mazar cautiously suggested a connection between the inscription and the biblical figure of Elisha, a "Man of God", a mediator, charmer, miracle worker and healer, speculating whether Building CP could have been the place where such a person may have been approached while conducting rituals and public meals (Mazar 2015, pp. 43-45). The Bible tells us that Elisha held new moon and Sabbath celebrations at his home (2 Kings 4: 23). In view of the finds from Tel Rehov, I suggest that the Tell el-Far'ah shrine model may have served on such rituals celebrated in the Northern Kingdom of Israel. Being portable, shrine models could be used anywhere to invoke the deity.

Conflicts of Interest: The author declares no conflict of interest.

\section{References}

Amiet, Pierre. 1960. Le temple ailé. Revue d'Assyriologie 54: 1-10.

Attinger, Pascal. 1993. Eléments de linguistique sumérienne. La Construction de du11/eldi "dire". OBO Sonderband. Fribourg: Editions universitaire; Göttingen: Vandenhoeck \& Ruprecht.

Bartelmus, Rüdiger. 2001. Šāmajim-Himmel. Semantische unde traditionsgeschichtliche Aspekte. In Das Biblische Weltbild und Seine Altorientalischen Kontexte. Forschungen zum Alten Testament 32. Edited by Bernd Janowski and Beate Ego. Tübingen: Mohr Siebeck, pp. 87-124.

Bauer, Josef, Robert K. Englund, and Manfred Krebernik. 1998. Mesopotamien-Späturuk Zeit und Frühdynastische Zeit Annährungen 1. OBO 160/1. Edited by Pascal Attinger and Markus Wäfler. Freiburg: Universitätsverlag; Göttingen: Vandenhoeck \& Ruprecht.

Beck, Pirhiya. 2002. Imagery and Representation. Studies in the Art and Iconography of Ancient Palestine: Collected Essays. Edited by Nadav Na'aman, Uza Zevulun and Irit Ziffer. Journal of the Institute of Archaeology of Tel Aviv University Occasional Publications 3. Tel Aviv: Emery and Claire Yass Publications in Archaeology.

Berkheij-Dol, J. 2012. Sacred or Prophane? Identifying Cultic Places in the Early Iron Age Southern Levant. A Study on the Pillared Courtyard-Building of Tel Kinrot and Its Shrine Model. Ph.D. dissertation, Protestant Theological University Kampen, Kampen, The Netherlands.

Bernett, Monika, and Othmar Keel. 1998. Mond, Stier und Kult am Stadtor. OBO 161. Freiburg: Universitäverlag; Göttingen: Vandenhoeck \& Ruprecht.

Beyer, Dominique. 2001. Emar IV Les Sceaux: Mission archéologique de Meskéné-Emar Recherces au pays d'Aštata (OBO SA 20). Fribourg: Editions Universitaires; Göttingen: Vandenhoeck \& Ruprecht.

Black, Jeremy, and Anthony Green. 1992. Gods, Demons and Symbols of Ancient Mesopotamia. London: British Museum Press.

Boehmer, Rainer Michael. 1965. Die Entwicklung der Glyptik während der Akkad-Zeit. Untersuchungen zur Assyriologie und Vorderasiatischen Archäologie 4. Berlin: der Gruyter \& Co.

Brunner-Traut, Emma. 1970. Das Muttermilchkrüglein: Ammen mit Stillumhang und Mondamulett. WdO 5: 145-64. 
Chambon, Alain. 1984. Tell el-Far'ah I: L'âge du Fer. "Mémoire" nº 31. Paris: Éditions recherché sur les Civilisations.

Collon, Dominique. 1975. The Seal Impressions from Tell Atchana (Alalakh). AOAT 27. Neukirchen-Vluyn: Neukirchner Verlag and Verlag Butzon \& Bercker Kevelaer.

Collon, Dominique. 1987. First Impressions. Cylinder Seals in the Ancient Near East. London: British Museum.

Collon, Dominique. 1992. The Near Eastern Moon God. In Natural Phenomena. Their Meaning, Depiction and Description in the Ancient Near East. Koninklijke Nederlandse Akademie van Wetenschappen Verhandelingen, Afd. Letterkunde, Nieuwe Reeks, deel 152. Edited by Diederik J. W. Meijer. Amsterdam, Oxford and New York: Royal Netherlands Academy of Arts and Sciences, pp. 19-37.

Cook, Edward M. 2015. Dictionary of Qumran Aramaic. Winona Lake: Eisenbrauns.

Couto-Ferreira, Maria Erica. 2014. She Will Give Birth Easily: Therapeutic Approaches to Chilbirth in 1st Millennium BCE Cuneiform Sources. Dynamics 34: 289-315.

Dalley, Stephanie, and Beatrice Teissier. 1992. Tablets from the Vicinity of Emar and Elsewhere. Iraq 54: 83-111.

Dasen, Veronique. 2003. Les amulettes d'enfants dans le monde gréco-romain. Latomus 62: 275-89.

Daviau, P. M. Michele. 2008. Ceramic Architectural Models from Transjordan and the Syrian Tradition. In Proceedings of the 4th ICAANE, Berlin 2004. Edited by Hartmut Kühne, Rainer Maria Czichon and Florian Janoscha Kreppner. Wiesbaden: Harrassowitz, pp. 294-308.

Del Olmo Lete, Gregorio, and Joaquín Sanmartín. 2003. A Dictionary of the Ugaritic Language. Translated by W. G. E. Watson. Leiden and Boston: Brill.

Delougaz, Pierre. 1968. Animals Emerging from a Hut. JNES 27: 184-97.

Dever, William G. 2016. Archaeology and Ancient Israelite Iconography: Did Yahweh Have a Face? In Proceedings of the 2nd ICAANE Copenhagen 2000. Edited by Ingolf Thuesen. Bologna and Winona Lake: Eisenbrauns, pp. 191-201.

Donner, Herbert, and Wolfgang Röllig. 2002. Kanaanäische und Aramäische Inschriften 1. 5., erweiterte und überarbeitete Auflage. Wiesbaden: Harrassowitz.

Erbele, Dorothea. 1999. Gender Trouble in the Old Testament. Three Models of the Relation between Sex and Gender. SJOT 13: 131-41.

Fales, Mario, and Roswitha Del Fabbro. 2017. Mankind and the Gods in Mesopotamia. In Signs before the Alphabet. Journey to Mesopotamia at the Origins of Writing. Edited by Adriano Favaro. Exhibition Catalogue, Palazzo Lorendan, Venice. Venice: Giunti Editore, pp. 141-87.

Fleming, Daniel E. 2000. Time at Emar. The Cultic Calendar and the Rituals from the Diviner's House. Mesopotamian Civilizations 11. Winona Lake: Eisenbrauns.

Frankfort, Henri. 1944. A Note on the Lady of Birth. JNES 3: 198-200.

Garfinkel, Yosef. 2018. Chasing Away Lions and Weaving: The Longue Durée of Talmudic Gender Icons. In Sources and Interpretations in Ancient Judaism. Studies for Tal Ilan at Sixty. Edited by Meron Piotrowski, Geoffrey Herman and Saskia Dönitz. Leiden and Boston: Brill, pp. 11-31.

Golani, Amir. 2013. Jewelry from the Iron Age II Levant. OBO SA 34. Fribourg: Academic Press; Göttingen: Vandenhoeck \& Ruprecht.

Goldwasser, Orly, and Colette Grinevald. 2012. What Are "Deteminatives" Good For? In Lexical Semantics in Ancient Egyptian. Edited by Eitan Grossman, Stéphane Polis and Jean Winand. Lingua Aegyptia Studia Monographica 9. Hamburg: Wiedmayer, pp. 17-53.

Hijara, Ismail, R. N. I. B. Hubbard, and J. P. N. Watson. 1980. Arpachiyah, 1976. Iraq 42: 131-54.

Horowitz, Wayne. 2012. Sunday in Mesopotamia. In Living the Lunar Calendar. Edited by Jonathan Ben-Dov, Wayne Horowitz and John M. Steele. Oxford: Oxbow, pp. 9-18.

Hunger, Hermann. 2009. Schaltmonat. Reallexikon der Assyriologie 12: 130-32.

Ilan, David. 2016. The Crescent-Lunate Motif in the Jewelry of the Bronze and Iron Ages Ancient Near East. In Proceedings, 9th ICAANE I, Basel 2014. Edited by Rolf L. Stucky, Oskar Kaelin and Hans-Peter Mathys. Wiesbaden: Harrassowitz, pp. 137-50.

Jacobsen, Thorkild. 1976. The Treasures of Darkness. A History of Mesopotamian Religion. New Haven and London: Yale University Press.

Jacobsen, Thorkild. 1987. The Harps that Once ... Sumerian Poetry in Translation. New Haven and London: Yale University Press.

Jasmin, Michaël. 2013. Tell el-Far'ah (N). In The Oxford Encyclopedia of the Bible and Archaeology. Edited by Daniel M. Master. Oxford: Oxford University Press, pp. 393-400. 
Jastrow, Marcus. 1903. A Dictionary of the Targumim, the Talmud Babli and Yerushalmi, and the Midrashic Literature I. London: Luzac \& Co.; New York: G.P. Putnam's Sons.

Jenni, Ernst, and Claus Westermann. 1976. Theologisches Handwörterbuch zum Alten Testament II. Müncehn: Kaisreverlag; Zürich: Theologischer Verlag.

Johnstone, Thomas Muir. 1977. Harsūsi Lexicon. London: Oxford University Press.

Kantor, Helene J., and Pinhas Delougaz. 1996. Choga Mish I The First Five Seasons of Excavations 1961-1971 Part 2: Plates. Oriental Institute Publications 101. Edited by Abbas Alizadeh. Chicago: The oriental Institute of the University of Chicago.

Katz, Hava. 2016. Portable Shrine Models. Ancient Architectural Clay Models from the Levant. BAR International Series 2791. Oxford: British Archaeological Reports Ltd.

Keel, Othmar. 1980. Das Böcklein in der Milch seiner Mutter und Verwandtes. OBO 33. Freiburg: Universitätsverlag; Göttingen: Vandenhoeck \& Ruprecht.

Keel, Othmar. 1989. Die $\Omega$-Gruppe. Ein mittelbronzezeitlicher Stempelsiegel-Typ mit erhabenem Relief aus Anatolien, Nordsyrien und Palästina. In Studien zu den Stempelsiegeln aus Palästina/Israel II. OBO 88. Edited by Othmar Keel, Hildi Keel-Leu and Silvia Schroer. Freiburg: Universitätsverlag; Göttingen: Vandenhoeck \& Ruprecht, pp. 39-87.

Keel, Othmar. 2010. Corpus der Stempelsiegel-Amulette aus Palästina/Israel von den Anfängen bis zur Perserzeit III: Von Tell el-Far'ah Nord bus Tell el-Fir. OBO SA 31. Fribourg: Academic Press; Göttingen: Vandenhoeck \& Ruprecht.

Keel, Othmar, and Chr Uehlinger. 1992. Göttinen, Götter und Gottessymbole. Neue Erkentnisse zur Religionsgeschichte Kanaans und Israels aufgrund bislang unerschlossener ikonographischer Quellen. Freiburg, Basel and Wien: Herder.

Kleiman, Assaf. 2018. Comments on the Archaeology and History of Tell el-Far'ah North (Biblical Tirzah) in the Iron Age IIA. Semitica 60: 85-104.

Kletter, Raz. 2015. Clay Shrine Model. In Yavneh II: The 'Temple Hill' Repository Pit. OBO SA 36. Edited by Raz Kletter, Irit Ziffer and Wolfgang Zwickel. Fribourg: Academic Press; Göttingen: Vandenhoeck \& Ruprecht.

Koehl, Robert B. 2016. The Ambiguity of the Minoan Mind. In Metaphysis. Ritual, Myth and Symbolism in the Aegean Bronze Age. Proceedings of the 15th International Aegean Conference, Vienna, 2014. Aegeum 39. Edited by Eva Alram-Stern, Fritz Blakolmer, Sigrid Deger-Jalkotzy, Robert Laffineur and Jörg Weilhartner. Leuven and Liege: Peeters, pp. 469-78.

Krebernik, Manfred. 1995. Mondgott. A. Reallexikon der Assyriologie 8: 360-69.

Lambert, Wilfred G. 1985. Trees, Snakes and Gods in Ancient Syria and Anatolia. BSOAS 48: 435-51.

Lambert, Wilfred G. 1987. Devotion: The Language of Religion and Love. In Figurative Language in the Ancient Near East. Edited by Murray Mindlin, Markham J. Geller and John E. Wansbrough. London: pp. 25-39.

Leinwand, Nancy. 1992. Regional Characteristics in the Styles and Iconography of the Seal Impressions of Level II at Kültepe. JANES 21: 141-72.

Leslau, Wolf. 1991. Comparative Dictionary of Ge'ez. Classical Ethiopic. Wiesbaden: Harrassowitz.

Levine, Baruch A. 2002. 'Seed' versus 'Womb': Expressions of Male Dominance in Biblical Israel. In Sex and Gender in the Ancient Near East. Proceedings of the XLVIIe Rencontre Assyriologique Internationale. Edited by Simo Parpola and Robert M. Whiting. Helsinki: Helsinki Institue for Asian and African Studies University of Helsinki, pp. 337-43.

Maier, Christl. 2014. Körperlich und emotionale Aspekte JHWHs aus der Genderperspektive. In Göttliche Körper-Göttliche Gefühle: Was leisten anthropomorphe und anthrpopathische Götterkonzepte im Alten Orient und im Alten Testament. OBO 270. Edited by Andreas Wagner. Fribourg: Academic Press; Göttingen: Vandenhoeck \& Ruprecht, pp. 171-89.

Matthews, Donald M. 1990. Principles of Composition in Near Eastern Glyptic of the Later Second Millennium B.C. OBO SA 8. Freiburg: Universitätsverlag; Göttingen: Vandenhoeck \& Ruprecht.

Mayer-Opificius, Ruth. 1984. Die geflügelte Sonne. Himmels- und Regendarstellungen im alten Vorderasien. UF 16: 189-236.

Mazar, Amihai. 2015. Religious Practices and Cult Objects during the Iron Age II at Tell Rehov and their Implications regarding the religion in Northern Israel. HeBAI 4: 25-55.

Mazar, Amihai. 2016. Discoveries from the early Monarchic period at Tel Rehov. In It Is the Land of Honey. Discoveries from Tel Rehov, the Early Days of the Israelite Monarchy. Exhibition Catalogue. Edited by Irit Ziffer. Tel Aviv: MUSA, Eretz Israel Museum Tel Aviv, pp. 9e-68e. 
Muller, Béatrice. 2002. Les "maquettes architecturales" du Proche-Orinet ancien. Mésopotamie, Syrie, Palestine du III au millieu du Ier millénaire avant J.-C. I. Bibliothèque Archaeologique et Historique 160. Beyrouth: Institut Français d'archéologie du Proche-Orient.

Na'aman, Nadav. 2007. Royal Inscriptions versus Prophetic Story: Mesha's Rebellion according to Biblical and Moabite Historiography. In Ahab Agonistes. The Rise and Fall of the Omri Dynasty. Library of the Hebrew Bible/Old Testament Studies 421. Edited by Lester L. Grabbe. London and New York: T \& T Clark, pp. 14583.

Ornan, Tallay. 2001. The Bull and its Two Masters: Moon and Storm Deities in Relation to the Bull in the Ancient Near East. IEJ 51: 1-26.

Ornan, Tallay. 2007. Labor pangs: The Revadim plaque type. In Images as Sources. Studies on Ancient Near Eastern Artefacts and the Bible Inspired by the Work of Othmar Keel. OBO Special Volume. Edited by Susanne Bickel, Silvia Schroer, René Schurte and Christoph Uehlinger. Fribourg: Academic Press; Göttingen: Vandenhoeck \& Ruprecht, pp. 215-35.

Ornan, Tallay, Shlomit Weksler-Bdolah, and Benjamin Sass. 2017. A Governor of the City Seal Impression from the Western Wall Plaza Excavations in Jerusalem. Qadmoniot 50: 100-3.

Otto, Adelheid. 2016. Much more than just a Decorative Element: The Guilloche as Symbol of Fertility. In Mille et une Empreints. Un Alsacien en Orient. Mélanges en l'honneur du 65e anniversaire de Dominique Beyer. Subartu XXXVI. Edited by Julie Patrier, Philippe H. Quenet and Pascal Butterlin. Tournhout: Brepols, pp. 379-93.

Özgüç, Nimet. 1965. The Anatolian Group of Cylinder Seal Impressions from Kültepe. Ankara: Türk Tarih Kurumu.

Özgüç, Nimet. 1987. Samsat Mühürleri. Belleten 51: 429-39.

Pardee, Dennis. 2002. Ritual and Cult at Ugarit. Writings from the Ancient World 10. Atlanta: Society of Biblical Literature.

Pittman, Holly. 2012. Glyptic Art of Konar Sandal South, Observations on the Relative and Absolute Chronology in the Third Millennium BCE. In Nāmvarnāmeh. Papers in Honor of Massoud Azarnoush. Edited by Hamid Fahimi and Karim Alizadeh. Tehran: Iran Negar, pp. 80-93.

Rendsburg, Gary A. 1983. Hebrew RḤM = "Rain". VT XXXIII: 357-62.

Rendsburg, Gary A. 2009. Israelian Hebrew Features in Deuteronomy 33. In Mishneh Todah. Studies in Deuteronomy and Its Cultural Environment in Honor of Jeffrey H. Tigay. Edited by Nili Sacher Fox, David A. Glatt-Gilad and Michael J. Williams. Winona Lake: Eisenbrauns, pp. 167-83.

Rochberg, Francesca. 1996. Personifications and Metaphors in Babylonian Celestial Omina. JAOS 116: 475-85.

Rochberg, Francesca. 2010a. In the Path of the Moon. Babylonian Celestial Divination and Its Legacy. Studies in Ancient Magic and Divination 6. Leiden and Boston: Brill.

Rochberg, Francesca. 2010b. Sheep and Cattle, Cows and Calves: The Sumero-Akkadian Astral Gods as Livestock. In Opening the Tablet Box. Near Eastern Studies in Honor of Benjamin R. Foster. Culture and History in the Ancient Near East 42. Edited by Sarah Melville and Alice Slotsky. Leiden: Brill, pp. 347-459.

Rochberg, Francesca. 2016. Before Nature. Cuneiform Knowledge and the History of Science. Chicago and London: The University of Chicago Press.

Schroer, Silvia. 2018. Die Ikonographie Palästina/Israels und der Alte Orient 4: Die Eisenzeit bis zum begin der achäminidischen Herrschaft. Basel: Schwab.

Schwemer, Daniel. 2006. Šāla. A. Philologisch. Reallexikon der Assyriologie 11: 565-67.

Schwemer, Daniel. 2008. The Storm Gods of the Ancient Near East: Summary, Synthesis, Recent Studies. Part 1. JANES 7: 121-68.

Seidl, Ursula. 1989. Die altbabylonische Kudurru-Reliefs. Symbole Mesopotamischer Gottheiten. OBO 87. Freiburg: Universitätsverlag; Göttingen: Vandenhoeck \& Ruprecht.

Sharvit, Shimon. 1972. New Light on Ehad Mi Yodea. Bar-Ilan Journal 9: 475-82.

Sjöberg, Åke W., and Eugen S. J. Bergamann. 1969. The Sumerian Temple Hymns. Locust Valley: J. J. Augustin.

Smith, Mark S. 1997. The Baal Cycle. In Ugaritic Narrative Poetry. SBL Writings from the Ancient World 9. Edited by Simon B. Parker. Atlanta: Scholars Press, pp. 61-180.

Smith, Mark. 2006. The Rituals and Myths of the Feast of the Goodly Gods of KTU/CAT 1.23. SBL Resources for Biblical Studies 51. Atlanta: Society of Biblical Literature.

Sokoloff, Michael. 1990. A Dictionary of Jewish Palestinian Aramaic in the Byzantine Period. Dictionary of the Talmud, Midrash and Targum II. Ramat-Gan: Bar-Ilan University Press.

Sokoloff, Michael. 2009. A Syriac Lexicon. Translation from the Latin, Correction, Expansion and Update of C. Brockelmann's Lexicon Syriacum. Winona Lake: Eisenbrauns; Piscataway: Gorgias. 
Steele, John M. 2011. Making Sense of Time: Observational and Theoretical Calendars. In The Oxford Handbook of Cuneiform Culture. Edited by Karen Radner and Eleanor Robson. Oxford: Oxford University Press, pp. 47085.

Stein, Diana L. 1988. Mythologische Inhalte der Nuzi-Glyptik. In Hurriter und Hurritisch. Edited by Volkert Haas. Konstanzer Altorientalische Symposien II. Konstanz: Universitäts Verlag Konstanz GmBH, pp. 173-209.

Steinert, Ulrike. 2017. Cows, Women and Wombs. Interrelations Between Text and Images from the Ancient Near East. In From the Four Corners of the Earth. Studies in the Iconography and Cultures of the Ancient Near East in Honour of F.A.M. Wiggermann. AOAT 441. Edited by David Kertai and Olivier Nieuwenhuyse. Münster: Ugarit Verlag, pp. 205-58.

Steinkeller, Piotr. 2016. Nanna/Suen, the Shining Bowl. In Libiamo ne' lieti calici. Ancient Near Eastern Studies Presented to Lucio Milano on the Occasion of his 65th Birthday by Pupils, Colleagues and Friends. AOAT 436. Edited by Paola Corò, Elena Devecchi, Nicla De Zorzi and Massimo Maiocchi. Münster: Ugarit, pp. 61525.

Stol, Marten. 1992. The Moon as Seen by the Babylonians. In Natural Phenomena. Their Meaning, Depiction and Description in the Ancient Near East. Koninklijke Nederlandse Akademie van Wetenschappen Verhandelingen, Afd. Letterkunde, Nieuwe Reeks, deel 152. Edited by Diederik Jacobus Willem Meijer. Amsterdam, Oxford and New York: Royal Netherlands Academy of Arts and Sciences, pp. 245-75.

Stol, Marten. 2000. Birth in Babylonia and the Bible. Its Mediterranean Setting. Cuneiform Monographs 14. Groningen: Styx.

Suter, Claudia E. 2000. Gudea's Temple Building. The Representation of an Early Mesopotamian Ruler in Text and Image. Cuneiform Monographs 17. Groningen: Styx.

Tal, Abraham. 2000. A Dictionary of Samaritan Aramaic. Leiden, Boston and Köln: Brill.

van der Toorn, Karel. 1999. Goddesses in Early Israelite Religion. In Ancient Goddesses: The Myths and the Evidence. Edited by Lucy Goodison and Christine Morris. London: British Museum Press, pp. 83-97.

van der Toorn, Karel. 2002. The Use of Images in Israel and the Ancient Near East. In Sacred Time, Sacred Place. Archaeology and the Religion of Israel. Edited by Barry M. Gittlen. Winona Lake: Eisenbrauns, pp. 45-62.

van Loon, Maurits. 1990. The Naked Rain Goddess. In Resurrecting the Past. A Joint Tribute to Adnan Bounni. Uitgaven van het Nederlands Historisch-Archaeologisch Instituut te Istanbul 67. Edited by P. Matthiae, M. van Loon and H. Weiss. Istanbul: Nederlands Historisch-Archaeologisch Instituut te Istanbul, pp. 363-79.

van Loon, Maurits. 1992. The Rainbow in Ancient Asian Iconography. In Natural Phenomena. Their Meaning, Depiction and Description in the Ancient Near East. Koninklijke Nederlandse Akademie van Wetenschappen Verhandelingen, Afd. Letterkunde, Nieuwe Reeks, deel 152. Edited by Diederik Jacobus Willem Meijer. Amsterdam, Oxford, New York and Tokyo: Royal Netherlands Academy of Arts and Sceinces, pp. 149-68. Veldhuis, Niek. 1991. A Cow of Sîn. Library of Oriental Texts 2. Groningen: Styx.

Verderame, Lorenzo. 2014. The Halo of the Moon. In Divination in the Ancient Near East. A Workshop on Divination Conducted During the 54th Rencontre Assyriologique Internationale, Würzburg, 2008. Edited by Jeanette Fincke. Winona Lake: Eisenbrauns, pp. 91-104.

Wehr, Hans. 1980. A Dictionary of Modern Written Arabic. Beirut: Librarie du Liban; London: MacDonald \& Evans Ltd.

Winter, Irene. 1989. The "Hasanlu Gold Bowl": Thirty Years Later. Expedition 31: 87-106.

Woolley, C. Leonard. 1934. Ur Excavations II The Royal Cemetery (Plates). Oxford: The University Press.

Zevit, Ziony. 2001. The Religions of Ancient Israel. A Synthesis of Parallactic Approaches. London and New York: Continuuum.

Ziffer, Irit. 1990. At That Time the Canaanites Were in the Land. Daily Life in Canaan in the Middle Bronze Age 2, 20001550 BCE. Tel Aviv: Eretz Israel Museum.

Ziffer, Irit, and Dina Shalem. 2015. "Receive my breast and suck from it, that you may live." Towards the imagery of two ossuaries from the Chalcolithic Peqi' in Cave. UF 46: 456-88.

(c) 2019 by the authors. Licensee MDPI, Basel, Switzerland. This article is an open access article distributed under the terms and conditions of the Creative Commons Attribution (CC BY) license (http://creativecommons.org/licenses/by/4.0/). 


\title{
Archaeology and Religion in Late Bronze Age Canaan
}

\author{
Aaron Greener \\ W.F. Albright Institute of Archaeological Research in Jerusalem, Salah e-Din St 26, 91190 Jerusalem, Israel; \\ aaron@aiar.org
}

Received: 28 February 2019; Accepted: 2 April 2019; Published: 9 April 2019

\begin{abstract}
Dozens of temples were excavated in the Canaanite city-states of the Late Bronze Age. These temples were the focal points for the Canaanites' cultic activities, mainly sacrifices and ceremonial feasting. Numerous poetic and ritual texts from the contemporary city of Ugarit reveal the rich pantheon of Canaanite gods and goddesses which were worshiped by the Canaanites. Archaeological remains of these rites include burnt animal bones and many other cultic items, such as figurines and votive vessels, which were discovered within the temples and sanctuaries. These demonstrate the diverse and receptive character of the Canaanite religion and ritual practices. It seems that the increased Egyptian presence in Canaan towards the end of the period had an influence on the local belief system and rituals in some areas, a fact which is demonstrated by the syncretic architectural plans of several of the temples, as well as by glyptic and votive items. Late Bronze Age religious and cultic practices have attracted much attention from Biblical scholars and researchers of the religion of Ancient Israel who are searching for the similarities and influences between the Late Bronze Age and the following Iron Age.
\end{abstract}

Keywords: Late Bronze Age; Canaan; religion; cult; temples; Egypt

\section{Introduction}

Numerous excavations and a fairly large number of contemporary written documents give us a good picture of the religious system and cult practices in Canaan ${ }^{1}$ during the Late Bronze Age (ca. 1600-1180 BCE). Most of this period was characterized by an Egyptian dominance and influence over large parts of the Southern Levant, and though not a significant core area, Canaan served as a cultural and commercial crossroads of the region that was essential to Egyptian strategic and economic goals in the area. The study of the extensive Amarna archive discovered in Egypt ${ }^{2}$ teaches us that during the fourteenth century BCE, Canaan was divided into c. 20 major city-states. These city-states were independent territorial units held by a local ruler who inherited his status from his ancestors and was recognized by the Egyptian authorities, who provided for his protection and well-being. Some have suggested (see below) that the interaction between the Canaanite and Egyptian cultures may have influenced the cult practices in Canaan, especially during the end of the period, when the Egyptians increased their physical presence in the region.

1 The term "Canaan" is a geopolitical entity that includes Israel, Jordan, the West Bank and the Gaza Strip, Lebanon, and southern Syria. It is possible to identify, archaeologically speaking, a second-millennium material culture in this region that has many features in common. The term "Canaanites" does not represent an ethnic entity, but rather a group of people who share a common culture and live within a region that was defined by others as "Canaan". The geographic area studied here is somewhat more restricted than the general Canaanite area described above, and includes sites within the modern state of Israel, as well as in the Palestinian Authority.

2 This archive contained a collection of hundreds of cuneiform tablets that testify to the wide-ranging international commerce and political networks which existed during the period (e.g., Bunimovitz 1995; Moran 1992, p. 124; Finkelstein 1996; Goren et al. 2004). 
The paper will begin by presenting a background on Canaanite religion and cultic activities based on texts of the period. Following the textual background, I will move on to describe Late Bronze Age archaeological finds which are related to cult activities-mainly temples and other smaller religious paraphernalia. The paper will end with a short summary of our current understanding pertaining to the Canaanite religion and cult during the Late Bronze Age.

\section{Ugaritic Texts: Religion, Cult Practices, and Rituals}

\subsection{Canaanite Pantheon}

The excavations at Ugarit on the Mediterranean coast of Syria, have revealed a vast metropolis of the Late Bronze Age (e.g., Yon 2006). The destruction of Ugarit in the late thirteenth century BCE resulted in the preservation of an important archive of poetic (mythological and epic) and ritual texts which illuminates many aspects of religion in this Late Bronze Age city (e.g., Hess 2007, p. 97). Although one must be cautious not to equate Ugaritic religion with Canaanite religion, they both shared West Semitic elements of religion, architecture, language, and material culture. Furthermore, the Ugaritic texts contain mythological and cultic information that is closely related to that of Canaan (Hess 2007, p. 95; Alpert-Nakhai 2001, p. 41; Smith 2001, pp. 14-18). It seems that there was a rather broad cultural continuum. ${ }^{3}$

The emphasis in the Ugaritic ritual texts was on the major components of religious rites and particularly on animal sacrifice (see below). Additional texts from thirteenth-century BCE Emar (northern Syria) describe in detail rituals of priestly installation and of festivals celebrated throughout the cultic year. The Canaanite religion was polytheistic. The deities listed below are the major ones mentioned in the Ugaritic and additional local texts, though various others were worshipped alongside them. By one account, there are 240 divine names and epithets found at Ugarit. ${ }^{4}$ It seems that there were tiers of deities: the highest level was occupied by El and his consort Athirat/Ashera; the second level by their children, the divine assembly; the third level by craftsmen and trader deities; and the fourth level by minor deities such as messenger gods.

Nevertheless, it was El, creator of earth and man, who was the chief god, and the begetter of the gods (seventy in number). He bore the title "Father of Years" and is described as being wise and kind, with gray hair. He lived at the source of the rivers amid the springs of the two oceans. Athirat, mother of the gods, was El's consort. Her title was "Lady Athirat of the Sea". She was sometimes called Qds in Ugaritic texts and was depicted in Egypt in the nude with a Hathor wig (similar depictions in Canaan may also represent Athirat). She gave birth to the gods Shachar (dawn) and Shalem (dusk). It seems they both represent Venus, one at dawn and the other at dusk.

Although El was the chief god, Ba'al Hadad (meaning Lord of Thunder) was the most active. He was the "bringer of the rain" and was called "rider of the clouds". He also controlled thunder and lightning. Several of the texts from Ugarit are known as the Ba'al cycle. The first is his conflict with the sea god, Yamm. The second describes the building of his temple or palace. The third and last is his struggle with death (mot), in which he died and then rose again. Some scholars maintain that El and $\mathrm{Ba}^{\prime}$ al were in conflict. However, the evidence that El appointed Ba'al king, and then showed remorse at Ba'al's death and rejoiced at his resurrection, leads to the opposite conclusion, although there were occasional tensions.

The god Dagon (Lord of the grain) also sometimes appears as Ba'al's father. It is possible that El was Ba'al's grandfather and Dagon his father, since he is put between the two in the Ugaritic Pantheon. Dagon is a god of minor importance and appears only in sacrificial lists and not in mythological texts.

3 Similar practices are reflected in the Biblical texts, but given their relatively late date and apologetic nature, specific Biblical passages are unhelpful in elucidating Canaanite cult practices and religion (e.g., Cross 1998 and Smith 2007).

4 The descriptions of the Canaanite deities are summarized from (Day 1992 and Van der Toorn et al. 1999). 
Ba'al's main consort was the goddess Anat, who was devoted to him. She cut up Mot, who killed Ba'al. She also defeated the multi-headed dragon (leviathan). However, the goddess Astarte is also mentioned in Ugarit as Ba'al's consort, although she is less prominent than Anat. Astarte is associated with feline imagery. To make things more complicated, the deities Athirat and Astarte, distinct in some contexts, are sometimes identified with each other.

Although Mot is the primary deity associated with the underworld at Ugarit, there were several other gods connected with the underworld. One was the god Reshef, who was the god of plague and pestilence. He is equated at Ugarit with the plague god Nergal. He is the porter of the sun goddess at the time of her setting. Molech is also an underworld deity, often associated with human sacrifice. The sun was worshipped as a goddess—Sps. She scorched the earth while Ba'al stayed in the underworld. The moon god, Yarikh, does not play a major role in Canaanite mythology, but its name is preserved in places such as Beit Yarikh and Jericho.

\subsection{Cult Practices and Rituals}

The act of slaughter and the sacrifice of live animals lay at the emotional core of many early religions. Ancient sacrifice originated from the need to sanctify the consumption of animal flesh, because the spilling of animal blood was an act of violence that required divine sanction (e.g., Alpert-Nakhai 2001, p. 40). Indeed, examination of the ritual texts from Ugarit demonstrates that overall, sacrifice was the primary ritual in ancient Near East religion and was an essential part of Canaanite worship (see also below). In fact, the principal category of cultic vocabulary was that of sacrifice (Alpert-Nakhai 2001, p. 39), which the Canaanites considered as food for the gods. Royal success required the complicity of the divine, which was asked for and acknowledged through the gesture of offerings. Sacrificial liturgies most often included a list of offerings specifying the divine recipients. Alpert-Nakhai (2001, pp. 42-44) wrote that along with livestock, agricultural products (especially oils, vegetables, and grains) were offered. From the perspective of the royal center, sacrifice was not an act of individual piety, but rather a function of the social group. Kings undertook the expense and the responsibility of sacrifice in order to promote their relationship with their patron gods, and to ensure that their city and its inhabitants were favored. The loss incurred by offering sacrifices was compensated for by the overall gain in societal well-being. Animals were also slaughtered and placed (complete or parts only) within tombs of the period (Lev-Tov and Maher 2001).

Some have argued that the evidence from Ugaritic texts demonstrates that Canaanite culture preserved ideas about personal, moral, and religious guilt for sin. Expiation could be obtained from the divine world through animal sacrifices (Hess 2007, pp. 104-6). Burnt offerings were used to attract the deity to the temple, while the "peace of fellowship" offerings functioned as a gift of greeting that the worshiper presented in the courtyard of the temple. Although not found in Ugarit, evidence of human sacrifice from the later Phoenician world may teach us about such rituals in the Canaanite world as well, especially in connection with the Canaanite god Molech.

Besides sacrifices, prayer was a means to communicate with the gods (e.g., Day 1992). The Canaanites believed in an afterlife and funerary liturgies are known in the mythological texts, with lamentations, rites, and curse formulas for disturbing the dead. The term Rephaim refers to the shades of the dead. Ugaritic kings were thought of as divine after their death and possibly even while they ruled. The Marzeah festival was an assembly comprising members from a higher economic class who celebrated a festival with a banquet (Hess 2007, p. 110-11). These ceremonies had legal sanction; met in cities and villages for drinking; could involve substantial money, including the leasing of houses and vineyards; possessed a defined membership; continued for generations; and often had a patron deity. Other rituals which were practiced by the Canaanites included sacred prostitution and the reading of animal livers-hepatoscopy (e.g., Van der Toorn et al. 1999).

At Ugarit, cultic personnel (including a variety of titled figures such as high priests, priests, and servants) were royal dependents and the needs of the temples were mostly supplied by the royal treasury (Alpert-Nakhai 2001, p. 123). However, it is certainly possible that worship was 
also a localized affair, with open-air sanctuaries or even simple household shrines serving most ordinary people in everyday practice. Anyone could build an altar, plant a sacred tree, erect a stela, or offer sacrifices. The most prominent rituals were simply the frequent presentation of food and drink offerings.

\section{Temples}

The Ugaritic texts mentioned above permit speculation about material remains from sacrificial rites that might be found in the excavation of Canaanite temples. Indeed, in this section, we will turn to evidence presented by archaeological data and investigate the remains of sacred structures and installations, and of cultic paraphernalia (see Figure 1 for a map of the sites mentioned in the text). During this period, cult centers in Canaan flourished and temples and altars were the primary bearer of religious traditions for the various city-states. In fact, Faust (2010, p. 26; and see also Faust 2019 in this issue) wrote that despite the limited archaeological exposure, over the years, more than 20 Late Bronze Age temples have been unearthed in the southern Levant, making it clear that during this period, temples were common and widespread. He argued that there was at least one temple in each settlement (including relatively small settlements), and in some cases, there was more than one such structure at a single site. Furthermore, several temples have been unearthed outside settlements (e.g., the Fosse Temple at Lachish and the 'Amman airport temple [below]), providing additional evidence for the widespread distribution of temples in this era. Faust (2010, p. 27; Faust 2019 in this issue) further suggested that temples were prevalent in rural settings, and there was probably a temple or cultic building in every Canaanite village.

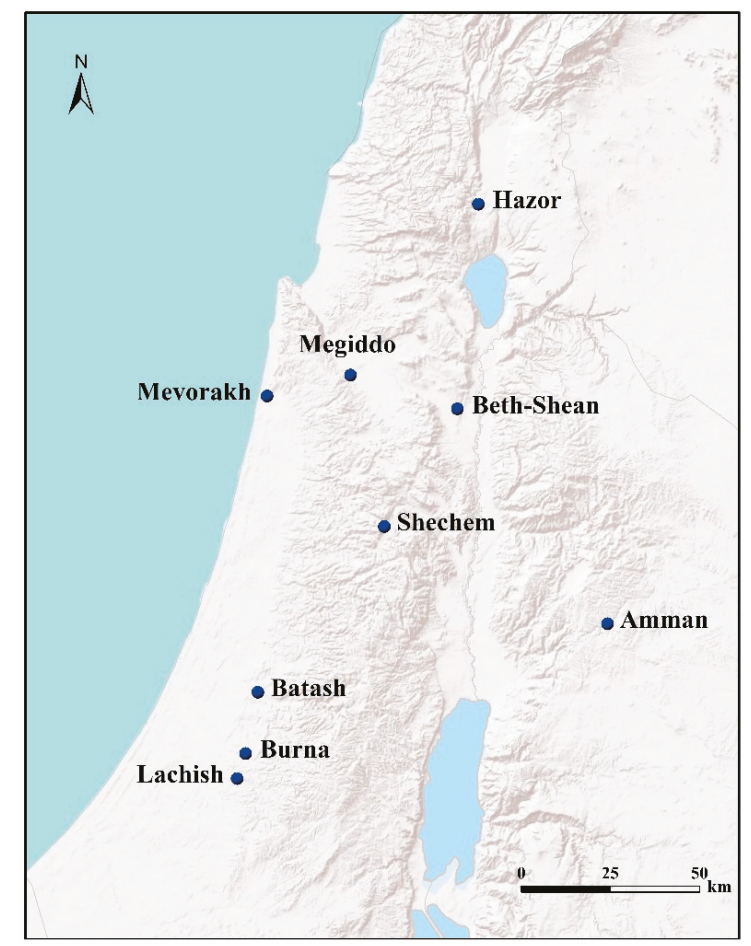

Figure 1. Late Bronze Age sites mentioned in the text (Prepared by H. Cohen-Klonymus). 
Emphasis in the survey and brief discussion below is placed upon sites with representative or particularly significant architectural or artifactual assemblages (for a more thorough survey of the Late Bronze Age temples, see Alpert-Nakhai 2001, pp. 125-52). The examination of the temple's plans reveals a great diversity, making it difficult to establish patterns and clear rules which governed their development during this period (see Figure 2 for several plans of Late Bronze Age temples). However, Mazar (1992b, p. 169) attempted to classify a number of these structures into homogenous categories displaying common characteristics (and see also Bunimovitz 2019, pp. 48-55). Some of the temples are unique in plan, and contemporary parallels cannot be easily pinpointed.

A. Open cult places-A good example was uncovered in Area F at Hazor. This is a paved plaza with a monolithic stone altar with depressions in the upper surface to drain the blood of the sacrificed animals.

B. Monumental symmetrical temples-the quintessential type of Canaanite temple used during the Late Bronze Age was actually a Middle Bronze tradition which continued in use into the Late Bronze Age. Such temples were found at Megiddo (temple 2048), Shechem, and Hazor (Areas $\mathrm{A}$ and $\mathrm{H}$ ), though with differences. Although these temples underwent substantial changes during the course of the Late Bronze Age, their main characteristics remained the same: they were long monumental and symmetrical buildings situated in the center of a sacred precinct. They were divided into two or three rooms-the forecourt, the main hall, and an inner sanctuary (often called "holy of holies"). In most cases, the main hall of the building was an almost-square broad room. A niche or stage for the placement of a statue of the god was often placed at the back end of the inner sanctuary. The walls of these temples were thick and their facades were sometimes flanked by two columns. A monumental structure was discovered in the center of Hazor's Upper City (Building 7050). This structure was interpreted as a palace by Amnon Ben-Tor (2006), though Sharon Zuckerman (2010), the co-director, preferred to identify it as a Temple. She based this interpretation on the prominent location of the structure, which is typical for temples of the period, as well as on the structure's plan, which includes only a small number of rooms which are surrounded the central hall. One of the back rooms had a basalt base (for a statue of a deity?). The large forecourt had an alter which was surrounded by animal bones, as well as evidence of votive vessels and metal figurines, which all testify to the cultic function of this structure. Finally, we must mention the abundant evidence for a "ruin cult" nearby in which the ruins of the Late Bronze Age temple were venerated by the Iron Age inhabitants of the city (Ben-Ami 2006). Two additional temples were found nearby Building 7050 — the Northern Temple and the Southern Temple (though not much was left of the latter). The "Northern Temple" was built in the northwest part of Area A and might have been a part of the ceremonial precinct. This "long Temple" was a large rectangular structure whose corners were oriented towards the compass and whose entrance faced the east. The courtyard was paved with plastered cobbles and its walls were probably lined with basalt orthostats. A plastered raised podium was located opposite the entrance and probably served as the main cultic locus (Zuckerman 2012, pp. 112-13). Hazor's Area H had a sequence of temples which began during the Middle Bronze Age and continued through the Late Bronze Age. At first, benches were added to the main hall, the inner sanctuary was closed from public view, and a stand for a cult statue was placed at one side. In the final stage, large basalt orthostats with lion images were placed to guard the temple's entrance (Figure 3), and additional well-cut orthostats were placed along the inner sides of the walls. The inner courtyard contained two stone altars surrounded by animal bones and ashes (Bunimovitz 2019, p. 51). Numerous cultic vessels and fragments of clay liver models were found nearby, as well as a basalt statue of a deity standing on a bull-possibly representing the storm god Baal. The Megiddo temple was also enclosed in a sacred compound and was comprised of a large forecourt surrounded by auxiliary rooms and storage spaces. At Shechem, a broad temple was built within a courtyard with a sacrificial altar and a huge standing stone (massebah). 

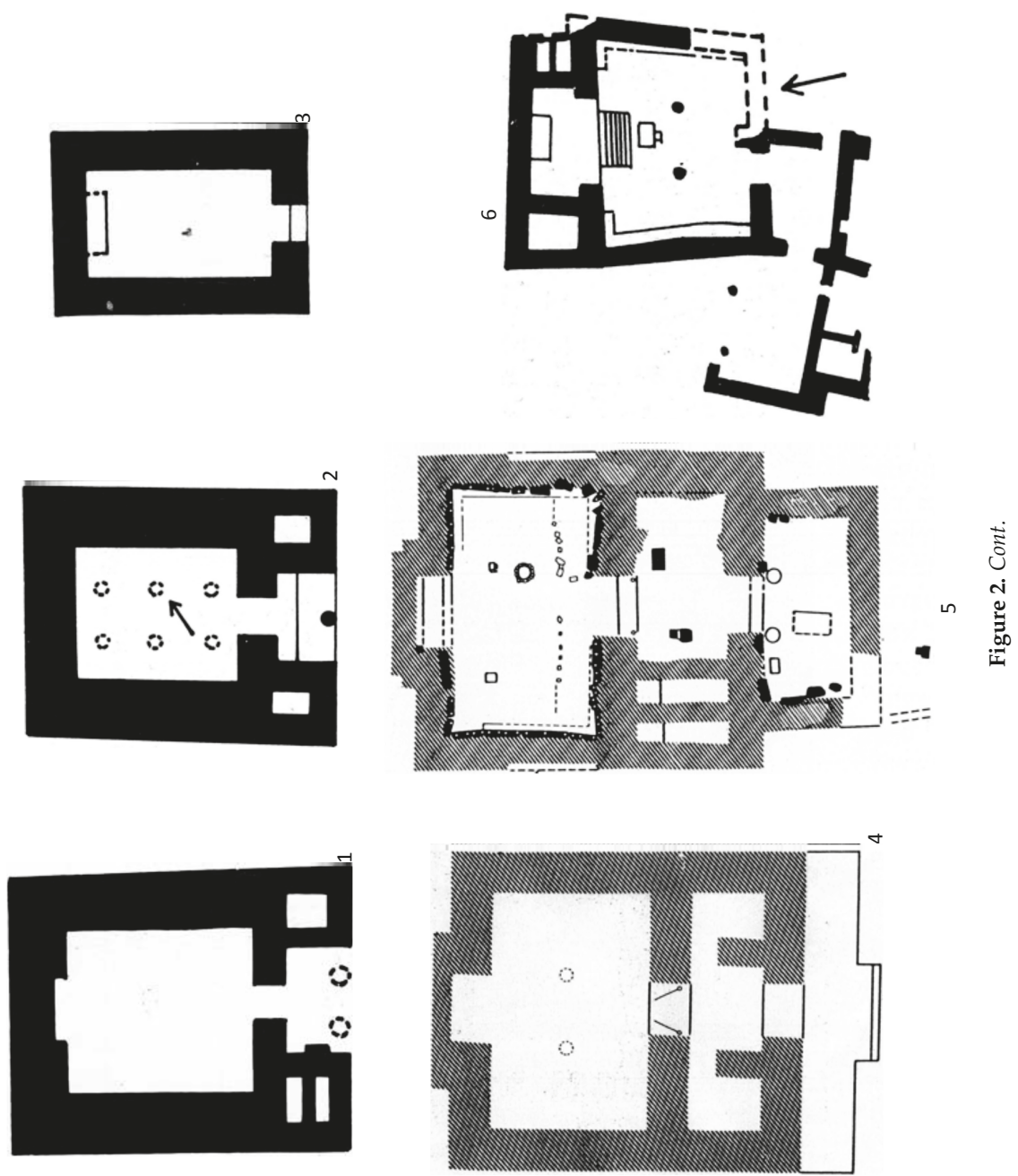


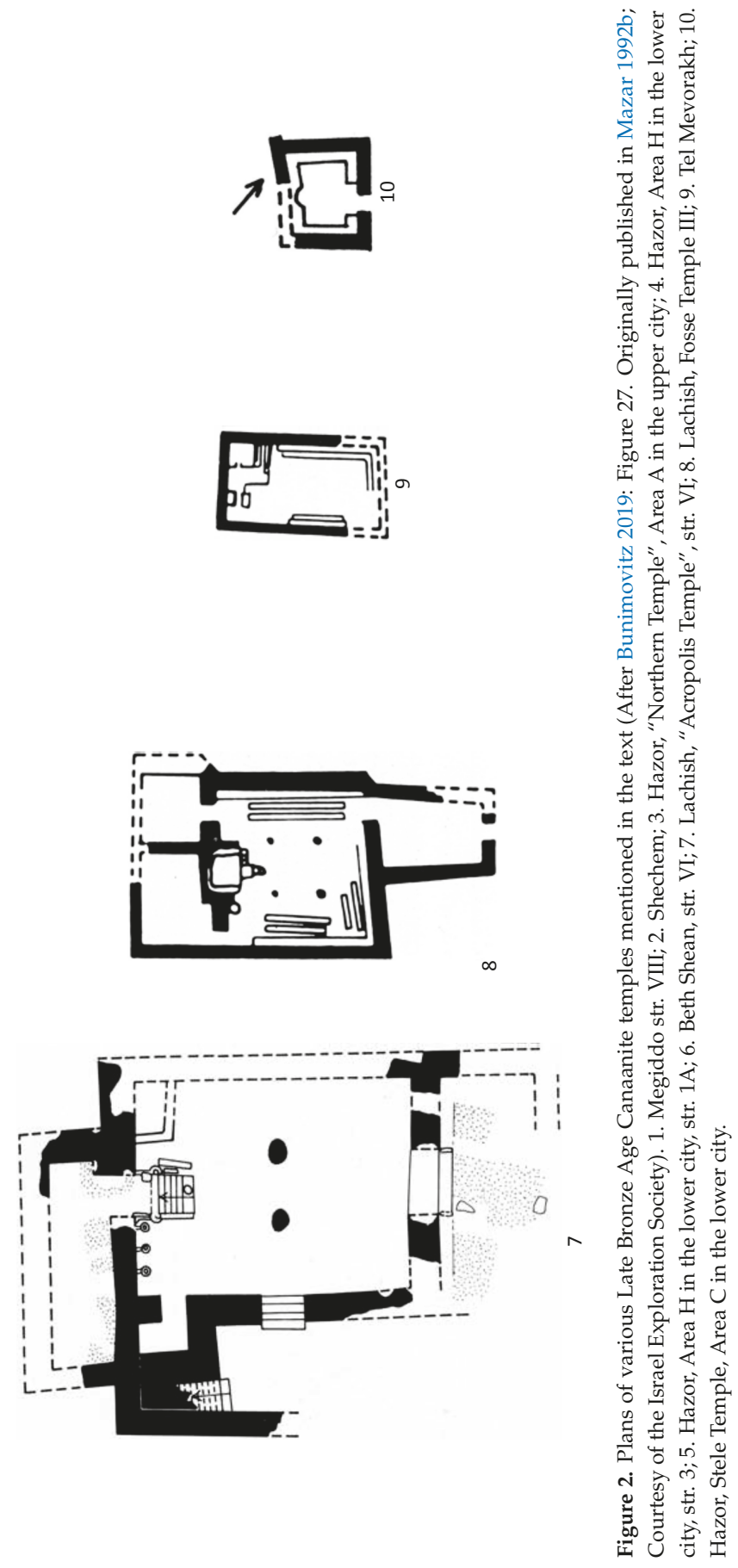




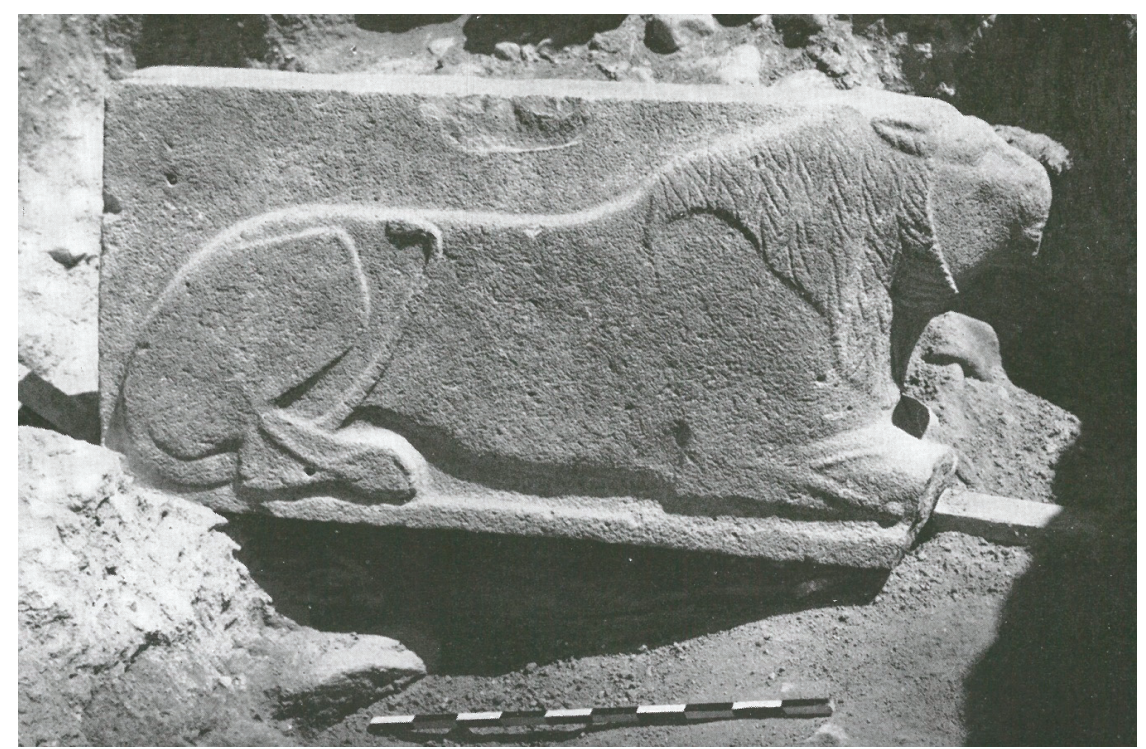

Figure 3. Basalt orthostat depicting a lion from the Area H temple at Hazor (From Yadin 1961: Plate CXX:2; courtesy of Amnon Ben-Tor and the Israel Exploration Society).

C. Temples with a raised inner sanctuary-the temples discovered in strata VIII-VII and VI at Beth-Shean and in stratum VI at Lachish exhibit many common characteristics, and thus form a separate category. The points of resemblance include the internal division of the building, the dimensions and proportions of the main hall, the elevated inner sanctuary (which was approached by a staircase and set in a separate architectural niche), and the Egyptian architectural elements incorporated into the buildings-especially the stone column capitals (Mazar 1992b, p. 173). The two successive Beth Shean temples and the Acropolis temple at Lachish-all dated to the thirteenth-early twelfth century BCE, when the Egyptian presence in the country was at its peak - had a combination of Canaanite concepts and Egyptian architectural decoration. Egyptian-styled architectural fragments were found at Beth-Shean, including stone friezes and papyrus-shaped capitals. The Acropolis temple at Lachish (Figure 4), located at the center of the mound, had two main columns with papyrus-shaped stone capitals in the Egyptian style, as well as decorative columns, some featuring Egyptian fluted shafts. Rare remains of interior wall painting in black, white, red, yellow, and blue are another reflection of Egyptian influence.

The architecture of these temples may reflect religious syncretism, also suggested by some cultic art objects which combined Egyptian and Canaanite motifs (e.g., Bunimovitz 2019, p. 54; Mullins 2012). Mazar (1992b, p. 177) wrote that, whereas the temples at Beth-Shean were founded in the center of the Egyptian government and were most certainly used by Egyptian soldiers, officials, and mercenaries, the temple at Lachish was erected on the acropolis of a royal Canaanite city and should be regarded as a reflection of Egyptian influence on Canaanite architecture and cult. 


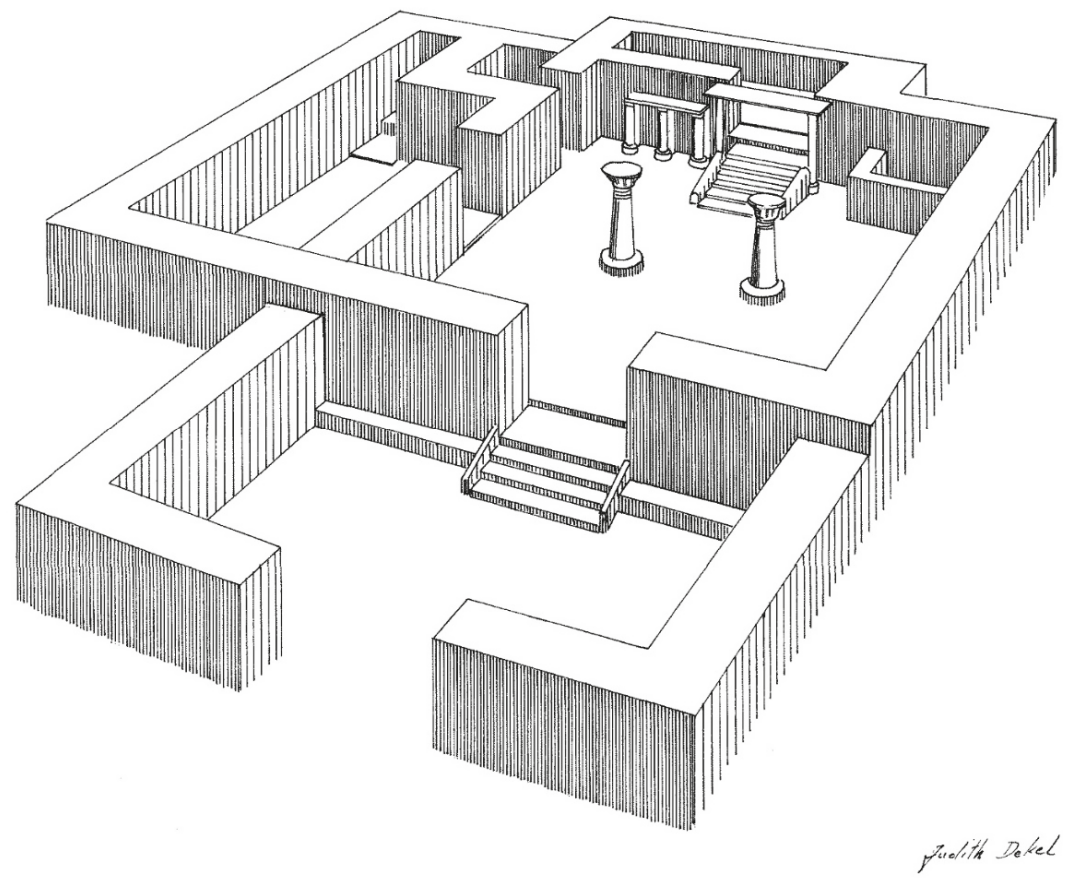

Figure 4. Suggested reconstruction of the main Acropolis Temple Complex at Lachish (From Ussishkin 2004: Figure 6:4; courtesy of the Institute of Archaeology of Tel Aviv University).

D. Temples with indirect entrances and irregular plans-This group of Late Bronze temples is characterized by an indirect entrance and a plan which lacks any attempt at symmetry or clear architectural rules and principles. In these temples, one could not see the inner sanctuary from the entrance; they had benches along the walls, columns supporting the ceilings, and an elevated inner sanctuary. Additional rooms were built for storage around the temple (Mazar 1992b, p. 182). This group includes the succession of Fosse temples at Lachish, the Tel Mevorakh road sanctuary, one of the Beth-Shean temples (level R2 which had a trapezoid inner sanctuary; see Figure 5), and several other buildings whose identification as temples is not certain (Mazar 1992b, p. 177). The excavators argued that the Lachish Fosse temples served nomads or shepherds, since they were built outside of the settlement. Bunimovitz (2019) suggested that these temples may represent foreign elements who settled in Canaan. Bietak (2002) suggested that funerary ceremonies were conducted within them, as they resembled Egyptian temples with similar functions. Although situated in the northern reaches of Canaan, we should also make note of the Late Bronze Age sequence of Temples at Kamid el-Loz which had irregular plans (DePietro 2012, p. 59). This structure gained rooms and surface area as time went on, so that by the end of its use, the original three-room construction had become a veritable double temple. This constant enlargement may be seen in connection with a continuous increase in importance of the institution (Heinz and kulemann-Ossen 2014).

E. Small temples with direct access-a small number of Late Bronze Age temples cannot be assigned to any of the above groups (Mazar 1992a, p. 253). These include the temple in Area C at Hazor and perhaps the temple at Timna, to name a few (the identification of others as temples, like the structure discovered in the 'Amman airport, were not universally accepted). The small temple in Area $\mathrm{C}$ in Hazor had benches along its interior walls and a cultic focal point near the entrance. Its final stage contained eleven basalt stele which stood in a line (Figure 6). The middle one had a 
relief of a pair of hands pointing upwards with a crescent containing a disc above them. A statue of a man sitting on a chair with an upside-down crescent was discovered near the stele. These elements were explained by the excavator Yigael Yadin as representing the moon god and his consort. In addition, a small orthostat with a crouched lion was found, as well as another basalt plate used for offerings. It would seem that this temple served the residential quarters nearby.

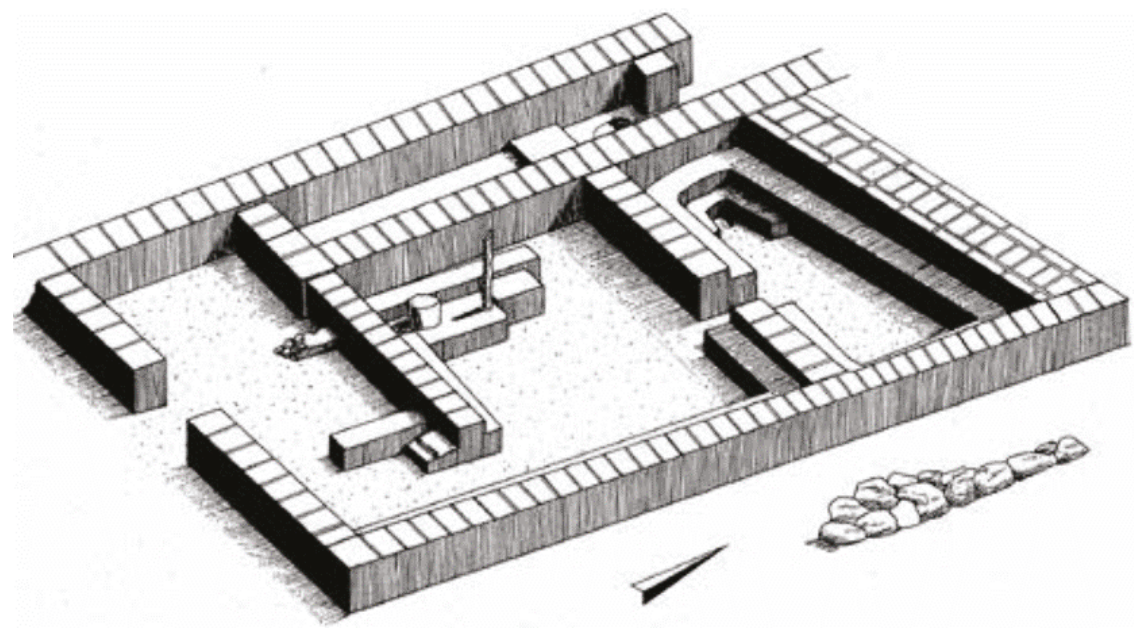

Figure 5. Isometric view of the Level R2 temple at Beth-Shean (From Mullins and Mazar 2007: Figure 3.19; courtesy of Amihai Mazar and the Israel Exploration Society).

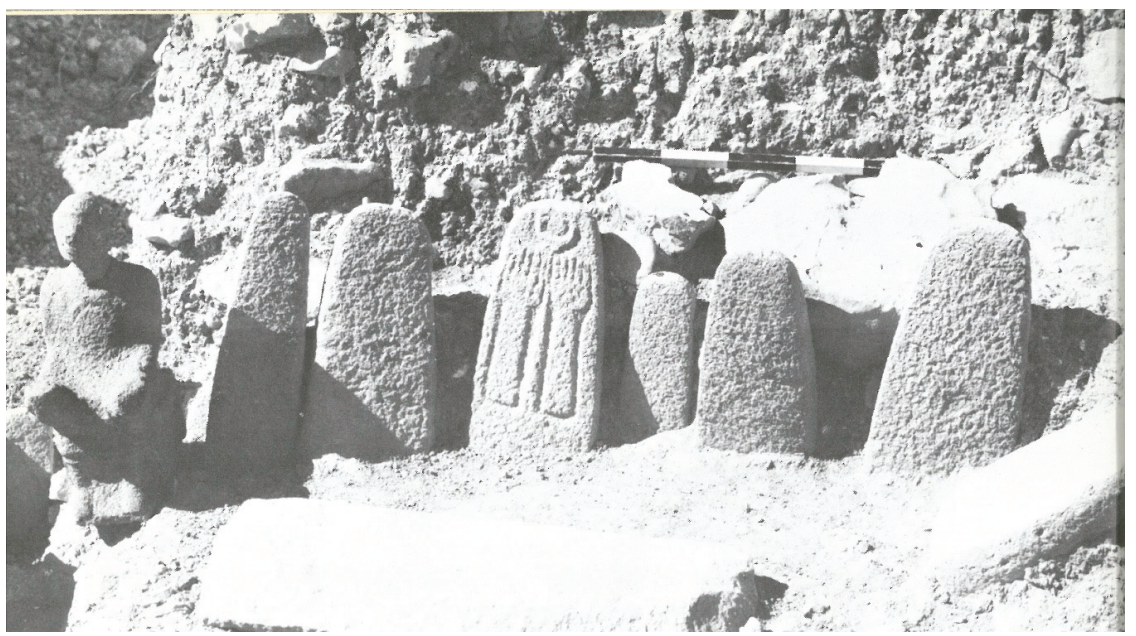

Figure 6. Cultic objects from the "Stelae Temple" in Area C at Hazor (From Yadin 1975: Page 46; courtesy of Amnon Ben-Tor and the Israel Exploration Society).

The temple at Timna in the Arava was erected as part of the Egyptian copper mining and smelting operation. It consisted of a broad room; the entrance was located in the middle of the eastern wall and the inner sanctuary was opposite it on a raised platform. Stone stelae, some with relief decorations depicting the head of Hathor, were placed in the temple. The varied finds in the temple included 
small Egyptian offerings such as seals, jewelry, and art objects. The Egyptians dedicated this temple to Hathor, the patroness of the mine. Mazar (1992b, p. 182) claimed that there is no close parallel to the Timna temple in the Egyptian architectural tradition.

Mazar (1992a, p. 257) proposed that the variations in religious architecture in Late Bronze Age Canaan may reflect not only the complexity of religious practices during that time, but also demographic heterogeneity. Alpert-Nakhai (2001, p. 122) wrote that in the Late Bronze Age, Canaan was increasingly the subject of external imperial strategies. Although northern sites such as Hazor continued to reflect Syrian influences over time, Egyptian control over the southern regions increased and so did the number of Egypto-Canaanite temples designed to serve Egyptian imperial needs (see also Koch 2018, pp. 101-16 and DePietro 2012). The Egyptian presence thus had a strong influence not only on the political and organizational framework in Canaan, but also on its demography and social and religious horizons (for more about strong Egyptian influences on Canaanite burial practices during this period, see Gonen 1992).

Shai et al. (2015) examined the artifacts found within a recently excavated temple at Tel Burna in order to better understand the cultic activities and rituals which took place within the temples. Samet (2017, p. 152) noted that a surprising feature of the ceramic assemblage in Late Bronze Age temples is that vessels made especially to be used in cults (i.e., miniatures, decorated stands, decorated goblets, chalices, etc.) form a very small part of the ceramic assemblage. Rather, the ceramic assemblage is dominated by serving vessels, indicating that food and drink consumption was the predominant activity. In other words, votive activity (common during the previous Middle Bronze Age) was replaced by commensality in Late Bronze temples.

Samet (2017, p. 159) suggested that the Canaanite elite residing in the palaces suffered a sharp decrease in its political power following the Egyptian conquest. While competitive dedications did persist, the popular ceramic dedications were replaced by evidence of large-scale feasting, in which food and drink were consumed. These were likely means to rally popular support of their rulership in difficult times, which could only be answered by placing a heavy burden on the Canaanite commoners. The small number of storage jars and cooking pots indicates that storage was not an important feature in the temples. This may mean that participants in these religious feasts were expected to bring foodstuffs and beverages with them (Samet 2017, p. 271). It seems that the dedication of foodstuffs replaced the dedication of cultic vessels. This may indicate the important social role of the Late Bronze temples.

\section{Figurines}

Small clay figurines which depict naked women were a popular Canaanite cultic item during the Late Bronze Age. These figurines were produced by pressing clay into an open cast (Figure 7). The women were usually depicted holding lotus flowers or their breasts. Their hairstyle resembled that of the Egyptian Goddess Hathor (see Cornelius 2004 for a possible typological grouping of these figurines). Most of these figurines were discovered in domestic contexts (the ones found in tombs should also be understood as 'domestic' and continuing their same function). They were usually found in secondary contexts, recently leading Levavi-Eilat (2014) to the conclusion that they were not ceremoniously disposed of, but may have been intentionally broken during apotropaic rituals. 


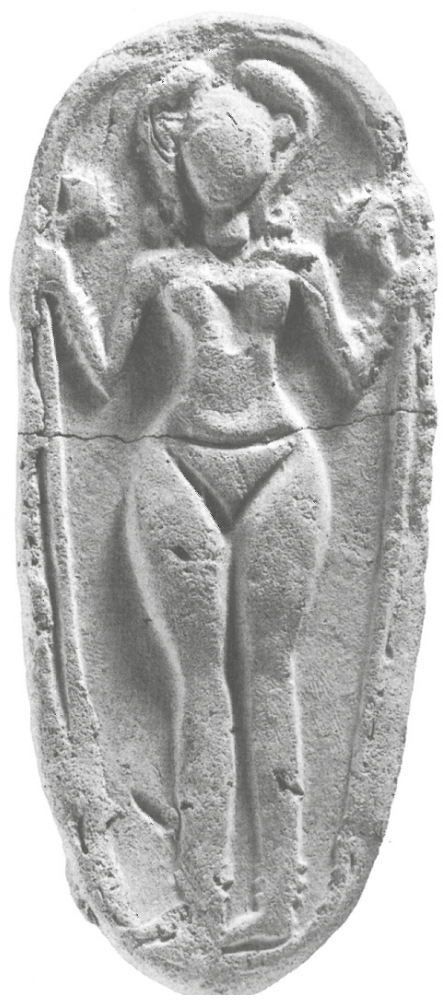

Figure 7. Canaanite Figurine plaque of a naked goddess from Tel Batash (From Mazar 2006: Photo 104; courtesy of Amihai Mazar and the Institute of Archaeology, The Hebrew University of Jerusalem).

These figurines are usually assumed to be representations of one of the Canaanite goddesses of sex and fertility-Asherah, Anat, or Astarte. Within one individual deity, this goddess perhaps combined the powers of mother earth, giving birth to humans and animals, nourishing them and helping them flourish. In any case, it is not only difficult to determine which goddess is depicted, but also the function of the figurines within the local cult practices (Bunimovitz 2019, p. 56). Hess (2007, p. 138) suggested that the female deity terra-cotta forms demonstrate a popularization and privatization of cultic worship. Additional figurines were made of metal. The most popular subjects were the young warrior god, most probably Baal, striding and holding weapons. Other popular figurines include enthroned male gods, identified as El, dressed in a long mantle (See example from Hazor in Figure 8).

The Canaanite goddesses were also portrayed on plaques or triangular gold pendants. Sometimes, the full body of the goddess is shown, while in other cases, only the head and fertility organs are featured. The goddess is usually depicted riding a horse, though there are several representations of a naked goddess standing on a lion. A variation of this figure appears on a large gold sheet found in the Acropolis temple at Lachish (Figure 9). This is an exceptional work of art illustrating the cultural and religious interchange between Canaan and Egypt. 


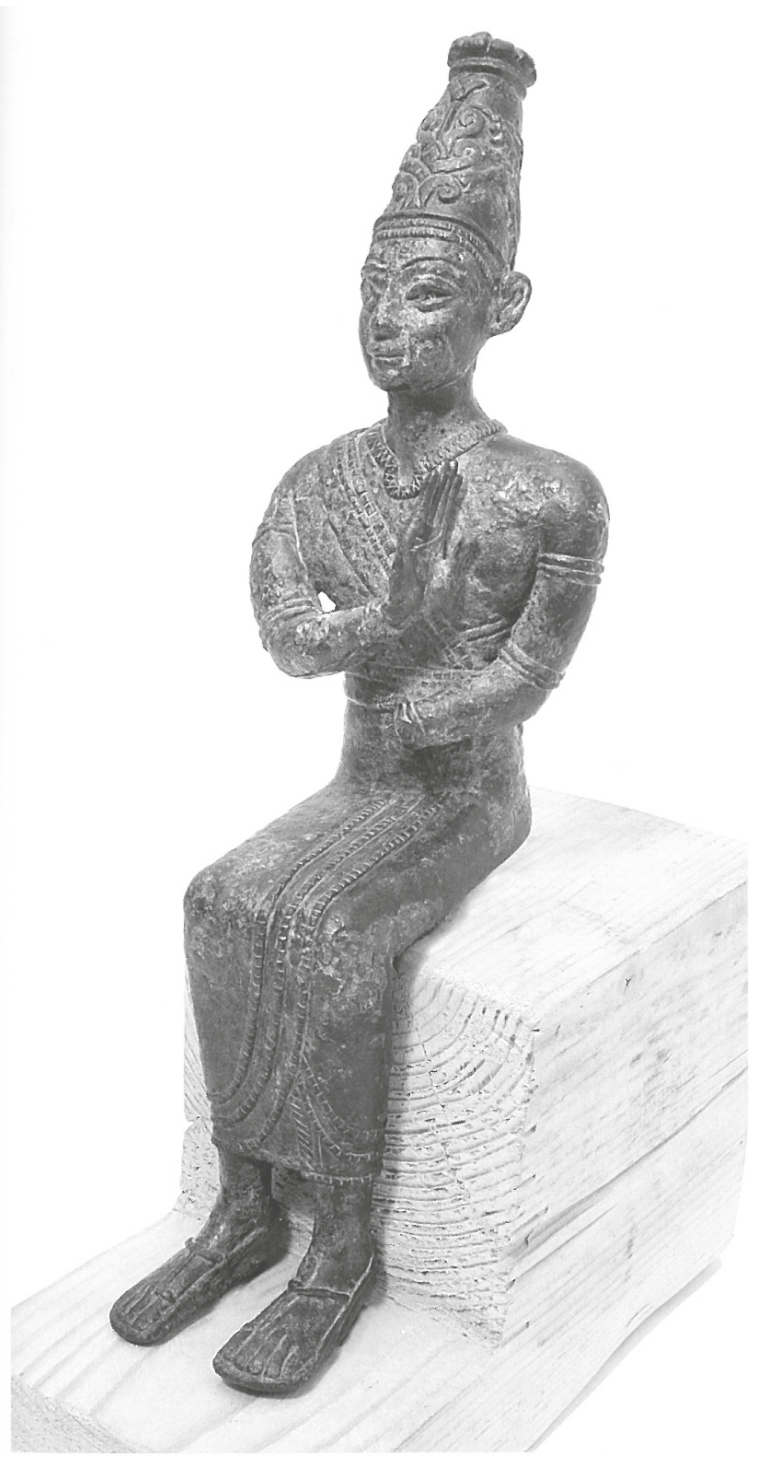

Figure 8. Enthroned male god figurine from Hazor (From Ornan 2017: Photo 10.6; courtesy of Amnon Ben-Tor and the Israel Exploration Society).

The figure of the goddess is simply, but rather gracefully, designed. She is shown in profile wearing a huge crown, which seems to be composed of two ostrich feathers flanked by two pairs of cow horns, all set onto a pair of ram's horns. It resembles the feather crown of Lower Egypt called the anedtj-crown, which is composed of several elements. The goddess is standing on a horse and holding two lotus flowers. The Lachish goddess, as characterized by nudity, her posture, a Hathor wig, the crown, and with attributes such as lotus flowers, is known from Canaan, as well as from Egypt, where she is identified as Qudshu, and related to the cult of fertility and love. Egyptian elements are evident in other parts of the plaque as well. In any case, the mythological personality of Qudshu, and her 
equation with Asherah, Astarte, or Anat, is rather elusive in Canaan, due to the lack of literary and epigraphic sources on the Canaanite pantheon and the difficulty in clearly defining the functions and personalities of Canaanite and Egyptian divinities (Clamer 2004, pp. 1314-20).

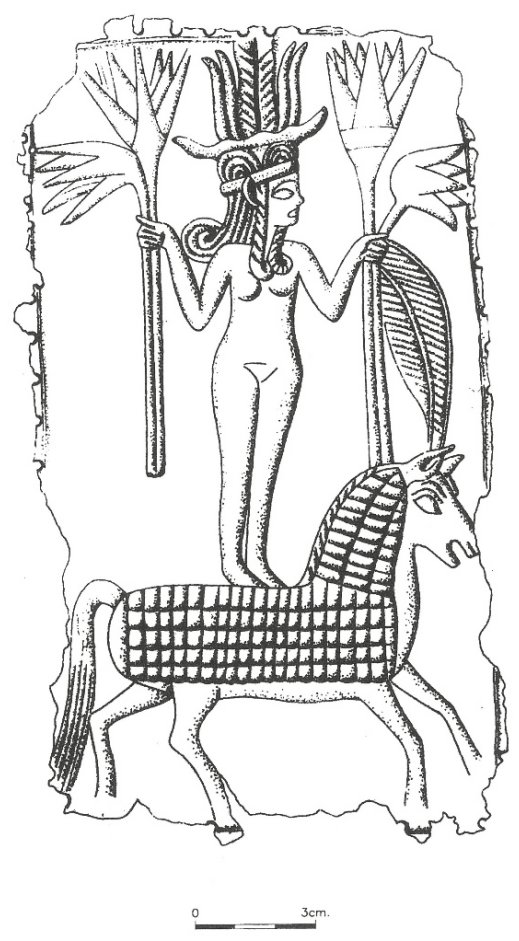

Figure 9. Canaanite Goddess depicted on a gold plaque found in the Lachish Acropolis temple ((From Clamer 2004: Figure 21:21; courtesy of the Institute of Archaeology of Tel Aviv University).).

Examples of painted vessels with a highly stylized palm tree, flanked by caprids, have been found in many Late Bronze contexts (Bunimovitz 2019, p. 62). In some representations, the tree is replaced by a pubic triangle, reflecting the association of the tree with a goddess and fertility. Similar motifs have been identified on contemporary cultic stands. These stands themselves may be stylized versions of the tree of life, one of the oldest and most widespread motifs in ancient Near East art and iconography.

\section{Lamp-and-Bowl Deposits}

Another phenomenon, usually associated with popular cults, are groups of vessels, mostly new bowls and lamps, which were deposited under the foundations of various structures (Figure 10). Bunimovitz and Zimhoni (1993) noted that these were found mostly in the areas with a strong Egyptian influence and connected this practice to a similar one which is known from contemporary Egyptian foundation rituals. The deposits found in Egypt included small versions of real vessels, as well as materials which were used to construct the building. The phenomenon therefore hints to an Egyptian cultural influence, though the vessels were local (for a slightly different view, see DePietro 2012, pp. 99-124). 


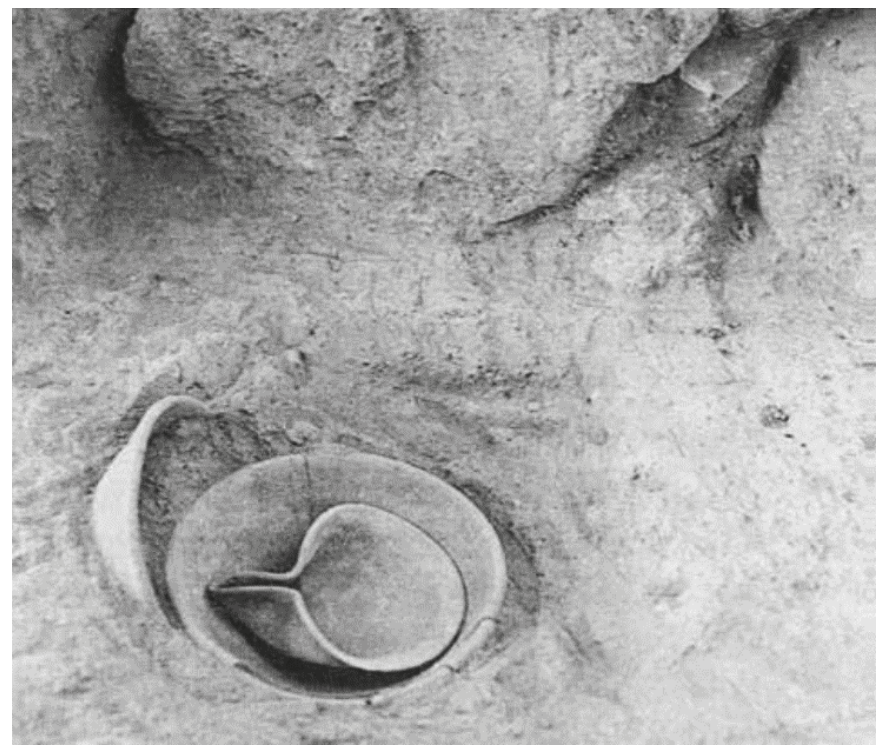

Figure 10. Lamp-and-bowl foundation deposit from Area S (Level VI) at Lachish (From Bunimovitz and Zimhoni 2004: Figure 19:60; courtesy of the Institute of Archaeology of Tel Aviv University).

\section{Summary}

Both the written and archaeological evidence for cultic activities during the Late Bronze Age is abundant. The written texts, and the variety of temples, figurines, and other cultic paraphernalia, demonstrate the openness of the Canaanite religion during the Late Bronze Age. Different regions and settlements may have worshipped different sets of gods and goddesses. The cultic activities seem to have been influenced by neighboring powers, such as the Hittites and especially the Egyptians and their pantheon of gods and symbolism. In fact, there seems to have been a syncretism and mix of symbolisms between the Canaanite and Egyptians—especially towards the end of the period. The long-lasting Canaanite religious traditions and cult practices persevered despite the collapse of the Canaanite city-state organization at the end of the Late Bronze Age, and had a great influence (in both belief systems and cultic practices) on the developing nation states and cultures during the Iron Age.

Funding: This research received no external funding.

Acknowledgments: I would like to thank Avraham Faust for the invitation to contribute this article to this special issue on Archaeology and Israelite Religion. Thanks also to the anonymous reviewer whose thoughtful comments helped to improve the paper.

Conflicts of Interest: The author declares no conflict of interest.

\section{References}

Alpert-Nakhai, Beth. 2001. Archaeology and the Religions of Canaan and Israel. Boston: American Schools of Oriental Research.

Ben-Ami, Doron. 2006. Early Iron Age Cult Places. New Evidence from Tel Hazor. Tel Aviv 33: 121-33. [CrossRef] Ben-Tor, Amnon. 2006. Ceremonial Palace, not a Temple. Biblical Archaeology Review 32: 8, 78-79.

Bietak, Manfred. 2002. The Function and Some Architectural Roots of the Fosse Temple at Lachish. In Beer-Sheva XV. Studies in Archaeology and Related Disciplines. Aharon Kempinski Volume. Edited by Shmuel Ahituv and Eliezer Oren. Beer Sheva: Department of Bible and Ancient Near East. 
Bunimovitz, Shlomo. 1995. On the Edge of Empires-Late Bronze Age (1500-1200 BCE). In The Archaeology of Society in the Holy Land. Edited by Thomas E. Levy. London: Continuum, pp. 320-29.

Bunimovitz, Shlomo. 2019. The Late Bronze Age. In Introduction to the Archaeology of the Land of Israel from the Neolithic to Alexander's Conquests. Edited by Avraham Faust and Hayah Katz. Ra'anana: The Open University of Israel. (In Hebrew)

Bunimovitz, Shlomo, and Orna Zimhoni. 1993. "Lamp-and-Bowl" Foundation Deposits in Canaan. Israel Exploration Journal 43: 99-125.

Bunimovitz, Shlomo, and Orna Zimhoni. 2004. Appendix: Lamp-and-Bowl Foundation Deposits in Areas P and S. In The Renewed Archaeological Excavations at Lachish (1973-1994), Volume III. Edited by David Ussishkin. Tel Aviv: Emery and Clair Yass Publication in Archaeology, pp. 1147-54.

Clamer, Christa. 2004. The Pottery and Artefacts from the Level VI Temple. In The Renewed Archaeological Excavations at Lachish (1973-1994), Volume III. Edited by David Ussishkin. Tel Aviv: Emery and Clair Yass Publication in Archaeology, pp. 1288-325.

Cornelius, Sakkie. 2004. A Preliminary Typology for the Female Plaques Figurines and their Value for the Religion of Ancient Palestine and Jordan. Journal of Northwest Semitic Languages 30: 21-39.

Cross, Frank Moore. 1998. From Epic to Canon: History and Literature in Ancient Israel. Baltimore: The Johns Hopkins University Press.

Day, John. 1992. Canaan, Religion of. In The Anchor Bible Dictionary. Edited by David N. Freedman. New York: Doubleday, pp. 831-37.

DePietro, Dana D. 2012. Piety, Practice and Politics: Ritual and Agency in the Late Bronze Southern Levant. Ph.D. dissertation, U.C. Berkeley, Berkeley, CA, USA.

Faust, Avraham. 2010. The Archaeology of the Israelite Cult: Questioning the Consensus. Bulletin of the American Schools of Oriental Research 360: 23-35. [CrossRef]

Faust, Avraham. 2019. Israelite Temples: Where Was Israelite Cult Not Practiced and Why. Religions 10: 106. [CrossRef]

Finkelstein, Israel. 1996. The Territorial-Political System of Canaan in the Late Bronze Age. Ugarit-Forschungen 28: 221-55.

Gonen, Rivka. 1992. Burial Patterns and Cultural Diversity in Late Bronze Age Canaan. Winona Lake: Eisenbrauns.

Goren, Yuval, Israel Finkelstein, and Nadav Na'aman, eds. 2004. Inscribed in Clay: Provenance Study of the Amarna Tablets and Other Ancient Near Eastern Texts. Tel Aviv: Emery and Clair Yass Publications in Archaeology.

Heinz, Marlies, and Sabina kulemann-Ossen. 2014. Chapter 35. The Northern Levant (Lebanon) during the Late Bronze Age. In The Oxford Handbook of the Archaeology of the Levant C. 8000-332 BCE. Edited by Margreet L. Steiner and Ann E. Killebrew. Oxford: Oxford University Press, pp. 524-40.

Hess, Richard S. 2007. Israelite Religions: An Archaeological and Biblical Survey. Grand Rapids: Baker Academics.

Koch, Ido. 2018. The Shadow of Egypt: Colonial Encounters in Southwest Canaan during the Late Bronze Age and Early Iron Age. Jerusalem: Yad Yitzhak Ben-Zvi. (In Hebrew)

Levavi-Eilat, Sarah. 2014. Discarded Women: A Contextual Study of the use of Canaanite Terracotta Plaque Figurines. Master's thesis, Tel Aviv University, Tel Aviv, Israel. (In Hebrew)

Lev-Tov, Justin S. E., and Edward F. Maher. 2001. Food in Late Bronze Age Funerary Offerings: Faunal Evidence from Tomb I at Tell Dothan. Palestine Exploration Quarterly 133: 91-110. [CrossRef]

Mazar, Amihai. 1992a. Archaeology of the Land of the Bible 10,000-586 B.C.E.. New York: Doubleday.

Mazar, Amihai. 1992b. Temples of the Middle and Late Bronze Ages and the Iron Age. In The Architecture of Ancient Israel: From the Prehistoric to the Persian Periods. Edited by Aharon Kempinski, Ronnie Reich and Hannah Katzenstein. Jerusalem: Israel Exploration Society, pp. 161-87.

Mazar, Amihai. 2006. Clay Figurines and a Zoomorphic Vessel. In Timna (Tel Batash) III: The Finds from the Second Millennium BCE (Qedem 45). Edited by Nava Panitz-Cohen and Amihai Mazar. Jerusalem: Institute of Archaeology, The Hebrew University of Jerusalem, pp. 251-54.

Moran, William L., ed. 1992. The Amarna Letters. Baltimore: Johns Hopkins University Press.

Mullins, Robert A. 2012. The Late Bronze and Iron Age Temples at Beth-Shean. In Temple Building and Temple Cult: Architecture and Cultic Paraphernalia of Temples in the Levent (2.-1. Mill. B.C.E.). Edited by Jens Kamlah. Wiesbaden: Harrassowitz Verlag, pp. 127-57. 
Mullins, Robert A., and Amihai Mazar. 2007. The Stratigraphy and Architecture of the Middle and Late Bronze Ages: Strata R-5-R-1A. In Excavations at Tel Beth-Shean 1989-1996, Volume II: The Middle and Late Bronze Strata in Area R. Edited by Amihai Mazar and Robert Mullins. Jerusalem: Israel Exploration Society, pp. 39-199.

Ornan, Tallay. 2017. Metal Statuary. In Hazor VII (The Selz Foundation Hazor Excavations in Memory of Yigael Yadin): The 1990-2012 Excavations. The Bronze Age. Edited by Amnon Ben-Tor, Sharon Zuckerman, Shlomit Bechar and Debora Sandhaus. Jerusalem: Israel Exploration Society and the Institute of Archaeology, The Hebrew University of Jerusalem, pp. 514-18.

Samet, Inbal. 2017. Pottery Consumption and International Trade in Middle Bronze Age Kabri and Other Canaanite Palatial Polities. Ph.D. dissertation, University of Haifa, Haifa, Israel.

Shai, Itzhaq, Chris McKinny, and Joe Uziel. 2015. Late Bronze Age Cultic Activity in Ancient Canaan: A View from Tel Burna. Bulletin of the American Schools of Oriental Research 374: 115-33. [CrossRef]

Smith, Mark S. 2001. The Origins of Biblical Monotheism. Oxford: Oxford University Press.

Smith, Mark S. 2007. Recent Study of Israelite Religion in Light of the Ugaritic Texts. In Ugarit at Seventy-Five. Edited by K. Lawson Younger Jr. Winona Lake: Eisenbrauns, pp. 1-25.

Ussishkin, David. 2004. Area P: The Level VI Temple. In The Renewed Archaeological Excavations at Lachish (1973-1994), Volume I. Edited by David Ussishkin. Tel Aviv: Emery and Clair Yass Publications in Archaeology, pp. 215-81.

Van der Toorn, Karel, Bob Becking, and Pieter W. Van der Horst, eds. 1999. Dictionary of Deities and Demons in the Bible. Leiden: Brill Publishing.

Yadin, Yigal. 1961. Hazor III-IV. Jerusalem: The Hebrew University.

Yadin, Yigal. 1975. Hazor: The Rediscovery of a Great Citadel of the Bible. New York: Random House.

Yon, Marguerite. 2006. The City of Ugarit at Tell Ras Shamra. Winona Lake: Eisenbrauns.

Zuckerman, Sharon. 2010. "The City, Its Gods Will Return There ... ". Towards an Alternative Interpretation of Hazor's Acropolis in the Late Bronze Age. Journal of Near Eastern Studies 69: 163-78. [CrossRef]

Zuckerman, Sharon. 2012. The Temples of Canaanite Hazor. In Temple Building and Temple Cult: Architecture and Cultic Paraphernalia of Temples in the Levent (2.-1. Mill. B.C.E.). Edited by Jens Kamlah. Wiesbaden: Harrassowitz Verlag, pp. 99-125.

(C) 2019 by the author. Licensee MDPI, Basel, Switzerland. This article is an open access article distributed under the terms and conditions of the Creative Commons Attribution (CC BY) license (http:/ / creativecommons.org/licenses/by/4.0/). 

Article

\title{
Philistine Cult and Religion According to Archaeological Evidence
}

\author{
David Ben-Shlomo \\ Department of Land of Israel Studies and Archaeology, Ariel University, Ariel 40700, Israel; \\ davben187@yahoo.com
}

Received: 6 January 2019; Accepted: 16 January 2019; Published: 23 January 2019

\begin{abstract}
The paper surveys and discusses the updated archaeological evidence for Philistine cult and religion, and cult and religion in Philistia during the Iron Age. The evidence can be related to public or official cult, represented in temple and shrine structures, and to that coming from households, representing possibly more popular religion. The evidence of public cult, so far mostly from peripheral sites, includes largely cultural elements linked with the local Canaanite cult and religion. Yet, within households at the Philistine cities there is more evidence for cultic elements of Aegean affinity during Iron Age I. In particular, figurines and ceramic figurative vessels and objects will be discussed. It seems that the Philistine religion may have retained certain distinctive elements also during Iron Age II. Nevertheless, it is still difficult to reconstruct the details of the nature of the Philistine religion due to the limited amount of evidence and lack of textual records.
\end{abstract}

Keywords: Philistines; Iron Age; Aegean-style; temples; shrines; household; figurines

\section{Introduction}

The evidence regarding Philistine cult and religion includes several biblical and extra-biblical references, but mainly archaeological evidence from excavation in sites of Iron Age Philistia (Figure 1). The Philistine material culture can be considered to be one of the most typical examples where a distinct material culture appears in a limited geographical and chronological context (Dothan 1982). This culture reflects the arrival of new population from the West to the southern coast of Israel as it includes components which are not found in the Late Bronze Age and early Iron Age local cultures of the southern Levant, showing links to the Aegean region and Cyprus; thus, probably indicating the arrival of immigrant population during the beginning of the 12th century BCE (e.g., Dothan 1982; Yasur-Landau 2010; Ben-Shlomo 2010, 2014). During the subsequent stages of the Iron Age, late Iron Age I, and Iron Age II, the material culture of Philistia changes and many of the elements attesting to links with the West disappear. Yet, Philistia maintains a degree of political and cultural independence and distinction (see, e.g., Ehrlich 1996; Shai 2006) and, thus, it seems justified to continue and treat the material culture of Philistia throughout the Iron Age as a well-defined cultural unit. This material culture also includes certain cultic and religious aspects (e.g., Mazar 2000; Yasur-Landau 2001; Maeir et al. 2013, pp. 15-22; Ben-Shlomo 2014) which will be the focus of this article. 


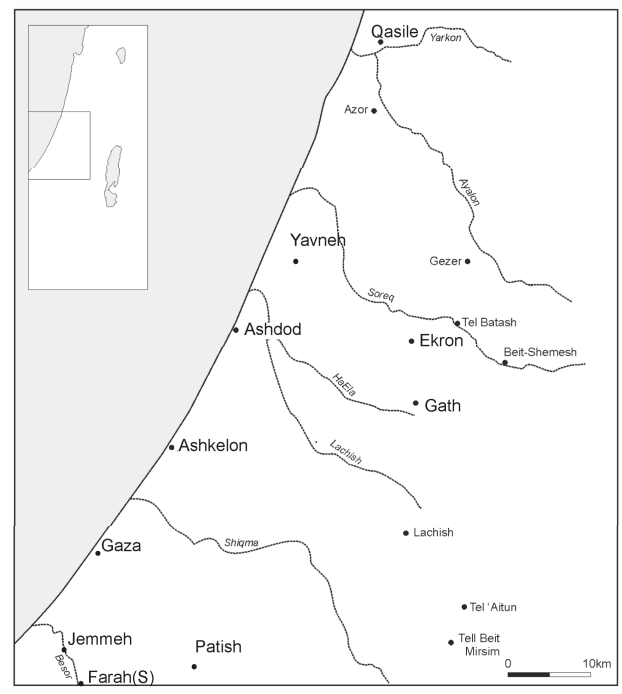

Figure 1. Map of Philistia.

The textual evidence on Philistine cult and religion is limited. The cult of a Near-eastern male god by the Philistines is mentioned in the Hebrew Bible, either in regards to Dagon of Ashdod (1 Sam 5) or Gaza (Judg 16:23) or Ba'alZebub of Ekron (2 Kgs 1:2-3). (Singer 1992) related the Philistine god Dagon to the Hebrew-dag (fish), yet it is more reasonable to associate this with the Semitic agricultural god of Dagon (related to 'dagan' = grain). Another relevant story is the mentioning of the Philistines making five gold images of mice and 'Opalim' (emerods) in the story of the capture of the arc (1 Sam 6:4-5, see Maeir 2007). This passage mentions the priests and the diviners of the Philistines, suggesting to construct these images, symbolizing the five Philistine cities of Serens in order to make amends with the Hebrew god. Whether this reflects any actual religious practice carried out by the Philistines is of course doubtful. In any case, the few biblical passages related to the Philistine cult seem to comply with standard description of local Canaanite pagan cult. In addition, several inscriptions found in archaeological excavation may also contribute evidence towards the nature of Philistine religion. Several inscriptions from Philistine contexts mention the Canaanite generic god Ba'al (see below), while the royal inscription from Ekron (Tel Miqne Complex 650) mentions implicitly a goddess name with an Aegean background (see below); these will be discussed below.

Therefore, archaeological evidence can only shed more light of any specific characteristic attributes of Philistine religion and cultic practices. The material culture from the region of Philistia during the Iron Age related to cult will be inspected. The study of Philistine material culture including its cultic aspect has advanced substantially during the past years. This is mainly due to the increase of evidence from new archaeological excavation at the Philistine city sites of Ekron (Tel Miqne), Ashkelon, and Gath (Tell es-Safi). This adds up to the previous evidence from Ashdod and the peripheral site of Tell Qasile. Several studies describe various aspects of Philistine religion and cult both in Iron Age I (Mazar 2000; Yasur-Landau 2001; Dothan 2003) and Iron Age II (Gitin 2003; Ehrlich 1996; Maeir 2006, 2007, 2008; Maeir et al. 2013; Dagan et al. 2018). More data has emerged from excavations at peripheral sites of Philistia, as at an Iron Age IIA favissa pit near Yavneh (Kletter et al. 2006, 2010) and at a late Iron Age I temple at Nahal Patish (Nahshoni 2009; Nahshoni and Ziffer 2009). Specific aspects of Philistine material culture or finds from Philistia that can be related to cultic practices and religion were studied on various occasions (e.g., head cups, Maeir 2006; Meiberg 2013; phallus-objects, Maeir 2007; male figurine, Maeir 2008; pomegranates, Dothan and Ben-Shlomo 2007; zoomorphic vessels, Ben-Shlomo 
2008; figurines, Schmitt 1999; Ben-Shlomo and Press 2009; altars, Gitin 1989, 1993, 2002, 2008, altars; household religion, Ben-Shlomo 2014).

While the boundaries between household or family religion and public, state, or official religion are not always straightforward, in relation to archaeological interpretation, this division should probably be maintained, as it is the most intuitive and achievable one. Generally, public and official religion is reflected in structures identified as temples or shrines, and the finds in them. These structures, which have an inherent and rather constant cultic function, can often be identified according to several objective parameters. These include a special ground plan, building techniques, separation of spaces, installations and type, quantity and location of specific finds (see Renfrew 1985, pp. 1-26).

Household religion is reflected by installations and artifacts found in domestic context, that can be considered cultic; on several occasions, areas within the household could be defined as 'cultic corners' or 'house shrines'. If household religion is defined as the cultic practices conducted in the household, one still has to define a household, and how to recognize traces of cultic activity within it. While, as we know, almost any artifact, or immovable, within the house could on a certain occasion be used in relation to cultic or religious activities or beliefs, this approach cannot be very useful in common archaeological research. If one desires to identify ritual activity, a search for objects or behaviors that have apparent symbolic character, and cannot be regularly employed in daily activities, is warranted. Therefore, objects such as figurines, figurative models, stands and libation vessels, altars and incense burners are natural candidates for reflecting ritual in household contexts in most cultures.

The following discussion will be thus divided into two 'types' of cult: 'official' or public cult and religion and household, family or 'popular' cult. Along these lines, the discussion of the archaeological evidence relating to Philistine cult may be separated according to the chronological division of Iron Age I (ca. 1200-1000 BCE) and Iron Age II (ca. 1000-600 BCE) periods. Although this division is somewhat artificial, it represents to a high degree two different stages in the evolution of the Philistine society. The characteristics of cultic activities and items recovered from Philistine households will be compared with those from temples from Philistia. In addition, an attempt to reconstruct the character of the Philistine religion and its evolution during the Iron Age according to the archaeological evidence will be made.

\section{Public (Official) Religion}

Iron Age I Temples or shrines in Philistia: To date, three sites from Iron Age I Philistia can definitely be defined as temples. These include the temples of Tell Qasile (Figure 2; Mazar 1980, 1985, 2000), the temple in Nahal Patish (Nahshoni 2009; Nahshoni and Ziffer 2009); both of these are apparent temples, according to both their architectural plan and finds (which also resemble each other). In addition, an Iron Age I/IIA transition temple was reported from Area D at Tell es-Safi-Gath (Figures 3 and 4, Dagan et al. 2018; this will be discussed below). At Tell es-Safi-Gath, Area A, Strata A6-A4, under the Iron Age IIA shrine (see below), the excavators reported a possible temple (Maeir et al. 2013, pp. 12-13, Figure 5) with two finely worked stone pillars. Note that all these structures are dated to the later phases of Iron Age I. A large structure in Field IV Lower at Ekron (Building 350, Strata V-IV) was also interpreted as a temple, in particular by (Dothan 2003). Yet, this identification is not secure and is more likely to be a public or affluent building (see e.g., Mazow 2005; Ben-Shlomo 2010, pp. 186-87). Therefore, the finds from this structure, which include many objects of possible cultic properties, will be discussed under 'household' cult section (see below). Thus, a major Iron Age I temple in the main Philistine cities is yet to be discovered. 


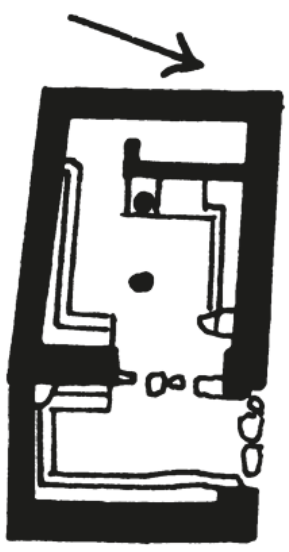

Figure 2. Tell Qasile Temple 131 schematic plan (after Mazar 1992: Figure 28).

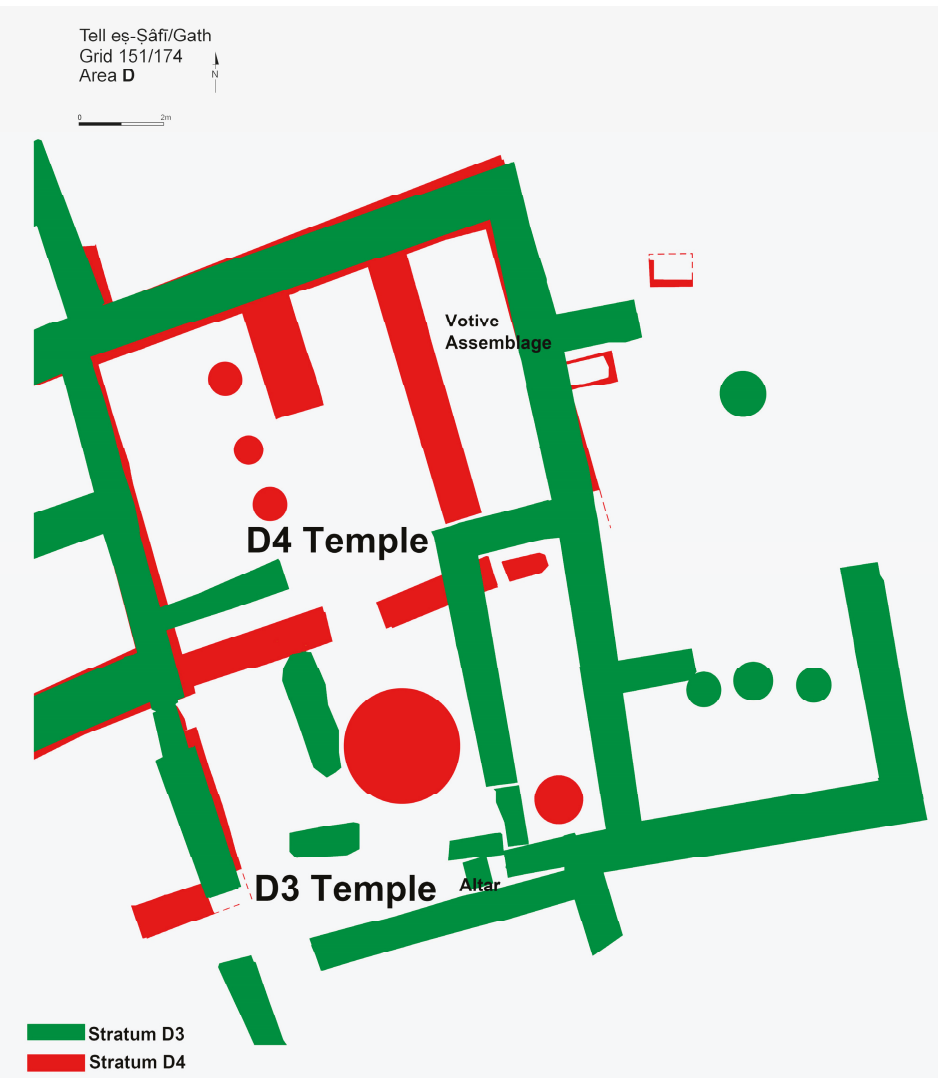

Figure 3. Gath Area D temples (Dagan et al. 2018: Figure 2, courtesy of A.M. Maeir). 


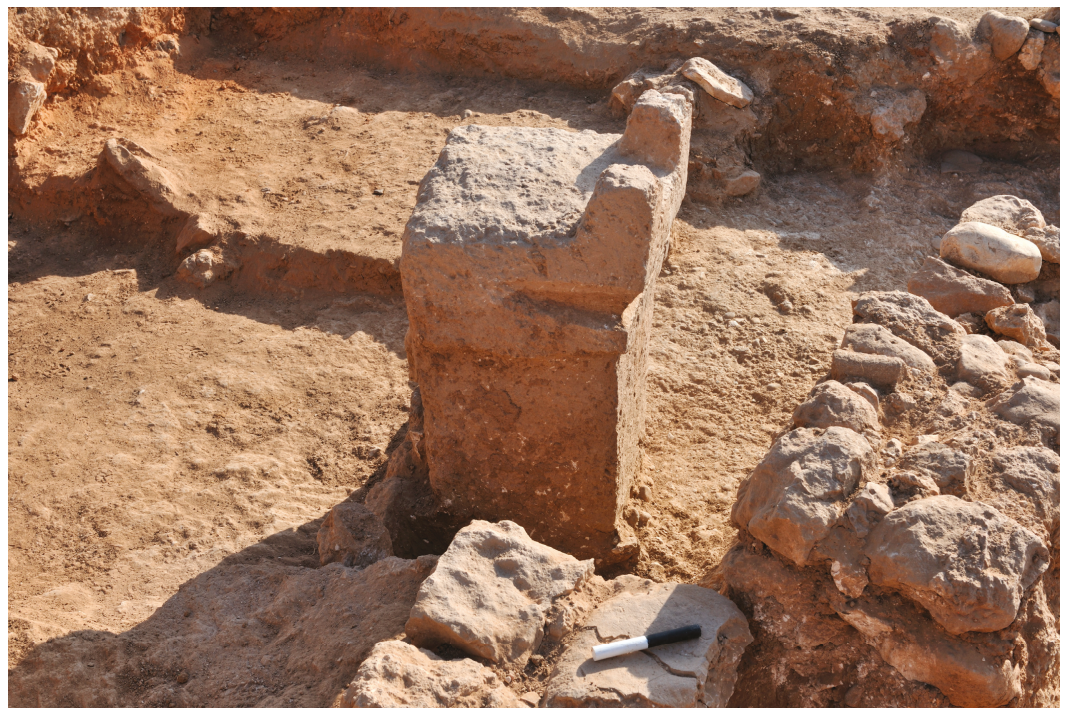

Figure 4. Two-horned altar from Gath (Dagan et al. 2018: Figure 4, courtesy of A.M. Maeir).

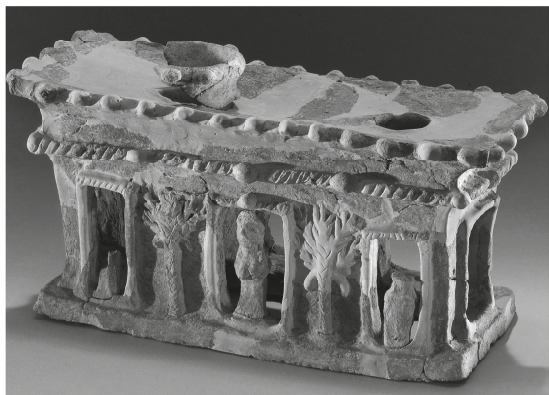

1

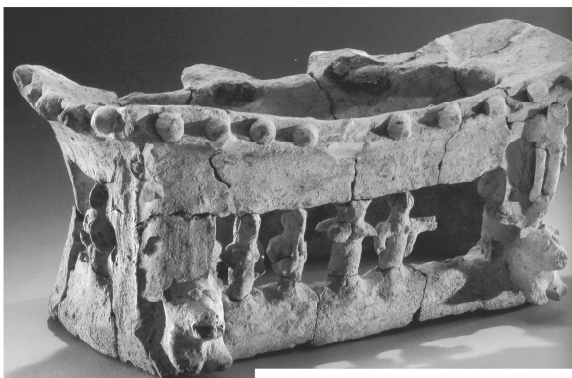

2

Figure 5. Stands from the Yavneh favissa (courtesy of R. Kletter).

The Iron Age I temples from Tell Qasile (Strata XII-X) are well known and published (Mazar 1980, 1985) and will only be briefly described here (Figure 2). In the lower level (Stratum XII), only a small one-room shrine with benches along the walls and a platform (bamah) was erected; it was somewhat enlarged in Stratum XI. The main evidence comes, however, from the later stage in Stratum X (Temple 131, Figure 2). In the phase, the structure was enlarged and included a rectangular structure with an indirect entrance, entrance room, main hall with pillars, and a back room (cela) with another indirect entrance. Adjacent to it, another small one-room shrine was located (Shrine 300) containing many cultic vessels (Mazar 1980).

The plan of the Qasile temples resembles LB II-Iron Age I temples from Beth Shean, Lachish, and other sites (denoted the 'temples with raised cela' or indirect entrance temple, possibly a reflection of Egyptian influence, see Mazar 1992, pp. 173-83) seem to be rooted in Late Bronze Age traditions (see, e.g., Negbi 1988; Mazar 2000). The similarities between the plans of the temples of Qasile and Phylakopiin the Aegean were noted (Negbi 1988), yet were interpreted to indicate a Canaanite influence on the Aegean.

The finds from the Qasile temples indicate ritual activity and include various anthropomorphic and zoomorphic libation vessels decorated in the Philistine Bichrome style (Mazar 1980; Dothan 1982), 
yet their iconography do not indicate clear Aegean affinities; see Mazar 2000; Ben-Shlomo 2010). Other notable finds are a lion-shaped head cup, bowls in the shape of birds with cylindrical stands carrying them, and figurative stands and terracottas (including two pomegranate vessels; see Dothan and Ben-Shlomo 2007). Recently, (Hitchcock et al. 2016) suggested that a bronze axe found in Temple 131 at Qasile is related to the 'double axe' ritual motif known from Crete and possibly Cyprus; yet, clearly, the tool form is not of a 'double axe' and is more similar to local tools.

The temple at Nahal Patish was excavated in a small rural site of an area of 12 dunam (1.2 hectares) and dates according to the pottery to late Iron Age I (Nahshoni 2009; Nahshoni and Ziffer 2009). Its date and plan are similar to the Tell Qasile temples Strata XI-X (and the structure is accordingly interpreted). The structure is an asymmetric L-shaped building (Nahshoni and Ziffer 2009). The entrance is into a courtyard with favissae pits (depositories of cultic furnishings) and an altar in it; one figurative offering stand was found here (Nahshoni and Ziffer 2009, Figures 2-5), as well as spools (cylindrical loom weights). From the courtyard there are two passages: to the right, there is an entrance to a square store room with a pit/favissa with cooking vessels and other vessels and cooking pots; to the left, there is an indirect entrance to the temple's cela. This room includes stone benches, a stepped bamah, and a rubble standing stone mazeva; near the bamah, two jars, two rounded stands, a strainer spouted jug (in the 'Late Philistine' decoration style), a bronze knife, and gold foil pieces were found here. Outside the courtyard, another small rectangular structure was excavated with a pebbled floor; here, the intact lion head cup was found (Nahshoni and Ziffer 2009, Figure 18). The finds and plan show mostly local Canaanite characteristics, although the decoration of some of the cultic objects is in the Philistine Bichrome style. The figurative offering stand was published in detail (Nahshoni and Ziffer 2009). The stand decorated in Philistine Bichrome style includes several figures at its base depicting a human, a ram, and a palmette. The shape and iconography of the stand illustrate Cypriote (the shape is an imitation of Cypriote metal stands), Egyptian, and Canaanite characteristics (Nahshoni and Ziffer 2009, pp. 547-54).

Iron Age II temples or shrines in Philistia. There is now more evidence on temples in Philistia with the excavation of Area D at Gath (Dagan et al. 2018) and the very rich favissa from Yavneh (Kletter et al. 2010), which is located in the heart of Philistia (although not in one of the main cities); this adds to the excavation of the temple at late Iron Age Ekron (Complex 650).

In a recent publication (Dagan et al. 2018), two temples dated to late Iron Age I and Iron Age IIA were reported from Gath (Figures 3 and 4). While most cultic objects belong to Stratum D3 (Iron Age IIA, destroyed by Hazael, ca. 830 BCE), the area was used for cultic activities also during Stratum D4 (late Iron Age I) and maybe even Stratum D5 (Iron Age IB). The complete plan of the Stratum D4 temple is not known, yet it is comprised of two elongated rooms lined by three pillars oriented north to south, and a third elongated room on its eastern side (Figure 3; Dagan et al. 2018, p. 31); the entrance was on the south and led to an open courtyard. Among the finds of note from the building is the assemblage of seventeen votive ceramic vessels and a "Tonna Galea" conch shell (Dagan et al. 2018, Figure 3), the latter well known as a cultic object from the Aegean Bronze Age cultures (Hitchcock et al. 2016). The Stratum D4 structure went out of use without signs of destruction, and a temple and associated structures and features of Stratum D3 were constructed above it.

The Gath Stratum D3 temple structure (Figure 3) was comprised of an outer courtyard to the North, three lengthwise rooms (one with stone paving and one with plastered floors and walls), and a broad room at the back of the structure in which a unique monolithic two-horned altar was placed (Figure 4; Dagan et al. 2018, Figure 5). The two-horned stone alter is similar to Iron Age II 4-horned altars, yet the two-horned may allude to the Cypriote horned cultic items (e.g., Maeir 2012). The excavators suggested that the basic plan of the structure is similar, in part, to the plan of the 'four-room house' that is often associated with Israelite/Judahite culture. Many finds of cultic nature were found in the structure (Dagan et al. 2018, pp. 31-33), including 200 astragali; notably very few figurines were found. Next to this building, rooms with additional cult-oriented finds were located, and to the East of the temple, an area with evidence of metal production may also be related to the cultic function in this 
area (see Eliyahu-Behar and Workman 2018). Additional cultic items from Tell es-Safi/Gath include decorated chalices (see below; Gadot et al. 2014).

The Yavneh favissa included at least 120 figurative house models or cultic stands depicting a rich iconographic world (Figure 5; e.g., Kletter et al. 2010). Other finds included over 1000 chalices, shovels, and few other stands and figurative vessels and hardly any figurines. This favissa reflects the furnishing of a nearby temple, probably at Tel Yavneh. The main themes appearing include naked females sometimes standing on lions, bulls, lions as architectural supporters, and the palm tree flanked by two ibexes. Also appearing are musicians in groups and individuals. All these are very distinctive and important Canaanite and Levantine iconographic and religious motifs (see, e.g., Keel and Uehlinger 1998; Ziffer and Kletter 2007). Moreover, the bird motif which is a popular Philistine motif (Dothan 1982; Yasur-Landau 2008), appearing in various media (pottery decoration, figurative pottery, ivories), is absent from the Yavneh assemblage. However, the style of the depictions, especially the human ones, recalls Philistine iconography, as appearing in Aegean-style figurines, Iron Age II figurines and the musicians stand from Ashdod, which also shares the theme (see Ziffer and Kletter 2007; Ben-Shlomo and Press 2009, pp. 41, 58).

The most important temple in Iron Age Philistia so far is the monumental temple-palace structure of Stratum IC dated to the 7th century BCE at Ekron (Figure 6; Temple-Palace Complex 650, sized $38 \times 57 \mathrm{~m}$; Gitin 1998, 2003, Figures 1 and 2). The background for this temple is the flourishing of Ekron under Assyrian and Egyptian rule during the 7th century, and it is becoming a major center in the Near East for olive oil production. The structure was destroyed by the Babylonians in 604 BCE (Stratum IB). The plan of this structure, which was probably a palace or public building that contained a temple within it, resembles both Neo-Assyrian courtyard palaces and Phoenician public structures, especially from Kition (see, e.g., Gitin 1998).

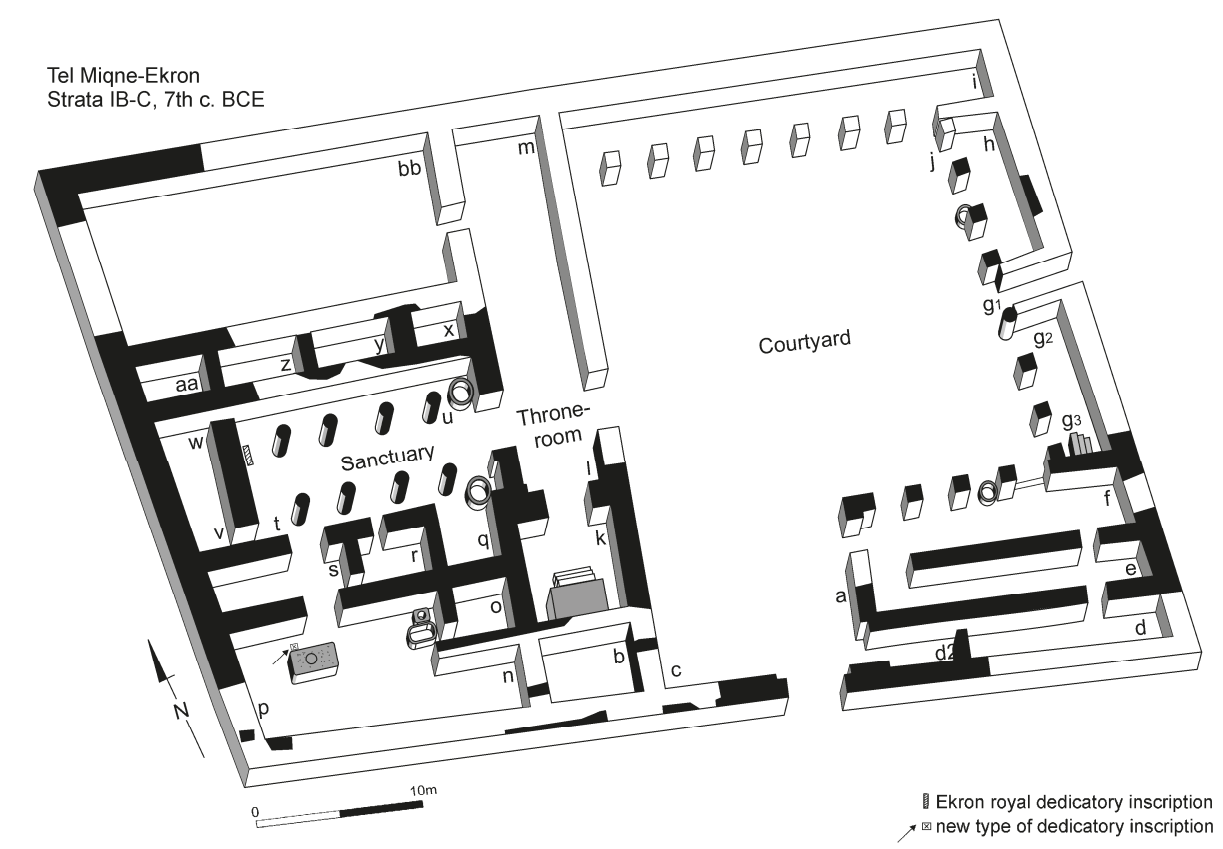

Figure 6. Complex 650 at Ekron (Gitin and Naveh 1997; courtesy of S. Gitin). 
The most important find in this structure is the royal inscription found on its cela (Figure 7; Gitin and Naveh 1997; Gitin 2003, pp. 284-86, Figure 3). It reads: "The house (which) Akhayush (Ikausu/Achish), son of Padi, son of Ysd, son of Ada, son of Ya'ir, ruler (sar 70$)$ of Ekron, built for Pythogaia (Ptgyh), his lady. May she bless him, and protect him, and prolong his days, and bless his land." This inscription mentioning explicitly a goddess of Ekron which is clearly non-Semitic and probably with Aegean affinities will be discussed in more detail below.

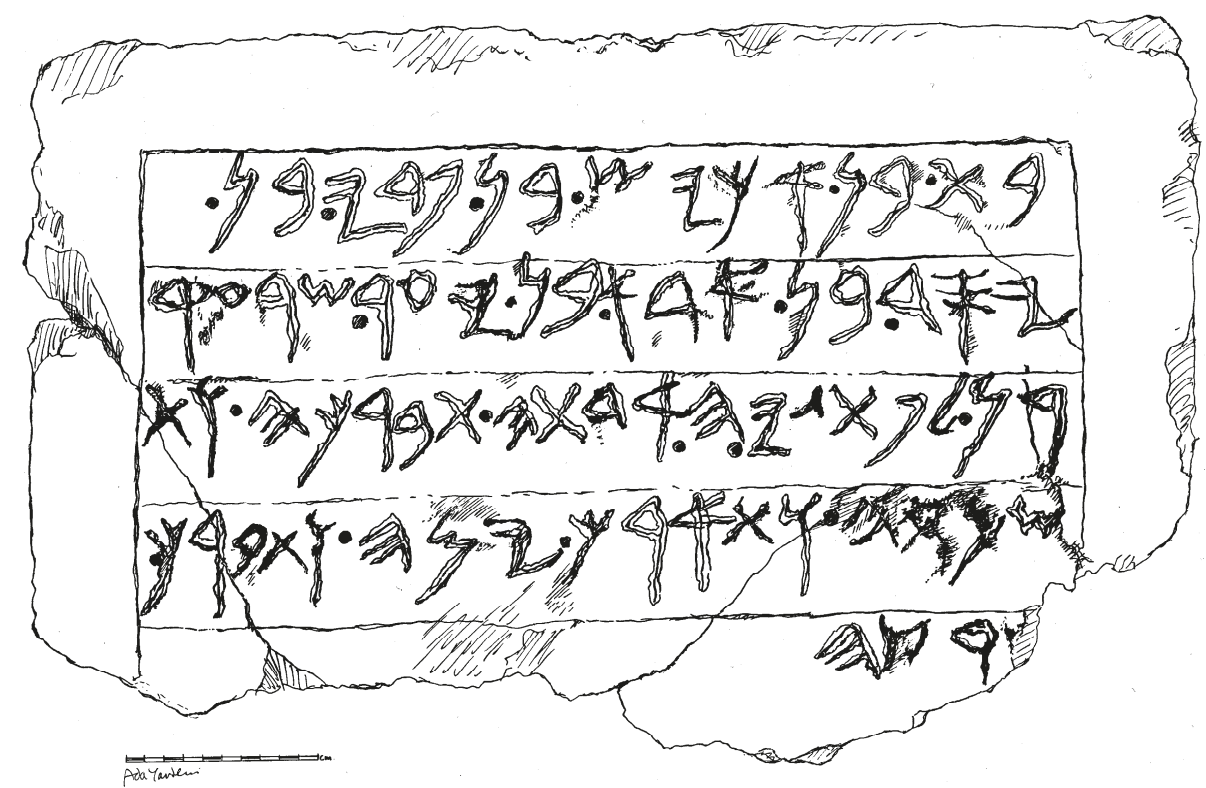

Figure 7. The royal dedicatory inscription from Ekron (Gitin and Naveh 1997; courtesy of S. Gitin).

The structure also contained hundreds of complete vessels, mostly storage jars, as well as a large assemblage of elephant ivories (some are very large and may come from earlier periods in Egypt). Figurative items from the temple and its vicinity are rare, including one hollow female figurine (see below Figure 14:1; Gitin 2003), a bovine zoomorphic vessel, and a possible fragment of a lion head cup (see Ben-Shlomo 2008, pp. 32, 40, Figure 8:3). This structure still awaits, however, a final publication. 


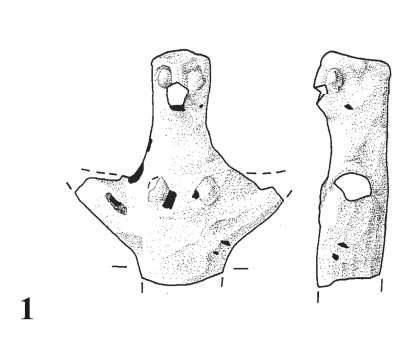

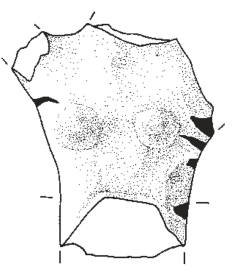

2
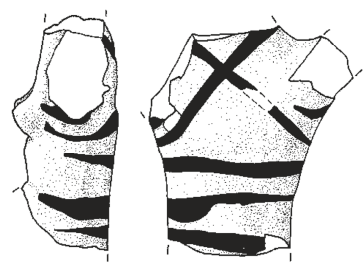
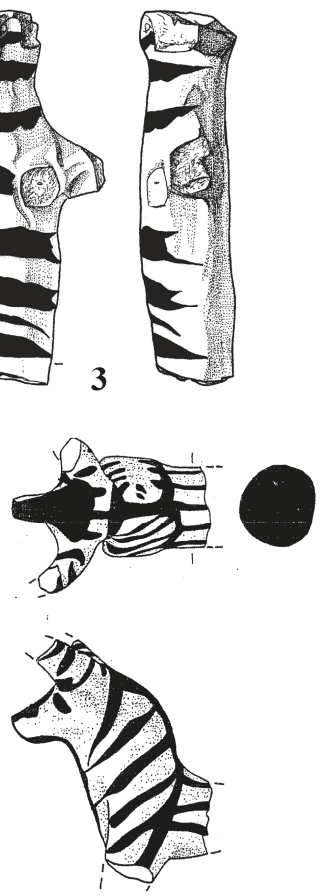

5
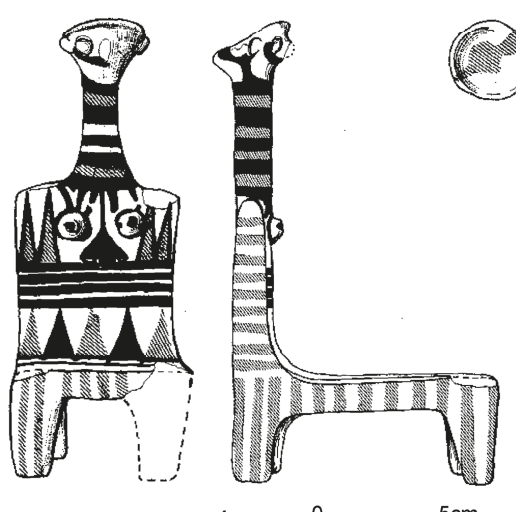

4

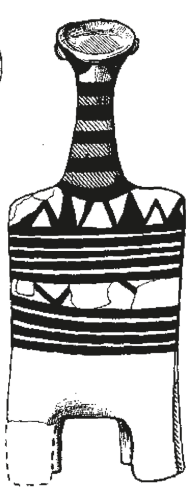

$5 \mathrm{~cm}$

Figure 8. Aegean-style figurines from Philistia (Ben-Shlomo 2014: Figure 1). 1: Psi-type figurine from Ekron (Ben-Shlomo and Press 2009: Figure 1:1). 2: Psi-type figurine from Ekron (Ben-Shlomo and Press 2009: Figure 1:2). 3: Psi-type figurine from Ashkelon (Ben-Shlomo and Press 2009: Figure 1:9). 4: Ashdoda figurine from Ashdod (Dothan 1971: Figure 91:1). 5: Bovine figurine from Ekron (Ben-Shlomo and Press 2009: Figure 16:1).

\section{Household ('Popular') Cult and Religion}

Iron Age I household cultic corners: At Ashkelon Grid 38, a 'house shrine' dated to Iron Age I was reported (Master and Aja 2011). This feature is located in Building 572 of Stratum 20 (12th c. BCE), in a narrow room (Room 572, Installation 539) and is a lime-plastered earth installation, set against the wall, with four protrusions on its upper corners, appearing as a four-horned altar. The identification of the room with this installation as a cultic corner or a 'house shrine' is based on the shape of this unique 
installation; Master and Aja relate it to 'horns of consecration' installation known from Cyprus (Master and Aja 2011, p. 139). Several objects were clustered nearby in the room, including loom weight, a pestle, and a faience grape cluster (Master and Aja 2011, p. 140). At Ekron Area INE 3, a cultic room was also reported from Stratum VI (Dothan 2003, p. 203, Figure 17; Ben-Shlomo 2010, p. 165), on account of its small size and a bench or a 'bamah' attached to the wall; also, a few figurative items were found here (an animal head and a zoomorphic figurine, Ben-Shlomo 2010, p. 165). Also at Ekron, Building 350 includes a room with a 'bamah' which may be a cultic corner or a 'house shrine' (for the finds see below).

Iron Age II household cultic corners: Excavations in Philistia have yielded some evidence for Iron Age II household cults (see Ben-Shlomo 2014). Important evidence comes from the industrial zone in Area D of the lower city (Dothan and Freedman 1967; Dothan 1971), and to a lesser extent from the gate area, in Area M (Dothan and Porath 1982). At Ashdod Area D, a shrine or cultic corner was defined near the pottery workshop (Dothan and Freedman 1967, pp. 130-36; Dothan 1971, pp. 86-92). It should be noted, however, that from the 'shrine' itself (Locus 1010; Platform 1022) no cultic objects were recovered, while many of these were found in refuse pits in the vicinity of the kilns. From the 7th century BCE, a commercial center of the port of Ashkelon was excavated (Grid 50) and some figurines and other cultic objects (as altars, see below) were found in the structures uncovered (Stager et al. 2008, pp. 1584-85;). A cultic corner was excavated in Area A, Stratum A3 at Gath (Locus 62023), probably within a household (Maeir 2008; Maeir et al. 2013, pp. 22-23). The finds in this corner include a ceramic pomegranate, a kernos with bird and cup/vessel, and a zoomorphic vessel (Maeir et al. 2013, p. 22, Figure 9). Two elongated pottery vessels interpreted by Maeir as phallus vessels (Maeir 2007) were also found in the vicinity.
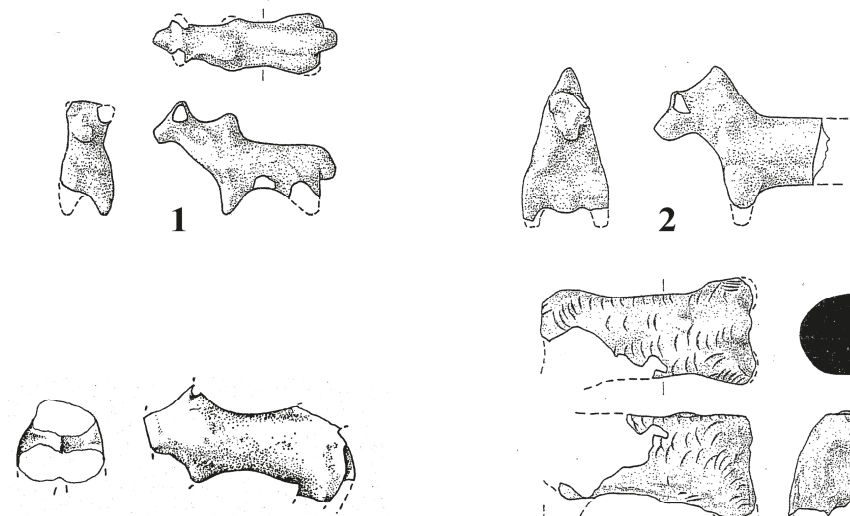

3
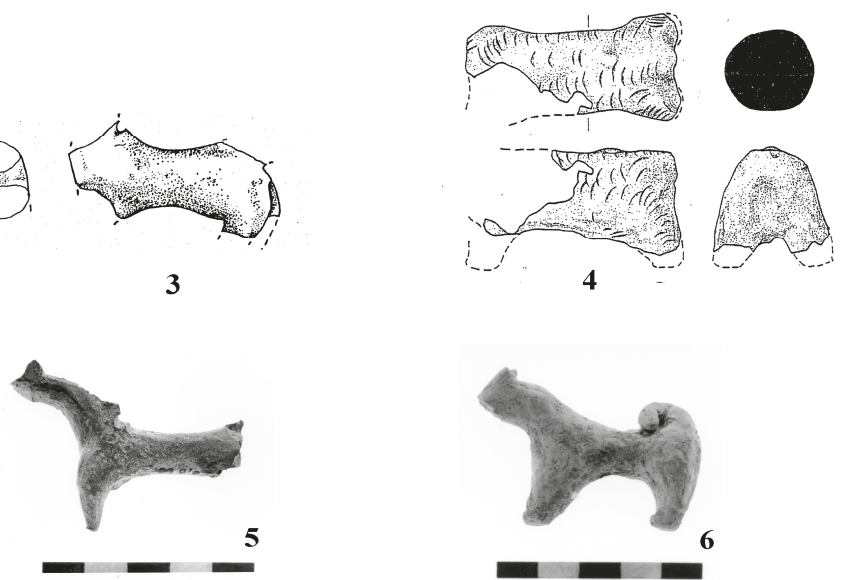

Figure 9. Undecorated animal figurines from Iron Age I Ekron (Ben-Shlomo 2014: Figure 2).

During the late Iron Age II, Ekron flourished, and a vast quantity of olive oil installations were uncovered (see, e.g., Gitin 1998, 2003). From these, especially in Field III, some zoomorphic vessels 
and altars were found; this could be considered an 'industrial context' and the interpretation of cultic activities here could be similar to those in Ashdod Area D (see below).

Several elements of material culture found in household or other domestic or industrial contexts that have apparent relationship to cult and religion will be described (although we have less data on some of these categories). These include mainly figurines, figurative terracottas (including stands and libation vessels), chalices, and altars.

The Iron Age I: Aegean-style figurines. One of the most important pieces of evidence for Philistine domestic cult practices is the Aegean-style figurines appearing in Ekron, Ashdod, and Ashkelon during Iron Age I (Figure 8; Ben-Shlomo and Press 2009). While these finds are not very common, they are important both because of their links to Aegean and Mycenaean culture, and as they seem to be the only type of human figurines appearing in Iron Age I Philistine households. These depictions of clothed or partly clothed females are highly schematic in comparison to the naturalistic and nude Levantine and Canaanite tradition of plaque female figurines appearing during the late 2nd and early 1st millennium BCE (which the former replace in the Philistine cities). Three major types include standing, 'Psi-related' female figurines (Figure 8:1-3), seated female figurines (Figure 8:4, 'Ashdoda'), and decorated bovine figurines (Figure 8:5).

Psi figurines (Figure 8:1-3; Ben-Shlomo and Press 2009, pp. 42-48, Figures 1-4) depict a schematic standing female with its hands uplifted (for the Mycenaean prototype, see Furumark 1941, p. 86; French 1971, pp. 133-39, pl. 22). This type of figurine appears at Tel Ashdod (Dothan and Ben-Shlomo 2005, p. 122, Figures 3.36:2-3, 3.62:2, 3.80:4, 3.115:5), Ekron (Figure 8:1-2; Ben-Shlomo and Press 2009, Figure 1:1-2) and Ashkelon (Figure 8:3; Ben-Shlomo and Press 2009, Figures 1:3-4 and 4; Stager et al. 2008, p. 266; Press 2012) (Schmitt 1999, pp. 594-99, Type I), and a surface find from Tell Qasile (Mazar 1986, p. 14, Figure 6:2, pl. 3b). Various narrow heads with bird-shaped faces may also belong to this type (Ben-Shlomo and Press 2009, pp. 54-55, Figures 10-12), while shorter heads with a concave 'polos' hat (or hair-dress) may belong to seated female figurines or other unknown types of figurines. Several examples preserve the painted decoration depicting the dress and including horizontal lines and an X-shaped strap on the back (Figure 8:2) or a hatched pattern appearing on the front of a figurine, as seen in an example from Ashdod (Ben-Shlomo and Press 2009). This decoration recalls similar Late Helladic (LH) IIIC figurines (Ben-Shlomo and Press 2009; Ben-Shlomo 2014), and indicates that the Philistines had a knowledge of the details of the LHIIIC figurines. 

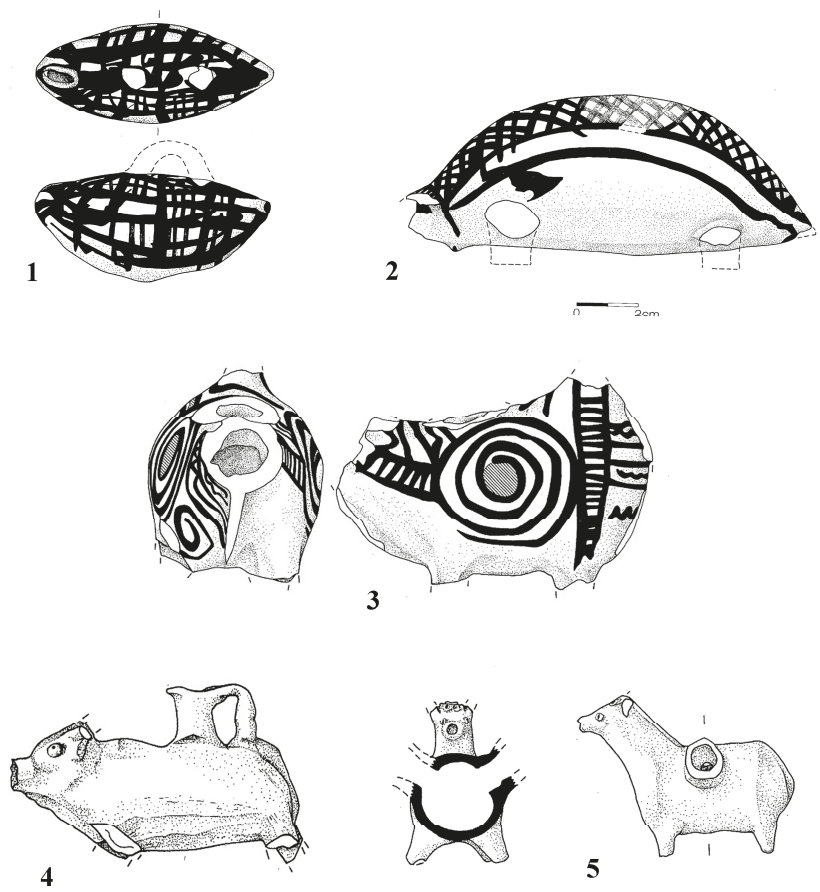

Figure 10. Libation vessels from Ekron (Ben-Shlomo 2014: Figure 3). 1: Bird askos (Ben-Shlomo 2008: Figure 1:2). 2. Hedgehog vessel (Ben-Shlomo 2008: Figure 1:1). 3: Bovine vessel decorated in Philistine style (Ben-Shlomo 2008: Figure 2:1). 4. Bovine libation vessel (Ben-Shlomo 2008: Figure 9:1). 5: Vessel in the shape of a donkey carrying jars (Ben-Shlomo 2008: Figure 9:2).
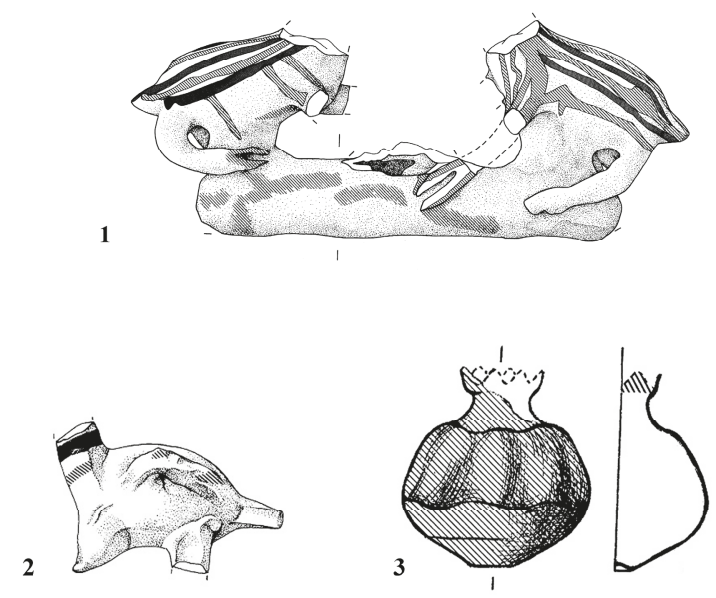

Figure 11. Various cult objects of Iron Age I (Ben-Shlomo 2014: Figure 4). 1: A ring kernos from Ekron (Ben-Shlomo 2008: Figure 10). 2. A bird rattle from Ashdod (Dothan and Ben-Shlomo 2005: Figure 3.36:1). 3. A pomegranate vessel from Ashdod (Dothan and Ben-Shlomo 2005: Figure 3.61). 

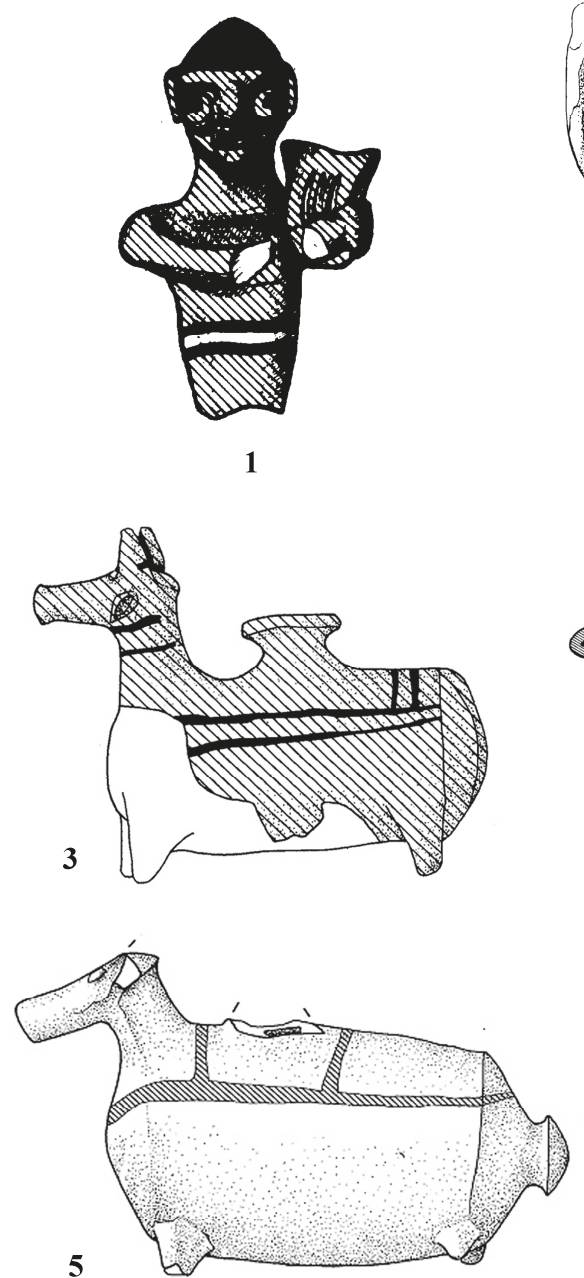
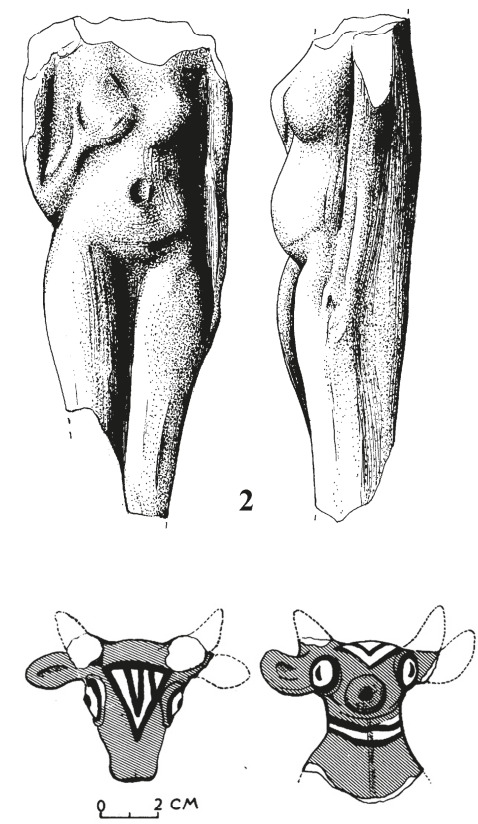

4

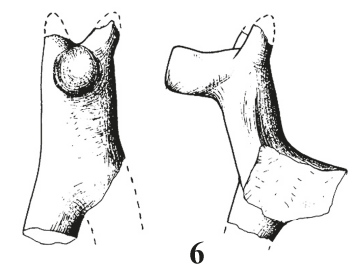

Figure 12. Various Iron Age II terracottas (Ben-Shlomo 2014: Figure 5). 1: A male(?) figurine from Ashdod (Dothan 1971: Figure 62:1). 2. A female plaque figurine from Ashdod (Dothan and Ben-Shlomo 2005: Figure 3.96:5). 3. Bovine libation vessel from Ekron decorated in the 'Late Philistine style' (Ben-Shlomo 2008: Figure 5:1). 4. A bull's head spout from Ashdod (Dothan 1971: Figure 68:6). 5. A late Iron Age bovine vessel from Ekron (Ben-Shlomo 2008: Figure 7). 6. tA 'Judean' style horse figurine from Ashdod (Dothan and Porath 1982: Figure 34:7).

A second type of terracotta figurine which is typical of the Philistine material culture throughout the Iron Age, and is better known, is the seated female figurine, nicknamed Ashdoda (Figure 8:4; Ben-Shlomo and Press 2009, pp. 49-54, Figures 5-9; Dothan 1971; Dothan 1982, pp. 234-37; Schmitt 1999, pp. 608-16, Type III; Yasur-Landau 2001; Press 2014). Based on the nearly complete example from Ashdod (Figure 8:4), which stands $17 \mathrm{~cm}$ high, the basic features of this type can be reconstructed. The figurine represents a seated female: there is a small schematic head with a low, flaring polos, a long neck, a very schematic vertical flat body with applied breasts, and a seat with four legs. The details of the face include two applied pellet eyes and applied nose, relatively prominent when preserved. Some head fragments also have applied ears (Dothan and Porath 1993). The breasts are usually very small, 
adding to the schematic nature of this figurine. The shape of the seat is either rectangular or square. Larger examples of Ashdoda figurines also occur, as indicated by the large leg of a seated figurine found in Ekron Stratum IV, with Philistine Bichrome decoration, and possibly by large heads from Ekron and Ashkelon (Ben-Shlomo and Press 2009, p. 53, Figure 5:2, Figures 8 and 10:5). It is possible that the Ashdoda figurines were typically larger than other female figurines, specifically the Psitype; the nearly complete example, however, is relatively small.

The Ashdoda figurine shows in its form a mixture of Aegean and Canaanite features (Brug 1985, p. 186), yet its concept originates from Mycenaean seated female figurines (French 1971, pp. 167-72; Dothan 1982, p. 234). According to the evidence from Ekron, Ashdod, and Ashkelon, this type of figurine does not appear before the latter part of the 12th century BCE, nor does it appear in the typical Philistine Monochrome decoration or fabric (the figurines are either decorated in Philistine Bichrome style or undecorated). Although there is only one complete example yet found, it seems that both the Psi-type and the Ashdoda-type appear in domestic contexts (Yasur-Landau 2001, pp. 336-37; Ben-Shlomo and Press 2009, pp. 61-62).

Another type of Aegean-type female figurine, the mourning female figurine (also depicted standing with raised arms), was noted by (Dothan 1969), yet none of these were found in archaeological excavations.

A type appearing so far only at the earliest Iron Age I levels at Ekron is the decorated bovine figurine (Figure 8:5; Ben-Shlomo and Press 2009, pp. 58-60, Figures 16-18). Decorated zoomorphic figurines are not known otherwise in the early Iron Age southern Levant. The most complete example was found on the east slope of the acropolis in Stratum VIIA. Parallels come from the Aegeam LH IIIC and Cyprus (Ben-Shlomo and Press 2009).

Other Iron Age I zoomorphic figurines. Undecorated crude terracotta zoomorphic figurines from early Iron Age Philistia (Figure 9) appear in rather large numbers in the Philistine cities, especially at Ekron (Figure 9), and may be a significant phenomenon related to the Philistine material culture, as such figurines are not common in LBII contexts of southern Israel. More than forty undecorated zoomorphic figurines (most are fragments) were found in Iron Age I levels at Ekron (Figure 9). Few Iron Age I examples were published from Ashdod (Dothan 1971; Dothan and Ben-Shlomo 2005, p. 123, Figure 3.36:8; Dothan and Porath 1993, p. 79, Figure 35:7), and some were also reported from Iron Age I levels at Ashkelon (Press 2012). Most of these figurines are made of coarse clay rich with organic temper; they were not fired in a high temperature and in many cases carry black soot residues, as if they were put in a fire. The figurines are schematically modeled by fingertips and usually only few typical characteristic details are portrayed, although more detailed and naturalistically shaped ones occur as well (as in Figure 9:1). In the smaller figurines, most details are created by pinching the clay rather than by application; the only decoration of these figurines is by incisions or fingernail marks (Figure 9:4). In some cases, the animal depicted cannot be identified, as the objects are too fragmentary, or lack indicative anatomic details. However, it seems that the most dominant animal depicted is the bull (see Ben-Shlomo 2010, 2014). Undecorated crude zoomorphic figurines were published from LHIIIC contexts in the Aegean and Cyprus (see Ben-Shlomo 2014, pp. 80-81). These figurines were possibly used in Philistine houses for some sort of cultic practice. Similar crude zoomorphic figurines appear in various locations in the eastern Mediterranean during the 12th c. BCE and, although these finds are not predominant, they do not seem to occur prior to the 12th century BCE and their appearance at this stage could indicate a new culture. These figurines may represent domestic cult or other symbolic practices, maybe of a voodoo-like or 'sympathetic witchcraft' nature (similar in a way to those attested, for example, by similar Neolithic figurines, Schmandt-Besserat 1997).

The Aegean-style figurines from Philistia probably represent domestic cultic activities of Philistine immigrants, who retained elements of the religion of their motherland; the argument is based both on the contexts of these finds in Philistia, and on those of similar finds in the LHIIIC Aegean (Ben-Shlomo and Press 2009). This evidence does not seem to indicate the presence or activities of an elite or priesthood class originating from a palatial Mycenaean society (related to the 'wanax-hearth' ideology), 
but rather indicates nonpublic activities of a nonelite population. Analysis of numerous immigrant societies has shown that usually migrants do not belong either to the highest strata of society, neither to the lowest (see Berry 1997; Burmeister 2000, pp. 545-46 for references); they often are constituted from various groups of medium socioeconomic strength in their origin society. Thus, it may not be surprising that the Aegean elite affiliated palatial cultural elements are not evident so far in the Philistine culture. Burmeister has indicated that, when dealing with reflection of immigrants on material culture, more emphasis should be given to domestic daily practices and assemblages rather than to public, or burial ones (Burmeister 2000, p. 542). It should be noted, however, that no clear public temple context was yet excavated from the Philistine main cities.

Iron Age I Libation vessels. Figurative libation vessels from Philistia (Figure 10), mainly in the shape of animals, were also probably used for some ritual or cultic activities (both in temples and in households). Several of these vessels show strong links to Mycenaean vessels, and can be added to the group of Aegean-style cultic objects appearing in early Iron Age Philistia (Ben-Shlomo 2008). These include bird-shaped 'askoi' (Ben-Shlomo 2008, p. 25, Figure 1:2) and a hedgehog vessel (Figure 10:2; Ben-Shlomo 2008, p. 25, Figure 1:1, references and discussion therein). These belong to the 'Philistine Monochrome' ware, and show similarities to LHIIIB-C examples from the Aegean and Cyprus in their shape, decorative pattern, technique, and fabric. Other libation vessels appearing in Philistine houses at Ekron and Ashdod include bovine and bird vessels decorated in Philistine Bichrome decoration style (but showing local tradition in morphology and iconographic style, Ben-Shlomo 2008, pp. 27-29, Figures 2 and 3). Other libation vessels depicting bovines (Figure 10:4) or equines carrying jars (Figure 10:5), which appear in Iron Age I Philistia, reflect a continuation of Canaanite and Levantine traditions (Ben-Shlomo 2008, pp. 36-39, Figure 9).

A somewhat different type of ceramic figurative vessel is the kernos (Figure 11:1) which is a tubular ring with various head spouts and vessels attached to it. Kernoi appear during the late Iron Age I and Iron Age IIA in Israel and are essentially a Levantine form, but are especially popular in Philistia (Mazar 1980, pp. 109-11; Ben-Shlomo 2008, p. 39) also during Iron Age IIB-C (see below). A nearly complete kernos with two animals, probably ibexes or goats, was found in Building 350 at Ekron (Figure 11:1; Ben-Shlomo 2008, p. 39, Figure 10). Bird-shaped rattles (Figure 11:3, from Ashdod) may also be related to cult.

Lion-shaped head cups decorated in Philistine Bichrome style were previously associated with Philistine cult (Dothan 1982, pp. 229-334; Mazar 1980, pp. 101-3, Figures 34 and 35; Mazar 2000; Maeir 2006; Ben-Shlomo 2008, pp. 34-35, Figure 8), yet this is probably a Levantine vessel-type as well (see Ben-Shlomo 2008, p. 35, Ben-Shlomo 2010, pp. 125-30; Meiberg 2013; for references). These vessels are rare and appear mostly in temples (i.e., Tell Qasile and Nahal Patish, see below); it seems that this vessel continues to appear during Iron Age II as well (Maeir 2006; Ben-Shlomo 2008).

Pomegranate vessels, always decorated in red slip, are also probably a Canaanite vessel-type but, again, especially popular in this period, and appear both in temples and households (Figure 11:3; Dothan and Ben-Shlomo 2007, with examples from Ekron, Building 350, Ashdod and the Tell Qasile temple).

The Iron Age II: Figurines and figurative stands and models. During Iron Age II, the typical Canaanite naturalistic nude female plaque figurines or the 'Astarte' figurines (see, e.g., Pritchard 1943; Tadmor 1982; Keel and Uehlinger 1998, pp. 97-105; Moorey 2003, pp. 35-46) reappears in Philistia (Figure 12:2). These figurines return to the Philistine sites during Iron Age IIA-B at Ashdod (Figure 5:2; Dothan and Freedman 1967; Dothan 1971; Dothan and Porath 1982; Dothan and Ben-Shlomo 2005, p. 213, Figure 3.96:4-5; see also Keel and Uehlinger 1998, p. 228, Figure 217), Ashkelon (Press 2007, pp. 105-9, Figure 9, cat. nos. 62-67), Ekron (Gitin personal communication) and Gath (Maeir personal communication) (see Also Tell Jemmeh, Ben-Shlomo et al. 2014). The symbolism communicated by these figurines is quite clearly also associated with female fertility. Examples of a plaque figurine depicting a 'drummer' were also found at Ekron. These Canaanite style plaque figurines appear alongside with 'debased' or late Ashdoda figurines at Ashdod (Ben-Shlomo and Press 2009, p. 53, 
Figure 8:1 and Figure 9, references therein), possibly indicating influence or certain adaption of local religious practices. Also to be noted is a seated male figurine recently published from Gath (Maeir 2008); Maeir interprets it as depicting the Canaanite god $E l$; this is so far a unique example of such a male figurine in Philistia.

During this period, Israelite- or Phoenician-type female figurines also appear, especially at Ekron (Figure 12:1; Gitin 2003, p. 287, Figure 4, an example which comes from the cela in Temple Complex 650), and Ashkelon (Press 2007, pp. 216-32, Figures 6 and 7, cat. nos. 31-61); these are rather rare at Ashdod. Judean pillar figurines ('JPF', e.g., Kletter 1996, 2001), probably related to some 'Asherah cult' (see, e.g., Olyan 1988; Hadley 2000, more references therein), were also found in small numbers in eastern Philistia as at Ekron (Gitin personal communication) and Gath (Maeir personal communication), as well assites on the border of Philistia (as at Batash, Beth Shemesh and Gezer, see Kletter 1996, 2001). Very few of these types of figurines were found at Iron Age II Ashdod, presumably, due to its greater distance from Judah in comparison to Ekron and Gath (Kletter 2001, pp. 185-88). At Ashkelon, a regional style of Iron Age II hollow female figurines is suggested (Press 2007, pp. 216-32).

The typical Iron Age IIB-C horse or 'horse and rider' figurines (Figure 12:6), which are very common in Judah, are also very rare in the Philistine cities (except at Ashkelon). Another group of terracottas includes figurines and depictions on cultic stands that illustrate a certain continuation of the Philistine style. These include several figurine heads (of either male or female) from Ashdod (Figure 12:1), Ashkelon and Ekron (Ben-Shlomo and Press 2009, p. 58, Figure 15:2-3) and the Musicians' stand from Ashdod (Figure 13) (as well as depictions on the cultic stands from Yavneh, see above Figure 5:2). The Musicians' stand (Figure 13; Dothan and Ben-Shlomo 2005, pp. 180-84, Figures 3.78-3.79), dated to Iron Age IIA (Stratum X), is a rare depiction of a complete ensemble of musicians from the Iron Age (Paz 2007, pp. 50, 68-71), now paralleled to some extent at Yavneh (Ziffer and Kletter 2007, pp. 24-25, 70-75, no. 1036; see below; the stand from Temple 131 at Tell Qasile depicts a group of dancers, Mazar 1980, pp. 87-89, Figure 23, is also made in the same technique). This could be a depiction of an orchestra (the 'Canaanite orchestra', Paz 2007, pp. 98-101) playing in a temple or in a certain religious ritual. The relationship between musicians and cult and temples is attested also in the Old Testament: musical instruments mentioned are cymbals, lyres, harps (violin), tambourines, and trumpets (e.g., 1 Chr 13:8, 15:16,19, 25:1,6; 2 Chr 5:12-13). These instruments, associated with prophets, priests, and Levites, facilitated emergence into an ecstatic state. For example, note the passage describing the anointment and prophecy of Saul, which specifies a group of prophets playing the flute, lyre, tambourine, and harp (violin) (1 Sam 10). In what way these themes were incorporated in the Philistine religion is still obscure to us. 

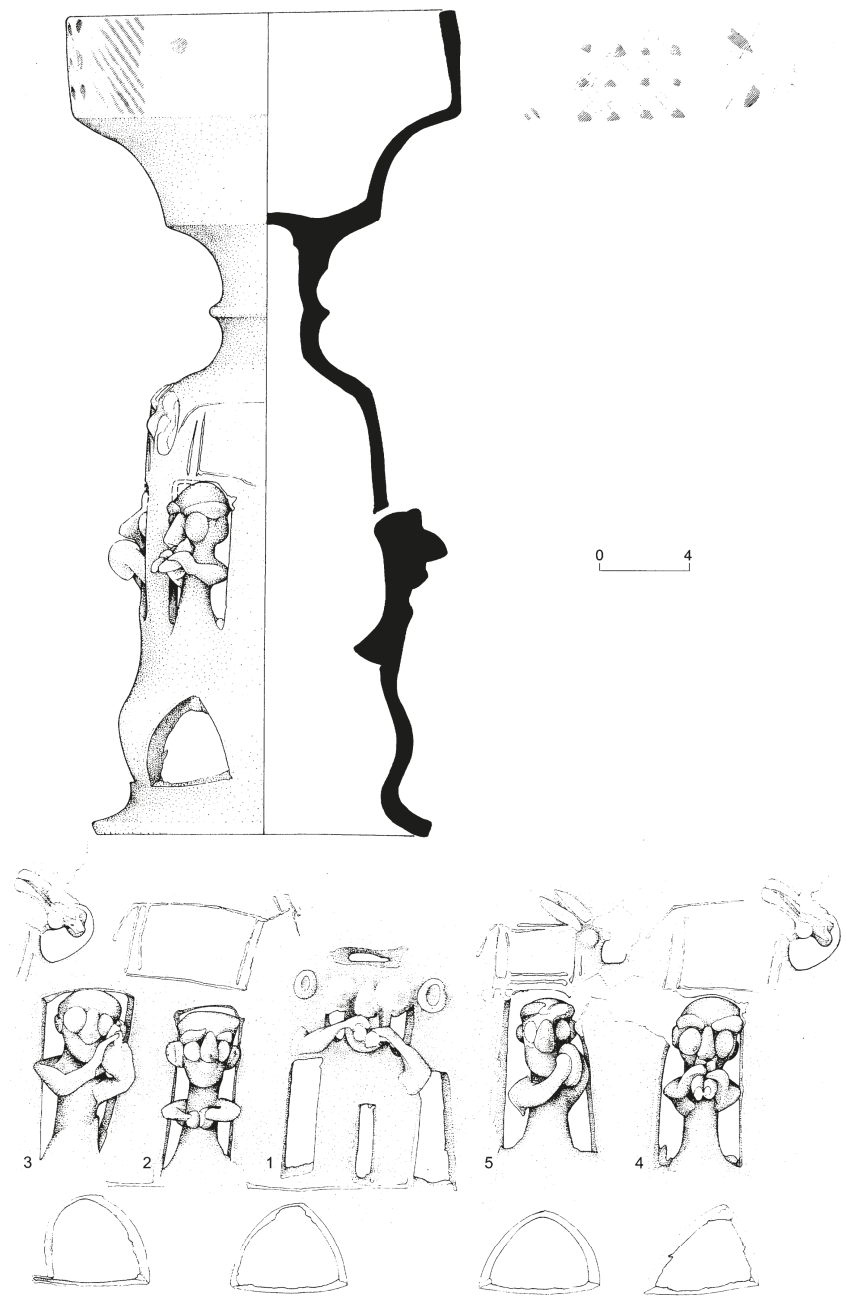

Figure 13. The Musicians' stand from Ashdod (Dothan and Ben-Shlomo 2005: Figure 3.76).

Also to be noted are rare and peculiar items unique to Ashdod, that may have been cultic objects used in Iron Age II in this Philistine city. These are 'knobbed stands' (Figure 14:2; having a row of knobs on their lower part) appearing in Ashdod in Area D in the cultic room or shrine (Dothan and Freedman 1967) and in a possible cultic corner from Area K (Dothan and Ben-Shlomo 2005, Figure 2.48). 

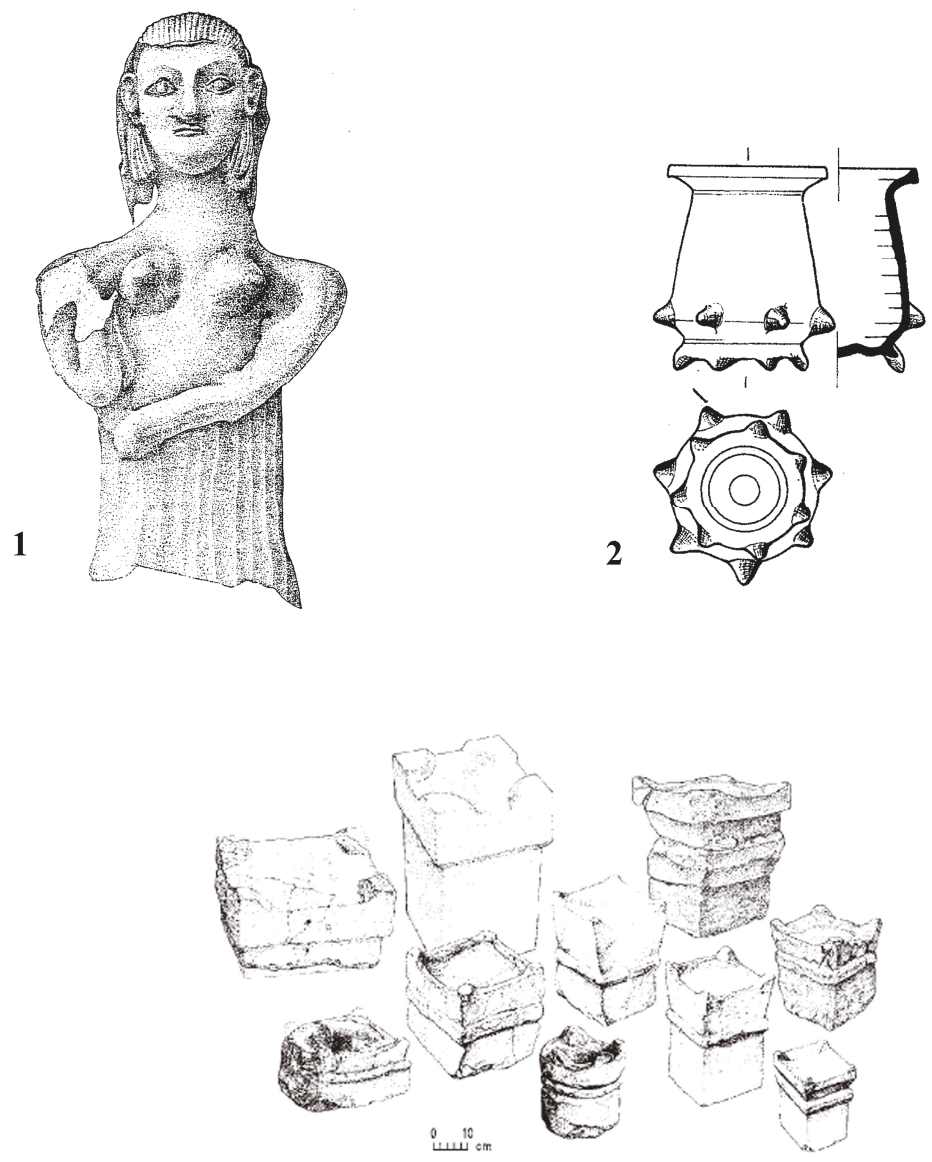

3

Figure 14. Late Iron Age II cultic objects from Philistia (Ben-Shlomo 2014: Figure 7). 1: A hollow female figurine from Ekron, Temple Complex 650 (Gitin 2003: Figure 4). 2: A knobbed stand from Ashdod (Dothan and Freedman 1967: Figure 38:7). A group of four-horned portable altars from Ekron (Dothan and Gitin 2008, p. 1955).

Iron Age II libation vessels. Libation vessels (especially zoomorphic) continue to be popular in Philistia, and even more so, during Iron Age II (Figure 12:3-5). This is especially evidenced by a large group of kernoi and libation vessels from Ashdod (Figure 12:4; e.g., Dothan 1971, pp. 125-35, Figures 66-71; Dothan and Ben-Shlomo 2005, p. 197, Figure 3.86; dating mostly from the tenth-eighth centuries BCE (Strata X-VIII). Most are depicting bovines and are decorated in the Late Philistine Decorated style or Ashdod Ware (Figure 12:3,4; Ben-Shlomo et al. 2004) with red burnished slip and black and white pained patterns (Ben-Shlomo 2008, p. 30, Figure 5). Several of the horned head spouts are decorated with triangles, circles, or other shapes on their forehead (Figure 12:4; Dothan 1971; these also appear in Ekron). This could be a depiction of an ornament hung on the bull's forehead, or possibly a reference to the Egyptian god Apis, depicted with the sun rising between his horns.

Another distinctive group of late Iron Age libation vessels comes from the 7th century BCE Ekron, and includes a large group of rather standardized and large schematic bovine vessels (Figure 12:5; Ben-Shlomo 2008, pp. 32-33, Figures 6 and 7, references therein). This is a large, wheel-made bovine 
libation vessel with a large barrel-shaped body and a hollow button-shaped protrusion depicts the tail; the body is decorated with red design, probably depicting a harness. Two complete examples were found in relation to an oliveoil installation in Field IIINE (Figure 12:5); another complete example was found in the Stratum IB destruction debris in Room V of Temple Complex 650, just behind the sanctuary's cela (Gitin 1998, pp. 173-74, Figure 11). These wheel-made, schematicallydepicted uniform types of bovine zoomorphic vessel may have been produced on a more 'industrial' scale (and they also appear in connection to the olive oil industry).

Possibly, the concentration of kernoi, libations vessels, late Ashdodas, offering tables and plaque-type figurines in several pits in Area D at Iron Age IIB Ashdod (Dothan 1971; Hachlili 1971) may be related to the industrial activities taking place in this area as well. Cultic activities in local industrial contexts can also be linked or similar to 'household religion', as it is equally ranked on a lower sociohierarchic tier. Other examples of the industry-cult linkage come from the mining temple at Dan (Biran 1992, p. 143, Figure 118), Timna (Rothenberg 1988, pp. 270-76), the Iron Age at Khirbet el Mudeyina, Jordan (Daviau 2007), and Late Bronze Age Cyprus (Begg 1991, pp. 47, 69); these relate to metallurgical and agricultural industries. In the case of the bovine libation vessels from Ekron, the bull may represent an agricultural/industrial fertility symbol, a specific deity, or its vehicle.

It is difficult to reconstruct either the cultic practices conducted with these libation or figurative vessels or their exact ritual and religious meaning and significance without further archaeological and especially textual evidence. Yet, naturally, the bull as well as lion are important symbols in the Canaanite and Aegean cultures and religions (see Ben-Shlomo 2008, pp. 40-42, and more references therein); pomegranates are also important in various aspects of Mesopotamian, Canaanite, Israelite, and Greek religions and mythologies (see Dothan and Ben-Shlomo 2007).

Chalices: Chalices found in Philistine sites during Iron Age II can also be considered cultic (Gadot et al. 2014), yet they probably reflect Canaanite religious culture. These vessels, often covered by white chalky slip and decoration applied after firing, may have been used in temple, shrine, or household rituals, related to religion or otherwise. A multidisciplinary study of chalices from temples at Philistia (at Yavneh and Nahal Patish) and domestic (Tell es-Safi) contexts, employing petrography and residue analysis, was carried out (Gadot et al. 2014). All chalices analyzed were locally produced and, according to residue analysis, were used as incense burners, employing mild head, in which an oily bed was liquefied probably in order to help evaporate hallucinogenic substances (as trimyristin compound was detected, highly abundant in plants that are known to cause hallucinogenic effects; Gadot et al. 2014, p. 71).

The Iron Age II: Altars and other items. Another important group of items relating to cult and religion in late Iron Age Philistia are the four-horned portable stone altars, studied in detail by Gitin (Figure 14:3; Gitin 1989, 1992, 1993, 2002, 2003, 2008). These appear especially at Ekron and Ashkelon also in relation to olive oil installations (at Ekron and Batash; see also at Jordan, Daviau 2007) and in the commercial center of the port of Ashkelon, and were probably used for incense burning. However, their connection to household cult and religion is rather questionable. Gitin sees them as evidence for 'decentralized' official religion, and as reflecting Israelite influence (2008). Other items occasionally found in Philistine sites and related to cult of some sort are massebot (standing stones), notched bovine scapulae (see Zukerman et al. 2007; Dagan et al. 2018).

\section{Discussion: Can We Reconstructing a Philistine Religion?}

The evidence so far indicates that temple or official cult in Iron Age Philistia shows stronger links to the local Canaanite culture continuing from the LB II through the Iron Age. In particular, this is evidenced in the ground plan of the temples known so far from Qasile, Gath, and Patish. Notably, these are mostly peripheral sites in Philistia, and a public Iron Age I temple from the main Philistine cities was not yet excavated. While these sites may not be considered originally Philistine sine (as the five main cities), they are located in the geographic region of Philistia, which was likely under influence from the Philistine material culture by late Iron Age I. The finds from these temples (including 
the Yavneh Favissa) also indicate a continuity of Canaanite iconography in motifs, yet the style and decoration is often in the Philistine Bichrome style. On the other hand, especially during Iron Age I, evidence of household cult in Philistia, including the main Philistine cities, shows meaningful links with contemporary household cult in the Aegean and Cyprus (Ben-Shlomo 2014). In particular, this is evidenced by the figurines showing Aegean affinities in the main Philistine cities, while no traditional Canaanite figurines appear in Philistia during Iron Age I. This changes during Iron Age II, as Aegean affinities of household cult are fewer and the Canaanite and local-style figurines appear. This change could be due to a certain assimilation or acculturation of the Philistine population, intermarriages, etc., or a decrease in the motivation of this population to 'resist' local cultic practices.

Various modern examples show how immigrants are more faithful to their homeland practices in their private domain and confirm more with the host culture in the public domain (see, e.g., Ostergren 1988, pp. 199-203; Burmeister 2000, p. 542). The differences between household-temple and Iron Age I-Iron Age II Philistine cultic assemblages were summarized in Table 1 and seem to strengthen the immigrant nature of the Iron Age I Philistine phenomenon.

The issue of the actual contents and nature of the Philistine religion itself, as the identity of the gods worshipped, however, is still relatively obscure. This is due to the lack of texts and the fact that no major temple from the main Philistine cities was excavated during Iron Age I-IIA. Moreover, no temple was discovered dating to the initial stage of the Philistine settlement. Nevertheless, one may attempt to reconstruct at least segments of this religion according to the archaeological evidence from Philistia, the few short biblical references, and iconographic and textual references, though few and sometimes indirect, from contemporary Near Eastern sources.

The Aegean-style female figurines in Philistia could be interpreted in various ways. They can be seen as representing goddesses, priestesses, devotees, or votives. Concerning the identification of the seated figurines (Figure 15:3), it has been suggested that they depict an Aegean goddesses seated on a throne ('the enthroned goddess', see, Yasur-Landau 2001, 2008), in line with various Aegean depictions of a similar type of goddess (Figure 15:1, depicted on a seal from Mycenaean Tiryns; see, Nilsson 1968, pp. 350-51; Rehak 1995, pp. 106, 116-17). Similar seated figures appear on a cylinder seal from Ashdod (Figure 15:4), and possibly on a krater from Ashkelon (Figure 15:2; as suggested by Yasur-Landau 2008), there, holding a drinking vessel. The Ashdoda figurines have been interpreted as goddesses in several studies dealing with Philistine cult and religion (Singer 1992; Schmitt 1999, pp. 635-43; Mazar 2000; Yasur-Landau 2001), although the identity of this goddess has not been agreed upon: while (Dothan 1982, p. 234, Mazar 2000, p. 223), and (Yasur-Landau 2001, 2008) have stressed its Aegean identity, Brug proposed a Canaanite origin (Brug 1985, p. 186) and Sherratt suggested a connection with the cult of sailors and merchants of the eastern (Mediterranean, Sherratt 1998, pp. 306-8). Singer, meanwhile, suggested a connection to the Anatolian Kybele/Kubaba (Singer 1992). 
Table 1. Comparison between cultic elements appearing in households, possible temples, and temples in Philistia.*

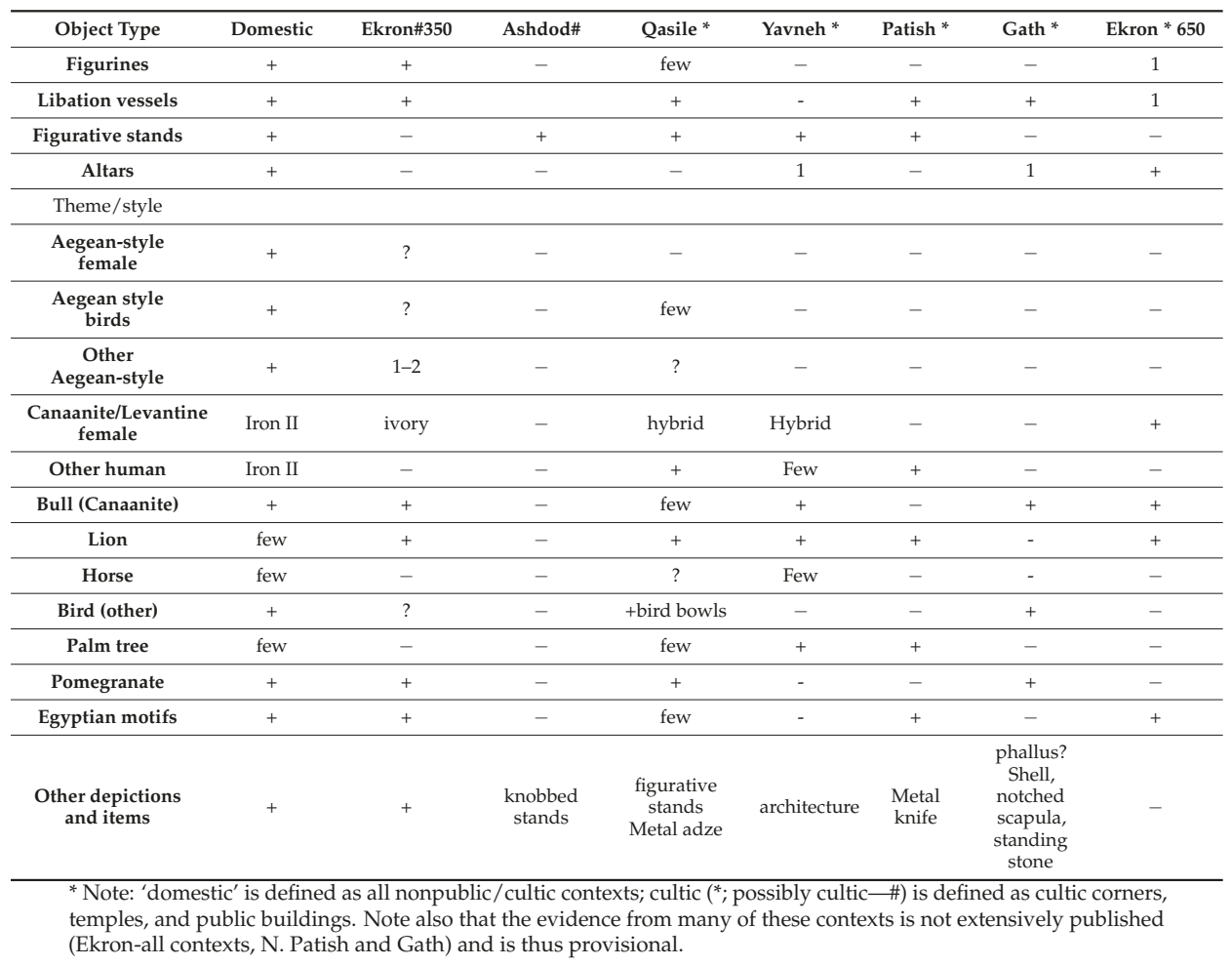

Given the iconographic depiction-a seated and clothed figure-the Aegean identity is most probable, and is likely to be related to the important or even principal role the seated female image (an 'enthroned goddess', queen goddess or 'mother goddess') played within the Aegean society and cult (Rehak 1995). Therefore, there is good reason to conclude that the deity worshiped by the dwellers of at least some of the households in the main Philistine sites during Iron Age I was depicted by these Ashdoda figures (and also possibly the Psi figurines), linking it with an Aegean or Mycenaean goddess.

Interestingly, there might be a late Iron Age II (8th century BCE) reference to this Philistine goddess (see also Ziffer and Kletter 2007, p. 29). A group of deity statues is seen on a depiction of a procession of god statues looted from captured cities from the Tiglath-pileser III southwest palace of Nimrud (Figure 15:5; Barnett and Falkner 1962). There is a good possibility that these gods come from Gaza in relation to the rebellion of king Hanun (Uehlinger 2002, p. 115, and references therein). In the procession, the female seated goddess on the far right (Figure 15:5, far right) seems to be depicted holding a conical cup (a kylix[?], similar to the Ashkelon depiction in Figure 15:2) (see also Ziffer and Kletter 2007, p. 29, though, the item held is interpreted there as a flower or a ring and sheaves of grain, linking it with the Anatolian goddess Kubaba). If so, it would be a depiction somewhat similar to Aegean depictions of the seated goddesses (see above). The other goddess in Figure 15:5 holds a ring and may not be clearly identified (as well as another small-sized standing god/goddess), while the male god depicted on the left resembles the Mesopotamian/Levantine weather god (e.g., Uehlinger 1997, p. 127). This Assyrian depiction could have thus indicated that the major official temples in the Philistine cities did have life-size (probably composite) statues depicting their gods in them. 
1

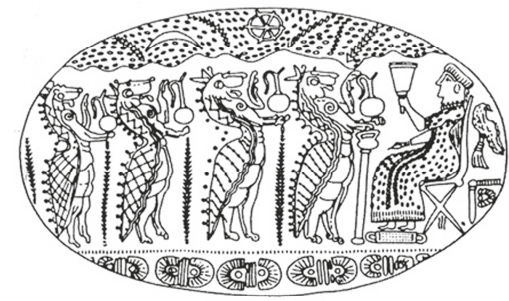

2
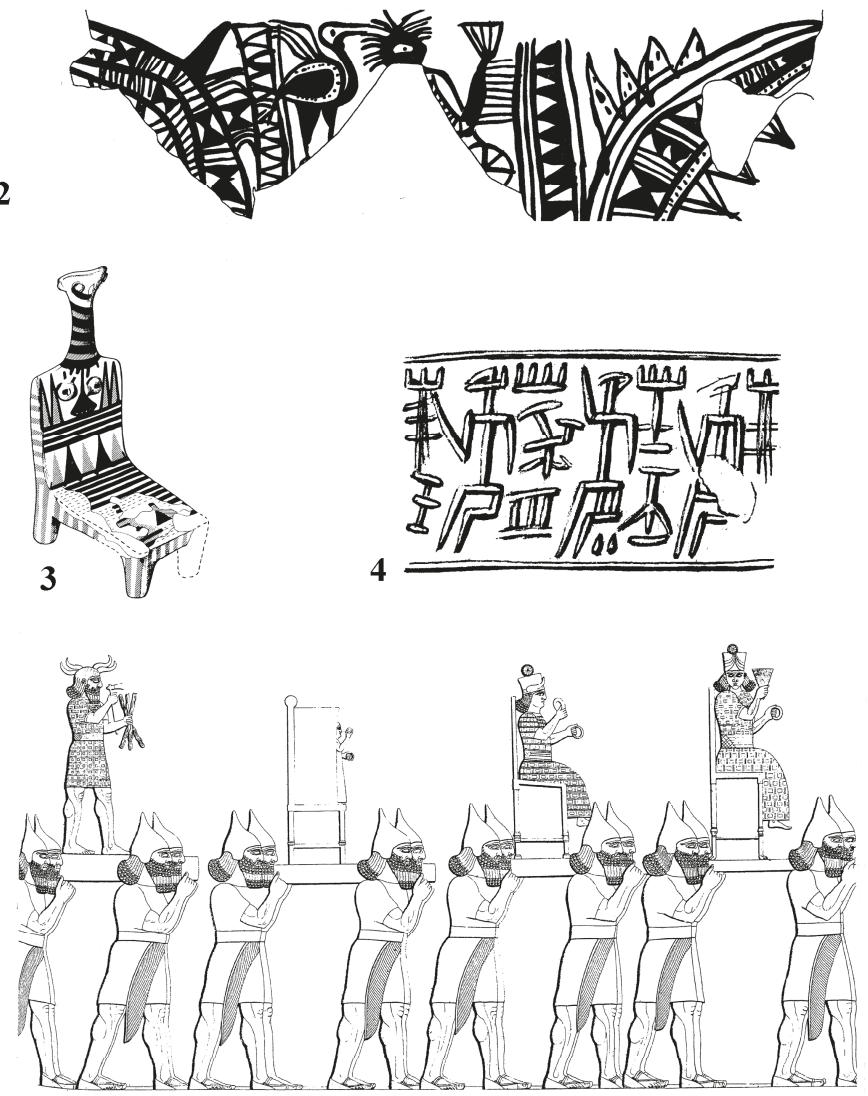

5

Figure 15. The 'enthroned goddess' motif (Ben-Shlomo 2014: Figure 9). 1. A seal from Mycenaean Tiryns, Greece (after Yasur-Landau 2008: Figure 3:3). 2. A pictorial krater from Ashkelon (Stager et al. 2008: Figure 15.40; courtesy of the Leon Levy Expedition to Ashkelon). 3. The Ashdoda figurine (Dothan 1971: Figure 91:1). 4. A cylinder seal from Iron Age I Ashdod (Dothan and Ben-Shlomo 2005: Figure 3.66). 5. A procession with statues of gods looted from Gaza(?), from the Tiglath-pileser III southwest palace of Nimrud (after Barnett and Falkner 1962: pl. 92).

As noted, the royal inscription from 7th century Ekron (see above Figure 7) also mentions a goddess of a probable Aegean name: Ptgyh, king Ikausu's 'lady' (note, Potnia in the Mycenaean world $=$ lady). Ptgyh has been associated with the sanctuary at Delphi known as Pytho, the shrine of 
Gaia, the Mycenaean Mother Goddess (e.g., Schäfer-Lichtenberger 2000; Gitin 2003, p. 286; Berlant 2008). This goddess is mentioned as the local king's 'lady' in the royal inscription found in the very cela of the large temple complex of Iron Age IIC Ekron (e.g., Gitin and Naveh 1997; Schäfer-Lichtenberger 2000). This is indeed the 'smoking gun' indicated by (Gitin 2003, p. 286) in regards to evidence of late Iron Age Philistine religion, probably linking it with the western origin of the immigrants, arriving at the Levantine coast some 600 years earlier.

On the other hand, the god Ba'al is mentioned in an inscription from the Temple Complex at Ekron ('to ba'al and Padi' לבעלולפד, Gitin and Coogan 1999; Stern 2001, pp. 120-29; Gitin 2003, p. 288, Figure 5). The cult of Asherah could fit the usage of Canaanite female figurines during Iron Age II, which could have been linked to the Asherah cult. Asherah is also mentioned in ostraca from the Ekron Temple Complex 650 ('to Asherat' לאשרת, Gitin 2003, p. 289, Figure 8:4), and may also be depicted by the only figurine found in its cela (Figure 7:1; Gitin 2003). Gitin also links this goddess with the Phoenician culture and its influence in this period (Gitin 2003, p. 288).

Both the evidence from Ekron and the Assyrian depiction may indicate a late Philistine cult combining Aegean and Canaanite gods. This 'pantheon' includes two or three goddesses (a Levantine one, maybe Ashera and an Aegean goddess, maybe Ptgyh), and one male Levantine god (a weather god, maybe Ba'al). The cult of a Near-Eastern male god by the Philistines is mentioned in the Hebrew Bible, either in regards to Dagon of Ashdod or Ba'al Zebub of Ekron (see above). Thus, while in the household religion as well as at town temples at Yavneh the Asherah cult was probably practiced in some way, the main 'state' official temples also acknowledged the 'old time' Aegean goddess as well as a local male god (conceived by the bible and Near-Eastern tradition as the 'main god', see Schäfer-Lichtenberger 2000, p. 88). The Aegean deities or later variants thereof may have not been forgotten, and wereworshipped in a more locally Levantine manner.

Thus, from the evidence we have so far (biblical narrative, Assyrian reliefs and texts, and inscriptions and figurative representations from Philistia, see above), it seems that during the 8th-7th centuries $\mathrm{BCE}$ the Philistines worshipped a combination of deities with some Aegean background and the common Canaanite deities as Ba'al and 'Asherah (see for Ekron see, Dothan and Gitin 1993, p. 1058; Gitin 1993; Gitin and Coogan 1999; Stern 2001, pp.120-29; Gitin 2003). While it is still very difficult to reconstruct the details of the Philistine religion during the entire Iron Age, we have evidence of the existence of distinctive household religious practices of some sort. These practices seem to reflect the special origin and nature of the immigrant population of Philistia during the initial stage of the Iron Age. Later on, during Iron Age II, there is a fusion with the local religious traditions as both textual and material remains of Iron Age II in Philistia more explicitly indicate.

Funding: This research received no external funding.

Conflicts of Interest: The author declares no conflict of interest.

\section{Captions:}

Figure 1. Map of Philistia.

Figure 2. Tell Qasile Temple 131 schematic plan (after Mazar 1992: Figure 28).

Figure 3. Gath Area D temples (Dagan et al. 2018: Figure 2, courtesy of A.M. Maeir).

Figure 4. Two-horned altar from Gath (Dagan et al. 2018: Figure 4, courtesy of A.M. Maeir).

Figure 5. Stands from the Yavneh favissa (courtesy of R. Kletter).

Figure 6. Complex 650 at Ekron (Gitin and Naveh 1997; courtesy of S. Gitin).

Figure 7. The royal dedicatory inscription from Ekron (Gitin and Naveh 1997; courtesy of S. Gitin).

Figure 8. Aegean-style figurines from Philistia (Ben-Shlomo 2014: Figure 1). 1: Psi-type figurine from Ekron (Ben-Shlomo and Press 2009: Figure 1:1). 2: Psi-type figurine from Ekron (Ben-Shlomo and Press 2009: Figure 1:2). 3: Psi-type figurine from Ashkelon (Ben-Shlomo and Press 2009: Figure 1:9). 4: Ashdoda figurine from Ashdod (Dothan 1971: Figure 91:1). 5: Bovine figurine from Ekron (Ben-Shlomo and Press 2009: Figure 16:1).

Figure 9. Undecorated animal figurines from Iron Age I Ekron (Ben-Shlomo 2014: Figure 2). 
Figure 10. Libation vessels from Ekron (Ben-Shlomo 2014: Figure 3). 1: Bird askos (Ben-Shlomo 2008: Figure 1:2). 2. Hedgehog vessel (Ben-Shlomo 2008: Figure 1:1). 3: Bovine vessel decorated in Philistine style (Ben-Shlomo 2008: Figure 2:1). 4. Bovine libation vessel (Ben-Shlomo 2008: Figure 9:1). 5: Vessel in the shape of a donkey carrying jars (Ben-Shlomo 2008: Figure 9:2).

Figure 11. Various cult objects of Iron Age I (Ben-Shlomo 2014: Figure 4). 1: A ring kernos from Ekron (Ben-Shlomo 2008: Figure 10). 2. A bird rattle from Ashdod (Dothan and Ben-Shlomo 2005: Figure 3.36:1). 3. A pomegranate vessel from Ashdod (Dothan and Ben-Shlomo 2005: Figure 3.61).

Figure 12. Various Iron Age II terracottas (Ben-Shlomo 2014: Figure 5). 1: A male(?) figurine from Ashdod (Dothan 1971: Figure 62:1). 2. A female plaque figurine from Ashdod (Dothan and Ben-Shlomo 2005: Figure 3.96:5). 3. Bovine libation vessel from Ekron decorated in the 'Late Philistine style' (Ben-Shlomo 2008: Figure 5:1). 4. A bull's head spout from Ashdod (Dothan 1971: Figure 68:6). 5. A late Iron Age bovine vessel from Ekron (Ben-Shlomo 2008: Figure 7). 6. A 'Judean' style horse figurine from Ashdod (Dothan and Porath 1982: Figure 34:7).

Figure 13. The Musicians' stand from Ashdod (Dothan and Ben-Shlomo 2005: Figure 3.76).

Figure 14. Late Iron Age II cultic objects from Philistia (Ben-Shlomo 2014: Figure 7). 1: A hollow female figurine from Ekron, Temple Complex 650 (Gitin 2003: Figure 4). 2: A knobbed stand from Ashdod (Dothan and Freedman 1967: Figure 38:7). A group of four-horned portable altars from Ekron (Dothan and Gitin 2008, p. 1955).

Figure 15. The 'enthroned goddess' motif (Ben-Shlomo 2014: Figure 9). 1. A seal from Mycenaean Tiryns, Greece (after Yasur-Landau 2008: Figure 3:3). 2. A pictorial krater from Ashkelon (after Stager et al. 2008: Figure 15.40; courtesy of the Leon Levy Expedition to Ashkelon). 3. The Ashdoda figurine (Dothan 1971: Figure 91:1). 4. A cylinder seal from Iron Age I Ashdod (Dothan and Ben-Shlomo 2005: Figure 3.66). 5. A procession with statues of gods looted from Gaza(?), from the Tiglath-pileser III southwest palace of Nimrud (after Barnett and Falkner 1962: pl. 92).

\section{References}

Barnett, Richard D., and Margaret Falkner. 1962. The Sculpture of Aššur-Nasir-Apli II (883-859 B. C.), Tiglath-Pileser III (745-727 B. C.) and Esarhaddon (681-669 B. C.) from the Central and South-West Palaces at Nimrud. London: The British Museum.

Begg, Patrick. 1991. Late Cypriote Terracotta Figurines: A Study in Context. SIMA 101. Jonsered: Paul ÅströmsFörlag. Ben-Shlomo, David. 2008. Zoomorphic Vessels from Tel Miqne-Ekron and the Different Styles of Philistine Pottery. IEJ 58: 24-47.

Ben-Shlomo, David. 2010. Philistine Iconography: A Wealth of Style and Symbolism. Orbis Biblicus et Orientalis 241. Göttingen: Vandenhoeck\& Ruprecht.

Ben-Shlomo, David. 2014. Philistine Cult and Household Religion according to the Archaeological Record. In Family and Household Religion: Toward a Synthesis of Old Testament Studies, Archaeology, Epigraphy, and Cultural Studies. Edited by Rainer Albertz, Beth AlpertNakhai, Saul Olyan and Rudiger Schmitt. Winona Lake: Eisenbrauns, pp. 73-102.

Ben-Shlomo, David, and Michael D. Press. 2009. A Re-examination of Aegean Style Figurines in Light of New Evidence from Ashdod, Ashkelon and Ekron. BASOR 353: 39-74.

Ben-Shlomo, David, Itzhak Shai, and Aren M. Maeir. 2004. Late Philistine Decorated Ware ("Ashdod Ware"): Typology, Chronology, and Production Centers. BASOR 335: 1-35. [CrossRef]

Ben-Shlomo, David, Ron Gardiner, and Guss W. Van Beek. 2014. Ceramic Figurines and Figurative Terracottas. In The Smithsonian Institution Excavation at Tell Jemmeh, Israel 1970-1990. Edited by David Ben-Shlomo and Guss W. Van Beek. Smithsonian Contributions to Anthropology, No. 50, 804-827. Washington: Smithsonian Institution.

Berlant, Stephan. 2008. The Mysterious Ekron Goddess Revisited. Journal of the Ancient Near Eastern Society 31: 15-21.

Berry, John W. 1997. Immigration, Acculturation and Adaptation. Applied Psychology: An International Review 46: 5-34. [CrossRef]

Biran, Avraham. 1992. Dan-25 Years of Excavations at Tel Dan. Tel Aviv: Hakibbutz Hameuhad Publishing House and IES (Hebrew).

Brug, John F. 1985. A Literary and Archaeological Study of the Philistines. B.A.R. International Series No. 265; Oxford: Archaeopress.

Burmeister, Stefan. 2000. Archaeology and Migration. Approaches to an Archaeological Proof of Migration. Current Anthropology 41: 539-67. [CrossRef] 
Dagan, Amit, Maria Enuikhina, and Aren M. Maeir. 2018. Excavations in Area D of the Lower City Philistine Cultic Remains and Other Finds. NEA 81: 28-33.

Daviau, Michelle P. 2007. Altars Large and Small. The Iron Age Altars from Hirbet el-Mudeyine (Jordan). In Bilderals Quellen/Images as Sources. Studies on Ancient Near Eastern Artefacts and the Bible Inspired by the Work of Othmar Keel. Special Volume. Edited by Susanne Bickel, Silvia Schroer, René Schurte and Christoph Uehlinger. Fribourg: OBO, pp. 125-49, Pl. XXI.

Dothan, Trude. 1969. A Female Mourning Figurine from the Lachish Area. Eretz Israel 9: 42-46, 135. (Hebrew, English summary)

Dothan, Moshe. 1971. Ashdod II-III. 'Atiqot 10-11. Jerusalem: Department of Antiquities.

Dothan, Trude. 1982. The Philistines and Their Material Culture. Jerusalem: IES.

Dothan, Trude. 2003. The Aegean and the Orient: Cultic Interactions. In Symbiosis, Symbolism, and the Power of the Past: Canaan, Ancient Israel, and Their Neighbors from the Late Bronze Age through Roman Palaestina. Edited by William G. Dever and Seymour Gitin. Winona Lake: Eisenbrauns, pp. 189-213.

Dothan, Moshe, and David Ben-Shlomo. 2005. Ashdod VI: Excavations of Areas H and K: The Fourth and Fifth Seasons of Excavation (1968-1969). IAA Reports 24. Jerusalem: IAA.

Dothan, Trude, and David Ben-Shlomo. 2007. Ceramic Pomegranates and their Relation to Iron Age Cult. In Up to the Gates of Ekron. Essays in Honor of Seymour Gitin. Edited by Sidnie W. Crawford, William G. Dever, J. P. Dessel, Amnon Ben-Tor, Amihai Mazar and Joseph Aviram. Jerusalem: IES, pp. 3-16.

Dothan, Moshe, and David N. Freedman. 1967. Ashdod I. 'Atiqot 7. Jerusalem: Department of Antiquities.

Dothan, Trude, and Seymour Gitin. 1993. Miqne, Tel (Ekron). In The New Encyclopedia of Archaeological Excavations in the Holy Land. Edited by Ephraim Stern, Ayelet Lewinson-Gilboa and Joseph Aviram. Jerusalem: Israel Exploration Society, pp. 1051-59.

Dothan, Trude, and Seymour Gitin. 2008. Miqne, Tel (Ekron). In The New Encyclopedia of Archaeological Excavations in the Holy Land 5. Edited by Ephraim Stern. Supplementary Volume. Jerusalem: Israel Exploration Society, pp. 1952-58.

Dothan, Moshe, and Yosef Porath. 1982. Ashdod IV: Excavation of Area M. 'Atiqot 15. Jerusalem: Department of Antiquities.

Dothan, Moshe, and Yosef Porath. 1993. Ashdod V. Atiqot 23. Jerusalem: IAA.

Ehrlich, Carl S. 1996. The Philistines in Transition. A History from ca. 1000-730 B.C.E. Leiden: Brill.

Eliyahu-Behar, Adi, and Vanessa Workman. 2018. Iron Age Metal Production at Tell es-Sâfi/Gath. NEA 81: 34-36.

French, Elizabeth B. 1971. The Development of Mycenaean Terracotta Figurines. Annuals of the British School in Athens 66: 101-87. [CrossRef]

Furumark, Arne. 1941. The Mycenaean Pottery. Analysis and Classification. Stockholm: Kungl. Vitterhets, Historieoch Antikvitets Akademien.

Gadot, Yuval, Israel Finkelstein, Mark Iserlis, Aren M. Maeir, Pirhiya Nahshoni, and Dvory Namdar. 2014. Tracking Down Cult: Production, Function, and Content of Chalices in Iron Age Philistia. Tel Aviv 41: 55-76. [CrossRef]

Gitin, Seymour. 1989. Incense Altars from Ekron, Israel and Judah: Context and Typology. Eeretz Israel 20: 52-67.

Gitin, Seymour. 1992. New Incense Altars from Ekron: Context, Typology and Function. Eretz Israel 23: 43-49.

Gitin, Seymour. 1993. Seventh Century B.C.E. Cultic Elements at Ekron. In Biblical Archaeology Today, 1990. Edited by Avraham Biran and Joseph Aviram. Jerusalem: IES, pp. 248-58.

Gitin, Seymour. 1998. Philistia in Transition: The Tenth Century B.C.E. and Beyond. In Mediterranean Peoples in Transition. Thirteenth to Early Tenth Centuries BCE. Edited by Seymour Gitin, Amihai Mazar and Ephraim Stern. Jerusalem: IES, pp. 162-83.

Gitin, Seymour. 2002. The Four-Horned Altar and Sacred Space: An Archaeological Perspective. In Sacred Time, Sacred Space: Archaeology and the Religion of Israel. Edited by Barry M. Gittlen. Winona Lake: Eisenbrauns, pp. 95-123.

Gitin, Seymour. 2003. Israelite and Philistine Cult and the Archaeological Record: The "Smoking Gun" Phenomenon. In Symbiosis, Symbolism and the Power of the Past: Canaan, Ancient Israel, and Their Neighbors from the Late Bronze Age through Roman Palaestina. Edited by William G. Dever and Seymour Gitin. Winona Lake: Eisenbrauns, pp. 279-95.

Gitin, Seymour. 2008. The Late Iron Age II Incense Altars from Ashkelon. In Festschrift Lawrence E. Stager. Edited by David Schloen. Winona Lake: Eisenbrauns, pp. 127-36. 
Gitin, Seymour, and Michael D. Coogan. 1999. A New Type of Dedicatory Inscription from Ekron. IEJ 49: 193-202. Gitin, Seymour Trude Dothan, and Joseph Naveh. 1997. A Royal Dedicatory Inscription from Ekron. IEJ 48: 1-16. Hachlili, Rachel. 1971. Figurines and Kernoi (Areas D H, Trench C1). In Ashdod II-III, 'Atiqot 9-10. Edited by Moshe Dothan. Jerusalem: Department of Antiquities, pp. 125-35.

Hadley, Judith M. 2000. The Cult of Asherah in Ancient Israel and Judah. Evidence for a Hebrew Goddess. Cambridge: University Press.

Hitchcock, Louise A., Aren M. Maeir, and Amit Dagan. 2016. Entangling Aegean Ritual in Philistine Culture. In METAPHYSIS: Ritual, Myth and Symbolism in the Aegean Bronze Age. Aegaeum 39. Edited by Eva Alram-Stern, Fritz Blakolmer, Sigrid Deger-Jalkotzy, Robert Laffineur and Jörg Weilhartner. Liège: Peeters, pp. 519-26.

Keel, Othmar, and Christoph Uehlinger. 1998. Gods, Goddesses and Images of God in Ancient Israel. Edinburgh: T\&T Clark.

Kletter, Raz. 1996. The Judean Pillar-Figurines and the Archaeology of Asherah. B.A.R. International Series 636; Oxford: Archaeopress.

Kletter, Raz. 2001. Between Archaeology and Theology: The Pillar Figurines from Judah and the Asherah. In Studies in the Archaeology of the Iron Age in Israel and Jordan. Edited by Amihai Mazar. JSOT Supplement 331. Sheffield: Academic Press, pp. 179-216.

Kletter, Raz, Irit Ziffer, and Wolfgang Zwickel. 2006. Cult Stands of the Philistines. A Genizah from Yavneh. Near Eastern Archaeology 69: 146-59.

Kletter, Raz, Irit Ziffer, and Wolfgang Zwickel. 2010. Yavneh I: The Excavation of the 'TempleHill' Repository Pit and the Cult Stands. OBO SA 30. Göttingen: Vandenhoeck \& Ruprecht.

Maeir, Aren M. 2006. A Philistine 'Head Cup' (Rhyton) from Tell es-Safi/Gath. In "I Will Speak the Riddle of Ancient Times": Archaeological and Historical Studies in Honor of Amihai Mazar on the Occasion of His Sixtieth Birthday. Edited by Aren M. Maeir and Pierre de Miroschedji. Winona Lake: Eisenbrauns, pp. 335-45.

Maeir, Aren M. 2007. A New Interpretation of the Term 'Opalim (עפלים) in the Light of Recent Archaeological Finds from Philistia. Journal of the Study of Old Testament 32: 23-40. [CrossRef]

Maeir, Aren M. 2008. A Seated Figurine from Tell es-Safi/Gath: A Philistine Image of El? In Birkat Shalom: Studies in the Bible, Ancient Near Eastern Literature, and Postbiblical Judaism Presented to Shalom M. Paul on the Occasion of His Seventieth Birthday. Edited by Chaim Cohen, Victor A. Hurowitz, Avi Hurvitz, Yochanan Muffs, Baruch J. Schwartz and Jeffrey Tigay. Winona Lake: Eisenbrauns, pp. 627-35.

Maeir, Aren M. 2012. Prize Find: Horned Altar from Tell es-Sâfi Hints at Philistine Origins. BAR 38: 35.

Maeir, Aren M., Louise A. Hitchcock, and Liora Kolska Horwitz. 2013. On the Constitution and Transformation of Philistine Identity. Oxford Journal of Archaeology 32: 1-38. [CrossRef]

Master, Daniel M., and Adam J. Aja. 2011. The House Shrine of Ashkelon. IEJ 61: 129-45.

Mazar, Amihai. 1980. Excavations at Tell Qasile, Part One. The Philistine Sanctuary: Architecture and Cult Objects. Qedem 12. Jerusalem: Hebrew University.

Mazar, Amihai. 1985. Excavations at Tell Qasile II: Various Objects, the Pottery, Conclusions. Qedem 20. Jerusalem: Hebrew University.

Mazar, Amihai. 1986. Excavations at Tell Qasile, Preliminary Report. IEJ 36: 1-15.

Mazar, Amihai. 1992. Temples of the Middle and Late Bronze and Iron Age. In The Architecture of Ancient Israel. Edited by Ehud Nezer, Aharon Kempenski and Ronny Reich. Jerusalem: IES, pp. 161-89.

Mazar, Amihai. 2000. The Temples and Cult of the Philistines. In The Sea Peoples and Their World: A Reassessment. Edited by Eliezer D. Oren. University Monograph 108, University Symposium Series 11; Philadelphia: University Museum, pp. 213-32.

Mazow, Laura B. 2005. Competing Material Culture: Philistine Settlement at Tel Miqne-Ekron in the Early Iron Age. Unpublished Ph.D. dissertation, University of Arizona, Tucson, AZ, USA.

Meiberg, Linda. 2013. Philistine Lion-Headed Cups: Aegean or Anatolian? In The Philistines and Other Sea Peoples. Edited by Ann E. Killebrew, Gunnar Lehmann and Michal Artzy. Atlanta: SBL, pp. 131-44.

Moorey, Peter R.S. 2003. Idols of the People. Miniature Images of Clay in the Ancient Near East. Oxford: University Press. Nahshoni, Pirhiya. 2009. A Philistine Temple in the Northwestern Negev. Qadmoniot 42: 88-92. (In Hebrew)

Nahshoni, Pirhiya, and Irit Ziffer. 2009. Caphtor, the throne of his dwelling, Memphis, the land of his inheritance The Pattern book of a Philistine offering stand from a shrine at Nahal Patish. UF 41: 543-80.

Negbi, Ora. 1988. Levantine Elements in the Sacred Architecture of the Aegean. Annuals of the British School in Athens 83: 339-57. [CrossRef] 
Nilsson, Martin P. 1968. The Minoan-Mycenaean Religion and its Survival in Greek Religion. Lund: Gleerup.

Olyan, Saul. 1988. Asherah and the Cult of Yahweh in Israel. Atlanta: Scholars.

Ostergren, Robert C. 1988. A Community Transplanted: The Trans-Atlantic Experience of a Swedish Immigrant Settlement in the Upper Middle West, 1835-1915. Uppsala: Almqvistand Wiksell.

Paz, Sarit. 2007. Drums, Women and Goddesses. Drumming and Gender in Iron Age II Israel. OBO 232. Fribourg: Vandenhoeck \& Ruprecht Göttingen.

Press, Michael D. 2007. Philistine Figurines and Figurines in Philistia in the Iron Age. Unpublished Ph.D. dissertation, Harvard University, Cambridge, MA, USA.

Press, Michael D. 2012. Ashkelon 4. The Iron Age Figurines of Ashkelon and Philistia. Winona Lake: Michael D. Press.

Press, Michael D. 2014. The Chronology of Philistine Figurines. IEJ 64: 140-71.

Pritchard, Jonathan B. 1943. Palestinian Figurines in Relation to Certain Goddesses Known through Literature. American Oriental Series 24; New Haven: American Oriental Society.

Rehak, Paul. 1995. Enthroned Figures in Aegean Art and the Function of the Mycenaean Megaron. In The Role of the Ruler in the Prehistoric Aegean: Proceedings of a Panel Discussion Presented at the Annual Meeting of the Archaeological Institute of America, New Orleans, Louisiana, 28 December 1992. Edited by Paul Rehak. Aegaeum 11. Liège: Université de Liège, pp. 95-118.

Renfrew, Colin. 1985. The Archaeology of Cult: The Sanctuary at Phylakopi. London: BSA.

Rothenberg, Benno. 1988. The Egyptian Mining Temple at Timna. London: The Institute for Archaeo-Metallurgical Studies.

Schäfer-Lichtenberger, Christa. 2000. The Goddess of Ekron and the Religious-Cultural Background of the Philistines. IEJ 50: 82-91.

Schmandt-Besserat, Dennis. 1997. Animal Symbols at'Ain Ghazal. Expedition 39: 48-58.

Schmitt, Rudiger. 1999. Philistäische Terrakottafigurinen. UF 31: 577-676.

Shai, Itzhak. 2006. The Political Organization in Philistia during the Iron Age IIA. In "I Will Speak the Riddles of Ancient Times" (Ps. 78:2b): Archaeological and Historical Studies in Honor of Amihai Mazar on the Occasion of his Sixtieth Birthday. Edited by Aren M. Maeir and Pierre de Miroschedji. Winona Lake: Eisenbrauns, pp. 347-59.

Sherratt, Susan E. 1998. "Sea Peoples" and the Economic Structure of the Late Second Millennium in the Eastern Mediterranean. In Mediterranean Peoples in Transition: Thirteenth to Early Tenth Centuries BCE. Edited by Seymour Gitin, Amiha Mazar and Ephraim Stern. Jerusalem: IES, pp. 292-313.

Singer, Itamar. 1992. Towards the Image of Dagon, the God of the Philistines. Syria 69: 431-50. [CrossRef]

Stager, Lawrence E., David J. Schloen, and Danirl M. Master, eds. 2008. Ashkelon 1: Introduction and Overview (1985-2006). Final Reports of the Leon Levy Expedition to Ashkelon 1. Winona Lake: Eisenbrauns.

Stern, Ephraim. 2001. The Archaeology of the Land of the Bible. Volume II: The Assyrian, Babylonian, and Persian Periods (732-332 B.C.E.). New Haven: Tale University Press.

Tadmor, Miriam. 1982. Female Cult Figurines in Late Canaan and Early Israel: Archaeological Evidence. In Studies in the Period of David and Solomon and Other Essays: Papers Read at the International Symposium for Biblical Studies, Tokyo, 5-7 December, 1979. Edited by T. Ishida. Tokyo: Yamakawa-Shuppansha, pp. 139-73.

Uehlinger, Christoph. 1997. Anthropomorphic Cult Statuary in Iron Age Palestine and the Search for Yahweh's Cult Images. In The Image and the Book. Iconic Cults, Aniconism, and the Rise of Book Religion in Israel and the Ancient Near East. Edited by Karl Van der Toorn. Leauven: Peeters Publishers, pp. 97-156.

Uehlinger, Christoph. 2002. Hanun von gaza und seine Gottheited auf Orthostatenreliefs Tiglatpilesers III. In Kein Land fürsichallein, Studienzum Kulturkontact in Kanaan, Israel/Palästina und Ebirnârifür Manfred Weippertzum 65 Geburstag. Edited by Ulrich Hübner and Eernst Axel Knauf. Friboug and Göttingen: Vandenhoeck \& Ruprecht, pp. 92-125.

Yasur-Landau, Assaf. 2001. The Mother(s) of All Philistines? Aegean Enthroned Deities of the 12th-11th Century Philistia. In Potnia, Deities in the Aegean Bronze Age. Edited by Robert Laffineur and Robin Hägg. Aegeum 22. Liège: Uneiversitede L'Etat, pp. 329-43.

Yasur-Landau, Assaf. 2008. A Message in a Jug: Canaanite, Philistine and Cypriote Iconography and the "Orpheus Jug". In Bene Israel. Studies in the Archaeology of Israel and the Levant during the Bronze and Iron Ages in Honor of Israel Finkelstein. Edited by Alexander Fantalkin and Asaaf Yasur-Landau. Culture and History of the Ancient Near East. Leiden: Brill, vol. 31, pp. 213-330.

Yasur-Landau, Assaf. 2010. The Philistines and Aegean Migration at the End of the Late Bronze Age. Cambridge: University Press. 
Ziffer, Irit, and Raz Kletter. 2007. In the Field of the Philistines. Cult Furnishings from the Favissa of a Yavneh Temple. Tel Aviv: Eretz Israel Museum.

Zukerman, Alexander, Liora Kolska-Horwitz, Justin Lev-Tov, and Aren M. Maeir. 2007. A Bone of Contention? Iron Age IIA Notched Scapulae from Tell es-Sâfi/Gath, Israel. BASOR 347: 57-81.

(c)

(C) 2019 by the author. Licensee MDPI, Basel, Switzerland. This article is an open access article distributed under the terms and conditions of the Creative Commons Attribution (CC BY) license (http:/ / creativecommons.org/licenses/by/4.0/). 
Article

\title{
Iron Age Cultic Sites in Transjordan
}

\author{
Margreet L. Steiner \\ Independent Scholar, 2300 Leiden, The Netherlands; msteiner@freeler.nl \\ Received: 29 January 2019; Accepted: 20 February 2019; Published: 27 February 2019
}

\begin{abstract}
In the area east of the river Jordan, eight Iron Age structures identified as cultic have been excavated. This paper presents the evidence as published and discusses the relevance of the cultic identification of the structures.
\end{abstract}

Keywords: cult sites; Transjordan; Iron Age; Deir Alla; Pella; Damiyah; Ataruz; Mudayna Thamad; WT-200; Busayrah

\section{Identification of Cultic Places}

Cult places such as temples, shrines, or open-air cultic complexes are an important part of the 'religious landscape' of ancient peoples. However, the identification of excavated buildings as cult places is not unambiguous. Much research has gone into the question of how cult practices and ritual behaviour express themselves in the material culture and how to follow the trail, so to speak, from cult to excavated remains (see for instance Blake 2005). The problem many field archaeologists are struggling with is rather how to interpret archaeological remains and which criteria to apply in order to define these remains as related to cultic practices. This may be the same trail, but walking it backwards. Not: which traces do cult practices leave in the archaeological record, but: which archaeological remains may be connected to cultic practices. To establish this is a much harder endeavour. Two examples are below.

Rituals concerning the communal consumption of meat may leave traces in the ground in the form of hundreds of animal bones. But not every find of large amounts of animal bones should be interpreted as evidence of those rituals and thus of the cultic nature of the site in question. Other explanations are possible, such as butchering for household consumption, the communal consumption of meat not connected with a religious ritual but, for instance, a wedding, or it being the remains of a dump site.

The placing of figurines as votive objects in a shrine often results in the excavations of many such objects in a building, but not every building containing figurines is by definition a shrine. Figurines may have been used and are often found in domestic contexts and tombs. The building may be the place where such objects were made, stored or sold, or maybe figurines were used not only as votive objects. Arguing from cult practices (the placing of votives in a shrine) to archaeological finds (the presence of figurines in a building) is much more straightforward than arguing from the excavated remains (figurines in a building) to cult practices (so this building is a shrine). As the 'backward trail' is hard to follow, archaeologists have to use the criteria that argue from cult practice to material culture, bearing in mind that other explanations are possible and should be examined.

\section{Criteria}

Various criteria have been used to identify buildings and objects as religious or cultic in nature. Coogan (1987) formulated four such criteria: isolation as a result of the separation of the sacred from the profane, the presence of exotic materials, continuity of religious buildings on multi-period sites and parallels of architectural features. 
In his report on the site of Phylakopi, Renfrew (1985) established 18 criteria. The list has been repeatedly modified and adjusted, recently by Zevit (2001, p. 82) who adapted it "to reflect the possibilities of the Iron Age sites in Syria-Palestine" and by Daviau (2012) who concentrated on the rituals taking place at cultic sites.

These criteria argue from ritual to material remains, not the other way around. Zevit's first two criteria, for instance, postulate that "Rituals may be performed in a place of natural significance, such as a cave, spring, mountain top, or a groove of trees" and that "They may be performed in a place of historical significance, e.g., the site of a theophany to an ancestor, or a famous event, or a grave". It is easier to argue that a ritual may have taken place in a cave than to interpret the remains in a certain cave as cultic.

Moreover, most criteria are 'fluid'. How many criteria have to apply? Do they have to apply completely or partly? How many special pottery types have to be present to define a site as cultic? How great the investment of wealth? How tight the parallels? The danger of circular argumentation is lurking. The presence of 'cultic vessels', for instance, strengthens the interpretation of a site as cultic, but the vessels are deemed 'cultic' in the first place because they are often found not in domestic contexts but in what is interpreted as temples or shrines.

Some indicators are more convincing than others. The presence of animal bones can be an indicator for offering practices, but need not be, as argued above. Food such as fruits may have been consumed in a ritual, but may also have constituted the daily evening meal. So these are weak indicators. Statues and inscriptions, on the other hand, are strong ones. The more indicators are present and the stronger they are, the more certain the identification as cultic.

So, whereas in Mesopotamia and the northern Levant the identification of a site or building as cultic is mostly secure and generally accepted because of the overwhelming evidence in the form of specially designed buildings, inscriptions, large statues, continuity over centuries and the presence of exotic materials, as for instance in the temples at Aleppo and Ain Dara in Syria (Kohlmeyer 2012; Novak 2012), in the southern Levant, the interpretation is often uncertain and per force based on insufficient data.

\section{Iron Age Cultic Sites Excavated in Transjordan}

In the area east of the river Jordan, eight possible Iron Age cult places (temples or shrines) have been excavated: three in the Jordan Valley (part of ancient Ammon), four in Moab, and one in Edom (Figure 1). ${ }^{1}$ These buildings have been identified as cultic by their excavators, followed sometimes by much scholarly discussion. This paper will present the evidence as published so far and discuss the identifications, using the criteria of Zevit and Daviau outlined above (Figure 1).

1 A complex interpreted as an Iron Age moon temple has recently been discovered at Rujm al-Kursi near Amman (see also the article by Tyson in this volume). A large building featured two stone reliefs at the entrance made of hewn white limestone blocks, each depicting a moon sickle on a pedestal. However, only the outlines of the building have been traced (it has not been excavated), and no Iron Age pottery from it has been published so far. Thus, both the dating and the plan of the complex remain uncertain, and in my view an interpretation as an Iron Age temple is premature. See further (Hübner 2009; Elkowicz 2014; and Tyson 2014, pp. 38-39). 


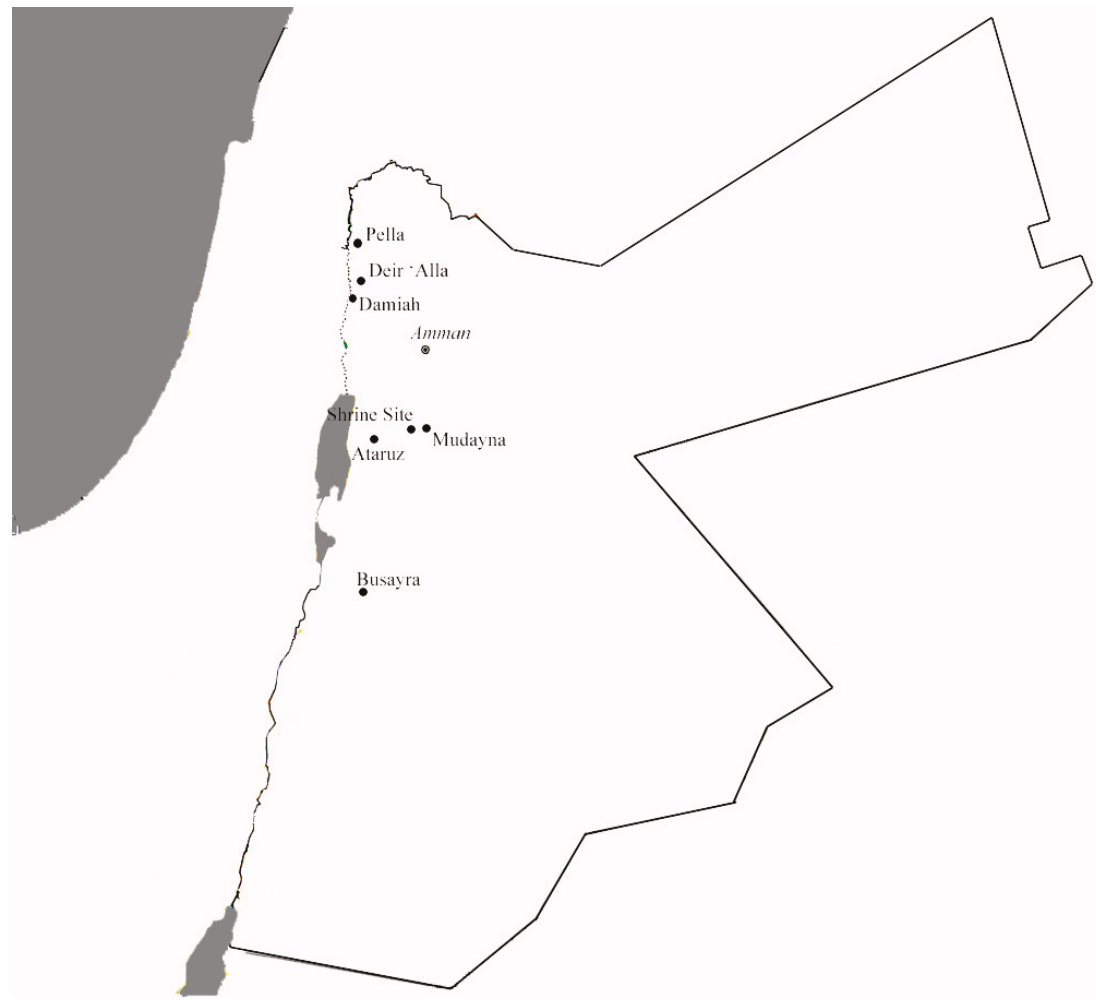

Figure 1. Map of sites mentioned in the text.

\subsection{Deir Alla}

In the Jordan Valley, the most renowned cult place is at Tell Deir Alla. In 1967, a large text, painted on the plaster of a wall, was found in a small building. The text refers to the seer Balaam, son of Beor, known from the Bible (Numbers 21-24). The plaster was found in two heaps east and west of the wall on which the text was supposedly written, thrown there when an earthquake struck the village around 800 BC (Hoftijzer and van der Kooij 1976, 1991).

The text is clearly religious in nature and the room it belonged to $(\mathrm{E} 335,3 \times 4.3 \mathrm{~m})$ had benches on four sides. Benches in a building are often seen as a sign of its cultic nature. The benched room is part of a complex of rooms and courtyards in Phase IX. All in all, some forty rooms have been excavated in this unwalled village, forming 14 to 15 households. Ordinary household wares, bread ovens, storage facilities, and loom weights were found in every household. The benched room yielded no exotic or cultic materials, but some interesting finds were made in a nearby complex.

North of the benched room was an open courtyard with three bread ovens. From this courtyard one entered a complex of three rooms in which 18 loom weights were excavated. Boertien (2008) connects this weaving complex with the benched room and suggests that textiles were woven here for the goddess Shagar, the main goddess mentioned in the Balaam text. This interpretation is based on the special kind of textile made of hemp that was woven at Deir Alla and on a parallel with Kuntillet Ajrud, where another kind of rare textile was found in connection with a shrine.

Near the entrance of the weaving complex north of the benched room, an inscribed stone was found as well as a goblet and a very large loom weight, which all may have had cultic functions. The stone was inscribed with the words eben shar'a ("stone of shar'a"). Franken (2008, p. 44) connects the 
name 'shar'a' with the river Zerqa that runs close by the tell. The same words were incised on a jug found in another room of this complex.

Interpretations of the benched room vary from a Balaam height or cultic cave where people could come into contact with the gods while dreaming (Franken 2008) to a shrine for the goddess Shagar (Boertien 2008), with outlyers such as a classroom for the teaching of scribes (Van der Kooij 2002, p. 69) and "a meeting place of a group of prophets ... were the visions and deeds of that Balaam were remembered" (Wenning and Zenger 1991, p. 198).

Although the benched room and the building complex it belonged to did not yield many exotic or cultic materials, the benches, the special fabrics woven at the site, the inscribed stone and libation goblet and the outsize loom weight found in adjacent rooms as well as the content of the Balaam text undeniably point to the cultic nature of the building. There is no continuity with the Late Bronze Age temple excavated at the site which was located more to the west of the tell. The parallel with the shrine at Kuntillet Ajrud has been mentioned above. Zevit (2001, p. 250, n. 201) concludes that the Balaam inscription justifies the interpretation of the building as a shrine. Which rituals were performed in the shrine at Deir Alla remains unclear.

\subsection{Pella}

Some $30 \mathrm{~km}$ north of Deir Alla and on the edge of the highlands lies Pella, a large site consisting of two tells and a Roman/Byzantine city located between the tells. In recent years, a temple complex has been excavated here, with six superimposed temples, the earliest one from the Middle Bronze Age I, ca. 1900 BC (Bourke 2004, 2012).

The uppermost temple was built ca. $950 \mathrm{BC}$. It is much smaller (ca. $12 \times 8 \mathrm{~m}$ ) than its Bronze Age predecessors and built in a 'bent-axis' design (Figure 2). It consists of a central room with benches around its north and west sides and what appears to be a stepped podium for the display of votive objects. This room was found empty except for several red-slipped plates. The smaller northern room was filled with baskets of lentils and bags of grain burnt in the final destruction which took place around $800 \mathrm{BC}$. This destruction may be the result of the same earthquake that destroyed Deir Alla, although the excavator does not exclude "a human agency in the destruction" (Bourke 2012, p. 191).

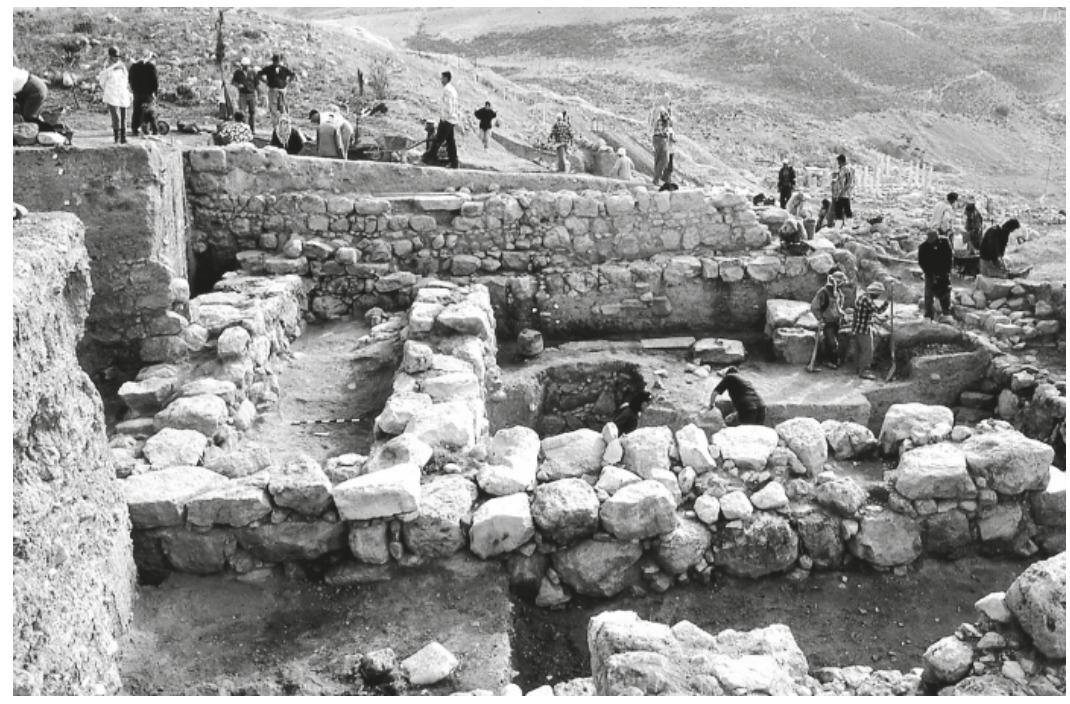

Figure 2. The uppermost temple at Pella (Courtesy Stephen Bourke). 
To the east of the room is an open courtyard with several pits and a stone-built altar. Many objects were recovered from these 'votive offering pits' and from the destruction debris besides the altar. These include ring kernoi, petal-garlanded chalices, fragments from several square stands, a model shrine with bulls-head protomes, incense cups and fragments of at least one large cauldron with ceramic bulls-head protomes. Not many figurines were found, but these include a fragment of an Ashdoda figurine and a male head wearing a polos headgear.

A variety of basalt and limestone vessels, braziers, and scoops were among the non-ceramic finds. Household vessels were abundant, such as large storage jars, cooking pots and bowls. According to the excavator, this may indicate a less strict division between sacred and profane than in the earlier temples or a remarkable change in offering rituals (Bourke 2012, p. 190). Burnt offering seems to have taken place in the courtyard, as many pits contained animal bones, mostly of young sheep and goat.

This building can be identified confidently as cultic because of the continuity with the earlier Bronze Age temples, the presence of special pottery vessels such as the kernoi, chalices and model shrines, and the altar and favissae in the courtyard. To which deity the temple was dedicated remains a mystery, however. Bourke (2012, p. 191) tentatively connects this temple with a change in religious beliefs and practices, possibly connected with the arrival of Aegean-type people in the Jordan valley. His arguments are based on parallels with the Iron Age II Level X temple at Tell el-Qasile and the finds of the incomplete Ashdoda figurine and the scoops, as these objects are supposed to have an Aegean origin.

\subsection{Damiyah}

Southeast of Deir Alla and close to the Jordan lies the small tell of Damiyah, near a ford in the river. Excavations in 2014 and 2015 have unearthed a $14 \times 6$ m mudbrick building with one or two platforms. Its walls were covered by white wash or lime plaster. This partially excavated building and the street south of it so far yielded eight complete unbroken terracotta horse figurines (Figure 3) and four female figurines as well as a pottery stand, two headless terracotta anthropomorphic statues, the head of another statue and fragments of a kernos ring (Petit and Kafafi 2016). On the floor of the building, two cattle skulls had been carefully positioned, looking south and east.
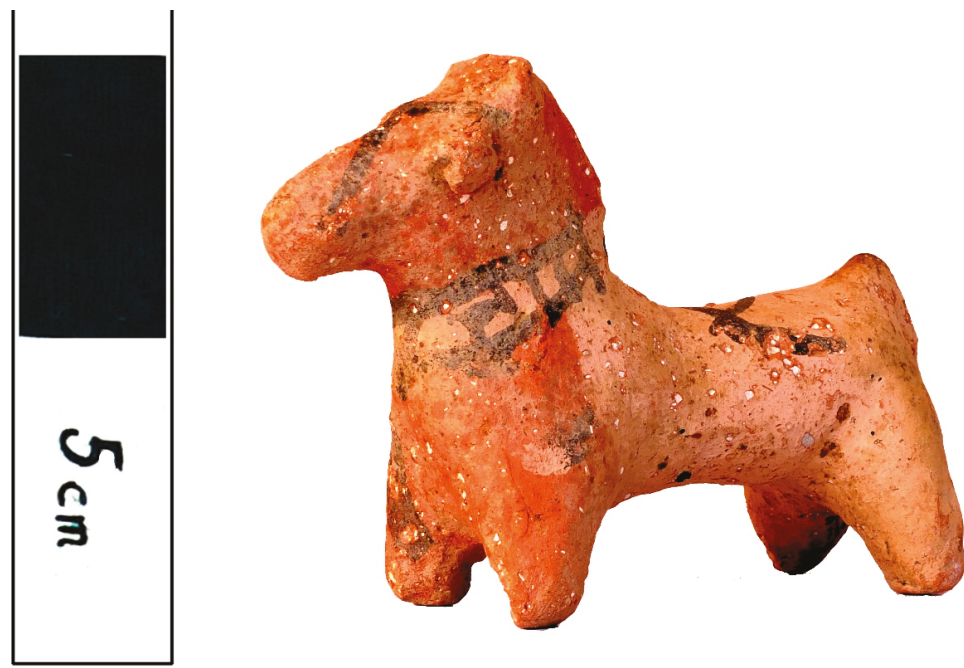

Figure 3. Horse figurine found at Tell Damiyah (Photo by Yousef al-Zu'bi. Courtesy Rijksmuseum van Oudheden Leiden and Yarmouk University, Jordan). 
The building was located amidst several small houses, of which so far one has been excavated, containing ordinary household wares, bread ovens, grinding stones and loom weights. This occupation phase dates to the late 8 th-early 7 th century BC. The buildings were destroyed by a fierce fire.

Based on the size of the building, the objects found in and around it, and the lack of ordinary household wares, an identification as a temple or shrine is legitimate. Further excavations may clarify whether this is an isolated building or the uppermost of a series of temples.

\subsection{Ataruz}

At Khirbat Ataruz in ancient Moab, a large temple complex has been excavated from 2000 onwards. The first phase of this building consisted of a main room with a niche with a pedestal-like installation and a platform. In the courtyards around the building a possible 'high place' and an altar were found (Ji 2012).

In the next and final phase II, the complex consisted of a multi-chambered building with at least three parallel long rooms fronting a courtyard (Figure 4). The main room $(8.5 \times 11 \mathrm{~m})$ had a large unhewn stone slab standing upon a pedestal built in the niche and contained a variety of objects, among which were a large pottery bull, jars decorated with bulls heads and a fenestrated altar with two male figures. The other rooms featured a square stone-built hearth of $2 \times 2 \mathrm{~m}$ in one room and two stone-built platforms in the other. All in all, "hundreds of cultic objects" have been retrieved from the temple complex (Ji 2012, p. 210). According to the excavator, the principal deity is symbolized by the standing stone in the main sanctuary room and by the bull figurine; which deity this is remains a question mark (Ji 2012, p. 218).

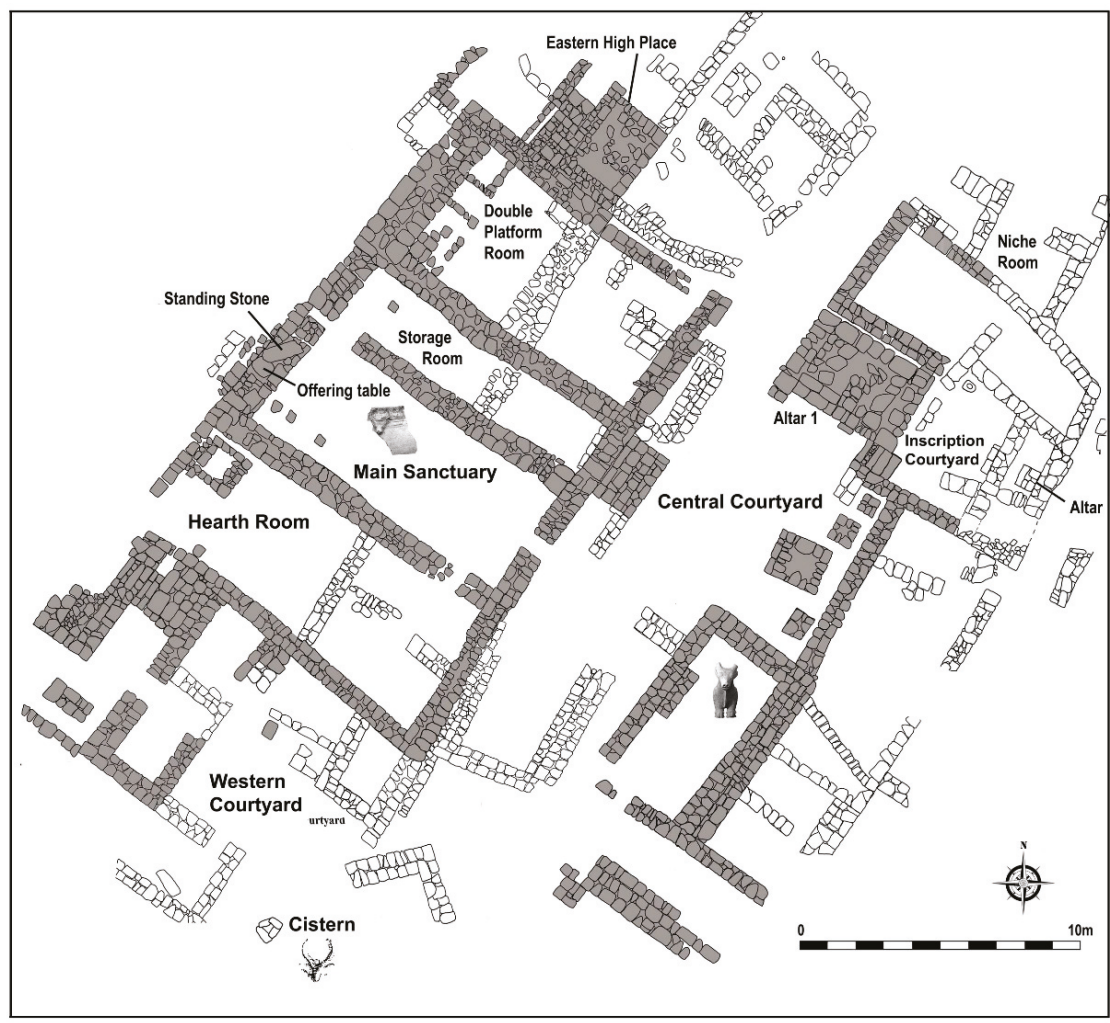

Figure 4. Plan of phase II building at Khirbat Ataruz (Courtesy Chang-Ho Ji). 
The stone pedestal of an incense altar with an inscription was recently discovered in one of the smaller courtyards. The text has not yet been published, but Rollston writes on his web blog that it is written in the Moabite language and he dates the writing 'comfortably' in the 9th century BC on paleographic grounds. $^{2}$

The excavator dates both phases to the end of Iron Age I and the beginning of Iron Age II, late 10th to early 8th centuries BC (Ji 2011, 2012). The site was destroyed by fire. Very little pottery has been published so far, which hinders a more precise dating of the complex.

After the fire that destroyed this building complex, the town was rebuilt and the eastern side of the large courtyard continued to be used for cultic activities in Iron IIB-C (7th century BC), but on a much smaller scale, according to the excavators (Ji and Bates 2014, p. 51). Not much information is as yet available on this phase III. This new town was destroyed at the end of Iron IIC.

The architecture of the building at Ataruz in phases I and II and the overwhelming number of special vessels leave no room for doubt that this is a cultic building, a large temple. It closely resembles the temple at Arad in Israel, also dating to the Iron IIB. Both have more or less the same dimensions, they have stone-built platforms, large stone altars for offering and niches. Whether the temple at Ataruz was dedicated to Jahweh or Kemosh or both is a matter of debate. Cultic activities seem to have continued in some form into the later Iron Age II (phase III).

\subsection{Mudayna Thamad}

A smaller possibly cultic building was unearthed at Khirbet al-Mudayna in the Wadi ath-Thamad, located in the norther part of ancient Moab and dating to the 7th century BC (Daviau and Steiner 2000). The structure (B149) was $5.5 \times 5.5 \mathrm{~m}$ with plastered benches on three sides (Figure 5). Two pillars connected by a bench divided the room into the main area and a small annex.

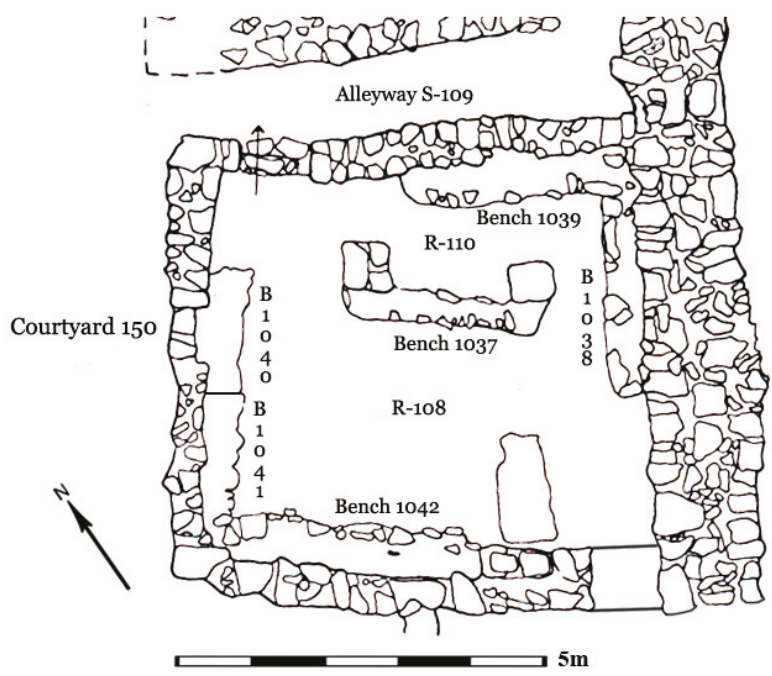

Figure 5. Plan of Building 149 at Mudayna Thamad (Courtesy Wadi ath-Thamad Project).

One libation altar and two shaft altars, all three made of stone, were found inside the building, one bearing an inscription reading "the incense altar that Elishama made for YSP, the daughter of WT" (Dion and Daviau 2000; Daviau 2002; Rainey 2002). Other finds in the shrine include five ceramic oil

2 http://www.rollstonepigraphy.com/?p=631. 
lamps, several fragmentary female figurines, two large stone pegs, two Wadjet-eye amulets, two murex shells, a spouted vessel and some beads. Some household pottery (bowls, storage jars) was also found.

It seems that most material was removed from the building when the town was attacked and it was used to forge iron arrowheads. A large pit was cut into the floor and later resealed while the building was still in use. Only a few objects were found in this pit: ceramic sherds from seven fragmentary vessels and a stone with a depression, possibly a mould for the manufacture of metal tools.

The courtyard west of the building was an open plaza behind the gate through which one entered the town. Embedded in the floor of the plaza, thousands of animal bones were excavated, mostly of sheep and goat. These remains have been tentatively interpreted as butchering waste for rituals involving the offering of meat in the shrine (Popkin 2009). However, the connection with B149 is not clear.

The town was destroyed when it was attacked around $600 \mathrm{BC}$. It is remarkable that the gate and many buildings in the town were destroyed by a heavy fire, but that the shrine remained relatively unscathed. This can be coincidental, or the attackers respected the shrine and did not set fire to it.

The identification of the building as a shrine or small temple was based on its architecture with benches, the (admittedly few) finds therein, particularly the three altars and the stone pegs, the inscription on the stone altar and the animal bones on the adjacent courtyard, possibly the remains of meat offerings in the building. To which deity the place was dedicated is unknown.

\subsection{A Gate Shrine at Mudayna Thamad?}

Outside the gate of Mudayna, a possible cultic installation was excavated, with two standing stones, 0.60 and $1.05 \mathrm{~m}$ high, the largest of which had fallen over (Figure 6). These two stones were held in place by a number of smaller chink stones carefully placed around them to act as supports. The two standing stones abutted a large $1.30 \mathrm{~m}$ long stone, placed on its side into the ground directly to the east. The excavators interpreted the upright stones as masseboth and the construction as a gate shrine, even though no cultic material was found nearby (Daviau et al. 2006, p. 252 and Figure 4).

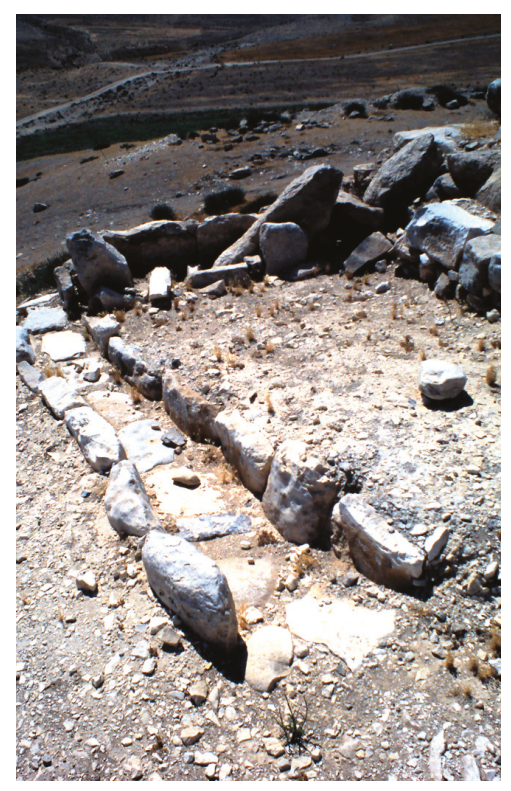

Figure 6. Photo of possible gate shrine at Mudayna Thamad (Courtesy Wadi ath-Thamad Project). 
The identification of this construction as a shrine rests on the find of the large stones only. In the absence of pottery and other special finds, the cultic nature of this site remains doubtful. ${ }^{3}$

\subsection{WT-13}

Some $3 \mathrm{~km}$ west of Mudayna Thamad, an open-air site has been excavated (site WT-13 of the Wadi ath-Thamad survey) (Dolan 2007; Daviau 2012, 2017). On a hilltop, a perimeter wall enclosed an area of c. $7 \times 14 \mathrm{~m}$. Large stones inside the wall may have served as benches (Figure 7). Inside the enclosure wall, a large collection of ceramic statuettes and figurines was found. Many statuettes hold a disc in their hands, comparable to the figurines of Horvat Qitmit in the Negev and 'Ein Hazeva in the Wadi Araba on the border with Edom. Other finds include architectural models and attached figures, miniature furniture, amulets and scarabs, miniature ceramic vessels, jewellery, marine shells, fossils and exotic geological samples. All in all, more than 500 broken objects were retrieved from this site, along with more than 25,000 pottery sherds. The pottery dates this complex firmly in the later Iron II period, 8th and 7th centuries BC.

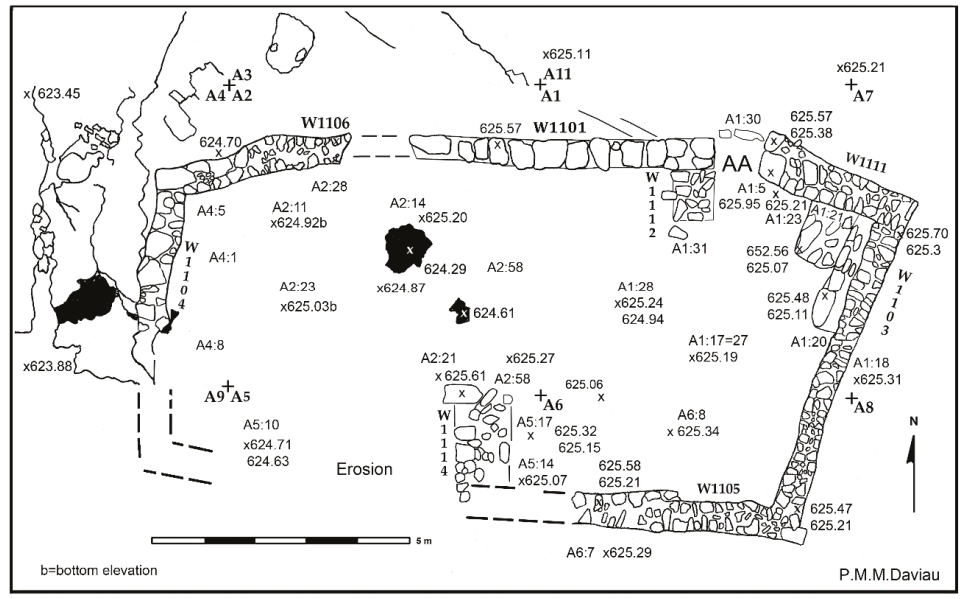

Figure 7. Plan of cultic complex at WT-13 (Courtesy of Wadi ath-Thamad Project).

An earlier occupation phase consisted of five cooking installations with ashes and a large number of animal bones, dating to the Iron I/IIA period (11th-10th centuries BC). It is unclear whether these finds constitute an earlier phase of the sanctuary or if they are the remains of household activities.

The architecture and large amount of votive objects of the later phase leave little doubt that this is an open-air cultic complex, comparable to Horvat Qitmit; the cultic nature of the earlier phase with the cooking installations is not established.

\subsection{Buseirah}

A possibly cultic building was excavated at Buseirah, which is ancient Bozrah, the main city of the Edomites in the 7th and 6th centuries BC. In area A, the acropolis, two wings of a building were excavated, consisting of rooms around inner courtyards, a staircase flanked by two circular stone bases, plastered rooms and plastered water drains. Some of the smaller rooms contained a large number of cylindrical jars and may have served as storerooms. Bennet (1983, p. 15) interpreted the complex as a temple, an interpretation followed by Reich (1992, p. 219) though no objects were found in the building

3 Another possible gate shrine in Jordan is discussed in Tyson (this volume, paragraph 4.1.4). 
to corroborate this. In the publication of the excavations, Bienkowski (2002, p. 95) very cautiously accepts the notion that the building was a temple rather than a palace or public building.

Some elements of the Buseirah building can be compared with those in other temples in the Levant, such as the long narrow plastered room, the steps flanked by stone pedestals and the storerooms with storage jars, presumably with oil for use in temple ceremonies (Bienkowski 2002, p. 95). However, none of the parallels fits neatly and the lack of cultic objects indicates that another interpretation is possible.

\section{Classification of the Iron Age Cult Sites of Transjordan}

Zevit has drafted a consistent terminology for the various kinds of cultic sites (Zevit 2001, pp. 123-24):

- $\quad$ Cult place: general designation for a place where cultic activities took place.

- Cult room: room designated for cultic purposes. This could be a room in a domestic or a public building, or it could be attached to such a building.

- Cult corner: part of a room or courtyard designated for cultic purposes.

- Cult cave: natural or man-made cave where cultic acts were performed.

- Cult complex: large cult place comprised of more than one structure, but one that does not contain within it any dedicated buildings.

- Cult center: a large cult place comprised of more than one structure, that does not contain a dedicated building, and for which the term 'temple' seems inappropriate.

- $\quad$ Temple: large single-roomed or multi-roomed structure with adjacent or internal open spaces and courts used for cultic purposes.

- Temple complex: a combination of temples or of temples and cult rooms.

- Shrine: closet-size freestanding structures that housed images or symbols of a deity.

- Cult site: general designation for any of the above or an ill-defined cult room or cult corner.

Zevit's research shows that the cult places of Ancient Israel are very varied. There were small cult rooms and corners in towns and outside the gates, temples and large temple complexes inside and outside the towns, open-air sanctuaries and cult caves. No one building is identical to another one. The same seems to apply to Transjordan-see Table 1.

Table 1. Presents the Iron Age cult places excavated in Transjordan discussed above and the rituals that might have taken place in them.

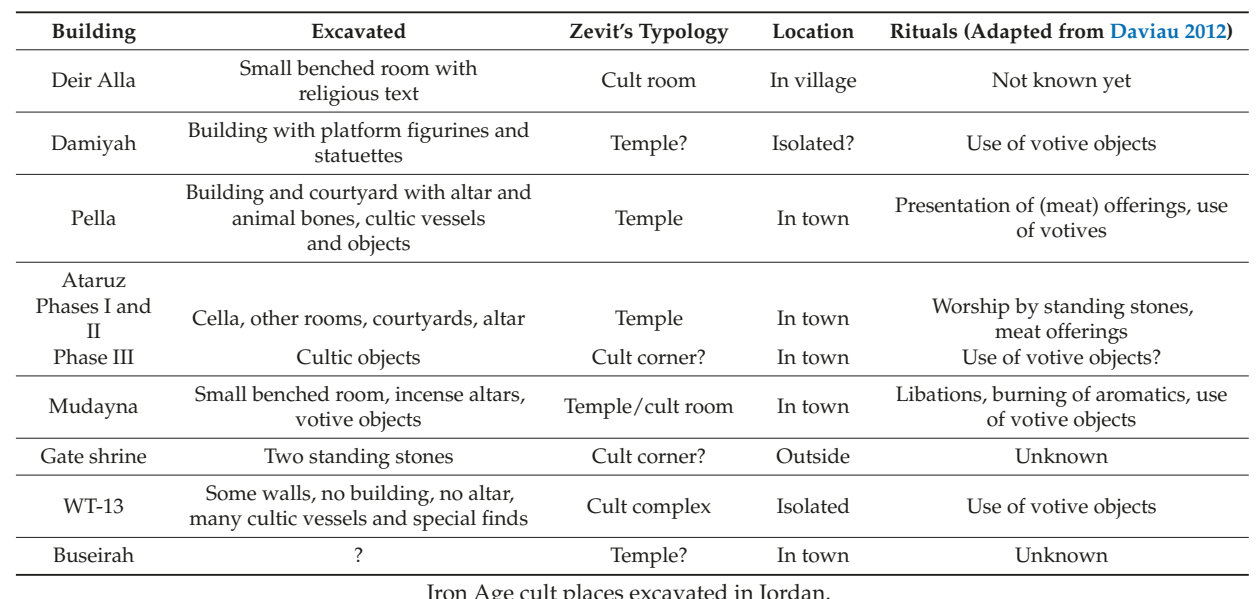




\section{To Which Gods?}

To which deities these temples and cult sites were dedicated remains unclear. Except for Deir Alla, no inscriptions mentioning a god have been found, nor any statues that could be identified with known deities.

The Balaam inscription at Deir Alla (Section 3.1) mentions an interesting combination of gods: El, Shagar, the Shadday gods and Ashtar. El was the supreme deity of the Canaanite pantheon, while Ashtar is probably the male counterpart of the female Ashtarte. Shagar, the acting deity in this story, is a goddess not known in the Canaanite or Phoenician pantheon. The Bible mentions 'the shagar of thy cattle and the ashtarot of thy sheep' (Deut. 7:13, 28:4, 18, 51). This is usually translated as 'the fruit of thy cattle and the flocks of thy sheep'. With this translation, of shagar as 'fruit' and ashtarot as 'flocks', the translators don't seem to do justice to the original text. Apparently, Shagar and Ashtarte were goddesses guarding the fertility of the flocks, and were well known in ancient Israel. The Shadday-gods seem to represent a particular group of gods. In the Bible, El Shadday is one of the names of the god of Israel.

The temple of Ataruz (Section 3.4) may have been dedicated to the main deity of Moab, Kemosh. The excavator, however, interprets the building as a temple dedicated to the god of Israel, JHWH. No solid proof is available for either position.

\section{Conclusions}

Several cult places have been excavated in the area east of the river Jordan, from large temples to smaller shrines to open-air complexes. The architectures and inventories of these sites show a wide variety, with stone-built altars, standing stones possibly representing deities, and the deposition of votive objects in pits and on benches. Meat offerings may have been presented next to libations and the burning of aromatics. The shrines may have been locally used or may have served a wider region. Some temples were undoubtedly dedicated to the main state deities Milkom, Kemosh, and Qos, or the god of Israel, JHWH, while smaller shrines seem to be related to other gods, such as the cult room at Deir Alla where Shagar is mentioned.

Although not all cult sites have as yet been fully published, they are an important addition to the corpus of cult places known from the areas west of the river Jordan.

Funding: This research received no external funding.

Conflicts of Interest: The author declares no conflict of interest.

\section{References}

Bennet, Crystal M. 1983. Excavations at Buseirah (Biblical Bozrah). In Midian, Moab and Edom; The History and Archaeology of Late Bronze and Iron Age Jordan and North-West Arabia. Edited by John F. A. Sawyer and David J. A. Clines. Sheffield: JSOT Supplement Series, vol. 24, pp. 9-17.

Bienkowski, Piotr. 2002. Busayra Excavations by Crystal-M. Bennett, 1971-1980. Oxford: Council for British Research in the Levant/Oxford University Press.

Blake, Edward. 2005. The Material Expression of Cult, Ritual and Feasting. In The Archaeology of Mediterranean Prehistory. Edited by Edward Blake and Bernard Knapp. Oxford: Blackwell, pp. 102-29.

Boertien, Jeannette. 2008. Unravelling the threads; Textiles and Shrines in the Iron Age. In Sacred and Sweet; Studies on the Material Culture of Tell Deir 'Alla and Tell Abu Sarbut. Edited by Margreet L. Steiner and Eveline J. van der Steen. Leuven: Peeters, pp. 135-51.

Bourke, Stephen. 2004. Cult and Archaeology at Pella in Jordan: Excavating the Bronze and Iron Age Temple Precinct (1994-2001). Journal \& Proceedings of the Royal Society of New South Wales 137: 1-31.

Bourke, Stephen. 2012. The Six Canaanite Temples of Tabaqat Fahil. Excavating Pella's Fortress Temple (1994-2009). In Temple Building and Temple Cult: Architecture and Cultic Paraphernalia of Temples in the Levant (2.-1. Mill. B.C.E.), Proceedings of a Conference on the Occasion of the 50th Anniversary of the Institute of Biblical Archaeology 
at the University of Tübingen, Tübingen, Germany, 28-30 May 2010. Edited by Jens Kamlah. Wiesbaden: Harrassowitz, pp. 159-202.

Coogan, M. D. 1987. Canaanite origins and lineage: reflections on the religion of ancient Israel. In Ancient Israelite Religion: Essays in Honor of Frank Moore Cross. Edited by P. D. Miller, P. D. Hanson and S. Dean. McBride: Fortress Press, pp. 115-24.

Daviau, P. M. Michèle. 2002. Stone altars large and small: The Iron Age altars from Hirbet el-Mudeyine (Jordan). In Sacred Time, Sacred Space. Archaeology and Religion of Israel. Edited by Barry M. Gittlen. Winona Lakes: Eisenbrauns, pp. 125-49.

Daviau, P. M. Michèle. 2012. Diversity in the Cultic Setting. Temples and Shrines in Central Jordan and the Negev. In Temple Building and Temple Cult: Architecture and Cultic Paraphernalia of Temples in the Levant (2.-1. Mill. B.C.E.), Proceedings of a Conference on the Occasion of the 50th Anniversary of the Institute of Biblical Archaeology at the University of Tübingen, Tübingen, Germany, 28-30 May 2010. Edited by Jens Kamlah. Wiesbaden: Harrassowitz, pp. 435-58.

Daviau, P. M. Michèle. 2017. A Wayside Shrine in Ancient Moab; Excavations in Wadi ath-Thamad. Wadi ath-Thamad Project I. Leiden: Brill.

Daviau, P. M. Michèle, and Margreet L. Steiner. 2000. A Moabite Sanctuary at Khirbat al-Mudayna. Bulletin of the American School of Oriental Research 320: 1-20. [CrossRef]

Daviau, P. M. Michèle, Robert Chadwick, Margreet L. Steiner, Michael Weigl, Annlee Dolan, Zoe McQuinn, Noor Mulder-Hijmans, Margareth Judd, and Jonathan Ferguson. 2006. Excavation and Survey at Khirbat Al-Mudayna and its Surroundings; Preliminary Report of the 2001, 2004 and 2005 Seasons. Annual of the Department of Antiquities in Jordan 50: 249-83.

Dion, Paul, and P. M. Michèle Daviau. 2000. An Inscribed Incense Altar of Iron Age II at Hirbet el-Mudeyine (Jordan). Zeitschrift des Deutschen Palastina-Vereins 116: 1-14.

Dolan, Annlee. 2007. Wadi ath-Thamad Site WT-13. A Hermeneutical Approach to Moabite Religion. Ph.D. Dissertation, University of Toronto, Toronto, ON, Canada.

Elkowicz, Dominik. 2014. Der ammonitische Mondtempel von Ruğm el-Kursi und die Tempel des "Syrischen Tempeltypus". Biblische Notizen 160: 51-57.

Franken, Hendricus. 2008. Deir Alla and its Religion. In Sacred and Sweet; Studies on the Material Culture of Tell Deir 'Alla and Tell Abu Sarbut. Edited by Margreet L. Steiner and Eveline J. van der Steen. Leuven: Peeters, pp. 25-52.

Hoftijzer, Jacob, and Gerrit van der Kooij. 1976. Aramaic Texts from Deir Alla. Leiden: Brill.

Hoftijzer, Jacob, and Gerrit van der Kooij, eds. 1991. The Balaam Text from Deir 'Alla Re-Evaluated, Proceedings of the Symposium, Leiden, The Netherlands, 21-24 August 1989. Leiden: Brill.

Hübner, Ulrich. 2009. Der Mondtempel auf Ruğm al-Kursī in der Ammonitis. In Israel zwischen den Mächten. Edited by Michael Pietsch and Friedhelm Hartenstein. Münster: Ugarit-Verlag, pp. 145-53.

Ji, Chang. 2011. Khirbat 'Ataruz: An interim overview of the 10 years of archaeological architectural findings. Annual of the Department of Antiquities of Jordan 55: 561-79.

Ji, Chang. 2012. The Early Iron Age II Temple at Hirbet 'Atarus and Its Architecture and Selected Cultic Objects. In Temple Building and Temple Cult: Architecture and Cultic Paraphernalia of Temples in the Levant (2.-1. Mill. B.C.E.), Proceedings of a Conference on the Occasion of the 50th Anniversary of the Institute of Biblical Archaeology at the University of Tübingen, Tübingen, Germany, 28-30 May 2010. Edited by Jens Kamlah. Wiesbaden: Harrassowitz, pp. 203-21.

Ji, Chang, and Robert Bates. 2014. Khirbat Ataruz 2011-2012: A Preliminary Report. Andrews University Seminary Studies 54: 47-91.

Kohlmeyer, Kay. 2012. Der Tempel des Wettergottes von Aleppo. Baugeschichte und Bautyp, räumliche Bezüge, Inventar und bildliche Ausstattung. In Temple Building and Temple Cult: Architecture and Cultic Paraphernalia of Temples in the Levant (2.-1. Mill. B.C.E.), Proceedings of a Conference on the Occasion of the 50th Anniversary of the Institute of Biblical Archaeology at the University of Tübingen, Tübingen, Germany, 28-30 May 2010. Edited by Jens Kamlah. Wiesbaden: Harrassowitz, pp. 55-78. 
Novak, Mirko. 2012. The Temple of Ain Dara in the Context of Imperial and Neo-Hittite Architecture and Art. In Temple Building and Temple Cult: Architecture and Cultic Paraphernalia of Temples in the Levant (2.-1. Mill. B.C.E.), Proceedings of a Conference on the Occasion of the 50th Anniversary of the Institute of Biblical Archaeology at the University of Tübingen, Tübingen, Germany, 28-30 May 2010. Edited by Jens Kamlah. Wiesbaden: Harrassowitz, pp. 41-54.

Petit, Lucas, and Zeidan Kafafi. 2016. Beyond the River Jordan; A Late Iron Age Sanctuary at Tell Damiyah. Near Eastern Archaeology 79: 18-26. [CrossRef]

Popkin, Peter. 2009. The Society and Economy of Iron Age Transjordan: A Contextual Zooarchaeological Analysis. Ph.D. Thesis, University College London, London, UK.

Rainey, Anson F. 2002. The New Inscription from Khirbet el-Mudeiyineh. Israel Exploration Journal 52: 81-86.

Reich, Ronny. 1992. Palaces and Residences in the Iron Age. In The Architecture of Ancient Israel from the Prehistoric to the Persian Periods; in Memory of Immanuel (Munya) Dunayevsky. Edited by Aharon Kempinksi, Ronny Reich and Hannah Katzenstein. Jerusalem: Israel Exploration Society, pp. 202-22.

Renfrew, Colin. 1985. Archaeology of Cult. The Sanctuary at Phylakopi. London: British School of Archaeology at Athens, supplementary vol. 18.

Tyson, Craig W. 2014. The Ammonites; Elites, Empires, and Sociopolitical Change (1000-500 BCE). London and New York: Bloomsbury T\&T Clark.

Van der Kooij, Gerrit. 2002. Use of Space in Settlements, An Exercise upon Deir Alla-IX. In Moving Matters. Ethnoarchaeology in the Near East, Proceedings of the International Seminar, Cairo, Egypt, 7-10 December 1998. Edited by Willeke Wendrich and Gerrit van der Kooij. Leiden: Nino, pp. 63-73.

Wenning, Robert, and Erich Zenger. 1991. Heiligtum ohne Stadt-Stadt ohne Heiligtum? Anmerkungen zum archäologischen Befund des Tell Der 'Alla. Zeitschrift für Althebraistik 4: 171-93.

Zevit, Ziony. 2001. The Religions of Ancient Israel; A Synthesis of Parallactic Approaches. London: Continuum.

(C) 2019 by the author. Licensee MDPI, Basel, Switzerland. This article is an open access article distributed under the terms and conditions of the Creative Commons Attribution (CC BY) license (http:/ / creativecommons.org/licenses/by/4.0/). 

Article

\title{
The Religion of the Ammonites: A Specimen of Levantine Religion from the Iron Age II (ca. 1000-500 BCE)
}

\author{
Craig W. Tyson \\ Department of Humanities, D’Youville College, Buffalo, NY 14201, USA; tysonc@dyc.edu \\ Received: 7 January 2019; Accepted: 26 February 2019; Published: 2 March 2019
}

\begin{abstract}
In the Iron Age II (ca. 1000-500 BCE), the region around Amman, Jordan, was home to a sociopolitical group known as the Ammonites (literally, "the sons of Ammon"). This paper investigates the religious traditions of the Ammonites through an analysis of the extant archaeological and textual sources. The analysis leads to the conclusion that the religious tradition of the Ammonites is a specimen of the broader religious tradition of the Iron Age II Levant. One distinguishing feature of Ammonite religion is the state god Milkom, whose name is probably an epithet for the god 'El, and who appears to be represented in a tradition of stone sculptures that have been found in the vicinity of Amman. The rest of the non-physical realm was understood to be inhabited by gods, goddesses, a variety of other non-human beings, and dead ancestors. Also visible in the extant evidence is a blending of local and foreign elements, especially those from Mesopotamia. Unique in this respect is the probable temple to the moon-god at Rujm al-Kursi, which most likely reflects a local tradition of lunar worship influenced by the iconography of the Mesopotamian moon-god Sîn.
\end{abstract}

Keywords: Ammon; sons of Ammon; Ammonite; gods; Milkom; iconography; Jordan; Iron Age

\section{Introduction}

Centered on the region around the modern city of Amman, Jordan (Figure 1), the tribally organized, agropastoralist society of the Ammonites (literally, "the sons of Ammon") flourished during the Iron Age II (ca. 1000-500 BCE), and especially in the latter half of this period. Like other aspects of its culture, Ammonite religion shares much in common with the other cultures of the ancient Levant (Judah, Israel, Aram, Phoenicia, Philistia, Moab, and Edom). These shared traits include a state god, a variety of other gods and goddesses, a special place for the ancestors, public and private cultic areas, and indicators of adaptations from regional peers and from the major political powers of the day located in Mesopotamia and Egypt. While Ammonite religion shares much with the surrounding cultures, there are also unique features. One distinguishing feature of Ammonite religion is the state god Milkom, whose name is probably an epithet for the god 'El, and who appears to be represented in a tradition of stone sculptures that have been found in the vicinity of Amman. Also unique is the probable temple to the moon-god at Rujm al-Kursi, which most likely reflects a local tradition of lunar worship influenced by the iconography of the Mesopotamian moon-god Sîn. 


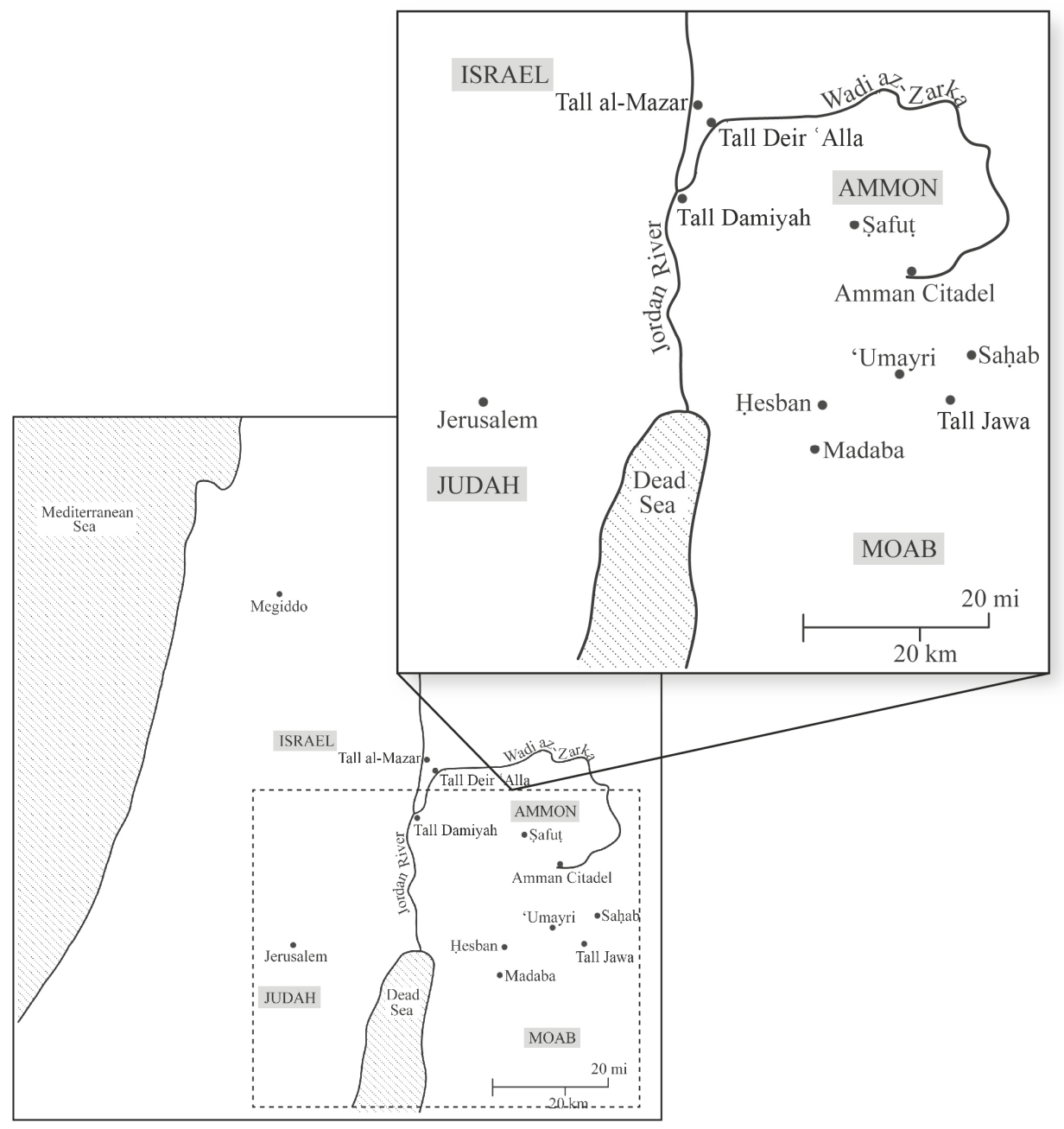

Figure 1. Map of Iron Age II Ammon.

\section{Defining the Area of Inquiry}

As is well-known, religion is a notoriously slippery term, and it is understood in disparate ways by different scholars. It is therefore useful to establish a working definition. For this investigation, I will use the broad collection of human behaviors and ideas that evolutionary models of religion are often used to explain, as proposed by Boyer and Bergstrom (2008, p. 112):

- mental representations of nonphysical agents, including ghosts, ancestors, spirits, gods, ghouls, witches, etc., and beliefs about the existence and features of these agents;

- $\quad$ artifacts associated with those mental representations, such as statues, amulets, or other visual representations or symbols;

- $\quad$ ritual practices associated with stipulated nonphysical agents;

- moral intuitions as well as explicit moral understandings that people in a particular group connect to nonphysical agency; 
- $\quad$ specific forms of experience intended to either bring about some proximity to nonphysical agents or communicate with them;

- $\quad$ ethnic affiliation and coalitional processes linked to nonphysical agents.

The nature of the evidence for Ammonite religion is not robust enough to say something about each of these categories. For example, there is essentially no evidence for moral intuition connected to nonphysical agency. On the other hand, there is material evidence for rituals, but such evidence often only allows for the reconstruction of the basic outlines of rituals.

\section{Primary and Secondary Sources for Ammonite Religion}

A few words on the sources available for this study will be useful to orient the reader. The study of the ancient past is dependent on the available archaeological and textual sources. For the Ammonites in particular, two primary sources, and one secondary source exist. The primary sources are materials unearthed through archaeological excavations (architecture, pottery, and other manmade items) and inscriptions (which are a special subset of archaeologically excavated material). The secondary source for the Ammonites is the Hebrew Bible/Old Testament, whose texts were not written contemporaneously with the events that they purport to record. There are a few possible exceptions to this (e.g., the book of Jeremiah) that I will note where relevant. For the most part, it will be the archaeological and inscriptional material that will serve as the basis for the discussion, with biblical texts brought in and evaluated where relevant.

\section{Nonphysical Agents}

\subsection{Milkom and 'El}

The main sources of information about nonphysical beings in Ammon are a small corpus of short inscriptions, various types of images recovered in the archaeology (statues, figurines, and iconography on seals), and several texts from the Hebrew Bible. While the evidence is incomplete, it provides some clues about the gods and goddesses known among the Ammonites. Of these, Milkom and 'El are of particular importance.

The earliest reference to an Ammonite deity appears to be on the Amman Citadel Inscription (CAI, no. 59), ${ }^{1}$ which has been dated paleographically between the mid-ninth and early eighth century BCE (CAI, no. 59). ${ }^{2}$ The block of limestone on which the inscription was incised was reworked for use in a later building, leaving eight lines of partially preserved text. The exact function of this inscription is debated; however, its composition on stone and the fact that it was discovered in the capital of the Ammonites, suggests that it was a monument commemorating a building project or other accomplishments of the king. The beginning of the first extant word on the inscription is missing, but most agree that it should be restored as $[\mathrm{m}] \mathrm{lkm}$ and vocalized as the name of the deity Milkom (CAI, no. 59), giving us our earliest attestation of this deity name in Ammon. This is significant for two reasons. First, because monumental inscriptions are regularly associated with kings in the Iron Age Levant, and the deities mentioned on them are understood to support the king in his activities - especially military and building activities (Green 2010). Second, because later texts from the Hebrew Bible identify Milkom as "the god of the Ammonites" (1 Kings 11:5, 33; 2 Kings 23:13),

$C A I=$ Aufrecht, Walter E. Forthcoming. A Corpus of Ammonite Inscriptions, 2nd ed. University Park: Eisenbrauns.

2 In keeping with the principle that our understanding of the ancient world should be built on inscriptions and other artifacts recovered from known archaeological contexts rather than items purchased on the market (Rollston 2004; 2010, pp. 137-44), all inscriptions discussed in the main body of the article are provenanced. Non-provenanced inscriptions are noted in the footnotes where relevant, and the symbol $\varnothing$ is placed before the reference to flag their non-provenanced status. 
a role that is parallel in the mind of the biblical author to the Israelite and Judean state ${ }^{3}$ god Yahweh, as well as the gods of other political groups in the region.

Milkom also appears as part of personal names on two Ammonite inscriptions. As with names in other Semitic languages, Ammonite names are often constructed from a deity name and a predicate (e.g., Abdallah, "Servant of Allah"). The first is a seal found at Tall al-'Umayri, a site just to the southwest of the modern city Amman. Dated to about 600 BCE, the seal reads, "(Belonging) to Milkom 'or, servant of Ba'alyašu'" (CAI, no. 129). Milkom' or, whose name means "Milkom is light," was apparently part of the court of king Ba'alyašu', who is regularly identified with the Ammonite king Baalis mentioned in the biblical book of Jeremiah 40:14 (Becking 1993; Herr 1985, p. 172). The second name, Milkomyat, appears in a list of names of unknown purpose on an ostracon (ink on pottery) from Tall al-Mazar, and is dated to the fifth century BCE (CAI, no. 147). ${ }^{4}$ The name, Milkomyat, means something like, "May Milkom come." While the sample is tiny, the use of Milkom in personal names at the end of the Iron Age II illustrates the ongoing place of Milkom amongst the Ammonites.

As mentioned above, the Hebrew Bible speaks of the role of Milkom among the Ammonites. Written in ancient Israel and Judah, and then subsequently compiled in Judah, the biblical texts portray the gods of other people as a danger to the people of Israel and Judah, a snare that will lure them away from the proper worship of their god Yahweh. Milkom is unambiguously attested three times in the Hebrew text (1 Kings 11:5, 33; 2 Kings 23:13). ${ }^{5}$ In each occurrence, Milkom of the Ammonites is part of a list of non-Israelite deities whom king Solomon is said to have followed, an act described by the biblical author as doing "what was evil in the sight of Yahweh" (1 Kings 11:6). The illicit nature of Solomon's attention to the deities of the surrounding peoples has to do with the exclusive nature of the relationship between Yahweh and the Israelites (Exodus 20:1-3). Following after gods other than Yahweh is presented as a perennial problem for the Israelites in much of the Hebrew Bible, but perhaps nowhere more systematically than in the Deuteronomistic History (Deuteronomy-2 Kings). There, the worship of Yahweh only is connected closely with the only true place to worship him, Jerusalem.

In several other biblical texts, there was confusion in antiquity as to what the consonant sequence $m l k m$ represented. The translators of the Hebrew Bible into Greek (often referred to as the Septuagint or LXX) struggled with the meaning of the Hebrew mlkm in 2 Samuel 12:30; 1 Chronicles 20:2; Amos 1:15; Jeremiah 49:1, 3 [Greek 30:17, 19]; Zephaniah 1:5. This series of Hebrew consonants is variously rendered into Greek as melchom, melchol, molchom, molchol, 6 or translated as basileus, "king." Should this word be read as "their king" (the final $-m$ representing the third masculine plural suffix attached to the word for king) or as the name of the Ammonite god?

In 2 Samuel 12:26-31, David's army captured Rabbah, the capital city of the Ammonites. Once the city was captured, the text states, "[David] took the crown of $m l k m$ from his head-its weight was a talent of gold and it had a precious stone-and it was put on the head of David. And he brought out a great amount of the spoil of the city" (2 Samuel 12:30). The key word in Hebrew is mlkm, which the MT reads as malkām, "their king." However, the Greek translation of 2 Samuel 12:30 (paralleled in

3 The choice of the designation "state god" is a matter of convenience. Several other possibilities, such as "national god," "dynastic god," or "royal god", are possible alternatives. Each comes with its own problems of meaning.

4 Milkom appears on several non-provenanced inscriptions, either as part of a name (ØCAI, nos. 1b, 127, 136), or in a blessing in the form of, "so-and-so, blessed of Milkom" (ØСAI, nos. 55, 57).

5 The traditional Hebrew text that is the basis for all modern translations is often called the Masoretic Text, abbreviated as MT. When it was originally written, Hebrew (as with other Semitic languages) was written with consonants only and did not graphically represent vowels. In 1 Kings 11:7, there is what appears to be a scribal mistake. In the same chapter and context as two other references to Milkom (vv. 5, 33), the MT says that Solomon built a bāmâ, "high place" for Chemosh, the detestable (god) of Moab, and for molek the detestable (god) of the Ammonites. The context alone suggest that this was a simple scribal error, the consonants $m l k$ being very close to the consonants for Milkom's name, $m l k m$. The Lucianic Greek translation of this verse represents it as melchol, which might be a confusion of M and L in Greek uncial script (on which, see the following note). In addition, the rest of the biblical evidence on molek (whether a god or as a designation of a sacrifice) is not connected with Milkom, nor with the Ammonites (Heider 1999). It thus seems most likely that this was a simple mistake on the part of the copyist.

6 On the confusion of M and L in Greek uncial script, see (Puech 1999, p. 575). 
1 Chronicles 20:2) has melchol tou basileōs autōn "Melchol their king." It is thus difficult to determine whether the crown was taken off the human king of the Ammonites, or whether the crown was taken off of the head of a statue of Milkom. Involving the gods of enemy peoples in warfare was a common phenomenon in the ancient Near East, so David's despoliation of Milkom's crown would not be out of the ordinary in terms of military practice. Also, the weight of the crown is stated as one talent, which is about 75 lbs, suggesting that a statue might be in view here (Driver 1913, p. 294; Knoppers 2004, p. 734). Werse is correct to point out; however, that using the weight of the crown as an argument for it being on a statue runs square in the face of the following words that it was placed upon David's head (Werse 2018, p. 511). Other manuscript evidence also supports the MT, indicating that the Greek has added a reference to Milkom, while also preserving the reference to "their king." In this instance, the shorter reading that takes this as a simple reference to the Ammonite king is probably the best (Werse 2018, p. 511).

There are some issues with understanding the consonant sequence $m \mathrm{lkm}$ in the biblical prophetic books as well. Some Greek manuscripts of Amos take the occurrence of $m l k m$ in Amos 1:15 to represent the Ammonite deity Milkom; however, in this case, the majority of the manuscript evidence indicates that "their king" is the proper translation (Werse 2018, pp. 512-13, n. 30). Likewise, the wider context of this verse has a focus on human rulers, making the reading of Milkom less likely (Paul 1991, pp. 70-71; Puech 1977; Werse 2018, pp. 512-13, n. 30).

In Jeremiah 49:1, 3 (Greek 30:17, 19) the Greek renders mlkm as melchom, while the MT reads mlkm as "their king." As part of a set of oracles aimed at the nations surrounding Israel and Judah, Jeremiah 49:1-6 accuses the Ammonites of wrong doing against Israel (v. 1) and hubris (v. 4), and subsequently issues a prediction of judgment (vv. 2-3,5), and a final promise of restoration by the Israelite god Yahweh (v. 6). Since each of the oracles in this series are constructed in the same form, the textual problem in vv. 1 and 3 is best resolved by considering the parallel oracle against Moab in Jeremiah 48. There, in v. 7, the judgment is on the Moabite god Chemosh, who will "go out into exile, his priests and officials together." The similar wording in Jeremiah 49:3, "For mlkm will go into exile, his priests and his officials together" argues strongly in favor of reading Milkom rather than "their king" in 49:1 and 3 (Werse 2018, p. 512).

Finally, in Zephaniah 1:5, while the MT and some Greek manuscripts read "their king," the Lucianic recension of the Greek translates mlkm as melchom, a reading also supported by the Syriac and the Latin Vulgate. Here, the key is to recognize the clear focus on illicit worship that makes "Milkom" the most likely translation. In this oracle of judgment on Judah, illicit religious practices are the target in 1:4-6. The worship of the god Ba' al, astral worship ("the host of heaven"), and oath taking in the name of the Judean god Yahweh, as well as the being indicated by $m l k m$, are all condemned, along with a generalized lack of not following Yahweh. The act of swearing or oath-taking mentioned in v. 5 is a particularly important piece of evidence here, as the Hebrew Bible always identifies the entity that is sworn by as a deity (Werse 2018, p. 506). Thus, in this case, the manuscript evidence and the context support reading "Milkom" in Zephaniah 1:5.

The biblical passages that mention Milkom are not a significant source of evidence about Milkom, but they do regularly understand him as the god of the Ammonites, parallel in the mind of the writers to Chemosh of Moab and Astarte of Sidon. The epigraphic and biblical evidence thus overlap in the image of Milkom as a state god of the Ammonites. The earliest evidence (the Amman Citadel Inscription) comes from the late ninth to eighth centuries BCE, and the two seals and biblical texts provide data on the later end, dating to the seventh and sixth centuries BCE. What is interesting is that despite the connection between Milkom and the state, the rest of the Ammonite epigraphic record shows a surprising trend in the Ammonite onomasticon, where the deity name 'El is much

7 On the practice of deporting cult images, see (Cogan 1974, pp. 9-21). 
more common than the theophoric element than Milkom. ${ }^{8}$ Additionally, the names of several known Ammonite kings are 'El names, ${ }^{9}$ while none contain Milkom.

The preponderance of 'El names in the onomasticon appears to parallel a trend in the iconography. A collection of nine male sculptures carved from stone (Abou Assaf 1980, nos. I, III-VII, XVIII, XIX, XX; Amr 1990, no. 1), as well as a small clay head (Daviau and Dion 1994) have been discovered in the region around Amman, and they date from the eighth to sixth centuries BCE. While varying somewhat in their appearances, they all wear an atef crown, which has its origins in Egypt, but has a long history in the iconography of the Levant (Figure 2). In its application in the Levant, and in Ammon particularly, the atef crown is worn by a deity-including 'El-who is typically in support of royal power (Burnett 2016, pp. 63-65; Daviau and Dion 1994, pp. 160-61). In combination with the number of 'El names, all of the items in this corpus most likely represent an important-perhaps chief-god of the Ammonites, who is associated with royal power (Burnett 2009, pp. 153-58; Burnett 2016, p. 65). In the Ammonite context, this god is most likely 'El (Daviau and Dion 1994, pp. 164). ${ }^{10}$

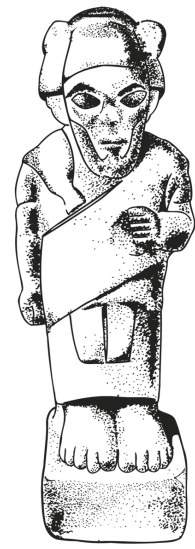

Figure 2. Atef crowned statuette from the Amman Citadel. Drawing by Thomas Norman.

Identifying 'El as an Ammonite state god based on the epigraphic and iconographic evidence creates tension with the biblical texts that identify Milkom as the god of the Ammonites. There are several possible ways of dealing with this tension. First, it is entirely possible that 'El and Milkom are two separate gods, with Milkom perhaps related to kingship. However, this solution has not been the one that scholars have often pursued. The patterns in the epigraphic, iconographic, and biblical record seem to call for something more. One main solution has been to argue that Milkom was indeed the god of the Ammonites, the state god or head of the pantheon, who was or had been identified with 'El over a period of time, as seems to be the case with Yahweh in Israel and Judah (Lemaire 1994,

8 For a list and discussion of names from provenanced Ammonite inscriptions and non-provenanced inscriptions that are plausibly Ammonite, see (Aufrecht 1999, pp. 156-58). One other possible Milkom name from the nearby site of Deir 'Alla appears on a worn seal that may or may not be Ammonite (CSAJ, pp. 404-5, Deir' Alla 27).

9 King Pado'il appears in several texts from the Neo-Assyrian Empire, which mention him paying tribute, or giving gifts and supplies to the Assyrian king (Grayson and Novotny 2012, p. 175, no. 22 ii 55; Leichty 2011, p. 23, no. 1 v 62; Postgate 1974, p. 337, ADD $1110+$ A.i. $\left.5^{\prime}-6^{\prime}\right)$. See also the non-provenanced seal in ØCAI, no. 13.

10 Abou Assaf also argues that these represent the chief god of the Ammonites, but identifies him as Milkom (Abou Assaf 1980, p. 78). 'Amr argues that they represent humans (Amr 1990, pp. 116-17), but he assumes an unmediated Egyptian influence, which seems unlikely in the eighth-sixth centuries BCE considering Egypt's relative inactivity in the Levant, except in the coastal areas at the end of the seventh and beginning of the sixth century. Daviau and Dion's argument assumes a more likely diffusion of the artistic motifs mediated by the coastal cultures. Furthermore, these heads may be seen as part of a sequence, beginning in the ninth century BCE with the clay head from Tall Jawa that Daviau and Dion publish (Daviau and Dion 1994, p. 163), and continuing down into the seventh century (Abou Assaf 1980, p. 71). 
p. 143). ${ }^{11}$ This proposal, based on the reconstructed history of religion in ancient Israel and Judah, is dependent on the assumption that parallel processes operated in Israel and Judah on the one hand, and in Ammon on the other. While it is certainly possible that parallel processes worked out in both areas, the extant evidence for the two adjacent areas is different. In Judah and Israel, the biblical and epigraphic material demonstrate a distinct preference for personal names using the theophoric element Yahweh, as well as the use of Yahweh's name in blessings and salutations (Tigay 1987). Likewise, biblical texts such as Exodus 6:2-3 and others point to Yahweh's identification with 'El, at least in the minds of some biblical authors (Smith 2002, pp. 32-43). The extant material from Ammon, consisting largely of names, does not fit this pattern strongly, and hence does not demonstrate that such a merger is likely (Cornell 2015). ${ }^{12}$

The other main proposal argues that 'El was the head of the Ammonite pantheon and that Milkom was an epithet, or a way of speaking of 'El (Burnett 2009; Daviau and Dion 1994, p. 164 n. 17; Tigay 1987, pp. 171, 187, n. 66). This takes seriously the reality that 'El names far outnumber Milkom names in the Ammonite onomasticon, as well as the representations of 'El in Ammonite iconography. It also lays emphasis on the linguistic connection between Milkom's name $(\mathrm{mlkm})$ and the consonants for the Northwest Semitic root $m l k$, on which the verb for ruling and the noun for king (melek) are built. Milkom's name is most likely built on this root and thus has something to do with ruling, a proposal that is supported by the appearance of similar god names in earlier Semitic inscriptions from Ugarit (on the coast of Syria) and elsewhere (Puech 1999, p. 575). Burnett's formulation of this position is probably the best when he says that Milkom is a "title distinct to the Ammonite form of 'El in his capacity as a royal god" (Burnett 2009, p. 161). While material uncovered in future archaeological excavations might necessitate a reconsideration of this position, the current state of the evidence favors the view that Milkom is a title or epithet of an Ammonite state god 'El. In keeping with many of the state gods of the Levant, he was in all likelihood understood as a weather god (Hübner 1992, p. 262).

\subsection{Ba'al}

The god Ba' al is known from three provenanced Ammonite inscriptions. ${ }^{13}$ The Amman Theatre Inscription (CAI, no. 58) is a small basalt fragment with two broken lines of text dated to around 600 BCE. It was part of a longer inscription, perhaps meant for display. The first partial line of text has the name Ba' al, followed by what is probably the verb, "I will build." Given the tiny amount of preserved text, it is not possible to say much about the inscription other than to discuss the individual words. It does seem significant though that the name Ba'al appears on the type of inscription (an inscription on stone that was likely much bigger) that would normally record kingly deeds.

$C A I$, no. 129 , which was discussed above $(\S 4.1)$, is a seal found at Tall al-'Umayri that reads, "(Belonging) to Milkom'or, servant of Ba'alyašu'." The name of the person served—Ba' alyašu' —is most likely the king of the Ammonites (cf. Jeremiah 40:14). His name means, "Ba' al is salvation" or "Ba' al has saved." That a king would have a Ba' al name does not mean that Ba' al was necessarily closely connected to kingship in Ammon. On the other hand, someone among the Ammonite elite saw $\mathrm{Ba}$ 'al to be important enough to invoke him in their child's name. The last provenanced inscription that includes the name Ba'al again comes from Tall al-'Umayri, this time in the form of a seal impression on a jar rim (CAI, no. 173). The script on the inscription is likely Aramaic and dated to the late sixth or early fifth century BCE. The first line has the name Ba' al and the second line only contains the first two letters of a word. It is possible that the two lines should be taken together as one name breaking

11 On this phenomenon in Judah and Israel see (Smith 2001, pp. 47-53).

12 Cornell's study also raises important methodological questions about the priority of the textual material from Ugarit (14th-13th c. BCE) for reconstructing Israelite and Judean religion. If the Ammonite material is prioritized as the closest analogue in time and space to Israel and Judah, the pattern for god mergers through which to view the history of Yahweh is not as strong (Cornell 2015).

13 This deity name also occurs in the following non-provenanced inscriptions that are possibly Ammonite: $\varnothing C A I$, nos. 1, $9 \mathrm{~b}$, $38 \mathrm{a}, 59 \mathrm{~b}, 175,212$. 
over two lines, but whatever the case, the Ba' al part is clear. Assuming it is part of a personal name, it provides one more bit of evidence for the worship of $\mathrm{Ba}$ 'al in the region.

It is not surprising to find references to Ba'al in Ammonite inscriptions, as he was, in his various local permutations, well-known through much of the ancient Near East beginning in the third millennium BCE and well down into the first millennium. In some cases, the word $b a^{\prime} a l$, which means "lord" or "owner," seems to have been used as an epithet for other deities, while in others it is clearly a proper name of a god (Herrmann 1999, p. 132). The Ugaritic texts from Ras Shamra on the coast of Syria (14th-13th c. BCE) provide the most robust portrayals of Ba'al and his various roles in kingship, fertility of the land via his control of the weather, and control over the sea, which was so important to sailors (Herrmann 1999, pp. 132-36). The significant friction on display in the Bible between the followers of Yahweh and the followers of Ba'al highlights Ba' al's role in nationalist politics and in the arena of fertility (see especially 1 Kings 17-19). It would thus not be surprising to find that Ammonites and their rulers included Ba' al among the gods that they looked to for protection and sustenance. Ba' alyašu's name suggests such a line of thinking, though it must also be admitted that the "salvation" included in his name most likely relates to his birth rather than anything to do with kingship. Whatever the precise role Ba' al was understood to have among the Ammonites, the few occurrences of his name secure him a spot in the Ammonite pantheon and further demonstrate Ammonite participation in the much more broadly attested patterns of religion in the Iron Age.

\subsection{Celestial Bodies}

\subsubsection{Moon}

The moon and its various phases played an important role in the profane aspects of ancient Near East life in the marking of time. The moon also enjoyed a lively sacred history as a part of ritual calendars and in association with a variety of lunar deities. Deification and worship of the moon is attested across the ancient Near East, most famously at the Mesopotamian sites of Ur and Harran (by the names Nanna and Suen [=Sîn] respectively), where traditions of moon-god worship span several millennia (Green 1992; Margueron 1992). In the West Semitic sphere, second and first millennium epigraphic texts, mid-first millennium biblical texts, and a variety of iconographic material underscore the importance of the moon and the moon-god, whose name is usually derived from the West Semitic word for the moon, yrh (Schmidt 1999; Theuer 2000). In Ammon, there are a handful of items that make it clear that the West Semitic moon-god played an important role in Ammonite perception of nonphysical beings.

On the epigraphic side of things, two bits of evidence have come to light. A small statue, now generally called the Statue of Yarh' azar (CAI, no. 43), was found outside the Roman city wall on the north end of the Amman Citadel. The statue is carved from limestone and stands $45 \mathrm{~cm}$ high, and was found with traces of red paint on the body and garments (Barnett 1951, pp. 34-35, and pl. XI). Because the statue was not found in a secure archaeological context, it is usually dated to the late eighth or seventh century BCE, based on the script of the inscription on the pedestal base (CAI, p. 108). The partially preserved two-line inscription reads:

Line 1: [broken]šwyrḥ'zr [broken]šw Yarh' azar

Line 2: [broken] $k r$ br šnb $b^{14}$ [broken] $k r$ son of Šanib

Despite the broken parts of the inscription, it appears to preserve a chain of three generations with only the last two letters $(k r)$ of the middle generation being visible. Reconstructed, the names would most likely run as such: "Yarh' azar, [son of ?]kr, son of Šanib."

14 This has been read as either a " $\mathrm{b}$ " or " $\mathrm{p}$ " (CAI, p. 210). 
The grandfather mentioned at the end of the inscription is plausibly identified with "Šanipu of the House of Ammon," a king mentioned as paying tribute to the Neo-Assyrian monarch Tiglath-pileser III in 734 BCE (?, pp. 122-23, no. 47 [Summ. 7r. 10']B114-religions-432110) Whether this means that Šanipu's son and grandson were kings too, one cannot say for sure, but they were certainly related to one of the power-players in Ammon. Whatever Yarh' azar's specific status, his name includes the name of the West Semitic moon-god Yarah, and means "Moon is help." As a representation of what must have been a member of the Ammonite elite, the inscription shows that the West Semitic moon-god had a meaningful place in the Ammonite pantheon.

Apart from the statue of Yarh' azar, only one other plausibly Ammonite inscription contains the yarah element. A badly burnt ostracon from Tall al-Mazar, Ostracon IV, has only one partially legible word that appears to read lyrh, "to Yarah." This could represent a sacrifice to the moon-god or something given to a person with the same name (CAI no. 145). The poor state of preservation of the ostracon precludes certainty.

Iconographic representations of the moon from the region of Ammon also attest to the worship of the moon-god. Two nearly identical architectural examples come from the site of Rujm al-Kursi, about $10 \mathrm{~km}$ west of the center of Amman, Jordan. There, on either side of the entrance to a building that is plausibly identified as a temple, are smoothed, nearly cubical blocks of limestone measuring slightly less than $1.0 \mathrm{~m}$ per side. On the front face of each block there is a relief presenting a lunar crescent standing on a table and supported by a pillar (Figure 3). ${ }^{15}$ Inside the crescent there is a disk which may represent the full moon (Keel 1998, p. 113). The pillar on the better-preserved block shown in Figure 3 has two rectangles inside it. The pedestal or platform on which the pillar rests has feet rather than the solid or stepped pedestals known on other stelae and seals. Inside the table are two crossing lines that look like an ' $X$.' The iconography of these reliefs is similar to the iconography of the crescent moon standard typical of the Mesopotamian moon-god Sîn of Harran. The main exception is that the standards here lack the tassels that are typical of the lunar crescent of Sîn of Harran (Hübner 2009, p. 150), but stelae depicting the crescent standard without the tassels are known, even from areas closer to Harran (Keel 1998, pp. 63-64, figs. 3-4). As Keel points out, the thickened pillar, and the style of the platform have parallels on seals from the region (Keel 1998, p. 113, especially figs. 36-37). One wonders whether the ' $X$ ' inside the platform is a simplified version of the more extensive cross-hatching visible on some seals (Keel 1998, figs. 33-34, 38-39, 42-49). While a full analysis of this site must await the final publication of the excavations, the reliefs have been dated on stylistic grounds to roughly the seventh century BCE, at the height of Assyrian power in the region. If the date is confirmed by the pottery, these reliefs will furnish evidence of the spread of the iconography of Sîn of Harran well into the Assyrian periphery. Whether this indicates the worship of Sîn of Harran in Ammon, or the adaptation of Sîn's iconography for application to the local moon-god Yarah is difficult to determine (Hübner 2009, pp. 149-50). Given the relative popularity of the moon-god among the Arameans in Syria, including stelae with moon-god iconography at Bethsaida and the Hauran to the northwest and north of Ammon (Bernett and Keel 1998; Keel 1998, pp. 116-20), moon-god traditions from Harran were most likely mediated through the Arameans. ${ }^{16}$

15 The Iron Age material from the site has not been published by the excavator, Abdel-Jalil 'Amr, who has since died. A brief note from 'Amr mentions Iron Age material in deep layers (Amr 1986). The material published from the site comes from the Roman, Byzantine, and Islamic periods. For bibliography see (Hübner 1992, p. 152, n. 121). The possible Iron Age temple and its reliefs were first discussed by Keel, who had been informed of the site by Ulrich Hübner (Keel 1998). Hübner later published an article on the site (Hübner 2009). Subsequent discussion of the possible temple can be found in (Elkowicz 2012, pp. 90, 114, Taf. 62, 66; Elkowicz 2014; Hübner 2015; Tyson 2014, pp. 37-39). The drawing from Keel (1998, fig. 105) was reproduced and mentioned briefly in Staubli (2003, p. 67).

16 Aramean cultural influence on Ammon can be seen in other ways, for example, the adoption of the Aramaic script in Ammon sometime in the late ninth or early eighth centuries BCE (Tyson 2014, pp. 102-4), and artistic influences visible in Ammonite sculpture from the eighth century BCE (Dornemann 1983, pp. 156-59; Zayadine 1991, pp. 49-51). 


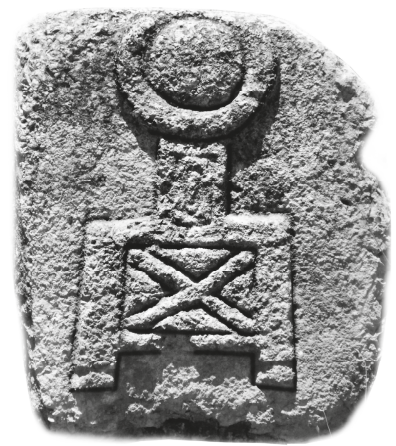

Figure 3. Lunar crescent relief from one side of the entrance to the Rujm al-Kursi building. Photo courtesy of the author.

The images on seals from Ammon likewise contribute to the evidence for the moon-god. Three main categories of seals are typical of the Iron Age II in Syro-Palestine and are based on shape: cylinder seals, conoid stamp seals, and scaraboid stamp seals. ${ }^{17}$ By all accounts, the scaraboid stamp seals represent the indigenous tradition of sealing. The cylinder seals that are somewhat common in Syro-Palestine during the Neo-Assyrian Period (734-612 BCE), and the conoid stamp seals that become more common in Syro-Palestine in the Neo-Babylonian and first part of the Persian Period (ca. 600-450 BCE), have their home in Mesopotamia (Keel and Uehlinger 1998, pp. 367, 374; Ornan 1993, pp. 52-53). ${ }^{18}$ As such, it is not always clear whether cylinder seals and conoid stamp seals found in Syro-Palestine represent local perceptions of the divine world. However, contemporary parallels in the iconography of the three main types suggest convergences of foreign and indigenous perceptions of the divine world.

Two cylinder seals from the region depict the standard of Sîn of Harran. On Nebo 1 (CSAJ, pp. 192-93), ${ }^{19}$ which dates to the 8th-7th centuries BCE, two worshippers approach a tasseled crescent moon standard of Sîn of Harran (Figure 4a). The worshippers carry what are probably instruments, and are separated by ankh symbols. On the opposite side of the crescent moon standard is a stylized tree. The seal also has other astral symbols, including the eight-rayed star of Venus, and three dots, likely representing stars (CSAJ, p. 192; Keel and Uehlinger 1998, p. 302). Another cylinder seal dating to the eighth-seventh centuries BCE (CSAJ, pp. 306-7, Tall al-Mazar 23) shows two falcon-headed figures, which attend the tasseled standard of Sin of Harran (Figure 4b). The scene also contains the eight-rayed star of Venus and a schematic, seven-dot representation of the Pleiades. On the outside of each of the figures are what seem to be stylized trees. ${ }^{20}$ An additional exemplar (CSAJ, pp. 356-57, Tall al-'Umeiri 78) with a less clear image appears to portray a crescent moon standard, along with other astral symbols (Figure 4c). While the iconography on these cylinder seals probably does not arise from local sources, it does illustrate the full repertoire of symbols and figures that could appear in such a scene. On stamp seals, which have less surface area, one tends to find more limited representations of worship scenes.

17 The term "scaraboid" as a description of the slightly oblong shape of these seals, comes from scarab seals, which have scarab beetles inscribed on the convex side of the seal.

18 The shape of a seal affects the amount of space for images and the way in which the seal is used. Cylinder seals are typically carved all the way around the cylinder, and when used for sealing, they create an image that repeats if rolled more than one rotation. Conoid and scaraboid stamp seals on the other hand, have a single main, roundish stamping surface that has a smaller space than what is typical on a cylinder seal, hence limiting what can be carved on it.

19 CSAJ = Eggler, Jürg, and Othmar Keel. 2006. Corpus der Siegel-Amulette aus Jordanien vom Neolithikum bis zur Perserzeit. Fribourg: Academic Press.

20 Two other cylinder seals that were purchased in Amman, and are hence not from a secure archaeological context, appear to have a crescent moon along with other astral symbols (CSAJ, pp. 58-59, 'Amman 87-88). 


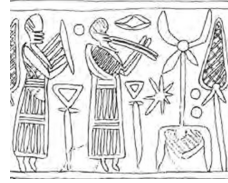

(a)

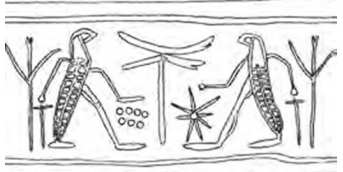

(b)

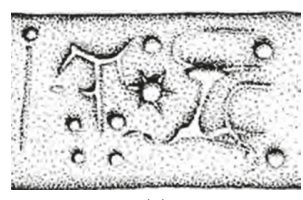

(c)

Figure 4. Cylinder seals with crescent moon standards: (a) Nebo 1; (b) Tall al-Mazar 23; (c) Tall al-'Umeiri 78.

A number of stamp seals from regions around Ammon depict the standard of Sîn of Harran. The elements that flank the standard of Sîn of Harran can be humans, plants, or some combination of the two (Keel and Uehlinger 1998, pp. 304-6). The total scene remains relatively stable, but the flanking figures alternate between a single person, two people, or a person and a stylized tree. One of the seals of this group seems to take the scene in yet another way. It appears to represent the deity in anthropomorphic form flanked by two stylized trees. This is arguably the moon-god, because the scene follows the pattern, and the figure is sitting on top of a low table or bench that is parallel to the bench on which the standard of Sîn of Harran usually sits (Keel and Uehlinger 1998, pp. 306-7).

In Ammon, two main variations appear on stamp seals. The first includes a worshipper with an upraised hand standing in front of several cult symbols, including a crescent moon. Four conoid stamp seals follow this pattern. In two of them with very similar styles from the 7th-6th centuries BCE ('Amman 3, Meqabelein 1; Figure 5a,b), there is a worshipper standing with their hand raised before a platform that houses the symbols of two Mesopotamian deities: the stylus of Nabu and the spade of Marduk. Above stands the crescent moon (CSAJ, pp. 10-11, 190-91). These scenes clearly emphasize the roles of Marduk and Nabu, but at the same time, they include the crescent moon. Two conoid stamps from Tall al-Mazar display worshippers before cultic symbols (Figure $5 c, d$ ). In the case of Tall al-Mazar 1 (sixth century BCE), the image shows a worshipper with their hand upraised before the lamp of Nusku, with a crescent moon at the top of the scene (CSAJ, pp. 296-97). A relatively minor god for much of Mesopotamian history, Nusku became more important in Neo-Assyrian times through an association with Sîn of Harran (Black and Green 1992, p. 145). Tall al-Mazar 14 (seventh century BCE) has two worshippers standing in front of the symbols of Nabu and Marduk. The top of the scene is filled out by astral symbols: the eight-rayed star of Venus, the crescent moon, and the winged sun disk (CSAJ, pp. 300-1).

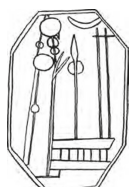

(a)

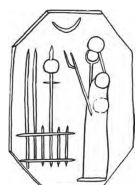

(b)

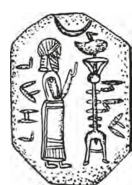

(c)

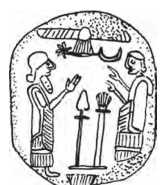

(d)

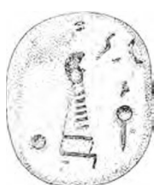

(e)

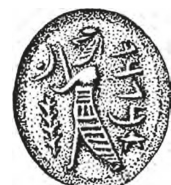

(f)

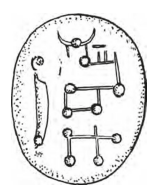

(g)

Figure 5. Stamp seals with worshipper and crescent moon: (a) 'Amman 3; (b) Meqabelein 1; (c) Tall al-Mazar 1; (d) Tall al-Mazar 14; (e) Tall al-'Umeiri 51; (f) Tall al-'Umeiri 52; (g) Umm Udeina 5.

Several scaraboid stamp seals also display a worshipper with a crescent moon. The best-preserved example is Tall al-'Umeiri 52 (8th-7th centuries BCE; Figure 5f). There is a worshipper-whether human or not is hard to tell-with both hands out towards a crescent moon with a full moon inside. In front of the figure is a branch or stylized tree (CSAJ, pp. 340-41). The limits of space on the seal mean much of the larger scene could not be included. The seal cutter retained the moon and the tree or branch that would otherwise flank the scene. Two others (Tall al-'Umeiri 51; Umm Udeina 5; 
Figure $5 \mathrm{e}, \mathrm{g}$ ) seem to preserve a similar scene with a worshipper before a crescent moon, but both are worn and somewhat difficult to decipher (CSAJ, pp. 340-41, 476-77). ${ }^{21}$

The second main variation includes an animal along with a crescent moon, which often also has a full moon inside it. Two conoid stamp seals fit this variation. 'Amman 4 (Figure 6a), which comes from the 6 th-5th centuries, depicts a sphinx-like animal with what is perhaps a stylized ankh, as well as a crescent moon above (CSAJ, pp. 10-11). Tall al-'Umeiri 66 (Figure 6b), a seal from the seventh century, displays a quadruped with horns bending forward, a nursing child, and a very schematic set of celestial imagery above including what appears to be a lunar crescent (CSAJ, pp. 348-49). Several scaraboid stamp seals also fit this variation. Hisban 2, Tall al-Mazar 18, and Tall al-'Umeiri 11, and 54 all pair quadrupeds with a crescent moon (Figure 6c-f). On Tall al-Mazar 18 and Tall al-'Umeiri 11 the animals appear to be bovine, with bodies carved in three segments. Horns are clearly visible on the two bovines on Tall al-'Umeiri 11, while they are less clear on Tall al-Mazar 18. The exact animal on Hisban 2 and Tall al-'Umeiri 54 is a bit more difficult to discern, though both have horns curved backwards. All but Tall al-'Umeiri 54 contain a full moon inside the crescent moon (CSAJ, pp. 168-69, 302-3, 318-19, 340-41). Tall al-'Umeiri 4 (Figure 6g) is a seal impression on clay dated to the early sixth c. BCE, which combines lunar symbols with a scarab beetle (CSAJ, pp. 312-13; = CAI, no. 129). Flanking the beetle are two standards with a disc (perhaps a full moon) above which are downward facing lunar crescents.

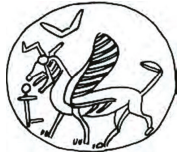

(a)

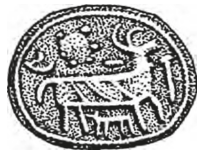

(b)

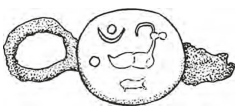

(c)

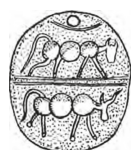

(d)

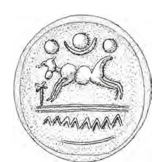

(e)

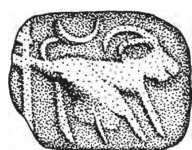

(f)

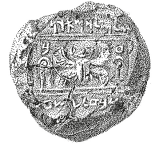

(g)

Figure 6. Seals with an animal and crescent moon: (a) 'Amman 4; (b) Tall al-'Umeiri 66; (c) Hisban 2; (d) Tall al-Mazar 18; (e) Tall al-'Umeiri 11; (f) Tall al-'Umeiri 54; (g) Tall al-'Umeiri 4.

A number of stamp seals have astral symbols without any other attending imagery. The badly damaged conoid stamp seal 'Amman 53 (seventh-sixth centuries BCE; Figure 7a) shows the crescent moon and the eight-rayed star of Venus (CSAJ, pp. 40-41). ${ }^{22}$ The scaraboid stamps seals Tall al-'Umeiri 39 (seventh-sixth centuries BCE; Figure 7b) and Umm Udeina 1 (eighth century BCE; Figure 7c) are both largely epigraphic, but 'Umeiri 39 has what appears to be a crescent moon with full moon at the bottom, and Umm Udeina 1 has a crescent moon and star (CSAJ, pp. 332-33, 474-75).

21 Cf. also the scaraboid seal Tall Deir 'Alla 28 from the nearby site of Tall Deir 'Alla (CSAJ, pp. 406-7).

22 Cf. Tall as-Sa'idiya 8 (CSAJ, pp. 370-71). 


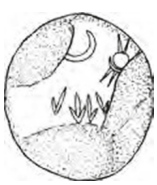

(a)

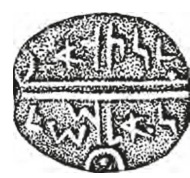

(b)

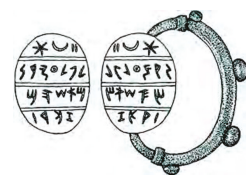

(c)

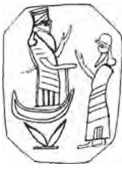

(d)

Figure 7. Seals with astral symbols: (a) 'Amman 53; (b) Tall al-'Umeiri 39; (c) Umm Udeina 1; (d) 'Amman 5.

A variation of Sîn iconography that is common in Assyria and the northern part of Syria between the ninth and fifth centuries BCE is an anthropomorphic deity standing in a crescent moon with a hand raised in a blessing posture (Keel and Uehlinger 1998, p. 309). A conoid stamp seal from Amman ('Amman 5) contains just such an image (Figure 7d). The seal, which probably dates to the seventh century BCE, has a deity standing in a crescent moon blessing a worshipper (CSAJ, pp. 12-13). ${ }^{23}$

The varied evidence available for the moon-god in Ammon-epigraphic and iconographicdemonstrates the active role that the moon-god played in Ammonite society. The cylinder seals that portray the standard of Sin were most likely imported or came to Ammon with a trader or official from Assyria. The depiction of the lunar crescent on the six conoid stamp seals discussed above appears invariably alongside the symbols for other identifiably Mesopotamian gods (Marduk, Nabu, Nusku). Since the tradition of conoid stamp seals generally emanates from Syria and Assyria, it is possible to regard them as imports similar to the cylinder seals. The scaraboid stamp seals are, on the other hand, a distinctly Levantine tradition. The exemplars from Ammon preserve three main variants: a worshipper before a lunar emblem, a lunar emblem with an animal (bovine or other quadruped), and a lunar emblem with an inscription (in one case also including a star). Absent from the scaraboid stamp seals are Sîn's standard and the symbols of other Mesopotamian gods, and this fact makes the scaraboid stamp seals the most potentially polyvalent of the three types of seals found in Ammon. A crescent moon is a nearly universal emblem of moon-gods across the ancient Near East and thus could invoke any locally or more broadly known moon-god. Is there a way then to specify which moon-god is referenced in a specific context such as Ammon?

Given the occurrence of Yarah as a theophoric element in an elite Ammonite name, the default should be that these lunar emblems represent this local deity. However, the iconography of Sîn of Harran used on the reliefs at Rujm al-Kursi suggests a more complicated situation. Was Sîn worshipped in Ammon alongside Yarah? Was Sîn's iconography applied to the West Semitic moon-god Yarah? Or were Sîn and Yarah identified or otherwise thought to be the same deity? There is at present no way to answer the question definitively. Nonetheless, we do know that Sîn of Harran played a special role in Neo-Assyrian expansion and management of the western part of the empire. In part, this seems to be related to the location of Harran as a kind of gateway to Assyria's western periphery, but also because of the ease with which one moon-god could be identified with another (Holloway 1995, pp. 279-308). This reality favors the conclusion that some kind of identification took place between Sîn of Harran and the West Semitic Yarah.

Along different lines, iconographic analysis of the representation of deities in the first millennium BCE ancient Near East shows significant overlap and mixing of the iconographic attributes of the various local versions of the weather god and the moon-god. A particular point of similarity is their common attribute animal, the bull (Novák 2002; Ornan 2001, pp. 19-26). The mixing of such attributes is visible on seals, and reliefs on stelae and orthostats. Closest to Ammon is the stele from Bethsaida (Figure 8 ) that combines weather god, bull, and lunar symbolism in one figure (Bernett

23 An unprovenanced seal that may be from the region of Ammon seems to incorporate the boat motif, the stylized tree, and the anthropomorphic deity sitting on a bench facing an ankh (Keel and Uehlinger 1998, pp. 307, illus. 305a; Avigad and Sass 1997 , p. 446 , no. 1177 ). 
and Keel 1998; Ornan 2001). The apparent amalgamation or merging of weather god and moon-god iconographic features might well have taken place in Ammon given the connection between a lunar crescent and bovine figures on Tall al-Mazar 18 and Tall al-'Umeiri 11 (Figure 6c,d). Finally, as Keel and Uehlinger have shown, the night time celestial powers in general—the stars, Venus, and the moon-were popular in the iconography of Iron IIC seals from the Levant, similar to the way in which the sun and its iconography had been popular in the preceding Iron IIB (Keel and Uehlinger 1998, pp. 287-323). In this broad iconographic context, it is possible to see a further amalgamation of deity attributes in which state gods such as Yahweh and Milkom, who had already been identified with 'El, took on the additional imagery of the moon (Keel and Uehlinger 1998, pp. 306-16). Along these lines, Theuer has called attention to the seal of Milkom' or as highlighting the connection between Milkom and the moon. On the seal (Tall al-'Umeiri 4; CSAJ, pp. 312-13), the central register displays a four-winged scarab beetle flanked by two poles or standards with a ball (probably a full moon) inside a downward facing moon crescent. In addition to the clear lunar aspects of the iconography, Theuer notes that the second part of Milkom 'or's name, which means "light," is a known epithet of the moon-god (Theuer 2000, p. 414). While we cannot reach a definitive conclusion on the amalgamation or identification of 'El, the weather god (which was usually the state god), and the moon-god in Ammon, the evidence is suggestive that some such process did take place. In addition, the imperial context of the evidence, with all of its pressures and opportunities for cultural exchange, was ripe for such processes. ${ }^{24}$

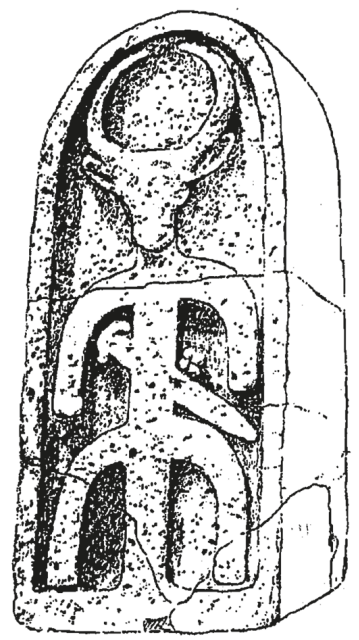

Figure 8. Stele from the gate area of Bethsaida from (Keel 1998, fig. 107). Note the bull head and horns that form a crescent moon.

\subsubsection{Sun}

Much less can be said about the status of the other celestial bodies in Ammon. With regard to the sun, its cyclical course across the sky, and its attendant ability to see everything, led to the association of the Semitic sun god (Šamaš) with justice (Black and Green 1992, p. 184). In Judah and Israel, solar imagery of largely Egyptian origin is common in the ninth and eighth centuries BCE, and

24 There is now a significant body of scholarship discussing the ways in which the conception of Yahweh of Israel and Judah slowly absorbed the attributes of other gods and goddess, eventually yielding something like monotheism. The key period for this is under imperial power, during the Neo-Assyrian, Neo-Babylonian, and Persian empires (ca. 730-323 BCE). On this topic, see (Dietrich and Klopfenstein 1994; Edelman 1996; Gnuse 1997; Smith 2001, 2002). 
associated with Yahweh rather than an independent sun god (Keel and Uehlinger 1998, pp. 256-61, 278-79; Lipiński 1999). The sun, along with the stars and the moon, was understood to be created and controlled by Yahweh.

In Ammon a few provenanced seals provide examples of solar imagery in the form of the sun disk. Four scaraboid stamp seals have the sun disk combined with an animal ('Amman 7; Tall al-Mazar 7, 8, 11; CSAJ, pp. 14-15, 298-301; Figure 9a-d). They are all dated to the 7th-6th centuries BCE. One conoid stamp seal from Tall al-Mazar depicts two worshippers facing the spade of Marduk and stylus of Nabu, and includes a winged sun disk, star, and crescent moon above the worshippers. It is dated to the seventh century BCE (Tall al-Mazar 14; CSAJ, pp. 300-1; Figure 9e). Tall al-Mazar 24, a cylinder seal from the eighth century BCE, depicts two winged griffins, each facing a stylized palmette. A winged sun disk and ankh serve as a scene divider behind the two griffins (CSAJ, pp. 306-7; Figure 9f). ${ }^{25}$ In addition to the iconographic representations of the sun disk, one Ammonite ostracon from Tall Hisban that dates to the second half of the sixth century BCE includes the name šmšl $l(C A I$, no. 137), which can be translated as "Šamaš (sun) is god," or "Šamaš is 'El."

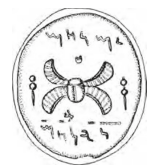

(a)

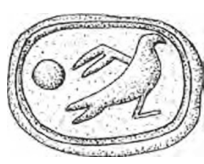

(b)

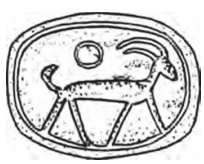

(c)

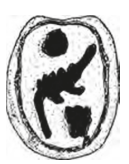

(d)

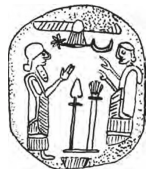

(e)

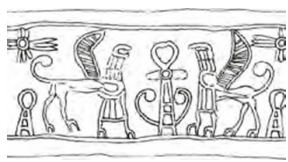

$(\mathbf{f})$

Figure 9. Seals with solar symbolism: (a) 'Amman 7; (b) Tall al-Mazar 7; (c) Tall al-Mazar 8; (d) Tall al-Mazar 11; (e) Tall al-Mazar 14; (f) Tall al-Mazar 24.

\subsubsection{Stars}

Alongside the moon and the sun, the stars were also objects of worship and fascination in the ancient Near East. Biblical texts variously view the stars as lesser gods, angels, or merely natural phenomena controlled by the god of Israel (Lelli 1999). Stars are visible on seals from across the southern Levant, often in association with the moon crescent, the eight-rayed star of the goddess Ištar (i.e., Venus), or both (Keel and Uehlinger 1998, pp. 292-94). The Pleiades, represented as seven dots (Black and Green 1992, p. 162) are also a common astral symbol on seals.

A number of seals from Ammon depict stars, often in association with the moon crescent and other symbols. The 8th-7th century BCE cylinder seal Tall al-Mazar 23 (Figure 4b) depicts the seven-dot Pleiades along with two falcon-headed beings, a moon crescent standard, and the eight-rayed star of Ištar (CSAJ, pp. 306-7). Nebo 1 (Figure 4a); another cylinder seal from the 8th-7th centuries BCE, depicts two worshippers standing before the crescent standard of Sîn. The eight-rayed star of Ištar also appears in this scene, along with several dot stars and ankh symbols (CSAJ, pp. 192-93). Two other cylinder seals portray stars. Dating to the 9th-8th centuries BCE, 'Amman 88 depicts a worshipper standing before a seated god. In between them stands an altar, and in the upper part of the scene is a crescent moon and six triangles most likely representing stars (Figure 10a) (CSAJ, pp. 58-59). Tall al-Mazar 25 (Figure 10b), a cylinder seal that dates to the 8th-7th centuries BCE, depicts an animal in front of a standard holding a six-rayed star (CSAJ, pp. 306-7). Tall al-'Umeiri 78 (Figure 4c) has

25 Two non-provenanced seals display winged sun disks. A scaraboid stamp seal that is supposedly from Amman and probably dates between the end of the eighth and beginning of the 6th century BCE, depicts a winged sun disk in the middle of three registers with the owner's name split across the top and bottom registers ( $\varnothing^{\prime}$ Amman 74; CSAJ, pp. 50-51). There is also a scarab stamp seal supposedly from Salt, which dates to the Persian Period (end of 6th-5th centuries BCE), and hence may fall outside the temporal parameters of this paper. This piece depicts the Egyptian deities Isis and Harpokrates facing one another inside what appears to be a shrine. The roof of the shrine is depicted as a winged sun disk. Another sun disk without wings and yet another winged sun disk sit above the shrine roof (ØSalt 4; CSAJ, pp. 276-77). 
a six-rayed star, a moon crescent standard, and several dots presumably representing stars (CSAJ, pp. 356-57).

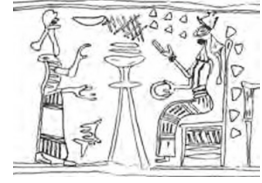

(a)

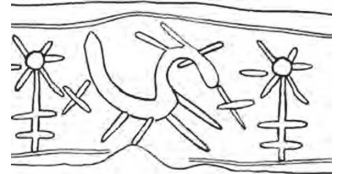

(b)

Figure 10. Seals with astral symbolism: (a) 'Amman 88; (b) Tall al-Mazar 25.

Three conoid stamp seals dating to the 7th-6th centuries BCE depict stars. The simplest of these is 'Amman 53, which depicts a crescent moon, a star, and plants (Figure 7a). The main scene in Tall al-'Umeiri 66 is of a cow with a calf beneath it, and above it a moon crescent and disk surrounded by dots most likely representing stars (CSAJ, pp. 348-49; Figure 6b). Tall al-Mazar 14 is by far the most complex of these scenes, depicting two worshippers before the symbols of Marduk and Nabu, with a winged sun disk, crescent, and star above (CSAJ, pp. 300-1; Figure 5d). ${ }^{26}$ Only one provenanced scaraboid stamp seal from Ammon depicts a star. Umm Udeina 1, which dates to the eighth century BCE (Figure 7c) is mostly taken up by an inscription identifying the owner. In the upper register there is a crescent moon and a six-rayed star (CSAJ, pp. 474-75). ${ }^{27}$

The sample of seals from Ammon containing stars is rather small, and hence it is difficult to draw too many firm conclusions from it. Given that the eight-rayed star of Ištar appears only on two of the cylinder seals, it is difficult to assess whether this goddess or her representative symbol had much impact in Ammon. The eight-rayed star of Ištar is known on scaraboid stamp seals from elsewhere in the Levant (Keel and Uehlinger 1998, pp. 292-97, illus. 288a, b, 289), and there is a linguistic-if not conceptual—connection between Ištar and the Levantine goddess Astarte (Pettinato 2005). The present state of the evidence, however, does not allow any firm conclusions for Ammon. ${ }^{28}$ The iconographic evidence for stars more generally, which is still not abundant for Ammon, does suggest a minor role in Ammonite religion especially in association with the moon.

\subsection{Other Gods, Goddesses, and Mythological Creatures}

A number of other deities and mythological creatures are attested to in the textual and material record from Ammon. From provenanced Ammonite inscriptions the following additional deity names are attested: 'Adon (CAI, no. 40), ${ }^{29}$ 'Ali (CAI, no. 147:8), 'Anat (CAI, no. 211), Baga' (CAI, no. 147:3), ${ }^{30}$ Gad (CAI, no. 147:4), ${ }^{31}$ 'Ilon (CAI, no. 179), ${ }^{32}$ Nanay (CAI, no. 65:5, and possibly in 137:11), ${ }^{33}$ Qoš (CAI,

26 Non-provenanced conoid seals whose inscriptions might be Ammonite ØCAI, no. 1b (Ammonite or Aramaic).

27 ØSalt 5 is a very stylized non-provenanced scaraboid stamp seal dating to the seventh century BCE. In the upper part of the field between two worshippers is what appears to be a star (CSAJ, pp. 276-77). Other possibly Ammonite scaraboid stamp seals that depict stars are ØС AI, nos. 1, 8c (probably Moabite), 11, 17a (round, possibly Aramaic), 20 (probably Moabite), 28 , 29a (probably Aramaic), 31 (probably Moabite or Edomite), 69, 97 (probably Moabite), 98 (probably Moabite), 111, 126, 136, $142,158,190,209$.

28 On the possible connection between the "Queen of Heaven" mentioned in Jeremiah 7:18 and 44:17-25 and Ištar, see (Houtman 1999; Keel and Uehlinger 1998, pp. 292-94).

29 This deity name also occurs in the following non-provenanced inscriptions: ØCAI, nos. 17, 17a.

30 A Persian deity name.

31 Means "fortune," but also appears to be a deity name. This deity name also occurs in the following non-provenanced inscription that is probably Ammonite: ØCAI, nos. 127.

32 Linguistically related to 'El.

33 Consort of the Babylonian god Nabu. 
no. 238), ${ }^{34}$ and Yahu (CAI, no. 147:7).$^{35}$ While many of these deity names appear only once, the list demonstrates a diversity of gods and goddesses, ${ }^{36}$ including several that are normally associated with other regions (Baga', Nanay, Qoš, Yahu). ${ }^{37}$ The mechanisms by which non-native names made their way to the region are surely diverse, most likely including migration, commercial contacts, diplomatic, and military contact.

The iconography on seals found in Ammon attests to several other nonphysical beings that might have been known. It is possible that many of the conoid stamp seals listed below were produced elsewhere, but having been found in Ammon, some familiarity with the images on the seals is likely, even if that familiarity is not attached to a specifically named god, goddess, or other nonphysical being. As with the names from seals, some of which are of foreign origin, a number of the beings or symbols of gods originated from outside the region of Ammon and made their way to the area by a variety of mechanisms. From the available seals, the following nonphysical beings or their symbols are attested: 38

1. Bes-An Egyptian god known for his dwarf-like features and protecting pregnant women appears on the scarab seal 'Amman 62 found in a grave (CSAJ, pp. 44-45; Figure 11a). Figures of Bes have been found throughout much of the ancient Near East, (Black and Green 1992, pp. 41-42; Te Velde 1999). ${ }^{39}$

2. Gula-A Mesopotamian goddess of healing (Black and Green 1992, p. 101) appears on the conoid stamp seal 'Amman 5 (CSAJ, pp. 12-13; Figure 7d).

3. Lamp of Nusku-This symbol of a minor Mesopotamian god of fire and light who rose to some prominence during the Neo-Assyrian Period in connection with Sîn of Harran (Black and Green 1992, p. 145) appears on the conoid stamp seal Tall al-Mazar 1 (CSAJ, pp. 296-97; Figure 5c).

4. "Lord of the animals"-This polyvalent type scene, typically with a figure holding animals on either side was widely used in the ancient Near East and thought to represent many different deities (Eggler 2009). A cylinder seal from the tomb at Meqabelein that dates to the 6th-5th centuries BCE depicts an anthropomorphic figurine between two bulls (CSAJ, pp. 190-91, Meqabelein 2; Hübner 1993, p. 142). Given that it is a cylinder seal, it was probably imported and might originally have been meant to depict a Mesopotamian god. Locally, it might have represented Milkom.

5. Spade of Marduk-This symbol of the patron god of Babylon appears on a number of seals, all of which (with the exception of one bulla, i.e., a seal impression) are conoid stamp seals of the kind more common in Aramaean areas and Mesopotamia. They are the following: 'Amman 3 and

34 Name of the Edomite state god.

35 The name of the Judean and Israelite god. This deity name also occurs in the following non-provenanced inscriptions that have been identified by some scholars as possibly Ammonite: ØCAI, nos. 4, 9c.

36 A pair of statuettes that is most likely a male-female pair might represent ' $\mathrm{El}$ and his consort were found at Khirbat al-Hajjar (Ibrahim 1971; Abou Assaf 1980, pp. 21-22, tafeln I-II). One of the statuettes bears the atef crown and fits with the iconography of 'El discussed above. The other statuette appears to be female, though the face is damaged badly, and so an identification remains uncertain (Dornemann 1983, p. 157 n. 2). Four other female double-faced heads were found in secondary deposition on the Amman Citadel (Zayadine 1973, pp. 34-35, pls. XXI-XXIII). These were in all likelihood designed to be integrated into decorative architecture and viewed from both sides (Abou Assaf 1980, p. 83; Dornemann 1983, pp. 160-61; Prag 1987, pp. 123-25; Zayadine 1973, p. 34). A general identification of these as representing a goddess is possible though not by no means certain (Hübner 1992, pp. 265-66).

37 Non-provenanced inscriptions that are possibly Ammonite add a few more deity names to the list. Inscriptions that are non-provenanced but probably Ammonite include the following theophoric elements: 'Astarte (ØCAI, no. 56:4), Bes (ØCAI, no. 44 [there are major disagreements over how to decipher this inscription]), Dagon (ØCAI, no. 78a [the seal is damaged and difficult to reconstruct]), 'Ešem (ØCAI, no. 71b), 'Inurta (ØCAI, no. 55), and Mot (ØСAI, no. 44).

38 Several non-provenanced seals that are possibly Ammonite add several other deities or symbols to the list. $\varnothing C A I$, no. 103 depicts a naked female with hands on her breasts. Hübner suggests she is a representation of the consort of Milkom, a dea nutrix figure (Hübner 1993, p. 142). A local adaptation of the Egyptian god Harpokrates is visible on ØCAI, nos. 110, 111 (Hübner 1993, p. 143).

39 Bes may also appear epigraphically in a name on the non-provenanced inscription ØCAI, no. 44 
49 (CSAJ, pp. 10-11, 38-39), Meqabelein 1 (CSAJ, pp. 190-91; Figure 5b), Tall al-Mazar 14 (CSAJ, pp. 300-1; Figure 5d), Tall Safut 5 (CSAJ, pp. 436-37).

6. Stylus of Nabu-This symbol of the Babylonian god of writing (Black and Green 1992, pp. 133-34; Millard 1999, p. 607) appears on a number of seals from Ammon, often alongside the spade of Marduk. Together they were two of the most popular gods in Mesopotamia during the first millennium BCE (Millard 1999). All of the seals are conoid stamp seals except 'Amman 88, which is a cylinder seal, and Tall Safut 5, which is a bulla: 'Amman 3 and 88 (CSAJ, pp. 10-11, 58-59; Figures 5a and 10a), Meqabelein 1 (CSAJ, pp. 190-91; Figure 5b), Tall al-'Umeiri 44 (CSAJ, pp. 336-37); Tall Safut 5 (CSAJ, pp. 436-37).

7. Mischwesen-Mixed or hybrid beings are a common feature of ancient Near Eastern art and mythology. They compile features of multiple types of living beings (humans, birds, lions, bulls, fish) into a hybrid that then often serves as a protector of liminal spaces, such as temple entrances, as well as in other apotropaic functions.

a. Bull-man-Varying somewhat from depiction to depiction, a bull-man has the body of a bull, a human head, and sometime wings (Black and Green 1992, p. 51). One appears on the scaraboid stamp seal 'Amman 6 (CSAJ, pp. 14-15; Figure 11b), and on another scaraboid stamp seal, Tall al-'Umeiri 55 (CSAJ, pp. 342-43).

b. Genius-Genius is a generic name used to cover a number of figures with human heads and bodies with the addition of wings (Black and Green 1992, pp. 87-88). What appears to be a four-winged genius is visible on one side of the scaraboid stamp seal 'Amman 6 (CAI, no. 41; CSAJ, pp. 14-15), but the head area is damaged and hence impossible to know for sure. Another four-winged genius appears on Tall Safut 4 (CSAJ, pp. 436-37). ${ }^{40}$

c. Griffin-A mythological creature with leonine body and tail, wings, and an eagle/bird head (Black and Green 1992, pp. 99-101) appears on two conoid stamp seals 'Amman 4 and 54 (CSAJ, pp. 10-11, 42-43; Figure 6a). Two more appear on the cylinder seal Tall al-Mazar 24 (CSAJ, pp. 306-7; Figure 9f), with an additional example on the scaraboid stamp seal Tall Dschalul 2 (CSAJ, pp. 420-21). Two additional griffin-like figures appear on Tall al-Mazar 23, a cylinder seal, but the body type is difficult to identify (CSAJ, pp. 306-7; Figure $4 \mathrm{~b}){ }^{41}$

d. Lion-demon (ugallu) - This creature has a lion head with upright ears or horns, a human body, and clawed bird feet (Black and Green 1992, pp. 119-21). It appears on the conoid stamp seal 'Amman 5 (CSAJ, pp. 12-13; Figure 7d). A second figure on the same side of this seal may be likewise be a lion-demon, but the area where the head would appear is damaged.

e. Mušuhuššn-This mythological protective beast is a mix of snake, lion, and bird, and over time was associated with several of the main gods of Mesopotamia, including Marduk, Nabu, and Aššur (Black and Green 1992, p. 166). It appears in stylized form on the conoid stamp seal 'Amman 49 (CSAJ, pp. 38-39; Figure 11d) in association with the spade of Marduk.

40 A non-provenanced scaraboid stamp seal that is possibly Ammonite has a four-winged humanoid wearing the Egyptian double crown and could possibly be considered a genius (ØСAI, no. 107). Another similar image appears on a scaraboid stamp seal that might be Ammonite, but is likely either Phoenician or Aramaic (ØCAI, no. 1a).

41 The following non-provenanced seals that are probably Ammonite have griffins as well. ØCAI, no. 17; ØCAI, no. 50 (scaraboid stamp seal); ØCAI, no. 55 (conoid stamp seal with griffin-like being). 


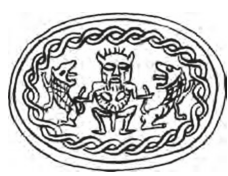

(a)

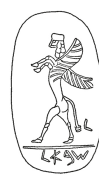

(b)

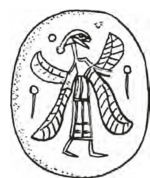

(c)

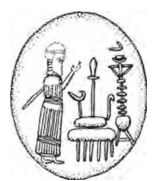

(d)

Figure 11. Other gods and mythological creatures: (a) 'Amman 62; (b) 'Amman 6; (c) Tall Safut 4; (d) Amman 49.

Noticeable in the iconography of these nonphysical beings is a significant bent towards beings whose origins are in Mesopotamia. This is not necessarily surprising, given the military and economic ascendency of Assyria and Babylonia in the late eighth through sixth centuries, which brought many other types of cultural borrowings to the Levant. Given that there are no mythological texts from the Ammonites, nor architectural representations of these beings from Ammon, we can say little about how they were perceived, whether they had names specific to the Ammonites, or how they fit within the Ammonite pantheon. Mentions in the Hebrew Bible of the Mesopotamian god Nabu (Isaiah 46:1) and the Egyptian god Bes (in a personal name; Ezra 2:49), along with descriptions of cherubim (e.g., Exodus 25:17-22; 1 Kings 6:23-38) and seraphim (Isaiah 6), that are Hebrew categories of Mischwesen, suggest that people in the southern Levant were aware of some foreign gods, and had indigenous categories of beings that paralleled those found in other areas. Without arguing that all of the gods, goddesses, and other nonphysical beings listed here were explicitly known in Ammon, the list provides a sense of the variety of beings that were understood to inhabit the nonphysical world of the Ammonites. That world was multilayered and populated by beings with varying roles to play in individual, family, and political life.

\subsection{Ancestors}

The status, role, and treatment of the dead in the ancient Levant, and more broadly the ancient Near East, has stimulated several decades worth of serious scholarly study that goes well beyond the scope of this essay. ${ }^{42}$ At a minimum, concepts of kinship linked the living and the dead, as did mortuary practices. Two main sets of evidence suggest the ongoing place of the dead within Ammonite society: (1) onomastic data, including the ethnonym or tribal name bn 'mn, "the sons of Ammon," and Ammonite personal names; (2) grave goods that indicate ongoing interactions with the dead.

\subsubsection{Onomastic Data Relating to the Ancestors}

The linguistic construction that refers to an individual as the "son of $\mathrm{X}^{\prime}$ or to a group as the "sons of X" is common in the Semitic languages. In the case of an individual, the second part of the construction represented by the " $X$ " is normally that person's father. In the case of a group, the second part of the construction is normally the name of a real or fictive ancestor to which the group traces its roots (Routledge 2004, p. 126). The ways in which the Ammonites are named, both from within and without ${ }^{43}$, follows this model and suggests that "Ammon" is to be taken as the name of the eponymous ancestor of the Ammonites (Hübner 1992, p. 244). In addition to "Ammon" being in the

42 For recent discussion and bibliography see (Albertz and Schmitt 2012, chp. 5 and 7; Hays 2015; Herrmann and Schloen 2014; Porter and Boutin 2014; Stavrakopoulou 2010, pp. 1-28). Several earlier treatments of the dead and relations with them present different assessments of what the material and textual evidence can tell us are (Bloch-Smith 1992; Schmidt 1996; Van der Toorn 1996b, pp. 42-65, 151-77, 206-35).

43 The Tall Siran Bottle Inscription (CAI, no. 78) mentions three successive kings of the Ammonites all designated as mlk bn 'mn, "king of the sons of Ammon." In the cognate Hebrew language, the Hebrew Bible characteristically refers to the Ammonites as bny 'mn, "the sons of Ammon," (e.g., Genesis 19:38, Joshua 12:2), and less often as "Ammon" (e.g., 1 Samuel 11:11). In its records of the interactions with its imperial subjects, the Neo-Assyrian Empire refers to the Ammonites as "the house of Ammon," "the sons of Ammon," or simply “Ammon" (Tyson 2014, pp. 70-79). 
place of the eponymous ancestor in the ethnonym "the sons of Ammon," the name itself has ancestral overtones. This is because the name is built on the Semitic root ' $m(m)$ that has to do with clan or tribal relationships, particularly those on the paternal side. Depending on its use, it can refer to a paternal uncle, a paternal clan, more generically a kinsman, and in the plural, to groups of people (HALOT, pp. 837-38). ${ }^{44}$ It may be coincidence that the eponymous ancestor of the Ammonites has a name with ancestral overtones, for ' $m(m)$ is a productive noun in the West Semitic onomasticon (Jackson 1983, p. 515; Landes 1956, pp. 3-12). Nonetheless, one cannot help but wonder whether the eponymous ancestor was named with ancestral language for a particular purpose that is no longer discernable.

In addition to the use of ' $m(m)$ in the tribal name of the sons of Ammon, it also appears in the names of two Ammonite kings named 'mndb, "Amminadab," who are mentioned on the Tall Siran Bottle (CAI, no. 78$)$ in a list of three kings, where the grandfather and grandson have the same name. A seal also bears the name Amminadab and most likely corresponds to the grandfather listed on the Tall Siran Bottle (CAI, no. 40). ${ }^{45}$ The name Amminadab, which appears in other Semitic languages as well, can be translated as "My kinsman is noble." 46

Several other Ammonite inscriptions contain kinship elements that add to the impression that deceased ancestors played a role in Ammonite understanding of the non-physical world. These include the following:

1. ' $b$, "father"-This element appears in the name 'bwt'b, "My father has longed for" (CAI, no. 243:2; Gane 2008, p. 77) It is conceivable that this name refers to a living father. For parallels and discussion of the use of ' $b$ see (Huffmon 1999b). ${ }^{47}$

2. ' $h$, "brother"-This element appears in the name ' $h$ ', which is the word for "brother", plus a hypocoristic ending that replaces the predicate (CAI, nos. 211:4; 243:1; Gane 2008, p. 76). For parallels and discussion of the use of ' $h$ see (Huffmon 1999a).

3. $h l$, "uncle"-This element appears in the name $h l$ ', which is the word "maternal uncle" plus a hypocoristic ending that replaces the predicate (CAI, no. 243:3; Gane 2008, p. 78; cf. ØCAI, no. 130).

44 It is possible that ' $m(m)$ could be the name of a god 'Amm. A lunar deity named 'Amm is known from South Arabian inscriptions from Qataban (in modern Yemen), but it is not clear that 'Amm was a deity known in the West Semitic sphere of which Ammon was a part (Hübner 1992, p. 243, n. 95; Seow 1999). It is also possible that it is an epithet of a deity-perhaps 'El or Milkom-who is thus referred to with kinship terminology. This use of ' $m(m)$ is possible for a name such as 'ĕlî' $\bar{a} m$, "Eliam," which appears in the Hebrew Bible (2 Samuel 11:3) and can be translated as "My god is a kinsman" (Jackson 1983, p. 510), rather than "My god is 'Amm." A similar name occurs on a non-provenanced seal thought to be Ammonite (ØCAI, no. 10). However, gods are not normally referred to with kinship epithets other than 'b, "father" (Van der Toorn 1996a). Another issue with the name Ammon is understanding the morphology of the word (Hübner 1992, p. 243, n. 95). The difficulty stems from the $-n$ ending, which can be understood as a diminutive ending, thus yielding something like, "little uncle" (HALOT, p. 843). The - $n$ ending can also function as an adjectival ending (GKC § 86f), which would hypothetically mean something like "ancestral." It can also be understood as a hypocoristic ending that replaces the theophoric element so common in Semitic names (Hübner 1992, p. 243, n. 95; Landes 1956, pp. 9-12). On this latter understanding, the name would have either asserted that a particular deity was a kinsman, or it would have ascribed some attribute or action to a deceased kinsman. GKC = Kautzsch, Emil, ed. 1910. Gesenius' Hebrew Grammar, 2nd ed. Translated by Arthur E. Cowley. Oxford: Clarendon. HALOT = Koehler, Ludwig, Walter Baumgartner, and Johann Jakob Stamm. 2001. The Hebrew and Aramaic Lexicon of the Old Testament. Study ed. Translated and edited under the supervision of M. E. J. Richardason. Leiden: Brill.

45 This name also appears in a seventh century BCE Assyrian inscription from the reign of Ashurbanipal, probably referring to the earliest of the three kings mentioned on this inscription. In the Assyrian inscription, which uses a syllabic script, the name appears as mam-mi-na-ad-bi LUGAL kur bìt am-ma-na, "Amminadab, king (of the land) of the house of Ammon" (Borger 1996, pp. 19, 212). A non-provenanced seal thought to be Ammonite also contains the name Amminadab (ØCAI, no. 17).

46 For cognate names see (Jackson 1983, p. 515).

47 Several non-provenanced inscriptions that are possibly Ammonite include the noun for father in names. These include 'byb 'l, "My father is Ba' al" (ØCAI, no. 1); 'b'l, "My father rises" (ØСAI, no. 22a); 'byhy, "My father is alive," or "The father has preserved" (ØCAI, no. 23); šm 'b, "The (divine) name is father" (ØCAI, no. 35); 'b", "Father" or "Father is ('El)" (ØCAI, no. 37a); 'bndb, "My father is noble" (ØCAI, no. 56); ' $h$ ' $b$, "The brother/kinsman is father" (ØCAI, nos. 98, 188, 216); 'btl, "My father is dew" (ØCAI, no. 143a); 'b' $d n$ "My father has granted fertility" (ØCAI, no. 152); 'b, "Father" (ØCAI, no. 180); ' $h t^{\prime} b$, "Sister of (my) father" (ØCAI, nos. 182); 'bh, "Father" (ØCAI, no. 205). 
4. hm, "father-in-law"-This element appears in the name $h m s ̌ g b$, which can be translated as "My father-in-law is exalted" (CAI, no. 137:7; Jackson 1983, p. 512; Cross 2003, p. 83, with literature). ${ }^{48}$

It is not surprising that Ammonite names accord kin relations a place of honor, as is the case for the societies throughout the ancient Near East. Perhaps unique in this respect is the "sons of Ammon" tribal name, which traces tribal identity to an eponymous ancestor whose name itself has ancestral connotations.

\subsubsection{Grave Goods and the Ancestors}

A variety of tombs and one cemetery have been excavated in and around Amman, providing a glimpse into Ammonite funerary and mortuary practice in the Iron Age II. Tombs are normally cut into the rock or used natural caves. In the case of Tall al-Mazar Cemetery A, burials are in individual pits. The earlier burials, dating to the 11th eleventh through ninth c. BCE, tend to use coffins of some sort-whether anthropoid or large jars - and were buried with some pottery, jewelry, and an occasional seal. Burials from the eighth c. BCE through the Persian period do not use coffins. Grave goods from these tombs include a wide variety of ceramic vessels (jugs, bowls, flasks, decanters, tripod cups, chalices, lamps, juglets, painted bottles, and a few Assyrian style vessels), jewelry, and other metal items (kohl sticks, fibulae, bracelets, anklets, rings, earrings, mirrors, seals, arrowheads, knife blades, daggers, swords), figurines (female tambourine type, horse and rider, and one "hermaphrodite" in Amman Tomb C), a model shrine (Amman Tomb E), a bronze censer (at Umm Udayna), and other high status or unusual items (Mediterranean shells, Assyrian style pottery, seals, and items made of glass most likely imported from the Aegean. ${ }^{49}$

From this brief review, it is clear that the tombs in the vicinity of Amman represent what must have been the wealthier class. The much poorer individual burials at Tall al-Mazar Cemetery A highlight the wealth of the tombs found closer to Amman (Yassine 1984, 1999). Second, and more important for a study of beliefs about and practices related to the dead, is that the assemblage of ceramic vessels (especially tripod cups, chalices, juglets, and lamps), figurines, as well as the high status or unusual finds, is similar to that which Daviau isolates as relating to the domestic cult (Daviau 2001; on which see below $\S 4$.2.1). The question then is, what can we say about the religious aspects of these burials?

Some of the items found in the tombs, such as kohl sticks, jewelry, and seals, are personal items that represented the identity of the person interred rather than any specific religious practice. On the other hand, the number of pottery vessels generally associated with eating and drinking (but not storage) point to a nourishment of the deceased in their ongoing existence-whatever it was conceived to be. Lamps suggest the presence of the living in the tombs on some occasion. Some items were possibly used for fumigation (incense burners, and possibly tripod cups). Seals found in tombs are often thought of in functional categories, but they might also have served apotropaic purposes. Figurines and model shrines ${ }^{50}$ were probably used in some type of ritual practice that was related to the dead, but they are also found in non-mortuary contexts, suggesting that there was a range of uses for these objects. The form that such rituals took and the beliefs that they might imply are difficult to pinpoint. Nonetheless, it is reasonable to assume that such rituals were understood to have salutary effects upon the dead, as well as on relationships between the dead and the living.

At a minimum, it seems that the dead were understood to have a continued existence and need of sustenance that the living could provide. Commemorative acts were also common (Albertz and

Cf. ØCAI, no. 9, which contains the feminine name ' $l \check{g} g b$, " 'El is exalted." Here, the theophoric element is clearly a deity, and uses the same predicate. For more on this name and inscription, see (Hübner 1992, p. 69; Jackson 1983, p. 511). ØCAI, no. 215:1 uses the $h m$ element in the name $h m d n$, "My father-in-law is judge."

49 For a summary of the tombs, see (Tyson 2014, pp. 23-26, 30, 39-45, with literature).

50 For recent discussion of figurines and some of their possible uses, see (Darby 2014). For the collection and analysis of the Iron Age model shrines, see (Daviau 2008). 
Schmitt 2012, pp. 455-69; Bloch-Smith 1992, pp. 122-26; Schmidt 1996, p. 275). A cult of the dead or cult of the royal ancestors has been assumed for Ammon, in part based on discussions of other areas in the Levant (Hübner 1992, p. 279; Israel 1990, pp. 323-24). Certainly, the pottery related to food, figurines, and items related to incense are suggestive of rituals involving eating. Whether the tomb assemblages imply worship, placation, or other forms of manipulation of the dead is more difficult to know. If we take the definition of religion presented at the beginning of this paper as the starting point, then a distinction between the feeding and care of, or the deification and worship of ancestors becomes less important for the bigger picture. The extant material remains in tombs suggest that the dead in Ammon fall in the category of nonphysical agents (rather than being non-existent), and that there were beliefs and ritual practices associated with them, even if we cannot fully reconstruct them.

\section{Cultic Space}

For the purposes of this paper, I divide spaces used for relating to the nonphysical world into two broad categories: public cultic space and private or domestic cultic space. By the term "public cultic space" I mean only that the space seems to be intended to be used by a group that is most likely larger than a single family. A public cultic space is thus not contained within a domestic space even if it is physically built next to domestic buildings. By "private or domestic cultic space", I designate those spaces which appear to have some cultic or religious significance, but which are contained within a house, or in the case of tombs, relate to individuals or individual families. These are pragmatic distinctions used in part because of the dearth of remains and their state of preservation that does not allow for more refined analyses.

\subsection{Public Cultic Space}

The history and archaeology of the Iron Age II Levant furnish examples of a range of public cultic space types. The most well-known of these come from the Hebrew Bible, whose texts describe a portable public shrine known as the tabernacle (Exodus 25-31,35-40) and then the more permanent temple said to have been built by Solomon (1 Kings 6) and then later destroyed in $586 \mathrm{BCE}$ when the Babylonians destroyed Jerusalem and its temple (2 Kings 25:8-10). It is also clear from the Hebrew Bible that other public cultic spaces existed, though they are polemicized as illegitimate. In one of the classic passages describing the destruction and desecration of illegitimate places of worship we hear of the radical actions ordered by the reformer king, Josiah and of some of the places at which people were engaging in religious actions. The types of places mentioned are set in boldface to make them more visible.

The king commanded the high priest Hilkiah, the priests of the second order, and the guardians of the threshold, to bring out of the temple of the LORD all the vessels made for Baal, for Asherah, and for all the host of heaven; he burned them outside Jerusalem in the fields of the Kidron, and carried their ashes to Bethel. He deposed the idolatrous priests whom the kings of Judah had ordained to make offerings in the high places (bāmôt) at the cities of Judah and around Jerusalem; those also who made offerings to Baal, to the sun, the moon, the constellations, and all the host of the heavens. He brought out the image of Asherah from the house of the LORD, outside Jerusalem, to the Wadi Kidron, burned it at the Wadi Kidron, beat it to dust and threw the dust of it upon the graves of the common people. He broke down the houses of the male temple prostitutes that were in the house of the LORD, where the women did weaving for Asherah. He brought all the priests out of the towns of Judah, and defiled the high places where the priests had made offerings, from Geba to Beer-sheba; he broke down the high places of the gates that were at the entrance of the gate of Joshua the governor of the city, which were on the left at the gate of the city. The priests of the high places, however, did not come up to the altar of the LORD in Jerusalem, but ate unleavened bread among their kindred. He defiled Topheth, which is in the valley of Ben-hinnom, so that no one would make a son or a daughter pass through fire as an offering to Molech. He removed the horses that the kings of Judah had dedicated to the sun, at the entrance to the house of the LORD, by the chamber of the eunuch Nathan-melech, which was 
in the precincts; then he burned the chariots of the sun with fire. The altars on the roof of the upper chamber of Ahaz, which the kings of Judah had made, and the altars that Manasseh had made in the two courts of the house of the LORD, he pulled down from there and broke in pieces, and threw the rubble into the Wadi Kidron. The king defiled the high places that were east of Jerusalem, to the south of the Mount of Destruction, which King Solomon of Israel had built for Astarte the abomination of the Sidonians, for Chemosh the abomination of Moab, and for Milkom the abomination of the Ammonites. He broke the pillars in pieces, cut down the sacred poles, and covered the sites with human bones.

Moreover, the altar at Bethel, the high place erected by Jeroboam son of Nebat, who caused Israel to $\sin -$ he pulled down that altar along with the high place. He burned the high place, crushing it to dust; he also burned the sacred pole. As Josiah turned, he saw the tombs there on the mount; and he sent and took the bones out of the tombs, and burned them on the altar, and defiled it ... (2 Kgs 23:4-16a).

The clear polemical tone and purpose of this text means that a lot of questions remain about the seeming ubiquity of the "high places"; nonetheless it gives some sense of the range of public cultic spaces that are visible to the biblical author. Among other things, we hear of the bammôt, "high places," high places at the gates, the Topheth (apparently a place for child sacrifice), houses of haqq de $\bar{e}$ šìm, "the holy ones" (often thought to be male prostitutes), and altars in other places (roofs, in the Temple, in Bethel). Some of these spaces are understood to have cultic functionaries (i.e., priests) and paraphernalia such as pillars/standing stones (maș̣êbôt) and poles ('ăšêrîm; related to the name of the goddess Asherah).

Archaeological excavations provide examples of a range of public cultic spaces as well. Iron Age II temples of varying sizes and construction have been excavated at sites such as Tell Tayinat in southern Turkey (Haines 1971, pp. 53-55; Harrison and Osborne 2012), Tel Dan (Davis 2013) and Arad in Israel (Aharoni 1968; Herzog et al. 1984), and Deir 'Alla in Jordan (Franken 1969; Hoftijzer and van der Kooij 1991; Ibrahim and van der Kooij 1991). Small yet public cultic spaces have been discovered at gates such as at Bethsaida (Bernett and Keel 1998). Shrines separate from urban areas have been excavated at sites such as Kuntillet 'Ajrud (Meshel 2012), and at Tell Damiyah (Petit and Kafafi 2016) ${ }^{51}$ and Wadi ath-Thamad WT-13 in Jordan (Daviau and Steiner 2017). Given this cross-section of public cultic spaces known from the Levant, it is to be expected that the Ammonites had a similar range of sites even though the extant textual and archaeological records provide only a few hints and clues to their existence. ${ }^{52}$

\subsubsection{Rujm al-Kursi}

The site of Rujm al-Kursi discussed above in relation to the moon-god (§ 4.3.1), despite not being fully published, may well provide the clearest example of an Ammonite temple or sanctuary. The major remains excavated at the site have been Byzantine or Umayyad in date (Hübner 2009, p. 146). Although it has not been excavated yet, the contours of an Iron IIC building that might be a temple are visible (Figure 12).

51 Tell Damiyah is very close to the traditional border of the Ammonites along the Zarka River, and might eventually prove to be Ammonite as excavations progress further. Regardless of its political affiliation, which we may never know for sure, its location near a ford in Jordan River make it a potentially important node for traffic through the area.

52 For recent discussions of temples and other cult places in the Levant and the ancient Near East, see (Elkowicz 2012; Hundley 2013). 


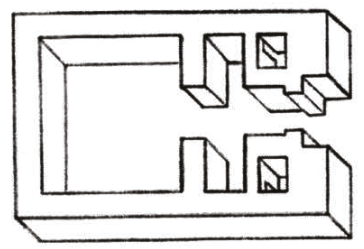

Figure 12. Isometric plan of the Rujm al-Kursi temple (Hübner 2015, p. 194, abb. 3).

The structure is oriented east-west, with the entrance facing east, an orientation typical of Iron Age temples. The outer dimensions of the structure are approximately $18.70 \mathrm{~m} \times 12.60 \mathrm{~m}$, with walls 1.50-1.60 m thick. The walls on either side of the entrance are $2.60 \mathrm{~m}$ thick. On either side of the entrance, there is a smoothed, nearly cubical block of limestone measuring slightly less than $1.0 \mathrm{~m}$ per side. On the front face of each block there is a relief presenting a lunar crescent standing on a table supported by a pillar (Hübner 2009, pp. 147-49; Figure 3).

The location of these reliefs at the entrance to the building suggests its identification as a temple to a moon-god. Compared with other representations of crescents in Syro-Palestine, the reliefs probably date to the seventh century; a more secure dating must wait for full publication of the pottery and excavations of the site. If the building does date to the seventh century, it furnishes evidence for the development of the region under Neo-Assyrian rule, and may provide evidence for the local adoption of the worship of Sîn of Harran, or at least the use of a symbol very much like his (Hübner 2009, pp. 149-51). ${ }^{53}$

\subsubsection{Amman Citadel}

The Amman Citadel, which stands near the center of the modern city of Amman, was the capital of the Ammonite kingdom. In the Bible, the site is called Rabbah of the Ammonites (i.e., "the great [city] of the Ammonites"). It was common in the ancient Near East, as it is in some places even today, for political and religious power to be connected in capital cities. Often palaces and temples were built near each other, and this might in fact be the case for the Amman Citadel. The partial remains of a large building dating to about $700 \mathrm{BCE}$ were located on the second plateau of the Amman Citadel. The extant remains of the building measure $10.0 \mathrm{~m}$ by at least $15.0 \mathrm{~m}$, and appear to be built in Assyrian open-court architectural style (Humbert and Zayadine 1992, pp. 249-58; Zayadine et al. 1989, p. 362). Close to this building, four bifacial female stone heads were found built into a Hellenistic drain. Each head has two faces back-to-back such that they look essentially identical from either side. Each head has holes drilled in the top and the bottom suggesting that they may have been a decorative architectural function as part of a balustrade or other architectural feature (Abou Assaf 1980, p. 83; Dornemann 1983, pp. 160-61; Prag 1987, pp. 123-25; Zayadine 1973, p. 34). Whether or not the bifacial female heads were actually in the large building found nearby remains a matter of speculation; nonetheless, the building and the decorative architectural elements point to elite buildings of some sort (a palace?), and confirm the nature of the occupation on the Amman Citadel during the latter part of the Iron Age II.

53 Many questions remain about this building and its architectural context that cannot be answered until the excavations have been properly published, and even then, further excavations might be necessary to clarify the layout of the building and its relationship to other buildings in the same stratum. One aspect of the architecture that is debated is the building's relationship to other temple types known in the ancient Near East. Hübner maintains that the architecture is a combination of Migdal temple architecture with Syrian Langraum ("long room") temple types (Hübner 2009, 2015). Elkowicz on the other hand, argues that the two structures on either side of the entrance, which Hübner identifies as towers, are not towers, and hence, the Migdal temple identification is incorrect (Elkowicz 2012, p. 90; Elkowicz 2014). While I remain hesitant to draw definite conclusions about the structure because of the lack of excavation reports and vagaries of the interior architecture, I visited the site in July of 2012 and agree with Hübner that the structures on either side of the entrance look very much like towers with a small entrance to each from the interior (west) side. 
Given the elite nature of at least part of the Amman Citadel, it is a reasonable assumption that there was a temple or temples located somewhere nearby as well. Excavations conducted on the first plateau of the Amman Citadel just outside and under the Roman temple of Hercules uncovered a building dating to the seventh-sixth century BCE. The exposed portion of the building consists of an east-west wall $21.30 \mathrm{~m}$ long and a north-south wall $6.0 \mathrm{~m}$ long. A wall found in another square may continue the north-south wall, bringing its length to about $19.0 \mathrm{~m}$. The walls are made of an irregular collection of large and small stones, and they have a preserved height of 1.2-1.9 m and width of $0.7-1.0 \mathrm{~m}$. The plaster floor stands on top of an earth and stone layer used to create a level surface above the bedrock. There is no evidence for partition walls in the exposed part of the building, which points to a rather large (public?) room. Finds include Iron IIC pottery, a partially legible ostracon, figurine fragments, a part of a model,$^{54}$ beads, spindle whorls, and some shells (Momani et al. 1997, pp. 160-70). The size of the building and its location under the Roman temple of Hercules may suggest a temple (Momani et al. 1997, p. 164). The reuse of sacred precincts through time is relatively common, and that may be what we see here. Speaking against such an interpretation of the Iron Age remains is the relatively crude construction of the walls, and the rather mundane collection of pottery and domestic objects.

A few other finds are suggestive of cultic space at the Amman Citadel. The Amman Citadel Inscription (CAI, no. 59) might provide some evidence for cultic architecture. This inscription on stone was discovered in 1961 in the remains of Iron Age fortifications on the southwest crest of the Amman Citadel. It was seriously damaged in antiquity when it was cut for use in a building and hence, only eight lines or partially readable text are left. The first partially preserved line seems to mention the name of the Ammonite god Milkom and a command to build an entryway or some kind of defensive structure (CAI, no. 59). Assuming the reconstruction of the partially preserved name Milkom is correct, it is possible that Milkom is seen as commanding the building of some sacred architecture. The badly preserved text precludes certainty. ${ }^{55}$

The nine male stone sculptures mentioned above ( $\$ 4.1)$, which most likely represent 'El, also suggest the presence of a sacred precinct on or near the Amman Citadel. One of them was found on the Amman Citadel (Abou Assaf 1980, pp. 22-23, statuette III; Barnett 1951, p. 34 sculpture A, pl. X), two of the heads were found near Amman (Abou Assaf 1980, pp. 24-25, head VII, pp. 30-31, head XVII), two were purchased in Amman (Abou Assaf 1980, pp. 23-24, head V, p. 32, head XX), and three are of unknown provenance though likely from around Amman (Abou Assaf 1980, p. 23, head IV, p. 24, head VI, pp. 31-32, head XIX). Of these nine sculptures, the one found on the Amman Citadel is a full statue on a pedestal (Figure 2), the other eight are only the heads. The find of a stone torso on the Amman Citadel with a socket into which a head could fit (Abou Assaf 1980, p. 27, statuette fragment X; Barnett 1951, p. 36, sculpture D, pl. XIII), suggests that these the male heads might have been carved separately and attached then attached to the rest of the statue. There is no way to be certain that these sculptures were related to a temple, because all of them were found in secondary contexts or purchased on the antiquities market. Nonetheless, as statues representing a god or gods, an original cultic context is likely, even if we do not know its whereabouts precisely. ${ }^{56}$ Given their concentration in and around Amman and the Amman Citadel, the case for a temple there is strengthened. ${ }^{57}$

54 Presumably a model shrine, but the excavation report does not specify (Momani et al. 1997, p. 167).

55 The Amman Theatre Inscription (CAI, no. 58) also seems to contain a command to build something. This inscription is such a tiny piece of what it probably was originally that it is very difficult to tell.

56 It is possible that the story about David conquering Rabbah of the Ammonites (presumably the Amman Citadel) found in 2 Samuel 12:26-31 and 1 Chronicles 20:1-3 that describe David taking the crown off of Milkom or "their king" and putting it on his own head, might be reference to the despoliation of cult statue of Milkom. On this see the discussion above in § 3.1 .

57 For more bibliography see (Tyson 2014, Appendix B). 


\subsubsection{An Open Air Sanctuary at Tall al-'Umayri?}

A relatively large, apparently open-air structure with plastered floors was excavated in the Late Iron Age I Strata 11-10 (ca. 11th c. BCE) in Area H at Tall al-'Umayri. Several fragments of model shrines were found on the floor, and in the middle of the area, there is a stone, perhaps used for presentation or as an altar. Given the religious implications of the model shrine fragments, the excavators suggest the area is an open-air sanctuary (Herr and Clark 2009, p. 89). ${ }^{58}$ What is important here is that one of the floors from the following Strata 9-8 (ca. 10th-9th c. BCE) might continue this building into the Ammonite period under consideration here (Herr and Clark 2009, p. 90). While the evidence is not overwhelming for the continuance of this potentially cultic space into the Iron Age II, it is suggestive. ${ }^{59}$

\subsubsection{Gate Cult at Tall al-'Umayri}

What is most likely a small cult corner was uncovered in Field F at the entrance to the late Iron IIC settlement at Tall al-'Umayri, consisting of a standing stone $0.90 \mathrm{~m}$ tall and a cobble-lined pit or basin (Herr and Najjar 2001, p. 337; Low 1991, p. 187). Cultic areas outside city gates have been found at Tirzah, Dan, and Bethsaida (Zevit 2001, pp. 149-53, 191-96, 238-41). The excavator compares this one specifically to the Stratum VII gate at Tell el-Far' ah (North), which also had a standing stone and a basin (Low 1991, p. 187). Though their function is not fully known, the basins and associated pottery suggest that people entering the city may have paid homage to the city god(s) by pouring or sprinkling water, or there may have been some significance to the association of the water and the stones (Zevit 2001, pp. 153, 192-94, 241). What we can say for sure is that these installations testify to public expressions of religiosity that may have focused on the local (perhaps city) god(s). ${ }^{60}$

\subsection{Private or Domestic Cultic Space}

Identifying private or domestic cultic space can be challenging because it often lacks architecture that is easily identified as cultic. Cultic interpretations of a private or domestic nature are thus normally dependent on identifying an assemblage of artifacts that point beyond mundane daily life. Daviau describes such assemblages as "those artifacts and ceramic vessels which are present in uncontested shrine sites, but may also appear in a domestic setting as evidence of religious activities practiced by family members in the home" (Daviau 2001, p. 199). ${ }^{61}$

\section{Domestic Cult at Tall Jawa}

A domestic cult assemblage has been identified in several rooms at Tall Jawa. When excavated, the interiors of a number of buildings were found to have a thick layer of debris approximately $1.0 \mathrm{~m}$ thick in which a collection of items that parallel other known cultic assemblages in Israel and Judah

58 On the model shrine see (Elkins 2017).

59 For further bibliography see (Elkowicz 2012, p. 89).

60 Another example of public cult just to the south of Ammonite territory in Moab comes from a room just inside the city gate at Khirbat al-Mudayna ath-Thamad. The cultic nature of this room is easily identified by the existence of three small stone altars, benches along the walls, two female figurine heads, and the naked torso of a third, two bronze rings, a Wadjet-eye amulet, carved limestone "pegs," and a ceramic assemblage of lamps, a spouted vessel, a juglet, a decanter, small bowls, a small jug, and some store jars (Daviau and Steiner 2000). The three stone altars provide the most specific evidence in terms of actual practice. Two of them (the unpainted altar MT-4/014 and the conical altar MT-4/015) had soot on the top indicating that something was burned there, probably some king of incense or aromatic substance (Daviau and Steiner 2000 , pp. 10-11). The tall conical one also has an inscription on it that reads "The incense altar [mqtr] that Elishama made for ysp, the daughter of ' $w t^{\prime}$ ' (Dion and Daviau 2000, p. 5), and thus confirms the function inferred from the burning. The painted altar (MT-4/011) has a small hole that connects to a larger depression that is likely used for drainage of liquid offerings (Daviau and Steiner 2000, p. 10). Taken together with the other finds, one can imagine this shrine as a place in which inhabitants of the city made small offerings or left a votive and prayed for divine assistance.

61 In this regard, Daviau builds on Holladay's essay on Israelite religion (Holladay 1987), which emphasized the importance of such an approach in identifying loci of domestic and other small-scale religious practices. 
were found. This layer separated the cultic material from the pottery that was smashed on the floor, suggesting that this material came from the roof or upper story (Daviau 2001, p. 202). ${ }^{62}$ Among the assemblage were "male and female figurines, zoomorphic figurines or vessels, one-handled cups, chalices, tripod cups, lamps, strainer bowls, small vessels, miniature vessels and basalt trays", as well as unique items such as a possible baetyl (a sacred stone), a Tridacna dish (a dish made from a giant clam), imported vessels, and a libation table (Daviau 2001).

That the material came from the upper level is significant because texts from Late Bronze Age Ugarit (coastal Syria) and Emar (northern Syria), as well as biblical texts dating from the seventh century BCE and later, mention cultic acts performed on roofs (Daviau 2001, p. 201). The prophet Ezekiel issues this judgement on the people of Jerusalem: "The Chaldeans [i.e., Babylonians] who are fighting against this city shall come, set it on fire, and burn it, with the houses on whose roofs offerings have been made to Baal and libations have been poured out to other gods, to provoke me to anger." Far from being a full explanation of domestic rituals on roofs, this and other texts nevertheless provide some clues for the uses of such an assemblage as that found at Tall Jawa. Specifically, it indicates that offerings (probably of the plant or incense variety) and libations (fluid offerings) took place on the roofs of city-dwelling individuals. For the assemblage at Tall Jawa, Daviau proposes the following set of possible activities that took place in these domestic spaces:

... the setting up of a figurine or symbolic stone in a particular area on the roof or upper storey, food and drink offerings, use of scented materials, lighting of lamps, sprinkling of the figurine, the baetyl, or the sacred area itself, offerings in small or miniature vessels, casting of lots or divination, and libations. (Daviau 2001, p. 221)

Whatever set of rituals this assemblage represents, it is likely that they were designed to invoke or create closeness with the gods or otherwise amplify the experience and effectiveness of communication with the gods (Keel and Uehlinger 1998, p. 348; Zevit 2001, p. 274). Given the regular finds of some of these items at other sites-especially figurines-it is probably a good assumption that small-scale cultic practices were common in Iron Age II Ammonite homes. ${ }^{63}$

\section{Religious Specialists}

The evidence for gods and goddesses as well as cultic space and associated practices implies the existence of religious specialists (priests, diviners, prophets, etc.) and rituals (offerings, divination, ecstatic utterances, etc.) about which we know little specific. ${ }^{64}$ One indication of a tradition of religious specialists close to Ammon comes from the famous site of Deir 'Alla where the plaster inscription of Balaam son of Beor, a seer ( $h z h)$ known from the Bible (Numbers 22-24) was found. The function of room EE335 (the room containing the Balaam texts written on the wall plaster) at Tall Deir 'Alla is generally considered to be religious in nature because of the content of the text itself. The benches in the room also suggest a cultic function (in connection with the texts), because other known sanctuaries have benches in them, ${ }^{65}$ but the room was otherwise empty of artifacts. ${ }^{66}$ The entrance to the room

62 On the excavations of the relevant buildings (102, 113, 200, 300, 700, 800, 900, 910), see (Daviau 2003, chp. 6-9).

63 For figurines found in tombs and other sites in Ammon see (Clark 2017, pp. 379-81; Dabrowski 1997; Dabrowski 2000, 2009; Daviau 2002, pp. 51-73; Dornemann 1983, pp. 131-40; Herr 2014, pp. 400-7; Herr and Platt 2002, pp. 393-99; Platt 1989, p. 361; Platt and Herr 2002, pp. 166-69)

64 Texts from the biblical book of Jeremiah suggest the titles of some of these religious specialists amongst the peoples surrounding Israel (Jeremiah 27:9, 49:3), but it is impossible to know whether these titles represent categories native to the Ammonites (Hübner 1992, p. 276). Presumably, Ammonite religion conformed to the general trends in Levantine religion, and so some of these titles were relevant to the Ammonites. A non-provenanced seal (ØCAI, no. 1b) that is partially damaged contains the name $b d m l k m$, which some have suggested can be reconstructed as 'bdmlkm, "servant of Milkom," and thus may represent a priest. The reconstruction is not certain though, and even if it is, the name does not necessarily indicate profession.

65 Notably, the bench room at Kuntillet 'Ajrud (where plaster texts were also located on the walls), and Lachish cult room 49 (Zevit 2001, pp. 298-306).

66 (Ibrahim and van der Kooij 1991, pp. 20-21). 
also provided public access. ${ }^{67}$ The rest of the excavated areas appear to be rather modest storage and work areas, ${ }^{68}$ thus not giving any specific clues to the function of room EE335 except to say that it was not related to any items obviously sponsored by the state. The text discovered and reconstructed from the wall plaster that had fallen to the floor presents Balaam's oracular vision from 'El of what the Šaddayin gods were going to do, which apparently involves upheavals of the natural order of things. ${ }^{69}$ In addition to Balaam being a seer, Combination 1: line 11 mentions a priestess (khnh). The proximity of Deir 'Alla to Ammon suggests that these regular categories of religious specialists were probably also known in Ammon.

\section{Ethnic Affiliation and Coalitional Processes}

While there is precious little information from which we can reconstruct the role of religion in ethnic affiliation and coalitional processes among the Ammonites, there is little doubt that religion did play some role. It is a well-known part of ancient societies to have a state god that was understood to support the ruler, especially in military matters. For the Ammonites, this god was, in all likelihood Milkom (see above $\S 4.1$ ), a position that is also understood from the biblical author's perspective when listing Milkom as the "god of the Ammonites", along with "Astarte the goddess of the Sidonians" and "Chemosh the god of Moab" (1 Kings 11:33). Whether the Ammonites or other peoples of the Transjordan had groups within them that argued for exclusive devotion to the state god, as some did in Judah, cannot be determined at present. Nonetheless, as one salient aspect of individual and group identity, devotion to or acknowledgement of a particular deity—whether exclusive or not—is a likely aspect of Ammonite sociopolitical formation, even if only at the level of the ruling elite. What we do not know is whether the sons of Ammon were the only tribal or kinship group in Ammon, or if they were the ascendant or apical tribe for whom a coalition of tribes was known. If it is the latter, it is possible that part of what bound the group together was Milkom's place as the state god, who represented the political regime and aided the Ammonites in their military ventures.

\section{Conclusions}

This investigation of Ammonite religion reveals a typical specimen of Iron Age II Levantine religion. The non-physical realm was understood to be inhabited by gods, goddesses, and a variety of other non-human beings. The living had continued relations with dead ancestors through memory and ritual. Several types of cultic space have been discovered in Ammon. Unique among these is the probable temple to the moon-god at Rujm al-Kursi, which most likely reflects a local tradition of moon worship influenced by the iconography of the Mesopotamian moon-god Sîn. One distinguishing feature of Ammonite religion is the state god Milkom, whose name is probably an epithet for 'El, and who appears to be represented in a tradition of stone sculptures that have been found in the vicinity of Amman. In sum, the archaeological and textual material point to the lively place of religion among the Ammonites, and to a distinct-if not entirely unique-configuration of religious life.

Funding: This research received no external funding.

Acknowledgments: I would like to thank Avraham Faust for the invitation to contribute this article to this special issue on Archaeology and Israelite Religion. My thanks also to Walter Aufrecht for access to his forthcoming second edition of A Corpus of Ammonite Inscriptions.

Conflicts of Interest: The author declares no conflicts of interest.

67 See the top plan in (Ibrahim and van der Kooij 1991, p. 19).

68 (Ibrahim and van der Kooij 1991, p. 18).

69 The editio princeps of the text is (Hoftijzer and van der Kooij 1976). For a recent presentation of the text and commentary on it, see (Ahituv 2008, pp. 434-65). 


\section{Abbreviations}

$C A I$

CSAJ

GKC

HALOT

Aufrecht, Walter E. Forthcoming. A Corpus of Ammonite Inscriptions, 2nd ed. University Park: Eisenbrauns.

Eggler, Jürg, and Othmar Keel. 2006. Corpus der Siegel-Amulette aus Jordanien vom Neolithikum bis zur Perserzeit. Fribourg: Academic Press.

Kautzsch, Emil, ed. 1910. Gesenius' Hebrew Grammar, 2nd ed. Translated by Arthur E. Cowley. Oxford: Clarendon.

Koehler, Ludwig, Walter Baumgartner, and Johann Jakob Stamm. 2001. The Hebrew and Aramaic Lexicon of the Old Testament. Study ed. Translated and edited under the supervision of M. E. J. Richardason. Leiden: Brill.

\section{References}

Abou Assaf, Ali. 1980. Untersuchungen zur ammonitischen Rundbildkunst. Ugarit-Forschungen 12: 7-102.

Aharoni, Yohanan. 1968. Arad: Its Inscriptions and Temple. Biblical Archaeologist 31: 2-32. [CrossRef]

Ahituv, Shmuel. 2008. Echoes from the Past: Hebrew and Cognate Inscriptions from the Biblical Period. Jerusalem: Carta. Albertz, Rainer, and Rüdiger Schmitt. 2012. Family and Household Religion in Ancient Israel and the Levant. Winona Lake: Eisenbrauns.

'Amr, Abdel-Jalil. 1986. Ruğm al-Kursī. Archiv für Orientforschung 33: 211.

'Amr, Abdel-Jalil. 1990. Four Ammonite Sculptures from Jordan. Zeitschrift des Deutschen Palästina-Vereins 106: 114-18, Tafeln 7-8.

Aufrecht, Walter E. 1999. The Religion of the Ammonites. In Ancient Ammon. Edited by Burton MacDonald and Randall W. Younker. Leiden: Brill, pp. 152-62.

Avigad, Nahman, and Benjamin Sass. 1997. Corpus of West Semitic Stamp Seals. Jerusalem: The Israel Academy of Sciences and Humanities.

Barnett, Richard D. 1951. Four Sculptures from Amman. Annual of the Department of Antiquities of Jordan 1: 34-36. Becking, Bob. 1993. Baalis, the King of the Ammonites: An Epigraphical Note on Jeremiah 40:14. Journal of Semitic Studies 38: 15-24. [CrossRef]

Bernett, Monika, and Othmar Keel. 1998. Mond, Stier und Kult am Stadttor: Die Stele von Bethsaida (et-Tell). Freiburg: Universitätsverlag.

Black, Jeremy, and Anthony Green. 1992. Gods, Demons, and Symbols of Ancient Mesopotamia: An Illustrated Dictionary. Austin: University of Texas Press.

Bloch-Smith, Elizabeth. 1992. Judahite Burial Practices and Beliefs about the Dead. Sheffield: Sheffield Academic Press. Borger, Rykle. 1996. Beiträge zum Inschriftenwerk Assurbanipals. Wiesbaden: Harrassowitz.

Boyer, Pascal, and Brian Bergstrom. 2008. Evolutionary Perspectives on Relgion. Annual Review of Anthropology 37: 111-30. [CrossRef]

Burnett, Joel S. 2009. Iron Age Deities in Word, Image, and Name: Correlating Epigraphic, Iconographic, and Onomastic Evidence for the Ammonite God. Studies in the History and Archaeology of Jordan 10: 153-64.

Burnett, Joel S. 2016. Egyptianizing Elements in Ammonite Stone Statuary: The Atef Crown and Lotus. In Proceedings of the 9th International Congress on the Archaeology of the Ancient Near East. Edited by Rolf A. Stucky, Oskar Kaelin and Hans-Peter Mathys. Wiesbaden: Harrassowitz, pp. 57-69.

Clark, Douglas R. 2017. The Objects and Artifacts. In Madaba Plains Project 7: The 2000 Season at Tall al-'Umayri and Subsequent Studies. Edited by Larry G. Herr, Douglas R. Clark and Lawrence T. Geraty. Winona Lake: Eisenbrauns, pp. 365-432.

Cogan, Mordechai. 1974. Imperialism and Religion: Assyria, Judah and Israel in the Eighth and Seventh Centuries B.C.E. Missoula: Society of Biblical Literature.

Cornell, Collin. 2015. A Moratorium on God Mergers? The Case of El and Milkom in the Ammonite Onomasticon. Ugarit-Forschungen 46: 49-99.

Cross, Frank M. 2003. Ammonite Ostraca from Tell Hisbān. In Leaves from an Epigrapher's Notebook: Collected Papers in Hebrew and West Semitic Palaeography and Epigraphy. Winona Lake: Eisenbrauns, pp. 70-99. 
Dabrowski, Boguslav. 1997. Clay Figurines from Tall al-'Umayri and Vicinity (The 1987 and 1989 Seasons). In Madaba Plains Project 3: The 1989 Season at Tell el-'Umeiri and Vicinity and Subsequent Studies. Edited by Larry G. Herr, Lawrence T. Geraty, Øystein S. LaBianca and Randall W. Younker. Berrein Springs: Andrews University Press, pp. 337-49.

Dabrowski, Boguslav. 2000. A Preliminary Report on Figurines and Clay Objects. In Madaba Plains Project 4: The 1992 Season at Tall al-'Umayri and Subsequent Studies. Edited by Larry G. Herr, Douglas R. Clark, Lawrence T. Geraty, Randall W. Younker and Øystein S. LaBianca. Berrein Springs: Andrews University Press, pp. 215-37.

Dabrowski, Boguslav. 2009. Terracotta Figurines from Tell Hesban and Vicinity. In Small Finds: Studies of Bone, Iron, Glass, Figurines, and Stone Objects from Tell Hesban and Vicinity. Edited by Paul J. Ray Jr. Berrein Springs: Andrews University Press, pp. 57-89.

Darby, Erin Danielle. 2014. Interpreting Judean Pillar Figurines: Gender and Empire in Judean Apotropaic Ritual. Tübingen: Mohr Siebeck.

Daviau, p. M. Michèle. 2001. Family Religion: Evidence for the Paraphernalia of the Domestic Cult. In The World of the Aramaeans II: Studies in History and Archaeology in Honour of Paul-Eugène Dion. Edited by p. M. Michèle Daviau, John W. Wevers and Michael Weigl. Sheffield: Sheffield Academic Press, pp. 199-229.

Daviau, p. M. Michèle. 2002. Excavations at Tall Jawa, Jordan, Volume II: The Iron Age Artefacts. Leiden: Brill.

Daviau, p. M. Michèle. 2003. Excavations at Tall Jawa, Jordan, Volume I: The Iron Age Town. Leiden: Brill.

Daviau, p. M. Michèle. 2008. Ceramic Architectural Models from Transjordan and the Syrian Tradition. In Proceedings of the 4th International Congress of the Archaeology of the Ancient Near East, 29 March-3 April 2004, Freie Universität Berlin. Volume 1: The Reconstruction of Environment: Natural Resources and Human Interrelations through Time. Art History: Visual Communication. Edited by Hartmut Kühne, Rainer M. Czichon and Florian Janoscha Kreppner. Wiesbaden: Harrassowitz, pp. 293-308.

Daviau, p. M. Michèle, and Paul-Eugène Dion. 1994. El, the God of the Ammonites? The Atef-Crowned Head from Tell Jawa, Jordan. Zeitschrift des Deutschen Palästina-Vereins 110: 158-67.

Daviau, p. M. Michèle, and Margreet Steiner. 2000. A Moabite Sanctuary at Khirbat al-Mudayna. Bulletin of the American Schools of Oriental Research 320: 1-21. [CrossRef]

Daviau, p. M. Michèle, and Margreet Steiner, eds. 2017. A Wayside Shrine in Northern Moab: Excavations in the Wadi ath-Thamad. Oxford: Oxbow Books.

Davis, Andrew R. 2013. Tel Dan in Its Northern Cultic Context. Atlanta: Society of Biblical Literature.

Dietrich, Manfred, and Martin A. Klopfenstein, eds. 1994. Ein Gott allein? JHWH-Verehrung und biblischer Monotheismus im Kontext der israelitischen und altorientalischen Religionsgeschichte. Freiburg: Universitätsverlag.

Dion, Paul-Eugène, and p. M. Michèle Daviau. 2000. An Inscribed Incense Altar of Iron Age II at Hirbet el-Mudēyine (Jordan). Zeitschrift des Deutschen Palästina-Vereins 116: 1-13.

Dornemann, Rudolph H. 1983. The Archaeology of the Transjordan in the Bronze and Iron Ages. Milwaukee: Milwaukee Public Museum.

Driver, Samuel Rolles. 1913. Notes on the Hebrew Text and the Topography of the Books of Samuel with an Introduction on Hebrew Palaeography and the Ancient Version and Facsimilies of Inscriptions and Maps, 2nd ed. Oxford: Clarendon Press.

Edelman, Diana V., ed. 1996. The Triumph of Elohim: From Yahwisms to Judaisms. Grand Rapids: Eerdmans.

Eggler, Jürg. 2009. Iconography of Animals in the Representation of the Divine (Palestine/Israel). In Iconography of Deities and Demons in the Ancient Near East. Edited by Jürg Eggler and Christoph Uehlinger. Available online: http://www.religionswissenschaft.uzh.ch/idd/prepublications/e_idd_iconography_of_animals. pdf (accessed on 20 December 2018).

Elkins, Stefanie p. 2017. A Model Shrine from Tall al-'Umayri. In Madaba Plains Project 7: The 2000 Season at Tall al-'Umayri and Subsequent Studies. Edited by Larry G. Herr, Douglas R. Clark and Lawrence T. Geraty. Winona Lake: Eisenbrauns, pp. 433-46.

Elkowicz, Dominik. 2012. Tempel und Kultplätze der Philister und der Völker des Ostjordanlandes: Eine Untersuchung zur Bau- und zur Kultgeschichte während der Eisenzeit I-II. Münster: Ugarit-Verlag.

Elkowicz, Dominik. 2014. Der ammonitische Mondtempel von Ruğm el Kursi und die Tempel des "syrischen Tempeltypus". Biblische Notizen 160: 51-57.

Franken, Henk. J. 1969. Excavations at Tell Deir 'Allā I: Stratigraphical and Analytical Study of the Early Iron Age Pottery. Leiden: Brill. 
Gane, Roy E. 2008. Jalul Ostracon I. Bulletin of the American Schools of Oriental Research 351: 73-84. [CrossRef] Gnuse, Robert Karl. 1997. No Other Gods: Emergent Monotheism in Israel. Sheffield: Sheffield Academic Press. Grayson, A. Kirk, and Jamie Novotny. 2012. The Royal Inscriptions of Sennarcherib, King of Assyria (704-681 BC), Part 1. Winona Lake: Eisenbrauns.

Green, Tamara M. 1992. The City of the Moon-God: Religious Traditions of Harran. Leiden: Brill.

Green, Douglas J. 2010. "I Undertook Great Works": The Ideology of Domestic Achievements in West Semitic Royal Inscriptions. Tübingen: Mohr Siebeck.

Haines, Richard C. 1971. Excavations in the Plain of Antioch II: The Structural Remains of the Later Phases: Chatal Hüyük, Tell al-Judaidah, and Tell Ta' yinat. Chicago: University of Chicago Press.

Harrison, Timothy P., and James F. Osborne. 2012. Building XVI and the Neo-Assyrian Sacred Precint at Tell Tayinat. Journal of Cuneiform Studies 64: 125-43. [CrossRef]

Hays, Christopher B. 2015. A Covenant with Death: Death in the Iron Age II and Its Rhetorical Uses in Proto-Isaiah. Grand Rapids: Eerdmans. First published 2011.

Heider, George C. 1999. Molech. In Dictionary of Deities and Demons in the Bible. Edited by Karel van der Toorn, Bob Becking and Pieter W. van der Horst. Leiden: Brill, pp. 581-85.

Herr, Larry G. 1985. The Servant of Baalis. The Biblical Archaeologist 48: 169-72. [CrossRef]

Herr, Larry G. 2014. The Objects. In Madaba Plains Project 6: The 1996 and 1998 Seasons at Tall al-'Umayri and Subsequent Studies. Edited by Larry G. Herr, Douglas R. Clark, Lawrence T. Geraty, Randall W. Younker and Øystein S. LaBianca. Berrein Springs: Andrews University Press, pp. 384-423.

Herr, Larry G., and Douglas R. Clark. 2009. From the Stone Age to the Middle Ages in Jordan: Digging up Tall al-'Umayri. Near Eastern Archaeology 72: 68-97. [CrossRef]

Herr, Larry G., and Mohammed Najjar. 2001. The Iron Age. In The Archaeology of Jordan. Edited by Burton MacDonald, Russell Adams and Piotr Bienkowski. Sheffield: Sheffield Academic Press, pp. 323-45.

Herr, Larry G., and Elizabeth E. Platt. 2002. The Objects from the 1989 Season. In Madaba Plains Project 5: The 1994 Season at Tall al-'Umayri and Subsequent Studies. Edited by Larry G. Herr, Douglas R. Clark, Lawrence T. Geraty, Randall W. Younker and Øystein S. LaBianca. Berrein Springs: Andrews University Press, pp. 358-99.

Herrmann, Wolfgang. 1999. Baal. In Dictionary of Deities and Demons in the Bible. Edited by Karel van der Toorn, Bob Becking and Pieter W. van der Horst. Leiden: Brill, pp. 132-39.

Herrmann, Virginia Rimmer, and J. David Schloen, eds. 2014. In Remembrance of Me: Feasting with the Dead in the Ancient Middle East. Chicago: The Oriental Institute of the University of Chicago.

Herzog, Ze'ev, Miriam Aharoni, Anson F. Rainey, and Shmuel Moshkovitz. 1984. The Israelite Fortress at Arad. Bulletin of the American Schools of Oriental Research 254: 1-34. [CrossRef]

Hoftijzer, Jean, and Gerritt van der Kooij. 1976. Aramaic Texts from Deir 'Alla. Leiden: Brill.

Hoftijzer, Jean, and Gerritt van der Kooij, eds. 1991. The Balaam Text from Deir 'Alla Re-evaluated: Proceedings of the International Symposium held at Leiden, 21-24 August 1989. Leiden: Brill.

Holladay, John S., Jr. 1987. Religion in Israel and Judah Under the Monarchy: An Explicitly Archaeological Approach. In Ancient Israelite Religion: Essays in Honor of Frank Moore Cross. Edited by Patrick D. Miller Jr., Paul D. Hanson and S. Dean McBride. Philadelphia: Fortress Press, pp. 249-99.

Holloway, Steven W. 1995. Harran: Cultic Geography in the Neo-Assyrian Empire and its Implications for Sennacherib's 'Letter to Hezekiah' in 2 Kings. In The Pitcher is Broken: Memorial Essays for Gösta W. Ahlström. Edited by Steven W. Holloway and Lowell K. Handy. Sheffield: Sheffield Academic Press, pp. 276-314.

Houtman, Cornelius. 1999. Queen of Heaven. In Dictionary of Deities and Demons in the Bible. Edited by Karel van der Toorn, Bob Becking and Pieter W. van der Horst. Leiden: Brill, pp. 678-80.

Hübner, Ulrich. 1992. Die Ammoniter: Untersuchungen zur Geschichte, Kultur und Religion eines transjordanischen Volkes im 1 Jahrtausend v. Chr.. Wiesbaden: Otto Harrassowitz.

Hübner, Ulrich. 1993. Das ikonographische Repertoire der ammonitischen Siegel und seine Entwicklung. In Studies in the Iconography of Northwest Semitic Inscribed Seals: Proceedings of a Symposium Held in Fribourg on April 17-20, 1991. Edited by Benjamin Sass and Christoph Uehlinger. Fribourg: University Press Fribourg Switzerland, pp. 130-60.

Hübner, Ulrich. 2009. Der Mondtempel auf Rugm al-Kursi in der Ammonitis. In Israel zwischen den Mächten: Festschrift für Stefan Timm zum 65. Geburtstag. Edited by Michael Pietsch and Friedhelm Hartenstein. Münster: Ugarit-Verlag, pp. 145-53. 
Hübner, Ulrich. 2015. Noch einmal zum ammonitischen Mondtempel auf Ruğm al-Kursī. Die Welt des Orients 45: 193-99. [CrossRef]

Huffmon, Herbert B. 1999a. Brother. In Dictionary of Deities and Demons in the Bible. Edited by Karel van der Toorn, Bob Becking and Pieter W. van der Horst. Leiden: Brill, pp. 178-79.

Huffmon, Herbert B. 1999b. Father. In Dictionary of Deities and Demons in the Bible. Edited by Karel van der Toorn, Bob Becking and Pieter W. van der Horst. Leiden: Brill, pp. 326-28.

Humbert, Jean-Baptiste, and Fawzi Zayadine. 1992. Trois Campagnes de Fouilles à Ammân (1988-1991): Troisième Terrasse de la Citadelle (Mission Franco-Jordanienne). Revue Biblique 1992: 214-60.

Hundley, Michael B. 2013. Gods in Dwellings: Temples and Divine Presence in the Ancient Near East. Atlanta: Society of Biblical Literature.

Ibrahim, Moawiyah M. 1971. Two Ammonite Statuettes from Khirbet El-Hajjar. Annual of the Department of Antiquities of Jordan 16: 91-97.

Ibrahim, Moawiyah M., and Gerritt van der Kooij. 1991. The Archaeology of Deir 'Alla Phase IX. In The Balaam Text from Deir 'Alla Re-Evaluated: Proceedings of the International Symposium Held at Leiden, 21-24 August 1989. Edited by J. Hoftijzer and Gerritt van der Kooij. Leiden: Brill, pp. 16-29.

Israel, Felice. 1990. Note Ammonite II: La religione degli Ammonite attraverso le fonti epigrafiche. Studi e materiali di storia delle religione 56: 307-37.

Jackson, Kent p. 1983. Ammonite Personal Names in the Context of the West Semitic Onomasticon. In The Word of the Lord Shall Go Forth: Essays in Honor of David Noel Freedman in Celebration of His Sixtieth Birthday. Edited by Carol L. Meyers and Michael P. O'Connor. Winona Lake: Eisenbrauns, pp. 507-25.

Keel, Othmar. 1998. Goddesses and Trees, New Moon and Yahweh: Ancient Near Eastern Art and the Hebrew Bible. Sheffield: Sheffield Academic Press.

Keel, Othmar, and Christoph Uehlinger. 1998. Gods, Goddesses, and Images of God in Ancient Israel. Translated by Thomas H. Trapp. Minneapolis: Fortress Press.

Knoppers, Gary N. 2004. 1 Chronicles 10-29: A New Translation with Introduction and Commentary. New York: Doubleday.

Landes, George M. 1956. A History of the Ammonites. Ph.D. thesis, The Johns Hopkins University, Baltimore, MD, USA.

Leichty, Erle. 2011. The Royal Inscriptions of Esarhaddon, King of Assyria (680-669 BC). Winona Lake: Eisenbrauns.

Lelli, Fabrizio. 1999. Stars. In Dictionary of Deities and Demons in the Bible. Edited by Karel van der Toorn, Bob Becking and Pieter W. van der Horst. Leiden: Brill, pp. 809-15.

Lemaire, André. 1994. Déesses et dieux de Syrie-Palastine d'après les inscriptions (c. 1000-500 av. n. è.). In Ein Gott allein? JHWH-Verehrung und biblischer Monotheismus im Kontext der israelitischen und altorientalischen Religionsgeschicte. Edited by Walter Dietrich and Martin A. Klopfenstein. Fribourg: Fribourg University Press, pp. 127-58.

Lipiński, Edward. 1999. Shemesh. In Dictionary of Deities and Demons in the Bible. Edited by Karel van der Toorn, Bob Becking and Pieter W. van der Horst. Leiden: Brill, pp. 764-68.

Low, Russanne D. 1991. Field F: The Eastern Shelf. In Madaba Plains Project 2: The 1987 Season at Tell el-'Umeiri and Vicinity and Subsequent Studies. Edited by Larry G. Herr, Lawrence T. Geraty, Øystein S. LaBianca and Randall W. Younker. Berrein Springs: Andrews University Press, pp. 170-231.

Margueron, Jean-Claude. 1992. Nanna. In Book Nanna. Edited by David Noel Freedman. New York: Doubleday, vol. 6, p. 767.

Meshel, Ze'ev. 2012. Kuntillet Ajrud (Horvat Teman): An Iron Age II Religious Site on the Judah-Sinai Border. Jerusalem: Israel Exploration Society.

Millard, Alan. 1999. Nabû. In Dictionary of Deities and Demons in the Bible. Edited by Karel van der Toorn, Bob Becking and Pieter W. van der Horst. Leiden: Brill, pp. 607-10.

Momani, Ahmed, Anthi Koutsoukou, Glen L. Peterman, Peter Warnock, and Paul-Eugène Dion. 1997. The 1993 Excavations. In The Great Temple of Amman: The Excavations. Edited by Anthi Koutsoukou, Kenneth W. Russell, Mohammad Najjar and Ahmed Momani. Amman: American Center of Oriental Research, pp. 157-71.

Novák, Mirko. 2002. Zur Verbindung von Mondgott und Wettergott bei den Aramäern im 1. Jahrtausend v. Chr. Ugarit-Forschungen 33: 437-65. 
Ornan, Tallay. 1993. The Mesopotamian Influence on West Semitic Inscribed Seals: A Preference for the Depiction of Mortals. In Studies in the Iconography of Northwest Semitic Inscribed Seals: Proceedings of a symposium held in Fribourg on April 17-20, 1991. Edited by Benjamin Sass and Christoph Uehlinger. Freiburg: Universitätsverlag, pp. 52-73.

Ornan, Tallay. 2001. The Bull and its Two Masters: Moon and Storm Deities in Relation to the Bull in Ancient Near Eastern Art. Israel Exploration Journal 51: 1-26.

Paul, Shalom M. 1991. Amos: A Commentary on the Book of Amos. Minneapolis: Fortress Press.

Petit, Lucas, and Zeidan Kafafi. 2016. Beyond the River Jordan: A Late Iron Age Sanctuary at Tell Damiyah. Near Eastern Archaeology 79: 18-26. [CrossRef]

Pettinato, Giovanni. 2005. Inanna. In Book Inanna. Edited by Lindsay Jones. Detroit: Thomson Gale, vol. 6, pp. 4402-6.

Platt, Elizabeth E. 1989. 'Umeiri Objects. In Madaba Plains Project 1: The 1984 Season at Tell el-'Umeiri and Vicinity and Subsequent Studies. Edited by Lawrence T. Geraty, Larry G. Herr, Øystein S. LaBianca and Randall W. Younker. Berrein Springs: Andrews University Press, pp. 355-66.

Platt, Elizabeth E., and Larry G. Herr. 2002. The Objects. In Madaba Plains Project 5: The 1994 Season at Tall al-'Umayri and Subsequent Studies. Edited by Larry G. Herr, Douglas R. Clark, Lawrence T. Geraty, Randall W. Younker and Øystein S. LaBianca. Berrein Springs: Andrews University Press, pp. 156-70.

Porter, Benjamin W., and Alexis T. Boutin, eds. 2014. Remembering the Dead in the Ancient Near East: Recent Contributions from Bioarchaeology and Mortuary Archaeology. Boulder: University Press of Colorado.

Postgate, J. Nicholas. 1974. Taxation and Conscription in the Assyrian Empire. Rome: Biblical Institute Press.

Prag, Kay. 1987. Decorative Architecture in Ammon, Moab, and Judah. Levant 19: 121-27. [CrossRef]

Puech, Emile. 1977. Milkom, le dieu ammonite, en Amos I 15. Vetus Testamentum 27: 117-25. [CrossRef]

Puech, Emile. 1999. Milcom. In Dictionary of Deities and Demons in the Bible. Edited by K. van der Toorn, B. Becking and p. W. van der Horst. Leiden: Brill, pp. 575-76.

Rollston, Christopher A. 2004. Non-Provenanced Epigraphs II: The Status of Non-Provenanced Epigraphs within the Broader Corpus of Northwest Semitic. Maarav 11: 57-79.

Rollston, Christopher A. 2010. Writing and Literacy in the World of Ancient Israel: Epigraphic Evidence from the Iron Age. Atlanta: Society of Biblical Literature.

Routledge, Bruce. 2004. Moab in the Iron Age: Hegemony, Polity, Archaeology. Philadelphia: University of Pennsylvania Press.

Schmidt, Brian B. 1996. Israel's Beneficent Dead: Ancestor Cult and Necromancy in Ancient Israelite Religion and Tradition, pbk. ed. Winona Lake: Eisenbrauns.

Schmidt, Brian B. 1999. Moon. In Dictionary of Deities and Demons in the Bible. Edited by Karel van der Toorn, Bob Becking and Pieter W. van der Horst. Leiden: Brill, pp. 585-93.

Seow, Choon-Leong. 1999. Am. In Dictionary of Deities and Demons in the Bible. Edited by Karel van der Toorn, Bob Becking and Pieter W. van der Horst. Leiden: Brill, pp. 24-26.

Smith, Mark S. 2001. The Origins of Biblical Monotheism: Israel's Polytheistic Background and the Ugaritic Texts. Oxford: Oxford University Press.

Smith, Mark S. 2002. The Early History of God: Yahweh and the Other Deities in Ancient Israel. Grand Rapids: Eerdmans.

Staubli, Thomas. 2003. Sin von Harran und seine Verbreitung im Westen. In Werbung für die Götter. Heilsbringer aus 4000 Jahren. Edited by Thomas Staubli. Fribourg: Academic Press, pp. 65-89.

Stavrakopoulou, Francesca. 2010. Land of our Fathers: The Roles of Ancestor Veneration in Biblical Land Claims. New York: T \& T Clark.

Tadmor, Hayim, and Shigeo Yamada. 2011. The Royal Inscriptions of Tiglath-Pileser II (744-727 BC) and Shalmaneser $V$ (726-722 BC), Kings of Assyria. Winona Lake: Eisenbrauns.

Te Velde, Herman. 1999. Bes. In Dictionary of Deities and Demons in the Bible. Edited by Karel van der Toorn, Bob Becking and Pieter W. van der Horst. Leiden: Brill, p. 173.

Theuer, Gabriele. 2000. Der Mondgott in den Religionen Syrien-Palästinas: Unter besonderer Berücksichtigung von KTU 1.24. Freiburg: Universitätsverlag.

Tigay, Jeffrey H. 1987. Israelite Religion: The Onomastic and Epigraphic Evidence. In Ancient Israelite Religion: Essays in Honor of Frank Moore Cross. Edited by Patrick D. Miller Jr., Paul D. Hanson and Samuel Dean McBride. Philadelphia: Fortress Press, pp. 157-94. 
Tyson, Craig W. 2014. The Ammonites: Elites, Empires, and Sociopolitical Change (1000-500 BCE). London: Bloomsbury T \& T Clark.

Van der Toorn, Karel. 1996a. Ancestors and Anthroponyms: Kinship Terms as Theophoric Elements in Hebrew Names. Zeitschrift für die Alttestamentliche Wissenschaft 108: 1-11. [CrossRef]

Van der Toorn, Karel. 1996b. Family Religion in Babylonia, Syria and Israel: Continuity and Change in the Forms of Religious Life. Leiden: Brill.

Werse, Nicholas R. 2018. Of Gods and Kings: The Case for Reading "Milcom" in Zephaniah 1:5b $\beta$. Vetus Testamentum 68: 505-13. [CrossRef]

Yassine, Khair. 1984. Tell el Mazar I: Cemetery A. Amman: University of Amman Press.

Yassine, Khair. 1999. Burial Customs and Practices in Ancient Ammon. In Ancient Ammon. Edited by Burton MacDonald and Randall W. Younker. Leiden: Brill, pp. 137-51.

Zayadine, Fawzi. 1973. Recent Excavations on the Citadel of Amman. Annual of the Department of Antiquities of Jordan 18: 17-35.

Zayadine, Fawzi. 1991. Sculpture in Ancient Jordan. In Treasures from an Ancient Land: The Art of Jordan. Edited by Piotr Bienkowski. Phoenix Mill: Alan Suttone, pp. 31-61.

Zayadine, Fawzi, Jean-Baptiste Humbert, and Najjar Mohammed. 1989. The 1988 Excavations of the Citadel of Amman, Lower Terrace, Area A. Annual of the Department of Antiquities of Jordan 33: 357-63.

Zevit, Ziony. 2001. The Religions of Ancient Israel: A Synthesis of Parallactic Approaches. London: Continuum.

(C) 2019 by the author. Licensee MDPI, Basel, Switzerland. This article is an open access article distributed under the terms and conditions of the Creative Commons Attribution (CC BY) license (http:/ / creativecommons.org/licenses/by/4.0/). 
MDPI

St. Alban-Anlage 66

4052 Basel

Switzerland

Tel. +41616837734

Fax +41 613028918

www.mdpi.com

Religions Editorial Office

E-mail: religions@mdpi.com

www.mdpi.com/journal/religions

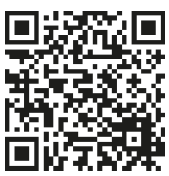



MDPI

St. Alban-Anlage 66

4052 Basel

Switzerland

Tel: +41 616837734

Fax: +41 613028918

www.mdpi.com 